On Ballance: a biography of John Ballance, journalist and poiltician, 1839-1893.

A thesis submitted in partial fulfillment of the requirements for the degree of Doctor of Philosophy.

by

Timothy J. McIvor 


\section{ACKNOWLEDGEMENTS}

Many people assisted in the preparation of this thesis. I had a considerable number of enjoyable interviews with descendants of the Ballance and Anderson families. Shirley McKnight of Ohingaiti and John Hatherly of New Plymouth were particularly helpful, and were supportive in their genuine interest in what I was doing. My research in Wanganui benefited from the advice, information and practical assistance given to me by Arthur Bates, Managing Director of Wanganui Newspapers and author of The Wanganui Story, and Brian Henderson, Director of Wanganui Museum.

This thesis was written under the supervision of Professor D.A. Hamer. His breadth of knowledge of nineteenth century New Zealand politics was invaluable; his advice and assistance was always helpful and constructive; and his efficiency in reading and returning drafts, enabling me to complete the project within a fairly tight time schedule, was more than I had a right to expect. A number of other historians gave their time and energies at various stages, and I would especially like to thank Professor Keith Sinclair and Dr. James Belich in this respect. Dr. John Crisp of Wellington took much trouble in reading and commenting upon the recorded information on Ballance's illness.

Some material on Ballance's early life in northern Ireland was kindly provided by Brendan Colgan of Belfast, and by Brian Trainor, Director of the Ulster Historical Foundation. Andrew Watkin spent many hours on Birmingham sources. 
Mrs Gloria Biggs typed the thesis with remarkable accuracy and equally remarkable speed. Judith Wigglesworth took great care in drawing the map, and Gerry Keating reproduced the photographs. Mrs Gwen Wright assisted in the final stages of preparing the thesis for binding. I would also like to thank the History Department at Victoria University for the facilities they provided, and for making my time in Wellington so pleasant. My study in New Zealand has been financed by a Commonwealth Scholarship, and in connection with this I would like to acknowledge the help and cooperation of Kay Wills of the University Grants Committee.

Fina1ly, to my wife Paula I owe my greatest debt. She read and commented upon the first draft, correcting amongst other things some indifferent grammar; she proof-read the typed script and, perhaps most important, kept me at the job in hand when energies flagged. 


\section{CONTENTS}

$\begin{array}{lr}\text { Acknowledgements } & \text { Page } \\ \text { Plates and map } & \text { iii } \\ \text { Abbreviations } & \text { vi } \\ \text { Introduction } & \text { vii } \\ \end{array}$

\section{Chapter}

1 From Belfast to Birmingham

2 Wanganui and War: frontier politics and insecurity

3 The Politics of Progress

4 An Early Taste of Power

5 Years of Uncertainty and Change

6 Philosophy for Improvement: state-help and self-help

7 A Curious Combination

8 Reluctant Leader

9 The Tide of Events: land for the people 10 New Zealand for New Zealanders: self-reliance and
nationalism

11 Consolidation and Compromise

12 Cut Short

Conclusion: the Ballance tradition

Appendixes

A The Development of Ballance's Career and Philosophy

B Ballance to John Notman, 27 May 1888

C Statistical Tables

Bibliography

Abstract 
facing page

1. Wanganui, $1867 \quad 40$

2. Evening Herald, $1868+80$

3. Wanganui, circa 1860s 120

4. John Ballance, circa $1868 \quad 160$

5. Kathleen Ballance, 1885200

6. John Ballance, circa $1884 \quad 240$

7. Wanganui, circa 1890s 280

8. John Ballance, circa $1892 \quad 320$

9. Ballance Cabinet, $1892 \quad 360$

10. Ballance's Funeral, April $1893 \quad 400$

11. Ellen Ballance in 01d Age 440

12. Parliament Buildings and the Ballance Statue 480

MAP

Wanganui district and the war against Titokowaru 59

(Photographs reproduced with the kind permission of the Turnbull Library) 


\section{ABBREVIATIONS}

AES Auckland Evening Star

AJHR Appendices to the Journals of the House of Representatives

BMSS Ballance Papers

EH Evening Herald

EP Evening Post

LB Ballance Letter Book, I: 1878-79 volume

II: 1891-92 volume

III : $1892-93$ volume

LT Lyttelton Times

M.H.R. Member of the House of Representatives

NZH New Zealand Hera1d

NZJH New Zealand Journal of History

NZT New Zealand Times

ODT Otago Daily Times

PD New Zealand Parliamentary Debates

WC Wanganui Chronicle

WH Weekly Herald

$\underline{Y} \quad$ Yeoman 
The Statue of John Ballance stands at one end of the grounds of New Zealand's Parliament Buildings. Around its base are inscribed the words: HE LOVED THE PEOPLE. It is not a tall or imposing statue; and in fact it has been increasingly hidden from view by the growth of trees and shrubs near by. Nor is it a good likeness. Edward Tregear said on its unveiling that it was 'hideous beyond words; it is very good style for a cemetery but no more like our dear dead chief than I am like the Apollo Belvedere- and that's 'a far cry' '. 1

Further down the hill, in the paved area leading to the steps and the main doors of Parliament, stands Seddon: tall, defiant, with a flag placed at his feet and pigeons on his head. ${ }^{2}$

When erected, the Ballance statue stood in the centre of a circular lawn, directly in front of what was then the Parliament Building, but now houses the General Assembly Library. Ballance was the first New Zealand Premier so honoured. He was the first Liberal Premier, and also the first Premier to die whilst still in office. The colony had never seen quite such a funeral. The procession began in Tinakori Road, and then crept down to the railway station, to the trains waiting to convey the mourners to Wanganui. The main train carried two hundred persons. As it stopped for water on its way north crowds greeted it in silence, whilst bands played slow marches. On arrival in Wanganui the procession continued up Victoria Avenue, and by way of Guyton Street to the cemetery. Meanwhile special boats

1. Quoted in A.H. McLintock (ed.), An Encyclopaedia of New Zealand, Volume 1 , Wellington, $1966, \mathrm{p} .146$.

2. See W.H. Oliver's delightful poem, Poor Richard, Wellington, 1982. 
and trains had brought another two thousand mourners to the town. 3

Since his death Ballance has been overshadowed by subsequent Premiers, and by Seddon in particular. The predominance of Seddon's statue over that of Ballance is symbolic of the preference historians have shown for, and the much greater attention they have paid to, Seddon.

Very little has been written about Ballance. There are two short theses over fifty years old: J.L. Dighton, 'The Life and Work of John Ballance', and G.S. Maloney, 'A History of the Ballance Ministry'. The latter is the more interesting, because its author interviewed Ballance's wife, Ellen, during the course of his research. A much more recent M.A. thesis, T.J. Young, 'The Political Career of John Ballance', ha's been of considerable help to the present writer, but it concentrates on the electoral contests in Wanganui and stops at 1890 , before the climax of Ballance's career. Ballance's entries in the Dictionary of New Zealand Biography, Scholefield's Notable New Zealand Statesmen, the Encyclopedia of New Zealand and New Zealand's Heritage, contain little that cannot be gleaned from his obituaries.

There are, of course, a number of reasons for the neglect of Ballance. He was only two years in office, compared to Seddon's thirteen. He is not, some would argue, a particularly attractive subject for a biography: he was neither a great orator and 'crowd-puller' like Grey, nor of the intellectual force of Stout and Reeves. Modest, retiring, uninspiring, at times lacking in self-confidence, Ballance seems an unlikely candidate for Premier, 
never mind for an historian's pen and energies.

Finally, and perhaps most telling, is the lack of source material relating to Ballance.

Thus Ballance has' remained somewhat of a 'shadowy' figure, appearing from nowhere in 1890 , to dart only fleetingly across the stage of New Zealand history.

This thesis was undertaken after consideration of these and other problems, the writer having concluded that, in fact, a biography of Ballance was not only viable but well overdue. Ballance is a key figure in New Zealand's political history and in the development of liberalism in particular. His importance was acknowledged by contemporaries at the time of his death. Later, both Liberal and Labour politicians actively sought to lay claim to be carrying on where he had left off.

As this thesis hopes to show, Ballance was much more 'typical' of the liberals who won the 1890 election than Reeves. At the same time he was distinctly more radical in his liberalism than Seddon. Ballance represented Wanganui, a town that looked to the surrounding countryside for its prosperity, and the solution to its problems. Land, not labour, was central both to his own philosophy and to that of the Liberal party in 1890. Closer settlement was the key, and land nationalisation the best means, to progress and the resolution of the country's ills. Ballance's position on many issues coincided with that of Sir Robert Stout, although there were (for example on the question of prohibition) some differences. The two 
men were close personal friends. Yet it was Ballance who held office in those crucial early years of the Liberal regime, and this fact alone demands his detailed study.

Unquestionably the lack of personal material relating to Ballance is the biggest problem faced by a prospective biographer. The Ballance Papers and the three Letter Books in the Alexander Turnbull Library, contain correspondence from his years as Premier and his term as Colonial Treasurer in the Grey Government. It is the dearth of private matter outside these periods that is the greatest difficulty. There is, however, considerable 'public' material, in the form of editorials of the Evening Herald (later the Wanganui Herald), the newspaper Ballance founded in 1867. Ballance edited the paper himself until he first entered Parliament in 1875. Thereafter, he returned to the editorial chair during each recess (and when he was out of Parliament between 1881 and 1884), right up until the appointment of James Duigan as full-time editor in January 1891. ${ }^{4}$ There is a wealth of useful material in the Herald, and through it the early development of Ballance's views, as well as the progress of the town itself, can be traced.

The Ballance Papers and the Herald form the two major sources for this thesis. Ballance put out a weekly version of the Herald from 1869 onwards, which was aimed at country readers and contained all the news and other content of the daily paper, plus some additional items. This paper, which later underwent a change in name from the Weekly Herald to the Yeoman, is available on microfilm

4. $\stackrel{\text { Y }}{2}, 21$ Mar. 1891. 
at the Turnbull Library. The Evening Herald, later called the Wanganui Herald, is much less accessible. For much of the $1880 \mathrm{~s}$, for example, the only extant copies seem to be in the basement of Wanganui Museum. For this reason it is the Yeoman that is generally referred to throughout this thesis. The writer has read all issues of the Weekly Herald/Yeoman up to the end of 1893. Much of the Evening Herald/Wanganui Herald was also consulted, although a close comparison of the daily and weekly issues soon made clear the duplication of content.

The Wanganui Chronicle was the Herald's rival in the town and Ballance's constant political opponent. Most issues for this period can be found either ị the Wanganui City Library, or the General Assembly Library in Wellington. The Herald and Chronicle could usually be counted upon to take up opposing positions on any given political question.

The search for other material did not turn up a great deal. The Ballance's had no children of their own and their adopted daughter, Kathleen, never married. However Ellen's father, David Anderson, a prominent Wellington merchant, wrote diaries for many years until his death in 1889. These are deposited with the Turnbull Library. They provide an interesting insight into Ballance's relationship with the Anderson 'clan', but there is practically no 'political' content. Much the same can be said about the diaries of Sarah Jane Spinks, a sister-in-law of Ellen Ballance. These are in the possession of Mrs Carol Anderson of Wellington, who kindly entrusted them to the writer for a period of time. 
Tracking down members of the Anderson, Willis and Duigan families, and descendants of Robert McKnight, John Ballance's nephew, was an enjoyable, if not terribly fruitful, experience. A good deal of 'oral' information was gathered, essentially family gossip. How many times was it revealed that Ellen Ballance had a considerable dislike (and she was, like her husband, a mild and kindly person) for the Seddons.

More substantial was a letter in the possession of Mr John Haterly of New Plymouth. Written by Ballance in 1888, it told, amongst other things, of his intention of retiring from politics for good. It has been reproduced in the appendix.

Secondary works that have been particularly helpful, aside from the ones already mentioned, include D.A. Hamer's very thorough biography of Sir Robert Stout and his article on the New Zealand Agricultural Company. Hamer points to Ballance's 'almost chronic lack of self-confidence' and stresses his dependency on Stout. Both characteristics are borne out by this thesis, although they can be taken too far. Ballance's deference was to Stout alone. There was a strong personal and intellectual relationship, and Ballance undoubtedly believed Stout to have the greater claim to the leadership of the liberals. However with Stout defeated in 1887, Ballance saw himself as next in line. Ballance hesitated at this time, not so much because of a lack of confidence in himself, but owing to his personal financial difficulties, ill health and what appeared to be a gloomy political outlook. Both Ballance and Stout failed to predict the significance of the 1890 election. 
Once in power Ballance offered on a number of occasions to step down if Stout re-entered the House. This may well have been purely for public consumption, a recognition of Stout's popularity and high profile in the country. Only when he knew he was dying, did Ballance himself press Stout to return to Parliament. Stout was content to leave things to Ballance for as long as Ballance was in control. It is hard to imagine that Ballance was unaware of this.

Two further points can be made. First, a certain amount of deference was required from an aspiring party leader. It did not look good to appear too eager. Commenting on his elevation to acting Premier in September 1892 (when Ballance became ill) Seddon told the House: 'I took the position with great hesitation, and, if there have been any shortcomings on my part, I hope the same may be overlooked...'.5 Ballance had said much the same in 1889.

Secondly, Ballance's 'lack of confidence' was often in reality a misinterpretation of a kind and conciliatory nature. '[0]f all the successful and able men, I have known, he was absolutely the most unassuming and unpretentious', Reeves said of Ballance two months after the Premier's death. However he continued:

There used to be a notion spread about at one time rather sedulously that $\mathrm{Mr}$ Ballance was deficient in determination and even in political courage. Those who formed this strange idea had not, of course, served in a Cabinet with him. If they had, they would have known that as a Premier- and I say it emphatically- he knew how to be master in his own house. 6

5. PD, 1892,78, p. 892 .

6. Reeves speech in Dunedin, quoted by $\underline{Y}, 10$ June 1893 . 
The 'standard' work on the rise of the Liberal party is the thesis by T.G. Wilson. He argues that such a party did not coalesce finally until 1890, and was only victorious after the discrediting and bankruptcy of 'conservative' rule. He sees the Grey Government as growing out of the struggle of Otago and Auckland against the abolition of the provinces, and quite rightly points out that after its fall the Liberal party 'virtually ceased to exist'.

This thesis qualifies, rather than contradicts, these observations. First, Ballance was neither opposed to abolition nor from Otago or Auckland. He therefore complicates Wilson's view of the Grey Government; a government in which Ballance, as Colonial Treasurer, played a major part. Secondly, there was an element of continuity between the Grey and Ballance ministries, but of ideas rather than personnel. When Colonial Treasurer Ballance had a land tax passed. It was abolished by the subsequent administration, and its re-introduction became central to Ballance's philosophy thereafter. Further, it was a consistent rallying point for liberals and was at the core of the 1890 party platform.

Since Wilson's thesis historians have tended to concentrate on biographies rather than broad studies of the period. Most important is Keith Sinclair's William Pember Reeves, which emphasises the labour element in the liberal 'coalition' of 1890. This writer suggests, however, that land reform was by far the dominant concern both of Ballance and of the Government and Party he led.

Other relevant literature will be referred to and commented upon in the course of this biography. For example, M.R. Stenson's thesis 
on 'Advances to Settlers' is very persuasive, although it is argued here that the question of borrowing was not as crucial to Ballance as Stenson suggests. Judith Bassett's biography of Atkinson was helpful. On the 1890 election, H. Crook, 'The Significance of the 1890 Election' and C. Campbell, 'Parties and Special Interests in New Zealand, 1890-93', are the two most useful theses. Very little of worth has been written specifically on land legislation. W.R. Jourdain's Land Legislation and Settlement in New Zealand, published by the Department of Lands and Survey in 1925, has yet to be made redundant.

Individuals, especially politicians, do not lead isolated lives. Rather they are constantly interacting with events and other people, and so, to a lesser or greater degree, can be considered characteristic of their surroundings. This biography hopes not only to analyse Ballance's political life, his philosophy and 'place' in New Zealand history, but in doing so to also say something about that history itself.

Very little is known of Ballance's early life in the north of Ireland and Birmingham. Such research for this thesis as was possible without actually travelling to Britain, has turned up some new material. Members of the Ballance family, and their economic circumstances, have been identified. Pieces of information have been gleaned from the Ulster Historical Foundation's file relating to 
Ballance's birthplace, from contemporary tithe and valuation records and from some later articles in the Belfast Telegraph, written in celebration of Ballance's birth and death. Some research was carried out in Birmingham, on behalf of the author, but in the limited time available little was discovered. Ballance attended classes at the Midland Institute; he did not, however, appear to have sat and passed any exams. He was also known to have been secretary of a literary society; yet his name does not appear on the list of office bearers of the Central Literary Association in existance at the time. He may well have belonged to a less prominent organisation. The Aris Birmingham Gazette was scanned for the years 1858 to 1866 , for any mention of Ballance, but without success.

Further research may well prove more fruitful, and it is the present writer's intention to pursue the matter on his return to the United Kingdom. In the meantime the first chapter of this thesis, on Ballance's early life, is unfortunately, but under the circumstances necessarily, brief.

The second chapter discusses Ballance's arrival in Wanganui, the establishment of the Herald, and his participation in the war against Titokowaru. It shows the precarious state of his personal finances and that of the town itself. Also, this period reinforced Ballance's belief in self-reliance, in the desirability of not relying upon any resources but one's own.

The war over, Wanganui's progress was tied directly to the development of the hinterland it served. The dependency of the town's (and the port's) growth upon the closer settlement of the 
surrounding countryside, examined in chapter three, was Ballance's central experience of these years. He was intimately involved in this relationship, for the Herald relied on advertising and circulation, both of which fluctuated with the general level of prosperity of the town. Ballance had no independent means, drawing his income entirely from the paper's profits.

A second feature of this period (1869 to 1875), was Ballance's opposition to the provincial system, which he saw as an unnecessary obstacle to more rapid economic development. Wanganui was an 'outlying district' within Wellington Province and constantly felt neglected by the provincial capital. Ballance was, perhaps, 'unusual' in that he was (unlike Stout and Grey) both a liberal and a centralist. In fact he supported abolition not only because of the 'raw deal' Wanganui received from Wellington, but as a matter of political principle. He consistently advocated a unitary democratic system, based on a strong centralised Parliament with a sovereign Lower House. The only upper chamber that he could tolerate was a weak one.

It was Ballance's opposition to the provincial system that led him to side initially with Atkinson. Once abolition had been achieved he quickly pursued a more fundamental and lasting alliance with Stout and other liberals. As Colonial Treasurer in the Grey Government (chapter four), Ballance gained invaluable political and administrative experience at a relatively young age. More important, his championing of a land tax, indicates considerable continuity between this early period and his later premiership. In 1878 he was already arguing that a land tax was not only more equitable than the property tax, but would also provide a more permanent and stable 
source of government revenue, as well as encouraging closer settlement through penalising large unimproved holdings. Finally, Ballance was deeply affected by the budget deficit at the end of his term as Treasurer. He saw it (with much good reason), as essentially the product of circumstances outside his control. This experience brought home to him the need for prudent financing and the desirability of insulating, as far as possible, the country from 'harmful' external influences.

Chapter five covers the period 1879 to 1884 . With the onset of the depression, which affected the Herald and thus Ballance personally, and his electoral defeat in 1881, these were years of considerable turmoil. It was during this time, and in a sense out of these uncertainties, that he wrote his pamphlet on land nationalisation. The chapter argues that all the key elements of what was to be Ballance's programme in 1890 , centring on land reform, had coalesced by 1884 .

The following chapter, six, then examines in detail the broad base of his liberal philosophy. It shows how its different aspects are inter-related, all pointing to a democratic, secular society, with considerable emphasis on individual and national self-reliance.

Having looked briefly at Ballance's connection with the New Zealand Agricultural Company, chapter seven then discusses his term as Minister for Lands and Native Minister in the Stout-Voge1 Government. The special settlements he promoted can be seen as the physical embodiment of his philosophy, and at the same time a reaction to the depression. They aimed to provide land for the urban working 
classes; a means of self-improvement based substantially on self-reliance. Land settlement was the key to prosperity, of which the State would retain its share through a leasing system. Equally, Ballance's 'native' policy strove to find an accommodation between this goal of closer European settlement, and the interests of Maoris themselves.

Chapters eight and nine lead up to the election of 1890 . It is argued that in regarding the land question as central to the Liberal platform, Ballance was not only responding to the lessons of his own experience (closer settlement as vital to Wanganui's prosperity), but he also epitomised the reaction of many to the depression and the labour unrest. Land was seen as the major resource the country possessed. Further, the cry to 'open up the land' attracted so much support because it did not involve conflict between the urban classes. On the contrary, by pointing to the large landowner as the common enemy, it enabled the formation of an urban alliance.

Once in power (chapters ten to twelve), Ballance immediately replaced the property tax with a general and graduated land tax, and an income tax. His main concern in his years as Premier was the establishment of greater political and economic independence, in the face of opposition to the Government's policy from the Legislative Council (backed up by the Governor), and from overseas financial interests who, it was alleged, were rapidly withdrawing capital from the colony. Ballance posed the 'crisis' in nationalistic terms: his solution involved the securing of new appointments to the Council, as the right of a politically independent nation; setting up the Liberal 
Federation, to voice 'grass-roots', 'popular', support for the Government; and pursuing a financial self-reliant policy of non-borrowing.

Chapter eleven argues that the record budget surplus of 1892 , along with the Government's victory over the Legislative Council appointments, were seen as evidence that Ballance's policies had paid off. Critics were silenced and the Government's position greatly strengthened.

Yet this was despite the fact that in the meantime Ballance had conceded any hope of pursuing land nationalisation. The passage of the lease-in-perpetuity (affecting the disposition of remaining crown lands), reflected the growing preference for the freehold rather than the leasehold. Any land subsequently re-purchased by the State (assuming the money could be found, with or without overseas borrowing, or the scheme made self-financing), would undoubtedly come under the same political pressure. It was a defeat, in the face of popular opinion, both for Ballance and the left wing of the party he represented.

Closer settlement remained a major objective of the Liberal Government; only now there was no question that the leasehold and nationalisation be considered essential to it. The land was being subdivided without nationaisation, encouraged by, amongst other things, the 1 and tax. 


\title{
CHAPTER ONE
}

\section{From Belfast to Birmingham}

\begin{abstract}
While in religious devotion the people of Glenavy will never be accused of wasting their powers of soul in barren ecstasies, they are most reverential, and the fear of God exercises over them a healthy influence. There is almost an entire absence of the superstitious; fairies are never seen, the banshee never cries, and not a house is said to be haunted. 1
\end{abstract}

1. Charles Watson, The Story of the United Parishes of Glenavy, Camlin, and Tullyrusk, Belfast, 1892, p. 20. 
The parish of Glenavy lies on the eastern shore of Lough Neagh, in the north of Ireland, and to the west of the Lagan Valley. The gently undulating landscape on the edge of the Antrim plateau is occasionally accentuated by a small hill or a mound, the result of glacial activity or the creation of a Celtic past. Much evidence of early settlement has now disappeared- including the ancient cemetery at Pitmave called the Giant's Grave- though Crew Hill, upon which the Kings of Ulidia were crowned, still stands. ${ }^{2}$

The Ballances came to Ireland in the wake of Cromwell's rule. ${ }^{3}$ They were of English puritan stock, rather than of the more populous Scottish Presbyterians who dominated the counties of Down and Antrim. ${ }^{4}$ The Reverend Andrew Stewart, minister of the north Down coastal village of Donaghadee from 1645 to 1671, described the new settlers, not entirely unjustly, as follows:

And from Scotland came many, and from England not a few, yet all of them generally the scum of both nations, who, for debt, or breaking and fleeing from justice, or seeking shelter, came hither, hoping to be without fear of man's justice in a land where there was nothing, or but little, as yet, of the fear of God. 5

2. The parish takes its name from one Daniel, called Nanus Angelus ('Angelic Dwarf'), who was put in charge of the church by its founder, St. Patrick. Thus 'Church of the Dwarf' becomes Llan Abhaich in celtic (Llan meaning church and Abaich, pronounced avay, for dwarf); hence Glenavy. See Watson, p. 9.

3. Sir Robert Stout, 'Character Sketch: The Hon. John Ballance', Review of Reviews for Australasia, May 1893, p. 107.

4. See J.C. Beckett, The Making of Modern Ireland, 1603-1923, London, 1981 (2nd edn.), ch. 5, and T.C. Barnard, Cromwellian Ireland: English Government and Reform in Ireland, 1649-1660, London, 1975,

5. Quoted by A.T.Q. Stewart, The Narrow Ground. Aspects of Ulster, 1609-1969, London, 1977 , p. 81 . 
Settling initially in Lurgan, at the south-east corner of Lough Neagh, the Ballances later moved to Ballypitmave, less than two miles from the village of Glenavy. ${ }^{6}$ This corner of County Antrim was one of only two regions in east Ulster where Anglicans remained dominant and English settlement survived the Presbyterian influx. 'Its village structure dating back to the early seventeenth century, a testimony to landlord sponsorship, was unparalleled in the rest of Ulster'. 7 The land about Glenavy, originally part of the considerable possessions of the O'Neils, was taken by the English in the early seventeenth century, passing to Sir Fulke Conway (who introduced English and Welsh settlers) and in 1683 to the Hertford family, being handed down until the death of the fourth Marquis of Hertford in $1870 .^{8}$

Originally covered with forest, the land was gradually cleared, the slowly expanding population dependent entirely upon farming for its livelihood. John Ballance, the future Premier's grandfather, was a tenant on the Hertford estate at Ballypitmave, a townland to the east of Glenavy village. Sandwiched between the United Armies of Antrim and Down in the Rebellion of 1798, he had been wounded in the village, almost certainly as an Orangeman recruited to the Yeomanry by the English authorities. ${ }^{9}$ The area suffered considerably from the Rebellion, and declined for a time thereafter, reviving only with the

6. Correspondence of 26 May 1976, in the Ulster Historical Foundation's 'Ballance' file, relating to the birthplace of John Ballance.

7. L.M. Cullen, The Emergence of Modern Ireland, 1600-1900, London, 1981, p. 56.

8. Watson, pp. 11-14.

9. Stout, p. 107; Thomas Pakenham, The Year of Liberty, London, 1969, pp. 215-31; H. Senior, Orangeism in Ireland and Britain, 1795-1836,
London, 1966, ch. IV. 
erection of a cotton mill, a flour mill and a 'bleach green'.10 Along with weaving and agriculture, these were the sole industries upon which the area's prosperity rested. ${ }^{11}$ John Ballance's son, Samuel, took to tenant farming like his father. He remained at Ballypitmave, where by 1835 the Ballances lived in fairly cramped conditions and farmed generally poor soil. John had recently died, and the valuer at the time noted that with two dwelling houses the family now had more accommodation than was necessary, recommending that a quarter of it be taken away from them. ${ }^{12}$ The Ballance's holding consisted of around twenty-seven acres of third class, and an acre of fourth class, land, held in three separate lots. ${ }^{13}$

Tenants were more secure in the north-east of Ireland than elsewhere. The eighteenth century 'Ulster Custom', whereby a tenant had a right of occupancy subject to an agreed rent (though leases themselves explicitly limited the length of tenure) had become by the first half of the nineteenth century a more secure 'tenant right': a right of occupancy with leasing largely abandoned, compensation for improvements and, subject to the landlord's approval, the right to sell a holding to the highest bidder. ${ }^{14}$ Thus though the land was not of high quality, it offered some security. Further, the farmers of Antrim and Down were, generally speaking, more prosperous than their counterparts in the rest of Ireland (though still poor by contemporary

10. Bleach greens, required for part of the process of producing linen, were frequently leased by landlords on favourable terms in order to encourage the growing 'cottage' industry.

11. Watson, pp. 11-14.

12. Glenavy Townland Valuation, $4 \mathrm{Feb} .1835,1 \mathrm{~B} / 171$ in Public Records
Office, Belfast.

13. Tithe Applotment Book, Glenavy, 1834, 5A/147 in Public Records Office,
Belfast. 14. Beckett, pp. 179-82. 
English standards). ${ }^{15}$

Samuel Ballance was a wel1-known local figure. An Orangeman, ${ }^{16}$ a conservative in politics and with 'strict evangelical tendencies', he followed his family tradition of adherence to the Anglican Church. ${ }^{17}$ He married Mary McNiece, who came from a family once prosperous enough to purchase the twenty-three acre Ram's Island, off the Glenavy shore in Lough Neagh, for one hundred guineas. ${ }^{18}$ She was a Quaker, in practice associating with the Methodists and Moravians in Glenavy. ${ }^{19}$ Her religion was more liberal, and less 'outwardly enthusiastic', than that of her husband, though as was commonly the case, compromise was easily reached by attending the Parish Service in the morning and Chapel at $5.00 \mathrm{p} . \mathrm{m}$. in the afternoon. 20

Samuel and Mary's first child, a boy named John after his grandfather, was born at Ballypitmave on 27 March 1839. The house he grew up in still stands, within sight of the lough; a two-storey building with a slate roof, though now in a state of considerable disrepair. When John lived there it had a thatched roof, white mortar walls, tiny windows, and a huge open hearth. ${ }^{21}$

15. Useful background information on landlords and villages in this period can be found in Cullen, chs. 3 \& 4 .

16. A protestant political organisation established in 1795 amongst the peasantry, whose tradition came to give 'a kind of moral sanction to the subjugation of catholics', and which was utilised at various times by the English authorities for this purpose. See Senior, ch. 1.

17. Stout, p. 114 .

18. Her uncle, Conway McNiece, bought it from an old fisherman in 1804 . Watson, p. 57.

19. At this time there was no Quaker community itself in Glenavy. The Primitive Methodists were a significant minority, their preachinghouse dating from 1826. The Moravian conversions of John Cennick (he was initially a Methodist) from 1750 onwards, had established a following that, however, collapsed quite suddenly after a period of early rapid growth. Watson, pp. 38 \& 44.

20. E.P. Thompson, The Making of the English Working Class, London, 1980, ch. 2, gives a useful account of the English dissenting tradition.

21. Belfast Telegraph, 5 Aug. 1947. 
He was the eldest of a family of at least five. Both of his brothers became tenant farmers like their father. Henry succeeded to the property of his grand-uncle, Conway McNiece, at Crew Mount, which, along with a marriage to the daughter of James Smith, agent for the Hertford Estate, and undoubted ability, enabled him to rise to the position of Magistrate and Chairman of the Lisburn Rural District Council. $^{22}$ He was, again like his father before him, an Orangeman, and was to take a leading role in the building of a new hall and lecture-room at the Crew. ${ }^{23}$ Samuel, the other brother, remained at Ballypitmave, in the house that became known as 'Lakeview'. Jane, his sister, was born in February 1841, and married a John McKnight at Magheragal1 Presbyterian Church in September 1862. Their son Robert, was to follow John out to New Zealand, largely in consequence of unhappy relations with his step-mother, his father re-marrying shortly after the death of Jane in $1880 .^{24}$ There was also a second sister, named Anna.

John grew up in a family and culture of tenant farmers whose greater security and relative prosperity placed them at a distance from the majority of Irish peasantry, though still a considerable way from yeoman status. Before he was ten years old, however, the famine struck. Though the diet of Ulster farming families was more varied than is commonly believed, ${ }^{25}$ and despite the fact that the famine was

22. Details of the family given here are from the 'Ballance' file, Ulster Historical Foundation. Henry had two sons, 'one died a Capt in the army, and the other was mentally weak, as would also the past and present generation appear to be'.

23. Watson, pp. 18-19.

24. Details of the McKnight side of the Ballance are taken from a family bible in the possession of Ms Shirley McKnight of Ohingaiti.

25. See Cullen, ch. 7 . 
most severe in the south-west of Ireland, with Antrim and Down amongst the least affected counties, nevertheless the impact of repeated failures of the potato crop between 1845 and 1848 on the population of the two eastern counties was of major significance. 26 The young Ballance would have known of the starvation and evictions, even if he did not witness them for himself. And though the political repercussions of the famine, in terms of rising Irish nationalism focusing on land tenure, were felt only with time, the 'Hungry Forties' undoubtedly formed an important background to the development of Ballance's political beliefs. The evils of landlordism, with its ally the established church, were to be at the core of his political 'crusade' in his adopted country, New Zealand. 27

John attended the local National School, from which, despite being required to contribute to the work of the farm, he was rarely absent. His reputation for laziness arose from a dislike of farm work and a remarkable propensity, from an early age, to do nothing a11 day but read. 28 Leaving home in 1853, at the age of fourteen, he continued his education for a while at Belfast Model School, a move facilitated by the assistance of his uncle, Robert McNiece, who lived in Belfast at that time. ${ }^{29}$ Shortly afterwards he was apprenticed to an ironmonger (that is, a seller of 'hardware'), and remained in that position until he left Ireland in 1857.

26. On the famine see the classic work by Cecil Woodham-Smith, The Great Hunger, London, 1962. The province of Ulster lost $1 \overline{6 \%}$ of its population. This includes Donegal, which was particularly badly hit, and the loss for Antrim and Down would be considerably less.

27. Much the same could be said of another future New Zealand Premier, Sir George Grey.

28. See G.S. Maloney, 'A History of the Ballance Ministry', M.A. thesis, Canterbury, 1931. Maloney says that this was confirmed by E1len Ballance and Robert McKnight (Ballance's second wife and nephew respectively).

29. J.L. Dighton, 'The Life and Work of John Ballance', M.A. thesis, Victoria University of Wellington, 1929, p. 2; Watson, p. 20. 
Belfast was within easy reach of home, and Ballance's parents continued to influence his development. From an early age he showed an interest in, and knowledge of, political affairs. His father was directly involved in local politics, and often proposed the nomination of Conservative candidates for Belfast. By the age of sixteen John was helping him write his speeches. ${ }^{30}$ Yet if it was his father who brought John, at an early age, into contact with political life, it was his mother's influence which helped shape the direction of his own political. career. Considerably more liberal than her husband, she took, in Ballance's own words, 'an all-absorbing interest' in political affairs, ${ }^{31}$ and it was from her (she was practically a unitarian) that he took a dissenting belief that was to culminate in agnosticism and freethought.

He was to reject the Orangeism of his father and brother, and indeed all forms of political, religious and cultural sectarianism. Orangeism was for him an anachronism, engendering a bitterness and violence that could only alienate the catholic minority and be inherently damaging to the protestant faith. ${ }^{32}$ His acknowledgement of the diversity of the Ulster 'race' was a part of this, as well as being, even in the north-eastern counties, historically accurate. 33 'The men of Ulster, to their glory be it said', he wrote later,

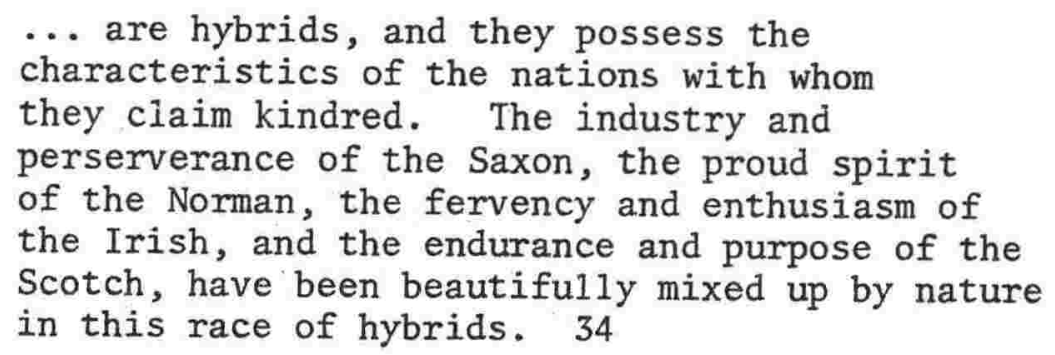

30. Stout, p. 114; Y , 6 May 1893; Wanganui Herald, 3 June 1967.

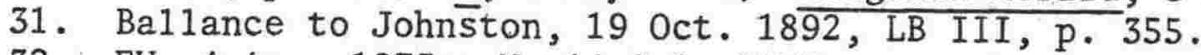

32. EH, 4 Apr. 1873; Y, 14 July 1877.

33. See Stewart, p. 41 .

34. EH, 21 Oct. 1869. 
The journey to Belfast was common to many sons of tenant farmers throughout the region. The population of Glenavy gradually declined throughout the century, being drained by job opportunities in Belfast and the lure of emigration overseas. The province had a tradition of emigration, 12,000 a year going to North America by the early 1770s, for example. Higher rents and a declining cotton and linen industry contributed to the exodus, which had at least one beneficial effect in reducing the pressure on land. ${ }^{35}$ It was, perhaps, because the more prosperous Ulster tenants could finance the trip, that they departed in such large numbers. When John arrived in Belfast it was booming, its population increasing by nearly 40 per cent between 1851 and $1861 .^{36}$ A local newspaper, in the year of his arrival, was jubilantly immodest:

... this great emporium of trade, manufacturing and commerce now exciting the attention and claiming the admiration of every community whose good example we have been following, and of every community to which, in our turn, we present a model of imitation. 37

Increasing prosperity was based on a rapid expansion of the linen industry, made possible by the new technology of power looms, and shipbuilding, now on the eve of a great expansion.

It was also an 'Age of Riots', though the town had already shown a propensity in this direction as early as $1813^{38}$ John witnessed a succession of sectarian riots that culminated in 1857 , when

35. Beckett, pp. 181, $206 \& 207$.

36. I. Budge \& C. O'Leary, Belfast: Approach to Crisis. A Study of

37. Belfast Politics, 1613-1970, London, 1973, p. 28.

37. Ibid., p. 73 .

38. Ibid., ch. 3. 
inflamatory anti-catholic preaching of the Reverend Thomas Drew invited a particularly serious series of clashes lasting between 12 July and 6 September. The protagonists were 'ably' fuelled by the Orange Order, and another anti-catholic preacher, the Reverend Hugh Hanna. 'Three hundred ship's carpenters, protestant to a man' joined in the fight. 39 Looking back, Ballance wrote later:

\begin{abstract}
Much bloodshed was caused by street preaching, and though the offensive practice of shouting on a highway that all papists were on the broad road to destruction was naturally objected to by those who were said to be doomed, the practice was persisted in even after it was found that riot had ensued. One character, 'Roaring Hanna', the pastor of a Presbyterian Church, obtained much notoriety by his open air effusions in critical times, and found immortality in Punch. "Allow", said this divine on one occasion vividly [remembered] ..." "a small passage for the papists to pass along, and it shall be known hereafter as the Pope's Pad!".
\end{abstract}

Contrasting the rising prosperity of Belfast at that time with continued rioting, he concluded:

The truth is that the Protestants of the North have long considered themselves the dominant class and cannot to this day tolerate the religious or political equality of the Catholics. The remembrance of the days of the yeoman and the rebellion of 1798 are still faithfully preserved, and Protestant ascendancy is still a principle and a sentiment in the breasts of the descendants of those who put it in practice in many questionable ways. 40

Soon after this rioting, in the autumn of 1857, Ballance left for Birmingham. On leaving Belfast, his attitude to the 'Irish question' 
would have already been at some variance with the majority of protestant opinion. The influence of his mother, and a sensitive nature, account at least in part for this. With absence, and over time, his position 'hardened'. Initially he saw agrarian discontent, in the form of poverty and misery, as the basis of dissatisfaction, and its removal the only means of restoring loyalty to the English Crown. 41 Later he would advocate Home Rule, arguing that Ulster protestants were by no means solidly against the idea and pointing to their leadership of the rebellions against the English in 1782 and 1798. In 1881 he moved a resolution, at a 'monster' meeting in Wellington, in support of the Irish National Land League, and in sympathy with evicted tenants, the victims of 'misgovernment, persecution, and tyranny'. ${ }^{2}$ The Irish Church and the land laws, he wrote in the Herald, were 'the foremost evils to be grappled with' in Ireland. ${ }^{43}$ And Ulster had 'suffered just as much from landlord tyranny and from castle government as any part of Ireland'. 44

These views were also to differ from another Ulsterman with a political future in New Zealand. William Massey, from County Londonderry in the north-west of the province, was to arrive in New Zealand with his father only five years after Ballance. His background was, significantly, Scottish Presbyterian rather than English dissenting. Massey

41. See EH, 6 Sept. 1867,6 Jan. 1868.

42. EP, 2 Aug. 1881. See also Ballance's speech at The Home Rule meeting held during Dillon's visit to New Zealand in 1889, New Zealand Tablet, 29 Nov. 1889.

43. $\overline{\mathrm{EH}}, 30 \mathrm{Jan} .1868$.

44. $\bar{Y}, 30$ Mar. 1889. See also, e.g., Y, 16 Feb. 1889, 16 Nov. 1889; Ballance to J.A. Tole, 29 Aug. 1892, LB III, p. 306. 
... judged moral issues in public life in the light of a simple but sometimes narrow faith, and his instinct was to see political opinions and the men who held them in an Irish manner, if not through Irish spectacles. Either they were 'sound', or they were not. 45

Though this would be characteristic of many Ulstermen (rather than Irishmen), it was certainly not so of the young John Ballance. He left Ireland with a, perhaps remarkable, lack of sectarian feeling. His experiences of sectarian warfare fuelled an increasing religious scepticism, which in turn placed his view of the Irish situation well outside that of the majority of Ulster protestants.

By the end of $1857 \mathrm{John}$ had migrated to Birmingham, where he got a job, most likely through connections of his Belfast employers, with a large hardware firm. This involved a considerable amount of travelling throughout the region. ${ }^{46}$ As a commercial traveller, the pressure for sales was always present. His employers, McLennan Brothers, were a firm who, Ballance later wrote, 'thought of nothing but making money'. 47

45. W.J. Gardner, 'The Rise of W.F. Massey, 1891-1912', Political Science, 15, 1 (1961), p. 6. Gardner's argument that the differences between tenant-farming in Londonderry and in Mayo account for Massey's slogan reading 'every man his own landlord' rather than 'burst up the big estates', is difficult to sustain when Ballance's similar background is considered. As an Ulster protestant Ballance's position was certainly the exception rather than the rule, but the relationship between the type of farming background and attitudes to land-holding in New Zealand is clearly much more complex.

46. Y, 6 May 1893.

47. Ballance to Mason, 8 June 1892 , LB III, p. 75. 
Birmingham in 1857 was quite different to his native Belfast. It had a history of popular radicalism based on middle-class leadership; the Birmingham Political Union, formed by Thomas Attwood, figured largely in the agitation for reform in 1832, and soon. afterwards promoted a national petition which marked the beginnings of the Chartist Movement. 48 In the year of Ballance's arrival, John Bright switched his parliamentary constituency from Manchester to Birmingham, opening his election address with a recognition that he had come to a city with an already established radical tradition. ${ }^{49}$

Whereas Belfast was expanding on the basis of heavy industry and large scale enterprise, Birmingham's growth depended upon finished metal goods produced in smaIl workshops. Originally a small market town, Birmingham by the 1850 s was servicing the whole Midlands area and beyond:

\footnotetext{
'Made in Birmingham' was the characteristic mark on ironmongery, household goods, ornaments, jewellery, buttons, trinkets and general bric-à-brac which littered Victorian homes... . It also contributed materials more basic to Britain's industrial pre-eminencenails, screws, staple items in railway construction, and a small-arms trade which flourished in an era of colonial expansion and European insecurity. More civilised needs were catered for by the Cadbury family's flourishing chocolate business. 50
}

The smaller scale of enterprise engendered close contact between employer and employed. Trade unionism was weak. Expansion took the

48. G. Kitson Clark, The Making of Victorian England, London, 1962, p. 125. 49. See Asa Briggs, Victorian Cities, London, 1963, ch. V. 50. Richard Jay, Joseph Chamberlain. A Political Study, Oxford, 1981, p.5. 
form of increased numbers and diversity of small units, where relatively well-off skilled artisans worked alongside 'masters' and interdependence was emphasised by both. Thus in Birmingham, comments Cobden, industry

... is carried on by small manufacturers
employing a few men and boys each, sometimes
only an apprentice or two; whilst the great
capitalists in Manchester form an aristocracy,
individual members of which wield an influence
over sometimes two thousand persons. The
former state of society is more natural and
healthy in a moral and political sense. There
is freer intercourse between all classes than
in the Lancashire town, where a great and
impassible gulf separates the workman from his
employer. The great capitalist class formed
an excellent basis for the Anti-Corn-Law
movement, for they had inexhaustible purses,
which they opened freely in a contest where
not only their pecuniary interests but their
pride as 'an order' was at stake. But I very
much doubt whether such a state of society is
favourable to a democratic political movement.

Part of Birmingham's 'greater democracy' was the considerable social mobility and opportunity for self-improvement that arose primarily from the presence of small-scale enterprise. As a London journalist found in the early 1850s, 'household' trades existed that 'gave the inmates independence, and often led- if the trade continued goodto competence or fortune'. 52

Political activity at the time was still governed by the fundamental influences of the earlier campaigns for political reform and the repeal of the corn laws. Though repeal was granted in 1846 ,

51. J. Morley, The Life of Richard Cobden, vol. 2, London, 1882, pp. 199-200.

52. Quoted by Briggs, p. 191. 
Bright, Cobden and their followers maintained a radical popular movement that was, especially with the revival of the protectionists in 1852 and the campaign for the repeal of the Navigation Acts (1854), still substantially intact.

Based on the philosophical writings of the Manchester School of economists, the free trade movement consisted of a broad and at times uneasy, alliance. The advantages of free trade had seemed obvious to all but the landowners and the Tory Party. For businessmen. it would reduce wages and therefore costs, while increasing demand and generally boosting industrial development. For the radicals the possibility of a redistribution of political power was equally important; and the attraction of working class support was based not simply on the desire for cheaper food, but in the hope that free trade would increase the political power of the lower middle class, and through pressure for extensions of the franchise, that of the working class itself. Free trade achieved legitimacy through the new economic science, popularised for political purposes:

There probably never was an age when economics was as popular, when its ideas and language informed so large a part of the public, from the poor who were aroused by the injustice of the 'bread' tax to the aristocracy which smarted under the label of monopolist. 53

Yet already by the 1850 s, some liberals were questioning the realities of a growing economy based on laissez-faire. In particular many saw the threat of capitalist monopoly and adopted a (perhaps

53. W.D. Grampp, The Manchester School of Economics, Stanford, 1960, pp. $80-81$. 
rather romantic) preference for 'healthy' small-scale manufacturing. For these liberals, who included Cobden, Birmingham was much closer to an ideal form of society than, say, Manchester. Thus though laissez-faire was in large part accepted, it was not denied that under that system economic development could take unpleasant and uncomfortable forms. As we shall soon see, making it more acceptable was seen in Birmingham to be the role of local rather than central government.

Concomitant with artisan independence and political radicalism was a tradition in Birmingham of religious dissent:

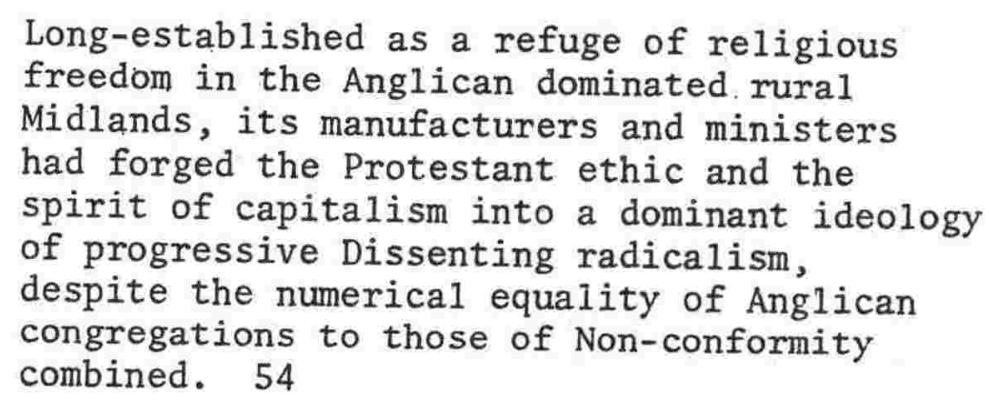

Both liberals and nonconformist ministers espoused a 'civic gospel' that emphasised the practical role of local government in improving the town and people. Sustained by individuals such as George Dawson, H.W. Crosskey and Joseph Sturge, the 'crusade' for improvements, particularly in public health and education, culminated in a 'civic renaissance' and the mayoralty of Joseph Chamberlain in the 1870 s. 55

54. Jay, p. 7. See also Conrad Gill, History of Birmingham, vol. 1, London, 1952, pp. 374-80; Briggs, pp. 203-07.

55. See Gill, chs. XVII \& XVIII. 
In $1863 \mathrm{John}$, at the age of twenty-four, married Fanny Taylor, four years his junior. ${ }^{56}$ Living in Pershore Road, ${ }^{57}$ working and traveliing during the day, he spent most of his spare time in furthering his education. He joined the Midland Institute (opened in 1857) studying at night history, biography and modern politics. 58 These evening classes comprised of a mixture of schoolboys and craftsmen. 59

Birmingham's Midland Institute was an integral part of a mid-Victorian culture of self-improvement. Similar Mechanics Institutes had been established elsewhere by Henry Brougham, and were 'in the vanguard of the utilitarian effort to enlighten the working classes'. ${ }^{60}$ Self Help, the title of the influential book by Samuel Smiles (published in 1859), was a central theme, emphasising industry, thrift, orderliness and the ultimate goal of upward social mobility. It had its roots in the earlier Chartist and Co-operative movements, and in religious dissent (especially Methodism). Though institutions such as the Mechanics Institutes can be seen as a means of indoctrinating the working classes with the social philosophy of the middle classes, popular education was 'a vital article of faith' in the radical creed:

56. Lyndall Greig, 'Wives of the Prime Ministers of New Zealand', Alexander Turnbull Library.

57. Information supplied to the writer by P. Baird, from directory entries in the Birmingham City Library.

58. Y, 23 July 1892 .

59. See Gill, p. 435.

60. Trygve Tholfsen, Working Class Radicalism in Mid-Victorian England, London, 1976, p. 130. On adult education in England see J.F.C. Harrison, Learning and Living, 1790-1960, London, 1961. 
An educated populace knowing its rights would resist oppression; the spread of knowledge would lead inexorably to progress. The radicals envisaged a society in which educational opportunities would no longer be restricted to the propertied classes. They had in mind a real education, not charity-school training in deference; nor were they willing to accept middle-class indoctrination in political economy. 61

So Ballance joined the ranks of many young men bent on a 'moral and intellectual' development that would form the basis for social and economic improvement. He was 'all for books'. ${ }^{62}$ He joined a debating society, became secretary of a Birmingham literary society, played chess and wrote articles for the local newspapers. ${ }^{63}$ He attended lectures and meetings of wel1-known figures, Faraday, ${ }^{64}$ Bright, Philip Muntz and Chamberlain. It was part of an all-encompassing religion of improvement and self-help. Mechanics Institutes aimed not only at providing information, but were intended a1so to 'form the character, to enlighten the mind, to soften the manners, to refine the taste, to enlarge the views, and to improve and civilise the whole man'. ${ }^{6}$ Physical activity was not neglected. Ballance learned to box, sparring with a friend, W.M. Charles, who later became a successful businessman. ${ }^{66}$

By 1865 the Ballances had resolved to emigrate. Fanny's failing health was a major factor in this decision, and as she had a brother,

61. Tholfsen, p. 64 .

62. A. Charles to Ballance, 1 Dec. 1891, BMSS, 407-08.

63. Stout, p. 107; Y, 23 July 1892; Dighton, p. 3 .

64. EH, 11 Nov. 1867. Ballance here mentions a Royal Institution Lecture given by Faraday in 1861 .

65. Tholfsen, p. 132 .

66. A. Charles to Ballance, 1 Dec. 1891, BMSS, 407-08; W.M. Charles to Ballance, 10 Aug. 1891, BMSS, 252. See also G. Scholefield, Dictionary of New Zealand Biography, vol. 1, Wellington, 1940, p. 32. 
H.S. Taylor, living in Wanganui, New Zealand was a sensible choice. ${ }^{67}$ Undoubtedly Ballance also believed that his prospects would be greater in the 'new land' than in Birmingham. It seems that towards the end of his time in England, he gave up his job as commercial traveller, to go into business for himself. He formed a partnership with a friend, but the venture was not a success, being dissolved owing to 'personal antagonism arising from different aims and opinions '. 68

There was some talk of taking up sheep farming in the new country, but lack of sufficient funds quickly ruled this out. ${ }^{69}$

- The couple left for Australia via the Cape in early 1866, having paid their own passages, but with few belongings and little capital behind them.

67. Y, 6 May 1893.

68. $\overline{\mathrm{N} Z H}, 5$ Aug. 1878, 'Biographical Sketch'.

69. $\overline{\mathrm{See}}$, e.g., Y, 23 July 1892 . 
CHAPTER TWO

Wanganui and War: frontier politics and insecurity 
John and Fanny reached Melbourne in July 1866, where they bought some jewellery with the intention of re-selling it at a profit in New Zealand. ${ }^{1}$ From Melbourne the Ballances travelled in the Albion (the 'crack ship' of the intercolonial service, running between Wellington and Melbourne by way of Hokitika and Nelson) to Wellington, arriving in the afternoon of 11 August. As they had light winds and fine weather, this seems to have been a pleasant final stage of their long journey from England. ${ }^{2}$ Captain Kidney of the Albion later recalled his impressions of the young Ballance on board his ship:

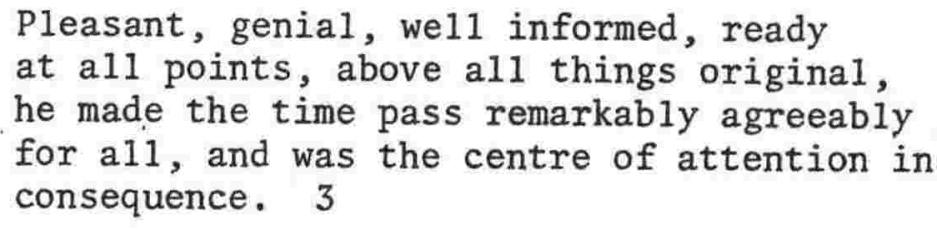

After a stay of only a few days in Wellington, the Ballances travelled on up the coast, arriving at their destination, Wanganui, on 18 August. 4

Wanganui in 1866 was a small town of about two thousand inhabitants. 5 It has been established as a New Zealand Company settlement. Land on the northern bank of the Wanganui River, four and a half miles from its mouth, having been purchased by Gibbon Wakefield's energetic son, Edward Jerningham, in 1840 , the first settlers arrived early the following

1. The jewellery included watches, rings and earrings. See WC, 19 Sept. 1866.

2. New Zealand Advertiser, 13 Aug. 1866.

3. NZT, 28 Apr. 1893.

4. $\overline{W C}, 22$ Aug. 1866.

5. The 1868 census gives the population of Wanganui as 2157 (of which 1226 were male), almost exactly the same as that of New Plymouth, New Zealand Census, 1868, table 3. 
year. 6 Yet though it was a Company settlement, it was not 'planned' to the same extent as, say, Wellington. Indeed it is more accurate to view Wanganui as a necessary offshoot of Wellington, being settled by those who, after their arrival in New Zealand, found themselves unable to purchase land in the disappointingly limited environs of Port Nicholson.

Wanganui (originally Petre) was chosen for this 'extension' because its hinterland was relatively flat and easily cleared, and because its river-mouth provided a safe anchorage. Trade was vital, and before the development of iand communications, it had to be by sea. ${ }^{7}$

It is tempting, with hindsight, to view the development and expansion of a town like Wanganui as inevitable, if at times erratic and uneven. In fact, not only the continued growth, but the very survival, of Wanganui, was for a while in doubt. Even once firmly established, by the early 1860s, its position remained fragile; its people and politicians were continually faced with the problem of insecurity and its underlying causes.

6. Wakefield junior himself took up residence, building one of the first 'houses' and trading with Maoris in pigs for the Wellington market in exchange for goods from his 'shop'. He provides one of the earliest recorded views of the Wanganui region in his two volume Adventure in New Zealand, published a year after his return to England in 1844. Ecqually informative are the writings of Reverend Richard Taylor, who, with his wife and family, arrived in April 1843 as resident Anglican missionary. See Rev. R. Taylor, Te Ika a Maui- New Zealand and its inhabitants, Wellington, 1974 facsimile. See also T.W. Downes, 01d Whanganui, Hawera, 1915.

7. See L.L. Pownall, 'The Origins of Towns in New Zealand', New Zealand Geographer, XII (1956), pp. 173-88. 
Initially the economy of the settlement was simple: ${ }^{8}$ exporting timber, pigs and potatoes purchased from local Maoris; ${ }^{9}$ importing manufactured goods and provisions. This was no basis for long term survival. Any degree of permanency necessitated the development of the immediate hinterland, and this was delayed by doubts over the original purchase of the land, and by the resulting skirmishes between settlers and Maoris. Some settlers left, an exodus halted only when Donald McLean, the Native Commissioner, 'repurchased' the land on behalf of the Government in 1848. By the 1850 s wheat, flour and wool were being exported to the Wellington market. ${ }^{10}$ In 1861 the first shipment of meat left for Auckland. ${ }^{11}$ Competition from Canterbury wheat, the nature of the land, and a new market for meat arising from the West Coast gold rushes, all contributed to an increasing concentration by local settlers on pastoral rather than arable farming.

Though attracting new settlers was seen as important to the town's development, more immediate was the problem of expanding the local economy rapidly enough to keep pace with a naturally increasing population. 12 Expansion was dependent upon developing the port and

8. On background to the following discussion see L.J.B. Chapple \& H.C. Veitch, Wanganui, Hawera, 1939, chs. 8, 9 \& 10; M.J.G. Smart \& A.P. Bates, The Wanganui Story, Wanganui, 1972, chs. $3,5 \& 7$; B.G.R. Saunders (ed.), Introducing Wanganui, Palmerston North, 1968.

9. 'The Natives had pigs ... such pigs! High in the bone and low in the flesh, as they were generally described; otherwise known as regular Captain Cooks'. C. Burnett quoted in Interesting Chapters from the Early History of Wanganui, a pamphlet published by Willis in Wanganui, 1887.

10. Out of total exports of $\$ 4005$ in $1856,31 \%$, by value, were wool, $22 \%$ wheat and $17 \%$ potatoes. Calculated from New Zealand Statistics, 1856 , table 27 .

11. See S.M. King, 'The Port of Wanganui and its Influence on Wanganui', M.A. thesis, Victoria University of Wellington, 1964, p. 7 .

12. That is, apart from immigration, population was increasing rapidly owing to the high proportion of young people: $58 \%$ of the population was under 21 years of age in 1861: calculated from New Zealand Census, 1861, table 4 . 
the land, and there were problems with both. A natural bar across the river mouth limited the size of ship that could enter the harbour, and presented difficulties to those that did. ${ }^{13}$ Secondly, though the area immediately alongside the banks of the river was flat, the hinterland further out was hilly and suitable only for grazing. Wanganui's future rested upon its ability to act as a supplier to, and exporter for, new farming communities to be established on the undeveloped flatter and richer land beyond: north towards the Waingongoro and south into the Rangitikei and Manawatu. Communications into these areas were vital to open up the land for settlement, and enable Wanganui to extract its share of trade.

Viewing development in terms of barriers to be overcome, was part of a general feeling of insecurity reinforced by the conflicting relationship between Wanganui and Wellington. Merchants such as the firm of T.B. Taylor and W.H. Watt, assisted by a growing local shipbuilding industry, were soon monopolising the wanganui trade that would otherwise have gone to Wellington. Once the town was made a Port of Entry in 1855, custom duties could be collected at Wanganui, where they had previously been imposed in Wellington. ${ }^{14}$ Ultimately however, it was Wanganui that saw itself threatened by the centralisation of political and economic power in Wellington, and felt insecure about its own ability to determine its future.

13. The bar formed in the still water where the outflowing river met the incoming wave motion of the sea.

14. King, p. 6 . 


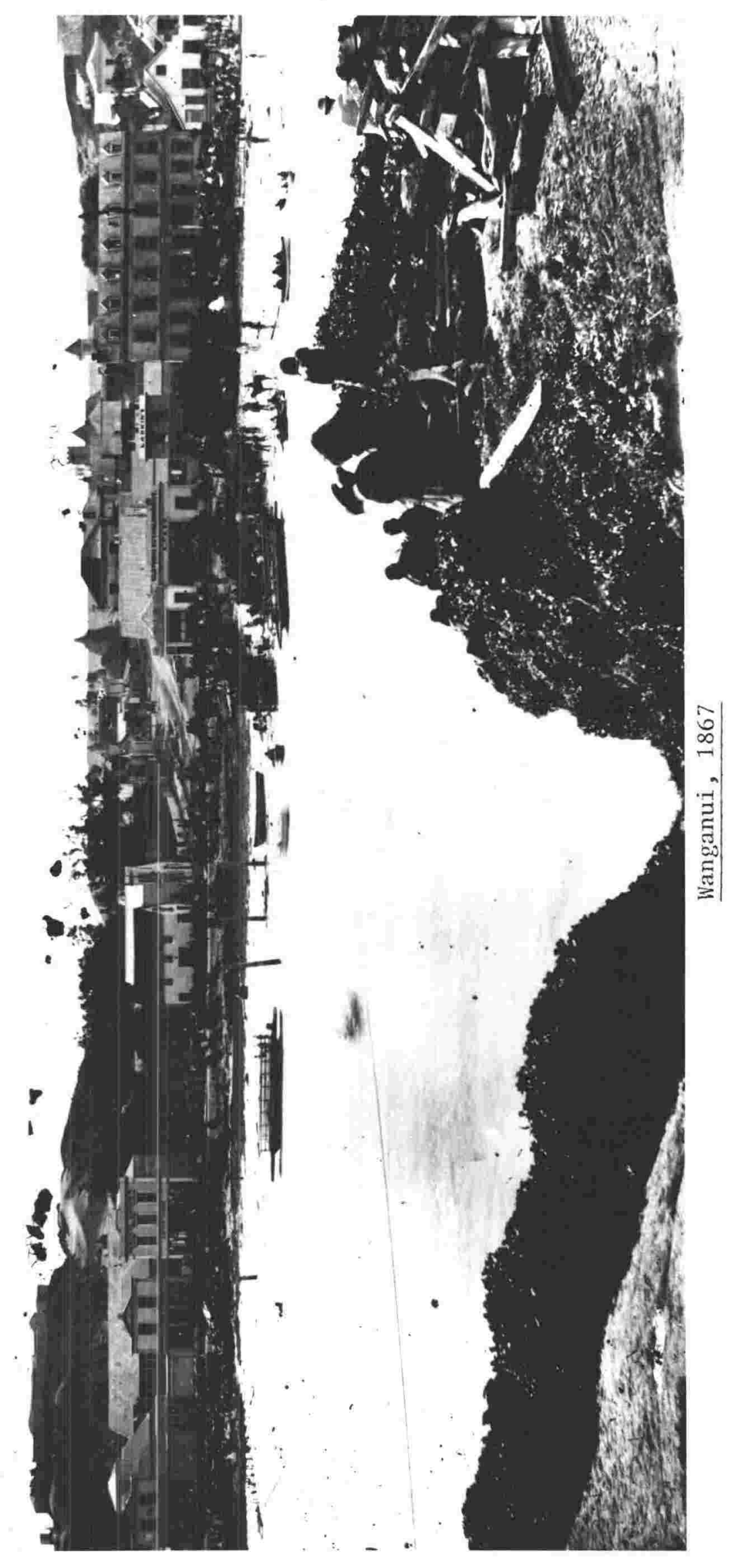


In the 1860 s Wanganui was still very much a frontier town, and had an attendant reputation for rowdiness and drinking. 15 The settlement was concentrated in a hollow between two hills, ${ }^{16}$ upon which Governor Grey had built the Rutland and York stockades, and through which Victoria Avenue ran towards the river. A gravel road ran in the opposite direction to St. John's Wood, other streets consisting of sand and swamp. There were a considerable number of hotels and breweries, which, along with shops, offices and a few private residences, made up the nucleus of the town at the lower end of Victoria Avenue and along Ridgeway Street and Taupo Quay. ${ }^{17}$ There were also four churches, one each for the Anglicans, Presbyterians, Roman Catholics and Methodists. ${ }^{18}$

Taupo Quay (known more accurately as 'The Beach'), running alongside the northern bank of the river, was the centre of commercial activity in the town, and it was here Ballance established a jeweller's

15. Tobacco, beer, spirits and wine accounted for $28 \%$ by value of Wanganui's imports in 1856, and $15 \%$ in 1860 . Calculated from New Zealand Statistics, 1856, table 26; 1866, table 18. At a temperance meeting in 1867 a speaker was reported to have declared 'that of all the places he had ever been in, Wanganui was the most drunken'. Quoted by Chapple \& Veitch, p. 113.

16. The present sites of Cook's Gardens and Queen's Park.

17. 'Hotels', often little more than public houses, included the Steam Packet, the Wanganui, the Rutland and the Exchange. See Smart \& Bates, ch. 6 .

18. A tight-rope walker, Vertelli, visited Wanganui in October 1867, and travelled across the river on the ferry wire, pushing a wheel-barrow before him. A photograph of this event, taken from the Durie Hill (south) side of the river, gives a good view of the town shortly after Ballance's arrival, (Harding-Denton Collection, Alexander Turnbull Library, Wellington). W.J. Harding, a photographer of Wanganui from 1856 to 1888 , took many interesting and valuable scenes of the town and its people. 
shop, opening for business on 19 September $1866 .^{19}$ It was not a success, quite simply because the town was too small to provide a permanent market for a limited range of goods.

Many of his Melbourne purchases remaining unsold, by December Ballance had decided to travel further afield in search of business. At that time Featherston, Superintendent of Wellington Province (of which Wanganui was a part), was engaged in the purchase of the Rangitikei-Manawatu Block. Realising that with $£ 25,000$ being handed over to the Maori owners there was a market for his wares of considerable potential, Ballance rode out to the meeting at Parewanui, and offered his goods to a number of chiefs. On showing a gold watch to Featherston, one chief was advised to return it to Ballance. It was impossible, said the Superintendent, to tell whether or not it was genuine. Walter Buller, the Resident Magistrate at Wanganui who was present at the meeting, later recalled the incident:

\footnotetext{
Presently the Native came back with a courteous note from $\mathrm{Mr}$ Ballance... protesting against this interference with legitimate business and offering to guarantee in writing the quality of any watches he might dispose of. I do not think Dr Featherston pressed his objection any further; but $\mathrm{Mr}$ Ballance shortly afterwards withdrew... and made no further attempt to do business with the Natives. 20
}

19. WC, 19 Sept. 1866. The shop was next door to Woons. Ballance advertised '... a splendid collection of Gold \& Plated Jewellery, Electro-Plate and fancy goods. Gold Watches from 6 guineas, Silver do., from 2 guineas, warranted. Gents' and Ladies' finger rings, earings, \&c., in great variety'.

20. Buller to the Editor of the Evening Post, Nov. 1892, pamphlet in the Alexander Turnbull Library. The sale is also recorded in J.G. Wilson, Early Rangitikei, Christchurch, 1914, ch. XX. 
Though Ballance had already shown himself to be determined, if courteous, he soon afterwards ceased trading altogether. The business, apart from being something of a financial failure, would never have satisfied his ambition and intellect, and it is more than likely that he never regarded it as anything more than a temporary but necessary stepping-stone to more interesting ventures.

His activities at this time were later criticised by political opponents who viewed this sort of occupation as disqualifying a person from aspiring to political office. Buller recorded the above incident in order to defend Ballance from a speech made by an ex-Governor, Lord Onslow, describing Ballance (Premier at the time) as having been 'an itinerant vendor'. Twenty years earlier, at the very start of his political career, the wellington Independent mischievously reported that it had heard that Ballance 'made his appearance in the colony as a travelling vendor of Birmingham jewellery among the Maoris'. Ballance, through the Wanganui Herald, put the record straight. At that time, he wrote, he 
and the unfortunate countries would have been left to be ruled and ruined by Foxes!

Meanwhile Ballance was making his mark on the cultural life of the community. He had soon acquired a reputation as an able formal debater with a wide-ranging knowledge, speaking at meetings of the town's Literary Society on such varied topics as 'Phrenology', 'Moses and Egypt' and the extension of the franchise. ${ }^{22}$ He became known for a 'racy and eloquent style'.23

With the failure of his jewellery business, he turned to other sources of income. One of these was writing occasional articles for the Wanganui Times, a bi-weekly newspaper established in 1865 and backed by the local merchants T.B. Taylor and W.H. Watt. ${ }^{24}$ Another was a partnership, probably with a man called Aitken, in a brewery; but this proved even more unsuccessful than his jewellery business. 25

21. EH, 25 Sept. 1872. The allusion is to Sir William Fox, a political opponent of Ballance, and one who himself had an impeccable background. Born in Durham he studied at Oxford and then became a lawyer, before emigrating to New Zealand in 1842 . 22. WC, 10, 31 Oct. 1866, 21 Nov. 1866 and $6 \mathrm{Feb} .1867$. Wanganui Times,

23. Wanganui Times, 3 May 1867, The Times reporter wrote, melodramatically, that Ballance spoke in this manner 'until he considered that he had made a sufficient breach in his opponent's battery, and then rushed to the assault with such a perfect phalanx of fact and argument as to compel any cidatel (sic) less ably defended to surrender at discretion'.

24. Y, 6 May 1893; G.H. Scholefield, Newspapers in New Zealand, Wellington, 1958 , p. 49. Articles and editorials were unsigned, and it is speculation as to which were written by Ballance. Issues of the Times for the early months of 1867 bear little of his later distinctive, proselytizing style, though an editorial on 9 April on the 'Irish Difficulty' (advocating home rule) is almost certainly

25. There is no record of this brief partnership in newspapers at the time, though shortly afterwards it is mentioned in a court case, Howe vs Aitken, involving some wine of dubious quality; EH, 4 Nov. 1867. G.H. Scholefield, A Dictionary of New Zealand Biography, 
It was at a weekly meeting of the Literary Society that Ballance met Archibald Duddingston Willis, a man who was to become one of his closest friends, as well as his business partner and political supporter. ${ }^{26}$ Willis was born in Middlesex in 1842, of English and Scottish parentage. At twelve he began working for Eyre and Spottiswoode, the Queen's Printers, and then on the death of his mother emigrated to New Zealand. Arriving penniless in Auckland (he worked his passage) in 1857, he soon left for Napier, having been offered a job as printer on a new paper to be started, the Hawkes Bay Herald. Before finally settling in Wanganui, about 1864, he worked as a compositor on the Wellington Advertiser and later the Canterbury Press, as well as spending six months on the goldfields at Gabriel's Gully. He brought a newspaper plant with him to Wanganui, intending to start a journal of his own, but sold it on being persuaded by J.U. Taylor, then editor of the Wanganui Chronicle, to work for him. 27

In early 1867 Ballance had begun to make plans to start a daily evening paper in Wanganui. There was a clear opening for such a venture. The two existing newspapers, the Wanganui Times and the

26. See Willis's reminiscences of Ballance, Y, 6 May 1893.

27. Shortly afterwards he married a Miss Dixon, daughter of a Wellington brewer (she was also sister to the wives of his old Wellington newspaper employers). See biographical sketches, Y, 17 June 1893 and Cyclopedia of New Zealand, vol. 1, Wellington, 1897, p. 1361. Willis became an important and influential person in the town in his own right. He later established and built up a very successful printing and publishing, stationery and book-selling business. He followed Ballance as Member for Wanganui in 1893. 'Daddy Willis', as he was known, had a large family (it went into double figures) that lived on the south side of the river. Amongst other publishing feats he produced the first colour lithograph in New Zealand, which was published in his New Zealand Illustrated in 1889. The writer is grateful to Judge Max Willis for his personal impressions of his grandfather. 
Wanganui Chronicle, were both morning bi-weeklies. Willis was an ideal partner. An experienced printer working for the Chronicle, ${ }^{28}$ he could provide the necessary technical expertise while Ballance wrote the editorial material. It was a partnership equally advantageous for Willis, who had, as we have just seen, originally hoped to found his own paper. Willis had been impressed by Ballance's. ' logical and clever arguments in debate, and was invariably on the same side with him'. When asked to join Ballance he readily accepted, a decision, he wrote many years later, that he never had cause to regret. ${ }^{29}$ Pooling their resources, Ballance and Willis bought a second-hand printing machine from John Martin in Wellington, ${ }^{30}$ and set it up in premises on Market Place, in the centre of town. 31

A prospectus for the Evening Herald, aimed at attracting both advertisers and subscribers, was issued early in May, ${ }^{32}$ and on Saturday 4 May the town was placarded with the announcement that publication would commence on 3 June. The Wanganui Times, unconvincingly, welcomed the new paper, on the grounds that it would assist the Times's 'advocacy of local progress', something its rival the Chronicle simply sneered at. It also, rather discreetly, mentioned that it would move to tri-weekly publication (on Tuesday, Thursday and Saturday) as from 1 June. 33 Soon after the Herald appeared, the Times

28. Now under the control of William Hutchison, who had bought Taylor out a year earlier, Scholefield, 1958, p. 47.

29. Willis said of Ballance that 'a more upright and straightforward partner no man ever had', Y, 6 May 1893.

30. Scholefield, 1958, p. 50 .

31. The Herald offices moved soon afterwards to Campbell Place, WH, 16 Nov. 1867.

32. Willis's name, as printer, did not however, as required by law, appear on the prospectus.

33. Wanganui Times, 7 May 1867. 
admitted that it had been approached by the Chronicle with the suggestion that they match up their publication days: the Times appearing on Tuesdays and Thursdays and the Chronicle on Wednesdays and Saturdays. This would have avoided the need by both to publish three times"a week, but the Times declined the offer, forcing the Chronicle into tri-weekly publication as well. ${ }^{34}$ The Herald was a considerable threat to both papers, though they reacted differently to its appearance. The Times took the opportunity to lecture the Chronicle on the proper role of the press, ${ }^{35}$ whilst the Chronicle simply ignored the Herald completely for months.

The first issue of the Evening Herald, (the second daily evening newspaper to be published in New Zealand), ${ }^{36}$ costing one penny, appeared as promised ón Monday 3 June. In his opening editorial, Ballance sought to justify the need for a third newspaper in Wanganui, and laid down the ground rules for its future policy. The discussion of political issues would be a central feature, (though he claimed that he would nevertheless be tied to no party), as would the provision of up-to-date information:

We make this our first appearance as a member of the Fourth Estate, with the strong assurance that, not only our friends, but the general public, whom we hope soon to include in the ranks of the former, will hail our

34. Wanganui Times, 13 June 1867. Six days before the Herald appeared, the Chronicle announced the change, arguing that the pressure of advertising had 'for a long time' occupied space that should have been devoted to editorial and general reading material, 28 May 1867. For the manoeuvrings of both the Times and the Chronicle, see EH, 3 June 1867.

35. See e.g., Wanganui Times, 4 June 1867.

36. The first was the Wellington Evening Post. 
advent with special favor, and bid us welcome to that position, which we desire to take up, as the representative of independent thought and action in Wanganui. Is there not room? The Herald... takes its stand upon the justness of its principles and the intelligence of the community. Two important duties lie before us- to place before our readers all information of local and general interest, and the advocacy of such measures as may tend to the prosperity of the place. It is an easy matter to have news... but old news is unpalatable,... it loses its freshness and flavour and we read without zest that which otherwise would give relief to the monotony of life. ...Much of our claim to public support rests upon our giving late news, which will be up to half-past two o'clock on the day of publication. ... Some kind friends have suggested that we should abstain from discussing politics- why the thing is impossible- they might as well cancel the constitution. The political concerns of the Colony affect every one in it in the most direct manner; our rights, taxes, national defences, and liberty, are all in the hands of politicians, and we cannot defer to the wishes of the timid when such principles are involved, while we are aware that all controversy should be carried on with calmness and moderation, as the best way to advance the interests of a cause, if it be just. We are bound to no party and are unbiased in our opinions by such influence; our colums (sic) are open to all and we shall report without suppressing, or by altering to suit a purpose, what we may not agree with. Let the public, therefore, be our censors- the impartial, neutral public- and we shall await with feelings of confidence its verdict. 37

These promises of neutrality Ballance found increasingly difficult to honour.

With a largely unsuccessful business venture behind him, Ballance cannot have been over-confident of the survival of the Herald. 
There were risks involved, and many newspapers at that time had only an ephemeral existence. Indeed it soon became clear that the town could only sustain a maximum of two newspapers, as the Times ceased publication in 1869 .

Journalism was much more to Ballance's liking than running a jewellery business, and it was a role for which he was particularly well equipped. He was well read, intensely interested in politics and, especially on paper, daring. Though his editorials were in the main well thought out and of considerable perspicacity and sophistication, he never forgot that sensational views, forceful views and a touch of audacity sold copies and advertising space. He fully realised the central influential role a newspaper played in a small town, and later, the use to which it could be put to further his own political career. Above all else, the Herald aimed to inform and therefore to convert- it was both didactic and proselytizing from the start, and never apologised for being so.

Given an able editor, efficient economic management and the requisite technical skills, the success of a newspaper such as the Herald depended ultimately upon the prosperity of the community it served. Circulation, and especially advertising, were extremely sensitive to the vagaries of the local economy. A slump in trade, for whatever reason, would very quickly be reflected by a reduction in advertising as businesses contracted. It is of crucial importance, for an understanding of Ballance's personal and political career, to realise that his own financial security rested directly upon the prosperity and development of Wanganui. His insistent campaigning for the expansion of the town's port facilities and the opening up of 
the hinterland to the east was more than mere politicking. On the town he depended- he had no independent source of income- and upon the new land depended the town. Thus though the tiny rural settlements that grew up around the town, stretching from Patea in the north to Bulls in the south, were never of critical importance to Ballance in terms of additional circulation or advertising, as the basis of Wanganui's expansion and prosperity, and indirectly that of the Herald, they were vital.

By the end of the first year of publication Ballance had developed a well-recognisable style and an even more obvious political stance. The Herald boasted a weekly circulation of over $2200,{ }^{38}$ but though it claimed a readership from Patea to Wellington, few copies got further than the town's most immediate hinterland. Owing primarily to problems of distribution, the Herald never really broke successfully into the rural market. It was essentially a paper of Wanganui town. ${ }^{39}$ Editorially, the central issues revolved around the removal of obstacles to Wanganui's progress. By the end of 1868 the basis for Ballance's own political career had already been laid in the columns of the Herald.

Ballance promoted, through the Herald, and frequently became personally involved in, any speculative venture that might assist in the development of the district. The possibility of discovering gold excited the town for much of 1868 , and Ballance chaired a meeting that

38. Wanganui Herald, 3 June 1967. Centennial Issue.

39. Its failure to achieve a significant rural readership was a major reason for the launching of the Yeoman, a weekly version of the Herald, a few years later. See ch. 3 . 
sent out a prospecting party to the country between Wanganui and Taupo. ${ }^{40}$ None was found.

Significantly, he saw the development and growth of the region as being dependent almost entirely on the efforts of the townspeople themselves. This was especially so given a firm belief in the reluctance of the Provincial Council to promote the welfare of any settlement outside Wellington. A spirit of self-reliance underlay his vision of progress. The following passage, remembering his own background of self-education and independence, is particularly revealing:

\begin{abstract}
Wanganui, in the midst of a large and fertile district, cannot remain stationary with 2000 inhabitants. Every new township will become another feeder; every farm occupied will minister to her resources. Extraneous assistance is not to be despised, but true prosperity is only to be found in our inherent power- in the capability of promoting our own greatness, without that uncertain aid which is derived from adventitious circumstances. 41
\end{abstract}

Not for the last time was Ballance to make a virtue out of necessity (see chapter 10).

More effectual than gold prospecting as a means of local self-development, was the establishment of the Wanganui and Rangitikei Land and Building Society. A similar society existed when Ballance arrived in Wanganui, ${ }^{42}$ but he soon realised the greater contribution that these bodies could make in providing finance for new settlement.

40. EH, 2, 6 May 1868 .

41. $\overline{\mathrm{EH}}, 22$ Oct. 1867 . My emphasis. In this editorial he also makes the important connection between economic self-reliance and military independence. The Imperial troops were due to leave Wanganui.

42. The Wanganui Land, Building and Investment Society, WC, 22 Aug. 1866. See also EH, 24 Jan. 1868, for an account of the society's annual general meeting. 
Within two weeks of the first issue of the Herald, Ballance was instructing his readers on their potential. 43 He himself became a director of the Wanganui and Rangitikei Building Society. ${ }^{4}$ In November 1867 he announced the formation. (he was again a director) of the Wanganui and Rangitikei Land and Building Society, ${ }^{45}$ which held its first meeting in January $1868 .{ }^{46}$ The addition of the word 'land' was a significant indication of the broadening role of such organisations.

Ballance unashamedly promoted the Society through the columns of the Herald, pointing out how advantageous it was for both investors (who would receive monthly compound interest on even small sums) and borrowers. 47 Money was lent only on the security of existing property, but Ballance was soon suggesting that societies might buy up land themselves, and then dispose of it to members over a period of time. ${ }^{48}$

Aside from land and building societies, the other major method of promoting local settlement was through the establishment of small farm associations. The idea behind such associations was that a combination of small investors could compete with the large capitalists and squatters in the purchase of land. By no means all the members of the association would ultimately farm the land, but those that did would do so much more intensively than a single squatter.

43. EH, 14 June 1867 .

44. EH, 30 Oct. 1867 .

45. $\underline{\mathrm{EH}}, 12$ Nov. 1867 .

46. $\underline{\mathrm{EH}}, 6$ Jan. 1868 .

47. E.g., EH, 21 Nov. 1867.

48. $\mathrm{EH}, 13 \mathrm{Nov} .1868$. 
When in September 1867 Featherston, ${ }^{49}$ on behalf of Wellington Provincial Council, purchased the 40,000 acre Parakino Block from its Maori owners, Ba1lance urged that 10,000 acres be immediately set aside for a small farm association. Earlier in the year he had argued that by placing unemployed men, and those of limited means, on the land, small farm associations would extend trade, help end depression, and stem the flow of population out of Wanganui to the gold fields on the West Coast. ${ }^{50}$ A Wanganui Sma11 Farm Association had already been formed, ${ }^{51}$ but there was great demand for another. Now Ballance regarded such associations as not only the best means of bringing prosperity to the district, but as essential to a successful contest with monopolists over land:

The natives will shortly have a large quantity of land in the market which will be speedily swallowed up by the capitalist, and the plan we propose would neutralise such monopoly. 52

The industrious man, of even small means, going upon his 200 acre farm will make it more productive than the squatter with his $(t)$ housand acres. He will cultivate every rood, and by his own industry turn the fern-covered hill, and flaxy marsh, which are now desolate, or with a sheep to the acre, into a garden, with fields of waving corn and hedgerows that ever remind one of old England. ... Small Farm Settlement appears to us the best way of possessing the country and we have the strongest grounds for asking the Government to comply with our request. 53

A major barrier to local development was, for Ballance, the Provincial Council in Wellington. Wanganui had become part of the

49. Isaac Earl Featherston, a doctor who emigrated to New Zealand in 1840, was Superintendent of Wellington Province from 1853 until 1871. He was M.H.R. for Wanganui and Rangitikei, and subsequently Wellington City. He died in 1876 when Agent-General in London, a post he had held for five years.

50. EH, 12 July 1867.

51. $\overline{\mathrm{EH}} .12$ Aug. 1867.

52. EH, 13 Nov. 1867.

53. $\overline{\mathrm{EH}}, 20 \mathrm{Sept}$. 1867. Smal1 farm associations, and Ballance's promotion $\overrightarrow{o f}$ them, will be discussed more fully in later chapters. 
Province of Wellington under the Constitution Act of 1852. It was a position that her inhabitants never came to be fully at ease with. Wanganui regarded itself, with much justice, as a neglected satellite of Wellington. There had been demands for separation, an early effort in 1869 being defeated largely through the opposition of Fox. In 1865, when the purchase of the Waitotara and Manawatu Block raised hopes of a substantial revenue, a petition for the constitution of Wanganui as a separate province reached the Governor, and one from the 'Wanganui Separation Committee' was presented to the General Assembly. Though Hawkes Bay, Southland and Marlborough were successful Wanganui was not. 54

In only the second issue of the Herald, Ballance launched an attack on the provincial system, arguing that the opposition of councils to the central Parliament was a negation of Anglo-Saxon democracy, and he urged that the former be abolished. 55 Specifically, opposition to provincialism (that 'absurdity of all absurdities', as Ballance described $\left.i t_{s}\right)^{56}$ centred on its economic unviability, on the Council's unfair distribution of a dwindling land fund, and its inability to secure loans to promote Wanganui's development. Commenting on the increased financial assistance being given by the Government to the Councils, he predicted that their end was in sight:

With their land fund well nigh exhausted, and many of them with a large debt... selfannihilation must in a short time take place. 57

54. On the background to Wanganui and the Provincial system, see W.P. Morre11, The Provincial System in New Zealand 1852-76, London, 1932 , esp. pp. 119, 163-64 \& 202 .

55. $\mathrm{EH}, 4$ June 1867.

56. $\overline{\mathrm{EH}}, 12$ Nov. 1867.

57. $\overline{\mathrm{EH}}, 10$ Sept. 1867. 
And with the consolidation of provincial loans, complete dependence on central government was an ultimate certainty. 58

Although Ballance believed in a substantial degree of local self-government, he always stressed that overall political and economic control must rest firmly with the central Parliament. He deprecated the separation of the two islands, or the complete independence of a particular province:

Insular separation is the root of all evils, with which the Colony is threatened. ...United, in a few generations, this Colony may defy the world. ... We have got all the materials for a great nation; resources, climate, race, and position; and we must not nullify these advantages by acceding to the demands of petty provincial jealousy, for insular separation. 59

Of immediate concern was the need to build a bridge across the Wanganui River, to secure the town's position as a vital link in internal communication along the west coast. There was considerable ill-feeling about the inaction of the Provincial Council on this matter: money had been voted for the bridge's construction, but it was under threat of misappropriation for alternative uses. If the town could raise the money itself this would, Ballance argued, remove the means by which the Council was forcing Wanganui to maintain its connection with Wellington. ${ }^{60}$ He was a major instigator of a meeting called to raise a petition for local self-government and discuss the question of financing the bridge. Publicly, for the first time, he

58. EH, 5 Sept. 1867.

59. $\overline{\mathrm{EH}}, 11 \mathrm{Dec}$ 1867. For a fuller discussion of Ballance's views on the provincial system see the following chapter.

60. EH, 31 July 1868 . 
laid his claim to speak on behalf of the working man:

He saw before him men of all classes who had come forward that night to maintain their rights, and he held that it was not alone the wealthy man, or the man with high position, whose views were to be considered, but that the man who toiled for his daily bread had likewise an important stake in the welfare of Wanganui, and should also have a voice in managing its affairs. Local Government was loudly called for, and the sooner a system that eats up $\$ 22,000$ of revenue in departmental expenses, in a community of 21,000 souls, is done away with the better for the district. 61

On wider political and philosophical issues, Ballance depended largely upon the ideological baggage he had brought with him from Birmingham, though often adapted to New Zealand conditions. He welcomed the extension of the franchise in England and was optimistic of the future:

...the principle embodied in every extension, is the individuality and responsibility of the person. The world cannot be governed by a few, mounted on a kind of promontory, and looking down upon and controlling the masses by a ubiquitous power, especially if those masses are capable of thinking. ... The art of government is to understand the spirit of the time, and to mould the institutions in accordance. ...The world is growing older and wiser, and the spirit of the present age is more enlightened than the spirit of any preceding age in human history. 62

As for the present, he was not blind to the operation of the class system, and pointed out that the equilibrium in England between 
democracy and aristocracy was maintained only because sufficient wealth percolated down the system, and the possibility of self-improvement was sufficiently alive, to induce 'a kind of contentment... in... the mind of the working man'.63 Opposing the view of many conservatives at the time, he argued that franchise reform stemmed rather than created 'mob rule' by admitting for the first time artisans and labourers, as well as the lower strata of the middle class, to the political system; though he recognised that traces of class subjection still existed. No country could be great where power rested in a single class. ${ }^{64}$

Finally, if reform was possible in England, a traditional society, how much easier it would be achieved in a new land:

They would have no more compunction in some of the Colonies about changing the entire constitution than the people at home would have about a simple extension of the franchise. Nations that have neither history nor tradition, are governed by expediency- the convenience of the greatest number, and are always subject to sudden changes and fluctuations of popular opinion. 65

This pragmatism, arising from the notion that the political 'ground-rules' were different in New Zealand than in the old country, was, as we shall see, fundamental to Ballance's philosophy. 
Wanganui was a frontier town not only in the economic sense of being on the edge of, and providing entry to, an undeveloped hinterland, but in a military sense as well. A series of disputes over land with local Maoris, at times leading to armed conflict, and the 'spillover' effects of war further to the north in Taranaki, both greatly added to the townspeople's sense of insecurity. These conflicts, though often low key, were sustained over a long period. The threat posed by Titokowaru in late 1868 and early 1869 to the town's very existence, meant that physical security remained an important issue in Wanganui after it had ceased to be one elsewhere. By the early 1870s, pushing back the frontier through public works and the purchase or confiscation of Maori land, reflected the desire for permanent peace as much as that for economic development.

For Ballance, the interrelationship between peace and prosperity posed a basic dilemma. He deprecated any overreaction on the part of the authorities or the people themselves to the possible danger Wanganui was in, since this tended to disrupt lives and was, for Ballance himself as well as the town, frankly bad for business. The increased market provided by imperial and colonial troops stationed in the town was, for Ballance, outweighed by the destabilizing effect they had on the everyday life of Wanganui and its ability to attract permanent settlers. On the other hand, if there came a point when the town itself was genuinely in danger, action would clearly have to be taken. In this case Ballance saw a ruthless and above all short campaign, as crucial to a successful return to normality. Thus vehement editorials in the Herald criticised government weakness, attacked incompetent local military commanders, and threatened chiefs of suspect loyalty. Ballance's Herald became the mouthpiece of a town under siege. When Ballance arrived in Wanganui fighting was 
temporarily in abeyance. Previous conflicts, attendant to the war in Taranaki in the early 1860s and the development of 'Hauhauism' closer to home, had reached a climax in the 'Battle of Moutoa' (an island in the upper reaches of the Wanganui River), between the Hauhau leader Matene Rangitauira and loyalist Whanganui Maoris under Haimona Hiroti and Mete Kingi. Skirmishes continued in the area but from the point of view of settlers in Wanganui things were relatively quiet until $1868 .^{66}$

Indeed Ballance saw the imminent departure of Imperial troops from the town in October 1867 as a clear indication that the war was over for good. Despite their economic benefits in terms of increased spending power in the town, he welcomed their leaving:

...the war is at an end- for ever at an end in this district ... and... the time for settlement has commenced. Let the era of exaggeration and excitement pass, and let us bring in a few of the armed constabulary who view not war as an occupation, and all our Maori troubles will directly cease. We want neither Imperial nor Colonial troops here now to make the district go ahead. There are surely resources enough on all sides to induce a spirit of self-reliance. 67

Underlying Ballance's attitude to the conduct of war and its relationship with economic progress, was a belief in the efficacy of a professional colonial constabulary and the damaging and disruptive consequences of continually calling up local volunteers:

The sooner ... that the Militia and Volunteers are abolished the better.

66. See Chapple \& Veitch, ch. XIII; Smart \& Bates, ch. 8 . 67. EH, 22 Oct. 1867. 


\section{THE WANGANUI REGION AND THE WAR AGAINST TITOKOWARU}

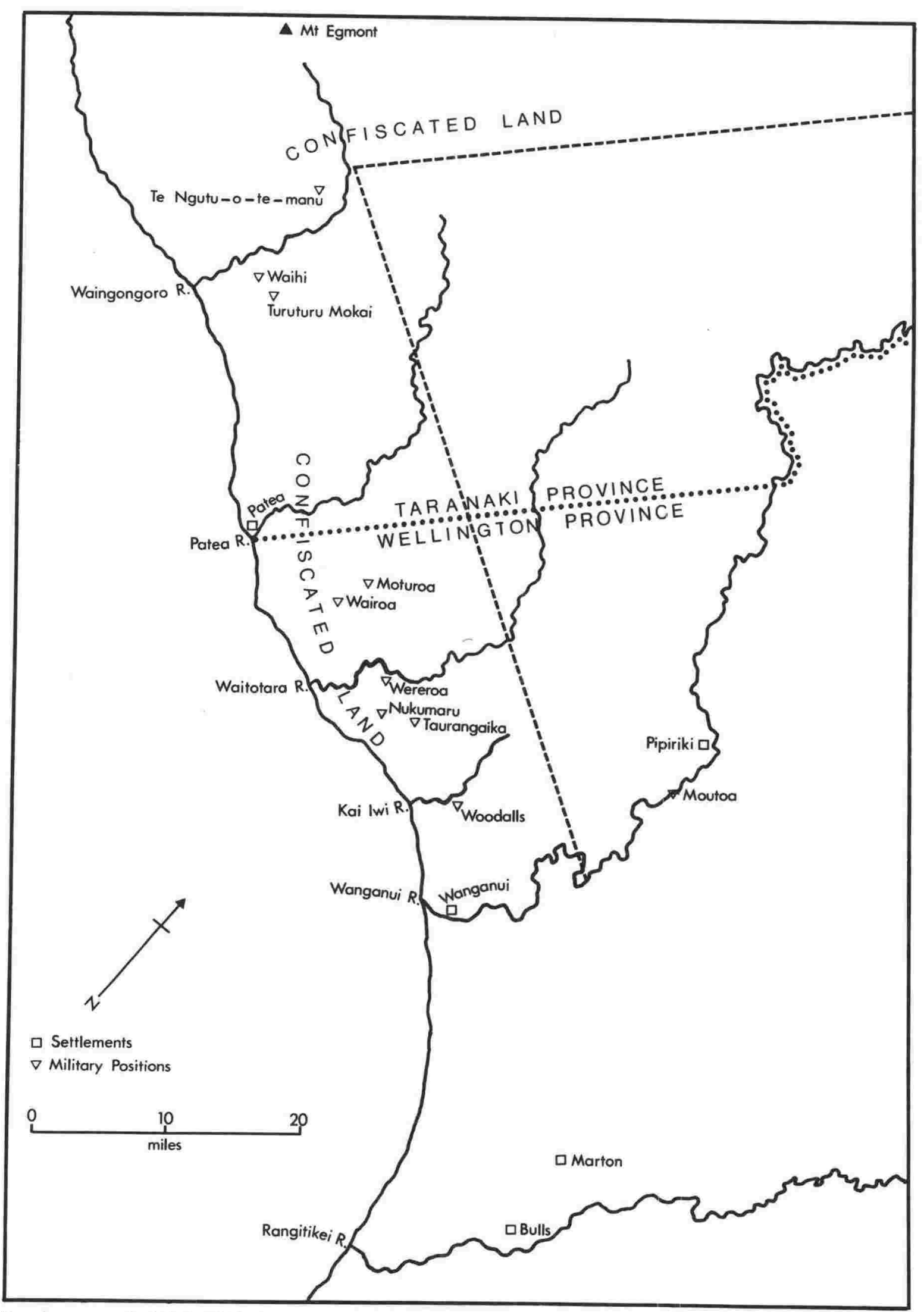

Based on a map in AJHR, 1869, A-3H. 
Nothing is more injurious to the
prospects of a young country ... than a
system of playing at soldiers... . When
there is fighting to be done, give... a few
hundred of the new constabulary (a)... carte
blanche, and native wars will almost cease ere
they have begun. But no more estimates for
Militia and Volunteers; and away with the
state of chronic alarm which exists among
tradesmen, who fear being called away from
their occupation to do sentry duty, or led
to the guard room, with the course (sic) oaths
of some military tyrant ringing in their ears.
An era of prosperity and peace has set in, and
we desire to reap its fruits in all their fulness. 68

But the war was not over. For the town the worst had yet to come, and for Ballance it was preceded by personal tragedy. In March 1868 Fanny died. Her general health had for a long time been suspect, indeed it was a major factor in their decision to emigrate to New Zealand, as we have seen. However she had been fully active in the town's affairs, and those of her husband, and died after an illness lasting only a fortnight. ${ }^{69}$ Ballance moved out of their house on Ridgeway Street, and went to stay for a while with Willis. ${ }^{70}$

In early June, soon after Ballance launched yet another attack on the Militia, arguing that there was no need for it and that the office of paid Commander of the Wanganui Militia District should be abolished, 71 disputes over land to the north led to a number of murders of settlers. ${ }^{72}$ Ngaruahine, led by Titokowaru, claimed land just south of the Waingongoro, and by the end of the month had decided to take a stand at

68. EH, 18 Nov. 1867.

69. $\overline{\mathrm{EH}}, 27 \mathrm{Mar} .1868$.

70. See Y, 6 May 1893.

71. EH, 16 May 1868 .

72. See EH, 11, 13 June 1868. 
Te Ngutu-o-te-manu. ${ }^{73}$ On 12 July a successful attack was made on a constabulary redoubt at Turuturu-Mokai nearby; and it was recognised as a defeat by Ballance, who put it down to a combination of a 'wily and desperate enemy' displaying some courage and strategy, and military incompetence on the part of the commander of the Colonial forces.

However, confident that the Patea forces would successfully counter-attack, Ballance saw no reason for panic in the town, and no excuse for calling out the Militia. ${ }^{74}$ Meanwhile he had been instrumental in the formation, as a 'legitimate' precautionary measure, of the Wanganui Cavalry Volunteer Corps ${ }^{75}$ which, on its first parade in late September had a strength of two officers and twenty-six men. ${ }^{76}$ The security of the town, and the protection of the immediate hinterland, were dependent upon these volunteers, along with the Kai Iwi Cavalry Corps (commanded by John Bryce and operating specifically in country districts) and a few Armed Constabulary. Imperial troops stationed in the town, part of the 2nd Battalion of the 18th Regiment and the only British force remaining in the country, had strict instructions to on no account take to the field, their role being purely a defensive one. In cases of extreme urgency the townspeople could be called upon for service in the Militia.

73. See James Belich, 'Titokowaru's War and its Place in New Zealand History', M.A. thesis, Victoria University of Wellington, 1979.

74. EH, 13 July 1868.

75. The Cavalry was formed on 9 July. Ballance was Chairman of the committee engaged in the Cavalry's foundation, but he was not, initially, elected an officer.

76. Wanganui Military Historical Society, 'Wereroa Redoubt', Wanganui, 1948, p. 4. This pamphlet, in the Turnbull Library, gives a brief history of the Wanganui Cavalry Volunteer Corps. 
Though Lt. Col. Gorton, commander of the Wanganui District, put a brave face on the defeat at Turuturu-Mokai, he was well aware of the immediate dangers of a local uprising, and wrote to Haultain, the Colonial Defence Minister, seeking approval to call out the Militia. He aimed to ballot for active service one hundred to one hundred and fifty men, out of a total First Class Militia strength of two hundred and thirty, confident that they would not come forward voluntarily. 77

Permission was granted and Gorton issued a proclamation calling out the Militia to parade on the morning of $23 \mathrm{July}$. At the appointed time, $10.00 \mathrm{a.m.,}$ hardly a man had appeared, and additions during the following half-hour brought the total to only sixteen. 'I was perfectly aware there was a great feeling against the militia here', wrote Gorton in his report to Haultain:

...but this feeling has been greatly encouraged by the scurrilous articles which have lately appeared in the Evening Herald when the militia have been positively recommended not to come forward for duty. 78

Gorton decided to make an example of Ballance, and wrote him a personal notice ordering him to attend parade. Ballance did not

77. Gorton to Hauitain, 15 July 1868, A.D. 1868/2385, Inwards Letters. 78. Gorton to Haultain, 25 July 1868, A.D. 1868/2507; C.L. Lovegrove, 'When Wanganui Stood to Arms in the 'Sixties', p. 9, a pamphlet reprinted from the Wanganui Herald, 1953(?), in the Turnbul1 Library. Unfortunately a number of editorials in July are missing from the extant copies of the Wanganui Herald, but correspondence between Gorton and Haultain, and the formers personal reminiscences, give a fairly detailed account of the incident. 
appear, and having sent 'an insubordinate reply' to Gorton's demand for an explanation, was promptly placed in jail, in preparation for a court martial. The Herald that evening had banner headlines, 'Military Tyranny: Editor in Gaol'. The town was in uproar. 79

The specific disagreement between Ballance and Gorton was the legality of the initial proclamation calling out the Militia. Under the terms of the Militia Act of 1858, Gorton was required to serve each militiaman individually with a notice. With a staff of only two this created considerable practical difficulties, and so Gorton hoped to entice the whole of the Militia onto parade, and then to give individual notices for actual service. 80 Techrically he was acting illegally, and knew it; Walter Buller, Resident Magistrate in the town, advised him as such. ${ }^{81}$ Ballance was therefore correct in his assertion that the initial call-out was illegal, but when he failed to respond to his own individual notice, he opened the way for his arrest. He did not respond this second time because he believed, like many others in the town, that he was exempt from service in the Militia,

79. E. Gorton, Some Home Truths about the Maori War 1863-1869 on the West Coast of New Zealand, London, 1901, ch. X.

80. Gorton to Haultain, 15 July 1868 , A.D. $1868 / 2385$.

81. Gorton, p. 80 . 
being already enrolled in the Wanganui Cavalry Corps. ${ }^{82}$ Combined with the standing grievance that it was always the town Militia that was called upon, disrupting the whole community, whereas the country Militia usually escaped, this created substantial local dissatisfaction (aimed specifically at the unpopular and unfortunate Gorton) which Ballance, first through the columns of the Herald and now personally and symbolically, represented to the authorities. 83

82. See Militia Act (1858).

Note on Militia Regulations. There was considerable confusion at the time as to whether members of Volunteer Forces were exempt from Militia service. This writer's reading of the regulations is as follows: Gorton believed that he was acting under the Militia Act of 1858. This Act was however amended in 1860, and both were repealed by the new Militia Act in 1865. For the purposes of the regulations on the procedure to be followed in calling out the Militia, this new Act was basically the same as the 1858 Act. (It divided the Militia into a First, Second and a Reserve Class, but Gorton was perfectly at liberty to call out all three, if done correctly, if. he deemed the circumstances warranted it and given he had Haultain's approval). However, the 1865 Act added to the list of persons exempted from Militia service in the 1858 Act, 'Al1. volunteers enrolled under any Volunteer Act for the time being in force within the colony' (section VII). There does appear to be a contradiction, however. The Volunteer Act of the same year excludes officers of the force, along with volunteers who have had at least three years service, from militia training. The implication is that all other volunteers were subject at least to training (and this would include Ballance). Finally, a Volunteer Act Amendment Act (1867), section 5, laid down that this 1865 Act (specifically section 25), did not, however, take away any exemption from training and exercise that volunteers may have had on 28 February 1866.

If Ballance was eligible for the Militia, then his individual call-up by Gorton (i.e. being served with a personal notice) was correct. This is a slightly different issue, however, to that of his eligibility in the first place; which is, as we have seen, a much more confused matter. This writer's suspicion is that the volunteers were not liable to be called up for militia service, whether the former were on active service or not, but that Gorton's and Ballance's concentration on the legality of the particular militia call-up, subverted this more fundamental issue. Gorton's own account, op. cit., chapter $x$, mentions only the problem of calling out the Militia individually, with a staff of only two at his disposal.

83. Lovegrove, p. 10. 
Having made his point, and realising that Gorton was in deadly earnest, Ballance apologised the following morning and was released. In the Herald he claimed that Gorton had let him out because he (Gorton) was afraid of him; which was, at least in part, true. To have proceeded with a court martial would have been much more trouble for Gorton, given Ballance's undoubted influential position in the town, than it was worth. For Gorton, though still unhappy about the unwillingness of the town's inhabitants to contribute their fair share, as he saw it, to the war effort, as much as for Ballance, taken aback by Gorton's determination to pursue with the court martial, it was a sensible compromise. ${ }^{84}$

Nevertheless Ballance continued to criticise the Militia, and Gorton personally, in the Herald. Only five days after his night in confinement an editorial went into considerable detail about the Militia's unpopularity in Wanganui. He explained why the original call-up was illegal, and how martial law threatened political liberty, and his own rights of habeas corpus when imprisoned. The failure of the parade he blamed on the incapability of Gorton and his officers in exercising their powers correctly and with tact; the former

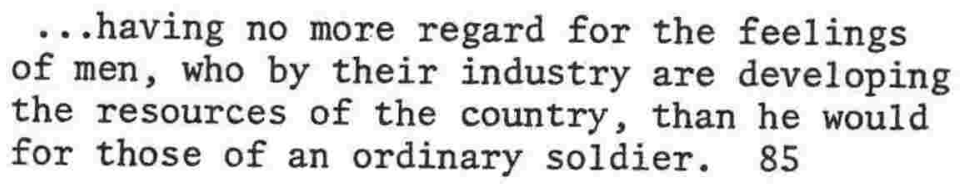

Criticism of the local military command was combined with advice on logistics and strategy as the situation deteriorated. A large part of the problem, Ballance argued, was that the economic and military 
dependence of the colony on the British Government and thus on British public opinion, restricted the actions of the military at the front. Concessions to the Maoris had failed, truces had been quickly followed by renewed outbreaks of violence, and the time had now come for every Maori to be removed from the 'disaffected' district. 86

In late August and early September attempts by Lt. Col. Thomas McDonnell, commander of the Patea District, to capture Te Ngutu-o-te-manu, ended in disaster. He resigned in consequence, being replaced by Colonel George Whitmore, who did not arrive in Wanganui until 20 october. $^{87}$ The northern position at Waihi was abandoned, and settlers evacuated much of the area between Patea and the Waitotara River as Titokowaru moved south to establish a new base at Otoia. ${ }^{88}$ On 1 October, with Wanganui receiving a steady flow of refugees, Gorton wrote to Haultain outlining his plans for the defence of the town. Immediate action was required, and though he again predicted a difficulty in persuading men to come forward, he was determined to call out the Militia on a regular basis. ${ }^{89}$

The Herald accepted the appointment of Whitmore as probably as good a one as could have been made. Although Whitmore was already unpopular with many settlers, he had as much military experience as anyone else in New Zealand. 90

86. EH, 7 Aug. 1868.

87. See T. McDonnel1, An Explanation of the Principal Causes which led to the Present War on the West Coast of New Zealand, etc., Wanganui, 1869. This pamphlet was published by Walter Taylor of the Times. Ballance reviewed it in the Herald, 2 June 1869. See also G.S. Whitmore, The Last Maori War in New Zealand under the Self-Reliant Policy, London, 1902, ch. III.

88. See Belich, pp. 42-3.

89. Gorton to Haultain, 1 0ct. 1868, A.D. $1868 / 3281$.

90. EH, 8 Oct. 1868. 
In the meantime Ballance had been elected chairman of the Council of the Wanganui Cavalry, ${ }^{91}$ which was now, with a strength of around sixty-five officers and men, being increasingly called upon for patrols and as escorts for ammunition and food. Combining the roles of private cavalryman and journalist, Ballance's accounts of such expeditions soon started appearing in the Herald.

One trip, to Wereroa Redoubt, described by Ballance as being a day 'as eventful as any immortalised by the enterprising Don Quixote', brought the news to the town that Titokowaru's southward advance had reached the Waitotara River. ${ }^{92}$ By tine end of October Titokowaru, having outflanked Whitmore who (accompanied part of the way by Ballance $9^{3}$ had moved forward to meet him, had established himself at Moturoa, winning over some previously loyalist and neutral Maoris in the process. 94 As Whitmore had burnt the settlements deserted by Maoris who joined Titokowaru, so too Titokowaru destroyed settler property as he moved south.

Meanwhile Gorton was still having trouble with Ballance, who continued to contrast the efficacy of the volunteers with that of a 'press-ganged' militia. On one occasion he described a militia call-out, when only a minority of those eligible turned up, as follows:

It was a really lamentable sight to see men, when called on for the protection of

91. Ibid.

92. $\overline{\mathrm{EH},} 19$ Oct. 1868 .

93. Whitmore, p. 34 .

94. Wanganui Times, $13 \mathrm{Apr} .1869$, gives a survey of the campaign in 
their hearths and homes, 'creeping like snails reluctantly to school', or being dragged like lambs to the slaughter by an escort of their comrades with fixed bayonets. These are not the men to meet Titokowaru... . 95

New grievances were added: poor pay when on active service and generally bad conditions. Ballance was certain that the minor concession of issuing a blanket to each militaman would do little to remove the bad feeling arising from Gorton's 'cheese-paring system'.

As the front shifted closer to the town, Ballance was able to provide increasingly detailed information on the movements of the Colonial forces and the enemy for his readers. ${ }^{96}$ On 7 November Whitmore attacked Titokowaru at Moturoa, and with the 1atter's defence 'most obstinate' retreated, in Ballance's unusually generous words, 'with great coolness and judgement' to Nukumaru. ${ }^{97}$ In fact it was nothing short of disaster. ${ }^{98}$ Titokowaru now directly threatened the land immediately to the north of the Kai Iwi stream, and a further influx of settlers to Wanganui testified to the seriousness of the situation. ${ }^{99}$ The Militia was called out to take their turn at the front, an action Ballance was again critical of, arguing that they should remain to protect the town. 100

With Titokowaru having moved on to Tauranga-ika, within eighteen miles and a days march of the town, Ballance finally succumbed to the

95. EH, 2 Nov. 1868.

96. $\bar{E}$. . . , see EH, 4 Nov. 1868. This was an expedition consisting of the Wanganui Cavalry and the First Class Militia, to Kai Iwi and Wereroa. Part of Whitmore's movements described above (p. 66, and reference 93).

97. $\mathrm{EH}, 10$ Nov. 1868 .

98. $\overline{\mathrm{Ba}} 1 \mathrm{l}$ ance had, in fact, already established a personal friendship with Whitmore, which was to deepen later as their political careers progressed. Ballance's high opinion of Whitmore was testified to by other contemporaries. See Belich.

99. Wanganui Times, 13 Apr. 1869.

100. EH, 10 Nov. 1868. 
urgency of the situation. On 13 November, in a dramatic editorial, he called all men to the full support of Gorton:

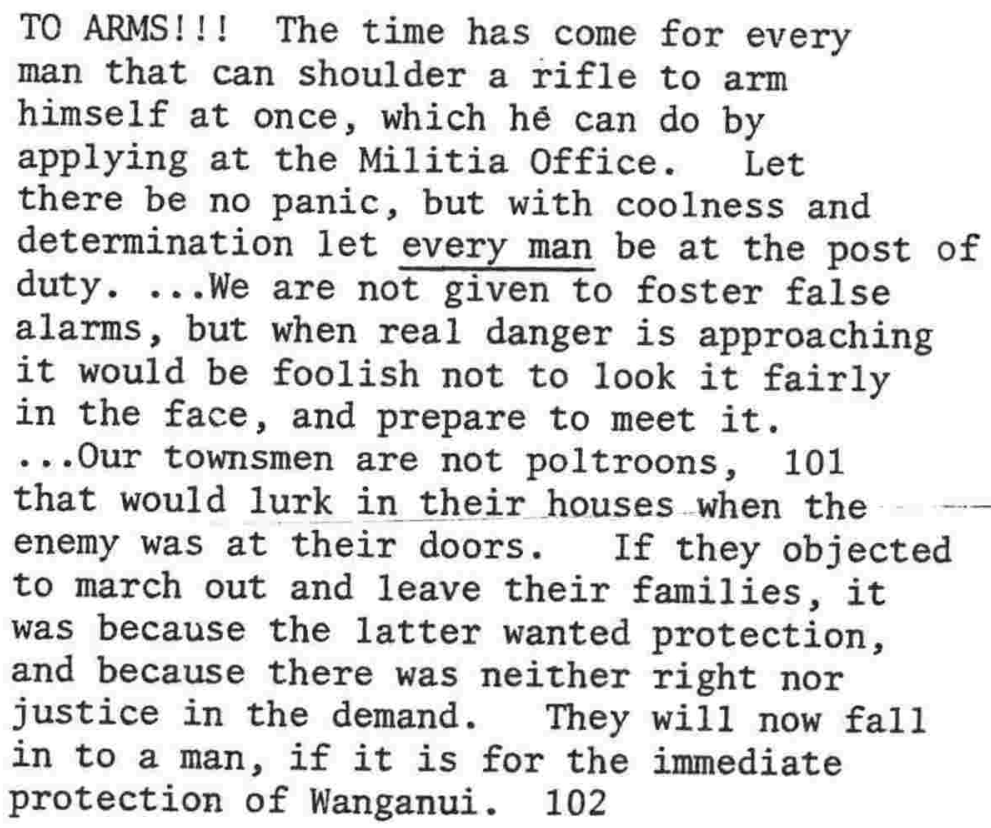

Ballance accompanied this editorial with reports and advice on the steps being taken by Gorton to defend the town. Wanganui had never before been in such imminent danger, he wrote, with 'Hannibal approaching the gates of Rome' and, which was perhaps even more serious, a distinct possibility of a rising of Maoris up-river. The town was at fever-pitch, especially so when the news arrived of Te Kooti's raid on Poverty Bay. People speculated about Titokowaru's and Whitmore's next move, rumours flew, and the place was believed to be 'swarming with spies'. Ballance said that if the Government did not immediately initiate a system of quarantine by which Maoris could only enter the town with a pass, wholesale lynch law would follow. ${ }^{103}$

101. That is, 'cowards'.

102. EH, 13 Nov. 1868. Only seven men had appeared on militia parade the day before, EH, 12 Nov. 1868.

103. EH, 13 Nov. 1868 . 
A defence meeting of the townspeople was held on Saturday 14 November, the day following Ballance's call to arms. A committee, to which Ballance was elected, was appointed to draw up a petition to impress upon the Governor the urgency of the situation and suggest practical defence measures that might be taken. Ballance unanimously carried a second resolution, calling for the resignation of Haultain, the Defence Minister (who with the Governor had just arrived in Wanganui), and urging the Government to pursue a more vigorous policy in what he saw as a war between civilisation and 'cannibalism'. Blockhouses were wanted, and a price should be put on the head of every 'rebel' as a means of securing the loyalty of the 'mercenary' kupapas. 104

The committee presented a petition along these lines to the Governor on 17 November, ${ }^{105}$ and when no satisfactory response was forthcoming, organised a second public meeting. Ballance again took the lead, urging the town to take upon itself its own defence. A resolution to that effect was carried and a sub-committee, including Ballance, was appointed to coordinate town patrols and other practical measures of defence that the committee might come up with. The Herald that evening carried, along with a report of the meeting, some rousing poetry:

TO THE MEN OF WANGANUI. The time for action has arrived, You must your battles fight; Relying on your own strong arm To aid you in the fight.

Then forward all with one accord, United heart and hand;

Go forth to meet the rebel foe, and sweep him off the land.

104. EH, 16 Nov. 1868. Kupapas were Maoris who fought on the British 105. EH, 17 Nov. 1868. 
The blood of slaughtered countrymen for vengeance calleth loud;

For vengeance on the treach'rous foe Who slew them in cold blood.

Then quickly gird your weapons on, And hasten to the fight;

And let this be your battle cry,For God and for our right. 106

The necessity for self-help, and the town's nervousness in general, were heightened by the departure of Whitmore, with the main force of Armed Constabulary, to the East Coast to deal with Te Kooti. It is questionable whether Titokowaru would in fact have risked a direct assault on the town, but the inhabitants clearly believed this to be a distinct possibility, and as Belich points out, 107 Wanganui's economic as well as physical survival depended upon a military victory over Titokowaru breaking the siege. ${ }^{108}$ The seige was ultimately as threatening as a direct military assault.

Whitmore was certainly worried about the possibility of an attack, and before leaving Wanganui made extensive plans for the town's defence. ${ }^{109}$ So too was Noake, a new local military commander. 110 And as Titokowaru recruited more allies and the campaign began on the East Coast, Ballance saw Wanganui's plight as simply part of a general uprising:

106. $\mathrm{EH}, 20$ Nov. 1868 .

107. $\overline{\mathrm{Be}} 1$ ich, p. 57.

108. B.J. Dalton, War and Politics in New Zealand, 1855-1870, Sydney, 1967 , p. 266 , argues that Wanganui was in no actual danger, but recognises that, especialiy given the background of Te Kooti's 'massacre' and the fact that the town was crowded with refugees, the place was 'prey to wild rumours'.

109. Whitmore to Haultain, 28 Nov. 1868 , A.D. $1868 / 4370$.

110. Noake to Haultain, 7 Dec. 1868 , A.D. $1868 / 4732$. 
The storm is gathering thicker and thicker, and before many weeks are over the whole island may be in a state of insurrection. 111

With Whitmore gone, and until his return to the town in January, action by the local forces was by necessity limited to minor skirmishing, patroling, and escorting of supplies and men to Kai Iwi. 112 Ballance, riding as a Corporal, and later Cornet, ${ }^{113}$ in the Wanganui Cavalry, was increasingly drawn into military.activity. The Cavalry, whose strength rose from thirty-four in November to over eighty by early January, had been taken on pay in October, and had already helped defend Wereroa Redoubt until its evacuation. 114 The Cavalry was extremely 'jumpy'. On one occasion a patrol, including Ballance, reported that Titokowaru's men were at a farm about three miles from the town. Finnimore, the Cavalry's commander, reported this to Gorton at $1 \mathrm{a} . \mathrm{m} .$, the latter then informing the Defence Minister, Haultain, who was in Wanganui at the time. It turned out to be a false alarm: the war-like cries heard by the patrol having emanated from a group of rather drunk Maori shearers. ${ }^{115}$

Other actions were more serious. The two cavalry troops, the Wanganui Cavalry under Finnimore and the Kai Iwi Cavalry under John

111. EH, 24 Nov. 1868. Though these fears were exaggerated, it is more significant that they were real and sincerely held. See also EH, 19 Nov. 1868.

112. Both Nukumaru and Wereroa redoubts had been abandoned on 17 November, and all forces drawn back to the Kai Iwi stream. See

113. Lovegrove's chronology of the campaign in Wanganui Herald, 29 May 1948. coln early December, thus rising to third in command after Capt. Finnimore, his future brother-in-law, and
Lieut. R. Day, EH, 3 Dec. 1868.

114. Wanganui Military Historical Society, p. 4.

115. See Gorton, pp. 86-9. 
Bryce, soon acquired a reputation for ruthlessness and a reluctance to take orders from the professional military commanders, the latter on the grounds that their local knowledge made them better judges as to tactics and strategy.

Ballance took part in four major expeditions of the Wanganui Cavalry. The first was in skirmishing connected with Whitmore's failed attempt to re-take Nukumaru in late November. According to Ballance's own dramatic account, none of the cavalry were wounded, only one member of the Armed Constabulary being killed. It was a 'gallant' affair, 'though, indeed, the object was slight and the results impossible to be great'. 116

The secand expedition, a week later, involved the capture of a pa on a hill opposite Woodhall's Redoubt (where the Cavalry was stationed). Ballance, who commanded the party that 'took' the hill, described it as yet another daring cavalry exploit. Unfortunately the pa was empty. ${ }^{117}$ More significant was a third, three-day skirmishing expedition further north towards Patea, which left town in mid-December. ${ }^{118}$ The Wanganui Cavalry was formed into three divisions, one each under Ballance, Day and Finnimore. They operated alongside the Kai Iwi Cavalry, the exploits of whose commander, Bryce, had already gained him a particularly ruthless reputation. ${ }^{119}$ In all,

116. EH, 2 Dec. 1868.

117. $\overline{\mathrm{EH}}, 8,9 \mathrm{Dec} .1868$. Wanganui Herald, 29 May 1948.

118. $\overline{\mathrm{See}} \mathrm{EH}, 14,15$ \& 18 Dec. 1868 .

119. Rusden's description of Bryce cutting down women and children, emerging from a pa, 'gleefully and with ease', led to a famous action for libel, which Bryce won, receiving $\$ 5000$ in damages. See G.W. Rusden, History of New Zealand, vol. II, London, 1883, p. 504. It referred to an incident, at Taurangaika $\mathrm{Pa}$, on 1 December. Ballance was not involved. See also J. Bryce, A Letter from the Hon. John Bryce to the Secretary of State for the Colonies, etc., n.p., n.d.; G.W. Rusden, Tragedies in New Zealand in 1868 and 1881 , London, 1888. 
five villages were attacked:

...growing crops of potatoes, canoes, and about twelve whares were destroyed, two Hauhaus killed, a large quantity of stock recovered, and the enemy laughted at in his very den,... all without a loss of a man or horse. ...Although the enterprise was bold, and to some may have seemed rash, yet every precaution was taken. 120

There was already 'a good deal of talk' about differences between the cavalry and Lyon, ${ }^{121}$ and these came to a head during a similar expedition that rode out of Wanganui a few days later. The cavalry commanders, Bryce and Finnimore, refused to continue the campaign as far as Patea; apparently on the grounds that Lyon's placing of the Maori troops at the head of the contingent involved both dishonour and danger to the pakehas. ${ }^{122}$ In fact this was only a part of the reason. Aside from the basic underlying stresses between the professional military and the local volunteers (continually reflected in the columns of the Herald), the cavalry were reluctant to venture too far from Wanganui since that left the town particularly vulnerable to attack. Both Bryce and Finnimore were arrested for disobeying orders. Writing to Lyon, and having received a report of the incident, Haultain said that it was only the valuable role performed by the cavalry and Lyon's plea that they should not be disbanded, that prevented further action being taken. ${ }^{123}$

120. EH, 17 Dec. 1868. See also WC, 17 Dec. 1868.

121. $\overline{W C}, 22$ Dec. 1868. Colonel Lyon commanded the Colonial Field Force based in Wanganui during Whitmore's absence.

122. See WC, 29, 31 Dec. 1868. The Chronicle saw the whole episode as very unfortunate, and wanted the dispute resolved through concessions on both sides.

123. Haultain to Lyon, 6 Jan. 1869, A.D. 6/19, Outward Letter Books. Under section 5 of the Volunteer Act Amendment Act, 1867, the Corps were not obliged 'to march or serve more than twenty miles' from their base, in this case Wanganui. 
Ballance continued to act in the combined roles of cavalry officer, war correspondent, and spokesman for the town on the general military situation. An article published in the Herald on 19 December 1868, was particularly outspoken. It commented upon enquiries being made by Booth, the Resident Magistrate, into the incident described above, where the cavalry killed two Maoris, one a woman:

The cavalry have always professed that they would kill every male Maori they came across on the other side of the Kai Iwi, unless there was some proof that he was a kupapa, and it is impossible at times, as it was the other day, to distinguish between the men and women. Let $\mathrm{Mr}$. Booth get up an inquiry- who cares?the thing will be treated, so far as the cavalry is concerned, with absolute contempt. War is not made with rose-water, and the cavalry do not live by war, and have no interest in seeing it prolonged. Indeed, it is every man's direct interest to put an end to the war as soon as possible. We question whether it is so with many officers and men in the 'regular' constabulary service. It appears that some are jealous of the cavalry, or disappointed that it has rendered services to the colony. 124

Having pointed out that desperate measures were sometimes required if the war was to be brought to a speedy conclusion, Ballance went on to make an unveiled threat on a Maori named Ngahina, who, Ballance alleged, was a spy for Titokowaru. 'A Maori in the enemy's country is', he wrote, 'prima facie, one of the enemy and that is sufficient evidence until the missionaries prove the contrary'.125

124. EH, $19 \mathrm{Dec}$. 1868. Ballance at the same time denied charges of cruelty that had been made against the Cavalry.

125. Ibid. In fact, what was more significant, Ngahina had been influential in getting the Pokaikai Commission set up to investigate alleged acts of cruelty by McDonnel1, Commander of Patea District, in August 1868. Ngahina was an obvious target for settler animosity. See AJHR, 1868, A-8. 
Unfortunately for Ballance, Booth passed a copy of the editorial to Haultain in Wellington. Haultain shortly afterwards wrote to Lyon instructing him to cancel Ballance's commission. ${ }^{126}$ Lyon in turn forwarded Haultain's letter to Ballance, the latter receiving it on Saturday 2 January. Ballance was told that this action was being taken

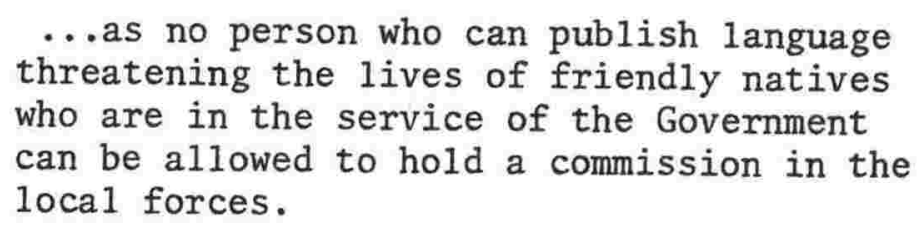

Naturally concerned not to alienate Maoris whom the Government hoped would at least remain neutral, and at most join the kupapa force, Haultain added that Lyon was to

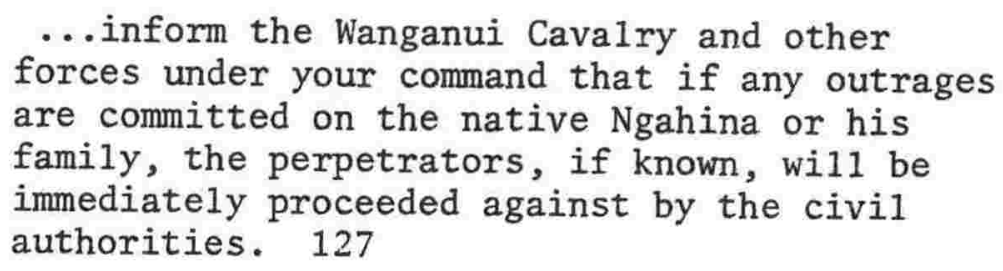

Unrepentant, Ballance launched a fierce attack on both Booth and Lyon only two days later, saying that although it had been an honour to have held command in the cavalry he had a duty to speak out, and that his independence 'could not be purchased by so cheap a thing as a commission'. 128

126. Haultain to Lyon, 28 Dec. 1868 , A.D. $6 / 19$.

127. EH, 2 Jan. 1869.

128. $\overline{\mathrm{EH}}, 4 \mathrm{Jan} .1869$. On 6 January the Herald published, in a number of 'acts', an imaginary scene of a court martial held in an 'ancient store' on Taupo Quay. Part of the proceedings included an exchange between two cavalrymen, one pointing out that the Wanganui Volunteer Cavalry were now such bad riders because they had lost their Ballance! Not for the last time was the Herald indulging itself in some, still quite amusing, satire. 
Ballance continued to serve in the Wanganui Cavalry as a private, and after Whitmore's return to Wanganui in late January, and the critical but somewhat mysterious desertion by Titokowaru of his pa at Tauranga-Ika, ${ }^{129}$ was involved in the early skirmishes that followed the chief's retreat north. Whitmore, reaching Nukumaru by 6 February, moved on in pursuit, sending the Wanganui Cavalry back to town and leaving the Kai Iwi Cavalry to guard and patrol their own district. ${ }^{130}$ Ballance, and the Cavalry, saw no further action. ${ }^{131}$

Editorials of the Herald continued to evince Ballance's 'hard line' attitude to the conduct of the war and race relations in general. They were views he would significantly modify in later life (see chapter 7). In the meantime, and particularly towards the end of the war, he argued that peace would only come about through the extermination of all 'rebels':

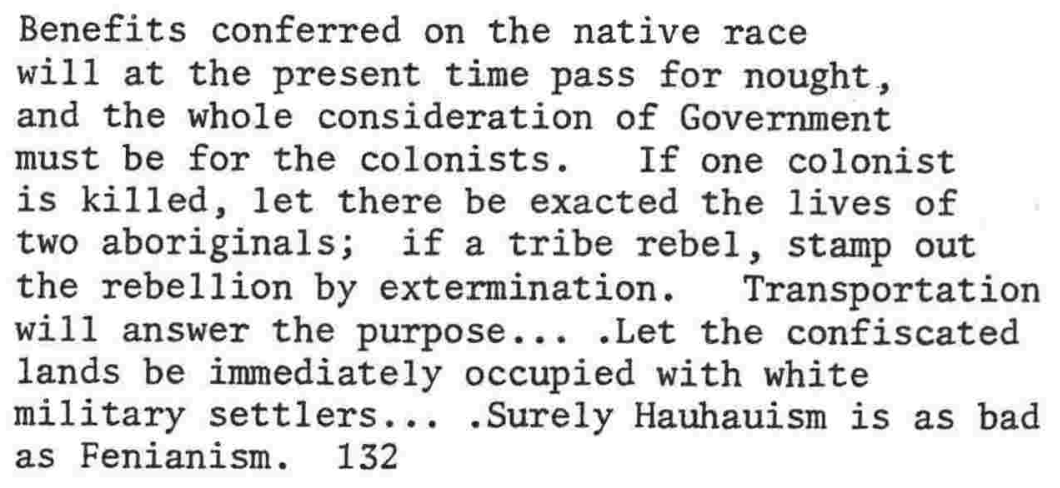

Benefits conferred on the native race will at the present time pass for nought, and the whole consideration of Government must be for the colonists. If one colonist is killed, let there be exacted the lives of two aboriginals; if a tribe rebel, stamp out the rebellion by extermination. Transportation will answer the purpose... . Let the confiscated lands be immediately occupied with white as Fenianism. 132

As the war petered out, he turned his attention also to the question

129. Belich, p. 58. Belich suggests the main reason was an affair Titokowaru was having with the wife of a lesser chief.

130. See Whitmore, ch. VII.

131. He remained a member until 1872, Lovegrove Papers, vol. 1, p. 661. The Papers are in the Wanganui Public Library.

132. EH, 29 June 1869. See ch. 1 for Ballance's views on Ireland. 
of Maori political representation. It is clear that his approach

to this, as to other matters of race relations, sprang from a belief

(held by many others) that the basic philosophical premises

underlying his attitude to European affairs did not apply to an

essentially uncivilised race:

There is scarcely a member in the House

(of Representatives) but is conscious of

the folly of placing natives among

Europeans to deliberate on the affairs

of state. The native is a failure in every

respect... . The Maori representatives in the

Assembly have failed to throw any light on

the problem of governing the natives.

... What is their use, then...? 133

Later Ballance would change his mind (see chapter 7, p. 287).

Precisely how Ballance felt about his own participation in the

fighting is difficult to aç̧ess. His editorials in the Herald were

W.

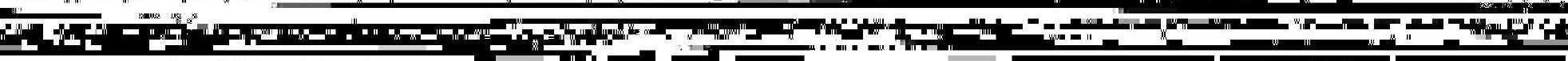

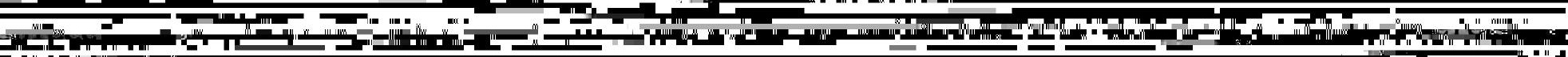

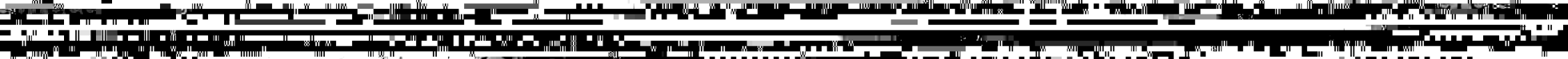

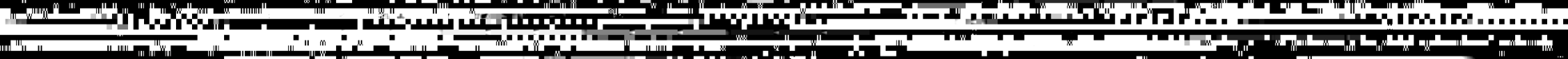

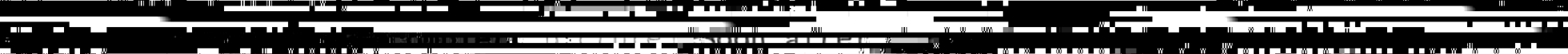
2 돌 7.

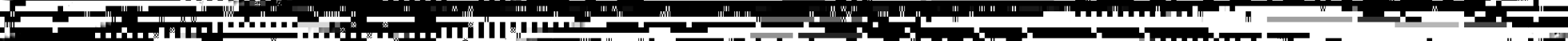

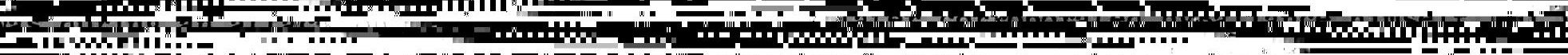
CIL M. ,

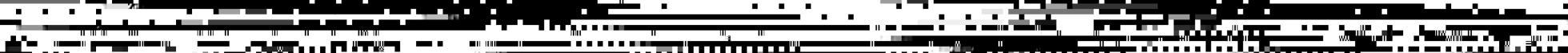

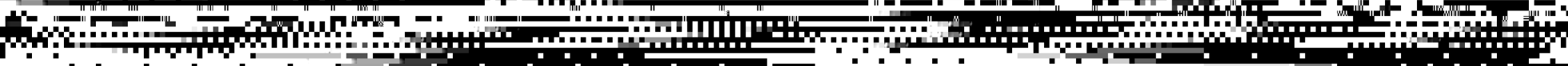

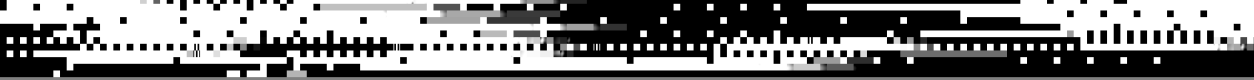


On the bodies being dragged out it was seen that one of the victims was that of a young girl. Mr Ballance came up shortly afterwards, and when he saw the dead body he was so overcome by the sad spectacle that he burst into tears. His companions, however... railled him on what they thought his weakness, not sufficiently appreciating his finely-strung organisation and deeply sympathetic nature. He only once spoke of the subject to me, and said it was one of those sad incidents he should never forget. 134

In later life Ballance referred to this period in only the most general of terms. Despite a reputation for 'calling a spade a spade', ${ }^{135}$ outlandish articles in the Herald and personal conflicts with authority, his participation in the fighting never produced such accusations of brutal pugnacity as clung to men like Bryce and McDonnell for the rest of their lives. As we shall see later, fundamental differences in character as well as belief, help explain the major contrasts between Ballance's and Bryce's terms as Native Minister. Ballance was not bellicose by nature, but nor was he a coward. Rather he displayed a remarkable combination of characteristics: aggressive on paper, morally and physically brave, yet at the same time revealing, in Willis's words, 'the softness of heart of a woman'. ${ }^{136}$ As he grew older this inner kindness was at times interpreted by many, not always unjustly, as deference grounded in a lack of confidence.

Ballance saw clearly that the war could help secure the Herald's future. It not only enabled the paper to outflank the Chronicle, which was milder and much less willing to criticise the authorities,

134. Y, 6 May 1893. Sir Robert Stout, 'Character Sketch: The Hon. John Ballance', Review of Reviews' for Australasia, May 1893, p. 115, also mentions the incident.

135. Lovegrove Papers, vol. 1, p. 660.

136. $\underline{Y}, 6$ May 1893. 
as the medium for the town's discontent; ${ }^{137}$ but through his first-hand accounts of the progress of the fighting, Ballance achieved a reputation outside Wanganui as well. Herald articles were reprinted in Wellington newspapers, at times providing Haultain with the first information available on the activities of forces ultimately under his command.

Through the Herald and his own clashes with authority, Ballance gained a personal notoriety that was never to damage the prospects of a political career. Indeed it was of positive benefit: he was now well-known, and in the eyes of many people in Wanganui had faithfully represented their needs and fears in critical times. Above all, these early experiences of the fragile nature of Wanganui produced in Ballance an almost religious conviction that only the comprehensive settlement of the land could guarantee, for himself and the town, physical security and economic prosperity.

His experiences also drove home his suspicion that peace and prosperity would only come through self-reliance. This theme dominated his thought in the period immediately following the end of the war. New Zealand's greatness was inherent, not imported. The opening up of the land, settlement and prosperity should not be dependent upon England, and would only come about when New Zealand could herself maintain law and order. ${ }^{138}$ The solution sounded

137. The Times, on its last legs, was similarly critical of Ballance's 'extreme editorials'. See for example, Wanganui Times, 1, 27 Apr. 1869,4 May 1869. 138. EH, 14 Apr. 1869. 


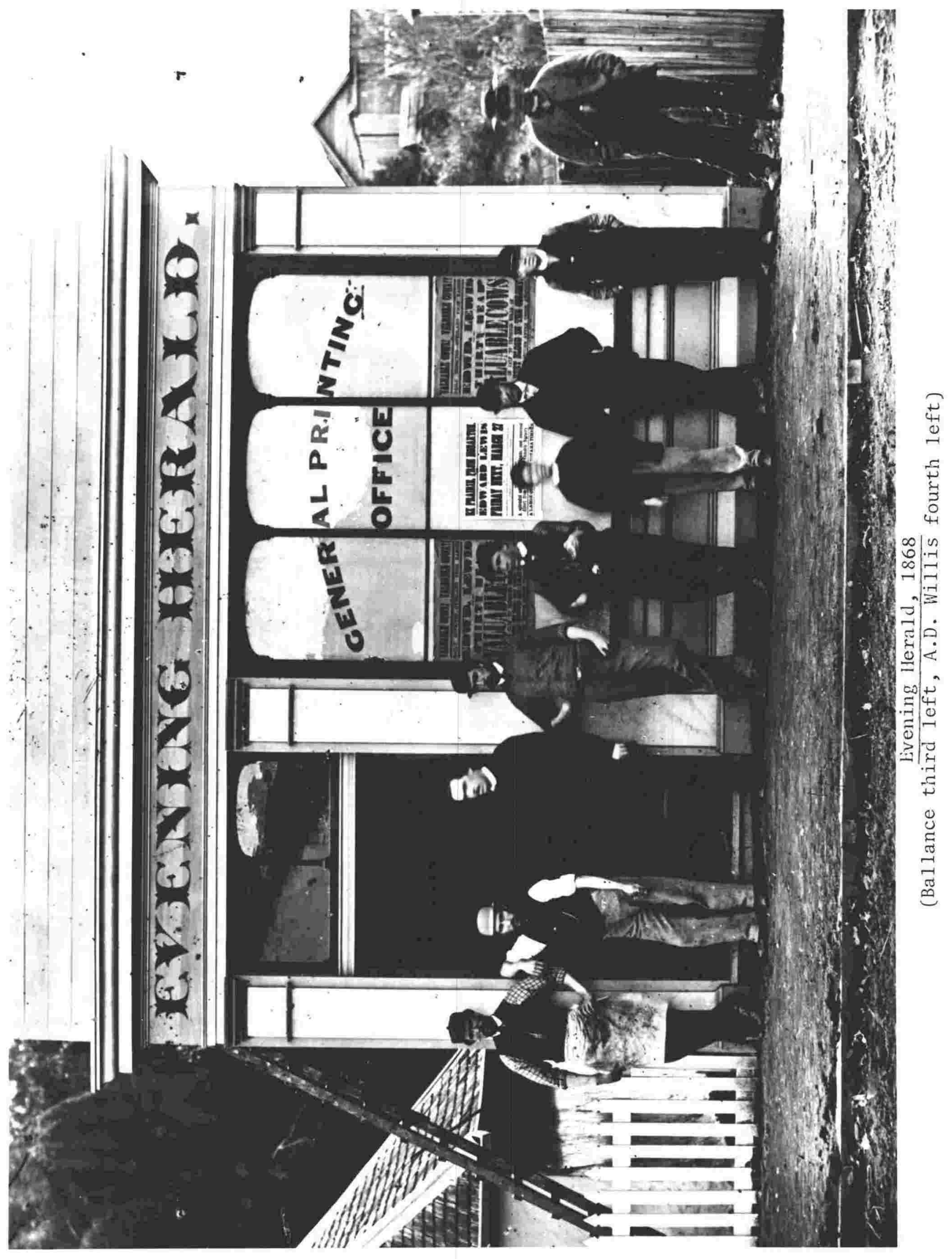


straightforward:

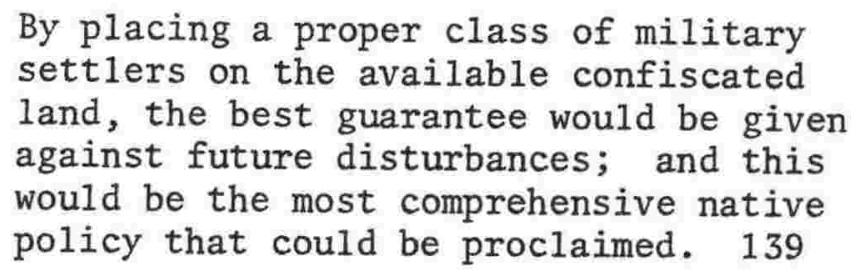

He urged the Government, while pursuing the war 'almost to extinction', ${ }^{140}$ to utilise both military, and (given the need to be financially independent) private land settlement enterprises, as the best way to establish permanent peace. ${ }^{141}$ Self-reliance and self-help were the moral as well as the political pre-requisites for personal, and popular, security and fulfilment. Specifically the means was through the settlement of the 1 and.

139. EH, 6 May 1869.

140. $\overline{\mathrm{EH}}, 29$ Mar. 1869.

141. $\overline{\mathrm{EH}}, 10$ Mar. 1869. 
Throughout the 1870 s Ballance was to be intimately concerned with the development of Wanganui Town and the settlement of its hinterland. He was increasingly involved in political activity on his own account; and, indeed, it was inevitable that this should have been so. Journalism was an ideal springboard into political life. In fact journalism was for Ballance simply a part of his consuming interest in politics.

What may be termed the 'politics of development' dominated this period. Specifically, the connected issues of Vogel's public works and immigration programme and the constitutional position of the provinces, were central to colonial politics. Politicians, it has been argued, acted primarily in the interests of the provinces to which they belonged. Politics involved essentially a scramble for money for development, and provincial pressures were the determinants of political power. Ministries differed only in the extent to which they were prepared to borrow for development; some were more 'cautious' than others. 1 One is tempted to conclude that the period is marked by a distinct lack of real issues. Few politicians could afford to oppose Vogel's development programme- particularly in the early 1870 s when it coincided with rising export prices- and all, to a lesser or greater degree, had to face their constituents on the basis

1. W.R. Armstrong, 'The Politics of Development: a study of the structure of politics from 1870 to $1890^{\prime}$, M.A. thesis, Victoria University of Wellington, 1960; A.M. Evans, 'A Study of Canterbury Politics in the Early 1880s, with special reference to the general election of 1881', M.A. thesis, Canterbury, 1959. view politics in this period in terms of 'bold' versus 'cautious' approaches to economic development. The 'traditional' view of William Pember Reeves sees the period as dominated by a conservative oligarchy, in the form of a 'continuous ministry', interrupted only in 1877-9 and 1884-7, and finally in 1890. W.P. Reeves, The Long White Cloud, London, 1899. 
of their ability to attract funds from the General Government for local development projects. Equally, the question of the abolition of the provinces seems relatively straightforward. Politicians from the richer provinces, fearing they would lose their land revenue to the central government, opposed abolition. Poorer provinces, with a smaller revenue, or outlying districts who felt neglected by their provincial capital, could only hope to gain out of abolition. Though through different means, both abolitionists and provincialists sought to maximise development. But to argue that politics was determined solely by developmental needs is too simplistic. The desire for economic development and prosperity has always been central to the functioning of political systems. Given this, the method by which it is achieved, and for whom it is to benefit, are more pertinent questions. Certainly the distribution of colonial revenue and borrowed funds imposed on contemporary politicians an over-riding law of political activity based on provincial interest, yet this was simply because, for reasons of political geography alone, it was the only sustainable basis. There remained other, ultimately more important, political cleavages that cut across provincial boundaries.

From the point of view of political biography- the political philosophy and activity of an individual- this is of particular importance. Concentrating on development per se emphasises continuity in the objectives of the political alignments formed, highlighting the superficial and obscuring the fundamental differences between individual politicians. Political alliances at the centre were based primarily on the development needs of provinces, but within this system those needs were, for Ballance in Wanganui, orientated towards the promotion of a particular class of settler. 
Similarities between politicians were obscured in the same way as differences. Ballance disagreed with his political contemporary, Robert Stout, over the 'basic' issue of the 1870s, abolition of the provinces. Yet the ends of both politicians were very similar. Both were concerned with the distribution of political and economic power: Stout believed that abolition would involve handing over Otago's considerable land fund to a central government dominated by squatters. ${ }^{2}$ Ballance argued that only abolition would allow for a more just distribution of government expenditure in favour of the genuine settler of limited means rather than the squatter. Thus although the issues of development and abolition per se appear critical factors in determining political cleavages, development for whom is both more fundamental and certainly more lasting, at least as far as Ballance and Stout are concerned. Their joining the Grey Government in 1878 reflected basic similarities in political philosophy that had been present since the commencement of both men's political careers.

Abolition for Ballance was never an end in itself. It was a prerequisite constitutional reorganisation, removing a barrier to a more equitable system of central and local government, that would respond to the interests of those he sought to represent. This necessarily affected his attitude to the public works and immigration programme: under the provincial system Ballance, and Wanganui, were unable to influence significantly the direction of development funds. Ballance saw abolition and 'Vogelism' in terms of what they could do for Wanganui, and in particular for the town's poorer settlers who saw their future in the development of small farms in the hinterland. Attacks 
made by Ballance, in the Herald and in his own speeches, on the provincial system, were more often than not combined with criticism of squatters and their hold on the political system. From the start he sought to combat the political and economic power of large capitalists, directly through the political system, and at grass-roots level through a number of 'class' organisations, the most important of which were the small farm associations.

On 19 May 1870 Ballance married Ellen Anderson, at St. Peter's Church in Wellington. ${ }^{3}$ Ellen was the second surviving daughter of David Anderson and Ann Thompson. Her father had travelled widely with the British Army before emigrating to New Zealand in 1849. He had married Ann in 1828, when he was twenty-two and she just fourteen, and they proceeded to have a large family born in various parts of the world. ${ }^{4}$ He had intended to settle in Ireland but, owing primarily to the onset of the famine, decided to emigrate to New Zealand. On arriving in Wellington he bought a store on the beach front, ${ }^{5}$ setting up business as a general merchant. As the firm was very successful he soon established a second store in Molesworth Street. 6

3. EH, 19 May 1870.

4. Including England, Ireland, East Indies, Gibraltar and Jamaica. 5. Now Willis Street.

6. He may well have been the first trader in New Zealand to use mail order. This information on David Anderson is from EP, 13 Mar. 1889 (his obituary), and from his great-grandson, Mr John Anderson of Wellington. David Anderson, or 'Paddy'. as he was known, built his Hankey Street Mansion in 1868. 
Ellen was born in County Down, Ireland, in 1847. Her childhood was privileged, though nevertheless difficult at times. Growing up in Wellington she attended a private school run by Jane and Florence Spinks, daughters of a businessman who had been elected to the Provincial Council. ${ }^{7}$ Lessons were held in the Spinks's home, on the corner of Willis Street and Macdonald Crescent, and attended weather and health permitting. ${ }^{8}$ Ellen's elder sister, Ann, had married William Finnimore of Wanganui, and it is undoubtedly through this connection that she met Ballance. ${ }^{9}$ A second sister, Margaret, married Samuel Griffiths and a third, Jessie, Stephen Foreman, both men being from Wanganui. ${ }^{10}$ With Ballance now a figure of some importance in Wanganui, and David Anderson a successful businessman in Wellington, the marriage was, socially, a good one. It was to be, as far as one can tell, a happy marriage. Ellen, a woman of considerable intellect,

7. Sarah Jane Spinks was to marry David Anderson junior. Her diaries, kindly lent to the writer by Mrs Carol Anderson, have given some valuable insights into the personal life of both Ellen and John Ballance. These Andersons saw the Ballances frequently when the latter were in Wellington.

8. Reading the Spinks and Anderson diaries, one is reminded of the extent to which health and the weather determined everyday town life, at least for the well-to-do. Children, ladies of leisure, and frequently men would simply not venture out of doors if the rain was persistent and heavy. Health was equally restricting and for some, perhaps not unnaturally given the high infant and child mortality rate, practically an obsession.

9. See ch. 2. William Finnimore was a businessman who fulfilled what might be described as a classic 'feeder' role. He was a government auctioneer, valuator, licensed custom house, shipping and commission agent, stock and cattle salesman and a land and estate agent. He epitomised the role of the town as a 'parasite' living off the country.

10. I am grateful to Mr John Haterly of New Plymouth, grandson of Margaret Griffiths (née Anderson) for personal reminiscences of the Anderson family. Finnimore was later to desert his wife, going to South Africa where he, bigamously, remarried. 
kindly though determined and strong-willed, ${ }^{11}$ was genuinely interested in politics on her own account. ${ }^{12}$

Ballance's own financial position was improving. The Herald was beginning to expand from a now secure base. On 10 July 1869 the Evening Herald announced that a new weekly paper would appear from 7 August. Called the Weekly Herald, it would contain articles and news already published during the week in the Evening Herald, as well as new material especially tailored to meet the needs of country readers. ${ }^{13}$ The weekly version was an attempt by Ballance to reach the outlying districts of Wanganui's hinterland that could not be served on a daily basis.

Established on the eve of an economic upturn and an expansion of settlement, the Weekly Herald was to have considerable initial success. Its very first issue surpassed Ballance's cautious expectations: the Evening Herald reported that as demand had exceeded supply, only previously paid-up subscribers would receive a copy. ${ }^{14}$ This impression of the success of both papers is heightened by Ballance's purchase, a little over a year later, of a new printing machine direct from England. ${ }^{15}$

11. Sharing, indeed, similar characteristics with her husband. Her father Paddy, tight-fisted in business affairs, was a strict, patriarchical figure in his family. One's impression is that the girls, in particular, had quite a lot to put up with!

12. She continued to be involved with a number of women's organisations after her husband's death. On her participation in the franchise movement see ch. 9, p. 342 , ch. 12 , p. 473.

13. EH, 10 July 1869 .

14. $\overline{\mathrm{EH}}, 7$ Aug. 1869 .

15. G.H. Scholefield, Newspapers in New Zealand, Wellington, 1958, p. 50, writes that in the early years the Herald lost a good deal of money. In fact Ballance was able, by 1882, to personally purchase 6,860 of the $7500 £ 1$ shares of the company established in that year. Information is scant, but it seems that though the war years were difficult, the Herald in the $1870 \mathrm{~s}$ prospered. The $1880 \mathrm{~s}$, as we should expect given the close connection between the paper's prosperity and that of the economy as a whole, saw a definite downturn in the Herald's profitability. 
Both papers were enlarged. ${ }^{16}$ According to Ballance's own figures (not necessarily accurate, of course), the Weekly Herald's circulation quadrupled in two years. ${ }^{17}$ In one particularly revealing editorial, Ballance emphasised the dependence of the town and his paper on new settlements, and the Herald's continual advocacy of the settler's cause :

\begin{abstract}
The rising district of Patea is fast becoming as important to the town of Wanganui as Rangitikei has always been. Every additional settler who locates himself there, is a fresh customer to our town, and the prosperity of that district brings corresponding prosperity to Wanganui. ...We believe that the great body of the settlers of the districts lately overran (sic) by the rebels are opposed to a single native being allowed to settle amongst them. We represent these settlers par excellence. Our journal is the only one that has a circulation worth mentioning among them, and we are in a position to know their sentiments on every public question. We know that they will not allow Titokowaru... to come amongst them again... . 18
\end{abstract}

With the war over and bright prospects for major new settlement, Ballance believed that the colony could extend its military self-reliance to economic and political independence. Distinctly nationalistic editorials began appearing in the Herald. Though New Zealand had a right to receive assistance from Britain during the war, Ballance argued

16. EH, 17 Dec. 1870. The Evening Herald was enlarged from five to six columns across, and the Weekly Herald to a total of sixty columns. At $2 \mathrm{~d}$ per copy the Weekly Herald was cheaper than equivalent weeklies in the colony.

17. EH, 21 Sept. 1871.

18. $\overline{\mathrm{EH}}, 29$ May 1871. Particularly interesting given Ballance's candidature, just over a year later, for the Egmont seat, which included Patea. 
that now only complete control over her own affairs could guarantee prosperity. ${ }^{19}$ He regretted the fall, owing primarily to its handling of the war, of the Stafford Ministry in June 1869. Ballance had regarded the Stafford Ministry as preferable to the alternative one of Fox, since the former's policy of 'colonial unity, self-reliance and local self-government' made up for many shortcomings, particularly in 'native' affairs. He was particularly scathing of Fox for sending Dillon Bell and Featherston to London to seek new military assistance from the British Government. ${ }^{20}$ Though Ballance had himself been critical of the performance of the colonial troops, he had always believed them sufficient to deal with the situation:

\begin{abstract}
A strong feeling of patriotism is growing up in the colony. ... The plain fact is that some change is coming over the minds of the colonists with regard to the relations between the mother country and the colony. ... Between the lofty proud spirit of self-reliance tinged with independence, of $\mathrm{Mr}$ Stafford and the truckling begging solicitations of Mr Fox we have no hesitation in deciding. We know not a single advantage... in maintaining a political connexion with the mother country. ...The disparagement of the colonial forces is bad policy, for upon them all our dependence must be placed, unless we get Imperial troops to fight our battles... Sir George Bowen might be sent home. ...Without troops we can also do without a Governor. 21
\end{abstract}

Ballance soon made it even clearer that he was talking about political as well as military independence. Self-reliance was broadened into national independence and a kind of crusading, visionary,

19. EH, 19 Apr. 1870.

20. See W.P. Morre11, The Provincial System in New Zealand, 1852-76, London, 1932, ch. IX.

21. EH, 10 Aug. 1869. Ballance's emphasis. See also EH, 14 Apr. 1869. 
nationalism:

The interests of the colony point to independence. ...This country, if an independent state, would command the moral support of every nation in the world. ... The energy that is implanted by noble aspirations would enable the nation to triumph over internal difficulties, and to treat lightly those sacrifices which it would have to make before attaining the goal of unity and peace. Independence will come to us sooner or later. Is the time not opportune? 22

Thus he viewed plans to establish a New Zealand University as enabling the colony to 'look within itself to satisfy its aspirations, instead of importing learnings of an exotic growth'. ${ }^{23}$ Finally, when the British Government refused to guarantee a loan, in mid-1870, Ballance welcomed the opportunity it gave for both sides to pursue a policy of 'non-interference'. 'We sha11 flourish best under a system of virtual independence' 24

Though the war was, apart from minor skirmishing, at an end, and Ballance's emphasis of this an inducement to new settlers, he insisted (at least initially) that the threat was still sufficient to justify government assistance, primarily in the form of military settlers. The confiscation of Maori land was legitimised by arguing that they had, through rebellion, forfeited their right to occupy it. And in any case, 'natives can make no use of the 1and'. ${ }^{25}$ placing on the land men who had served in the military forces during the war made military and economic sense.

22. EH, 27 Oct. 1870 .

23. $\overline{\mathrm{EH}}, 16$ Aug. 1870 .

24. $\overline{\mathrm{EH}}, 2$ June 1870 .

25. $\overline{\mathrm{EH}}, 8 \mathrm{Aug} .1870$. See also $\mathrm{EH}, 10 \mathrm{June} 1870$. Land should be alienated 'in the interests of civilisation', something, Ballance continued, that would be 'obvious to all but philo-Maoris and speculators'. 
However Ballance soon realised that the military settlements had serious flaws. The settlers were often ill-equipped as farmers, and frequently sold their rights to speculators, with land aggregation as the result. ${ }^{26}$ At the same time, Ballance's stance on confiscation itself also began to change. Whilst he continued to view settlement as essential to peace and economic development, he increasingly saw that extensive alienation of land created discontent and disorder, ${ }^{27}$ and threatened the very survival of the Maori race. 28

With the establishment of peace the necessary conditions had been laid for economic expansion and the extension of settlement in the Wanganui region. There was no shortage of land: further confiscations were made, more was bought, and the problem now was how it was to be developed. Communications were extended into the hinterland, to establish new settlements and to channel goods to and from Wanganui town. The initial phase of road and rail building served to strengthen Wanganui's position as an exporter of produce from the Manawatu and Waitotara regions. A coach service to Wellington had been established on a regular basis by 1868 , but only with the opening of the railway link with Wellington in 1886 and the reduction of rail as compared with sea freight rates, could Wanganui be by-passed and produce be sent direct to Wellington. In the meantime, Wanganui was the closest, most convenient and therefore the cheapest route for the increasing amount of wool and meat sent out through the port. Harbour facilities and shipping capacity responded to the expansion in

26. EH, 21 Oct. 1870. On the Waikato see, e.g., W.M. Robinson, 'The Pacification of the Waikato 1869-76'. M.A. thesis, Auckland, 1949. 27. EH, 14 Mar. 1872 .

28. E.g., EH, 24 Dec. 1874. See ch. 7 for a fuller discussion of BaIlance's views on race relations. 
trade. 29 Finally, the opening of the bridge across the river, a major event for the town, ${ }^{30}$ ensured not only Wanganui's position as a vital link in communications along the west coast, but her own expansion through new settlement on the south bank of the river.

The nature of the town changed as it began to have an economic existence in its own right; that is, beyond simply acting as a feeder of imports to local settlers and exporter of farm produce. By the mid-1870s small local industries had been established: breweries, soap works, an iron foundry, rope factory and there was a growing flax industry. ${ }^{31}$ Nevertheless, the town remained in a symbiotic relationship with its hinterland, for local industries depended upon a sufficient internal market as well as an export one. The expansion of the town still rested ultimately on the success of land settlement. Between 1867 and 1874 the immediate hinterland's population grew at a faster rate than that of the town itself. ${ }^{32}$ The future lay in the land.

Despite the brighter economic prospects, with increasing trade and a booming flax industry, ${ }^{33}$ Ballance was depressed about a lack of

29. See S.M. King, 'The Port of Wanganui and its Influence on Wanganui', M.A. thesis, Victoria University of Wellington, 1964, ch. 2.

30. The foundation stone was laid in November 1869 (see EH, 11 Nov. 1869) and the bridge opened by the Governor two years later (see EH, 28 Nov. 1871).

31. L.J.B. Chapple and H.C. Veitch, Wanganui, Hawera, 1939, ch. XVI.

32. The town population increased between 1867 and 1874 from 2,157 to 2,572 . The population of the electoral district, excluding the town, from 1,749 to 2,335 . This represents increases of $19 \%$ and $33 \%$ respectively. Figures calculated from New Zealand Census, 1867 and 1874 .

33. Supply couldn't keep up with demand, EH, 2 Mar. 1870. On the flax industry, and the high prices being obtained, see also EH, $14 \mathrm{Feb}$. 1871; EH, $15 \mathrm{Feb} .1871$. Statistics on Wanganui's trade are hard to procure. New Zealand Statistics are of 1ittle use. As Ballance himself frequently pointed out (e.g. EH, 15 Aug. 1872), official statistics on Wanganui trade did not reflect actual trade, since Wanganui had little direct trade with foreign ports, most going via other New Zealand ports which were credited with the volume. 
vitality in the town. It was a not unnatural reaction to the failure of Wanganui's earlier agitation for constitution as a separate province :

The river bank is crumbling... . There are no public institutions, except the hospital, and it has neither accommodation nor comforts of any kind. The signal-station is supported by shilling subscriptions; the gaol has so little room that 'justice has to be tempered with mercy', the police, like rats, are leaving the rotten hulk,...justice is limping on sticks... .

The fault lay with the provincial system:

Look to Wellington, and what do we see. Tottering imbecility represents us. ...We might wait until oxidation had removed the semblance of the bridge before one note would rise from the nocturnal labors of our representative. He perhaps works in secret... . Although ours is the sixth port in the colony, it has not a place even in the inter-colonial time table. Politically, it is absolutely nowhere- deserted, forgotten, even hated, it has surely attained its nadir, its lowest depths. ...(T)he people are apathetic... . ...The atmosphere of provincialism is miasmal, the waters stagnant, and both are acting on the system, causing depletion and enervation. We implore anything different from the present system; we cannot be worse governed, and any change will be received with a welcome only to be measured by the intensity of the desire to part with what we have. 34

Ballance was unremitting in his condemnation of the Provincial Council. He insisted that a system of a central government, and local bodies dealing with such things as roads, lighting, water and gas supply etc., 
must replace provincialism. 35

The town was simply not interested in the Council at Wellington. Local representatives had to be persuaded to stand for election to the Council, ${ }^{36}$ which was spending nearly all the income of the Province in Wellington, 37 and performing functions that could be much better carried out by either central government or a Iocal body. 38

Not only did provincialism inhibit local development, but it positively encouraged speculation in land. The Provincial Council in Wellington controlled, on behalf of the Province, the vast area of confiscated land, and set the terms of settlement. Ballance was well aware that simply selling this land off to the highest bidder would lead to speculation and aggregation, at the expense of the small, genuine, farmer. In 1869, for example, 220,000 acres of the Manawatu were acquired by the Wellington Provincial Council. Ballance, immediately on hearing the news, demanded that the 'interests of the

35. EH, $28 \mathrm{Dec}$. 1870; $\mathrm{EH}, 13$ June 1872. Ballance described the Provincial Council as a 'decrepid body' made up of 'fossils of the order of crustacea', EH, 10 June 1869. On the setting up of the provincial system and its early functioning, see R.M. Mullins, 'The Division of Power between the General and Provincial Governments, 1851-58', M.A. thesis, Victoria University of Wellington, 1953.

36. EH, 15 June 1869.

37. $\overline{E H}, 7$ July 1869. This was a complaint basic to Ballance's and Wanganui's opposition to the provincial system. To what extent this was true is difficult to assess. The statistics produced by the Provincial Government did not break down expenditure regionally. Separate figures were given for Wanganui's gaol, harbour and hospital, and expenditure on these items was roughly in accordance with the populations they served (see for example, Journal of Proceedings of the Provincial Council, 1872, 1875, part F). On the other hand, harbour finance, for example, would not bear a direct relationship to population, as there was a basic cost of necessary improvements. Control over its own finance was perhaps more important for Wanganui.

38. EH, 24 Apr. 1872 . 
working classes be considered' when the time came for the land's disposal. Specifically, he wanted a portion of the land sold on deferred payment, and at the same time urged that the Wanganui Small Farm Association be revived. Both would promote bonâ fide settlement:

Shall this large area of country be absorbed by the Wellington plutocracy, and shall the man of limited means, the small farmer, reap no benefit therefrom? ...Shall we have to witness the sacrifice of a splendid estate among a select number of monied monopolists? 39

Ballance pointed out examples of speculation elsewhere in New Zealand. In Otago, for example, a Melbourne speculator named Clark purchased 40,000 acres aiming to sell them at a considerable profit, once roads and railways had made them accessible to settlement. It was the fault of a reckless Provincial Government, said Ballance, and the sooner the control of land was in the hands of the General Assembly the better. 'Provincialism never was so dangerous or destructive to the interests of the colony as at the present time'. ${ }^{40}$ But even with central government control over land, there were dangers. The Legislative Council threatened to subvert the interests of the people and their representative. On various occasions Ballance urged either its outright abolition, ${ }^{41}$ or at least the appointment of new councillors to counteract the 'clique of large capitalists' in the Council, so that those 'few men alienated from public opinion and sympathy will not be permitted to usurp the functions of Government and direct the policy of the country'. ${ }^{42}$

39. EH, 14 Oct. 1869. The same arguments are used elsewhere, e.g. EH, 22 July 1870. On the advantages of leases with the right of purchase, see EH, 11 Feb. 1870.

40. $\mathrm{EH}, 27$ Sept. 1871 .

41. For example, EH, 20 Sept. 1869.

42. EH, 18 Sept. $\overline{1873 .}$ 
On 28 June 1870 Julius Vogel announced his Public Works and Immigration Policy. He proposed to borrow $£ 10$ million over the following ten years to facilitate a rapid expansion of settlement and development in the colony. ${ }^{43}$ Ballance recognised it as 'one of the most extraordinary Statements that has ever been presented to a Parliament'. He couldn't help but admire it-it was 'bold and uncompromising', though he was concerned that the capitation allowance to be given to the provinces would sustain their 1 ife, ${ }^{44}$ and predicted that they would ultimately cause the scheme to fail. ${ }^{45}$

He was considerably more enthusiastic once the details of the works to be carried out in the Wanganui district became known. Roads were to connect the east and west coasts, and to link with a major road running north-south from Foxton. Ballance emphasised that it was vital that the terms of settlement, facilitated by this expenditure, be clear; it had to be bonâ fide. ${ }^{46}$ Looking back on the session as a whole, he saw the measures as being 'conceived in the spirit of self-reliance'. The development proposals would see New Zealand 'come of age' as a nation:

\footnotetext{
... New Zealand statesmen have exhibited a patriotism, devotion, and foresight, of which other colonies may well feel envious. The colony has come forth from its pupilage, buckled on its armour, and is prepared to take its stand among the nations. 47
}

Over the following two years Ballance was to considerably alter his opinion. He had already pointed out the possible dangers of

43. PD, $1870,7, \mathrm{pp} .102-08$.

44. A careful reading of his financial statement makes it quite clear that Vogel would not hesitate to abolish the provinces if they obstructed his programme.

45. EH, 1 July 1870 .

46. EH, 12 July 1870

47. $\overline{E H}, 15$ Sept. 1870 . 
maladministration and waste of public funds in the scheme. ${ }^{48} \mathrm{He}$ accepted the premise that borrowing was necessary for development, but increasingly argued that in practice money was being misapplied. For example, it soon became clear that railway building was a slow process involving considerable expenditure and much less 'reproductive' revenue than Vogel had predicted. ${ }^{49}$ Secondly, the unwillingness of Parliament to adopt Vogel's plan to set aside land as a guarantee on the borrowed money, created a fatal flaw in the scheme. ${ }^{50}$

Most important, the predominance of provincial interests meant that political alliances were being formed simply on the basis of the distribution of borrowed money. 'The expenditure of money is popular' he wrote, 'and it matters 1ittle how the Government proposes to effect it'. 51 He deplored a situation where each representative was left to fight for his own district, without considering colonial interests as a whole. 52 Worst still, with the house 'full of speculators ... of the worst possible political characters', not only would provincial interests dominate, but the small farmer, the genuine settler, would be ignored. 53

There was, however, a considerable amount of new settlement, ${ }^{54}$

48. EH, 12 Aug. 1870 .

49. $\overline{\mathrm{EH}}, 19$ July 1872 .

50. $\overline{\mathrm{EH}}, 4$ Aug. 1872 .

51. $\overline{\mathrm{EH}}, 19$ Oct. 1871 .

52. $\overline{E H}, 17$ May 1872 .

53. $\overline{\mathrm{EH}}, 27$ Oct. 1871 .

54. Assessing exactly where, when, and how much land was sold, is not that straightforward. Figures for land holdings based on electoral districts give some indication, though comparisons over a number of years are difficult, as boundaries were constantly changing. Holdings in Wanganui Electora1 District (which did not include Rangitikei and Manawatu, two major areas of new settlement), increased from 121,584 in
1867 , to 168,767 in 1874 (in this year $63 \%$ of holdings were held freehold). Figures from New Zealand Statistics, 1867, table 22 and New Zealand Census, 1874, p. 258. Figures for the province as a whole are of course available. Land under crops, plus land broken up but not under crops, rose from 136,204 acres in 1869 to 203,171 acres in 1872 , New Zealand Statistics,
65,155 'country' 1876, p. 198 . In 1872, the province sold
New Zealand Statistics, 1872, part III, table 8. 
particularly once a decision on the positioning of railway lines in the province had been made. ${ }^{55}$ Ballance welcomed, in part as a vindication of his own efforts, the announcement in early 1872 that the Provincial Government was to set aside 45,000 acres for sale on deferred payment, under the Wellington Special Settlements Act of the previous year:

\begin{abstract}
The boon of obtaining land on deferred payments has been strenuously struggled for by a large section of the working men in this province for several years, and its realisation now will be a source of unalloyed satisfaction, not only to them but to those who believe that the settlement of the country can best be carried out in aiding the frugal and industrious, through a generous and liberal system of legislation, to occupy and cultivate the lands. 56
\end{abstract}

As editor of the town's evening paper, and because of his activities during the war, Ballance was by the end of 1869 a we11-known local personality. Over the following two years he was to establish his own political credentials as well. His decision to stand in a by-election for the General Assembly in 1872 came as no surprise. The foundation for his first venture into politics had been well laid by his involvement in local affairs and promotion of a wide variety of local organisations.

Indeed it seems safe to conclude that Ballance had politics as a career (albeit in tandem with journalism) in mind ever since his first year in New Zealand. The Herald provided the perfect medium for his views. Significant1y, he was never interested in standing

55. See, for example, EH, 1 Feb. 1872. On this occasion sections in Wanganui town, at Campbel1town, 21,800 acres in Manawatu (Foxton, Palmerston, Fitzherbert etc.), were being sold. By 1877 Wellington Province, an area of some 7 million acres, had disposed of 1.7 million acres, excluding the confiscated lands; New Zealand Statistics, 1877 , p. 196.

56. EH, 1 Feb. 1872. 
for local government or for the Provincial Council. He saw the General Assembly as the centre of political power, and was confident and ambitious enough to be satisfied with nothing less than a seat in that chamber.

Before becoming a candidate himself, he promoted others for office. His brother-in-law, William Finnimore, received Ballance's full support when he stood for the Superintendency of Wellington Province 57 on the basis that if elected he would make every effort to have the Provincial Council abolished. ${ }^{58}$ Ballance also supported Bryce's candidature both for the Provincial Council and the General Assembly. ${ }^{59}$ Though temperamentally quite different, Ballance and Bryce formed an early friendship. Bryce had come to Wanganui earlier than Ballance, and had been Wanganui's representative in the Provincial Council, with a gap of two years, since $1862 .^{60}$ They agreed on the unsatisfactory position of Wanganui within the provincial system, but with abolition more fundamental rifts soon became apparent, and they drifted apart, finally ending as political opponents. 61

57. EH, 18 Mar. 1871.

58. $\overline{\mathrm{EH}}, 19 \mathrm{Apr} .1871$. Finnimore (who with Watt, Hutchison and Morgan represented Wanganui on the Provincial Council, see EH, 13 Jan. 1871) was the local abolitionist candidate, and naturally polled well in Wanganui town. He did reasonably well elsewhere. Fitzherbert, a supporter of Featherston, the retiring Superintendent, won on his support in Wellington town: Fitzherbert 669, Finnimore 307, and a third candidate, Anderson, 15. See EH, 20 Apr. 1871.

59. For example, EH, 3 Oct. 1870; EH, 14 Oct. 1870.

60. John Bryce was born in Glasgow in 1833 , and emigrated to New Zealand with his father in 1840. He farmed at Brunswick, near Wanganui from 1853 to 1903 . Now an abolitionist, he had been elected to the General Assembly as Wanganui's representative in 1866.

61. Ballance nominated Bryce as a candidate for the General Assembly at the start of the latter's political career. Ironically, when Ballance was Premier, Bryce, following Atkinson's death, was for a while Leader of the Opposition. 
Another means Ballance employed to promote himself as a suitable representative of Wanganui, was his continual criticism of present representatives. This was done not only through the Herald. In late 1869 he chaired a meeting to grill members of the Provincial Council on their conduct during the session just ended. He felt particularly grieved at their support for the Schools Bill (which allowed the Provincial Government to impose a school rate), and complained that the proposed system would be fundamentally unjust, since 'the labourer who earned his bread by the sweat of his brow (would have) to pay the same as the wealthiest man in the community'. Education should be provided for out of general revenue. ${ }^{62}$ Ballance was the major figure at the meeting, making things rather uncomfortable for the representatives, and especially for Hutchison, who had been instrumental in having the Bill introduced. 63

Also, Ballance was at the fore of a campaign to bring a greater degree of local government to the town, through the acquisition of powers exercised by the Provincial Council. This could be done by constituting Wanganui a Borough, under the terms of the Municipal Corporations Act of $1867 .^{64}$ As soon as the Act was passed Ballance urged that a petition be drawn up, ${ }^{65}$ but it was not until early 1871 that one was ready for signing. 66 There was some opposition to the

62. For Ballance's early views on education, see also EH, 7 June 1872; 'Every child of poor parents ought to have its education free, and of the best to be had in any country in the world'.

63. EH, 15 Dec. 1869.

64. Eighty ratepayers could petition for a borough, and a corporation consisting of a mayor and nine councillors which could levy rates up to $1 /=$ per $f$. The Provincial Government had the power to withdraw the equivalent amount of its financial support for the town.

65. EH, 16 Oct. 1867 .

66. $\overline{\mathrm{EH}}, 16 \mathrm{Jan} .1871$. The question was raised by Finnimore at a meeting of the Town Board, a body which had been established in 1862 (under the terms of the Public Boards Act, of the Provincial Council, 1856) to manage local public works, streets, sewerage etc. See EH, 29 Dec. 1870. 
idea, ${ }^{67}$ but a second petition was successful and on 1 February 1872 Wanganui was constituted as a Borough. ${ }^{68}$ In supporting this extension of local government, Ballance at the same time made it quite clear what the limitations on the functions of the borough ought to be. On the eve of the Town Board meeting expected to discuss the question, he specified the division of responsibility between local and central government. Matters of local concern included paving, lighting, water and gas supply, parks and the provision of free libraries. 69

The Herald was frequently used by Ballance to organise, promote, and explain the purpose of, local organisations. One, called the Political Reform Association, seems to have had only an ephemeral existance. It was formed by a meeting in the town on 4 May 1871, when John Bryce was in the chair. Ballance proposed that the Association be established, and the resolution was carried unanimous $1 y .70$ The Association met again three weeks later, when its political principles were outlined. They were very general: the economic administration of the colony, the abolition of the provincial system, and the support of candidates sympathetic to the Association's views. Perhaps because of this very generality, the association seems to have disappeared without a trace; there are no accounts of its activities in subsequent issues of the Herald. 71

Much more significant was Ballance's promotion of, and participation in, the Odd Fellowship Society, formed in Wanganui in 1867. Though not

67. See Chapple \& Veitch, p. 284.

68. W.H. Watt was elected first Mayor, EH, 14 Feb. 1872.

69. Ballance used writings of John Stuart Mill to support his argument, EH, 28 Dec. 1870.

70. $\overline{\mathrm{EH}}, 5$ May 1871.

71. $\overline{\text { See }}$ EH, 25 May 1871 for a report of its second meeting. 
essentially a 'political' society, Oddfellowship reflected Ballance's own philosophical beliefs as well as his personal experiences.

The Ancient Independent Order of Odd Fellows (with 'Iodges' or branches in New Zealand, Australia and the U.S.A.) emulated its parent organisation, the English friendly society, the Manchester Unity of Odd Fellows. This latter body was the largest of its kind in England, with over 400,000 members in $1872 .^{72}$ Like other friendly societies, it aimed to provide sickness and life insurance through regular subscriptions of members, but the Oddfellows had extended these benefits to include such things as widow and child relief, and assistance for sickness in old age. Membership was drawn disproportionately from artisans in building trades and traditional handicrafts: the society represented upward social mobility; the success of self-made men who aspired to the ranks of the middle class. ${ }^{73}$

Ballance was involved in the Wanganui society from its foundation. He was 'Noble Grand Master' of the Lodge ${ }^{74}$ and later Deputy District Grand Master of the North Island. In fact the society was restricted to the Wanganui area, ${ }^{75}$ and to Dunedin in the South Island. ${ }^{76}$ For

72. This and the following information on the English society is taken from T.B. Tholfsen, Working Class Radicalism in Mid Victorian England, London, ch. 9.

73. The Oddfellows combined philanthropic and didactic functionsinterestingly, given Ballance's connection with the town, the

74. EH, 19 July 1871 .

75. Lodges were opened in Marton in 1872, and Bulls in 1873, EH, 1 July 187

76. EH, 27 Apr. 1869. The Manchester Unity itself had a much larger membership in New Zealand than the American-based I.0.0.F. See AJHR, 1877, H-19, Friendly Society Returns. H. Shepherd, 'The Nature and Role of Friendly Societies in Later Nineteenth Century New Zealand', Research Essay, Massey University, 1976, appendix table III, gives I.0.0.F. membership as 396 in 1880,724 in 1890 and 1,941 by 1900 . See also H.W. Gourlay, Odd Fellowship in New Zealand, Christchurch, n.d and J.K. Hoar, 'A Descriptive History of the Major Aspects of the Friendly Society Movement in New Zealand, 1840-1900', M.A. thesis, Idaho, 1963. 
Ballance the society epitomised his belief in self-help and self-reliance. It showed that through organisation the working classes could provide for their own material wants. More than this, it combined an educative role with the general aim of raising the whole position of its working class members: it was the 'great leveller of civil society':

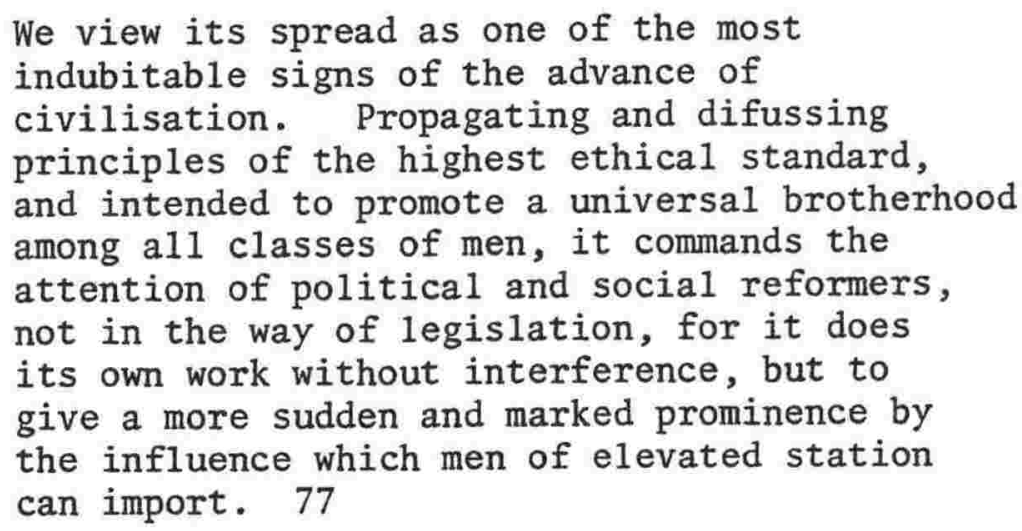

Apart from providing insurance and charitable relief, the Wanganui society concentrated in its early years on constructing a building, the upper floor of which was to be reserved for lodge meetings, with the lower floor devoted to a reading room available, free of charge, to the public. Ballance opened 'The Institute', as it was called, in July 1874. In his speech, and no doubt with his own debt to the Midland Institute in Birmingham in mind, he emphasised the importance of this latter 'noble' function. He hoped that soon the reading room would become a well-stocked library, promoting technical as well as general education:

This Institute, it is hoped, will be the centre of enlightened teaching in science, not only through books, but experimentally... . We suffer 
from the evils of defective laws and bad administration, or we should have had before now our technical school of art and science supported out of endowments and educational revenue. But... (w)e should not remain satisfied with what we have already achieved. All progress depends on the desire to accomplish greater results than what have gone before. Besides, the mind is in the healthiest state morally and intellectually, when it is braced for action. The principle of "rest and be thankful" 78 has been exploded; there is no finality in any work of man or in nature. 79

On 6 September 1872 the Fox Ministry, which was dominated by Vogel and had been in power since June 1869, resigned. It was defeated by three votes, after a long debate on the administration of the Public Works and Immigration Policy, being replaced by a Ministry bent simply on a more 'prudent' continuation of that policy. Stafford, an abolitionist who headed the ministry, had been Premier twice before. With him, somewhat incongruously, were the Superintendents of three provinces, Fitzherbert, Curtis and Gillies. The fifth member of the Ministry, Henry Sewe11, 'had been in so many ministries that no one regarded him with confidence'. 80 Ballance, who had been a supporter of Stafford, welcomed the fall of Fox, and hoped that Vogel's scheme might still be rescued from disaster:

78. Interestingly, this was Atkinson's plea when he was Premier of the 'scarecrow ministry' of 1887-90 and Ballance Leader of the Opposition.

79. EH, 1 July 1874. Ballance's interest in science connects with his freethought views (see ch. 6). It is a marvellous speech. Ballance, having outlined the short history of the Oddfellows in New Zealand, discussed its role in Wanganui and in society as a whole. It is thoughtful, well-prepared, at times amusing, and philosophical; revealing in Ballance a great sense of mission and optimism about the future. Ballance also sustained his interest in land and building societies. See EH, 17 Oct. 1872 on the Wanganui District Land and Building Society. 80. W.P. Morrel1, The Provincial System in New Zealand, 1852-76, London,
1932, p. 218. 
...the most corrupt and unprincipled Ministry that ever defaced the political annals of a country, has just been hurled from power into ignominy. ....Never did any Ministry assume office under more favourable auspices than did the Fox Ministry. ...The minds of the people were bewildered, and their senses dazzled with the gorgeous grandeur of schemes and the fulness of promises. (What has been the result?) ... (T)welve miles of railway, a few hundred miles of road, a handful of indifferent immigrants, on the one hand; and, on the other, the ordinary revenue and over a million of borrowed money expended. ... In the hands of careful administrators... the country has still a great future. ...The watchwords of the new Ministry should be, 'Reform and Economy'. 81

Meanwhile, Gisborne, who had been Colonial Secretary, and for a few weeks Minister of Public Works, in the Fox Ministry, resigned his seat for Egmont. ${ }^{82}$ Ballance decided to stand at the by-election. He published his address to the electors in the Herald on 13 September, saying that he felt justified in coming forward because of his promotion over the last five years, of bona fide settlement. He welcomed the change in government, since now prudence would replace recklessness: ' $(t)$ his is a time in the history of the colony when there should be capacity and economy in the Government and honesty in the Legislature'. Dëvelopment should continue, and great prosperity was possible, but there were grave dangers that excessive borrowing would lead to 'financial ruin and dishonourable repudiation'. His second plank concerned the constitutional position of the provinces. Quoting Mill (that human nature was continually changing and developing), he argued that gradual reform of the provincial system should commence at once, without waiting until the whole system might be abolished at one

81. EH, 7 Sept. 1872 .

82. $\overline{\mathrm{He}}$ had been appointed Commissioner for the Government Life Insurance Office and was obliged to resign under the terms of the Disqualification Act. 
Ballance's campaign lasted ten days. The constituency of Egmont consisted of two major settlements, New Plymouth and Patea, one at each end. It was this latter, 'Wanganui end' that would provide Ballance with his support. The Taranaki Herald, on hearing of Ballance's candidature, correctly asserted that he would receive 'little or no support' from New P1ymouth. ${ }^{84}$

Ballance exploited Patea's position as an outlying district of Taranaki Province: many in Wanganui had for a long time claimed that Patea's interests and future lay with her (Wanganui) rather than New Plymouth. He spoke in the town on 18 September. The Herald correspondent described the speech, lasting three and a half hours, as 'wonderfully good'. The meeting was held in an old corrugated iron shed. . Apparently Ballance later said '...how nervous he was that night, and that he was glad he was speaking in a dimly-lighted room, because the people could not see his knees knocking together when he rose to speak'. ${ }^{85}$ Two days later he addressed the Hawera electors, who were, again in the opinion of the inevitably partisan Herald, 'surprised and delighted' with Ballance's performance. ${ }^{86}$

83. EH, 13 Sept. 1872. Ballance said, in 1881, that abolition was his central policy at this election (see $Y, 4$ June 1881). He thus played down differences between himself and Vogel, whom he was to join in a ministry in 1884 .

84. 18 Sept. 1872. The Taranaki Herald supported Moorhouse, the Taranaki News Atkinson. The Wellington newspapers were equally divided: the Evening Post, interested in Ballance's candidature primarily as a means of defending him from the personal abuse of its riva1, the Independent, supported Atkinson (see for example, EP, 18 Sept. 1872). The Independent, under the strong influence of Fox, supported Moorhouse. The Post's defence of Ballance, referred to in ch. 2, concerned his activities as an 'itinerant vendor' of jewellery. See EP, 20 Sept. 1872 .

85. Quoted by W.K. Howitt, A Pioneer Looks Back Again, Auckland, 1947, p. 265 .

86. Both meetings were reported in EH, 26 Sept. 1872. 
Yet despite the optimism brandished through the pages of his own paper, Ballance soon realised that election would be difficult to achieve. There were two other candidates; W.S. Moorhouse, who had been Superintendent of Canterbury Province ${ }^{87}$ was a personal friend and supporter of Fox, and a consistent advocate of Vogel's public works' policy, and Harry Atkinson who, like Ballance, supported Stafford. It was clear that Moorhouse would probably win with Ballance and Atkinson splitting the pro-Stafford vote. Atkinson had been present at Ballance's Hawera meeting, ${ }^{88}$ and their campaigns were in general closely linked. Through pressure from Stafford ${ }^{89}$ and discussing the matter with Atkinson, ${ }^{90}$ Ballance decided to retire.

Retirement was facilitated by a 'face-saving formula', which pointed out that the rejection of about eighty freeholders in Patea and environs from inclusion on the electoral roll ('though despicable conduct on the part of someone') ${ }^{91}$ meant that Ballance could not hope to be successful. In withdrawing his candidature, he said:

As Major Atkinson is, like myself, an independent supporter of the present administration, I might by determining

87. Between 1857 and 1863. He was M.H.R. for Akaroa, 1858 to 1860 . In 1870 he was appointed Secretary for Lands and Land Claims Commissioner, and soon afterwards Registrar-General of Lands. He resigned these civil service posts in order to fight the by-election. The Herald criticised his policies and questioned the success of his campaign. It reported, for example, that only three people had attended his Patea meeting, EH, 24 Sept. 1872.

88. EH, 24 Sept. 1872 .

89. Writing to Stout years later, Ballance said that Stafford had made the initial suggestion. Ballance to Stout, 17 Nov. 1890 , Stout MSS.

90. See Ballance's account in $Y, 14$ May 1881 .

91. EH, 19 Sept. 1872 . 
to go to the po11, have injured the cause in allowing an ally of Mr Vogels to be returned, thus strengthening a party whose return to office I should consider fatal to the honor and financial stability of the colony. 92

He urged his supporters to vote for Atkinson.

As it turned out, Stafford, Atkinson and Ballance were right. Atkinson won by the slim margin of twenty-four votes, and it was his majority in Patea (forty-six to seventeen) that was the critical factor. 93 Once in the House, Atkinson asked for a return of the rejected claims to be produced (this may well have been a part of his agreement with Ballance, who continued to publicise his grievance through the Herald). ${ }^{94}$

The Stafford Ministry was short-lived, being defeated on 4 October by a no-confidence motion spearheaded by Voge1. The mixed personnel of the Ministry was a major cause of defeat, though Ballance put it down to its inability to attract the critical support of Donald McLean, the influential ex-Minister of Native Affairs. 95

92. EH, 23 Sept. 1872.

93. Atkinson won in New P1ymouth (38 to 34 ), Omata (14 to 9) and Patea 46 to 17$)$. He lost to Moorhouse in Oakura (16 to 30$), \mathrm{EH}, 7$ Oct. 1872.

94. See, e.g., EH, 24 Oct. 1872. In fact it was Bryce who asked the original question requesting the returns (PD, 1872, 13, pp. 669-70), Atkinson supporting him. Atkinson, two days later, asked the Government if the opinion of the Attorney-General could be sought on the matter. The return (see AJHR, 1872, G-49) showed that fiftyeight claims had been rejected in 1872 (only fifteen in 1871). It was a significant number in a total roll of 266 . What appears to have happened is that Ballance made a desperate effort to have prospective supporters placed on the roll. In the haste mistakes were made in the applications, and by the time claims had been returned to the electors for correction, it was too late to have them included on the final roll.

95. EH, 8 Nov. 1872 . 
The momentum of Ballance's political career was sustained by his promotion, six months after his withdrawal from the Egmont contest, of a revived separation movement in the town. This resurgence of separatist feeling reflected Wanganui's belief that it was being unfairly excluded from the increased revenue of the Province. ${ }^{96}$ It was not now a matter of overcoming stagnant economic conditions inherent in provincial finances, so much as the town seeking to obtain its fair share of rising prosperity. Ballance pointed out that of the proposed new loan of $\mathbf{f} 210,000$, to be expended on public works, the area between northern Wanganui and southern Rangitikei, containing at least one third of the province's total population, was to receive only $₫ 5,000$ :

We can only tolerate provincialism when we find it attempting to scatter the gifts with which our constitution has endowed it, with an impartial hand. When it appropriates them for its own aggrandisement or upon a system of favoritism, we look upon provincialism as a thing which should be reformed out of existence by short, sharp, and decisive means. .... Let us again demand separation from Wellington, with the formation of a cheap and economical county government, embracing the district from the Waingongoro river to the Rangitikei. ...A united and earnest attempt to obtain from the legislature the political independence which we consider necessary to our prosperity and growth, is most 1ikely to be favorably received in the Assembly. 97

Ballance was at pains to make it clear precisely what the Separation Committee, formed following a meeting in the Oddfellows hall

96. After declining between 1867 and 1870, revenue increased continuously over the following few years. The greatest increase was in 1873, the year of the separationist revival, when it rose to 240,433 , an increase of $80 \%$ on the previous year, New Zealand Statistics, 1876, p. 173.

97. EH, 22 Apr. 1873. On the earlier separation movement, see ch. 2, pp. 52-53. 
on 5 May 1873, wanted. They did not seek a new province, nor a county on the Westland mode1, 98 but rather a 'shire'. Most important, land sales and revenue would be administered by the general government. 99 Ballance was a leading figure of the campaign. He spoke at all the meetings held. Wanganui, he said, could survive on its own; in fact it was going to become the centre of the foremost district in the country. 100 Quoting from provincial statistics, he showed just how badly Wanganui fared under the existing system. ${ }^{101}$ He spoke for the first time at Marton, emphasising how closely the interests of that settlement were tịed to those of Wanganui. ${ }^{102}$ This theme of local independence was repeated in his speech, in June, at a meeting called to question the activities of Wanganui's provincial councillors. ${ }^{103}$

A petition calling for separation was organised. Containing 1108 signatures, it was presented by John Bryce (Wanganui's M.H.R.) to the House on 31 July. ${ }^{104}$ Shortly afterwards, Bryce moved the second reading of the Wanganui, Rangitikei and Patea Shires Bill, arguing that as Wanganui was already a corporate council, and as so few powers remained with the Provincial Government, there would be little difficulty in legislating for complete separation. ${ }^{105}$ Voge1, though accepting that

98. Westland, originally part of Canterbury Province, had been constituted a separate County in 1867. It was a 'half-way house' to full provincial status, with the powers of superintendents vested in the Governor, who was in turn advised by a County Council. Westland became a Province in 1873.

99. EH, 11 June 1873 .

100. $\overline{\mathrm{EH}}, 6$ May 1873.

101. $\overline{\mathrm{EH}}, 1$ May 1873.

102. $\overline{\mathrm{EH}}, 23$ May 1873.

103. $\overline{\mathrm{EH}}, 21$ June 1873.

104. $\overline{\mathrm{PD}}, 1873,14$, p. 191 ; EH, 28 July 1873.

105. $\overline{\mathrm{PD}}, 1873,14, \mathrm{pp} .662-6 \overline{8}$. Emphasising the lack of significant change that would be involved, Bryce's argument was much more 'conservative' than the one adopted by Ballance. 
it may not be the mover's intention, warned that the Bill would be a retrograde step, leading ultimately to the creation of a new province. He would by far prefer to see Wellington and Taranaki Provinces combined. ${ }^{106}$ More vigorous opposition came from Wellington city members, from Fox (M.H.R. for Rangitikei but closely identified with Wellington) and others. The supporters of the Bill, including the members from New Plymouth, Egmont, Wairarapa, and Bryce himself from Wanganui, were finally outnumbered eleven to twenty-five. Vogel abstained. 107

Ballance was well aware of Vogel's increasing frustration with the provinces, ${ }^{108}$ and soon the question of Wanganui's own position within Wellington Province became submerged in a general movement towards complete abolition. In August 1874 Vogel suggested that the provinces of the North Island be abolished. ${ }^{109}$ Ballance pointed out that provincialism had been created in the first place only in response to the limitations imposed by the geographical features of the colony. With those restraints no longer applicable, provinces in both islands should be abolished. 110 As the localisation of the land revenue was part of the Government's proposals, Canterbury and Otago need have nothing to fear. 111

106. PD, 1873, 14, pp. 668-69.

107. Ibid. See also EH, 28 Aug. 1873.

108. Particularly with regard to their borrowing activities, see for example, EH, 25 Sept. 1873.

109. The specific cause of Vogel's 'conversion' was opposition to his Forests Bill, but he was fed up with provincial interference in general. See Morrell, ch. X.

110. EH, 19 Aug. 1874 .

111. $\overline{\mathrm{EH}}, 9$ Sept. 1874. Land revenue accounted for a considerably larger proportion of total revenue in Otago and Canterbury than elsewhere. Indeed it was at times larger than the other major source of revenue, customs duties. In Auckland the situation was the reverse- revenue from land sales made up, approximately, only one-tenth of total revenue. New Zealand Statistics, 1876, p. 173. 
It was clear that Voge1's Bill to abolish the North Island provinces only was the thin edge of the wedge. ${ }^{112}$ Ballance stressed that with abolition control of the land must pass to the central government, though the appropriation of the revenue would remain the same; part going to general revenue, part returned to local bodies for public works. ${ }^{113}$ Maladministration of the 'waste lands' by the Provincial Governments he saw as a major reason for abolition. The reckless sale of land should cease, and genuine settlement be encouraged by central government. 114 'Genuine settlement' meant small farms for the working classes. Payment should be deferred, and the terms should be easy. Why should the working man,

...with 1ittle more than his 1abour,...pay

a greater price than the grazier or the mere speculator. Why indeed?...It is high time the barriers which favor capitalists in the Wellington province were broken down, and that the working man had a chance. .... (A) heavy responsibility rests on the Government of the colony in the first instance as to the way in which they deal with the public estate. 115

The Government promoted settlement of the less we11-off not only through a system of deferred payments, but in 'special settlement' schemes. Special settlements originally consisted of groups of immigrants (from the same country), the cost of whose passage and establishment on the land was at least partly borne by the government. Many of these early schemes, a means of clearing land heavily covered with bush, were in Wellington and Hawkes Bay provinces. ${ }^{116}$ Ballance

112. EH, 4 Dec. 1874 .

113. $\overline{\mathrm{EH}}, 27$ May 1875 .

114. $\overline{\mathrm{EH}}, 17$ May 1875 .

115. $\overline{\mathrm{EH}}, 24 \mathrm{Feb} .1873$.

116. A portion of, and in some cases a11, the money expended by the Government was to be repaid later by the settlers. See, for example, expenditure on special settlements in 1873, AJHR, 1873, D-13. In this year al1 the settlements were of Scandanavians: Palmerston, Manawatu, Mauriceville, Forty Mile Bush, Seventy Mile Bush, Dannevirke and Norsewood. See also part III of R. Arnold, The Farthest Promised Land, Wellington, 1981. 
was concerned that these and other immigrants should have at least some capital, and be determined and equipped to become 'genuine' small farmers. ${ }^{117}$ He saw emigration as a means employed by England to lessen the effects 'of its own pauperization'. The Imperial Government's support of colonial loans rested on her hope of working off her surplus population. ${ }^{118}$

In this period, between Ballance's withdrawal from the Egmont contest and his election for Rangitikei in 1875 , the broad base of his liberalism became apparent. The Herald followed closely events in England. Ballance supported Gladstone's liberal administration (1868-74), describing it as probably the best ministry England had ever had. 119 Using Gladstone's arguments, he urged that taxation should be reduced rather than increased. ${ }^{120}$ He favoured government assistance for colonial industry, though it should be in the form of bonuses rather than protection. ${ }^{121}$. Increasing the price of imported goods would be 'taking money out of the pockets of one class and putting it into the pockets of another', much less desirable than stimulating home industries through bonuses. ${ }^{122}$ He frequently quoted Mi11, for example in support of his own belief in granting women equal

117. EH, 13 June 1870; EH, 28 May 1872; EH, 15 Sept. 1874.

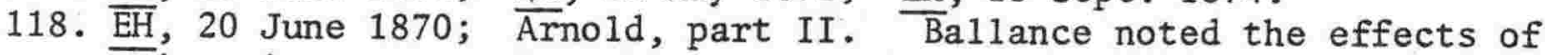
emigration on agrarian unrest in England. Though it might raise wages through a reduction of the supply of labour, he saw a general trend towards increasing demands by labourers for land tenure reform, EH, 26 Mar. 1873.

119. 'We, who believe strongly in the spirit of liberalism, and who have an unbounded admiration for $\mathrm{Mr}$. Gladstone and $\mathrm{Mr}$. Bright, should not be disclined (sic) to see them retire for a session in order to recruit those moral forces upon which party success so greatly depends'. EH, $18 \mathrm{Feb}$. 1874. See also EH, $21 \mathrm{Mar} .1873 ; \mathrm{EH}, 27$ Dec. 1873.

120. Through the reduction of ad valorem duties. EH, 4 May 1874.

121. EH, 5 July 1870 .

122. $\underline{\underline{E H}}, 27$ Nov. 1871. See also EH, 11 Feb. 1871. 
political rights: '(i)n every sense the interests of civilisation seem to demand that women shall be placed on a perfect legal equality with man'. ${ }^{123}$ He praised the Bill passed by the Victorian Government in Australia, on Industrial and Friendly Societies, pointing out the value of Owenite cooperatives in England:

The state must recognise the importance of cooperation amongst the working classes.... The labourer has no chance in this life against the capitalist except by cooperationthe strength of members working in unison. 124

Finally, Ballance's liberal sentiments were revealed through his views on education. The State had a duty to provide all children with a 'liberal' and 'popular' education; an education 'of the culture of the masses who subsist by physical toil of various kinds, and whose poverty places beyond their reach those educational advantages enjoyed by the wealthier classes'. 'Every child of poor parents ought to have its education free, and of the best to be had in any country in the world'. ${ }^{25}$ From the start Ballance favoured a state, non-sectarian, system of education. Religion had no place in schools, though religious liberty would permit catholics to maintain instruction of their own children:

Education will be judged by results, and the State has nothing to do with the amount of religious instruction which may be imparted. Roman catholics are quite as anxious for the secular education of their children as protestants can be for their own, and if they desire to superadd religious instruction, religious liberty will allow

123. EH, 6 Jan. 1874. See Ballance's memorial to Mil1, EH, 31 May 1873. 124. $\overline{\mathrm{EH}}, 15$ Nov. 1873. 
them to do so without injury to the civil rights of others. 126

At the beginning of 1875 , William Fox, the provincialist ex-Premier consistently opposed by Ballance, resigned his Rangitikei seat $i \bar{\Lambda}$ order to pay a visit to England. Ballance immediately declared his intention to stand at the by-election. ${ }^{127}$ He was the youngest candidate. His opponents were W.H. Watt and George Hutchison. Watt, a member of the Provincial Council and a provincialist allied to Fitzherbert, was supported by the Herald's rival, the Wanganui Chronicle. ${ }^{12}$ Realising however, the extent of anti-provincialist feeling in the town, he declared himself an abolitionist part way through the campaign. ${ }^{129}$ The third candidate, Hutchison, a lawyer whose loyalties were divided between business in Wellington and Wanganui, was from the first an 'outsider'.

The campaign brought the Herald and the Chronicle into closer combat than ever before. The Chronicle doubted that Ballance possessed a single qualification entitling him to the seat, ${ }^{130}$ and criticised the dubious character of his supporters. ${ }^{131}$ The Herald responded in

126. EH, 11 May 1874 .

127. $\overline{\mathrm{EH}}, 1 \mathrm{Mar} .1875$; $\mathrm{EH}, 3$ Mar. 1875.

128. William Hogg Watt had come to Wanganui in 1842 . With his partner, T.B. Taylor, he had established a shipping business along the coast, and later built a large store on Taupo Quay. He became a wealthy man, his firm at the centre of commercial activity in the town. Mayor from $1872-1873,1875-1878$ and $1880-1881$, he was the town's representative in the General Assembly between 1881 and 1884 . He died in 1894. (Incidentally, Taylor was drowned in Cook Strait in 1871. The firm was wound up in 1881). See Chapple \& Veitch, pp. $39-40,111$.

129. WC, 20 Apr. 1875.

130. $\overline{\mathrm{WC}}, 6 \mathrm{Feb} .1875$.

131. 'We know full well that the froth of the district is very loud spoken on Mr. Ballance's side, but unfortunately for their candidate they have few votes, and can do him no greater good than such tap-room politicians can be expected to render so fitting a representative', WC, 30 Mar. 1875. See also WC, 4 Mar. 1875; WC, 6 Apr. 1875. 
similar vein. Commenting on Watt's meeting at Bulls, it described his speech as

a weak attempt to answer Ballance, (which) ended in a ludicrous fiasco. Four held up their hands for a vote of confidence, two of them being the candidate's sons. $\mathrm{He}$ dwelt largely on the insinuations about the honorarium. Impossible to describe either speech or scene. 132

Ballance's election platform was more sophisticated than it had been three years earlier. Abolition of the provinces remained a major plank, with revenue to be divided between the General Government and local bodies. He favoured an educational system funded by the state, and supported the public works and immigration policy so long as economic conditions in the colony could sustain it. Finally, he argued that special facilities should be provided to encourage bonâ fide settlement. 133

Ballance delivered election addresses in all three polling areas: Marton, Bulls and Turakina. His 'painstaking' canvass of the upper part of the Rangitikei district, that closest to Wanganui, met, reported the Herald, with a good reception. Settlers dreaded the idea of having a representative (i.e. Watt or Hutchison) whose interests were connected with Wellington. ${ }^{134}$ His speeches enlarged on the policy outlined in his published address; criticism of the Provincial Government for its neglect of the district, and the need for central government control of land if settlement was to proceed apace. Education was the responsibility of the state; taxation should be kept 
to a minimum, spending no more than circumstances required. ${ }^{135}$ At Marton, where Ballance held his 'most successful meeting', he spent much of his speech defending himself against a libel being brought against him by Fox, whom the Herald had called 'an old fool'. 136 The Chronicle described Ballance's Turakina speech as having contained 'an even larger amount of bunkum' than generally belonged to election addresses. Neither the Herald or the Chronicle reported the speech in ful1, but the latter took particular exception to Ballance's opposition to knighthoods. ${ }^{137}$

Though by the eve of the poll a11 candidates were agreed on the major issue of abolition, there were important differences between them. The Chronicle stressed Watt's political experience and his position in the town as an old and respected settler. Ballance's liberal views were we $11 \mathrm{known}$, and in an attempt to divert some of the obvious appeal they had for the recent working class settler, the Chronicle argued that it was 'men, not measures', that counted. Ballance, the 'more noisy candidate', had argued the reverse: measures, not men, ought to be the decisive factor in the contest. ${ }^{138}$ Watt deplored Ballance's rowdy meetings. The Chronicle, disputing attendance figures with the Herald, said the meetings reflected Ballance's 'philosophy of bounce and balance'. 139

135. EH, 14 Apr. 1875. Report of the Bulls meeting.

136. $\overline{\mathrm{EH}}, 14$ May 1875 .

137. $\overline{W C}, 14$ Aprl. 1875. See ch. 11 for criticisms by Ballance of knighthoods.

138. WC, 23 Apr1. 1875. The Chronicle was concerned that Hutchison votes, that would otherwise have gone to Watt, would let Ballance in. See also the letter in WC, 1 May 1875 concerning this.

139. WC, 19 Apr. 1875. 
The election was held on Saturday 24 April. The results showed a narrow victory for Ballance, owing to his majority at Marton:

\begin{tabular}{|c|c|c|c|c|}
\hline & Marton & Bulls & Turakina & Tota1 \\
\hline Ballance & 70 & 22 & 20 & 112 \\
\hline Watt & 47 & 23 & 35 & 105 \\
\hline Hutchison & 18 & 4 & 5 & 27 \\
\hline
\end{tabular}

The Herald suggested that Ballance, who was 'not a large landowner', was supported by a very large majority of the 'best class' (i.e. genuine small farmer) of settlers. Were it not for plural voting (large property owners coming into the district from elsewhere to vote), Ballance would, for example, have won in Turakina. ${ }^{141}$

When the General Assembly opened on 20 July 1875, the Government immediately announced its intention to abolish the provinces of the whole of New Zealand, not simply in the North Island. Vogel had gone to England during the recess. Though Pollen became Premier, it was Atkinson, as Colonial Treasurer, who was the leading figure in the Ministry, and who was to pilot the Abolition Bill through the House.

During the previous session Vogel had pointed out the small contribution that provincial revenue was making to public works and immigration expenditure on the one hand, and the persistent political interference by the provinces in that policy on the other: ${ }^{142}$ Now,

140. EH, 24 Apr. 1875; EH, 26 Apr. 1875. 141. $\overline{\mathrm{EH}}, 26 \mathrm{Apr} .1874$. See also WC, $26 \mathrm{Apr}$. 1875. There was little interest in the election outside Wellington Province. In Wellington itself the Evening Post, which according to the Wanganui Chronicle (4 Mar. 1875) had initially favoured Watt, welcomed Ballance's victory on the grounds that he 'at least knows his mind, and is consistent'. The Post was not impressed by Watt's 'weak' campaign. EP, 26 Apr. $18 \overline{75 .}$

142. PD, 1874,16, pp. 571-81. 
in this respect, only the Wellington provincialists had, arguably, any cause for complaint at this generalisation. Though her land revenue was declining, customs duties receipts had increased sufficiently for the trend of rising total revenue since 1872 to be sustained. Revenue in 1875 , more than double that of 1873 and nearly triple that of 1872 , was now increasing more rapidly than in any other province. ${ }^{143}$ The province had recovered from a previous deficit, and had been able to fund its own public works out of revenue when the Government refused to guarantee a $\$ 100,000$ loan. With its substantial land revenue of 1873 and 1874, Wellington had now a 'nice little balance at the bank'. ${ }^{144}$

Thus Ballance first entered Parliament on the eve of a critical constitutional and political crisis. He made his maiden speech on the Abolition Bill, the debate on which being opened by Atkinson on 6 August $1875:^{145}$ Ballance rose to speak, 'amidst loud applause', on Thursday 17 August. The speech was carefully prepared, well argued and concise. ${ }^{146}$ He supported abolition not only because of 'financial convenience' but since it would make the political system more democratic. As a liberal, he was especially sensitive to Grey's insistence, in an earlier speech, that removing the Provincial Governments would involve a fundamental attack on the democratic constitution. 'If by abolishing provincial institutions', said

143. In 1875 revenue declined in Taranaki, Hawkes Bay, Ne1son, Marlborough, Canterbury and Westland. It was static in Otago and showed a tiny increase in Auckland. New Zealand Statistics, 1876, p. 173. 144. Morre11, pp. 229-30, 244-45, 255. 145. PD, 1875,17 , pp. $218 \mathrm{ff}$.

146. Ballance was always at his best when delivering prepared speeches. He was weak in the extempore cut-and-thrust of debate. 


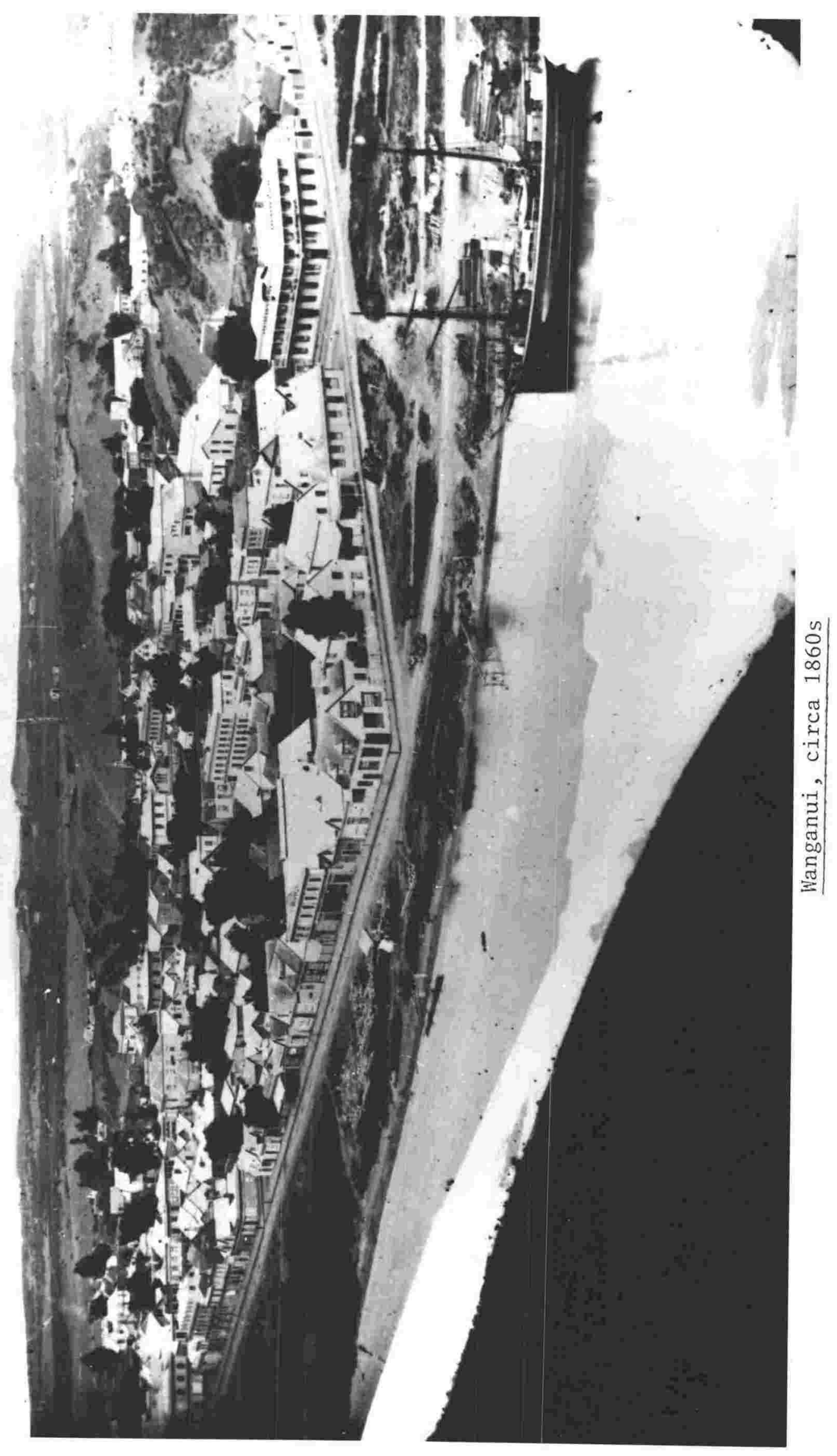


Ballance,

we destroyed our landmarks of 1iberty, or did anything whatever to curtail the calculated liberties of the people, I think that this House shculd seriously pause before it took any step in the matter. 147

Quoting Creasy's Constitutional History and De Tocqueville's Democracy in America, he argued that as the Councils were in fact already defunct, this would not be the case:

It appears to me that provincial institutions have not got within them that vital principle of liberty which would be a loss to us in case of their abolition. Liberty depends entirely upon power- that is to say, liberty will be reposed in the representative body which has the supreme power in the country. ... (T) his House is the seat of 1iberty, and not the Provincial Council. 148

Ballance, in the unusual position of being a liberal in favour of abolition, related the issue to broad political principles. ${ }^{149}$

147. PD, 1875,17, p. 391 .

148. Ibid.

149. Other leading liberals, for example Grey and Stout, opposed abolition. Ballance's position as a liberal abolitionist creates problems for those historians who regard abolitionists as wealthy men seeking greater control over land through their hold on political power in the General Assembly (for example, A. Saunders, History of New Zealand, Christchurch, 1896; W.P. Reeves, The Long White Cloud, London, 1899). It also means that viewing the opposition provincialists as the sole basis for the liberal party that emerged under Grey (e.g. G.H. Scholefield, New Zealand in Evolution, London 1909) is equally simplistic. Later historians have recognised that the situation was more complex. Though it is true that with abolition the centralistprovincialist cleavage was replaced by a more obviously liberal-conservative one, it does not follow that all abolitionists were conservatives and al1 provincialists liberals. A wide range of arguments were used by the protagonists during the abolition debate (see PD, 1875, 17, pp. 218ff.). As far as Ballance is concerned, it is clear that he used liberal principles upon which to base his opposition to the provincial system. 
Abolition ought to be seen in terms of the democratic nature of the New Zealand political system. Democratisation would come through abolishing the provinces and reforming parliament. Though he saw the existing franchise as sufficiently liberal, he believed that the Legislative Council should be reformed, so that it fairly represented the people. ${ }^{150}$ Finally, greater democracy would result if important functions were given to the local bodies. Decentralisation was for Ballance an essential prerequisite of abolition. Two years later he pointed out that there had been two types of abolitionist:

There is one kind who went in for placing more power in the hands of this Assembly, hoping that they might have more power to work out their selfish schemes. There is another kind of Abolitionist who, like myself, went in for Abolition because we thought we could focus the mind of the great mass of the people of the country in this Legislature, and have more liberal principles and sentiments established. 151

On the specific economic advantages of abolition, Ballance drew on Wanganui's experience as proof that provincial institutions dif not respond to the needs of the people. Especially with regard to the settlement of the land, it had been shown that the General Government, not the Provincial Council, encouraged bona fide settlement. He repeated the point that he had made many times in the Herald, that local bodies should retain a portion of the land revenue; though he disagreed with the section of the Bill that allowed part of this

150. Many abolitionists- large landowners whose political influence was exerted through the Legislative Council- would of course disagree with Ballance on this.

151. PD, 1877, 26, p. 538. 
revenue to be used for immigration purposes. ${ }^{152}$ He concluded:

I believe (this Bill) will make this a united colony. I believe the day of provincial institutions has passed; and that no mea.sures whatever, however skilfully framed, can rehabilitate a system which has become degraded and useless in the eyes of the people. 153

The speech was well received both inside and outside the House. ${ }^{154}$ Ballance instantly made his mark on colonial politics. ${ }^{155}$ The Herald printed the speech in full, and quoted other papers' praise of it. ${ }^{156}$ In Wellington the Evening Post, though it was critical of what Ballance had actually said, admitted that 'the House (had) rarely listened to a better maiden effort'. 157 There was equal praise from Auckland 158 and Christchurch. 159

During the remainder of the session, though Ballance concentrated his attention on promoting the interests of the district he represented, he did so through legislation embracing principles that he wished to

152. There was no guarantee, said Ballance, that immigrants would remain in the provincial district to which they had been brought. Also, if local bodies were to finance immigration, the General Government might respond by reducing its own expenditure on that item. PD, 1875,17, p. 396.

153. Ibid.

154. Stafford, commenting on the fact that his old rival, Fox, was no longer in the House, praised his successor, Ballance: 'we have already seen that the mantle of Elijah has fallen on a worthy successor; and there could not have been any speech more openly and conscientiously spoken, or one that has been better received, than that which has just been addressed to the House', PD, 1875, 17, p. 465. See also Bryce's comments, ibid., p. 530.

155. As did Stout, who was also making his maiden speech.

156. EH, 18 Aug. 1875; EH, 19 Aug, 1875; EH, 27 Aug. 1875.

157. $\overline{\mathrm{EP}}, 18$ Aug. 1875 .

158. $\overline{\mathrm{NZH}}, 19$ Aug. 1875; AES, 18 Aug. 1875.

159. $\overline{\mathrm{LT}}, 19$ Aug. 1875 . 
see applied to other parts of the colony. ${ }^{160}$ He moved the Municipal Corporations Loans Bill, which gave local bodies the power, given the approval of ratepayers, to contract loans. ${ }^{161}$ The Bill was defeated, though Atkinson supported it and promised to have its provisions included in a consolidating measure to be introduced the following session. ${ }^{162}$

Ballance also moved an amendment to the Abolition Bill, making hospitals and charitable institutions the responsibility of municipalities rather than central government. General Government control, he said, would be the 'thin end of the wedge of poor laws and State workhouses'. 163 Finally he urged the Government to introduce a bil1 next session providing for elementary education. 164

The Abolition Bill passed its second reading fifty-two votes to seventeen, ${ }^{165}$ though on condition that it was not to come into effect until after the general election due at the end of the year. In late October Ballance returned to Wanganui, ${ }^{166}$ where there was already speculation as to who might win the newly-created extra seat. Ballance

160. See, for example, Wanganui and Rangitikei District Court, PD, 1875, 17 , p. 123; Wanganui and Manawatu Railway, PD, $1875,17, \overline{\mathrm{p}}$. 375 . 161. PD, 1875, 18, pp. 363-68.

162. $\overline{\mathrm{EH}}, 27$ Sept. 1875.

163. The amendment failed; PD, 1875,18 , pp. $551,554,556$.

164. PD, 1875,19, p. 431 . Ballance's other activities include his successful lobbying, with Bryce, of the Government for an extra member for Wanganui (under the new Representation Act), and negotiation of Wanganui and Rangitikei claims to money voted by the Provincial Council. EH, 15 Oct. 1875.

165. The members from Hawkes Bay, Taranaki and Nelson (the poorest provinces) all voted in favour of abolition, as did members from the outlying districts of Auckland, Wellington, Canterbury and otago. Members from the provincial capitals, e.g., Grey, Sheehan, Fitzherbert, Bunny, Rolleston, Macandrew and Stout, made up the bulk of the opposition.

166. EH, 23 Oct. 1875. 
had been asked by the Government to assess the likelihood of Vogel filling the vacancy. Having spoken to a number of people about the matter, Ballance telegraphed Wellington to say that he thought that if Vogel stood he would be elected. He sought however, on the electors behalf, an assurance that if Vogel (who was still in England) was elected for other seats, he would sit for Wanganui. A meeting was held in the town, at which Ballance supported the resolution, carried unanimously, that Vogel be requested to stand. Ballance believed that Vogel would soon return from London, and be able to address the electors before christmas. ${ }^{167}$ His election would see great advantages for Wanganui; his influence would promote the settlement of the region, and he would be much preferable to the alternative, most likely a provincialist and opponent of the Government. 168

Ballance's own campaign, for the Rangitikei seat, largely reflected that of the by-election held nine months earlier. He looked forward to the abolition of the provinces, with part of the revenue from land sales being distributed by the General Government. Significantly, he did not oppose Grey's suggestion that the duties on tea, sugar and other necessities of life be completely removed. ${ }^{169}$ Taxation in general should be 'even'; 'all should contribute according to their means'. ${ }^{170}$ If there was to be new taxation, he would prefer a

167. Vogel didn't actually return until February 1876, a month after the election!

168. Details of Ballance's communications with the Government, and of the meeting in Wanganui, from EH, 12 Nov. 1875. The result of the Wanganui election was: Bryce $\overline{379}$, Vogel 360, Watt 191 (EH, 15 Jan. 1876). There was substance to the argument that if Vogel did not stand, a candidate (most likely Watt) much less sympathetic to the Government would have taken the second seat.

169. What he did say was that Grey did not propose an alternative. See J. Rutherford, Sir George Grey, London, 1961, p. 592.

170. EH, 16 Dec. 1875 . 
'tax on great estates or land monopolists to an income tax'. 171

Again he emphasised the importance of a state system of education.

Finally, land was for bonâ fide settlement and should not be viewed as simply a means of raising revenue. Small settlers on deferred payments must be encouraged rather than speculators.

James Bul1, Ballance's opponent, was an established settler in the Rangitikei, who had given the town of Bulls its name. He was a sawmiller, builder, storekeeper and hotel-owner. His businesses formed the commercial centre of the district. ${ }^{172}$ He had no political experience, and was not a strong candidate. The Chronicle, in its fairly luke-warm support for Bull, emphasised that he, unlike Ballance, was a resident of the district. ${ }^{173}$ Though it tended to criticise Ballance personally, rather than his policy, the Chronicle's labelling of him as 'flashy' and 'dangerous', had distinct implications of his political unacceptability:

We have from the first steadily and consistently opposed his (Ballance's) return; and we have done so- because, notwithstanding the command of language which enables him to charm a friendly audience, and the possession of ability sufficient to enable him to dilate pretty freely upon public questions generallywe esteem him to be an eminently unsafe man, who is a11 the more dangerous because of the flashy nature of his political accomplishments. ...It cannot be said that $\mathrm{Mr}$ Ballance disappointed the expectations of his supporters during the single session in which he represented the district in Parliament. 174

171. EH, 27 Dec. 1875 .

172. See L.J. Wild, The Life and Times of Sir James Wilson of Bulls, Christchurch, 1953 , pp. 18,22; M.H. Holcroft, The Line of the Road: History of Manawatu County, 1876-1976, Manawatu County Council, 1977, pp. 83-86. James Bull, settling in the district in 1858, 'seemed to become without conscious effort the central figure of a settlement'.

173. WC, 7 Dec, 1875 .

174. WC, $6 \mathrm{Jan}$. 1876. The Chronicle, as before, could not but support the establishment represented by Bull. 
What made Ballance's victory more certain, were the doubts sown by the Herald as to Bull's eligibility to take his seat if elected.

His firm of J. \& C. Bull was involved in a government contract for the building of the Oroua railway bridge, a fact that might well have forced him to resign under the terms of the Disqualification Act. ${ }^{175}$

In a turnout of around seventy-five per cent, Ballance won with a majority of seventy-four:

\begin{tabular}{|c|c|c|c|c|}
\hline & Marton & Bulls & Turakina & Total \\
\hline Ballance & 124 & 34 & 43 & 201 \\
\hline Bul1 & 59 & 41 & 27 & 127 \\
\hline
\end{tabular}

Bul1 was only just able to beat Ballance at Bulls, his home town. ${ }^{177}$

Shortly after the election the Herald made clear the direction of

Ballance's future policy, once the issue of abolition had been settled:

Those who retard settlement most are the land monopolists. They buy and buy until they swallow up half the country, to the exclusion of population and of homes. Sheep take the place of human beings, and civilization assumes a stunted growth in the "midst of a bleak and desolate country". The land monopolist will be found in the future the greatest obstacle to our progress, and an evil which will have to be met. ... (I)t is the bounden duty of Government to administer the Waste Lands so that they will not pass into the hands of speculators and monopolists... . 178

175. WH, 8 Jan. 1876.

176. Ibid.

177. There is little evidence to support Hunt's assertion that the campaign was a 'bitter' one, (J.L. Hunt, 'The Election of 1875-6 and the Abolition of the Provinces', M.A. thesis, Auckland, 1961, p. 247). The Wanganui Chronicle, recognising the much greater political ability of Ballance than of his opponent, was, if anything, less antagonistic to the former than on many other occasions.

178. WH, 22 Jan. 1876. See also WH, 4 Mar. 1876. 
Electors elsewhere had returned a substantial majority of abolitionist candidates. Only in Otago and Auckland were provincialists at all successful. None of the Wellington City candidates returned had stood on a provincialist platform. ${ }^{179}$

Before the opening of the new session Ballance made some changes to the Herald. John Notman, ${ }^{180}$ who had worked on the Herald staff before leaving for England, was persuaded to return to Wanganui to assume editorial control of the paper when Ballance was in Wellington attending Parliament. ${ }^{181}$ Willis, though still printing both the papers, had withdrawn from his partnership with Ballance, and Notman took his place. ${ }^{182}$ Ballance kept up with technological developments in the printing industry; a new 'labour saving' machine was imported (the first to use water power and to incorporate the self-delivery of papers when printed). Finally, Ballance changed the name of the Evening Herald to the Wanganui Herald. ${ }^{183}$

179. See Hunt, p. 244. Young's thesis, that 'in the Auckland Province, opposition to abolition was merely part of the radical protest against the Vogel regime' ( $\mathrm{J}$. Young, 'The Political Conflict of 1875', Political Science, XIII, 2 (1961), p. 78), is not inapplicable to Ballance, though in an altered form. Ballance's support for abolition centred on his belief that it was a necessary precondition for the promotion of central government policies favourable to working class settlers. The basis for his alliance with Grey and Stout had already been laid. See also J. Young, 'The Politics of the Auckland Province, 1872-1876', M.A. thesis, Auckland, 1960.

180. Notman, born in London, came to New Zealand in 1868. After spending some time on the Thames goldfield, he settled in Wanganui in 1870 , being employed by the Herald in that year. Cyclopedia of New Zealand, vol. 1, 1897, p. $13 \overline{69 .}$

181. Notman, who closely followed Ballance's political 'line', was frequently sent material for inclusion in the Herald by the latter when in Wellington. Until Duigan's appointment as full time editor in 1891 , Ballance would resume editorial control on his return from parliamentary duties. Some care is necessary, therefore, when attributing editorials to Ballance when he was out of Wanganui.

182. See $\underline{Y}, 6$ May 1893 . Willis started his own bookselling and printing busiñess, $\underline{Y}, 17$ June 1893 .

183. WH, 25 Mar: 1876. 
Vogel resumed the Premiership on his return from England in February 1876. With the abolition of the provinces now a certainty, Ballance devoted the session to making the new constitutional arrangements as favourable to the settlement and development of his district as possibie. Of especial interest was the Municipal Corporations Bill, a largely consolidating measure which, however, contained those powers of loan-raising that Ballance had sought to introduce with his own Bill of the previous session (see p.123). For Ballance it was not simply a matter of granting borrowing powers to local bodies so that they might pursue public works of their own. Through the rating system it involved an element of redistribution of wealth. ${ }^{184}$ He was convinced that it was the belief that granting borrowing and rating powers would 'endanger the rights of property' that had destroyed his Bill a year earlier. He agreed with Stout that local referenda held to decide on a special rate, should be on the basis of one man one vote. Finally, he objected to that part of the Bill that laid down that public meetings might be held only after a licence had been granted by the Municipal Corporation, ${ }^{185}$ and carried an amendment that extended the obligation of a Corporation to promote local education. 186

In August the question of abolition was finally settled. The provinces were replaced by counties and boroughs, subsidies and

184. See Municipal Corporations Act, 1876, part X.

185. PD, 1876, 20, pp. 403-04. 'The right of public meeting was as old $\overline{a s}$ the municipal laws themselves- even older; and that right should not be interfered with on slight grounds, or on the mere arbitrary wish of a Municipal Council'.

186. WH, 5 Aug. 1876. In this session Ballance also showed his opposition $\overline{\text { to }}$ temperance reform, speaking against Stout's Local Option Licensing Bill. He didn't believe, he said, in legislating on this issue. Combating drunkenness was 'a matter of education and of providing for the comforts of the people', PD, 1876, 20, p. 482 . 
obligations being laid down in the Financial Arrangements Act and the Counties Act. With only relatively small revenue-raising powers, it was clear that local bodies were to play a very limited role in developing the country, and that centralisation was to be almost complete.

Grey, fighting a rearguard action, proposed that the two islands be separated. Ballance, admitting that the House was to assume complete control over the administration of the land fund (though money would be expended in the districts where raised), believed that the new system could be altered to adequately meet local needs. In one of his 'visionary set-pieces', he was adamant in his opposition to separation in any form, seeing the future in a united, democratic, independent New Zealand:

(I) $t$ matters not whether we remain an integral portion of the British Empire or not-we should so lay the foundation of our constitution, and lay it so broadly, that whatever position we occupy in the future we may be able to take our stand as a great nation. That is the dream of my ambition- that is the hope and goal which should be in the mind of every New Zealander. ...We are now a united colony; we are pursuing the path of constitutiona1 government, one of the first principles of which is that whoever may sit on those (i.e. the Government) benches...will remain there only so long as they command the confidence of this House. 187

Ballance's participation in the 1876 session was limited. This was owing in part, no doubt, to a belief that the main concern of the

187. PD, 1876,21, p. 214. Grey's motion was lost 32 to 47 . Of Ballance the following speaker, De Lautour, said: 'I recogniged at once, when he spoke, that we had as able a statesman before us, advocating the cause he believed in, as had arisen in thes House for many a long day'. Vogel sent Ballance a personal letter congratulating him on his 'splendid' speech, Vogel to Ballance, 10 Aug. 1876, BMSS, 2. 
Assembly, abolition, was a fait accompli, and that there were sufficient members only too willing to spend the time firmly nailing the lid on the Provincial coffin. As well as this, Ballance was pursuing other interests at 'grass roots' level. He spent a considerable amount of time promoting small farm associations. ${ }^{188}$ As Arnold points out, there was a limit to the role such associations played during the sponsorship of special settlements and public works under Vogel's scheme. ${ }^{189}$ By 1876, however, the growing demand for land could not be met by government promotion alone, and a new batch of associations were formed. 190

Through the Herald Ballance encouraged the formation of small farm associations; outlining how they might be set up and the methods to be employed to obtain grants of land. ${ }^{191}$ He was intimately involved in the formation of the Wanganui Small Farm Association in June $1876,{ }^{192}$ which wanted the Government to make available a suitable block of land, near a market, for settlement on deferred payment. Improvements should be stipulated. ${ }^{193}$ The Government was unresponsive, arguing that the Association would have to compete in the open market for land being sold on deferred payment. ${ }^{194}$ This was precisely the unrealistic argument

188. He had earlier been involved with the Manawatu Small Farm Association, see e.g., EH, 13 June 1870.

189. See R.D. Arnold, 'The Opening of the Great Bush, 1869-1881', Ph.D. thesis, Victoria University of Wellington, 1971, p. 358.

190. As well as in Wanganui, associations were formed at Bulls, Normanby, Masterton and Hutt. The Herald followed the activities of these organisations closely, e,g., WH, 10 June 1876; WH, 15 July 1876; WH, 9 Dec. 1876; WH, 15 Dec. 1877.

191. Colonial prosperity, he had said, rested on the promotion of the 'right kind' of settlement- colonists with 'moderate' capital, experienced in agriculture, and self-reliant. EH, 15 Sept. 1874.

192. WH, 3 June 1876.

193. $\overline{\mathrm{WH}}, 24$ June 1876.

194. $\overline{\mathrm{WH}}, 9$ Dec. 1876. 
that Ballance had been fighting against. Free competition in land meant that the ordinary settler would be excluded; only the large capitalists and speculators could afford the high prices that were inherent in a competitive system. It was for this reason that associations were seen to be necessary in the first place.

The Wanganui Association disbanded in February 1877, its members 'irritated and disappointed' at their lack of success. Ballance, though disappointed and angry at the Government's attitude, urged the Association to be patient. ${ }^{195}$ At the same time he launched attack after attack on. what he saw as the increasing alienation of land by monopolists and land sharks:

In a few years in many if not all of the Provinces the open agricultural land will have passed into the hands of the monopolist and the landshark. Then will arise a great democracy demanding the bursting up of the large estates, the abolition of the nominee Chamber of the Legislature, and the enactment of all articles in the democratic creed. Would it not be wiser to prevent this by a patriotic effort to secure the availabie lands for actual settlement? 196

It was an unresponsive Government, and the frustration of organisations that epitomised his vision of New Zealand as a land of small, independent, 'yeoman' farmers, that, combined with the political realignments inherent in the settling of the abolition issue, laid the basis for Ballance's own break with Atkinson.

195. WH, 3 Feb. 1877.

196. $\overline{\mathrm{WH}}, 24 \mathrm{Feb}$. 1877. This vision of a rising 'great democracy' was in many respects to be fulfilled in his own Premiership between 1891 and 1893. The large estates were subdivided, the Legislative Council tamed, the franchise extended to include women, the property vote abolished and so on. See also, e.g., his attack on land sharks on the Waimate Plains, WH, 10 Feb. 1877. 
Signs of Ballance's dissatisfaction with the Ministry were already apparent by January 1877. He had been disappointed when Vogel resigned the Premiership the previous August to go to London as Agent-Genera1. ${ }^{1}$ The Government had been reconstructed under Harry Atkinson. Though his numerical majority was strong, his supporters were 'inert and supine'; there seemed 'a total want of healthy vitality in the body politic'. ${ }^{2}$ An early problem arose when Atkinson appointed more members to his Ministry than was permissible under the Constitution. Grey objected and after a few weeks wrangling in the House Atkinson was forced to reconstitute his Cabinet. Ballance was particularly unhappy, and surprised, when this included Whitaker as Attorney-Genera1. ${ }^{3}$ Frederick Whitaker, an Auckland businessman, was an archetypal land speculator detested by Ballance.

In his end of session speech to his constituents at Marton, on 16 January 1877 , Ballance showed that he was already a far from committed government supporter. Public works expenditure, he said, along with interest on loans and the costs associated with the abolition of the provinces, would produce a deficit in the current financial year. ${ }^{4}$ To resolve this problem, Ballance argued that further taxation would be necessary. Given the current rapid1y increasing land prices, he felt that this should be in the form of a land tax:

1. WH, 9 Sept. 1876.

2. Jane Maria Atkinson to C.W. Richmond, 19 Sept. 1876, G.H. Scholefield (ed.), The Richmond-Atkinson Papers, vol. 2, Wellington, 1960 , p. 426 .

3. WH, 9 Sept. 1876.

4. In fact the deficit was $2.75 \mathrm{~m}$, not as large as the previous year's deficit of $\mathbf{\$} 3.4 \mathrm{~m}$, AJHR, 1888 , B-12. 
...it was just that some portion of the unearned wealth should be contributed to the necessities of the colony. Small proprietors should be exempt, as they were already large contributors through the customs to the revenue. 5

Ballance was concerned about the sale of 80,000 acres of the Piako Swamp to the Auckland speculator, Russe11, particularly the way in which it was effected. 6 Finally he thought Whitaker to be an ill-fitted member of the Ministry: his appointment could only 'extinguish the enthusiasm of the party'. 7

It was the first time that Ballance had specifically mentioned the desirability of a land tax. The Herald was soon repeating the theme. ${ }^{8}$ It pointed out, for example, that the general election in Victoria was being fought on the question of a progressive land tax as a means of bursting-up the large estates. Soon New Zealand's large landowners would be faced with such a progressive tax: ' $(t)$ he efforts of the people of Victoria to plant and maintain a yeomanry population, will find many sympathisers in New Zealand'. 9 A land boom had begun, and with rising prices ordinary settlers were increasingly

5. WH, 20 Jan. 1877. My emphasis. A land tax was of course anathema to Atkinson.

6. The law required that land should be sold for at least $5 /=$ per acre, but in this instance the Government sold it for less on the grounds that it was largely swamp and of poor quality, intending to legalise the sale by proclamation. Grey objected. A select committee upheld the Government but admitted that there was a technical error to be corrected the following session. See PD, 1875, 17, pp. 271, 323, 402, 659 .

7. WH, 20 Jan. 1877 .

8. The Herald had begun criticising the Atkinson Government as early as November 1876, when the Evening Post noted that 'the Atkinson Ministry have in some way wounded the self-love of $\mathrm{Mr}$ Ballance, and so we find his organ, the 'Wanganui Herald' turning upon them in the most savage manner' (quoted by WC, 25 Nov. 1876). The Post suggested that Ballance was disappointed at not being included in Atkinson's Cabinet. A year later the New Zealand Herald reported the rumour that Ballance had been offered a place (2 Nov. 1877).

9. WH, 19 May 1877 . 
at a disadvantage. ${ }^{10}$ Land was 'either being swallowed up in the rapacious maw of the land shark, or passing into the hands of large proprietors.' Finally, the Herald complained that small farm associations were impotent, whilst government policy (for example the Waste Lands Act of the previous session) encouraged 'speculative settlement associations' such as the Manchester Corporation at File,1ding. ${ }^{11}$

This last accusation was unreasonable. The Herald's argument was that the wrong type of settlement was being promoted. There were 'village residences and sma11 suburban plots' where there should have been productive small farms. Given the favourable conditions (government concessions, good quality land and a rail connection with Foxton), more land ought to have been brought under cultivation. The Herald pointed to the Hutt Small Farm Association settlement at Sandon, where conditions were not so propitious, as a greater success. In fact the 1878 census shows that Sandon (including the town of Sanson) had a population of only 536. The Manchester block, purchased by the Corporation in late 1871 , contained 1,700 settlers. Even if the rate of new land cultivation in the former was greater, the value, scale and success of the later scheme was undeniable.

The Manchester Corporation was philanthropic rather than speculative. Indeed in $1872 \mathrm{Ballance}$ had welcomed the scheme, believing it would result in a 'population of hardy and industrious settlers... who as "producers" (would) add to the material wealth of the country,

10. C.G.F. Simkin, The Instability of a Dependent Economy. Economic fluctuations in New Zealand, 1840-1914, Oxford, 1951, p. 160.

11. WH, 12 May 1877 . 
and as "consumers" augment its customs revenue'. ${ }^{12}$ What lay behind the later charge was Ballance's political preference for land settlement by local small farm associations rather than under English schemes linking settlement to immigration. It was true that the Government's emphasis was on immigration (free passages were given and a certain amount of paid employment guaranteed) rather than on land settlement per se. Yet Ballance's suspicion of a private venture that undoubtedly contributed to settlement, appears inconsistent given his own connection with another similar enterprise, the New Zealand Land and Loan Company (c.f. pp. 169-72).

Three factors help explain this ambiguity. First, the Manchester Corporation was competing for land with organisations from Ballance's own district. What had stimulated Ballance's criticism was the Government allowing the Corporation to withdraw a 'large and valuable block of land from all occupation other than that promoted by itself'. There was resentment at privileges being given to 'strangers'. 13 Second, scattered small farm settlement was preferable to concentrated settlement around a town that might come to rival Wanganui. Neither of these considerations were applicable to the property of the Land and Loan Company in the south island Waimea Plains. Finally, Ballance would have been suspicious of the organisation's aristocratic patronage. The Corporation's ideals looked very similar to those of the Wakefield colonisation companies of the $1840 \mathrm{~s}$; the aim being to establish settlements whose sociai structure mirrored that of England.

Disillusioned with the performance, policy and personnel of the

12. EH, 1 Feb. 1872 .

13. $\overline{\mathrm{WH}}, 12$ May 1877. See T.A. Gibson, The Purchase and Settlement of the Manchester Block, Feilding, 1936; A J JHR, 1877, H-27, 27a (report on the Manchester settlement). 
Government, and at the frustration of settlement in his own district, Ballance could not but be exasperated when Atkinson opened the new session of Parliament saying that the country needed a time of 'political rest'. Charles Woolcock, the independent member for Grey Valley, did not agree: shortly after the Financial Statement he moved that the incidence of taxation be changed. It was a fundamental challenge to a Government already weakened by further personnel changes (along with Vogel, Richardson had retired and McLean had died) and a disintegration of policy once the removal of the abolition issue broke what was often the sole bond holding its supporters together. A debate on taxation followed, with Grey, through an amendment, specifying that the change sought was a tax upon income and property, and a reduction of customs duties. ${ }^{14}$

Ballance spoke on 22 August; it was one of his major 'set-pieces'. A 'new era of legislation' had dawned, he said. With abolition settled the House could only now consider fundamental questions in an unbiased 1ight. ${ }^{15}$ In his speech Ballance attempted to find an acceptable compromise between the Government's position and that of Grey. Political rest was, 'to a certain extent' necessary. ${ }^{16}$ Despite the fact that in the critical vote Ballance sided with the Government, it was clear that he supported a change in taxation. ${ }^{17}$ A 'readjustment' was needed since current taxation 'presses severely on the industrial classes, and because it does not press sufficiently on the wealthy classes, who ought to contribute more'. ${ }^{18}$ He favoured a 'reasonable' property tax, but was particularly eager to see the

14. PD, $1877,24,227 \mathrm{ff}$.

15. 'It would have been an impossibility' said Ballance, 'for any Superintendent to have brought down a question of this nature - a question in which a proposition was made for relinquishing a large portion of the Customs revenue', PD, 1877, 24, p. 579.

16. Ibid., pp. 580-81.

17. Ibid., p. 615 .

18. Ibid., p. 584. 
more specific land tax:

I have no apprehension of the future of this colony if a tax, fairly adjusted and wisely considered in the first instance, is put on the land. It will discourage the creation of those large landed estates, than which nothing can be more destructive to the welfare of a young community. The monopolist will be checked in that land-greed which causes him to take up the best land of the colony, and to hold it without improving or using it in any way. ... Our Land Fund is our capital; and, when that is exhausted, what are we to fall back upon? ... The small-farmer class must be encouraged. The great runholders are not the basis of colonial prosperity. ... (A)bove a11, we have a right to see that in the alienation of new territory it should not be alienated to monopolists, but should be conserved for the benefit of the people. 19

Two important considerations prevented Ballance's wholehearted support for Grey's amendment. Both foreshadow later problems of liberals in securing an alliance of urban and rural interests, and are worth stressing for that reason. First, pointing out that duties served protective as well as revenue purposes, he realised that reducing them could harm local industries. This marked for Ballance a distinct move away from a free trade policy, and indicated the general liberal dilemma that protection made sense only once taxation had been shifted away from essential goods. ${ }^{20}$ only with the burden of taxation placed on the larger landowners and capitalists, could the urban working class and rural small farmers be expected to support a protectionist policy. Secondly, though reductions would afford relief to the working classes (whom Ballance described as the 'stalking horse' of the debate), he complained that the interests of

19. Ibid., pp. 585-86.

20. This move towards protection, hinted at for a number of years (for example when Ballance talked about giving local industries 'bonuses') was predicted by the Herald (WH, 23 June 1877). 
the small farmer had been entirely excluded from consideration. ${ }^{21}$ Again this shows the extent to which Ballance saw the need for future liberal policy to accommodate rural as much as urban interests.

Grey's amendment was lost by ten votes and the Government, though now beginning to lose other divisions, was temporarily reprieved. As for Ballance's speech, the Evening Star said it was not as good as his major effort of the previous session, though it noted that his views on colonial finance had caused 'quite a flutter amongst the lords in the gallery'.22

Ballance's attitude to the Government became more clear with his criticism of the Native Land Court Bill. The Bill, initiated by Whitaker, removed the remaining restrictions to free trade in Maori land. In the Herald Ballance had already voiced his objections when the Bill was published just before the start of the session:

\begin{abstract}
Next to the fallacy of "free trade" in Native Lands is that of the policy of getting the land from the natives without regard to the use to which it is applied. ... Let (the Native estate) remain in the hands of its... owners until in the first place the colony can acquire it for settlement, and, in the next, until, the first condition being satisfied, the native shall obtain a fair and reasonable price for the land he desires to sell. Depend upon it that there is no distinction between the interests of colonisation and fair play to the Maori. It is the speculator or monopolist who wishes for laws to wrest from the native his land by fair means or foul; and it is the distinguishing character of the Native Lands Bill... that it is framed to serve that purpose. ...Has it then come to that deplorable result
\end{abstract}


that the party of abolition is governed and largely composed of the members and friends of land rings? 23

In August Ballance moved an amendment to the Bill using arguments along these lines. The Bill ought to be withdrawn he said, and its conditions altered. It was 'immoral'. The object should be 'to get for the natives the highest price possible for their land', which was quite consistent with the work of bonâ fide settlement. ${ }^{24}$ The Herald was again, as it could afford to be, more blunt. The Bill it said, was produced at the instigation of landsharks, and with increasing support for Ballance's amendment both inside and outside the House, the Government was in danger of being defeated. ${ }^{25}$

In fact the Bill was dropped. Less than a year later Ballance said that he had been told by Atkinson that seven Government supporters, 'intimately connected with land speculation' had said that they would put the Government out if the amendment passed. 26 The Herald explained that Ballance's action was 'direct and simple':

\begin{abstract}
Speculation in Native lands must be stopped; and not only in Native land, but all other must be protected against speculators and monopolists. The present Government are chiefly supported by a landed aristocracy and a landsharking horde of vultures outside the Houses of Assembly. ...The time has come when we must wring from the Government a liberal land policy, and if they resist, they must be
\end{abstract}

23. WH, 23 June 1877. Ballance could now beat the humanitarian and anti-monopolist drums at the same time. Atkinson had condemned a number of articles written by Ballance during the recess, see Ballance to Voge1, 1 Mar. 1878, Vogel MSS.

24. PD, 1877,24, p. 261.

25. $\overline{\mathrm{WH}}, 11$ Aug. 1877.

26. $\overline{\mathrm{WH}}, 18$ May 1878 . 
at once, for the welfare of the country, destroyed. He (Ballance) has commenced on the Native Lands Bill, but he will not end until the land of the colony shall be used for the settlement of the people, nor until the class now ruling the country shall have no privilege above the man of 40 acres. 27

Ballance now saw his role as fighting for a class of small farmers (or prospective farmers) against the power of a government backed by large landowners. The political party system was being realigned along this fundamental division of interests. Speaking just prior to his formal break with Atkinson, Ballance said he believed that there would soon be 'two clear parties' in the House:

They will be formed, not upon temporary or fleeting questions or principles, but upon principles that will endure- namely, the principles of conservatism and liberalism. Why, those principles are now embodied in this House- all around it. ...I must give (Grey) credit... for being the advocate of those principles which, in my opinion, should govern the country. I may say that I have done all I possibly could to prevail on the Government to adop $t$ those principles... . ... (T) he people of this colony will rule this colony. I believe that to a large extent in the past it has been ruled by cliques. I believe that now the first man who appeals to the people will obtain the victory. 28

This was a major statement of Ballance's own position, and of the development of party politics in general. The Lyttelton Times viewed it as undoubtedly the speech of the debate; although Ballance's vote was given to the Government, 'his speech was the most telling one against them'. ${ }^{29}$ Ballance felt bound to support the Government until

27. WH, 25 Aug. 1877 .

28. $\overline{\mathrm{PD}}, 1877,26, \mathrm{p} \cdot 107$. See also his speech of 29 October on the same theme, ibid., p. 542 .

29. LT, 3 oct. 1877. 
he had formally notified Atkinson of his change. He 'votes with the government' Ellen told Sarah Jane Spinks, 'but cannot agree with them'. 30 Having consulted Bryce, Ballance finally wrote to Atkinson on 3 October, saying that he should no longer be considered a Government supporter. ${ }^{31}$ 'No one could have listened to his strong and emphatic denunciation of the Ministry', said the Evening Post, 'without asking how long he would support a government in which he had no faith, and to which he accorded no respect'. 32 Ballance was expected to bring over others with him. Bryce and W.W. Johnston followed days later. It was a fatal blow to Atkinson: on hearing of Ballance's switch the New Zealand Herald was certain that the Ministry was doomed. 33 The Evening Star complained that Ballance ought to have made the move much earlier, and making the inevitable pun pointed out that now the opposition hopes had 'risen with the oscillation of the balance'. 34

In later years Ballance stressed that this switch was not a sudden impulse but the consequence of thought and events over a long period of time. He emphasised his consistent opposition to the Government's legislation of the session; his realisation that Atkinson, increasingly the 'puppet of the most powerful combination of the hour', would be unlikely to pursue a liberal policy that he (Ballance) had always pressed for. 35

Though Ballance's alienation from the Ministry had indeed been apparent for some time his final break with Atkinson was clearly

30. Spinks Diary, 2 Oct. 1877.

31. Ballance to Atkinson, 3 Oct. 1877, BMSS, 4. See also Ballance's later account, WH, 2 Aug. 1879.

32. EP, 4 Oct. 1877 .

33. $\overline{\mathrm{NZH}}, 5$ Oct. 1877.

34. $\overline{\mathrm{AES}}, 4$ Oct. 1877.

35. $\underline{\mathrm{WH}}, 2$ Aug. 1879; $\underline{\mathrm{WH}}, 30 \mathrm{Apr} .1881$; EP, 10 Jan. 1878. 
calculated to maximum effect. Six days after Ballance's defection, Atkinson was defeated in a no confidence motion moved by Larnach Despite Ballance's later claim that at the time he believed the Government to be secure, it was clear that his change of sides, followed by others, was going to be critical. ${ }^{36}$ More important, as the instigator of these final desertions, he was placed in a crucial position when the time came for a decision on Atkinson's replacement to be made. A 'middle party' of ex-Atkinson supporters had already emerged, including Montgomery, Gisborne, Fitzherbert and Rolleston. Only after he had dismissed the possibility of a government being formed from this group, did Ballance commit himself to Grey. ${ }^{37}$ At the Opposition caucus meeting following Atkinson's defeat, it was Ballance who nominated Grey as leader. ${ }^{38}$

Having proposed Grey it is curious that Ballance did not take up the invitation of a place in the Cabinet when Grey came to form his administration. The offer of the Colonial Treasury was certainly made, most likely on 12 October; Larnach was not appointed Treasurer until 15 October. ${ }^{39}$ Ballance did not join the Ministry until early January 1878. As late as 10 December he told his brother-in-1aw, David Anderson, that he still refused a Cabinet post. ${ }^{40}$

This initial reluctance needs some explanation. There were three major reasons for Ballance's hesitation. First, the Grey Ministry was dangerously weak. Grey urged the Governor to grant a dissolution confident that he had strong support in the country. Ballance kept his

36. WH, 2 Aug. 1879.

37. The Lyttelton Times (6 0ct. 1877) reported that Ballance had actually joined the middle party.

38. WH, 18 May 1878; LT, 12 Oct. 1877.

39. $\overline{\mathrm{AES}}, 12,13$ Oct. 1877; LT, 13, 15 Oct. 1877; WH, 13 Oct. 1877; NZH, 15 Oct. 1877; New Zealand Gazette, 15 Oct. 1877.

40. Spinks Diary, 10 Dec. 1877 . 
options open: the middle party had split on Grey's accession to power and an election might actually strengthen the non-Greyite liberal faction sufficient to make it the basis of a viable ministry. An election would also remove the possibility of an Atkinson comeback in coalition with the other wing of the middle party. ${ }^{41}$ Not until the end of the year did the Governor finally refuse Grey's request for a dissolution, and the possibility of an alternative liberal government disappear.

Secondly, Ballance was worried about a revival of provincialism. Though he argued in the House that Grey was committed to centralised government, only after Larnach's Financial Statement of 20 November announcing that the Government was to take complete control of the land fund was the 'separation bogey' finally laid at rest. ${ }^{42}$ Ballance, and other abolitionists such as William Gisborne, could now feel more comfortable in their support of Grey. The Ministry was in consequence substantially strengthened.

A third factor was Robert Stout. Stout had entered Parliament, as Member for Caversham, in the same year as Ballance. Son of a Shetland landlord and merchant, he made his mark on Otago provincial politics as a liberal who saw the future in a 'nation of small holdings, secured by the state'. ${ }^{43}$ From the very start of their political careers Stout and Ballance shared many fundamental beliefs. Both emphasised land as a central political issue, seeking more liberal

41. PD, 1877, 26, pp. 539, 542. The Evening Post (31 Oct. 1877), anti-Grey and anti-Atkinson, agreed with Ballance that an election would make party lines even clearer.

42. PD, 1877, 26, p. 537; T.G. Wilson, 'The Rise of the Liberal Party, 1877-1890', M.A. thesis, Auckland, 1951, pp. 47-48.

43. D.A. Hamer, 'The Law and the Prophet: a political biography of Sir Robert Stout (1844-1930)', M.A. thesis, Auckland, 1960, p. 2 . 
land laws and in particular the leasing of 1and. Both were concerned with the political power of large landowners, and sought reform of the Legislative Council. Their ideology rested firmly in a belief in individual self-help. The 'new world' offered a great opportunity for the establishment of a system facilitating self-improvement. From their first meeting in 1875 they quickly formed a close personal friendship. 'Their reading followed similar lines, and their views, except with regard to provincial questions, were in accord. A friendship... was formed that remained firm and mending till the last. They were, when both were in the House, continually together; and after the House rose, at whatever hour, they would be seen walking together'. ${ }^{44}$ Their wives too became friendly, spending time with each other when both were in Wellington. ${ }^{45}$

Ballance and Stout undoubtedly conferred on their responses to offers made by Grey to join his Ministry. With the possibility of an election dismissed, and the Government considerably strengthened, the remaining condition was that they would only join if the other was also asked. ${ }^{46}$ This desire for mutual inclusion, alongside the earlier hope of an alternative, reflected not only their personal and political friendship, but suggests that both men foresaw personality difficulties in a Ministry led by Grey.

When Ballance was appointed Commissioner of Customs and Minister of Education on 12 January 1878 it was on the understanding that he would take over the Treasury when Larnach left for England to negotiate

44. Sir Robert Stout, 'Character Sketch: The Hon. John Ballance', Review of Reviews for Australasia, May 1893, p. 109.

45. See e.g. Spinks Diaries, 8 Sept. 1878.

46. WH, 15 July 1879; A. Saunders, A History of New Zealand, vo1. 2, Christchurch, 1899 , p. 387. 
a loan. ${ }^{47}$ In fact Ballance was acting-Colonial Treasurer from the start. $^{48}$ As there was a constitutional limit to the number of salaried portfolios, Stout was not appointed Attorney-General until Larnach resigned on 18 March. ${ }^{49}$ It was to be a brief tenure for both Ballance and Stout. Pleading an urgent need to return to his law practice Stout resigned in late June of the following year. Ballance, after a much publicised quarre1 with Grey, followed days later.

Ballance's appointment to a key cabinet position was remarkable for one so inexperienced. He had been in the House less than three years. Press comment on his suitability was largely predetermined by political bias. His youth, lack of reputation and experience were serious flaws for the Dunedin Herald, whilst the Hawkes Bay Herald pointed out that as he was 'poor and ambitious', Ballance had from the first sought a Cabinet post. The Canterbury Press was sure Ballance, who had 'theories of his own', would only 'encourage the most flighty and impracticable fancies of his chief'. ${ }^{50}$ But Ballance did have a reputation, gained through his few 'set orations, carefully thought out, elaborately constructed, and ingeniously worded' that, delivered in the House, attracted attention outside. Most papers were prepared to wait and see how he performed in office. Vogel was pleased. 'I cannot say I am surprised', he wrote, 'for since I first met you I have been firmly persuaded (that such a) distinction awaited you'. 51

47. EP, 11 Jan. 1878; AES, $15 \mathrm{Jan} .1878$. Larnach a1so aimed to assist Vogel to float the $\overline{\text { New }}$ Zealand Agricultural Company. See D.A. Hamer, 'The Agricultural Company and New Zealand Politics 1877-86', Historical Studies, 10, 38 (1962), p. 145.

48. Ballance was dealing with Treasury correspondence from at least the end of January, though his appointment was not gazetted until $12 \mathrm{July}$. See T1 (1878) in the National Archives.

49. New Zealand Gazette.

50. These adverse comments were quoted by, not surprisingly, the WC, 12, 16 Jan. 1878.

51. Vogel to Ballance, 12 Apr. 1878, Vogel Letter Book. 
In the following eighteen months Ballance gained invaluable political and administrative experience. He learnt a number of lessons that were to critically influence his later Premiership. In this respect his participation in the Grey Government had a greater impact upon his later political activity than did the Stout-Vogel Government of 1884 to 1887 . The period also revealed important traits in his character.

Above a11, Ballance found that the exigencies of colonial finance placed considerable restraints on his ability to pursue liberal policies. The instability of the land revenue and dependency on overseas borrowing and prices negated any impact he might hope to make on the direction of policy. Liberal ideology was surrendered to economic necessity. The financial position of the colony deteriorated drastically between 1878 and 1879: the surplus Ballance had inherited became a large deficit. Initially discouraging, ultimately this experience confirmed Ballance in his views. He had already argued the need for greater economic and political independence. Speculators at home and financiers abroad had both to be tamed if a basis for liberal legislation was to be successfully laid. Revenue needed to be placed on a broader base. Ballance was to become practically paranoid about deficits. In later years, time and again, he would explain how the 1879 deficit had arisen. It was not simply that he was a 'conservative' financier. He hated deficits because they made him dependent upon factors beyond his control, factors that could therefore undermine liberal policies.

The most important measure of his term as Colonial Treasurer was, for Ballance, the land tax. Theoretically desirable it was shown (despite some initial technical difficulties) to be politically and 
administratively workable. It placed the burden of taxation upon those capable of bearing it, and encouraged genuine settlement through penalising aggregation. 'The Land Tax had been carefully thought out by him', Stout wrote later, 'and to him belongs the main credit of its introduction. He arranged the details, formed the estimates, and thought the system out'. ${ }^{52}$ A land tax was to be a central feature of the 1890 Liberal platform, and the 1878 tax the precedent.

Third, Ballance learnt that political reform required support from below not merely initiative from above. Grey led the way with a 'country-wide stump' during the recess of 1877-78 which considerably strengthened the Government and shook its opponents. Organisation at grassroots level was essential if a liberal party was to survive.

Further, Ballance learnt that internal dissension and conflict at cabinet level could prove fatal. Alongside changed economic circumstances this was the major cause of the fall of the Grey Government. It was a matter of both personality and policy clashes. Grey's leadership was autocratic and dogmatic; his touchiness and inability to compromise with strong-willed colleagues disastrous.

Finally, Ballance showed new sides to his character. His passion for politics included a fetish for administrative labour. A 'workaholic', a man of great activity, he liked to get things done rather than talk about them. He also showed flexibility when possible but strength of will when it mattered; a major characteristic of his later Premiership. Following his appointment the New Zealand Times,

52. Stout, p. 109. 
with foresight as well as precision, said that he had 'ideas and a tolerable amount of combativeness, and Sir George Grey may find it a hard job to have it all his own way with him'. 53

Ballance began his work with great vigour and enthusiasm. He delayed his annual address to his electors until May, remaining in Wellington absorbed in administrative duties and in acquainting himself with the state of the colony's finances. ${ }^{54}$ In March the Evening Post reported that he had 'achieved a somewhat notable distinction' :

At the present moment he is "running" the Government of New Zealand single-handed. A11 the other members of the Ministry are scattered north, south, east, and west. ...He is "Monarch of all he surveys, and his right there is none to dispute". ...To his great credit... Mr Ballance appears to accomplish wonders, and to get through an enormous mass of work. 55

He was cheerful and optimistic. Support was growing in the country. Reform Associations sprang up, advocating liberal land laws, changes in the incidence of taxation, and an extension of the franchise. 56 A political 'reviva1' had begun. In Wanganui the Herald argued that the division between conservatism and liberalism was clearer than ever. Discipline and organisation were essential not only with the coming election in mind, but as a means of setting up a more permanent party. ${ }^{57}$ Two great parties have been formed, echoed the Post, 'day by day men are joining either one or the other'. 58

53. Quoted by WH, 12 Jan. 1878 .

54. WH, 19 Jan. 1878.

55. 4 Mar. 1878.

56. EP, 7 Mar. 1878.

57. 2 Mar. 1878.

58. 9, 12, Apr. 1878. 
Ballance's immediate concern was preparing his financial statement to be delivered at the start of the coming session. Customs duties and the proceeds from the sale of crown 1 and made up the bulk of colonial revenue. The former had been fairly consistent over the preceeding years, whilst the latter varied considerably. Deficits in 1875 and 1876 had been financed out of borrowing for public works. A large increase in the land revenue the following year had produced a surplus. 59

The sale of land was critical to the colony's revenue. Some land, for example in Canterbury, was already in the hands of the crown and only awaited opening up. Much other land, in the North Island, had still to be purchased from its Maori owners. For Ballance there were important political as well as financial considerations. Land should be sold to genuine settlers. The Land Act of the previous session, reorganising and centralising land administration, had extended the system of deferred payment existing in a number of provinces to the whole country. However at the same time it increased the price of land on deferred payment by fifty per cent. In the open market, with land prices in general rising rapidly, the prospective small farmer remained at great disadvantage. The situation was made worse when Sheehan, Native Minister in Grey's Cabinet, stopped government vurchasing of Maori land on the grounds that it produced 'jobbing' and 
abandoned' he wrote to Vogel, '\& I fear the sharks will gorge more than ever'. ${ }^{61}$ The Cabinet soon reversed its policy. The Government recommenced purchasing, and through proclamations excluding private capitalists 'virtually restored' Crown pre-emption. ${ }^{62}$

In his first few months of office Ballance had reason to be optimistic. There were few signs of trouble to come. After sluggish growth from 1871 onwards, exports jumped from $\$ 5.5$ million in 1876 to 6 million in 1877 . Some export prices had begun to fall, but this had been more than offset by increased quantities. Ballance could announce a surplus on the current account. Major new land purchases were to be made. Conditions were propitious for liberal experiment.

Ballance's Financial Statement of 6 August 1878 was the most important one delivered since Vogel announced his public works policy in 1870. Part of it dealt with the reorganisation and simplification of accounts following abolition. For us the more important part set out the basic tenets of a liberal programme. 'This year has been looked forward to with more than ordinary interest by the people of the colony', said Ballance, 'as one in which large and extensive reforms are to be inaugurated, especially in questions of finance and taxation, when inequalities are to be removed and grievances redressed'. 63 His analysis of the state of colonial finance was logical and straightforward. He detailed the previous year's revenue and expenditure. There was a surplus of $\$ 120,468$. Exports had risen and

61. Ballance to Vogel, 1 Mar. 1878, Voge1 MSS.

62. R.C.J. Stone, 'The Maori Lands Question and the Fall of the Grey Government', NZJH, 1, 1 (1967), p. 59; Alan Ward, A Show of Justice, Auckland, $197 \overline{3, p} .278$.

63. PD, 1878,28, p. 80 . 
the loan authorised successfully floated. ${ }^{64}$

Next Ballance announced his proposals. The tariff was to be reformed, ad valorem being replaced by fixed duties. Imposing duty on the value of goods had been a failure: fradulent undervaluation was common and revenue had suffered. Imposing duty at a specific rate on the quantity of goods was more efficacious. Some duties were to be removed altogether, in particular those that 'clogged the wheels of local industry'. Ballance believed that industry would be fostered by removing duty on raw materials. 65

Other duties were to be abolished as a means of changing the incidence of taxation. Most important were two basic necessities, tea and sugar:

$(W)$ hen we consider the immense proportion of the taxation which these articles yield, and that the labouring classes are the principal consumers, we may be able to realise the justice of the... (demand for a "free breakfast-table"). 66

The duty on Australian wine was also reduced, in the hope that some reciprocity towards New Zealand exports might follow, though that on sparkling wine, which Ballance regarded as a luxury, was raised.

Having eased the burden of taxation on the 'wages class', Ballance announced that to further equalise its incidence he would impose a new

64. Vogel had been keeping Ballance in touch with events in London, and had advised him that despite the successful floating of the loan there should be no new borrowing for 15 to 18 months. See Vogel to Ballance 12, 25 Apr. 1878; 20 June 1878, Voge1 Letter Book.

65. PD, $1878,28, \mathrm{pp} .88-89$.

66. Ibid., p. 89 . 
tax on the landowning class. Greater equality would reduce rather than increase hostility between the classes. Land values had been increasing largely as a result of government expenditure on immigration and public works, and so a tax of $\frac{1}{2} \mathrm{~d}$ in $\mathrm{f}$ on 1 and over $\$ 500$ in value was legitimate. Improvements would be exempt so that industry was rewarded and speculation, 'which thrives only upon the labour of others', discouraged:

We believe that no form of wealth is more legitimately called upon to contribute a portion of the public colony than the value of land minus improvements. 67

The removal of duties on essentials and the imposition of a land tax were for Ballance the core of a liberal policy. Reducing the cost of raw materials was sufficient encouragement for local industry. Defending the interests of the urban working class through protection was not yet a major issue. First must come change in the basic principles of taxation. That this was the main aim of Ballance's statement is clarified by his remaining proposals. As well as a land tax he proposed a tax of $3 \mathrm{~d}$ in $\mathbf{f}$ on the net profits of joint-stock companies. Finally, as relief had been given to brewers through the halving of sugar duty, and to recover revenue lost elsewhere, Ballance recommended a beer tax of $1 \frac{1}{2} \mathrm{~d}$ a gallon. Compared with the duty on beer in England, he said, this was a modest proposa 1.68

The effect of these changes Ballance calculated would be a gain of $£ 24,000 .^{69}$ Deducting administrative costs, he predicted that the surplus for the current financial year would be $\$ 15,273$. In conclusion

67. Ibid., p. 90 .

68. Ibid., p. 92.

69. He estimated revenue from the respective tax as the following: land $£ 100,000$; beer $£ 30,000$; company $£ 10,000$, sparkling wines $£ 1,000$. Total $£ 141,000$. Remissions $£ 117,000$. Ibid. 
he said that the proposals, as well as being just, would accelerate the prosperity of the colony:

\begin{abstract}
To maintain... those inequalities of taxation which we propose to remedy would benefit no man who intended to remain and make his permanent home in the colony. It would be vain to expect that a11 interests can be blended in mutual compromise, or to suppose that human nature can be changed to break down the lines of demarcation between the allies of resistance and the advocates of progress; but we can easily imagine a progressiveness arising from the constitutional conflict of both elements... . ... These proposals) will show a country inviting labour as well as capital from all parts of the world by the justice and liberal character of its legislation. It cannot be doubted that the colony possesses inexhaustible resources; it is true that Nature has bestowed upon it the most lavish gifts; but the bounty of Nature must be matched by the beneficence of our institutions, and the equity of our public policy. 70
\end{abstract}

The speech, delivered in his now characteristic slightly monotonous style, lasted one and three-quarter hours. It was well received. Ellen and her sister Jessie, who had 1istened throughout, arrived at the Spinks's 'in high spirits'; the statement was a great success, they told Sarah Jane. 71 The proposals were 'moderate and just', said the Auckland Evening Star, and opinion throughout the colony favourable. 72 The New Zealand Herald viewed it as the best financial statement for years: 'all (members) admit that $\mathrm{Mr}$ Ballance has made a great hit, both on principle and detail'. 73 The Evening Post and Lyttelton Times eulogised Ballance. The former called the statement the 'most masterly production... ever 1aid before any New Zealand Parliament'; Ballance had established himself as one of the leading men in the House,

70. Ibid., p. 93.

71. Spinks Diary, 6 Aug. 1878.

72. 7, 8 Aug. 1878 .

73. 7,8 Aug. 1878 . 
a reputation that would last as long as his political career. ${ }^{74}$ 'The first thing that strikes one about it' said the latter, 'is the amount of ability which it shows. It is evidently the work of a clever, thoughtful man, master of his subject'. 75

It was not simply Ballance's ability that produced such favourable reaction. He gained reflected glory from the 'healthy' state of the colony's finances, and given this optimism his taxation proposals were seen as quite acceptable. Everyone loved a winner. The statement was also well rereived because both public and politicians had been prepared. The major points had been revealed in speeches during the recess. Speaking at Marton in May, Ballance had mentioned both a land and a company tax. 'The great principle the Government had in view was the distribution of land', he had said. 'If the aggregation of great estates was allowed to go on, the prosferity of the colony would soon' cease'.76 Equally, Grey had committed the Government to reductions in duties on necessities.

What made the land tax central to Ballance's philosophy was that it killed three birds with one stone. It involved a change in the burden of taxation from those who could least afford it to those that could afford it most, it provided a more stable, predictable and permanent source of revenue than that from land sales and it promoted genuine settlement through penalising aggregation and rewarding improvements. Above all it would guarantee the prosperity of the colony:

74. 7 Aug. 1878 .

75. 8 Aug. 1878 .

76. WH, 18 May 1878; EP, 14, 20 May 1878, 8 June 1878. At Marton $\overline{B a}$ liance urged that land over 320 acres be taxed. Stout pointed out that this would exclude many wealthy properties, so Ballance changed the basis to over $\$ 500$ in value. Wakefield gleefully noted the alteration, PD, 1878,28 , pp. 628-36. 
We have over and over again written of the small farmer as the life and soul of the industrial element of the colony. ...It is by him the continued growth and prosperity must be maintained... . (T) his colony should be made a country specially of yeoman farmers and peasant proprietors. Much has been done to make it not so. The public estate has been, and is being, wasted, in order to meet the necessities of empty treasuries, and to aggrandise the power and influence of monopolists and speculators. If further taxation be required this is the class that should yield it. 77

Within a year Ballance was being held responsible for a major depression in the economy as indiscriminately as he was now being associated with its prosperity. Within two months considerable opposition had arisen in the House to a number of his proposals.

The debate on the Land Tax Bill, opened by Ballance on 30 August, covered the whole of the Financial Statement. There was criticism of the land tax, and especially of the company and beer taxes, but most members were content to wait until the committee stage before proposing amendments. 78 Not so Edward Wakefield, a nephew of Gibbon Wakefield. He believed that there should be a general direct tax, and then only when the government ceased to use taxation revenue to subsidise local bodies. According to E.C.J. Stevens (the conservative member for Christchurch) who also opposed the land tax, Wakefield, apparent1y now given up drinking, had 'conceived an intense apathy for Ballance', and was 'resolved to smash him'. 79

In fact when the Bill returned for its third reading there were grumblings that insufficient time had been allowed for alterations to be made. One amendment, excluding leaseholders from taxation, had been 
defeated by only two votes. Nevertheless the Bill passed, in essence unaltered, forty-two votes to nineteen. ${ }^{80}$ It had been agreed by both sides that the debate should be on the financial proposals in general and the confusion that resulted, rather than an acceptance of the principle of a land tax, produced the large majority. 'There was a multiplicity of theories, a confusion of ideas, and a cross-fire of arguments which gave the debate an appearance which may be described as 'considerably mixed'. Conservatives and Liberals mingled together in undistinguishable groups'. 81 Ballance's reply to the debate consisted of a defence of the beer and company taxes and of the reduction of duties as much as of the land tax.

Quoting Mi11, Ballance had argued that the state had a right to appropriate the 'unearned increment'; that is, the increase in the value of land owing to factors (government expenditure and rising prosperity) independent of the owner's own efforts. Few speakers accepted this as a fundamental principle, and as Wilson points out, many saw the land tax as simply part of an inevitable movement towards a general property and income tax. 82

In practice the tax worked reasonably well. Valuations were made on 1 February 1879 , and returns showed that Ballance's estimate was very accurate. However the cost of collecting the tax turned out to be greater than expected. ${ }^{83}$ For the nine months to March 1880 the tax raised $\$ 92,803$, almost the same as revenue from stamps. 84

80. PD, 1878, 29, pp. 514-50.

81. $\overline{\mathrm{LT}}, 13$ Sept. 1878 .

82. T.G. Wilson, The Grey Government, 1877-9, Auckland University College, 1954, p. 27.

83. Land Tax Act 1878; WH, 7 Dec. 1878; EP, 21 May 1879.

84. AJHR, 1888, B-12. 
Ballance was determined to avoid an income tax, which he regarded as difficult to administer (self-assessment produced fraud) and inequitable. It could not be imposed 'with anything like fairness or consideration for the large number of people earning small incomes'. 85 Aside from his land tax, a company tax would place taxation on those that could afford it. It would be a tax on profits from investments made in the colony; an appropriation of 'surplus capital' which would not seriously damage the companies involved:

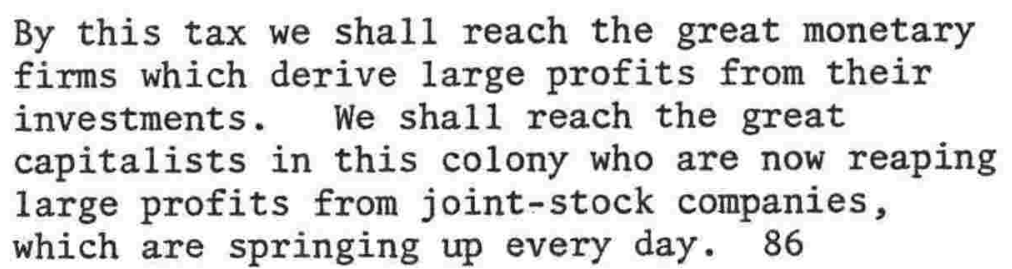

There was considerable opposition to the tax. Some thought it unjust to penalise companies that furthered the prosperity of the colony. 87 Others said that ordinary people, not just wealthy capitalists, were affected. 'The walls of the House rang with heart-rending accounts of aged widows who had invested their small savings in a joint stock company and were now to be unfairly penalised'. 88

Similar objections were made to Ballance's beer tax: it would hit the ordinary working man as much as the wealthy brewer. In fact brewers would simply pass the tax on to consumers:

\footnotetext{
$T^{\prime}$ was said by Ballance in his speech, "The beer-tax none will grudge it", And spite of brewers not one foot from His budget will he budge it.
}

85. PD, 1878,28, pp. 607-68; 29, pp. 114-18.

86. $\overline{\mathrm{PD}}, 1878,29, \mathrm{pp} \cdot 117-18$.

87. $\overline{\mathrm{NZ}} \mathrm{H}, 10$ Aug. 1878 .

88. Wilson, p. 27. 


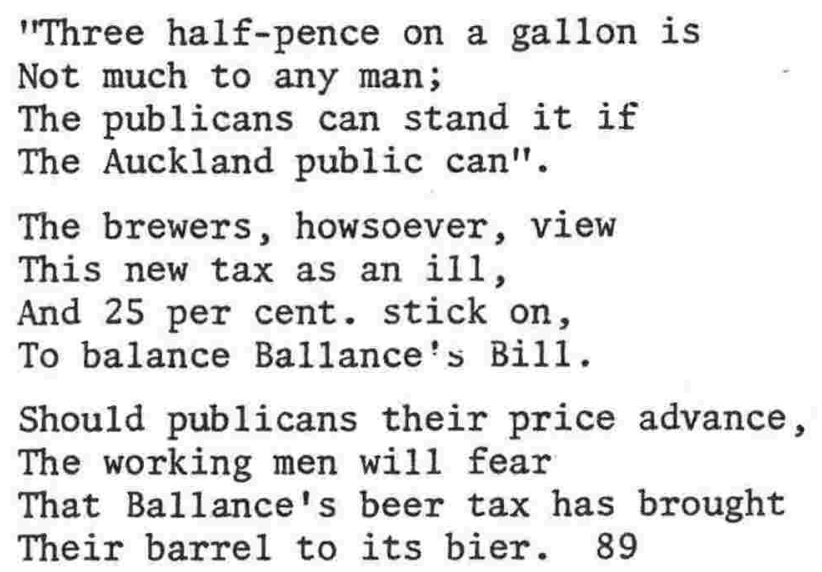

Ballance recognised this, arguing that beer was not 'altogether' a necessity, that consumers would reduce their consumption, and that this would not be a bad thing. However unlike Stout, Ballance was not a temperance reformer. U1timately he viewed the beer tax as a means, alongside the land and company taxes, of avoiding an income tax. Revenue from duty on English beer had consistently dropped as the consumption of the protected local product rose. Removing protection would restore revenue, though Ballance much preferred the alternative method of taxing colonial brewers. ${ }^{90}$

Ironically, Fox and other tee-totallers in the House voted against the Bill. Having previously argued in favour of increasing taxation on beer as a means of promoting temperance, Fox now declared that a new tax would only make the Government more dependent upon sales of alcohol. An alliance of Foxites, brewing interests and those who genuinely felt that the tax would harm the working man, defeated the Bill by two votes. 91

89. 'Ballance's Beer Bill' by a 'Working Man', AES, 9 Aug. 1878. 90. PD, 1878, 28, p. 609; EP, 22 Aug. 1878, a deputation of brewers to Ballance.

91. PD, 1878, 29, pp. 556-55; NZH, 5 Oct. 1878; AES, 4 Oct. 1878. Ironically the succeeding Colonial Treasurer, Atkinson, imposed a beer duty of $3 \mathrm{~d}$ a gallon. Ballance had the rate reduced to this from Atkinson's initial proposal of 6d a gallon! PD, 1880, 37, p. 606 


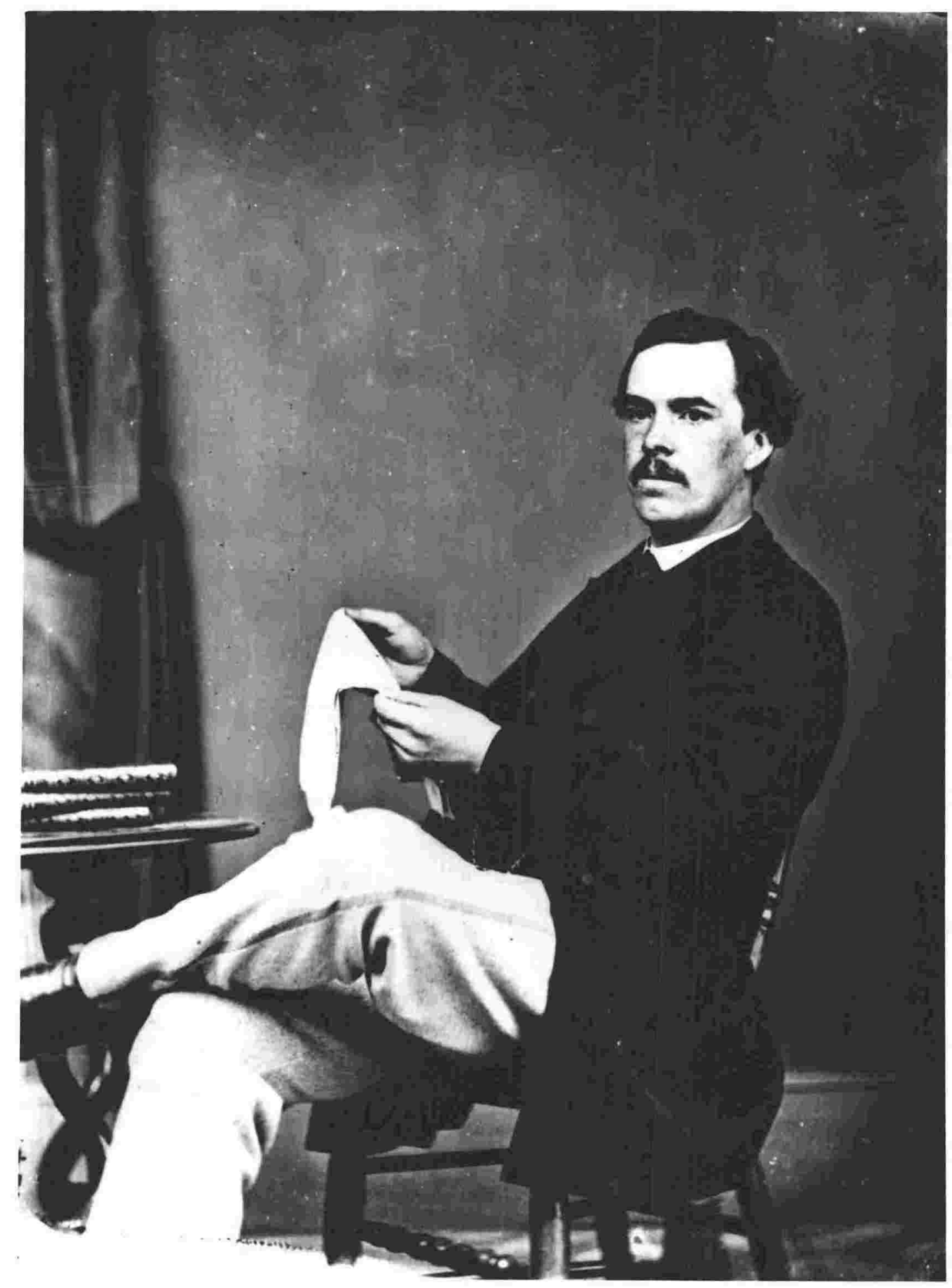

John Ballance, circa 1868 
A Cabinet meeting was hurriedly called to discuss the reverse. Ballance and Stout urged that the Government resign. 92 Grey, Sheehan and probably Macandrew, disagreed. The following day, 4 October, Grey announced that both the Beer and Company Tax Bills were being withdrawn. He recognised that this would 'embarass the finances' of the Treasurer, but there was such great feeling against the taxes that he had no choice.

Ballance and Stout had earlier declared that the Ministry would stand or fall on the taxes. Members were quick to notice division in the ranks of the Cabinet. 93 According to a later account, Grey had always opposed the taxes. Following the defeat Stout left the chamber 'burning with rage...declaring that he would resign next moment'.94 But for Ballance in particular it was a major upset. Principles had been lost and finances needed reorganisation. 95

The situation was especially serious as the Government had already been defeated on Stout's Electoral Bill. This Bill extended the franchise to al1 men who had been in the colony two years and in the one district six months. In May Ballance had said that the intention was to exclude only recent arrivals, to 'prevent the flooding of any roll by the importation of immigrants by Government aid'. He defended the retention of the property vote, as 'it was held that any man should have a vote for property wherever that property existed.' He argued that to be safe the constitution must rest on a broad base. Under the Bill women ratepayers were to be permitted to vote, and Ballance said that personally he would go further 'with respect to the equality of the sexes'. 96

92. PD, 1885,51, p. 263. Stout's retrospective statement.

93. $\overline{\mathrm{PD}}, 1878,29, \mathrm{pp} .46,568 \mathrm{ff}$.

94. $\overline{\mathrm{PD}}, 1879,31, \mathrm{p} .193$.

95. E1len too was 'much vexed about political affairs', Spinks Diary, 6 Oct. 1878 .

96. WH, 18 May 1878 . 
Grey wished to see the property vote abolished, and voted for an amendment to that effect. Ballance and Stout stuck to the provisions of the Bill and the amendment failed. ${ }^{97}$ At this stage Ballance viewed franchise reform as a liberal policy of only minor significance. The extension of manhood suffrage from its present level would, he said, have no great political effect. He was insistent that 'political power should not rest in the hands of a few', 98 but it was not until 1881 with his own electoral defeat by the narrow margin of four votes, that he fully appreciated the consequences of plural voting. The Bill passed through the House but was withdrawn by Grey when the Legislative Council excised Maori rights to vote as ratepayers. It was a politically immature act on the part of Grey. A bill extending the franchise through a residence qualification, albeit retaining the property vote he detested, would have been better than nothing. The coming election had now to be fought on the existing, 1imited franchise. 99

Ballance put a brave face on the rejection of so many of his key measures. Along with the beer and company taxes the House had refused the duty on timber, though Ballance said later that this was not originally part of his proposals. ${ }^{100}$ He announced that he would use funds from the public works account, originally meant for harbour defences, to make up the 1oss. ${ }^{101}$ Since demands on the land fund were already great, new public works would be financed out of a loan to be floated the following year. 'There is no fear, baring extraordirary

97. PD, 1878,29, p. 279.

98. $\overline{\mathrm{PD}}, 1878,28, \mathrm{pp} .355-58$.

99. $\overline{\mathrm{AES}}, 31$ Oct. 1878 . The New Zealand Herald (29 Oct. 1878) suggested that the Legislative Council made the amendment in revenge over the land tax (which, as a supply measure, it could not block).

100. WH, 23 Aug. 1879 .

101. $\overline{\mathrm{PD}}, 1878,29$, pp. 586-88. 
circumstances', he said as the session drew to a close, that 'if the prosperity of the colony continues... we shall not obtain the money we require. I believe our financial position is sound in every respeet'. 102 Nevertheless when Ballance and other ministers deserted Wellington for their respective homes, leaving only Fisher (the Postmaster-General) behind, it was to lick their wounds after a bitter and disappointing session.

In 1879 the land boom burst. The price of agricultural land was halved. At the same time export prices continued their downward .trend, wool from 103 to 90 and wheat from 122 to $105,(1870=100)$. The failure of the City of Glasgow Bank sparked off trouble in Australasia, where it had financial interests. There was a rapid contraction of credit; in New Zealand bank advances and discounts, which had increased 10 million from 1872 to 1878 , now fell by $\$ 2$ million in a single year. Banks were reluctant to enforce the sale of unprofitable mortgaged properties when the price of land was so low, yet despite this bankruptcies rose from 2.4 to 4.0 per thousand. 103 'Al1 the loan money of the place is gone and the Banks are drained', Stevens wrote from Christchurch:

The price of wheat must also operate powerfully in discouraging purchases of waste lands to say nothing of the fact

102. PD, 1878,30 , p. 1068 .

103. Simkin, pp. 160-61; W.B. Sutch, Colony or Nation?, Sydney, 1966, pp. 12,16 . 
that the 1and especially in Canterbury has gone. ... The prospects of Land Sales is very poor. Present owners cannot afford to add to their property this year. The returns of the season will be short and loan-money has risen to 9 and 10 per cent. 104

The remainder of this chapter will look at Ballance's attempts to deal with the worsening financial situation and at his deteriorating relationship with Grey. The two were connected. A series of disagreements with Grey culminating in one particularly well-publicised incident gave Ballance a pretext for resignation and allowed him to avoid at least some of the disapprobation concommitant with economic recession. Personal differences in turn rested in part on what Ballance saw as Grey's refusal to accept measures that would help restore the debilitated revenue.

Ballance's hopes of avoiding a large deficit rested initially on the sale of land on the Waimate Plains and when that failed on an extension of the 1and tax.

There was considerable Maori opposition to the sale of confiscated land on the Waimate Plains, which lay to the south of Mount Egmont in Taranaki. Sheehan, Grey's Native Minister, had stopped the surveying of the land in December 1877. In May 1878 Ballance and Macandrew (Minister of Public Works) urged the Cabinet to resume the survey, backed up with sufficient armed constabulary support. Macandrew, who was spending 'every farthing' he could collect, believed that the land would fetch nearly $\$ 500,000.105$ The survey began again in August, only to be

104. E.C.J. Stevens to Stafford, 3 Dec. 1878, 9 Jan. 1879, Stafford MS, vol. 6. Stevens was a director of the anti-Government Christchurch Press. Stevens to Stafford, 3 Dec. 1878, Stafford MS, vol. 6 . 
interrupted in December and February. By March 1879 Titokowaru and Te Whiti had turned all the surveyors off the Plains. A deputation of concerned local Maoris went to see Sheehan, who promised them that adequate reserves of land would be made for their use.

Meanwhile Ballance desperately needed the revenue. He telegraphed the Commissioner of Crown Lands instructing him to convene an emergency meeting of the Taranaki Land Board (which under the 1877 Land Act was the medium for land sales) 'to arrange for the sale of the Plains within the next few weeks'. 106 He then left with Macandrew for the area. Though Ballance's telegram gave the impression that the Cabinet had agreed to push on with the sale, this was not the case. Grey, when he heard of what had happened behind his back, sent a telegram to Ballance 'ordering' him to return, and when he did, proceeded to give him a 'good dressing down'.107 The sale of the land was postponed indefinitely shórtly afterwards.

There was a brighter side to the retention of land by the Crown: it would at least not pass into the hands of speculators. ${ }^{108}$ The Herald had already gleefully reported that government proclamation had removed about 50,000 acres at Waitotara from a 'knot of speculators'. It was a 'fatal blow to $\mathrm{Mr}$ Land-shark' on that coast. 109 Yet in the short term it placed Ballance's finances in serious straits:

The great discrepancy between the amount which the Colonial Treasurer estimated to receive from Land sales and the amount actually collected ... is, doubtless, a source

106. AJHR, $1880, \mathrm{G}-2$, pp. xxiv ff.

107. Fox's later account, PD, $1879,31, \mathrm{pp} .71-72$. See also NZH, 2 July 1879 .

108. EP, 26 Apr. 1879.

109. TDec. 1878. See also 14 Dec. 1878. 
of much trouble to the Government.

The inconvenience of the deficiency has

been alleviated, to a certain extent no

doubt, by the excess in other branches of

revenue; but the falling-off in the

Canterbury land sales, and the abandonment

of all hope of any return at present from

the Waimate Plains, must have caused $\mathrm{Mr}$

Ballance many anxious hours of thought how

to make ends meet. 110

Ballance wrote of the situation to Voge1: 'The land Fund has fallen off in a remarkable way... . By rigid economy I am trying to come out with a surplus, but it is hard work to make up for a deficit in the land estimate of probably $\$ 300,000.111$ Meanwhile the New Zealand Herald, now beginning to doubt Ballance's ability as a financier, predicted that there would be no recovery in land sales before the budget. 112

Imposing a higher land tax was a second means of increasing revenue. During the recess Grey 'talked wildly of raising the $\frac{1}{2} \mathrm{~d}$. land tax to $4 \mathrm{~d}$. or $6 \mathrm{~d}$. in the $\mathrm{f}$, and of breaking up the large estates'. 113 By June the Government was believed to be intending to increase the tax on properties over $£ 2,500 .^{114}$ In Wanganui the Herald carried on its own campaign. Landed property could afford to bear a much greater burden- the present tax, it said, was only the thin edge of the wedge. A graduated tax would not only increase revenue, but would break up the large 'unimproved' estates:

A class of 1 and monopolists is always a source of danger, and there can be no doubt that

110. EP, 26 Apr. 1879.

111. Ballance to Voge 1,25 Apr. 1879 , LB I, p. 118.

112. 9 Apr. 1879 .

113. J. Rutherford, Sir George Grey, K.C.B., 1812-1898: a study in colonia government, London, 1961, p. 620; EP, 19 May 1879.

114. E.C.J. Stevens to Stafford, 19 June 1879, Stafford MS, vol. 6. 
political power necessarily follows and remains with such a monopoly until... the pressure becomes intolerable, and then a violent popular upheaval shakes the very foundations of society. Fortunately the evil here is only in its infancy, and it can easily be nipped now. A graduated land tax... will render it impossible even for wealthy men to induige in the luxury of locking up from profitable occupation broad acres of land, on which people are hungering to settle. ... (T) he State has a right to impose such taxation upon land so held, that the owner will be obliged to part with it... . We regard a land tax as far more valuable in this direction than as a mere means of raising revenue... . 115

There would be a struggle, however, concluded the Herald; it would be a party one, a struggle for political power. Ballance undoubtedly agreed, though he had to be more cautious. In politics, especially in government, he could not always afford to be as radical as his own paper.

There is some evidence that Grey's extreme proposals aimed to destroy the tax entirely through stirring up strong feeling against it. Ballance later said he believed this to be the case. ${ }^{116}$ Indeed the financial proposals of Grey's Ministry, reconstructed following Ballance's resignation, included a new income tax (which Ballance at this stage opposed) but made no mention of an increased land tax. ${ }^{117}$ Although Ballance was to resign before the new session, for years afterwards he felt obliged to explain how the deficit of 1879 had come about. Had the land revenue not collapsed, he explained, the financial situation would have been satisfactory. He insisted that he could not be held responsible for circumstances, in particular the failure of the City of Glasgow Bank, over which he had no control. ${ }^{118}$

115. WH, 14, 28 June 1879.

116. $\overline{\mathrm{PD}}, 1885,53, \mathrm{p} .353$.

117. $\overline{\mathrm{PD}}, 1879,31, \mathrm{p} .6$.

118. $\overline{\mathrm{PD}}, 1879,32$, pp. $232-35 ; 1880,36$, pp. 185-88; 1881, 38, pp. 337-39; 1891, 72, pp. 116-17; AES, 12 July 1879. 
These problems over policy were reflected, and in turn reinforced, by serious personal conflicts within the Cabinet. Splits were already apparent by January 1879, and were eagerly reported by the conservative Stevens:

I think that the failure of the Ministry to either keep promises or perform any acts of utility either administrative or legislative has materially shaken Grey in the country. It must, however, be observed that he cares nothing for his government and loses few opportunities of holding himself up as something altogether distinct from them in sentiment and motive. ...His colleagues are insubordinate and both contradict and vote against each other. ...Grey continually puts forth one set of views whilst his colleagues clip his wings in Cabinet and propose to the House measures often diametrically opposed to Grey's statements. 119

Over the following four months two disputes in particular deepened the rift between Ballance and Grey. Whilst opposition papers had a field-day, pro-government journals were forced to take sides.

Ballance had become a director of two Wellington papers, both formed a year earlier to promote the liberal cause. One was the morning New Zealander, the other the Evening Chronicle. Neither survived beyond 1880. ${ }^{120}$ The Chronicle was edited by Henry Anderson, previously editor of the Post. Ballance was able to use it in particular to defend his own position against Grey. The Chronicle's accounts of Cabinet disagreements were based on information almost certainly provided by Ba1lance.

The first incident concerned the appointment of D.M. Luckie as Government Insurance Commissioner. Luckie had been a journalist, most

119. E.C.J. Stevens to Stafford, 3 Dec. 1878, 9 Jan. 1879, Stafford MS, vo1. 6.

120. G.H. Scholefield, Newspapers in New Zealand, Wellington, 1958, p. 35; NZH, 5 Aug. 1879; PD, 1879, 31, p. 70 . 
recently replacing Anderson as editor of the Evening Post. The appointment was a political one: the post had been a consistent supporter of the Government and Ballance- though Ballance genuinely thought Luckie able and as good a man as he could get. ${ }^{121}$ Ballance wrote to Luckie on 10 January 1879 offering him the position at $\mathbf{1 8 0 0}$ per annum. They had discussed the arrangements verba11y. ${ }^{122}$ It was a salary a good deal higher than the $\$ 200$ laid down by Parliament. Grey objected, insisting on the lower salary. ${ }^{123}$ Whitmore, a personal friend who was now Colonial Secretary and a member of the Legislative Council, wrote to Ballance pointing out that Grey's advocacy of reduced civil service salaries was a trump card from the point of view of public opinion. Luckie would accept $\$ 600$ and on that basis they could 'stand by him'. Ballance agreed to the compromise. ${ }^{124}$ The Evening Chronicle, on 26 February, reported that Grey had not opposed the appointment when it first came before the Cabinet. The following day it seemed that Grey had accepted the $\$ 600$ compromise. Only Sheehan had joined him in pressing for $\$ 200$; Stout, Whitmore and Macandrew all siding with Ballance. ${ }^{125}$

However in April Grey renewed his objection, and the issue broadened into the right of a minister to intervene in another minister's appointment. Ballance argued that there were many precedents for the larger salary, and proposed that the difference be charged to unauthorised expenditure. Grey refused to shift from $\$ 200 .{ }^{126}$ The

121. Ballance to Sheehan, 28 Nov. 1878 , LB I, p. 8.

122. Ballance to Luckie, $10 \mathrm{Jan}$. 1879, LB I, p. 22.

124. Whitmore to Ballance, 24 Jan. 1879, BMSS, 6-7; Ballance to Whitmore, 12 Mar. 1879, BMSS, 9.

125. Evening Chronicle, 27 Feb. 1879; NZH, 27, 28 Feb. 1879.

126. Grey to Ballance, $8,16,18,23$ Apr. 1879, BMSS, 12-30. 
issue then became simply a part of the widening gulf between the two men. Relations were so strained by April that Whitmore, who was leaving for New Plymouth to see Macandrew, advised Ballance to 'avoid any contact' with Grey until he returned. Ballance left for Wanganui the following day. ${ }^{127}$ Ironically Luckie's salary was finally fixed at $\$ 800$ by Parliament in December. ${ }^{128}$

An important cause of Grey's irritation with both Ballance and Stout was their participation in the New Zealand Land and Loan Company. The Company had been formed in 1878 to finance the settlement of the Waimea Plains, land just north of Invercargill that was to be sold by a second, Agricultural Company, to be floated in London. The land was infested with rabbits, and only by selling it in London, where this fact might not emerge, could the speculators involved hope to receive a high price. As Hamer has shown, though Grey knew about the Loan Company, of which Ballance and Stout were provisional directors, he had no idea of its connection with the Waimea Plains and the Agricultural Company. $^{129}$ When Vogel announced, in early 1879, that he had joined the board of the Agricultural Company, Grey insisted that it was incompatible with his position as Agent-General, and instructed Vogel to resign from the former. Vogel procrastinated and in the ensuing correspondence it emerged that both Ballance and Stout knew of his association with the Company. In an official letter of 26 April Ballance informed Vogel of the Government's decision to insist on his resignation. ${ }^{130}$ In a private letter of the previous day he had congratulated Vogel on the success of the Company and regretted that he was being asked to retire.

127. Whitmore to Ballance, $11 \mathrm{Apr} .1879$, BMSS, 1; WH, $12 \mathrm{Apr} .1879$. 128. NZH, 3 Dec. 1879.

129. Hamer, 1962 , p. 146.

130. AJHR, 1886, H-32. 
It was a Cabinet decision; personally Ballance had no objection to Voge1's position. 131

In January Ballance visited the South Island. At a banquet at Invercargill he made a speech emphasising how crucial railways were to the development of the 1 and. The only reproductive railway finance was that which directly promoted settlement. ${ }^{132}$ On 27 January he turned the first sod of the Waimea Plains Railway. The railway was an integral part of the Loan and Agricultural Companies' plans to dispose of the land, and was being financed by a third, allied company. Ballance telegraphed Voge1 in London:

Line through magnificent country waiting settlement by proposed Waimea Company. Success must contribute prosperity colony, and remunerate proprietors. 133

The telegram could not have arrived at a more fortuitous moment. The London Times had found out about the rabbits just as the Company was to be floated. Larnach had Ballance's telegram published and the Company was successfully launched.

Ballance was criticised for using his position as a government minister to promote a private undertaking. Criticism was minimal however; most attention was focussed on Voge1, and in any case the facts took some months to emerge. ${ }^{134}$ There were mitigating circumstances. When sending the telegram Ballance could not have known

131. Ballance to Voge1, $25 \mathrm{Apr}$. 1879, LB I, pp. 117-18; see also Ballance tc Larnach, 25 Apr. 1879, LB I, pp. 119-20.

132. Evening Chronicle. 28 Jan. 1879.

133. Hamer, 1962, p. 146. See also PD, 1879, 31, pp. 30-36.

134. See e.g. NZH, 17 Apr. 1879; EP, $\overline{5}$ May 1879. 
that events in London had reached a critical stage: the Times article revealing the presence of rabbits was not published until four days later. Also, although Ballance was a provisional director of the Land and Loan Company, most 1ikely brought in by Stout, there is no evidence to suggest that he had any personal financial interest in the Agricultural Company. He referred to it as 'your company' when writing to Voge1. 135

More important, Ballance quite simply saw nothing wrong with the venture. He viewed the Loan Company as a useful means of promoting settlement. When Fox brought up the matter at the election in September, Ballance had the prospectus of the Company printed in the Herald, saying that he was not ashamed to be associated with it and applauded in particular one of its chief objectives of subdividing large estates. A branch of the Company in Wanganui would, he continued, be of great benefit to the district. Land belonging to the local : firm of Taylor and Watt might be cut up into fifty farms and disposed of on deferred payment! 136

Ballance and Stout's involvement with the Company meant that their relations with Grey deteriorated still further. The Premier felt betrayed. He insisted that they resign their directorships, which they did. ${ }^{137}$ Stout said later that they did not resign; rather they were not asked to let their names be placed on the new prospectus of the Company when it was transferred to London- but it amounted to the same thing. ${ }^{138}$ Aside from contributing to the bad feeling already

135. Ballance to Voge1, 25 Apr. 1879, LB I, p. 117, see also EP, 5 May 1879; and ch. 7 on the Agricultural Company.

136. WH, 6 Sept. 1879.

137. Hamer, 1962 , p. 147.

138. See PD, $1886,56, \mathrm{pp} .641-44$. 
existing in the Cabinet the issue had no effect on Ballance's later decision to resign. He undoubtedly realised that it could be politically embarrassing but maintained that as it promoted genuine closer settlement it was a legitimate exercise. ${ }^{139}$ There were much better reasons for resigning.

By March 1879 disagreements within the Cabinet were being 'openly paraded'. The Evening Post urged that differences be patched up:

Knowing what we do of the autocratic idiosyncracies of Sir George Grey, we are quite prepared to believe that he is entirely in the wrong, and that he does not treat his colleagues with the consideration which they have a right to expect; but even if this be so, he has a right to expect loyalty from them while they remain his colleagues. 140

Meanwhile the Evening Chronicle launched another attack on Grey. It called him a coward for rushing off to his retreat on Kawau Island when trouble erupted on the Waimate Plains in March. Sheehan was Grey's last remaining ally in the Cabinet and the Chronicle sought to drive a wedge between them. The Premier had from the start tied the Native Minister's hands, it said. He was a stumbling block to progress whose conduct the country could stand no longer. ${ }^{141}$ Echoing the Chronicle the Herald in Wanganui pronounced Ballance the 'mainstay of the Ministry'; Ballance and Stout pulled together whilst Grey was going alone. ${ }^{142} \mathrm{~J}$. Murray, of the Bank of New Zealand, wrote to Ballance gravely concerned at the economic crisis- wool and wheat prices had

139. See Whitmore's explanation, PD, 1879, 31, pp. 34ff and Ballance's own later account, PD, $1885, \overline{5} 1$, p. 273.

140. 29 Mar. 1879.

141. 27 Mar. 1879.

142. WH, 19 Apr. 1879 . 
never before been simultaneously low- and at Cabinet disunity. 'Grey makes no secret of his intention to "put Ballance out"', he reported. Murray hoped that if anyone was to go it would be the Premier. ${ }^{143}$

By the beginning of May Ballance had decided to resign. 144 Having read the correspondence relating to Luckie's appointment Bryce advised him 'to take some means of retiring from the cabinet on broader grounds- grounds which might secure you sympathy in some parts of the colony at least'. ${ }^{145}$ Cabinet meetings had now ceased altogether. ${ }^{146}$ Stout had remained in Dunedin since the close of the previous session and by mid-May there were rumours of his resignation. ${ }^{147}$ With his partner in his law firm ill and his own health not good, he resigned a month later. The Wanganui Chronicle believed that the excuse of 'private affairs' was only a 'loophole for escape' from a 'blundering'. Ministry. ${ }^{148}$ Ballance too needed an excuse. There was no hope of a recovery of the economy before the financial statement was to be delivered. 'No one on the outside of a lunatic-asylum could view (the) finance without amazement and loathing' wrote the partisan Stevens. 'The Land Tax is a complete failure and its incidence is unjust beyond belief'. He added gleefully:

Report says that Stout will resign his office in the public interest. I shall not be sorry for it in the public interest... . I expect great fun from Wakefield this session. Last session he flew at nearly everybody and would have flared

143. J. Murray to Ballance, 2 Apr. 1879, BMSS, 10-11.

144. Bryce to Ballance, 12 May 1879 , BMSS, 31.

145. Bryce to Ballance, 25 May 1879, BMSS, 32-33.

146. PD, 1879, 31, p. 69; EP, 30 June 1879.

147. $\overline{\mathrm{EP}}, 18$ May $1879 ; \mathrm{NZH}, 27$ May 1879.

148. $\overline{16}$ June 1879 . 
up even more if he had not been next to a sober animal like myself but this year there will be no holding him and indeed I think I shall set him at Ballance. 149

Grey was now ruling by decree, 'seeing Ministers individually, telling them what he had decided and thinks should be done'. ${ }^{150}$ One such summons provided Ballance with a practically ideal pretext for resignation. He was called to Grey's office on Friday afternoon, 27 June. Grey had the Treasury Department draft estimates, prepared by Ballance, in front of him. He was unhappy that the salary of the Private Secretary to the Treasurer, E. Fox, had been removed from the Treasury estimates and placed elsewhere. In fact Fox was Secretary to the Cabinet and the Premier, and had long ceased to have any connection with the Treasury. Grey was intent on a showdown. He told Ballance that if this sort of thing was to happen he would take over the Treasury himself. Ballance, who had tried to explain that the estimates were only a draft and that if the Cabinet chose to charge Fox's salary to a department with which Fox had no connection, so be it, replied that in that case he had better resign. Grey, refusing to listen to further explanation, ordered Ballance to leave the room. Ballance, 'excited but calm' as a later report put it, claimed that as long as he was a minister he had a right to free discussion with all his Cabinet colleagues, from the Premier down. Grey threatened to have him physically ejected. Ballance replied that he wouldn't move 'if all the messengers in the building were summoned'. Sheehan, the only other person in the room, tried to quieten things down, but Grey left the room 'in a most excited state, crossed the passage, and entered Mr Fox's room opposite, slaming both doors after him'. Ballance then emerged 
'trembling with supressed excitement', apparently restrained by Sheehan, whose hand was on his shoulder. ${ }^{151}$

Three days later Ballance tendered his resignation. Grey asked him to reconsider, but this was a mere formality. ${ }^{152}$ The rift was too deep. It was inconceivable that relations might be patched up, primarily because at heart neither men wanted them to be. Grey had brought their conflict to a climax and Ballance was not going to let the opportunity for resignation slip. The specific issue was unimportant, though it angered Grey, who had consistently advocated retrenchment in the civil service. In removing Fox's salary from the Treasury estimates, Ballance revealed that Fox was in fact acting as Grey's personal assistant.

It was a remarkable incident, not so much because it occurred, but that it was so widely publicised afterwards. Ballance's version appeared in the Evening Chronicle, which said that the whole thing had been pre-arranged by Grey. Apparently, half an hour before Ballance was sent for by Grey he received a telegram from Whitmore in Auckland, saying that the papers there had just published an 'extra' containing news of a Cabinet disruption. ${ }^{153}$ Unfortunately no copies of this 'extra' seem to have survived, but it is most likely that it referred to Cabinet disputes in more general terms. Papers had for weeks been speculating about splits in the Ministry. The New Zealand Times noted that rumours of Ballance's resignation had reached it from Auckland in mid-June. Further speculation on Ballance's position occurred shortly

151. This account is gleaned from Evening Chronicle, 30 June 1879; NZH, 1 July 1879; EP, 1 July 1879; WH, 5, 12 July 1879.

152. Grey to Ballance, $3 \overline{0}$ June 1879, BMSS, $\overline{3} 4$. 153. 30 June 1879. 
before the specific incident took place. ${ }^{154}$ Ballance's resignation may have been predicted, but it does not follow that Grey stage-managed the whole affair. As it turned out, Ballance emerged in a more favourable light than the Premier. Those papers that did criticise Ballance, and they were in the minority, argued that he should not have allowed the facts of the dispute to have been made public. The facts themselves were not questioned.

Opposition papers were content to watch over the collapse of the Ministry. The New Zealand Times said that Grey 'quite forgot himself, and used language such as no colleague' could condone. ${ }^{155}$ The New Zealand Herald recognised that the dispute over Fox reflected more fundamental differences between the men; Ballance had no choice but to resign. 156 The pro-Government journals split, with the Lyttelton Times in Christchurch and the Evening Star in Auckland continuing to support Grey. The Times said that Ballance had been a drag on Grey and so his departure was the 'best thing' for the Liberal party. Details of the incident ought not to have emerged, and those that did were distorted. Politically Ballance was finished, for the Liberal party would not forget his efforts to supplant Grey. As for the Opposition, they viewed him

with scorn for reasons best known to themselves. One of its organs... lately informed him, in effect, that he is so black that the very sight of him drives the imagination of his critics into the contemplation of all that is most white and most beautiful, in order that his unpleasant figure may be quickly lost sight of. 157

154. Quoted by $\underline{\text { WH, }} 5$ July 1879.

155. Ibid.

156. $\frac{1,2}{1,4}$ Ju1y 1879.

157. LT, 5 July 1879; a1so 1 July 1879. 
He had not, recalled the Times, been a great success as Treasurer. His ability on paper had never been matched by his performance and influence in the House.

The Evening Post, on the other hand, agreed with the Evening Chronicle that the whole incident was orchestrated by Grey. As we have seen, Grey certainly used the dispute to bring his conflict with Ballance to a head, though the particular incident need not have been premeditated. The Post thought Ballance's version of the quarre1 'so entirely consistent with the course of action generally pursued by Sir George Grey that it may fairly be accepted as accurately representing what took place'. ${ }^{158}$ The Otago Daily Times urged that parties be reorganised to the exclusion of Grey. ${ }^{159}$ In Wanganui the Chronicle launched a series of fierce attacks on Ballance. He had long been trying to split the Liberal party in his favour, it said, but has now been found out 'people speak of him as a 'solemn humbug', and laugh at his finance with its ridiculous land tax, and no less ridiculous reduction of duties on tea and... sugar'. He had deserted his post at a time of need. ${ }^{160}$ The Herald responded by reprinting all those accounts favourable to Ballance that had appeared in other papers. ${ }^{161}$

Ballance's resignation sealed the fate of the Liberal Ministry by pushing already wavering supporters over to the Opposition. Parliament opened on 11 July with the Government promising a new f5 million loan to further public works and an increase in income tax to make up for the deficit in land revenue. Fox, the newly chosen Opposition leader, moved

158. 1 July 1879.

159. Quoted NZH, 3 July 1879.

160. WC, 7, 14 Aug. 1879. See also WC, 11 Aug. 1879.

161. $\overline{\mathrm{WH}}, 5$ July 1879. 
a no confidence motion almost immediately. There were suggestions that Ballance's resignation from the Ministry would also involve his defection from the Government benches. ${ }^{162}$ In fact that he remained loyal to Grey was of secondary importance to the effect his resignation had on the disintegrating Liberal party. Supporters of the Government who were already concerned at Grey's suitability as Liberal leader, his radicalism or at the failure to carry through policies in general, now lost all remaining confidence in him. The 'middle party' re-emerged. On $23 \mathrm{July}$ its leader, J.C. Brown, claimed that it commanded seventeen votes, which would be given to the Government only if Grey was replaced by Macandrew. ${ }^{163}$ In the event Brown voted with Grey, but the middle party, reflecting the evident disunity amongst ministerial supporters, had done its damage. The political situation was very confused, said the post on $22 \mathrm{July}$, political parties 'scarcely exist'. A week later Fox's motion was carried by forty-seven votes to thirty-three. The Governor acceded to Grey's request for a dissolution.

Throughout the debate Ballance remained quiet. Indeed he did not utter a single word in the House the whole session. According to the Evening Star he was annoyed at criticism of his actions in the press, and was actively plotting against Grey:

Official life has apparently agreed with him. He has grown very portly, and has a habit of placing his hands behind his back, and inclining his ear in a condescending style. He has been busy lobbying this afternoon, and prophesies a coup by the opposition. He inclines to the belief that the session will not last more than a month. 164

162. See e.g., EP, 5 July 1879.

163. NZH, 24 July 1879.

164. 12 July 1879. He was right- the session ended on 31 July. 
There is no evidence to support the Star's allegation that Ballance, to the extent of joining the Opposition, was working against the Ministry. Though he could never again join a government led by Grey, it was vital that his credentials as a consistent liberal be sustained. He had, after all, left Atkinson for Grey less than two years earlier. By emphasising personal rather than policy differences the circumstances of his dispute with Grey also helped to ensure that Ballance continued to be regarded as a prominent liberal. Ballance remained quiet because he had nothing constructive to offer. He was certainly not prepared to join the opposition in the condemnation of a Ministry of which he had been a member. He believed defeat inevitable and looked to the coming election as the only means of resolving the situation. Soon he left Wellington to commence preparations for his own campaign; according to the Wanganui Chronicle he was the first member to do so. ${ }^{165}$

Grey never forgave Ballance. Their public reconciliation in October, when Ballance, speaking at an opposition dinner, said he wished bygones to be bygones, was never matched in private. ${ }^{166}$ For Ballance, Grey was a stumbling block to the formation of another liberal ministry. Especially in Auckland Grey continued to have a personal following and weisld a personal influence that for a number of years made the formation of a liberal government without him impossible. Even when Premier Ballance had difficulty maintaining the support of liberals in Auckland. Had it not been for his deviousness, Ballance said later, Grey might have continued leader of a Liberal party. Instead he had destroyed it:

Not by want of talent, but destroyed by want of consistency, by want of political honesty 
and straightforwardness. This is what wrecked the Liberal party, and the honourable gentleman (Grey) as the possible leader of it... . There was never a man who came into this House more endowed with all the intellectual qualities and gifts to become a leader of a great party in this colony than the honourable gentleman. ...We want something more as a test of statesmanship than the making of great speeches before large masses of people, without any attempt in the slightest degree to give effect to what is uttered. 167 
CHAPTER FIVE

Years of Uncertainty and Change 
The years between the fall of the Grey Government and the formation of the Stout-Vogel Ministry in 1884 were critical ones for Ballance. Macandrew was chosen to replace Grey as Opposition leader. Ballance was the most able politician of the non-Greyite libera1s and recognised Macandrew's inadequacies, yet he hesitated to put himself forward believing that Stout (despite the fact that he was out of Parliament) had prior claims. At the same time Ballance's own financial affairs were deteriorating. The depression which began in 1879 and was to last until the mid-1890s hit the Herald hard (c.f. pp. 207-11.) Finally, his defeat at the 1881 election was an unexpected blow to his confidence and political career.

It was because of the uncertainties related with these events that this period of Ballance's life was so important. Defeat gave him time for reflection, re-assessment, time for his business affairs and time for Wanganui. By 1881 he had reached his political maturity. By then all the elements of what he was to regard as the central liberal platform of 1890 were apparent. Ballance saw himself as a liberal and long argued that politics ought to be fought along liberal versus conservative lines. He was confident that ultimately they would be. In 1884 he recognised that the formation of a ministry solely on the liberal principles to which he was committed was not possible. He accepted the delay and settled for second best.

The evolution of Ballance's philosophy involved an adaptation of English liberalism to New Zealand conditions. The precise way in which this was done was determined by Ballance's perception of politics based on his Wanganui experience. His radicalism centred on land reform because for Ballance politics in New Zealand was primarily a 
struggle for the control of land. His only published writing outside the Herald was on land nationalisation. This reflected his belief that as land held the key to prosperity, political debate and conflict must inevitably revolve around it. At the same time land was the core of his liberalism because it also held the key to individual advancement. The State had a crucial role to perform in providing the conditions under which individual self-help and self-reliance could be maximised (see chapter 6 ).

In 1879 Ballance switched his seat from Rangitikei to Wanganui, a recognition of his identification with the town's interests. Wanganui's prosperity continued to depend upon servicing the country. The close relationship between town and country was not to be overshadowed by predominantly urban issues as it was in the larger centres of population. The working classes in Wanganui continued to think primarily in terms of moving onto the land as the means of improving their economic circumstances, and for the town as a whole the closer settlement of small farms made a good deal more sense than an attempt to develop local industries. The solution to depression was seen not in tackling unemployment and low wages through trade union organisation and industrialisation, but in removing obstacles to the opening up of the 1 and.

Thus there was no paradox in a liberal 'rural' platform aimed at an urban electorate, for a policy tailored to urban needs that saw solutions in the land was particularly well suited to Wanganui. Land nationalisation, or at least the leasing of land, was attractive to prospective settlers in the town rather than established farmers. Equally it drew support from those, content to remain in Wanganui, who 
saw that closer settlement was the best guarantee of the town's prosperity. It would also, it was hoped, lessen those social evils wellknown in the old country to be associated with urbanisation.

Specifically, Wanganui was a town dominated by labourers and artisans. They comprised well over half the electorate in $1884 .^{1}$ Ballance's 1and and protection policies were directed mainly at these groups, and it was upon them that his political future rested. Such a platform also attracted support from those shopkeepers and businessmen who saw Ballance's primary aim as boosting the town's economy. 2

The following two chapters examine how Ballance arrived at this position on his return to power in the Stout-Vogel Government. This chapter will look at his political activity first as a national figure and second as a representative of Wanganui. It will stress the effects of the depression on Wanganui and on Ballance's own financial position. The chapter will conclude with a discussion of his electoral defeat in 1881 .

Chapter 6 deals with Ballance's political philosophy. while his views and writings on land nationalisation are of particular importance, this chapter also aims to show the broad base of his liberalism. Ideology is intimately related to practical politics, and so the strands

1. Calculated from 1884 Electoral Ro11s,

2. Ballance's electoral support is examined in ch. 9, which discusses the 1890 election. This was Ballance's first election in Wanganui at which there was more than one polling booth. 
of both chapters will finally be brought together in a discussion of Ballance's 1884 election campaign.

Liberal supporters of the Grey Ministry sought to fight the 1879 election along liberal versus conservative lines, and Liberal Associations were formed to promote candidates and policy. The Wellington Association established by Grey outlined a sixteen point programme, which included a progressive land tax, the abolition of plural voting at local government elections, redistribution of seats according to population, manhood suffrage, the promotion of village settlements, encouragement of local industries and the abolition of Legislative Councillors' honorarium. ${ }^{3}$ The election was the closest the country had come to such a clear political cleavage. A major source of opposition to the liberals came from conservative businessmen and landowners unhappy with Ballance's land tax.

Yet reality was not as simple as the Greyites suggested. As E. Bohan has pointed out with respect to the election in Canterbury, candidates far from fitted in to such a neat categorisation. There were opponents of the Grey Ministry, for example, who were distinctly more liberal than some of its supporters. ${ }^{4}$ It is undeniabie that Liberals, and Grey in particular, sought to impose such a cleavage;

3. NZH, 1 Aug, 1879.

4. E. Bohan, 'The General Election of 1879 in Canterbury', M.A. thesis, University of Canterbury, 1958; see also E. Bohan, 'The 1879 General Election in Canterbury', Political Science, XII (1960), pp. 45-61. 
Bohan simply argues that many at the time refused to accept it as fundamenta1. Only in a minority of cases did it accord with political reality.

As we sha11 soon see, in Wanganui too the liberal-conservative split was complicated by other factors. However it remains true that Ballance himself fought the election as a 1iberal, and was elected as such. His own political platform was unambiguous.

Aside from the fact that genuine liberals and conservatives did appear on the 'wrong' side, there were two other reasons why such a clear division was lacking at the election. First, it suited many conservatives to deny that politics was a matter of liberalism versus conservatism. By emphasising the need for retrenchment, concentrating on the maladministration of the Grey Ministry, and at the same time adopting those reforms (e.g. electoral) that were already widely accepted, they obscured and defused the fundamental cleavage the liberals hoped to create. Further, the label 'conservative' was used with disapprobation, and so might be rejected by a candidate irrespective of its applicability. Secondly, the genuine liberals were themselves divided. Many refused on past experience to accept Grey's leadership, preferring Macandrew instead. Although Grey's charisma and ability to draw large crowds was an asset to the liberals, his domination tended at the same time to narrow the base of the party to his personal following.

In fact the liberals had considerable success; more impressive given these internal divisions, the problem of defending a Ministry that had appeared ineffectual, and the background of economic depression. 5 
Ballance's decision to stand for Wanganui rather than Rangitikei made sense. He lived in the town and, as has been argued above, his political platform was more suited to it than to the country constituency. It was not simply that it would prove to be an easier contest. There had been signs of growing opposition to Ballance in Rangitikei, and his espousal of the land tax would no doubt stiffen it, but with such a prominent figure as Fox standing in Wanganui, the result there was by no means a foregone conclusion. 6

The Wanganui contest contained the same ambiguities as elections elsewhere. There were three candidates for two seats. On the one hand Ballance, a national liberal personality, faced Fox, the conservative Leader of the Opposition. On the other hand the third candidate, John Bryce, who was essentially a conservative, joined Ballance in an alliance aimed solely at excluding Fox. It was a classic case of personal considerations overriding political differences. Their friendship had survived because Bryce could sympathise with, support and advise Ballance in his split with Grey; especially to the extent that it involved what Bryce regarded as Grey's fundamental weakness over native affairs. Beyond this there was now no common political ground between the two men. Bryce voted for Fox's no-confidence motion while Ballance remained loyal to Grey. Bryce too had all along expressed doubts about the land tax. ${ }^{7}$ Writing to Ballance in May he thought Fox to be 'gaining popularity' and believed Watt to be standing alongside him. ${ }^{8}$ Bryce calculated that an alliance with Ballance was the best means of defeating both.

6. See WH, 30 Nov. 1878; WH, 16 Aug. 1879.

7. For example see his speech, WH, 26 Jan. 1878.

8. Bryce to Ballance, 25 May $18 \overline{79}$, BMSS, 33 . In the event Watt wasn't a candidate. 
Ballance preferred to see Bryce rather than Fox elected alongside himself, and his election committee ran both their campaigns. He emphasised how together they had supported abolition in the interests of Wanganui; their more recent political differences were simply ignored. Meanwhile Bryce's claim to be an 'independent' allowed him to appeal to the 'middle ground' between Ballance and Fox. 9

In his campaign Ballance was in the somewhat awkward position of having to defend the Grey Ministry and his own role in it whilst opposing Grey himself as leader of the party. He praised Grey's liberalism but insisted that he lacked the qualities necessary for leadership. He did not however specify who should replace him. In Wellington the Chronicle did. The party, it said, should ditch Grey for Macandrew. ${ }^{10}$ The Evening Post drew the distinction between 'true, honest 1iberalism' and the 'Red Republicanism gone mad' of Grey. It argued that the city's Liberal Association was a sham as its proposed candidates, Hutchison and Fisher, were simply Grey nominees. ${ }^{11}$

With three such prominent personalities'involved in the Wanganui election interest ran high. Between four and five hundred electors squeezed into the Oddfellows Hall on the evening of Tuesday 19 August to hear Ballance speak. It was one of the largest meetings to have been held in the town. ${ }^{12}$ Ballance began by saying that he had decided to stand for Wanganui in order to fight Fox, whose articles in the

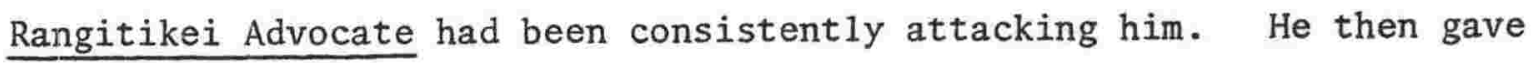
an account of past sessions, defending his own actions and activities. The most significant part of the speech however, concerned his views on

9. WC, 12, 20 Aug. 1879; WH, 23 Aug. 1879.

10. Evening Chronicle, 30 July 1879.

11. $\overline{E P}, 1,4,14,15,18$ Aug. 1879. Fisher later retired from the contest.

12. WH, 23 Aug. 1879; NZH, 21 Aug. 1879. 
land settlement.

First he argued that the land tax was the 'salvation' of bonâ fide settlers as only the monopolist, whose aim was to 'drive the small holder to the towns, and so retard the progress of the colony', would be penalised. Improvements were exempt: the more improvements the less tax to be paid. Fox had said that 'mechanics' and tradesmen had no interest in a liberal land law. Ballance replied that 'there was not an artizan in the colony who did not strive to get his little bit of freehold, even if it was only a quarter-acre section. Did not every man endeavour to provide for his family by leaving them a little property? 13 Five years later he would be much more explicit on the advantages of a liberal land law to urban labour.

Recognising the need for finance to carry out improvements, Ballance next proposed that an Agricultural State Bank be established to provide loans for small farmers. The colony's trust funds in savings banks would be transferred to the agricultural bank and money advanced on freehold security at six per cent.

On the mechanism required to make land available Ballance said that he had already drawn up an amendment to the Land Bill due next session, allowing for the establishment of village settlements alongside the line of railways. He also argued that a ballot system should replace the: auction of land on deferred payment. A few days earlier Ballance had attended a meeting called to form a new small farm association in the town. At it he had said that the association could do little as no provision was made for special settlements under existing laws; the selling of land on deferred payment by auction meant that it simply went to the highest bidder. ${ }^{14}$

13. On land ownership as a working class ideal, see Miles Fairburn, 'The Rural Myth and the New Urban Frontier', NZJH, 9, 1 (1975). 14. WH, 9 Aug. 1879. 
Finally, Ballance said that closer settlement would have the advantage of solving the 'native difficulty'. Where land was bought up by speculators and 'scattered with a few shepherds' there could be no guarantee of peace. 'Wherever the Government had a block of land with a good title' they should settle it. 'Never mind the price so much as planting settlers. They would repay the country by establishing peace, and also through the Customs'.

Other speeches at Waverley and Waitotara repeated these themes. Ballance also again claimed that there were two distinct partiesliberal and conservative- and that it was to the former he belonged. 15 Meanwhile the Wanganui Chronicle launched daily attacks on Ballance and his 'rowdy' supporters. ${ }^{16}$ It brought up his involvement in the Land and Loan Company, ${ }^{17}$ and argued that his 'sensational programme of reforms' would, if he was returned to office, mean an impoverished exchequer. ${ }^{18}$

On the eve of the poll a minor issue entered the election. In Otago and Canterbury associations had been formed to press for Bible reading in schools. Ballance had said in his speeches that he was not opposed to religious instruction but that its proper place was in church and at home. Introducing Bible reading into schools would also force Catholic children to leave. The Chronicle suggested that Ballance had actively wooed the Catholic vote by promising state aid to private schools. It reported that a meeting on 31 August of the town's Catholics had decided to support Ballance and Bryce. ${ }^{19}$ In fact the

15. WH, 30 Aug. 1879 .

16. See for example, 12, 14, 21, 22, 25 Aug. 1879.

17. 15, 30 Aug. 1879. See ch. 4, pp. 169-71.

18. 1 Sept. 1879 .

19. Ibid. 
Chronicle's allegation was unjust. The Herald pointed out that

Ballance had always supported a state secular system and denied that

he had made a deal with the Catholics. The Chronicle withdrew its claim. 20 Ballance's opposition to Bible reading in schools was sufficient reason for Catholics to support him rather than the unsympathetic Fox, but it was a small part of his programme and sprang from a liberal philosophy rather than expediency aimed at the Catholic vote.

That Ballance saw politics as essentially a contest between the landless poor in the towns and wealthy monopolists is shown by a revealing piece of doggerel printed in the Herald at the time:

Oh, Paddy dear, and did ye hear, The news that's going around, The Land Sharks claim thave a right

To all New Zealand ground.

So pluck that fond wish from your heart, That brought you out from home;

You'11 never own a sod of land In all the time to come.

I met with Bryce and Ballance, and They took me by the hand, Says they "Poor Man" why don't you get A little bit of land. Och thin, says $I$, 'tis what I want, But what's the chance for me, When all the many acre'd sharks Have said it shall not be.

I came out here because they said, An honest man was bound,

If he'd work hard and sober keep, To get a bit of ground.

If Parliament's returned by Sharks, Without a hope I stand,

Say's they poor man there's more as thinks That you should have your land.

20. WH, 6 Sept. 1879; WC, 3 Sept. 1879. 
And though the acred lordings here

Say Fox return you must,

If we but to ourselves are true, We in ourselves may trust.

So vote for Bryce and Ballance, boys, Who won't grind down the poor,

You al1 know well how much you'11 get

From Watt and Peat and Moore. 21

The result of the election was close. In a high turnout $(80.5$ per cent compared to the national average of 66.5 per cent) Ballance was thirteen votes behind Bryce, who headed the Poll:

\begin{tabular}{lrrrrr} 
& Ba1lance & & Bryce & & Fox \\
\cline { 2 - 2 } Wanganui & 424 & & 426 & 328 & \\
Waverley & 72 & & 81 & 116 & \\
Upokangaro & 24 & & 24 & 14 & \\
Maxwe11 & 22 & & 24 & 28 & \\
Marangai & $\underline{5}$ & $\underline{5}$ & $\underline{15}$ & \\
& $\underline{547}$ & $\underline{560}$ & $\underline{501}$ & 22
\end{tabular}

Ballance's strongest support came. from the town. In the main country settlement, Waverley, he polled fewer votes than both Fox (who lived there) and Bryce. In such a close contest the Catholic vote, though sma11, may have been critical to Ballance and Bryce. Though Bryce's candidature confused the contest to a certain extent, there can be no doubt that Ballance, who promoted himself as first and foremost a liberal who saw politics as a struggle for the control of land, was recognised by electors as such. Given a choice of three candidates of varying opinions, the Chronicle continually pointing out Ballance's 'sensational' policies, and a national background where 'liberal' and 'conservative' labels (however accurately) abounded, it would be naive

21. 23 Aug. 1879. Note the expectations of the immigrant, and the self-reliant theme in the final verse.

22. WH, 6, 13 Sept. 1879 . 
to suppose that he was elected upon any other basis. ${ }^{23}$

The result of the election nationally put the Government and Opposition on nearly equal terms. The Herald in noting this welcomed the clearer definition of parties; 'though nearly every one has claimed to be a Liberal', in reality conservatives and liberals were quite distinguishable from one another:

...instead of such issues as Provincialism, Separation, and Federation, we have great principles affecting the whole people awaiting decision. This is surely a great gain... . It must not be supposed that parties have been perfectly organised... but a great stride has been made. 24

There was indeed to be some further realignment. Shortly after Parliament assembled Grey was defeated in a no-confidence motion by two votes. The vote would have been tied had not Vincent Pyke of Dunstan in Otago decided at the eleventh hour to side with the Opposition. Ha11, who had replaced Fox as leader, then formed a Ministry. Meanwhile Grey stood down as leader of the liberals and was replaced by Macandrew. Pyke and Downie Stewart, also from Otago, then announced that they would no longer support Hall. It was only the desertion of four members of Grey's Auckland party (promised a fairer share of public works' expenditure for the city) that saved the

23. The writer disagrees entirely with Young's proposition that 'Ballance's use of party names bore little relation to political principles'. T.J. Young, 'The Political Career of John Ballance, 1875-1890', M.A. thesis, Victoria University of Wellington, 1964, p. 6 24. 20 Sept. 1879 . 
new Government. 25

Ballance played a critical role in these manoeuvrings, and at the same time made a half-hearted first bid for the leadership of the 1iberals. The Evening Star had before the election suggested that Ballance was the 'dark horse' who aspired to the office and was believed capable of holding the party together. ${ }^{26}$ In the complicated events that led to Hall's securing of a majority what seems to have happened was as follows: Ballance and Pyke agreed that the latter would vote against Grey, thus defeating the Government, but then refuse to support Hall. This would leave the way open for the formation of a Ministry including Ballance, Pyke and Macandrew. Such tactics would involve little political embarrassment for Pyke (never a firm Greyite) and none for Ballance, who could prove his loyalty and consistency publicly by voting with Grey. Pyke could argue that he simply wished to see greater Otago representation in the Government (which was true as far as it went) and Ballance would accomplish his aim of replacing Grey with an alternative liberal administration.

On the eve of the vote of no-confidence it seemed that Grey was safe:

Mr Pyke's vote has been secured by the Government. The Opposition had a deputation to the number of twenty prepared to meet $\mathrm{Mr}$ Pyke on arrival, with a carriage and pair, but Mr Ballance got hold of him, and marched him off in triumph, to the intense disgust of Messrs McLean and Hall. 27

25. R.C.J. Stone points out the role of the 'native question' in the motivations of the four 'Auckland Rats', 'The Maori Lands Question and the Fall of the Grey Government, 1879', NZJH, 1, 1 (1967), pp. 51-74. 
Only when Pyke voted against Grey was it at all apparent what had been going on. When the Opposition caucus met following the defeat there were forty-three members; but only forty-two had supported Grey. The addition was Pyke. Ballance toyed with the idea of putting himself forward as leader, but Reader Wood proposed Macandrew arguing that only he could unite the party. Macandrew was certainly more acceptable to the Greyite faction than Ballance, and he was elected unopposed. ${ }^{28}$ Ballance may not have pressed the matter because he did not wish to split the party further and in any case regarded Stout's return to Parliament to assume the leadership as inevitable.

The formation of a ministry by Macandrew looked probable until the four 'Auckland Rats'- including Wood(!)- changed sides. It was not simply a case of provincial interests reasserting themselves. In fact the four 'rats' were all from the right wing of Grey's Auckland coalition (all had business interests in that city) and their defection clarified the liberal/conservative alignment. ${ }^{29}$

The parties were evenly balanced and there was inadequate support for an undiluted liberal government. A Grey coalition involving conservative Auckland support was ruled out as past experience had alienatec other 1ibera1s; and the four Aucklanders knew it. The Evening Post had suggested an alternative: a Hall/Ballance/Macandrew coalition, ${ }^{30}$ but this was never a possibility. Ballance himself moved a resolution pledging the liberal caucus to resist combination. ${ }^{31}$ And in the event, of course, Hall did not need it.

28. NZH, 8, 9, 11 oct. 1879 .

29. See Wilson, pp. 52-56.

30. Persistent1y! EP, 8, 9, 10, 23, 28 Sept. 1879.

31. AES, 7 Oct. $187 \overline{9}$. 
Macandrew's leadership was not a success. With Hall secure, the Opposition (which had held together as long as there was the prospect of power) fell apart. Grey went his own way, to Hall's comfort preventing 'an effective Opposition from coalescing'. 32 Without Ballance, who was ill at the time, to provide effective criticism of the Government's financial proposals, a no-confidence motion moved by Macandrew was a damp squib.

By mid-1881 Ballance was frustrated at Macandrew's inability to gather about him a party espousing clear liberal principles. 'The secret of the success of our party must depend on its reliance on the people, and its firm adherence to its principles', he wrote to Stout:

We sadly want a (liberal) programme... that will lift the party from the dead level where no one can discover who's who. My own opinion is that without such a programme we cannot expect to do much. 33

Ballance complained that Macandrew, by putting forward a policy including the issue of paper money to pay for public works and Bible in schools, and by not specifying what should replace the property tax introduced by Hall, was failing to represent the opinions of his party. Yet Ballance would not put himself forward as an alternative: he told Stout that he believed himself 'utterly deficient' in the qualities necessary for leadership. 34

The Hall Government was a conservative one set on retrenchment as a means of coping with depression. Its 'liberal' measures of electoral reform it adopted because there was a consensus of opinion in 
the country and Parliament in favour of them, and because in passing them the Opposition could be further neutralised. There were advantages to be gained in not resisting the popular mood, and in any case retrenchment and the replacement of the land tax by a property tax were more important. Ballance did what he could to promote liberal policy. He proposed a radical amendment to the Electors Bill, opposed the return to the property tax, and supported the Representation Bill on the basis that it was a step in the direction of a more equitable electoral system. Each will be looked at in turn.

The Qualification of Electors Bill gave the vote to all male residents of twelve months, reduced the freehold requirement to 25 , abolished the ratepayers franchise, but retained the property vote. Numbers of Maori voters on European rolls were halved when land held communally was no longer considered eligible as a freehold qualification. 35 In committee Ballance carried an amendment substituting the word 'person' for 'man' in the freehold qualification, thus introducing a female franchise. He attempted to do the same with the residential qualification, though this time the amendment failed. ${ }^{36}$ The time for discussion on the woman's franchise was singularly ill chosen, complained the Wanganui Chronicle. And in any case, it said, the franchise was not sought by New Zealand women. Though the weaker sex were as able as men to take part in political discussions, few would vote if given the opportunity. 37

In fact the first amendment had been carried because many conservative members supported the franchise for women freeholders simply

35. G.A. Wood, 'The 1878 Electoral Bill and Franchise Reform in Nineteenth Century New Zealand', Political Science, 28, 1 (1976), p. 54.

36. PD, 1879, 33, pp. 173, 182 .

37. $\frac{\mathrm{PD}}{13}$ Nov. 1879. The Herald naturally supported Ballance, WH, 15 Nov. 1879. 
on the grounds of the rights of property. Ballance later indicated that he would have accepted this limited franchise as a step in the right direction, but was persuaded by friends to withdraw the amendment. They were concerned at the political effect of only women property owners voting: it should be all or nothing. Ballance was uncertain at the time, but by 1890 was convinced that it had been just as well he had taken the advice. 38

The financial policy of the Colonial Treasurer, Harry Atkinson, aimed at tackling the depression through administrative retrenchment, stopping subsidies to local bodies, imposing a property tax and a certain amount of 'bookkeeping'. He separated the land account from consolidated revenue to remove the temptation to 'dissipate New Zealand's land resources by selling land to raise revenue'. 39 As Ballance had found to his cost land sales were most unpredictable.

Ballance, not Macandrew, replied to Atkinson's speech moving the Property Assessment Bill. It was a strong condemnation of the Government's financial proposals as a whole, the high point of what was otherwise a dry debate. ${ }^{40}$ He claimed that the principle of the land tax had been accepted in the country because it bore lightly on the 'industrial' part of the community and heavily on the speculators. The property tax on the other hand was unjust in its incidence: small farmers would pay more under it than under a land tax, even if the land tax were doubled. If there was to be additional taxation to that on land, it should be on incomes. An income tax was a tax 'simply on the

38. PD, 1890,68, p. 394. See ch. 12 on Ballance's support for the female franchise.

39. Bassett, pp. 77-78, 82 .

40. EP, 5 Dec. 1879; NZH, 6 Dec. 1879; WH, 6 Dec. 1879; G.F. Thompson, The Politics of Retrenchment: the origin and some aspects of the politics of the Hall Ministry, 1879-82', M.A. thesis, Victoria University of Wellington, 1967, p. 79. 
capacity of the individual to pay it'. It would also be more equitable as unlike the property tax it would not exclude the professional class, 'one of the most prosperous in the country'. Ballance went on to defend his own actions as Colonial Treasurer, and then gave a point-by-point criticism of Atkinson's proposals. On the tariff he thought that the duty on tobacco should be halved, but at the same time welcomed the bonuses given to protect home tobacco production as they would benefit the small farmer, for whom tobacco would become a staple item of production. His stance on protection was therefore ambiguous. Again, if it could be statistically proven that the removal of timber duties had damaged colonial production and trade he would support their reimposition: 'I would not stand upon theory when I saw a great evil arising'. Yet he thought that the real cause of falling colonial production was the depression, and that while colonial industries might be encouraged in many ways, it would be 'very dangerous' to introduce a policy of protection. Only as the depression deepened did Ballance become a committed protectionist.

The main thrust of Ballance's argument was reasserted in his conclusion:

... I affirm that there can be no greater
evil in a young country than (the)...
consolidation of large properties...
$\ldots$..I deeply regret the abolition of the
land-tax. I think it will lead to a
continual agitation, and that the tax
will not be permanently repealed. I
believe that, while this agitation is going
on ...., while we are vacillating between one
system of taxation and another ...,great evils
will arise to the industrial prosperity of this
colony in the future. 41

...I affirm that there can be no greater evil in a young country than (the)... consolidation of large properties... . ...I deeply regret the abolition of the land-tax. I think it will lead to a continual agitation, and that the tax will not be permanently repealed. I believe that, while this agitation is going on ..., while we are vacillating between one system of taxation and another ...,great evils colony in the future. 41

41. $\mathrm{PD}, 1879,34, \mathrm{p} .713$. Ballance was later instrumental in having a measure protecting colonial tobacco production introduced, see $\underline{Y}$, 30 July 1881; Y, 20 Aug. 1881. 


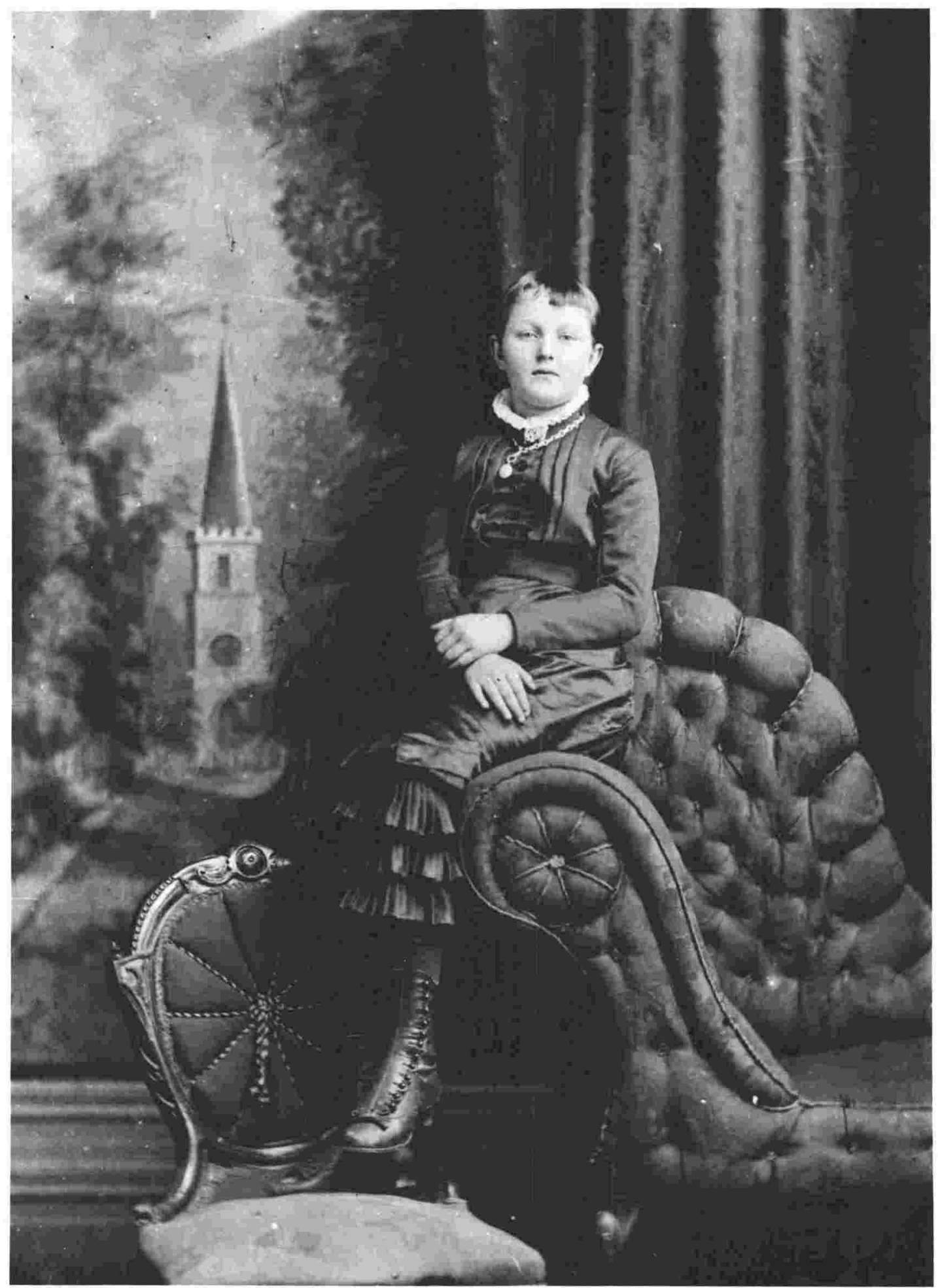

Kathleen Ballance, 1885 
In speeches over the following two years Ballance developed his criticism of the property tax:

We should see that a tax, when proposed, shall not take more out of the pockets of the people than is absolutely required for the services of the country. That is a fundamental principle.......(Further,) property must not escape taxation while you are piling taxes upon the working classes. 42

There was 1ittle opposition to the Representation Bill of 1881 . Few could deny that boundaries needed to be redrawn so that representation was based more squarely on population. The Government, however, sought to counteract the political consequences of this redistribution by increasing the total number of seats. ${ }^{43}$ Ballance supported the Bill as a move in the right direction. Ideally he would wish Maoris to be included on the same basis as Europeans, and he hoped ultimately they would agree to give up their special representation. If they did, he believed that there would be more Maori members in the House. More important, Ballance argued that town and country should be equally represented according to population (under the Bill the country remained over-represented). The country would not suffer; quite the contrary, for the towns had an interest in encouraging the maximum amount of settlement on the 1and. This was especially important said Ballance, as the opposite was occurring: property was being consolidated, large estates formed, and political power would inevitably follow. Redistribution would assist what should be the first duty of Government, 'the cutting-up of the land, the dispersion of property, and the location of people upon the land'. ${ }^{44}$

42. PD, 1880,37, p. 602 . See also PD, 1880,35, pp. 371-82; PD, 1881, 40, pp. $762-63$.

43. Thompson, p. 206.

44. PD, 1881, 39, pp. 548-51. 
The urgency of closer settlement, and awareness of the relationship between town and country in general, were particularly acute with the onset of depression. The population of Wanganui town had virtually doubled between 1871 and 1881 , to 4646 . The rate of increase over the following decade, however, was considerably slower; 4901 in 1886 and 5011 by 1891 . The settlement of the immediate hinterland was more rapid. Wanganui and Rangitikei Counties, for example, increased in population from 5901 in 1886 to 6719 in 1891.45 The town continued to perform its basic role as a distributive and servicing centre for country settlements. By 1885 it contained an iron foundry (no doubt producing agricultural implements amongst other things), flour and bone mills, a bacon factory that could handle 1500 pigs at a time, sale yards and a large sheep dip, vineyards, an abattoir and preserving factory, and a cheese factory. There were smaller firms producing for the local market, for example a confectionary and biscuit business and a sash and door company. ${ }^{46}$

The two major local development issues of the $1880 \mathrm{~s}-$ the extension of port facilities and the establishment of a freezing works- involved key projects that were viewed as essential if the processing and distributive functions of the town were to be maintained. Much discussion took place on harbour improvements, though little was achieved beyond an extra few feet to the breakwater; and that proved fairly ineffectual in deepening the harbour. A freezing works opened in the town in 1891. Until then Wanganui lost valuable trade to the Wellington

45. New Zealand Census for the respective years. The population of the boroughs of Wanganui and Marton rose from 5,809 to 5,987. Any changes in boundaries would distort the figures, but the slowing down of the rate of population growth is undeniable.

46. L.J.B. Chapple \& H.C. Veitch, Wanganui, Hawera, 1939, pp. 131-32. 
works. Once established the freezing works greatly boosted the town's economy, as farmers from the district were able to get a higher price for their sheep at Wanganui by saving the cost of rail freight to Wellington. ${ }^{47}$

For Ballance the rate of settlement was disappointingly slow. Legislation to promote it had been passed, but the Government seemed reluctant to make use of it. The 1877 Land Act established the system of selling land on deferred payment. Ballance was eager to see the revenue obtained contribute to the development of that land. He had successfully amended the Act (section fifty-nine) therefore, so that one third of the price paid was handed over to local authorities to be expended on new or improved road access to the land.

An Amendment Act two years later introduced provisions for Special and Village Settlements. The Special settlement scheme involved land being set aside for groups of prospective farmers. It would be sold at an upset price of $\$ 1$ per acre, with conditions of occupation and improvement attached. ${ }^{48}$ It was particularly appealing to the small farm associations that were being formed all over the north island. Land set aside for Village Settlements could be sold on deferred payment. Occupants would live on an acre of village land, sold at $£ 5$, and cultivate what was termed a 'small farm allotment' not to exceed fifty acres, and to be sold at $\$ 1$ per acre. ${ }^{49}$ The idea of Village Settlements to get working class men and their families out of the towns and onto the 1and. Given form by Macandrew, the Minister of Lands responsible for

47. See S.M. King, 'The Port of Wanganui and its Influence on Wanganui', M.A. thesis, Victoria University of Wellington, 1964, ch. 3. 48. Land Act 1877 Amendment Act, 1879, sections 24 and 25. 49. Ibid., sections $20-23$. 
this Act, it had earlier been introduced on a small scale by William Rolleston in Canterbury.

In 1880 Ballance produced a 'Handbook of the Law Relating to Crown Land in New Zealand', printed at the Herald. In the introduction he said that existing legislation gave the government adequate powers to settle the land. His single complaint was that the Legislative Council had amended the deferred payment clauses of the 1877 Act to the effect that when there was more than one applicant for a block of land it was to be sold by auction (see section fifty-four). Ballance had himself inserted the original clause establishing a ballot. It was an important point; auctions raised the price of land, frequently beyond the reach of working class settlers, and encouraged speculation. 50

Only when the revived Wanganui Small Farm Association came up against an unresponsive Government (in the same way as the 1876 Association had done) did Ballance fuily appreciate the failings of current legislation. Ballance assisted with the formation of the Association in 1879, and frequently chaired its meetings. 51 The Association soon appealed to the Government to set aside a block of land under the Special Settlement regulations. 'They had not a large amount of capital', said Ballance, 'but they had each a certain amount of capital, which would have enabled them to take up a section of 1 and, to go upon it, and to cultivate it'. 52 But the Government

50. Handbook of the Law Relating to Crown Land in New Zealand, Wanganui,

51. See e.g., Y, 10 Jan. 1880. The Association claimed a membership of eighty; $Y, 24 \mathrm{Jan} .1880$. Of the four members mentioned by the Yeoman on 9 Aug. 1879, the occupations of two have been identified; one was a carpenter (Timms) and the other a labourer (Ke11y).

52. PD, 1880,35, p. 290. 
at first vacillated, and then finally refused to grant any land; indeed it was not going to form any special settlement in the whole district. Rolleston, the Minister of Lands, argued that the provisions were aimed at attracting foreign capital, and that small farin associations must look to the deferred payment system to obtain land. ${ }^{53}$ Speaking in a debate on the setting up of a select committee to consider the best means of encouraging the settlement of the working classes on the 1and, Ballance alleged that the Government had no bonâ fide intention of using the special settlement clauses of the Act :

(T)hese clauses were passed for the benefit of foreign capita1, and not for the purpose of ${ }_{1}$ the investment of the capital which was floating about the country in the possession of the working-classes. ...(C)oncessions were made to middle men and foreign capitalists, who were entering into these matters for their own particular benefit, when the working-classes with some capital were debarred the privilege. 54

In a letter to the Wanganui Association Rolleston had said that only English capitalists could comply with the conditions laid down for special settlements. He cited the KatiKati special settlement as an example. This had been established, with the cooperation of the New Zealand Government, by a bankrupt Ulster linen manufacturer, George Vesey Stewart. The first settlers, Protestant and a high proportion being orangemen, had arrived in 1875. Ballance admitted that such a scheme might prove beneficial to the colony, but was suspicious, especially when Vesey Stewart, on gaining the concessions, called a meeting in the district to persuade its Member to vote with

53. Ibid., pp. 287-88.

54. Ibid., pp. 290-91. See also $\mathrm{WH}, 8$ May 1880; R.D. Arnold, 'The Opening of the Great Bush 1869-1881', Ph.D. thesis, Victoria University of Wellington, 1971. 
the Government. At the back of Ballance's mind was probably the concern that Stewart's immigrants were not of the type he wished to see settled in the colony. The second batch that arrived in 1878 for example, contained a large 'social element' of U1ster aristocracy and a number of army officers. Certainly they had capital (believed to be as much as $\{100,000$ ) but few were experienced farmers. The scheme bore a greater resemblance to the ideals of the Wakefield settlements than to the government sponsored immigration of the early 1870s. Ballance was also suspicious of Stewart's motives. Stewart, who had undoubtedly misrepresented the quality of the land to the prospective emigrants in Ireland, made something Iike $\$ 6000$ and 3500 acres of land out of the deal. Yet many would argue that this was fair reward for a good deal of effort. ${ }^{55}$ As he had shown in the case of the Manchester Corporation (see chapter 4), Ballance had at times an unreasonable cynicism of private immigration-land settlement schemes, while being himself to some extent connected with one.

Despite these criticisms Ballance did not come up with any real alternatives. He merely pointed to the Hutt Small Farm Association at Sandon as an example of what could be done if only existing legislation were utilised. (The Sandon Special Settlement had been established under provincial regulations similar to those of the later 1879 Act; see chapter 4). This reluctance to propose major legislative changes was reinforced by the fact that much of the 1881 session was concerned with administrative reorganisation of local government finance. Before returning to developments in Wanganui, Ballance's attitude to these changes- his 'tinkering' with the system in order to facilitate new settlement- will be examined.

55. See A.J. Gray, An Ulster Plantation, Wellington, 1950 (2nd ed.); Evelyn Stokes, A History of Tauranga County, Palmerston North, 1980. 
Atkinson replaced subsidies to $10 \mathrm{cal}$ bodies with rates levied on crown and native lands. It was significant only to the extent that it sought to use land rather than general revenue as the basis for local expenditure, specifically that on roads. In doing so it tied the expenditure of local bodies more directly to their ability to raise revenue. Funds for road-making and maintenance would be provided by rating the land through which the roads passed. It was a convoluted system whereby the Property Tax Commissioner valued the land to be rated and the Colonial Treasurer distributed the rates collected to the local bodies concerned. ${ }^{56}$ Ballance complained that the control of the system by a Board in Wellington would, given the inevitable political pressures that would be applied, result in money being spent in districts already settled. Further, ratepayers would not vote for new roads in unsettled regions in the first place: the development of new land could seem of little benefit to estạblished settlers: Thus money would be spent simply on maintaining existing roads. 57

With respect to the distribution of revenue from land sales, the Government proposed to add a sum to the upset price of land to be given to local authorities for road works. Ballance argued that the system he had had successfully adopted for deferred payments, whereby one third of the price of land was handed back to local bodies for new roads, should apply to all crown land sales. This scheme gave the local land board control over the way in which county and road boards distributed the money, and in Ballance's view made it more likely that funds would be spent on roads opening up new land. The road boards, he said, ought to be elected on a popular basis instead of being

56. PD, $1881,38, \mathrm{pp} .420 \mathrm{ff}$. Crown and Native Lands Rating Act, 1882; Rating Act, 1882 .

57. $\mathrm{PD}, 1881,39, \mathrm{p} .79$. 
nominated. In general he thought that local government failed to respond to local needs, since it 'exaggerated the power of property'.58 None of this got to the heart of the matter, which was that despite legislation it was virtually impossible for men with limited resources to get onto the land.

Initially Ballance thought that though the depression was 'unprecedented', it was at the same time temporary. He had no solutions to offer beyond halting immigration, removing duties on raw materials used by New Zealand manufacturers, and generally furthering land settlement. 59 Wool and wheat prices fell, only beginning to pick up at the end of the decade. Falling imports reflected reduced purchasing power and lower wages. Bankruptcies rose and the marriage rate dropped. ${ }^{60}$ Around Wanganui 'swaggers by the hundred roamed the crude coach roads, searching vainly for work'. Food became relatively dearer, and soup kitchens were set up. A considerable number of townspeople migrated to Australia. ${ }^{61}$

The depression hit the Herald in two ways. Circulation declined and advertising became more difficult to attract and sustain. Yet the effect of depression took some time to be felt. In June 1880 the Herald announced that it had the largest circulation in the district.

58. Ibid., p. 80. See also $\underline{W H}, 8$ May 1880; WH, 12 June 1880.

59. $\overline{\mathrm{WH}}, 8$ May 1880.

60. C.G.F. Simkin, The Instability of a Dependent Economy, Oxford, 1951, pp. 163-66; W. B. Sutch, Colony or Nation?, Sydney, 1966, pp. 26-32.

61. Wanganui Hera1d, 3 June 1967. 
To maintain this position it was going to make new changes. The

Evening Herald, which became the Wanganui Herald in 1876, had increased in size at regular interva1s. ${ }^{62}$ Now the Weekly Herald was to become the new enlarged Yeoman. The paper's politics would remain the same:

\begin{abstract}
Liberal land laws liberally administered has been our battle cry in the past, and so it will remain until the settlement of the country shows us that the end has been achieved. ...We have never lacked the courage of our opinions, and it is not our intention to learn timidity. Our interests are bound up with the advancement and prosperity of Wanganui, and for that end we shall strive earnestly and zealously. 63
\end{abstract}

The first issue of the Yeoman appeared on Saturday 31 July 1880 . It aimed, as the Weekly Herald had done, to reach the country districts not easily serviced by the daily Herald. By increasing the size of the paper Ballance was able to include more material specifically tailored to the needs of farmers, as well as providing them with a more detailed summary of the week's news. Every month a 'Farmers Supplement' appeared, giving information on developments in agricultural science. It was essential, said the Yeoman, that farmers kept up with the latest improvements. There were also regular columns on horticulture and gardening, of interest to townspeople as well as country folk.

Politics was not ignored; indeed coverage gradually became more intensive as Ballance's career progressed. Some later editors believed that his use of the medium to advance his own opinions was ultimately damaging to the paper's interests. ${ }^{64}$ The Yeoman was to publish many interesting political articles that would because of their length have been difficult

62. WH, 25 Mar. 1876.

63. $\overline{\mathrm{WH}}, 22$ May 1880 .

64. James Duigan, who became editor in 1891 , for example. I am grateful to his grand-daughter, Rev. S. Koreneff of Patea, for this information. 
to fit into the daily Herald. W.L. Rees, a liberal Auckland politician, wrote a series on 'New Zealand Politics and Politicians' less than two months after the paper first appeared. It was a thinly veiled attack on the Government. ${ }^{65}$ Later the Yeoman reprinted a lecture given by Stout at Napier, on 'True Democracy'. ${ }^{\text {ङ }}$ A third example, in early 1884, was a series on the 'Maori Wars', written by a Maori and translated from Maori into English for the Yeoman. ${ }^{67}$ The use of the name Yeoman was of course highly significant. It reflected Ballance's ideal of the nature of country settlement: small independent farmers cultivating land to the maximum extent. Political propaganda was an integral part of the paper, for policies had to be changed if this ideal was to reach fruition.

The Yeoman was more successful than the Weekly Herald had been. Statistics of newspapers delivered and posted in Wanganui were separated from the Wellington figures in 1879, and since only the Herald and Chronicle groups were involved (the Chronicle also produced a weekly paper), they give a good indication of the performance of the former. Circulation rose from 367,884 in 1879 to 641,251 by 1881 . In September 1882 the Yeoman claimed that its circulation had trebled over the previous three months and that it had now the largest readership of a weekly outside Auckland. ${ }^{68}$ The June figure cannot have been high, for 1882 saw the start of a decline in total circulation that was to continue for a number of years. By 1886 circulation in the Wanganui district had dropped to $566,839.69$

65. Y, 18 Sept. 1880 .

66. $\bar{Y}, 14$ Dec. 1883. Ballance disagreed with Stout's idea of dividing $\bar{N}$ ew Zealand into two colonies.

67. See Y, 11 Jan. 1884 .

68. Y, $1 \overline{5}$ Sept. 1882. The Auckland Weekly News was the most popular of the colony's weeklies.

69. Circulation figures are from New Zealand Statistics of the respective years. 
In 1882 Ballance reorganised his business, just as the effects of depression began to be felt. In May his partnership with John Notman (see chapter 3, p. 127) was dissolved. Notman, who was first employed by the Herald in 1871 and had become Ballance's partner six years later, set up his own business as a general commission and insurance agent. He became a prominent figure in the town and was at one time or another chairman of most local bodies. ${ }^{70}$ Ballance then formed the Herald and Yeoman papers into a joint stock company. It made sense given the lack of a new partner and the greater security of limited liability. Editorial control, he said, would remain in his hands. ${ }^{71}$ Ballance bought six hundred and eighty-six of the seven hundred and fifty $\$ 10$ shares himself. Other minor shareholders included a reporter and compositor working on the paper, a labourer, storekeepers, solicitors (including George Hutchison, one of Ballance's foremost political supporters in the town), a commission agent, an accountant, a woman teacher and a '1ady'. 72 There were seven directors. Shareholders had a vote for every share up to ten, and an additional vote for every thirty shares thereafter to a maximum of fifteen votes. ${ }^{73}$

Ballance's personal resources were not adequate to enable him to finance the company on his own. He had already borrowed $₫ 1,700$ from his father-in-law, David Anderson, in 1881, and now he borrowed a further $\$ 1,400 .^{74}$ In September Anderson turned down Ballance's request for another loan. ${ }^{75}$ As the depression deepened and circulation fell, 70. Wanganui Hera1d, 6 May 1882; Cyclopedia of New Zealand, vol. 1,

71. Wanganui Herald, 16 Oct. 1882; Y, 20 Oct. 1882.

72. Share Register, Wanganui Herald Newspaper Company Limited, in Wanganui Museum.

73. Wanganui Herald: Memorandum of Association, Companies Office, Wellington, dead file 13694. The directors were: Ballance, S.H. Manson, M.V. Hodge, J.W. Jackson, B.N. Manley, W.C. Watkins, S. Austin.

74. Anderson kept an account of loans in the back of his diary. The 1882 loans were in two sums, 1,100 at $10 \%$ and $\mathbf{1} 310$ at $8 \%$. See Anderson Diary, 1881, 1882 .

75. Anderson Diary, 22 Sept. 1882. 
Ballance found it increasingly difficult to repay these sums, and a little friction between himself and David Anderson resulted. ${ }^{76}$ In 1884, when substantial repayments seemed to begin in earnest, Ballance borrowed a further $\$ 1,500$. The money appears to have been finally repaid during Ballance's tenure as Minister of Lands and Native Minister between 1884 and 1887 .

Ballance's own financial position therefore worsened in the early years of the depression. Both the Chronicle and the Herald were soon losing money. ${ }^{77}$ The enlargement of the Yeoman cost money, and had come at an unfortunate time. Forming a limited company gave Ballance some security, though the dissolution of the partnership required him to buy out Notman. Over the following years Ballance was able to sell some of his shares in order to raise money. They were bought almost entirely by people closely associated with the Herald: employees, Anderson relatives, Ballance's nephew Robert McKnight and Ellen Ballance (who inherited some money on the death of her father in 1889). ${ }^{78}$

The rivalry between the Herald and the Chronicle intensified as time wore on. The control of each company remained with two opposing groups, each a 'family' of closely-knit prominent Wanganui citizens. The papers established respective 'core' (at times fiercely loyal) readerships- the one liberal and the other conservative- though the Herald's political bias weakened following Ballance's death. The amalgamation of the two companies nearly a century later was a sensitive step for all, and a great disappointment for some. Rivalry in the 1880s was political rather than financial. The depression affected

76. Anderson Diary, 25 Oct. 1882, 11 July 1883, 6 Aug. 1883, 16 Aug. 1883, 4 Oct. 1883, 25 Jan. 1884.

77. Wanganui Herald, 3 June 1967.

78. Share Register, share transfers. 
both papers, and as circulation fell there was little chance of successfully poaching on each other's readership. This would have been less true had the political bias of the papers been less strong, and if both had been morning or both evening papers (thus more obviously alternatives). The only solution to falling revenue, a merging of the companies, was not practicable. So both suffered together.

The rivalry between the Herald and the Chronicle was at times more friendly than it appeared to be on the surface. Gilbert Carson became owner and editor of the Chronicle in the $1880 \mathrm{~s}$. He was to be not only Ballance's rival in journalism, but his political opponent as we11. He stood against Ballance at the Wanganui elections of 1887 and 1890. A story told in Wanganui about the two men shows that they had a 'certain' understanding. Ballance and Carson had been engaged in one of their frequent and long editorial wars on some particular issue,

\begin{abstract}
when Ballance was called to Wellington on Parliamentary duties. He went down to the office of Carson and explained the position, requesting a truce until such time as he returned. "No", came the reply from Carson, "there will be no truce. You may go to Wellington and I'11 write both articles". And write both articles he did- until Ballance was back to occupy the Herald's editorial chair again. He castigated the Herald's leader writer in the columns of the Chronicle and in the evening he replied to himself, denouncing the vitriolic pen of the Chronicle's leader writer and deploring his sad lack of logic. 79
\end{abstract}

The arguments were clearly predictable and one wonders if Herald readers noticed the difference!

79. New Zealand Founders' Society, Wanganui Branch, 'Newsletter', 21 (1963), pp. 15-16. 
The December 1881 election was for Ballance full of indecision, ambiguity and uncertainty. He lost his Wanganui seat by four votes. At first sight he ought to have won easily. His opponent James Bamber, an ex-Mayor and owner of a blacksmith's shop in the town, was a weak candidate. He made no campaign speeches and indeed withdrew from the contest in mid-November. ${ }^{80}$ It looked as if Ballance was to be returned unopposed, until his old rival, W.H. Watt (see chapter 3) declared his candidature hours before nominations closed. It would be a disgrace to Wanganui, said Watt, if Ballance were to have a walk-over. ${ }^{81}$

Though Watt was Mayor of the town and a we11-known personality, his entering the contest at the eleventh hour meant that Ballance could still expect to win. Aside from the confusion of the opposition, boundary changes operated in Ballance's favour. Wanganui constituency was reduced in size, many country electors who would be less sympathetic to his land tax being transferred to a new Waitotara electorate. 'It must be clear', said Ballance in opening one of his campaign speeches, that he was 'more identified with the town of Wanganui than with the country districts' ${ }^{82}$

The cause of Ballance's defeat lies with his own uncertainty and in the political issues that emerged. Ballance was unsure both of his own political future and of the principles he ought to espouse. Writing to Stout in May he had outlined what he believed to be the main points

80. The Herald printed a satirical account of an imaginary Bamber speech, reported by a 'clairvoyant correspondent'. It concluded: 'An elector wanted to know Mr Bamber's views with reference to the inscription of New Zealand Stock? Mr Bamber replied that he believed all stock ought to be branded and ear-marked. (Great applause)'! Y, 12 Nov. 1881.

81. WC, 2 Dec. $18 \overline{8} 1 ;$ Y, 3 Dec. 1881.

82. $\bar{Y}, 5$ Nov. 1881 . 
of a liberal programme, but only to emphasise Macandrew's deficiencies and urge Stout to return to politics and assume the leadership. Ballance's pre-sessional speech was woolly and generally unimpressive. ${ }^{83}$ He told Stout that in it he had not put forward a liberal platform because doing so

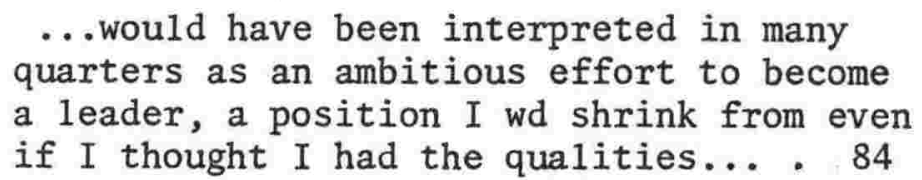

Ballance was unenthusiastic about the coming election. There are a number of probable reasons for this. Politically, with Stout still unwilling to re-enter Parliament, the Opposition split, and the Government boosted by Bryce's 'success' in dealing with Te Whiti at Parihaka, prospects were not bright. Personally, Ballance fe1t unable to take on the leadership of the liberals himself, and given the poor political outlook there was a strong case for his retiring from politics (if only temporarily) and devoting his time more fully to the Herald. Financial considerations may also have been an important factor. Rumours of Ballance's 'indifference to his election' began circulating in Wanganui; so much so that he found it necessary to publish a denial in the Herald:

We beg to give the rumour the most unqualified contradiction. Whatever Mr Ballance's private feelings may be, his duty to his friends... is to stand to his guns, and he will take all proper means to inform the electors of his opinions. 85

83. Y, 14 May 1881 .

84. Ballance to Stout, 23 May 1881, Stout MSS.

85. Y, 15 Oct. 1881 . 
In 1881 Ballance's political platform was more confused and in one important respect at least less radical than it had been two years earlier. He did not propose the reintroduction of the land tax, arguing that changes in the type of taxation were damaging to the country. Instead the property tax should be amended to include the 'best features' of the land tax; improvements, agricultural implements and machinery should be exempted, and a progressive tax on large holdings added. Though this amounted to the same thing, there was in his speeches noticeably less emphasis on taxation as a means of promoting land settlement and more on revenue considerations. Ballance also found himself in an awkward position over possible alternatives to the existing Government. He was, as we have seen, unhappy with Macandrew; Grey too was ruled out along with Stout. Pressed by Carson, editor of the Chronicle, Ballance said that he regarded Ormond (a large landowner from Hawke's Bay who had become leader of yet another 'middle' party in the House) as a liberal 'in most matters', and that he would be prepared to join him in a ministry. Ballance did, however, change his mind on free trade. It was 'most suitable for England' he said, but as Mill had argued, not for a young country. Local industries ought to be protected 'by every means in our power whether it means by import duties... or bonuses or taxation of raw materials'.86

From the standpoint of the progression of Ballance's own political philosophy this move to protection was highly significant. Yet in the short term it made the general charge of inconsistency appear well-founded. The Wanganui Chronicle talked a lot about 'sham liberals'.8 It pointed out that Ballance had 'recanted' from free trade to

86. $Y$, 5 Nov, 1881. For Ballance's two other campaign speeches see $\underline{Y}$, 87. WC, 12 Nov. $188 \overline{1}$. 
protection, and from a land tax to a property tax. He had called the 'acred' Ormond a 1ibera1; in fact he had 'patted the moneyed interest on the back'. ${ }^{88}$ At the same time Carson, with his own inconsistency serving a political purpose, wrote that Ballance would 'sweep the large farmer off the face of the earth'. Ballance's

...views on the land question are of such a character that no man owning an acre of land in freehold... could feel himself safe if the Wanganui apostle of Socialism had the power of settling the affairs of the nation according to his will. 89

It is ironic that Ballance was being labelled a socialist at a time when he least deserved it.

What made Watt a much more formidable opponent than he would otherwise have been was the support given him by Bryce. The rift between Ballance and Bryce had become pernament when the latter joined the Hall Government as Native Minister. The ending of a personal and political friendship of ten years brought charges of inconsistency and 'treachery' from supporters of both men. 90 The election came in the wake of Bryce's occupation of Parihaka, the arrest of Te Whiti and the subsequent breaking of Maori resistance to further European settlement on the west coast. It was a considerable political success to the Government in general and to Bryce, who was elected unopposed for Waitotara, in particular. Earlier in the year the Herald had criticised Bryce for resigning (temporarily as it turned out) as Native Minister. ${ }^{91}$ In his election address Ballance said that the trouble on the west coast was the result of a history of Government

88. WC, 2 Nov. 1881. See also WC, 11,12 Nov. 1881.

89. $\overline{\mathrm{WC}}, 14$ Nov. 1881.

90. $\bar{Y}, 23 \mathrm{Apr} .1881$.

91. $\mathrm{Y}, 2$ Apr. 1881 . 
mismanagement, inconsistency and weakness. He urged the resumption of crown pre-emption over 'native' land. However he fully supported Bryce's action when it came; things should not have been allowed to drift for so long.

Despite this approval there were complaints that Ballance was 'soft' on Te Whiti. 92 Part way through the campaign one of Ballance's supporters, John Duthie, declared himself in favour of Watt. A major cause of the defection was Duthie's belief that Ballance was 'ungenerous and unpatriotic' in his attitude to Bryce's handling of 'native' affairs. 93 (As we sha11 shortly see there was an additional reason). Bryce's public support for Watt was undoubtedly a major factor in the latter's victory. Watt was well aware of the possibilities of attracting reflected glory from Bryce's success. ${ }^{94}$ Ballance supporters managed to prevent Bryce from speaking at a Watt election meeting- they were throttling the freedom of speech, said the Chronicle- but the damage was done. ${ }^{95}$

Aside from Ballance's inconsistencies and his criticism of the popular Bryce, there was a third element to the election. This concerned the Harbour Board. The Board was formed in 1877 and immediately set about deepening the harbour. Initial work involving the extension of training walls was completed by 1880 . The Board was not, however, moving rapidly enough for some. A public meeting, critical in particular of the lack of dredging work done, passed a vote of no confidence in it. Two members of the Board, Duthie and Peat,

92. For example see the letter in WC, 31 oct. 1881.

93. WC, 11 Nov. 1881.

94. $\overline{W C}, 8$ Dec. 1881 .

95. 7 Dec. 1881 . 
resigned 'sick of the whole business' in June, Duthie being replaced by Ballance. Ballance was re-elected in February 1881, and 1ed a 'progress party' on the Board that sought to press ahead with further improvements. He succeeded in having accepted a proposal for new works at Castlecliff Heads that had originally been rejected by the Board and Duthie. ${ }^{96}$ The harbour issue was therefore in part the cause of Duthie's withdrawal of support from Ballance, and in that respect undoubtedly proved damaging to the latter. Yet the town's election of the 'progress party' onto the Board months earlier suggests that Ballance's stance on harbour improvements would if anything have attracted support.

The election was held on 9 December. Ballance polled three hundred and ninety-three votes to Watt's three hundred and ninety-seven. There was only one polling booth. ${ }^{97}$. It was later reported that seven of Ballance's supporters had arrived too late to vote after their carriage conveying them into town broke down. 98 The Chronicle attributed Ballance's defeat to the 'ill-advised action of his supporters in connection with Bryce at Watts meeting'. 99 In Wellington the Post said that defeat was 'not quite unexpected', except perhaps for Ballance himself. ${ }^{100}$ The Taranaki Herald, whilst recognising Ballance's ability, pointed critically to his 'plastic political creed'. 101 Stout was 'intensely vexed and disgusted at the result'. 102

96. $\frac{Y}{Y}, 19$ Nov. 1881; King, pp. 11-14, appendix M.

97. $\bar{Y}, 17$ Dec. 1881 .

98. $\overline{N Z H}, 12$ Dec. 1881 . The Chronicle reported however that they

99. 14 Dec. 1881 .

100. EP, $10 \mathrm{Dec} .1881$.

101. Quoted by NZH, 20 Dec. 1881.

102. Stout to Ballance, $10 \mathrm{Dec}$. 1881 , Stout MSS (telegrams). 
Publicly Ballance said that his defeat was merely that of a wing of the 'liberal' party, and put it down to Watt's superior organisation. ${ }^{103}$ He was in fact one of a number of prominent politicians to lose their seats: Fox, Saunders, De Latour, Gisborne, Reader Wood and Ormond all failed to get re-elected. Privately Ballance was taken aback by his failure. He had tended to take success for granted. Paradoxically, it was perhaps this over-confidence that was the source of his earlier 'indifference', as much as uncertainty as to his own political future.

Having committed himself to the contest Ballance was far from pleased at coming out the loser. During the campaigning there had been allegations of bribery and intimidation of voters. In March 1882 A.D. Willis, on behalf of Ballance, brought charges against John Anderson, a cabinet-maker and a leading watt supporter, under the Corrupt Practices Act. With such a narrow margin of victory the result might easily have been over-turned. Stout appeared for the petitioners, arguing that there had been two specific acts of bribery and undue influence involving the promise of employment and money, as well as other general cases. The hearing lasted a few days, the evidence closely followed by the Herald. At. its conclusion the Chief Justice found against Willis and Ballance, mainly on the grounds that the threats were vague, and that there was no evidence of them being carried out. ${ }^{104}$ The Herald disagreed, quoting the Wairarapa Standard's view that the judge must have been 'most obtuse' not to have recognised that intimidation had taken place. ${ }^{105}$ So Watt went

103. Y, 17 Dec. 1881.

104. Wanganui Herald, 15, 16, 17 Mar. 1882. See also the pamphlet printed by the Herald: Report of the Proceedings in the Election Petition of A.D. Willis and others against W.H. Watt, Wanganui, 1882 .

105. Wanganui Hera1d, 24 Mar. 1882. 
to Wellington as Member for Wanganui. For Ballance defeat was not as serious as he might at first have imagined. The 'continuous ministry' remained in office, led first by Whitaker and subsequently by Atkinson. There was little Ballance could have done.

If Ballance had been complacent before the election he was certainly not so following it. The absence of the pressure of parliamentary duties allowed him, as we have seen, to concentrate on and reorganise the Herald. And being placed at a distance from the centre of political activity enabled him to re-think old, and formulate new, ideas. Precisely what these were, and how they fitted into Ballance's broader philosophy, is a subject we shall turn to next. 


\section{CHAPTER SIX}

Philosophy for Improvement: state-help and self-help 
The three years leading up to the 1884 election saw the radicalisation of Ballance's political philosophy. The nature of his liberalism prior to this period determined the form this process was to take. He had viewed the promotion of land settlement, through a land tax and a system of deferred payments, as of critical importance. Now radicalisation simply brought this pre-eminent theme to its natural conclusion. By 1884 Ballance was convinced that land nationalisation and the leasing of land were essential to settlement, and to progress and prosperity in general. They were the 'cure-all' for society's ills.

Although Ballance was a pragmatic politician rather than a political theoretician, the ideological basis for his political activity was substantial and explicitly formulated. It involved an adaptation of liberal philosophy to New Zealand conditions. The first part of this chapter examines the core of his ideology- the nationalisation of the land- against the background of the writings of John Stuart Mill and Henry George. The second looks at other elements of Ballance's liberalism: at his views on protection, religion, education, and temperance. His support for the female franchise has already been mentioned, and the issue will be returned to in the final chapter. Chapters 10 and 11 discuss his attitude to constitutional reform. Chapter 1 has already examined Ballance's stance on the 'Irish question'. The final part of this chapter deals with the 1884 election. The election is emphasised because at it Ballance stood on a new radical platform, and one that was not to change substantially for the remainder of his life. 
Land nationalisation for Ballance implied not only the right of the State to purchase land, but the desirability of a programme of compulsory repurchasing of private 1and. It went far beyond the land tax that he had initially favoured, for it involved the State assuming ownership of the land for posterity. A combination of intellectual and political developments both in and beyond New Zealand influenced Ballance in this change. These stimulations came together in his realisation that the State's ability to promote new settlement was severely curtailed by the simple fact of a decreasing amount of available crown land. He also saw that the poor quality of the remaining crown land was frequently a critical flaw determining the fate of settlement schemes.

There was an upsurge of interest in land reform in England in the late 1870 s and early 1880s. This was largely the consequence of the onset of an agricultural depression. Britain began importing food from the New World, particularly from North America. Ireland was worst hit, and the plight of its peasantry led to political agitation that culminated in the formation of the Irish National Land League and a 'land war'. The League, supported by many English Liberals, demanded what was known as the 'Three Fs'; fair rent, fixity of tenure, and the free sale of the tenant's interest in land cessentially an extension of the Ulster Custom to all of Ireland; (see chapter 1). Land reform in Ireland became a major concern of the Gladstone Liberal Ministry formed in $1880 .^{1}$

1. See Roy Douglas, Land, People \& Politics. A History of the Land Question in the United Kingdom, 1878-1952, London, 1976. Land nationalisation was an 'extreme' form of land reform. One of its principal advocates in England was Alfred Russel Wa1lace. See his Land Nationalisation, London, 1882. 
The intellectual basis for Ballance's belief in land reform came from the writings of John Stuart Mill and Henry George. Mill had played a leading role in the formation of the Land Tenure Reform Association in England in 1870. The Association aimed, he wrote, to break up the remnants of the feudal system:

Our laws relating to land are the remains of a system which, as history tells us, was designed to prop up a ruling class. They were made for the purpose of keeping together the largest possible possessions in the families which owned the land, and by means of it governed the country. So long as those families were not obliged to share power with any other class, or with the people, the Land Laws were in many respects considerably worse than they are now; but what is left of them has still the same object: to contrive that the land of the family shall descend unbroken to the eldest son, and that the owner for the time being not be at liberty to defeat this purpose by selling the land. By these means the land has been prevented, to a large extent, from passing out of the hands of the idle into those of the industrious, and its ownership has been retained as the privilege of a small and decreasing number of families. 2

The methods employed to break the monopoly of land were to include the abolition of the law of primogeniture, the State acquisition and leasing of land, the encouragement of agricultural cooperatives, and the taxation of the future 'unearned increase of the rent of land'.

The notion of the 'unearned increment' was centra1 to advocates of land reform, especially to those like Mill and George who stopped short of complete nationalisation. It was the 'rent' which the landlord

2. J.S. Mil1, 'Explanatory Statement of the Programme of the Land Tenure Reform Association', in Dissertations and Discussions, vo1. IV, London, 1875, pp. 240-41. 
received, not from the application of labour to land but from the land's fertility and its value arising from the development of the surrounding community. It excluded profits from improvements, and was determined by the productivity of the most marginal land. That is, rent on land brought under cultivation because increased population makes it only just profitable to farm (i.e. land at the margin) is zero. More fertile land yields an increasing profit and rent; less fertile land remains virgin. As more land is brought under cultivation total rent increases. The greater the population the more land brought under use, and the greater the difference (and thus rent) between marginal land productivity and the productivity of land already under the plough. This difference is owing to the pressure of population and the progress of the community. It is the unearned increment that could be justifiably appropriated by the community.

Ballance's 1878 land tax attempted to recover, on behalf of the country, part of this rent. During the debate on the tax Ballance made it clear that he did not agree with Mill that the whole of the unearned increment should be appropriated. They may have that right,

but it would not be wise on our part to claim it, for the reason that it would discourage industry, and would keep people from investing money in that particular class of property. 3

By 1882 Ballance had moved well beyond this cautious approach. In doing so he was strongly influenced by Henry George's Progress and Poverty, published in New York in 1879. The core of George's theory 
was that the tendency of rent to increase over time was the cause of want existing alongside a general increase in the total wealth of society. The idea was based on Ricardian economics: product $=$ rent + wages + interest, so that product - rent $=$ wages + interest. In other words wages and interest remained static as increases in production were absorbed by those of rent. Though increased labour productivity increased total wealth, labour suffered an increase in rent greater than any increase in wages. Thus real wages fell over time.

Drawing in particular on his Californian experience, George noted the cyclical development of a 'progressing' society; the rapid increase in land values owing to land speculation (especially related to railway monopolists) which ultimately only checked production; and the subsequent excess of population over available land leading to reduced real wages, depression, and falling land values. The depression, through lower wages and rents; encouraged movement onto the 1and; eventual recovery then raised both, and so a new cycle commenced. George argued that wages in the primary (agricultural) sector were related, in the same way as profits, to those in the secondary (industrial) sector. Increases in available land attracted labour to agriculture, creating a shortage in the secondary sector which raised industrial wages. For example:

It was the discovery of the placer mines in unappropriated land to which labour was free that raised the wages of cooks in San Francisco to $\$ 500 \mathrm{a}$ month, and left ships to rot in the harbour without officers or crew until their owners would consent to pay rates that in any other part of the globe seemed fabulous. 4

4. Henry George, Progress and Poverty, London, 1932 edn., p. 208. 
Land was therefore the key to the whole economy. For George the solution to depression was simple: to make land common property by confiscating rent through taxation. ${ }^{5}$ The advantages were clear. The land tax would be the only tax, thus removing burdens from other sectors and stimulating production through incentive. The tax avoided nationalisation (and thus any 'shock to present customs and habits') and an extension of state intervention. The whole taxation system was in fact greatly simplified. The tax was on value and not on production, and it would increase agricultural productivity through destroying speculative rent. Finally it was equitable, since a tax on rent was one on the development of the whole community: the value of land would grow and be taxed as the community grew. 6

The most potent implication of George's writings was the identification of a single solution that could be easily understood by, and fitted into the experiences of, the land hungry of the New World. And it was a solution essentially prophylactic. It raised the issue of land to the forefront of politics (at the expense of all else) in an effort to maintain the fundamental capitalist structure from the threat of radical doctrines. For such radical ideas,

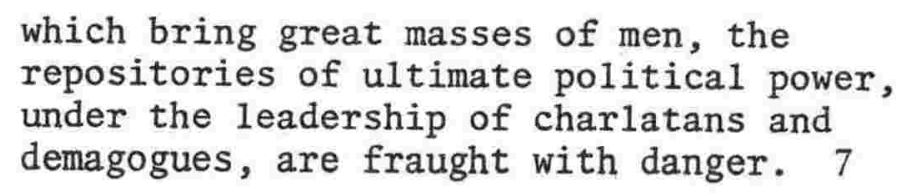

Ballance never accepted George's theory in toto. He did not believe in a single tax alone, and went beyond George by proposing the

5. Ibid., pp. 234, 286-89.

6. Ibid., pp. 298-99.

7. Ibid., p. 13. 
complete nationalisation of the land by the State. Yet George influenced Ballance in one particularly important respect. He provided theoretical support for something Ballance already suspected: that the solution to New Zealand's problems lay in the land. Land reform was to be the 'cure-all' for a new country's ills (see chapter 9). It was a complete theory of prosperity and stability; the opening up of land to closer settlement as a means of relieving pressure on towns and avoiding the political consequences of economic want. It appealed because it was an extension and adaptation of the ideas of English land reformers such as Mill to the development of new lands, and because it fitted Ballance's own experiences.

Ballance's views on land policy were set out in a series of articles that appeared in the Dunedin Echo, which was at the time edited by Stout, in 1882 . In 1887 the articles were published with an introduction as a pamphlet entitled A National Land Policy Based on the Principles of State Ownership. Ballance acknowledged his debt to Mi11, George, and to Stout, who he said had 'long been the ablest and most eloquent advocate of the Nationaligation of the Land in the Colony'.8

In the pamphlet Ballance emphasised the difference between the concepts of the unearned increment and land nationalisation. George sought to avoid the latter through the State taxing the whole of the former. Ballance accepted the principle of nationalisation, but believed that it would only come about gradually and that it would be encouraged in the short term by a progressive land tax aimed at breaking up large holdings. A land tax was justifiable on two levels: 
The appropriation of the unearned increment is defensible, on the ground that the State has the moral right to declare that no person in future shall be entitled to prosperity which others, not the person, may earn. (Second),... if a class enjoy exceptional privileges, it is called upon, under a system of abstract justice, to contribute more than do those classes which are not in the enjoyment of those privileges. 9

Land nationalisation was for Ballance a separate goal, and he defended it on different grounds:

In our opinion the principal reason in favour of the nationalization of the land is that the land of any country soon becomes a monopoly, the possessors being few in comparison with the population. The monopolists without effort grow rich. The landless, continually increasing their number, grow poor, and, having the franchise, live in a state of agitation, and attack the privileged. .... Let us suppose, now, that we have only national land. The phenomena presented in this case would be, on the one hand a body of cultivators paying rent to the State; and on the other a greater body living by wages, mainly in towns, deriving a beneficial interest from the rents, and remaining content in the knowledge that they participate in the prosperity of the agricultural tenant. On the ground of self-interest the more numerous class will cast their votes against the disturbance of a system which works in their favour. 10

This was Ballance's ideal: a country of small farmers leasing from the State. Wealth rested in the land, and only its equitable distribution, through nationalisation, would meet the demands of urban wage labour and thus guarantee political stability. Ballance saw grave danger in towns being dependent upon the country when political power rested with landed interests. 'The present system of monopoly is fast arraying the landless and landowning classes against each other.

9. Ballance, pp. 17,18 .

10. Ballance, p. 8 . 
This... seems inevitable' he wrote in the Herald:

\begin{abstract}
The ownership of land confers so many privileges not possessed by those who do not own land that it is impossible to secure that the unfavoured sha11 not cast an envious eye on the possession of what they cannot hope to obtain. 11
\end{abstract}

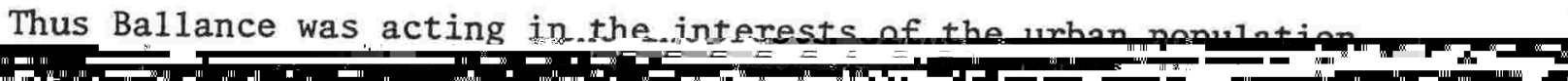
(2) 
'stronghold of individual property in land' would be assailed through

a system of progressive legislation:

\begin{abstract}
A chess player who understands something about the strategy of the game does not rush right away and concentrate all his forces on the quarters of the King, but operates on many parts of the field at the same time, hoping that the sum of his advantages will render his Majesty's position ultimately untenable. In actual warfare, great victories are won in the same manner. 13
\end{abstract}

Specifically Ballance suggested that the State should begin by repurchasing estates above 10,000 acres. Compensation based on the market value of the land would be given. Funds would come from overseas borrowing, and then also from internal loans. He was hopeful of the country's ability to raise the necessary finance, though a . later Yeoman editorial suggested that nationalisation was limited by factors affecting the colony's credi.t. ${ }^{14}$ Finally, Ballance argued that compulsory expropriation would be postponed for as long as adequate land could be purchased on the open market.

In the year following the publication of the Echo articles Ballance developed these proposals. He divided land in the colony into three. Land held by the crown (eleven million acres approximately) was to be retained by the State and leased. The twelve million acres of Maori land were to be either retained or leased by Maoris themselves, or sold only to the State. ${ }^{15}$ That left land held by private individuals, believed to be about fifteen million acres. Of that ten million acres were in holdings of more than five thousand acres.

13. Ballance, p. 8 .

14. Ballance, pp. 18-19; $\underline{Y}, 1$ Feb. 1884 .

15. Y, 2 Nov. 1883. See ch. 7 on. Ballance's re-introduction of crown pre-emption when. Native Minister. 
These were to be either broken up or repurchased by the State. Only the remaining five million acres of smaller holdings would not, for reasons of practical necessity, be nationalised:

The yeoman farmers... are the pillars on which the colony is resting, and it would be a dangerous policy to disturb them. 16

The early 1880 s saw a surge of interest in New Zealand in land reform, and Ballance was only one of a growing number of advocates. John McKenzie, for example, a liberal land reformer who farmed part of a sub-divided Otago run, was first elected to Parliament in 1881. He was later to become Minister of Lands in Ballance's Government. In explaining this growing agitation for land reform Frank Rogers and Eric Charman both point to the influence of writers and events outside New Zealand. Rogers emphasises the impact of George's ideas in particular, ${ }^{17}$ whilst Charman argues that Mill, and the land reform movement with which he was connected, were the chief inspirations of the leading New Zealand reformers of the period. ${ }^{18}$

The importance of external influence can easily be overstated. Two points can be made. First, land reformers such as Ballance and McKenzie were not doctrinaire theorists. They sought to fit theory to political reality, rather than vice versa, and the intellectual support provided by George and Mill was utilised only as far as it could be made applicable to New Zealand conditions. Secondly, an

16. Y, 16 Nov. 1883.

17. Frank Rogers, 'The Single Tax Movement in New Zealand', M.A. thesis, Auckland, 1949.

18. Eric Charman, 'Land Tenure Reform in New Zealand, 1875-1896: a study of the opinions of some leading land reformers', M.A. thesis, Auckland, 1953. 
emphasis on external influences blurs cause and effect. Land reform was undoubtedly seen as a solution to the depression. Yet it was not adopted with such vigour in New Zealand simply because of its popularity elsewhere. Nor indeed does the depression itself explain why that particular solution was sought. Liberals in New Zealand, unlike their English counterparts, seized on land reform as the answer to depression simply because New Zealand, unlike England, was essentially an agricultural country. For the same reason the demand for land reform was also prominent amongst early trade unionists. For example two leading unionists, W.M. Bolt from Dunedin and H.W. Farnall of Auckland were both followers of George. 19

As Wilson points out, Dunedin was the one major centre in New Zealand where 'liberal' issues retained some importance during this period. $^{20}$ Foremost amongst these was the 'land question'. When in March 1883. Stout formed a Land Nationalisation Society in the city, Ballance urged that branches be established throughout the colony, and that Stout become president of a national association. ${ }^{21}$ Months later Ballance himself set up a Wanganui society. ${ }^{22}$ At a public meeting in the town in october he said that land nationalisation was 'fast becoming a burning question in the colony'. He believed that the towns would soon come to dominate the country, and in doing so would tackle the political power of large landowners. The State should begin by purchasing estates over 20,000 acres; the money to be borrowed

19. See the discussions of the 1890 election in ch. 9.

20. T.G. Wilson, 'The Rise of the Liberal Party in New Zealand, 1877-1890', M.A. thesis, Auckland, 1951, p. 136. Otago liberals elected in 1881 included Thomas Duncan, an U1sterman who was later Minister of Lands in Seddon's Ministry, John Bathgate, Vincent Pyke and C.A. De Lautour.

21. Y, 30 Mar. 1883.

22. Wanganui Herald, 18 Dec. 1883. 
using the land as security. In general Ballance thought that

capital should be invested in improving leased land, rather than sunk in freeholds. 23

These views came in for much criticism. Some argued that they were communistic. Ballance replied that nationalisation would involve greater individualism, not less, and that it was therefore the antithesis of communism. ${ }^{24}$ The first number of an Auckland publication entitled Land, edited by the liberal politician F.J. Moss, complained that the issue would split. the 'Democratic' party. ${ }^{25}$ The Herald however, argued that nationalisation would benefit 'all classes except the mere land dealer':

We have little doubt that public opinion will declare itself in favour of the change, and consolidate the party that has made the nationalisation of the land the chief plank in its platform. ... The nationalisation of the land (wil1) redress gross inequalities. It will prevent those reaping where they have not sown, and return to the community the profits of its industry. There is no communism in this, but only justice. But even were it communism, it would be preferable to legalised robbery of the many for the sake of the few. 26

That Ballance had now a strong commitment to leasing rather than the freehold is shown in the circumstances surrounding the amendment

23. $\mathrm{Y}, 26$ Oct. 1883 .

24. $\bar{Y}, 24$ Aug. 1883 .

25. Unfortunately the present writer has been unable to trace any copies of this journal. This information is taken from the Herald's comments on it.

26. Wanganui Herald, 18 Dec. 1883; Y, 6 Dec. 1883. Ballance was echoing Shelly's poem on the plight of the English peasantry:

The seed ye sow, another reaps:

The wealth ye find, another keeps;

The robes ye weave, another wears;

The arms ye forge, another bears. 
William Rolleston, the Minister of Lands, proposed to make to the 1877 Land Act. Rolleston sought to introduce a new perpetual leasing tenure. Holdings would be leased by public tender at an upset rent of five per cent per annum of the cash value of the land. The lease would run for thirty years, with a right of renewal at the end of that period for another twenty years. 27 It was a significant change in land law, and Ballance hoped that it would be the 'thin edge of the wedge of nationalisation'. ${ }^{28}$ In fact he later claimed that his Echo articles, published before Rolleston announced his proposal, had influenced the latter's thinking. The second article in particular, in which he put forward specific proposals for leasing, 'might really have served as instructions to the Parliamentary draftsman'. ${ }^{29}$

Rolleston would almost certainly have read Ballance's articles, but there were other influences as well. Downie Stewart suggests that Rolleston's. proposal sprang from observation and experience, rather than from an acceptance of any 'doctrinaire' theory. 30 In the event the Legislative Council insisted on inserting the right of purchase in the amendment, which in effect turned the lease back into deferred payment. The leasing principle was to apply only to educational endowments and land in mining districts. Ballance correctly asserted that the Council had destroyed the 'vital part of the measure'. 31 Rolleston too was disappointed, especially when a second attempt in the following session also failed. ${ }^{32}$

27. See W.J. Jourdain, Land Legislation and Settlement in New Zealand, Wellington, 1925, pp. 27-28; E.J. Charman, 'Land Tenure Reform in New Zealand, 1875-1896', M.A. thesis, Auckland, 1953, ch. 6 .

28. Y, 1 Sept. 1882 .

29. Ballance, p. 4 .

30. W.D. Stewart, William Rolleston, Christchurch, 1940, pp. 144-45.

31. Y, 28 July 1882 .

32. Stewart, p. 147. 
In early 1884 a Herald editorial neatly summed up Ballance's position:
We... think that no more of the public lands whatever should be sold, but disposed of on perpetual lease. With respect to private land, we hold that nationalisation should be applied to the lands of absentees and to large freehold areas but that the cultivating - occupiers of 1and, within certain limits as to quantity, should be permitted to retain their freeholds. There is no reason for disturbing the freehold cultivator who wishes to retain that tenure. Nor would it be wise to interfere with a class forming the backbone of the colony. 33

Fina1ly, it was clear how central all of this was to Ballance. He concluded his pamphlet on land nationalisation in the following manner:

If the Liberal party desire a national policy on which it might with confidence stake its future prosperity and position, we know of none which affords the same scope, or which would yield such splendid results as the nationalisation of the land. 34

Ballance's commitment to protection was another means of defending and promoting the interests of the town in the face of the economic dominance of the country. The majority of settlers would remain in the towns, their security depending not only upon the State's appropriation of agricultural wealth through nationalisation, but on

33. Wanganui Herald, 15 Mar. 1884.

34. Ballance, p. 19. 
the development of local industries. 'A large population', he wrote, 'cannot be maintained by agriculture alone'. 35

Ballance moved to protection slowly. His budget of 1878 was in the Manchester School tradition of laissez faire liberalism: the removal of duties and the provision of a 'free breakfast table'. He followed Cobden and Bright, whom he had heard speak in England, 36 and his only concession to protection was a system of bonuses to 'infant' industries. However by 1882 Ballance was arguing that bonuses had proved ineffectual:

...bonuses are Protection in its worst form;
and they have utterly failed. A small
additional duty on jams did more to induce
people to establish jam manufacturies than the
tempting bonus. It is notorious that the
bonuses have generally been claimed by persons
who did not continue the industry. ... (T) he
manufactures of England were established under
a system of the most rigid protection the world
has ever seen. It pays England now to advocate
Free Trade because she is the great capitalist
and carrier of the world. When New Zealand has
a great system of manufactures... she may be
prepared to reconcile Free Trade with her interests. 37

Ballance also pointed out that despite free trade and England's great wealth, the country contained 'a seething mass of semi-pauperism living from hand to mouth on scantiest fare'. 38

In 1884 an Industrial Association was formed in Wanganui, in which Ballance played a leading part. The Association sought protection as

35. $Y, 1$ Feb. 1884 .

36. Sir Robert Stout, 'The Hon. John Ballance', Review of Reviews for Australasia, May 1893, p. 113.

37. Y, 17 Nov. 1882 .

38. $\underline{\mathrm{Y}}, 18$ Aug. 1882 . 
a means of tackling the unemployment concomitant with depression.

In the longer term protection would enable the town to achieve some independence from the country:

The old idea that the town depended on the country ought to be exploded. The truth is that they are mutually dependent. A large town population, if well sustained by local manufactures, is the best thing the surrounding farmers could desire, for it gives them a market at their own doors, and the highest price for their produce. On the other hand, where there are many producers in the country we have a corresponding population in the towns acting as distributors and manufacturers. 39

The argument that protection favoured farmers as well as town-dwellers was difficult to sustain. Ballance denied that protection would mean higher prices for manufactured goods. ${ }^{40}$ However as farmers were aware the small scale of production and the high cost of imported raw materials usually made New Zealand manufactures more expensive than imported equivalents. Advocacy of protection was to bring to the Liberal party support from both urban wage labour and local manufacturers and businessmen. At the same time it could only further alienate established farmers already concerned at the possibility of land nationalisation.

39. $Y, 27$ June 1884. See also Wanganui Hera1d, 26 June 1884. 40. $\underline{\bar{Y}}, 1$ Feb. 1884 . 
The next part of this chapter deals with Ballance's views on religion. As we have seen in chapter 1 his experience of sectarian feuding in Ireland had made him cynical of religion by the time of his arrival in New Zealand. Some early Herald editorials reflected this. They criticised, for example, the Anglican Church's ownership of property; emphasising the alliance between clergy ('greedy land sharks') and landlords in opposition to the people. Ballance warned of the 'evils of ecclesiasticism' being introduced into the colony. ${ }^{41}$ Finally he pronounced religious debate to be of little value and essentially backward looking:

If the brain tissue that is wasted in unseem1y wrangling over religious matters were devoted to progressive knowledge, the state of society would be improved, and man, would attain a higher intellectual state in the world. ... There is a higher vocation for the mind than theological speculations. 42

By the early 1880s Ballance was a convinced 'freethinker'. That is, he became a secularist, believing in rational thought rather than religious dogma. His freethought views were intertwined with other important elements of his philosophy. A belief in science rather than religion as the way forward for man led to an emphasis on self-education. And the pursuit of knowledge meant self-reliance for the individual; dependency on one's own intellectual resources rather than on those of religion and the church. For Ballance, self-education and self-reliance came together in practical form in societies such as the Oddfellows (see chapter 3). Freethought was also a culmination of his own experiences: a fusion of religious scepticism drawn from a 


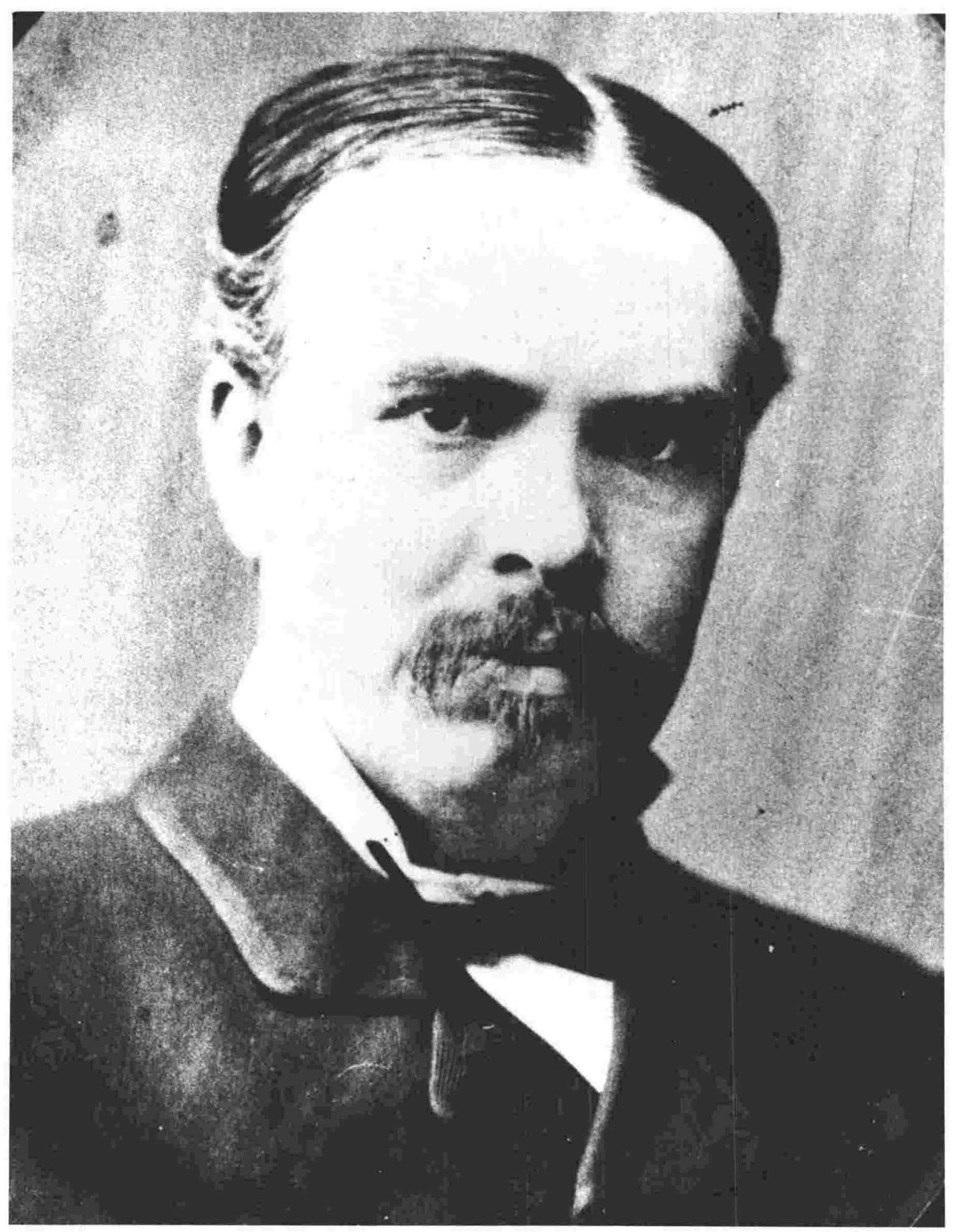

John Ballance, circa 1884 
dissenting mother and observation of sectarian feuding, and his self-education in Birmingham.

There was an upsurge of interest in freethought in the early 1880s, primarily the result of external influences. English freethought had roots in Thomas Paine's Age of Reason, in religious dissent and non-conformity, and later in utilitarianism, Darwinism and the radical liberalism of men like Mill. What brought it to the fore in the 1880 s was the refusal of a freethinking politician, Charles Bradlaugh, to take his oath on election to Parliament. Freethought left the domain of philosophical speculation and entered the sphere of practical politics. The stimulation was temporary but it reached New Zealand.

As Lineham has suggested, freethought in New Zealand tended to be weak because opposition to it was minimal. ${ }^{43}$ The persecution which made it flourish in England was largely absent in the colony. Nevertheless the 1880s saw something of a freethought 'revival', led by Ballance, Stout and others. Stout promoted his freethought views in the Echo. The Echo had recommenced publication in early 1880 after an absence of seven years, and was shortly afterwards purchased by a . Dunedin bookseller and freethinker, J. Braithwaite. Editorials reflected the fusion of freethought and radical liberalism. As we have seen the Echo published Ballance's articles on land nationalisation. The paper also carried news of both freethought and land nationalisation societies established in Dunedin at the time. ${ }^{44}$

43. P.J. Lineham, 'Secularists and Secularisation in Nineteenth Century New Zealand', unpublished paper.

44. E.g. Echo, 1 Jan. 1881, 13 Aug. 1881, 24 Mar. 1883. 
A Wanganui Freethought Association was formed in mid-1883.

Ballance and A.D. Willis were amongst its leading members, and in October they brought out the first issue of the Freethought Review, a monthly journal aimed at promoting freethought throughout New Zealand. The Echo ceased publication the following month, and so the Freethought Review became the sole mouth-piece of the colony's associations. Ballance wrote a number of editorials for the Review, as did Robert Pharazyn, an ex-Mayor of Wanganui and minor politician who was to be appointed to the Legislative Council in 1885. Edward Tregear, who became the head of Reeves's Labour Department in Ballance's Ministry, also contributed some material.

The first number of the Review declared its aim as the 'happiness of mankind in this life':

Whatever, in our opinion, may tend to hinder the advance towards this ideal, it will be our duty to assail. For superstition and prejudices, as we feel no reverence, we sha11 show no regard. ... Obedience to conscience is the highest moral injunction, transcending all creeds. Religious dogma covers over and obscures this sublime lesson, and people wonder that formalised religious instruction does not make them better than they are. The wonder rather is that it does not make them worse. 45

The Freethought Review ran for two years. Aside from reports on the activities of freethought associations, it contained articles on the philosophical arguments in favour of freethought along with comment on the role of the church in New Zealand society. ${ }^{46}$ Ballance's editorials

45. Freethought Review, 1 Jan. 1883.

46. E.g. Freethought Review, 1 Dec. 1883, 1 Jan. 1884. 
reflected the link between freethought and liberalism that had been present in the Echo. He attacked christianity as having always been a persecuting religion. Freethought aimed to undermine the 'enslaving theology' of both the Roman Catholic and Protestant churches. Freethinkers had their own creed. It was a higher faith,

...the enthusiasm of humanity- which will
give to the world a deeper morality and a
loftier conception of duty. Theology can
never supply the inspiration, as it cannot
afford demonstration of the truth of its
own dogmas, and, being based on rewards and
punishments, it does not appeal to the
highest sense of moral obligation. The
Freethinker, in a word, possesses an ideal
pure, lofty, and unselfish, attracting the
best and appealing to all- devotion to the
ever real and present cause of humanity. 47

Finally the spread of freethought was to be a part of a 'reforming Liberalism, constructive rather than destructive in its effects'. ${ }^{48}$

Freethought associations were also formed in Christchurch, Auckland, Wellington, Nelson, Picton and Woodville. They survivel at most a few years. A New Zealand Freethought Federal Union was formed in March 1884. Stout was elected president and Ballance vice-president. The Union met only this once. Aside from general sentiments on the promotion of freethought in New Zealand, there was little concrete it could focus on. Its programme included the abolition of religious oaths, and it passed a resolution in sympathy with Charles Bradlaugh in his 'arduous struggle against bigotry and injustice'. ${ }^{49}$ But that was it: a meeting of minds but little else.

47. Freethought Review, 1 May 1884.

48. Freethought Review, 1 Oct. 1884.

49. Freethought Review, 1 June 1884. 
For Ballance freethought was a critical element to the full development of individual liberty. It was much more than simply a belief in a secular society. Ironically his zeal for freethought bore resemblance to a religious crusade. Ballance seems ultimately to have recognised this, at least according to a story told by John Macmillan Brown, Professor or English, History and Political Economy at Christchurch University at the time. In his memoirs Macmillan Brown tells of am evening spent with Ballance in Wanganui:

Our host and I fell into a sharp discussion on his lyceum teaching. I held that he was contradicting his own tenets for he was turning his anti-religion into a religion. So warm was he in defence of his practice that when he came down next morning to see us off, he began the discussion again and carried it on till the train moved off. A few years after, when he was Premier, I met him again when going up the long staircase of the big matchbox (the large wooden building in which the Government Departments are housed) to see Mr Habens in the Education Department. We passed, saying 'good morning'; after a few steps, he turned and came back and said to me, 'Do you remember that discussion we had in Wanganui?' I replied 'Yes' and he said, 'I have come rourid to your point of view'. We parted and saw each other no more for in the following year his fatal malady carried him off. 50

The key remaining question is the extent to which Ballance's freethought views affected his political career. The evidence suggests that they did not. Freethought was never a political handicap. Religion entered elections in Wanganui only in connection with education, and Ballance's advocacy of a state secular education system was supported by many members of the Protestant churches. As with his opposition to Bible reading in schools, it was a cause independent of,

50. John Macmillan Brown, The Memoirs of John Macmillan Brown, Christchurch, 1974, pp. 122-23. 
and easily separated from, his freethought views. In other words it was not necessary to be a freethinker to add either plank to a political platform. In general Ballance sought to separate religious from political issues. The Herald reported the meetings of the Wanganui Freethought Association but editorials never promoted freethought views. 51 For the remainder of his 1 ife Ballance stuck to the opinion given to Stout in a letter written in 1881 . The letter also shows Ballance's belief in Positivism, the empiricist social philosophy of Auguste Comte adopted by many nineteenth century radicals:

I sympathise very heartily with you in your Freethought propaganda, \& am quite delighted with the tone and ability of the Echo. My own opinions have long been attracted towards Positivism, \& later reflections have confirmed my belief in the creed; but I think politics so all important at the present stage of the colony's growth, that I make religion a matter for private contemplation. 52

This desire for a separation of religion and politics was reflected in Ballance's views on education. He had held the education portfolio whilst a member of the Grey Government. The Education Department was a minor one, though it assumed greater importance with the passing of the 1877 Education Bill, which established a system of free primary education throughout the colony. 53 Ballance was concerned mainly with overseeing the implementation of the Act. Problems centered around 
financing the system, especially on the provision of school buildings and the setting aside of land as education reserves. 54

One of Ballance's first actions in the House of Representatives was to urge the Government to introduce a bill for elementary education. 55 He was committed to a free State education system as a matter of liberal principle. In 1881 he said that despite the difficulties that had arisen in connection with the 1877 Act 'there must be education for the people'. Education was liberating as it 'gave the people a great power to work their own ends'. He believed that a free State system beyond primary level should be established no matter how much it cost. 56 These views were not inconsistent with Ballance's belief in self-education and his support for Lyceums. Self-education was a necessity, especially for the working class, only because of the lack of State provision.

Thus from the start Ballance favour a State, non-sectarian system of education. Religion had no place in schools, though religious liberty would allow Catholics to maintain instruction of their own children. ${ }^{57}$ Obstacles to a State system would have to be overcome :

The intemperate opposition of religious partisans or the groans and grumbles of irritated taxpayers, should not be allowed to impede the progress of education. At the most, their grievances are inferior to the real interests of the State. 58

54. See e.g. PD, 1878,28 , pp. 104, 137-38, 183; PD, 1878, 30, pp. $701, \overline{790}-91$.

55. PD, 1875,19, p. 431.

56. $\mathrm{Y}, 5$ Nov. 1881 .

57. $\overline{\mathrm{EH}}, 11$ May 1874. See also the discussion of the 1879 election campaign in ch. 5 .

58. $\mathrm{EH}, 11 \mathrm{Dec} .1872$. 
The State had a duty to provide all children with a 'liberal' and 'popular' education:

The hands of the labourer's child were not made for the sole purpose of manipulating yard-measures and tapelines, ploughs, and pick axes. They could trace forms and hues of beauty, and produce sounds of rapture, as skilfully as those of his aristocratic neighbours, if... taught to do so. His eye could do higher and nobler things than scan the pages of legers and day-books, if it were taught to do so. ... The hereditary stock of wisdom is not a thing to be locked up, and transferred as idle capital from generation to generation. It must be traded with and increased, so that our children, when they succeed us, may find the edifice of civilisation a storey higher than their fathers found it... . 59

Finally education was to be progressive:

To speak of the Greek and Latin classes as a sine quâ non of a good education is now only usual with a few old-world folks, whom nothing but the fear of ridicule prevents from appearing in pig-tails and powder, if not in togas and sandals. 60

This combination of State provision and individual self-help was also characteristic of Ballance's opposition to prohibition. Ballance believed that the State should tackle intemperance not through prohibitive legislation but in the provision of the material wants, and

59. EH, $19 \mathrm{Feb}, 1875$.

60. $\overline{\mathrm{Ib}} \mathrm{id}$. 
the encouragement of the self-respect, of the individual. He presented a petition signed by nearly one thousand Wanganui citizens against the Local Option Bill of 1877, and successfully amended the Bill (which in the event failed to pass) to provide compensation for publicans who would lose their licence. ${ }^{61}$ Ballance put forward his views on temperance in a paper written in 1877 and read at a Christchurch meeting held in anticipation of the Local Option Bill coming before Parliament. His argument was that legislative prohibition would not effect reform, and that temperance depended instead upon 'the education and prosperity of the people'. ${ }^{2} \mathrm{He}$ used the experience of prohibition legislation in America and Sweden to support his claim. Specifically, he objected to the Local Option Bill on the following grounds: it allowed no middle course, it was all or nothing; it attacked the rights of property of public house owners; by introducing a referendum it reversed a basic principle of representative constitutional government; and finally it would not reduce temperance in any case:

The great hope of diminishing drunkenness must be by stimulating the intellect to find food for its own nourishment.

Intemperance and ignorance go hand in hand, and emancipation can only take place when education finds pleasures more attractive than strong drink. ... The cause of intemperance must be discovered in the man, and not in the facilities with which drink is supplied. 63

Ballance pointed out that public houses served a basic human need, and criticised the paternalism and hypocrisy of temperance reformers:

61. PD, 1877, 24, pp. 446-49; WH, 1, 8 \& 15 Sept. 1877.

62. $\overline{\mathrm{WH}}, 21$ July 1877.

63. Ibid. 
Nothing appears to my mind more unreasonable than the denunciation of the public house by those who have never done a single thing to establish any other source of enjoyment. Man is a social being, and there is in the public house, apart from any craving for alcohol, much that satisfied his social instincts. ...The system of paternal philanthrophy which would reform the working classes by keeping them in leading strings, has never yet succeeded, and is sternly resented by their most intelligent leaders. The attempt to deprive a working man of his glass while the more opulent member of the club can enjoy his at pleasure, or lay in a supply, is a specimen of paternal regard which is fast losing its hold even on the most philanthropically inclined. 64

The temperance issue varied in its political significance over time.

It assumed considerable importance in the mid-1890s for example. Essentially Ballance argued that temperance reformers were attacking the effect and not the cause. His opposition to prohibition was simply the other side of a belief in general 1iberal legislation aimed at satisfying the individual's material and intellectual needs.

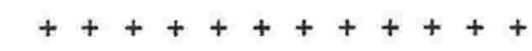

The remainder of this chapter discusses the 1884 election in Wanganui and Ballance's return to political life. By early 1884 the Atkinson Ministry was running out of steam. It was tainted by the deepening depression, and its chosen remedies of increased taxation and retrenchment alienated many of its supporters. Increased grain duties, for example, were anathema to Canterbury interests. However neither Montgomery (who had replaced Macandrew as Opposition leader) 
nor Grey could form a viable alternative, and so both sides settled on dissolution and a fresh election.

If Bryce's action over Parihaka had been the major factor in the 1881 election, it was Vogel's return to politics that formed the backdrop to the 1884 contest. The Agricultural Company was in dire financial straits, as was the connected Waimea Plains Railway Company, which was having difficulty collecting its rates. As Hamer has shown, Vogel aimed to rescue the enterprise through his returning to power. The new Government would restore confidence, end the depression and raise land values. It would also purchase the ailing Railway Company. ${ }^{65}$ For Vogel an alliance with Stout was essential if enough support was to be gathered to make such a Ministry possible. Together they formulated the plan months before the election. Stout had interests in the companies and connections with other South Island investors. Politically he could defend such ventures as 'patriotic efforts to develop that voluntary cooperation on which he believed depended 'real growth and progress in ${ }_{n}$ masses' '. 66

Ballance may or may not have known in advance of the agreement between Vogel and Stout. His own involvement with the company was minimal and had no bearing at all on his decision to stand again for the Wanganui seat. Ballance was a career politician whereas Vogel and Stout were not. Only Ballance's defeat in 1881 prevented him from being in Parliament continuously from his entry into politics in 1875

65. D.A. Hamer, 'The Agricultural Company and New Zealand Politics, 1877-1886', Historical Studies, 10, 38, (1962), pp. 150-52.

66. D.A. Hamer, 'The Law and the Prophet: a political biography of Sir Robert Stout, M.A. thesis, Auckland, 1960, p. 101. 
until his death in 1893. For Ballance what was important were the political consequences of Vogel's return independent of the raison d'être of the agreement. Vogel was able to attract considerable support through his own personal prestige. The suggestion that he might end the depression through development policies associated with the prosperity of the 1870 s was for many irresistible. Given this Ballance may well have seen, early on, that the only way of defeating Atkinson in the country was through an alliance of liberals and Vogel. The opposition was disorganised and disunited. Liberals comprised only a part of it, for there had been many independents elected in 1881.67 It was a question of alternatives; or rather the lack of them. Montgomery, like his predecessor, had not been an impressive leader, and his advocacy of separation was anathema to Ballance. Grey was a spent force, and there were in any case suspicions that he was seeking a coalition with Atkinson in order to keep Vogel out. Vogel's opposition to leasing and to land nationalisation would be an embarrassment to Ballance if an alliance were anticipated. The Herald also pointed to the logitimate doubt as to whether depression could be overcome by new borrowing alone. ${ }^{68}$ Nevertheless by the election Ballance was predicting that Vogel would become Premier, and saying that 'he would not be sorry for it'. As for himself, he would not accept office 'unless his principles were fairly represented'.69

Ballance's campaign reflected this contradiction between his advocacy of a radical liberal programme and political reality. It

67. See T.G. Wilson, 'The Rise of the New Zealand Liberal Party, 1877-1890', M.A. thesis, Auckland, 1951, ch. 7 .

68. Wanganui Hera1d, 6 May 1884, 14 June 1884.

69. $\bar{Y}, 25$ July 1884 . 
was in part an attempt to fuse liberalism and Vogelism, (rapid economic development through borrowing for public works) and as such required concessions from both. Ballance's liberalism was undeniable; but the need to accommodate Vogel meant that he was unable to fight the election on the basis of a Liberal party. Indeed such a party barely existed, and in his speeches Ballance made no reference to it. He foresaw the need for coalition and argued that Vogel was the best the opposition could come up with. ${ }^{70}$ As for Vogel's penchant for borrowing, Ballance admitted that Vogel

...might be inclined to go too fast unless he had a House which could put a drag on. (But) it was better to have a statesman that had a tendency to be a little too fast, rather than one that did not move at all. 71

Ballance's major campaign speech was delivered on 8 July to a crammed Princess Theatre in Wanganui. He was at his most radical. He opposed Atkinson's suggestion of federation with the Australian colonies on the grounds that it would involve a loss of sovereignty for New Zealand. He criticised the giving and acceptance of colonial titles. ${ }^{72}$ 'It was more noble to. reject these honors' he said, 'and die in the possession of the confidence of the people', than to be covered with them. These were republican and nationalist sentiments that would emerge again in Ballance's later 1ife. He believed that unemployment ought to be tackled through restricting immigration to those 'fitted for country life' and those with capital. The property tax ought to be replaced by a progressive land tax, for the former was

70. Y, 18 July 1884 .

71. $\bar{Y}, 25$ July 1884 .

72. Sir Henry Parkes had recommended the creation of colonial earldoms, and William Fitzherbert had just accepted a K.C.M.G. 


\begin{abstract}
'taxing industry, discouraging enterprise, and heaping taxation upon the working classes'. Though his advocacy of land nationalisation was not as strident as in his Echo articles, its importance to him was clear and it went far beyond anything he had proposed at previous election campaigns:
\end{abstract}

With regard to the nationalisation of land, he believed in the principle, and he would support it when the people were willing that it should be carried out. It was said now that the only system desirable was that of freehold, but he would ask anyone to look at the extent of available land, and say how long freeholds would be available for anyone in New Zealand. They now parted with 12 million acres, and the natives owned yet about 12 million acres, while of those owned by the Crown not more than 5 millions would be found suitable for cultivation, or small farmers. When the whole of this available land had passed away, then those gentlemen who were now crying out about the value of freeholds, would then be sorry they had urged the Government to part with it. ... (I)f the land was not valued too highly, and if the ballot took the place of auction, the value of the perpetual leasing system would soon be seen, and the people would come to believe in land nationalisation. Let them look at the land already sold; they found $7,000,000$ acres owned by 2500 people in the colony... . Then there were seven men in the colony owning $2 \frac{1}{2}$ million acres, and 20 people owned 4,000,000 acres. Could the colony progress while these large blocks were thus held! 73

Progress, Ballance concluded, lay in promoting land settlement through low rents and encouraging local industries through protective duties.

It was with respect to local development issues that Ballance's attempt to utilise Vogelism emerged. For example he wished to see the Wanganui River opened up so that the land through which it flowed might 
be settled. 'They would not have to ask Sir Julius Vogel twice to do it' he said. ${ }^{74}$ Yet though Ballance accepted that prosperity could be restored by expenditure on new settlement, he was cautious as to the extent to which a government ought to borrow for these purposes. He said that if elected 'he would insist upon the curtailing of borrowing, except judicious borrowing for railways and roads through native 1ands'. ${ }^{75}$ This was an important qualification of the Vogel tradition. It anticipated Ballance's later self-reliant policy (see chapters 10 and 11), and at the same time reflected a natural bias in favour of borrowing for the development of the North Island only. In general Ballance argued that

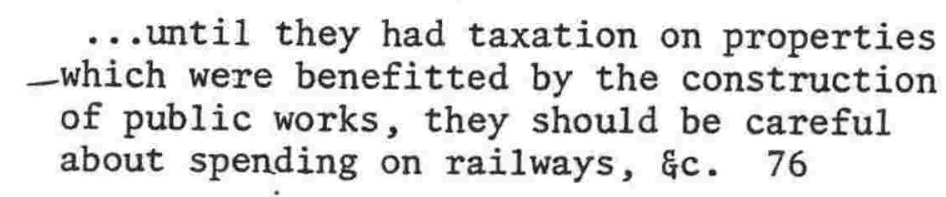

There was no place in Vogelism for this, nor indeed for land nationalisation. For Voge1, State intervention was aimed at promoting rapid development, and would stop well short of restricting the profits of private capital investment. It could also, of course, bail out a company that claimed to be contributing to the settlement of the colony. Ultimately therefore, Ballance's liberalism and Vogelism were incompatible, though political circumstances might for a time force them together. A radical programme involving a land tax and the repurchasing of large estates would be seen by Vogel as needlessly frightening capital away from the country (see chapter 10).

74. Ibid.

75. Ibid. There was no mention of borrowing to provide funds for 1and nationalisation.

76. Ibid. 
At the election Ballance was opposed by the same two men whom he had faced in 1875; W.H. Watt, the sitting member, and the lawyer George Hutchison (see chapter 3). Watt's performance in Wellington had not impressed his supporters. The Chronicle admitted that he was 'deficient in many of the qualities' that it would wish to see in a representative, but supported him on the grounds that he was a safer bet than Ballance. ${ }^{77}$ During the campaign it became clear that Hutchison was the stronger of Ballance's opponents. Hutchison was politically much closer to Watt than Ballance, and thus would split the anti-Ballance vote.

The campaign was fought on both local and national issues. Watt opposed Ballance's advocacy of both a rating bill to finance further harbour improvements and the need for river development. Hutchison, in his one major disagreement with Watt, supporter the former. ${ }^{78}$ Differences over the rating issue reflected the growing split between town and country. The Harbour Board and Ballance wished to rate the country areas that the port served as well as the town itself. Rural settlers however, despite their use of the port and town as distribution centre, had little sympathy for the Board's financial problems. ${ }^{79}$ They certainly did not feel obliged to dip into their own pockets to help it out. One of the foremost critics of the rating proposal was John Bryce. Like many other opponents of the bill, he farmed land outside the town, and regarded the question of harbour improvements as of no interest or responsibility of the

77. WC, 19 July 1884. See also WC, 3 July 1884. 78. $\overline{\mathrm{WC}}, 12$ July 1884; Wanganui Hera1d, 3 July 1884.

79. See S.M. King, 'The Port of Wanganui and its Influence on Wanganui', M.A. thesis, Victoria University of Wellington, 1964, p. 15; T.J. Young, 'The Political Career of John Ballance, 1875-1890', M.A. thesis, Victoria University of Wellington, 1964, p. 103. 
country. Ballance's later strenuous efforts to have the bill passed (see chapter 8) identified him clearly with the town and Bryce equally clearly with the country.

On broader issues Ballance was condemned both for his past record and his present policy. The Chronicle criticised his desertion of Atkinson and subsequent failure as Colonial Treasurer. It argued that his political principles did not run deep, though somewhat inconsistently at the same time deprecated his theory of land nationalisation. ${ }^{80}$ There was some criticism of Ballance's freethought views, in the form of correspondence to the Chronicle:

As a Freethinker and Infidel $\mathrm{Mr}$ Ballance ought to be rejected by every right-thinking Christian in the town. He who assists to pollute the minds of the little ones is not worthy to be trusted with the administration of the affairs of this colony. ...Christians, unite, and drive this infidel once more into private life. 81

And again:

...not content with denying his Maker, (Mr Ballance) is anxious to teach our children the tenets of a Bradlaugh or a Besant. ... Orangemen, be true to your colours, and refuse to be longer allied to the snake in the grass. 82

The Chronicle was content simply to publish these letters. Neither it nor Watt or Hutchison raised the issue to any significant extent during the campaign. As it turned out Ballance's freethought views, if they had any effect on his support at all, did him no harm. Yet 
he was sensitive to the mixing of religion and politics. If the two were to be regarded as inseparable, he said, the election would not be contested on a fair basis. ${ }^{83}$

The result of the election, at which there was only the one polling booth at the Court House, was as follows:

$\begin{array}{lll}\text { Ballance } & 541 & \\ \text { Hutchison } & 205 & \\ \text { Watt } & 154 & 84\end{array}$

It was an impressive victory, by a margin that seems to have been unexpected by Ballance and his supporters as well as his opponents. There had been suggestions that his majority might be fifty or one hundred. The Herald later described the scene as the crowd gathered in anticipation of the declaration of the poll. Some enthusiasts, running out of patience, began throwing eggs and. flour. When the result was eventually announced so many Ballance supporters climbed onto the hustings that the platform collapsed under the weight. Ballance was then carried shoulder high to the Court House steps, where he briefly addressed the crowd. The result, he said, completely atoned for his defeat three years earlier. He had never been prouder of Wanganui. 85

Three factors explain Ballance's large majority. First, though out of Parliament he had remained in the public eye, through the Herald, and on account of his activities on the Harbour Board and participation in local organisations such as the Protection Association.

83. Y, 25 July 1884 .

84. Ibid.

85. Ibid. 
Secondly, he clearly benefitted from the adverse reaction to Watt's term as Member for Wanganui. Third and most important, Ballance's platform was more forthright and positive than it had been in 1881 . It involved an unambiguous bid for working class support by advocating land nationalisation and protection policies that aimed to restore prosperity to the town, and to the country upon which the town depended. For the same reasons Ballance also appealed to the town's small businessmen and shopkeepers. His only reference to 'labour issues' per se came in answer to a question proffered at the conclusion of one of his speeches. It concerned the length of the working day, and Ballance replied that he believed in an eight hour day but that there should be freedom of contract. ${ }^{86}$ Ballance's radicalism was channelled primarily into land reform. Because of this he was able to attract support from Wanganui's business sector, for whom land nationalisation seemed at least of little danger, and at most (because of the larger market result from closer settlement) a positive boon.

Ballance left for Wellington on 5 August, and Parliament met two days later. When Atkinson resigned, acknowledging that a majority of members opposed the Government, Vogel and Stout set about forming a Ministry. Stout persuaded Ballance to join. ${ }^{87}$ The Herald had said on 6 August that Ballance's decision to accept office would rest 'mainly on how far his well known principles in connection with land administration' were accepted by his colleagues. The use of the word 'administration' rather than 'nationalisation' or 'reform' was perhaps significant. In fact Ballance joined as Native Minister and Minister 
of Defence. Only in the second, reformed Stout-Vogel Ministry was the Lands portfolio added. Even holding this post Ballance must have been well aware of the difficulty in persuading a Government strongly influenced by Vogel to adopt a radical land programme.

On 16 August Stout became Premier and Vogel Colonial Treasurer. Ill health and a dislike of administrative chores stopped Vogel from assuming the Premiership himself. This first Stout-Vogel Ministry contained a number of fatal flaws: many were astounded at the combination of liberals and 'conservative' speculators whilst the Evening Post was disappointed that Voge1 did not take on the Premiership himself. Stout had not been recognised during the election as a possible leader. ${ }^{88}$ Also in the Ministry were Macandrew, Montgomery and Richardson; a South Island dominance that could not hope to attract sufficient support from the north. ${ }^{89}$ 'We doubt whether any Government ever assimed office with a more decided public opinion against it' wrote the Post. 90

After less than a week in office the Ministry was defeated, primarily owing to this lack of North Island (and especially Auckland) representation. $91 \mathrm{~J} . \mathrm{W}$. Thomson of Clutha then attempted to form a Government. His failure was followed by that of Grey, who was unable to entice the necessary support of Atkinson. Atkinson himself then tried to form a cabinet with Vogel's support. When this too fell through, Atkinson formed a Ministry on his own. Without the cooperation

88. EP, 12 Aug. 1884 .

89. Wanganui Hera1d, 4 Sept, 1884.

90. EP, 18 Aug. 1884 .

91. $\overline{\mathrm{EP}}, 21$ Aug. 1884 . 
of either Vogel or Grey this attempt was also doomed, and indeed lasted only six days. ${ }^{92}$

What resolved the impasse was Stout and Vogel's reconstruction of their Ministry without Macandrew or Montgomery. ${ }^{93}$ It survived because it was less radical and could attract Greyite support through the inclusion of J.A. Tole from Auckland. The chain of events favoured Ballance as a representative from the North Island. He now held the important portfolios of Lands, Native Affairs and Defence. Yet some evidence suggests that for a time he hoped for a different outcome. On the eve of the vote of confidence on Atkinson's 'interim' Ministry, George Fisher of Wellington sent Ballance a note seeking his clarification as to the intention of the Opposition. Did they aim to return to the original Stout-Vogel Ministry, or force a combination if possible? Ballance replied:

Not to bring back the Stout-Vogel Ministry. Hope the result will be a combination. acceptable to House. But Atkinson lot must first be defeated. 94

As we have seen the Stout-Vogel Ministry, with some minor albeit important changes, did return. The question is whether Ballance had a realistic expectation of the formation of a Ministry excluding both Vogel and Atkinson, and including himself, Stout and perhaps Grey. The Evening Post reported on 2 September that Macandrew and Montgomery were seeking to reach agreement with Grey. Earlier Grey had been advised by his supporters to attempt an accommodation with

92. See Judith Bassett, Sir Harry Atkinson, Auckland, 1975, pp. 128-29. 93. EP, 21 Aug. 1884.

94. Fisher to Ballance, and reply, 29 Aug. 1884, Fisher Family Papers. 
the Stout-Vogel faction. ${ }^{95}$ Ballance perhaps hoped to attract Greyite support without having to include Grey himself, and in a sense this is what happened. His desire to split Stout from Vogel was natural, though it flew in the face of the position of the various factions in the House. It also suggests that Ballance was not fully aware of Stout and Vogel's commitment to each other, or that if he was he attached little importance to such an agreement.

In the event Ballance accepted his enhanced position in the reconstituted Stout-Vogel Government as second best. In further correspondence with Fisher, who looked to Ballance for guidance, he wrote:

The time has not yet come in this colony
when a pure Liberal party can be formed,
and until it does come we can only wait
and make the best of the position, yet
keeping in view the object we wish to
attain. The majority of the House is
probably (?) not guided by Liberal
principles, and no Govt. can go very far
ahead of public opinion. You and others
can do a great deal to hasten the time
when a distinctly Liberal programme can be
put forth by the party from the Hustings,
\& when such a programme will be honestly
given effect to in Parliament. I hope the
day is not far distant... . 96

95. NZH, 26 Aug. 1884 .

96. $\overline{\mathrm{Ba} 1}$ lance to Fisher, 31 May 1885, Fisher Family Papers. 
The Stout-Voge1 Government achieved and maintained power because a majority in the House believed it might end the depression and restore prosperity. The Ministry drew its support in particular from businessmen and merchants, lawyers and runholders. It also depended heavily upon South Island members. Canterbury especially had returned a high proportion of Vogelites; those of the 'commercial and landed aristocracy' who had been hit by the collapse of wool and wheat prices. ${ }^{1}$ They were represented in the Cabinet by a Christchurch contractor, Edward Richardson, whom Vogel appointed Minister of Public Works. The other members of the Ministry, aside from Stout, Vogel and Ballance, were: J.A. Tole, a Greyite Auckland lawyer who became Minister of Justice; Patrick Buckley, another lawyer who was Colonial Secretary; and W.H. Reynolds, a Dunedin businessman and merchant.

The Yeoman described both the Cabinet and the support it received somewhat extravagently as a mixture of 'placid conservatism and fervid liberalism'. 2 Those 'conservatives' were Vogelites much excited by the prospect of new borrowing for development projects (especially railway construction); though their vision of the role of the State might go no further than this, they were quite distinct from the many more 'comprehensive' (and generally rural based) conservatives in the ranks of the Opposition, whose immediate reaction to depression was to call for severe retrenchment. This diverse nature was a strength because it enabled the Government to attract support from different factions within the House, each believing that their own men in Cabinet

1. See T.G. Wilson, 'The Rise of the Liberal Party in New Zealand, 1877-1890', M.A. thesis, Auckland, 1951, ch. 8; D.A. Hamer, 'The Law and the Prophet: a political biography of Sir Robert Stout (1844-1936)', M.A. thesis, Auckland, 1960, ch. 5.

2. 28 Nov. 1884 . 
would be a check on the others. The Ministry was recognised as one of considerable ability and many conservatives (for example Scobie Mackenzie) believed that they could 'keep the men in' but their measures (especially liberal 'fads') out. ${ }^{3}$ It was a weakness because the Ministry could survive only as long as controversial legislation was avoided. When it became clear that Vogelism had failed to reverse the depression, and when the call for protection began to be loudly heard, the Ministry fell apart. In the meantime there was little chance of liberal measures, such as the abolition of plural voting, achieving a majority in the House.

Vogel and Stout's plan of rescuing the New Zealand Agricultural Company ultimately failed. The Government did finally purchase the Waimea Plains Railway, giving some relief to the Agricultural Company which as the major owner of the land through which the railway ran was liable to the Railway Company for a considerable sum of rates. However the Agricultural Company foundered as the depression continued, and was wound up in $1890 .^{4}$

The District Railways Leasing and Purchasing Bill passed through the House in October 1884, but was subsequently thrown out by the Legislative Council. The Bill enabled the Government to purchase any district railway, whilst the Council insisted instead on separate legislation. A second District Railways Purchasing Bill, for the acquisition only of the Waimea Plains Railway, was successful two years later. As the legislation was debated fresh allegations were made, by Grey in particular, of the involvement of members of the Ministry

3. EP, 25 Sept. 1885 .

4. $\overline{S e e}$ D.A. Hamer, 'The Agricultural Company and New Zealand Politics, 1877-1886', Historical Studies, 10, 38 (1962). 
in the Railway and Agricultural companies. Vogel in fact mentioned his connection with the Agricultural Company when he moved the second reading of the 1884 Bill. When the Speaker ruled that those with a pecuniary interest in the Company should not vote in the division on the Bill, Vogel, Stout and Ballance all abstained. 5

Ballance argued that though he had been associated with the Company he had no financial interest in it. He had been connected with it, but 'without any prospect of reward and without receiving one penny'. In any case, he said, he was not ashamed of the Company. It aimed at cutting up large estates for settlement, which was a 'perfectly legitimate' motive. Grey denied Ballance's statement that he (Grey) had as Premier known of and given sanction to the Agricultural Company. Grey correctly asserted that initially he knew nothing of it, and that when he did find out about it he insisted on Vogel's resignation from the Board of Directors. 6 .

The Government managed to play down the personal involvement of Stout and Vogel in the companies in a number of ways. There were other district railways in financial straits, so that the idea of Government purchase had more general appea1. Secondly, only Grey and a very few other members had any idea of the past history of the affairs of the Company. Further it was difficult for Grey not to appear to be motivated by personal spite. His accusations were inevitably associated with his political estrangement from Stout and Ballance since the fall of his Ministry in 1879.

5. $\quad$ PD $, 1884,49$, p. 433 .

6. $\quad \underline{\mathrm{PD}}, 1886,56, \mathrm{pp} .455-57,641 \mathrm{ff}$. See ch. 4 . 
The Agricultural Company was certainly of some embarrassment to Ballance, though as with the Loan Company (see chapter 4, pp. 170-71) he never suffered politically from his connection with it. As a member of the Cabinet he must have been aware of the reasons behind Vogel and Stout's eagerness to see the Waimea Plains Railway purchased, and would also have known of its link with the Agricultural Company. In 1891, when Ballance was Premier, his involvement with the Company was again mentioned in the House. Ballance, in a revealing statement, sought to put the record straight:

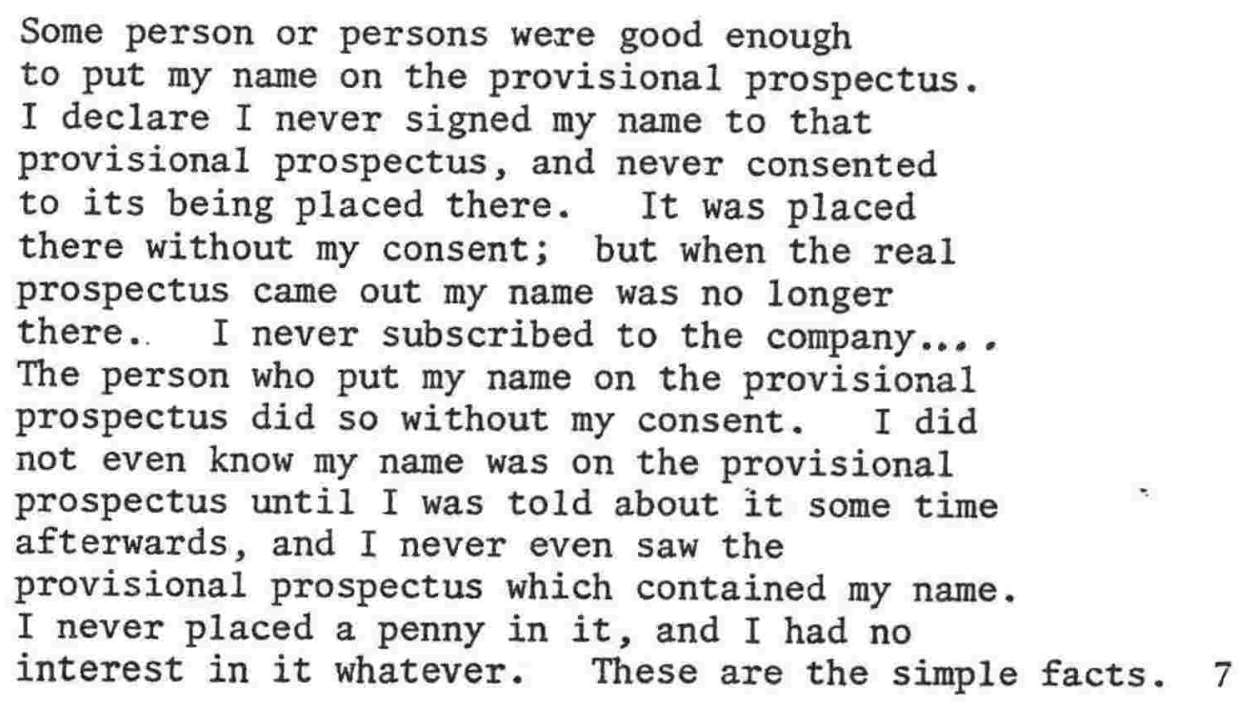

That Ballance did not mention this earlier may well be explained by his wish to protect Stout (who was most likely the person who put Ballance's name on the prospectus) from further embarrassment. It is clear that if Ballance is to be criticised over the affair, it should be for keeping quiet about what was going on, rather than for any personal financial involvement he had in the Company.

The financial policy of the Stout-Vogel Government was both inconsistent and unable to deal with the depression which deepened after 
1885. Export prices continued their long term decline and the country's annual deficit rose from $\$ 147,000$ in 1884 to nearly $£ \frac{1}{2}$ million by 1887 . Bank credit contracted further. ${ }^{8}$ Vogel's Financial Statement of 1884 proposed to reduce the property tax by one half, to convert the sinking fund and thus give some immediate relief to the burden of debt, and to float a new loan for public works. ${ }^{9}$ Within a year al1 optimism engendered by these measures had vanished. Vogel restored the property tax to its original level and proposed an increase in tariffs. ${ }^{10}$ It was an admission that Vogelism had failed. Plans for new loans were shelved with the collapse of the colony's credit in London. The vast majority of the tariffs were rejected by a House increasingly intent on retrenchment as the means of dealing with depression. A motion proposed by W.R. Russel1, Member for Hawke's Bay, to reduce public works expenditure by $\frac{1}{2}$ million was carried by a majority of fifteen. 11

Economic depression and the politically diverse nature of the Stout-Voge1 Government's support were two major restrictions on Ballance's room for manoeuvre during his three year tenure as Native Minister and Minister for Lands. Further, Vogel himself would resist any move towards land nationalisation or restriction of the free market in crown or Maori 1and. He had gained the support of the Canterbury members by assuring them that despite the presence of Stout and Ballance 'all fads and nonsense would be dropped'. 12 Despite these

8. C.G.F. Simkin, The Instability of a Dependent Economy. Economic fluctuations in New Zealand, 1840-1914, Oxford, 1951, pp. 147, 165; W.B. Sutch, Colony or Nation?, Sydney, 1966, p. 24.

9. $\mathrm{PD}, 1884,48, \mathrm{pp} .351-61$.

10. $\overline{\mathrm{PD}}, 1885,51, \mathrm{pp} .68-84$.

11. $\overline{\mathrm{PD}}, 1885,53, \mathrm{pp} .573,733-34$.

12. $\overline{\mathrm{NZ}} \mathrm{H}, 9$ May 1885 . 
limitations Ballance had considerable success in introducing innovatory legislation. Some was later reversed, but important precedents were set.

This chapter looks in turn at Ballance's policy and performance as Minister for Lands, Native Minister, and as Minister for Defence (the minor portfolio which he also held). Despite this separate treatment, necessary for practical purposes, it should be stressed that land and 'native' issues were closely connected. There was increasing pressure (an expanding population and contracting amount of suitable crown land) to acquire Maori land for European settlement. Further, of particular importance during Ballance's tenure was the purchase of the Maori land through which much of the proposed North Island trunk railway was to run. The rail aimed not simply at linking Wellington with Auckland, but at opening up new land for settlement, especially that between Marton and Te Awamutu.

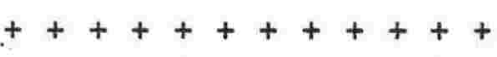

As Minister for Lands Ballance aimed to maximise settlement; that is, he aimed to place as many people as possible on a given acreage of land. He encouraged leasing and reduced the amount of land sold outright as a step towards nationalisation. James McKerrow, the Secretary for Crown Lands, wrote rather sourly in his 1885 report that there had been less crown land sold in the year ended March 1885 than in any previous year. This had not been owing to any lack of 
purchasers, he said. Instead extensive areas had been withheld from sale. ${ }^{13}$ over the following three years cash land sales continued to decline, and picked up only after Ballance left office. ${ }^{14}$ On the other hand, as Condliffe has shown, the number of new settlers rose, and the average size of holding fell, during Ballance's tenure. Settlement more than doubled between 1886 and 1887 , reaching a figure unmatched by the Liberal Government of the $1890 \mathrm{~s}^{15}$

Increasingly Ballance saw land settlement as a solution (alongside the development of industry and halting of immigration) to the immediate problem of urban unemployment. ${ }^{16}$ He extended existing, and devised new, settlement schemes with this object in mind. These schemes were at the same time the practical manifestation of ideas and propositions that Ballance had arrived at by 1884 .

The 1885 Land Act was a consolidating measure, replacing all previous land law. It was a major piece of legislation for it also established a number of new tenures and forms of settlement. The overall objective of the Bill, said Ballance, was to get, and keep, bonâ fide settlers on the land. His short pithy speech on the second reading of the Bill emphasised his preference for leasing:

\footnotetext{
...the best of all kinds of bonâ fide settlement is that which enables the State to retain control over the land, and which enables the people who want land to cultivate
}

13. AJHR, $1885, \mathrm{C}-1$.

14. Cash land sales were as follows: 1886, 65,267 acres; 1887, 33,336; $1888,28,626 ; 1889,69,626$. Figures are from AJHR, C-1 of the respective years.

15. J.B. Condliffe, New Zealand in the Making. A survey of economic and social development, London, 1930 , pp. 186, 188 .

16. See Ballance's speech at a banquet given in his honour in Wanganui, $\underline{Y}, 5$ Dec. 1884 . 
and not for speculative purposes to

go on the land and hold it so long as

they are complying with the conditions

of improvement and settlement. 17

Thus the freehold encouraged speculation, whilst 'where the object is to settle down and to make a home... there is nothing in the world which will compare with the system of perpetual leasing'. ${ }^{18}$

Under the Act land could be sold for cash or on deferred payment, or it could be leased. Leased land was let by tender at an upset price of five per cent of the capital value of the land. Owners of more than six hundred and forty acres of land in the colony were ineligible for leasing. There were residence and improvement conditions. Finally, lessees were able to acquire the freehold after six years. 19 Ballance would have preferred there to be no freehold right, but political pressure meant that its inclusion was essential to the successful passage of the Bill. Nevertheless he predicted that perpetual leasing would become the 'prevailing system in the colony'.20

In the Act Ballance introduced four new forms of settlement. The first of these, the leasing of 'small areas', he placed great emphasis on. Under this system town dwellers could lease up to fifty acres of land bordering urban areas. ${ }^{21}$ It was aimed primarily at labourers who, at times of temporary unemployment, could work and draw sustenance from their land. 'I maintain that the true outlet for the

17. PD, 1885,52, p. 45 .

18. Ibid. On the passage of the Act, see $\underline{Y}, 3$ July 1885 ; EP, 18 July 1885,24 Aug. 1885; NZH, 18 July 1885.

19. Land Act, 1885, sections $135-160$. This form of tenure was restricted by the provision that the amount of leased land could not exceed one third of the land open for sale in a given district.

20. PD, 1885,52, p. 45 .

21. Land Act, 1885, section 161 . 
labouring-classes', said Ballance, 'is to have sma11 holdings in the neighbourhood of large towns upon liberal conditions'. 22 In fact only fifty-two settlers on fifteen hundred acres of land were established under this tenure. Ballance recognised the flaws in it, the most serious of which was the lack of available land adjacent to centres of population. He argued that given this the Government ought to purchase the necessary land. ${ }^{23}$ The Yeoman, echoing his belief that small area leasing was a major provision of the Act, also acknowledged this problem. Success of the scheme, it said, would depend upon good land and the availability of wage labour near by. ${ }^{24}$ There had been criticism that lack of employment opportunities would quickly result in the pauperisation of settlers.

Despite the fact that very few settlers were established under this tenure, the scheme has considerable importance as a practical application of Ballance's philosophy. ${ }^{25}$ It was a qualification of the Yeoman ideal, involving a 'half-way house' between urban and rural living for the working classes. Advancement was achieved through working the land, though a settler would remain socially bonded to the town. Significantly the regulations denied the settler the right to acquire the land's freehold, a condition that would discourage those who wished to become full-time farmers.

22. PD, 1885,52, p. 45 .

23. Ibid.

24. 3 July 1885 .

25. Given the scheme's negligible impact, it is not surprising that historians have overlooked it. None of the following, who deal to a greater or lesser extent with Ballance's land legislation, mention it: T.J. Young, 'The Political Career of John Ballance, 1875-1890', M.A. thesis, Victoria University of Wellington, 1964; E.J. Charman, 'Land Tenure Reform in New Zealand, 1875-1896. A study of the opinions of some leading land reformers', M.A. thesis, Auckland, 1953; W.R. Jourdain, Land Legislation and Settlement in New Zealand, Wellington, 1925; P.E. Dempsey, 'The Land Policy of the Stout-Vogel Ministry, 1884-1887', M.A. thesis, Auckland, 1945. 
This dual urban-rural employment was a central feature of a second, and much more successful, form of settlement introduced by Ballance. This was the Village Settlement scheme. As we have seen (chapter 5, pp. 202-03), Rolleston had established village settlements on small scale in Canterbury in the 1870s, and a colony-wide scheme was provided for under the Land Amendment Act of 1879. The provisions were little used however, despite such recommendations as the following from the Evening Post:

Working men who live in the large cities of the colony should direct their earnest attention to the system (of village settlement) by means of which they obtain freehold homes for themselves and families. It is a serious evil that so many working men should remain in the large cities, often choking up the labor market, when they would have a far widely (sic) scope for their exertions in some of the country districts, besides the opportunity of acquiring a permanent home of their own. 26

Under Ballance's scheme, villages were to be established with each settler receiving up to one acre of 'urban' land, and up to fifty acres of rural land. The land could be bought or leased. The Act also gave the Minister the right to purchase land, with the approval of Parliament, for such settlements. ${ }^{27}$ What was significant however, was Ballance's later amendment of the regulations for village settlements on perpetual lease, through an order in council of 1 september 1886. Leases for these Village Homestead Special Settlements, as they were called, were to run for thirty years, with renewals for subsequent periods of twenty-one years. There was no right to acquire the freehold. Settlers were to be given loans to enable them to construct a house and clear the land, repayable along with the annual rent fixed 
at five per cent of the value of the holding. Certain improvements had to be made within a given period of time. ${ }^{28}$ Ballance's aim was to establish whole working class families on the land. In particular he hoped to attract, by fixing the rent and advancing sums for improvements, the unemployed and under-employed who were 'crowding' the towns.

Village Homestead Special Settlements were the most popular form of village settlement. By 1890, 23,552 acres were held under the scheme; 2,257 acres under the ordinary perpetual lease; 7,398 acres sold on deferred payment and 5,782 acres sold for cash. ${ }^{29}$ Between May 1886 when the scheme was announced and the end of March 1887, eight hundred and ninety-six settlers took up land under the homestead regulations. 30 This initial 'rush' was the consequence of the depression conditions prevailing and the incentives offered. As a report on homestead settlement published in 1891 pointed out, the scheme was seen originally 'as a relief measure to absorb the unemployed workmen who had congregated in the towns'. 31

Out of the 1,196 settlers established by 1889 , seven hundred and sixty-five were labourers and one hundred and three were carpenters. There were only ninety who classified themselves as farmers. ${ }^{32}$ Over half the homestead settlements were in the Auckland district, Canterbury

28. This order in council was published by Ballance as an appendix to his A National Land Policy, Wellington, 1887. See also EP, 7 May 1886

29. AJHR, 1890, C-1.

30. $\overline{\mathrm{AJHR}}, 1887, \mathrm{C}-1$.

31. Report on the Village-Homestead Special-Settlement System in New Zealand by Hon. W. Copley, AJHR, 1891 (Sess. II), C-5, p. 16. See also 'Special Settlement Records, 1871-1903', Lands and Survey Department, Series 22, National Archives, Wellington.

32. Jourdain, p. 29. 
and Wellington accounting for nearly all the remainder. The large scale of the former scheme was owing mainly to the enthusiasm and persistence of John Lundon, whom Ballance appointed to promote settlement north of Auckland. Lundon had been M.H.R. for Maunganui and Bay of Islands, and suggested to Ballance that the unemployment situation in Auckland might be relieved by placing families on land near the gumfields and sawmills of Northland. 33

There were a number of problems with the scheme. As with the small area leasing tenure, good quality land and a nearby source of employment were needed; and both were lacking in many of the Auckland settlements. By 1888 one hundred and thirty-three of the six hundred and thirty-nine Auckland sections had been abandoned, and one hundred and sixty-eight settlers were in arrears with their rent. ${ }^{34}$ There was greater success in Canterbury, where the land was free of bush and markets easily accessible. 35

Ballance visited a number of village settlements in the South Island in early 1885, before the homestead regulations appeared. 36 He was particularly pleased with a 'small farm settlement' (a type of village settlement held on deferred payment) called Beaconsfield, near Timaru. Its success, he discovered, lay in the fact that all the men, aside from farming their ten acre sections, had paid employment in town. The general shortage of land in Canterbury, however, led Ballance again to the conclusion that the Government ought to acquire it by compulsory purchase. 37

33. $Y, 17$ Sept. 1886, 5 Nov. 1886; J. Lundon to Ballance, 24 July 1892, BMSS, 626.

34. AJHR, 1888, C-11. See also AJHR, 1887 (Sess. I), C-1, for comments on problems of the Auckland schemes.

35. As at the Orari settlement, for example.

36. EP, 20 Apr. 1885 .

37. $\overline{\mathrm{Ba}} \mathrm{l}$ lance described this visit in a speech, $\underline{Y}, 15 \mathrm{Jan} .1886$. 
The village settlement, and in particular the homestead, schemes attracted considerable criticism. Ballance was condemned for the large amount of money he had spent on road works in Auckland in order to provide employment for the settlers. According to Lundon, Ballance had avoided a vote of censure in the House only because of the popularity of the scheme in Auckland. ${ }^{38}$ Not surprisingly Auckland members welcomed any expenditure that might lessen unemployment in their city. Aside from the high road works' expenditure there were two other types of criticism. The general one was that the scheme was basically unsound, evidence of which was the increasing sum of arrears owed by many of the settlers. ${ }^{39}$ A specific one was made by Grey. He complained that the regulations insisting on residence and limiting the holding to fifty acres meant that the scheme amounted to 'quasi-slavery'. The land could not be sublet, added to, and it could only be sold to a purchaser who agreed to the same terms as imposed upon the original 1essee. ${ }^{40}$ The point of course was that Ballance did not intend settlers to increase their holdings and become full-time farmers. The land was not meant to be the sole source of income. In this respect the scheme contained an internal contradiction. To be a successful solution to unemployment it required an adequate supply of part-time work for the settlers. In other words it was particularly vulnerable in the very depressed conditions that it hoped to tackle. Ballance realised this, and thus the need for the $\$ 15,400$ spent on road making in north Auckland. 41

38. J. Lundon to Ballance, 24 July 1892, BMSS, 626.

39. See the Yeoman's defence of the scheme, 17 June 1887, 26 Aug. 1887. 40. $\mathrm{PD}, 1886,56, \mathrm{pp} .607-08$.

41. $\overline{\text { AJHR }}, 1891, \mathrm{C}-5, \mathrm{p} .12$. Equally, the scheme would have less appea1, though greater prospect of success, in times of fuller employment. 
The Atkinson Ministry, which came to power in 1887 , halted all advances to settlers and the rate of new homestead settlement was brought to a virtual standstill. The scheme was revived, in an altered form, by John McKenzie, Minister for Lands in Ballance's own Government of the early 1890s:

\section{Village Homestead Special Settlement}

\begin{tabular}{lrr} 
& New Settlers & Acres \\
\cline { 2 - 2 } 1887 & & \\
1888 & 896 & 28,700 \\
1889 & 309 & 9,451 \\
1890 & 24 & 345 \\
1891 & 20 & 270 \\
1892 & 10 & 349 \\
1893 & 140 & 2,213 \\
& 33 & 491
\end{tabular}

The 1891 report on village homestead settlements detailed the problems that had been encountered, but said that the fault lay in the lack of consideration given to the location of settlements, rather than with the scheme itself. Good land, sufficient employment opportunities, a near market for the sale of produce, good road access to the settlement and the selection of suitable settlers were all critical to success. 43 Bällance meanwhile continued to defend his scheme, especially as a solution to unemployment. ${ }^{44}$ Aside from criticism of the practical working of the settlements, he faced political bias as we11. Foremost was the prejudice in favour of the freehold. Insistence on leasing made the scheme another step, in the eyes of many supporters and opponents alike, towards complete land nationalisation. The scheme had dissipated, Ballance believed, 'that old bogey, the assumption that

42. Figures taken from AJHR, C-1 of the respective years. 43. AJHR, 1891 (Sess. I $\overline{\mathrm{I}}$ ), C-5, p. 5. 44. $\overline{\mathrm{PD}}, 1887,57, \mathrm{pp} .605-06$; $\mathrm{PD}, 70, \mathrm{pp} .38-9$. 
people would not improve land unless they held it in the form of absolute freehold'. 'Wherever proper conditions have been observed', he said, 'the scheme has been a success'. 45

As for the settlers themselves, they were generally satisfied with the progress being made and were optimistic of the future. New born babies were named after Ballance, 46 as was a settlement itself, just north of Pahiatua on the edge of the Tararua Ranges. A meeting of the Hukerenui settlement in the Bay of Islands passed the following resolution in 1888, in expresising gratitude to Ballance:

Within the short space of eighteen months
a complete transformation has taken place in
this district. What was then a comparative
wilderness, with only an isolated whare to be
seen at intervals along the main road, has now
given place to comfortable dwelling houses and
well grassed paddocks, in most cases securely
fenced, and the condition of the cattle etc.,
grazing therein is ample proof of the good
quality of the land. The settlers are with few
exceptions we1l pleased with their holdings...
. We recognise that the village scheme is the only
one which has successfully grappled with the
difficulty of placing the people on the land-
thereby dealing a death-blow at the iniquitious
system of "land sharking" so long a veritable
curse to the colony. Notwithstanding the fact
that the scheme is looked upon with small favour
by the present Government and that we are
absolutely without roads- we have every
confidence in its ultimate success, and appeal to
all who claim to be the working man's friend, to
lift up their voices in favour of its extension. 47

Two other accounts, both concerning Northland settlements, were in similar vein. The first comes in a letter written to Ballance (when

45. Y, 7 Jan. 1887 (Ba1lance speech at Oamaru); AJHR, 1891, C-5, p. 10. 46. $\overline{E P}, 18$ July 1888 .

47. $\underline{Y}, 15$ Sept. 1888. See also $\underline{Y}, 7$ Mar. 1891, 6 June 1891, and Lundon's answer to criticisms of the north Auckland settlements, Y, 21 Mar. 1891. 
Minister for Lands) by the Pakahue village settlers, and the second in a personal view from a Herekino settler:

The undersigned village settlers tender you our sincere thanks for the assistance you have rendered in placing us on the land. We hope your efforts will, as they deserve, be crowned with success. Some malicious person, or persons, are circulating the report that the settlers are leaving Pakahue. This, we beg to state, is false. We are all pleased with the place, and feel sanguine of our future prospects. We believe the time is not far distant, when, with ordinary industry, we shall have gathered round us comfortable homes in this most beautiful valley, teeming with the good things of the earth... .

I like the place well, A few parties have gone back to Auckland. The land is good in general. I have a few acres cleared, and a hut up. have made it pretty snug. There is any quantity of mullet and other fish in the river. The man that would stop in Auckland looking for work, deserves to starve. I had not a shilling when I reached here, and I am quite satisfied I can make a home here comfortably, and before long the land will grow good crops... . 48

In terms of numbers the village homestead scheme made only a minor contribution to settlement in New Zealand. They did not survive in their intended form, that is, involving part farm work along with part wage employment. A few, such as Pahiatua and Te Aroha, merged with other settlements which grew into country towns. Others, for example Ballance itself and Herekino, remained tiny villages. Many more disappeared as settlers sold out and the land consolidated into larger holdings. Their political significance, however, in pointing to the practical means by which the land hungry in the towns might be satisfied, and the unemployed relieved, was well out of proportion to their actual

48. Quoted by John Bradshaw, New Zealand of To-Day (1884-1887), London, 1888, pp. 194-95. See on village settlement in Wellington province, S.H. Franklin, 'The Village and the Bush', Pacific Viewpoint, 1, 2 (1960), pp. 143-182; A.C. Bagna11, Wairarapa. An historical excursion, Masterton, 1976, ch. XIII. 
success. They greatly enhanced Ballance's mana, for they held out the prospect of what might be achieved. Finally, though the notion of 'dual' employment proved to be impractical, it was central to the rural myth of urban New Zealand: to the rejection of city and idealisation of country life which to this day finds form in the suburban section. 49

A third type of settlement developed by Ballance was the Special Settlement system. There had been such schemes before, whereby the government granted concessions to organisations wishing to establish whole new settlements. The KatiKati settlement has already been mentioned. The other major special settlement was at $\mathrm{Te}$ Aroha. Provision for special settlements had been made in the 1879 Land Amendment Act, but as Ballance had complained it had been largely ignored. 50

The Land Act of 1885 limited the land that could be set aside for special - settlements to one hundred thousand acres per year. Land could be sold or (and this was a significant change to the 1879 legislation) leased. 51 Associations would deal directly with the government, for it was Ballance's aim to 'cut out the middle-man'. The price would be fixed by valuation; there would be no auction or tender. The land thus gained would be distributed amongst the members of the association wishing to settle by ballot. 52

49. On this theme see Miles Fairburn, 'The Rural Myth and the New Urban Frontier. An approach to New Zealand social history, 1870-1940', NZJH, 9, 1 (1975).

50. See ch. 5, pp. 202-05.

51. Land Act, 1885 , sections 162-165.

52. $\underline{\text { PD }, ~} 1885,52$, p. 46 . See also $\underline{Y}, 12$ Dec. 1884 . 
The detailed regulations for the formation of special settlements were set out in orders in council of November 1884 and March 1885. By the latter date thirty associations of about two thousand members had applied for 203,900 acres of 1 and. The applications of twelve had been accepted. Associations were to consist of at least twenty-five persons. Full time residence was required, though a selector was allowed to appoint a substitute, the object being that

...while the principle is maintained of
residence being made compulsory on every
section, it meets a difficulty which has
long been felt in the case of persons in
trade or resident in towns desirous of
having improved land to retire to after a
time, but who cannot avail themselves of the
deferred payment system because of the
residence conditions, and yet are willing
to expend their saving in effecting the
improvements required through the agency of
another. 53

The use of substitutes involved the same 'compromise' between urban and rural living that was a central feature of both sma11 farms areas and village settlements. In this case a working class man could remain in town, placing a substitute on land (that need not be especially near by), and use his savings to develop what was essentially an investment for his retirement. Ballance denied that the substitute was simply a middle-man, and he opposed a motion in the House that sought to reduce the residence requirement from full time to three months per year. This would encourage speculation, he said, and the land would not be worked to its full potential. It would not be in the interests of the working classes. ${ }^{54}$ Ballance reduced, again through an order in council, the maximum area allowed under the special settlement regulations from

53. AJHR, $1885, \mathrm{C}-1$.

54. $\overline{\mathrm{PD}}, 1886,54, \mathrm{pp} .356,362$. 


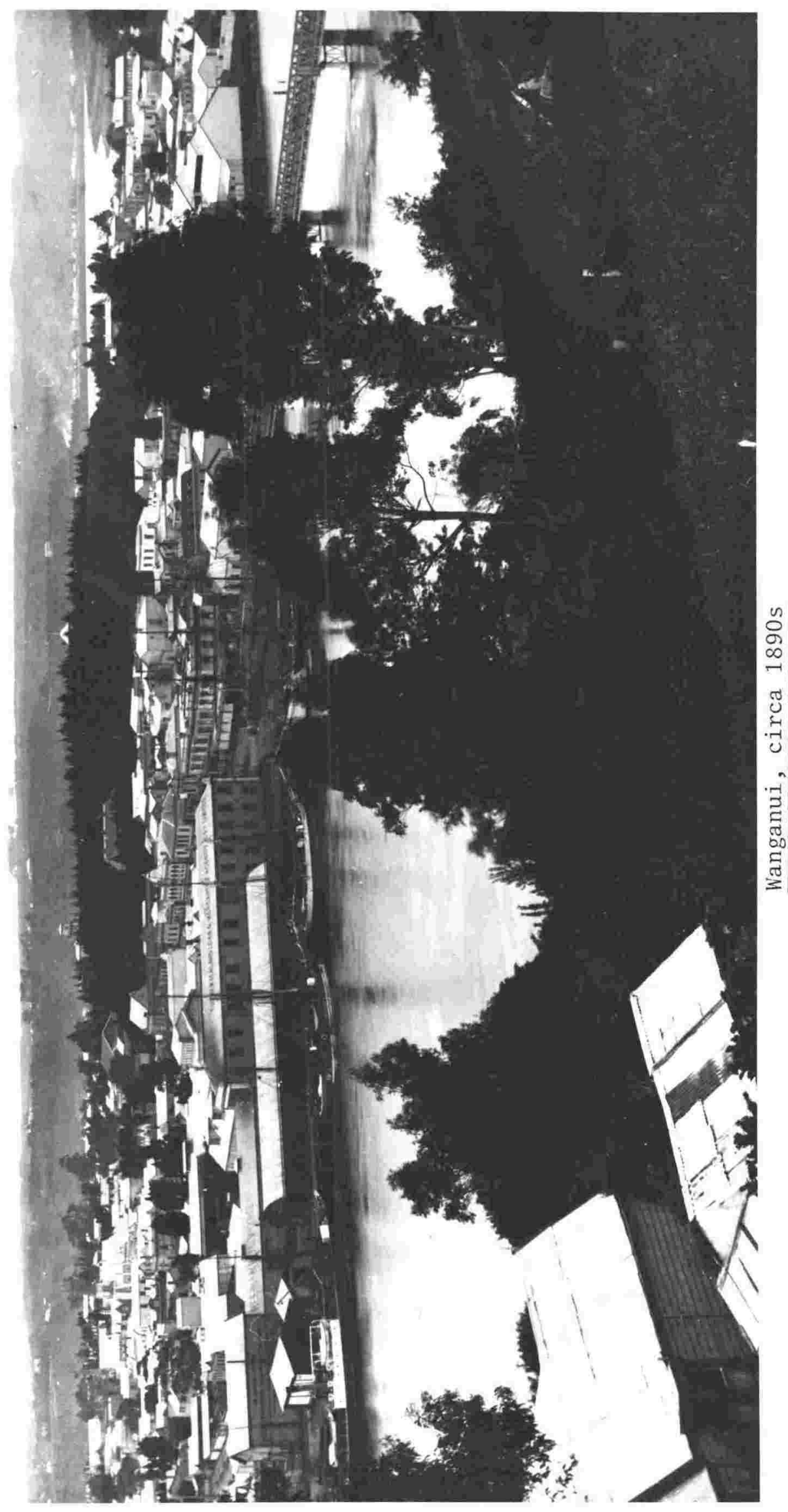


three hundred and twenty to one hundred and fifty acres in the case of land held on deferred payment, and from six hundred and forty to two hundred acres of leased 1and. 55

Ballance put considerable pressure on associations and individuals to opt for the perpetual lease rather than buying the land on deferred payment. The Masterton-Mangatainoka Special Settlement Association, for example, was advised that its application for land would be more likely to succeed if it chose the perpetual lease, rather than the deferred payment terms it had sought. The secretary of the Association complied with the suggestion, but when members found out they refused to take up the land. ${ }^{56}$ Yeoman articles also promoted leasing. The mortgaged freeholder, it said, was sooner or later enmeshed in the capitalist creditor's net. Perpetual leasing avoided years of slavery and high interest payments on land that would anyhow eventually be given up to the mortgagor. 57

Pressure from Ballance and argument both failed. The hunger for the freehold, inherent in man's nature (as Vogel put it in 1884), could not be denied. ${ }^{58}$ By 1892 there was only one association on leased land (thirteen settlers on 1,922 acres in the South Island). ${ }^{59}$. Nineteen associations, the vast majority in the Wellington district, held 96,096 acres on deferred payment. 60

55. Jourdain, p. 29.

56. James Bel1, A Farmers View on Land Nationalisation and the Working of the New Zealand Land Act, Palmerston North, 1886, pp. 2-3; EP, 10 Oct. 1885 .

57. $\bar{Y}, 16$ Sept. 1887. For a typical opposing view, see O.D.T., 22 Dec. 1885 .

58. Quoted by Be11, p. 19.

59. AJHR, $1892, \mathrm{C}-1$.

60. Jourdain, p. 29. The locations of associations formed by 1887 were as follows: 56 in Auckland land district, 58 in Hawke's Bay and 341 in Wellington, AJHR, 1887, C-1. 
The special settlements were for many ideal low premium, long term investments. The desire for the security of the freehold was naturally strong amongst the upper-working and lower-middle class regular wage earners that the scheme primarily attracted. These groups, unlike the labourers settled under the homestead scheme, could afford the higher deferred payment instalments. The Evening Post, reporting the formation of a Wellington association, pointed out that the regulations were particularly attractive to tradesmen and clerks who wished to get their sons onto the 1and, but who could not afford to buy the land outright. ${ }^{61}$ The limitation on the area permitted, and the full time residence requirement, made charges that the scheme encouraged speculation difficult to sustain. ${ }^{62}$ Above a11 the scheme provided a means of self-improvement for urban workers through regular sma11 saving.

For Ballance the objectives of the small area, homestead and special settlement schemes were the same. In the short term they would give immediate relief to the unemployed. In the long term land made available under '1iberal' conditions would provide opportunities for the self-advancement of the 'masses'. Liberalism in land settlement, he said, meant gradual land nationalisation, 'removing the land from the control of individuals and placing it under the control of the State in the interest (of) the people at large-giving all a chance of becoming land occupiers under terms conducive to the we11-being of a11'.63 Nationalisation was seen by Ballance as both utilitarian and democratic. His settlement schemes were the practical form of the radical liberalism that he hoped would head and at the same time satisfy 
the democratic movement in New Zealand. Land would be made available for all, and those that took it up were expected to remain content with the leasehold, and to continue to be politically aligned with the urban majority. A national leasing system itself, mixed urban-rural employment and the limitation placed on the size of holdings were all methods by which the advancement of the greatest number might be achieved, and at the same time the 'loyalty' of lessees be assured. The freehold would be seen as undemocratic and inequitable, whilst the small farmers would share with town dwellers an interest in the provision of generous leasing conditions. Nationalisation would guarantee for the urban population a fair distribution of the country's prosperity. Yet the town was not to dominate the country; rather, there would be an identity of interests. These were the terms of settlement 'conducive to the well-being of all'. And this bonding of town and country, involving high density settlement on nationalised land, was Ballance's ideal. It was ultimately unfulfilled.

A fourth form of tenure introduced by Ballance was the sma11

grazing run. Under this system land was leased by auction for twenty-one years (with the right of renewal), up to a maximum of five thousand acres. Residence was required for the first six years and certain improvements had to be made by the end of that period. ${ }^{64}$ This tenure was particularly successful in good but steep hill country, suitable only for grazing, that had to be cleared of bush before grass sowing. The rent was low and so capital could be expended mainly on improvements. ${ }^{65}$ The acreage brought under this tenure for the six years to 1892 (with the number of selectors in brackets) was as follows: ${ }^{66}$

64. Land Act, 1885, sections 197-219.

65. Jourdain, p. 28 .

66. Figures taken from AJHR, C-1 of the respective years. 


$\begin{array}{lrl}1887 & 105,857 & (68) \\ 1888 & 156,482 & (83) \\ 1889 & 161,652 & (81) \\ 1890 & 60,340 & (35) \\ 1891 & 86,161 & (43) \\ 1892 & 159,464 & (80)\end{array}$

The promotion of settlement through all these forms of tenure involved Ballance in an immense amount of work. The success of individual schemes depended initially upon his ability to find and set aside by proclamation suitable blocks of land. Much of course was done by the Lands Department staff, yet Ballance's enthusiasm and initiative were critical. The Evening Post reported in October 1886, that Ballance's efforts in establishing new settlement were 'almost universally eulogised', even by the opposition press. ${ }^{67}$ Yet Ballance was well aware that the shortage of land was severely curtailing the rate of settlement. The solution to this problem he had suggested many times, and he now came up with a specific proposal. In a speech delivered at Blenheim in December 1886, he announced that he was going to introduce a bill in the following session to allow the government to expropriate any private estates it might require. The owner of the land would receive a sum equal to the value of his holding (as determined for the purposes of the property tax) plus ten per cent. 68 Further details of this radical proposal emerged soon afterwards. Under the Land Acquisition Bill associations of at least twenty persons could contact a land owner and attempt to purchase, after due investigation by two commissioners and with the approval of the government, a block of land for small farm settlement. If the owner refused to sell the government could acquire the land compulsorily, provided that the owner's total holdings in the colony exceeded one

67. 4 Oct. 1886 .

68. Y, 3 Dec. 1886 . 
thousand acres. The land acquired was to be leased to the association's members, each individual receiving no more than one hundred acres. There was no right to purchase the freehold, and only one block of land could be held. ${ }^{69}$ Ballance argued that the State had a moral right to acquire land for settlement in this manner, so long as fair compensation was given. The time had come, he said, when the present monopoly of 1and, 'which was impeding settlement and robbing the country at large, should no longer stand in the way of the interests of the colony'.70

The Stout-Voge1 Government fell shortly after the 1887 session commenced, and so Ballance's Bill never reached a second reading. Two years 1ater, when Leader of the Opposition, Ballance revived the Bil1, and it was printed in full in the Herald. ${ }^{71}$ The proposals contained within it were central to his election campaign of 1890 , and it was the forerunner of the subsequent Liberal Government's purchasing legislation. ${ }^{72}$

Whilst Ballance was eulogised by some for his persistent advocacy of leasing and nationalisation as essential to closer settlement, for others he became the 'devil incarnate'. Annie Wilson, wife of James Wilson, the Member for Foxton, described Ballance in 1887 as follows:

(He) has a big head and a persuasive Irish tongue and Irish tact. He is one with Stout in his atheistic views and follows his lead exactly in stuffing the people with tales against property-holders, only going further,

69. Y, 8 Apr. 1887 .

70. İbid.

71. $\overline{Y,} 21$ Dec. 1889 , and comment $\underline{Y}, 28$ Dec. 1889.

72. See chs. 9 \& 12 . 
advocating the nationalisation of the land and 'bursting up' big estates and so on. He has a wretched little newspaper in Wanganui which pours out his views. As I said before, nothing pays in politics like flattering the mob. 73

Many welcomed Ballance's ends, but were, like Annie Wilson, horrified by his favoured means. Thus a contemporary commentator, John Bradshaw, applauded Ballance's promotion of closer settlement, but deprecated leasing and nationalisation. Men would not work for a state landlord, he said, and much preferred the deferred payment system. As for Ballance's Land Acquisition Bil1, 'a more socialistic measure ... (had)... never been laid by a pretendedly civilised Administration before a civilised peop1e'.74

In $186^{\circ}$ a Manawatu farmer, James Bell, wrote a twenty-four page pamphlet full of vehement criticism of Ballance, land nationalisation and the operation of the Land Act. The premise that underlay Bell's argument came in a revealing final paragraph:

It would be well if Messrs. Stout and Ballance and other agitators who win the noisy plaudits of a small unthinking section of town residents, would consider well whether really the supposed wants of this class are so all important. After all, the country was not made for the towns, but the towns for the country. 75

Bell had arrived at the crux of the matter, in the sense that one of Ballance's major aims was, as we have seen, to secure an equitable inter-dependent relationship between town and country. Achieving this

73. L.J. Wild, The Life and Times of Sir James Wilson of Bulls, Christchurch, 1953, p. 256.

74. Bradshaw, pp. 204, 254, 278,

75. Be11, p. 24 . 
through state ownership and control of land would mean that the question of 'town versus country' would no longer arise; neither sector would predominate for the interests of both would coincide.

Land ownership was also central to the activities of the Native Department, to which we shall now turn. Ballance's views on race relations had altered considerably since the days of Titokowaru's 'siege' of Wanganui. 76 This change came with the conclusion of major hostilities between the two races, and as part of the general radicalisation of Ballance's philosophy in the early 1880s. A Herald editorial written by Ballance in January 1873, for example, pointed out that disease, death and crime amongst Maoris had all increased as contact with Europeans increased. The Maori race was being decimated. ${ }^{77}$ Two years later he concluded that McLean (the Native Minister) had failed to pursue his declared policy of assimilation, that is, the 'merging' of Maoris into the European way of life. Rather the two races had grown further apart, for where Europeans had settled, Maoris had 'vanished'.78 Finally, in a remarkable statement (particularly given the widespread European hostility to the activities of Te Whiti at the time) in 1881, Ballance said the following:

...with regard to the Native difficulties in the past... there has scarcely been a single war in this colony- in which the Europeans have not been more to blame than the Natives. 79

76. See ch. 2, especially pp. 76-77.

77. EH, 13 Jan. 1873.

78. $\overline{\mathrm{EH}}, 24$ Dec. 1874.

79. $\overline{\mathrm{PD}}, 1881,39$, p. 550. 
Ballance's policy as Native Minister fell between his hope that ultimately the two races would become assimilated, and the realisation that in the foreseeable future Maori interests would have to be protected if assimilation was not simply to mean (as it had in the past), annihilation by Europeans. ${ }^{80}$ He wished that Maori and European could be treated alike, arguing, for example, that Maoris should eventually give up their special representation in the House. There would be more Maori members returned, he believed, if they did. Yet it would take time for the Maori population to be 'educated up' to the position where they could take advantage of representation on the same basis as Europrans. ${ }^{81}$ Until then Ballance acknowledged that Maoris were under-represented. 82

This recognition of the need for protection, alongside a desire for assimilation in the long term, was the basis for Ballance's approach to the key issue of the sale of Maori land. The crown's pre-emptive right to purchase Maori land, contained in the Constitution Act, had been repealed by the Native Land Act of 1865 . Since then land could be purchased by private individuals once its title had been ascertained by the Native Land Court. Maori land was held communally, so that the determination of title was far from simple. To get around this problem the Native Land Act restricted to ten the number of owners that could be listed in the sale of a block of land under five thousand acres. In fact it became common practice for this limit to apply to land over five thousand acres as well, and many Maoris lost their share in land to co-owners who were more willing to

80. For a useful definition of terms, see Joan Metge, The Maoris of New Zealand, London, 1976, pp. 302-10.

81. $\overline{\mathrm{PD}}, 1881,39$, p. 549 .

82. $\overline{\mathrm{PD}}, 1884,48$, pp. 298-300. 
sell and more suspect to the ploys of Pakeha purchasers. 'Land sharks' proliferated. As the Yeoman put it,

\begin{abstract}
Every disreputable trick and debasing agency have been freely used by these land devouring gentry, and hundreds of thousands of acres of native lands have been alienated from their aboriginal owners without the latter reaping any real benefit from the sale... 83
\end{abstract}

Ballance appreciated that Maori land was. held communally, and proposed legislation that allowed Maoris to retain control over their land in that form. European settlement, however, clearly required the individualisation of title as a prerequisite of sale. Yet individualisation had led to injustices, fraud and monopoly. In his Echo article on 'Native Land Policy', Ballance argued that individualisation was wise only when the government was the sole purchaser. He cited the Taranaki war; the origins of which lay in the purchase of land from a Maori chief whose ownership of that land was far from certain, as an example of the 'practice which places the tribe at the mercy of its worst and most irresponsible members'. ${ }^{84}$ This 'dishonest system of bribing individual Natives to se11, and then using these as decoy ducks for their more intractable compatriots' had, as we have seen, persisted. ${ }^{85}$ Thus Ballance wanted Maori land to be either leased by Maoris themselves, or bought and leased by the crown. His concern for the interests of Maori landowners, which involved at the same time an attack on European monopolists, was therefore consistent with a policy of closer settlement. It was also paternalistic:

83. 5 Dec. 1884 .

84. Ballance, p. 16. On Ballance's opposition to indiscriminate individualisation see also PD, 1884,49 , pp. 158-59. On the Taranaki war see Keith Sinclair, The Origins of the Maori Wars, Auckland, 1961.

85. Ballance, p. 16 . 
'...it is beyond doubt', he wrote, 'that the Native is in many respects an infant needing a guardian'.86

One of Ballance's first actions as Native Minister was to prohibit the private purchase of land alongside the route of the North Island trunk railway. He was confident, having spoken to a leading King Country chief, Wahanui, that the land required for the railway would be made available by its Maori owners. The Government would, on behalf of these Maoris, administer the land, which amounted to approximately four and a half million acres. A board was to be appointed for this purpose, though Ballance hoped that eventually it would be elected by Maoris themselves. ${ }^{87}$ In his speech on the Bill that gave effect to these proposals, Ballance outlined the general principles he would follow in formulating future policy. He recognised that Maoris still had to be convinced that they could trust the government. To gain their confidence he believed that control over Maori land should be invested in the whole tribe. He criticised the Native Land Court for failing to recognise this fact of Maori custom, attacked those who supported free trade in Maori land, and said that he had already discovered that many reserves were being wrongfully alienated from their owners. It was clear that Ballance wished to move towards complete prohibition of private dealings in Maori land, for Maoris were to be able, by application, to bring any land they desired under the restrictions of the Act. Specifically, he suggested that the powers of the existing Native Committees might be greatly extended, enabling them to deal with the sale of all land on a tribal basis. Ballance concluded that his

86. Ibid., p. 15

87. This was the main provision of the Native Land Settlement Act. See PD, 1884,50 , pp. 312-26; NZH, 29 Oct. 1884, 3 Nov. 1884. 
policy would differ from that of the past, for it would be a policy of the settlement of Maori land, 'contributing largely to their own welfare and to the stability. and prosperity of the colony ${ }^{88}$

This linking of a conciliatory 'native' policy and the promotion of European settlement was an important theme, and one that Ballance developed in a speech delivered in Wanganui in late 1884. He argued that the problems of race relations centered almost entirely on land, and that the solution therefore lay in giving Maoris 'a large amount of control over their own lands'. He proposed to stop all private land transactions between Europeans and Maoris. It was not a return to crown pre-emption, said Ballance, for that tended to limit the price Maoris received for their land. Rather it was a prohibition of direct private purchasing. All land transactions would have to pass through a body, containing Maori representatives, before being offered for -public sale. 'Under this system

( $t$ ) he natives would see that their interests were identical with the interests of colonisation... . If they could see that the Government were not encouraging the land sharks, and were not themselves to be a land-shark Government but rather prepared to see the natives utilise their own lands, they would become hearty co-operators in the work of colonisation. 89

Early success in gaining the cooperation of Maori leaders in the construction of the trunk railway greatly strengthened Ballance's position. Wahanui and Kemp (the Wanganui chief) had been brought round early on, and in December the assistance of the old Kingite leader,

88. PD, 1884,50, p. 317 .

89. $\bar{Y}, 5 \mathrm{Dec}$. 1884. Bailance's 'banquet speech'. See also the Yeoman's comment on 'Native Land Reform' in the same issue. 
Rewi Maniapoto, was gained. Ballance had written to Rewi seeking his help with the surveying and construction of the railway. Rewi, in consenting, asked to be kept informed of Ballance's intentions, and extended to him an invitation to visit. Thus Ballance had in a few months, remarked the Evening Post, 'succeeded in doing what his predecessors tried for years in vain to do'. 90 This consultation with chiefs, along with the use of Maori labour in construction, smoothed the way of the railway project. ${ }^{91}$

As he prepared new legislation and awaited the start of the 1885 session, Ballance was able in the meantime to do something to halt the alienation of Maori land by private purchasers. When Maori owners were granted title to a block of land, conditions were frequently attached that prevented sale without the consent of the government. In the past this consent, with the appropriate political connections, had normally been a formality. However on assuming office Ballance immediately refused to remove any restrictions:

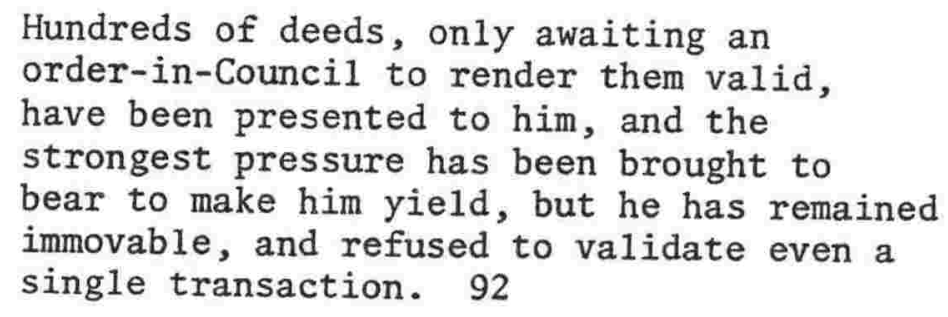

The Post was jubilant that 'the whole tribe of land sharks and speculators', which had monopolisec land purchasing, was 'exceedingly angry' and in despair. ${ }^{93}$ The New Zealand Herald however, voicing the opinions of Auckland speculators, was furious. 'Things cannot

90. 16 Dec. 1884 . See also EP, 19 Nov. 1884,28 Nov. 1884.

91. Y, 13 Mar. 1885 .

92. $\overline{E P}, 24$ Dec. 1884. See also PD, 1885, 52, p. 398.

93. Ibid. 
remain as they are', it said. Ballance had shut up the country by law and was generally making a 'pretty kettle of fish' of the Native Department. His policy amounted to government and 'native' landlordism, and as for his proposal to place control over Maori land in local committees, the Herald was sure Maoris could not possibly work a representative system. ${ }^{94}$

A variety of government-sponsored Maori bodies had existed since the founding of the colony. In the early 1880s Maoris themselves pressed for the granting to local committees power to administer tribal land, and a bill to this effect reached a second reading in 1882 . Ballance welcomed the idea, and indeed went further by arguing that the committees should only lease, not sel1, the 1and. ${ }^{95}$ A year later an Act was passed giving regional committees authority to discuss and advise on land claims. 96 Pressure for more significant powers continued. Particularly active in applying it were W.L. Rees, the Auckland 'Greyite' lawyer and M.H.R., and Wi Pere, who was elected Member for Eastern Maori in 1884. Rees's 'Memorandum on the Native Land Laws', recommending the election of committees that would have the legal right to deal with land tribally, presented a number of the arguments and suggestions upon which Ballance's legislation was based. ${ }^{97}$

Ballance worked on his proposals, which took shape in the Native Land Disposition Bill, throughout the 1884-1885 recess. Under the Bill Maori land owners could elect a Local Committee to decide on the sale or leasing of their land. The committee's recommendations would

94. 9 May 1985.

95. Ballance, p. 16 .

96. See Alan Ward, A Show of Justice. Racial 'amalgamation' in nineteenth century New Zealand, Auckland, 1974, p. 290.

97. AJHR, 1884 (Sess. II), G-2. 
be given effect by a Board of Management, consisting of a Commissioner and two government appointees. Committees could be dissolved by the Government on the application of at least two-thirds of the owners of the land. The Land Court would still investigate undetermined titles. Finally, in clause sixty-two, the Government was empowered to bring any land covered by the Act under the ordinary land laws of the colony. The Minister of Lands, in other words, could set the conditions of settlement. 98

In early 1885 Ballance made an extensive tour of the North Island in order to gauge Maori opinion both on his specific proposals and on general matters as we11. He was the first Native Minister since McLean to do so. He had discussions with Kemp and the Maoris of the upper Wanganui River; Te Kooti, the old warrior now pardoned; Tawhiao, the Waikato chief who had just returned from a visit to England to demand a separate Maori parliament; and with the Maoris of Thames, Rotorua and the East Coast (including Wi Pere). In May he visited Parihaka. At these gatherings Ballance heard criticism of the Native Land Court, for example of the high court fees and the tendency for land to be awarded simply to those who were able financially to conduct a case. The plans for the trunk railway, on the other hand, were generally favourably received.

At each meeting Ballance outlined the main provisions of the Land Disposition Bil1, though there was little discussion on it. The Bill itself had not yet been printed and distributed, and the Maoris would need time for debate and consideration amongst themselves 
before coming to any conclusion on $i t .^{99}$ Ballance was well received; his eagerness to meet Maoris on their own territory acknowledged. ${ }^{100}$ He made an effort to acquire some fluency in the Maori language, though it was never sufficient to dispose of the need for interpreters. ${ }^{101}$ Maoris were soon calling him 'Ngawari', meaning 'soft' or 'sweet' man, as opposed to Bryce, whom they pejoratively referred to as 'Maro', or 'hard man'. 102 Vogel wrote to Ballance congratulating him on the success of the meetings, but complaining that he (Ballance) was showing too great a 'concilliatory (sic) disposition' towards the Maoris. 103

Ballance too was confident of the outcome of his trip. At the opening of the new session in May the Governor's speech declared the Government's belief that European-Maori relations had 'never been of so friendly a character'. Maoris were cooperating over the railway, and the proposed Bill would do them justice whilst at the same time promoting settlement. 104 Later Ballance told the House of his tour, saying that he had warned Maoris of the consequences of parting with their 1and. 105 When the Native Land Disposition Bill came up for its second reading, he argued that his meetings had indicated that the 'great majority' of Maoris approved his proposals. He quoted letters

99. On criticism of the delay in publishing the full Bill, see NZH, 13 June 1885.

100. $\overline{\text { For }}$ reports of the meetings see AJHR, 1885, C-1. See also, on the Wanganui meeting, $\underline{Y}, 16$ Jan. 1885, EP, 12 Jan. 1885; on Ballance's meeting with Te Kooti, $\underline{Y}, 13$ Feb. $1 \overline{885}$; on the Taranaki meeting EP, $17 \mathrm{Feb}$. 1885; and on Ballance's visit to Parihaka, Y, 22 May 1885, 29 May 1885, EP, 13 May 1885. See also 'Traveliing letter book. Trip to King Country, 3 Feb. 1885 - 26 Feb. 1885', Maori Affairs Department, Series 30/3, National Archives, Wellington.

101. The present writer has in his possession the dictionary used by Ballance during his tenure as Native Minister.

102. PD, 1886,54, p. 448 .

103. Vogel to Ballance, 8 Feb. 1885, BMSS, 36-7.

104. PD, 1886,54, pp. 1-2.

105. $\overline{\mathrm{PD}}, 1886,54, \mathrm{pp} .28-30$. 
he had received from chiefs and officials to prove his point. Through competition, he said, the Bill would give Maoris a better price for their land. Direct private purchase would be prohibited, but having passed through the bodies established by the Bill, land could be sold or leased in the same way as crown 1and. 106

In fact there was growing opposition to the Bill from Maori and Pakeha alike. The New Zealand Herald argued that the Bill was simply a part of Ballance's 'mischievous' plan to nationalise all land. It also noted that the Cabinet was split over the matter. ${ }^{107}$ The Herald was not far off the mark, for Ballance undoubtedly hoped to use the extensive power contained in clause sixty-two (see above), which he described as the 'main feature of the Bill', to impose leasing conditions on as much land as possible. 108

Objection to this clause was prominent amongst the many criticisms made when the Bill went to the Native Affairs Committee. 109 Amendments by Wi Pere and Wahanui placed the power to prescribe the terms of settlement with the boards instead of the government. 110 The general complaint, made for example by James Carroll (a half-caste Maori who was interpreter in the House of Representatives, and later to be a member of Ballance's Cabinet) and F.D. Fenton (an ex-judge of the Native Land Court) was that the Bill gave too wide powers to the Government. The recommendations of the boards, local committees and of the Native Land Court, were al1 subject to government approval.

106. PD, 1885, 52, pp. 390-99.

107. $\overline{12}$ June 1885, 13 June 1885, 22 June 1885. The Herald did not mention names, but Vogel would certainly have been unhappy with the Bill.

108. PD, 1885,52, p. 398.

109. The Bill passed its second reading (35 votes to 15 ) on the basis that full discussion would take place in the Native Affairs Committee. See Ballance's summing-up, PD, 1885, 52, pp. 515-20. 
This was not acceptable to Maoris, they said. ${ }^{111}$ Wahanui denied that he had written the letter conveying his approval of the Bill, cited by Ballance during the Bill's second reading. ${ }^{112}$ There were as well problems over the provisions concerning the granting of titles, arising mainly from legal complications, but also frequently related to existing grievances against the Native Land Court. Ballance was made particularly uncomfortable by some questioning from Grey; and after an exchange with the highly experienced Fenton, asked rhetorically, and with obvious frustration, what would reconcile the interests of settlement with those of Maoris themselves. ${ }^{113}$

Ballance made a number of amendments to the Bill, for example changing the constitution of the boards to a commissioner and two Maoris. 114 Further amendments by Wi Pere (which had the sanction of Carro11, Wahanui and others), removed the right of owners to sell or lease land to the crown without going through a committee, and genera11y placed more power in the hands of the committees and boards. The Native Affairs Committee recommenued that the Bill be dropped for the current session. Too many problems had arisen, and Maori members requested more time to hold meetings to consider both the Bill and the suggested amendments.

These meetings were held during the recess, and having attended a number of them Ballance came up with a new Native Land Administration Bi11. The change in title was significant; 'disposition', Ballance said, implied the giving away of land. The Bill replaced the boards

111. Ibid., pp. 1-2, 30-34.

112. Ibid., p. 7.

113. Ibid., p. 34 .

114. Ibid., p. 63. 
by comnissioners, for Ballance had found that many Maoris believed that their own representatives on the boards would be too open to corruption. The local committees remained much the same as before, though with greater powers. They could, for example, direct the commissioner in the allocation of money received from the sale of land. The clauses permitting land owners to deal directly with the crown, and giving the government the power to fix the conditions of settlement of land brought under the Act, were retained. The private purchase of land from Maoris was, as before, made illegal. ${ }^{115}$ The new Bill, however, excluded that part of the Disposition Bill which had caused much discussion, concerning the legalisation of leasing transactions made prior to 1883. Also, the Public Trustee was no longer permitted to deal with Maori land. ${ }^{116}$

Ballance argued that the Act would protect Maoris from themselves. The 'great danger is, not that the Maoris will conserve their 1 ands and create great estates, but that they will too readily part with them. My own experience is that they will part with their last acre if they get the opportunity'.117 Opposition to the Bill, he said, came primarily from land speculators. 118 Having this time survived the Native Affairs Committee, and with the support of Maori members, the Bill passed its third reading by a majority of twenty votes. ${ }^{119}$

The Act was a substantial advance towards the protection of Maori land, the key to which was the recognition of communal ownership as a

115. PD, 1886, 54, pp. 327-31; Native Land Administration Act, 1886. 116. See Ballance's comments on the changes in a speech delivered at a meeting with Maoris at Aramoho, Y, 2 Apr. 1886. See also his King Country visit and speech, Y, 13 Nov. 1885.

117. PD, 1886,54, p. 330 .

118. $\overline{\mathrm{PD}}, 1886,54, \mathrm{pp} .460-64$.

119. $\overline{\mathrm{PD}}, 1886,55, \mathrm{pp} .311-12$. Minor amendments were made by the Legislative Council, see PD, 1886, 56, pp. 356-57, 360-62. 
legal entity. The next 'natural' step, sought by Wi Pere amongst others, would have been to grant committees the power to determine title; but Ballance was reluctant to interfere with the Land Court, and certainly any attempt to do so would have met with fierce resistance in the House.

For a number of reasons, however, the Act was never brought into operation. Ward suggests, first, that Maoris, overlooking the powers of the committees, feared to place land in the hands of government commissioners. Secondly, the mana of tribal leaders had over a period eroded so far that ordinary land owners were reluctant to give committees any control over communal land. ${ }^{120}$ The reports of the commissioners for 1887 show that no land at all had been invested with the committees. One application made had been withdrawn, apparently, because of suspicion between the owners rather than of the Government. ${ }^{121}$

The Act was repealed by the Atkinson Ministry in 1888; direct purchasing was restored, and a new wave of land buying (including that of major Maori reserves) commenced. ${ }^{122}$ At the 1887 election three of the four Maoris elected had campaigned against the Act. The defeat of Wi Pere in particular was seen as evidence that Maoris themselves opposed Ballance's legislation. 123 However the new members soon discovered that the Atkinson administration was much less sympathetic to their wishes than its predecessor. ${ }^{124}$ Ballance accurately predicted

120. Ward, p. 297.

121. AJHR, 1887 (Sess. II), G-8.

122. Ward, p. 298.

123. Ballance made vain attempts to influence the result of the Eastern Maori election, see Y, 13 May 1887; EP, 24 Aug. 1887, 10 Sept. 1887. 124. See Ward, pp. 298-30 $\overline{3}$. 
that the removal of purchasing restrictions would result in the rapid accumulation by 'companies and capitalists' of vast amounts of Maori land. People such as these, he said, who had a financial stake in land purchasing, had destroyed his Act because

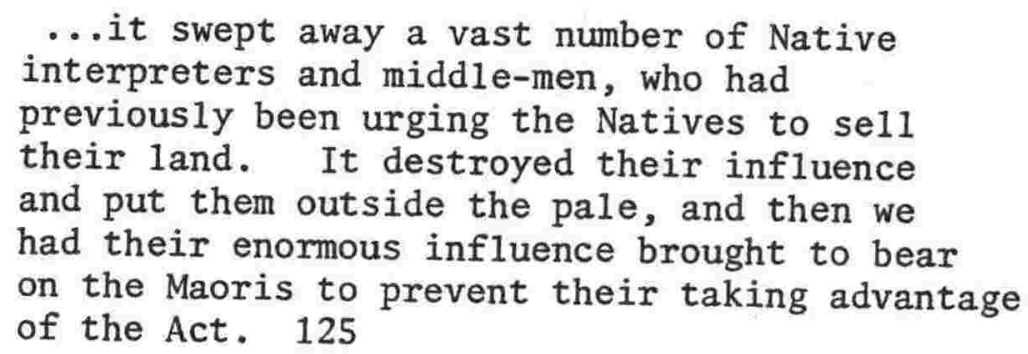

Thus ended, in Ward's words, 'perhaps the fairest attempt to balance the interests of settlement and Maori landholders that the Colony had yet seen... . 126

To a certain extent the remaining significant activities of Ballance as Native Minister also concern his defence portfolio. They involve the continuing saga of Maori protest based at Parihaka, and Ballance's approach to 'law and order' and to Maori grievances in general. Ballance's policy on these issues was quite different to that of Bryce who, it will be remembered, had led an armed assault on Parihaka in November 1881. ${ }^{127}$ Shortly after coming to office Ballance began to reduce the paramilitary Armed Constabulary throughout the North Island. Stations with substantial numbers of constabulary were, he

125. PD, 1888, 61, p. 673.

126. Ward, p. 297.

127. Ch. 5, p. 216. 
said, 'irritating' to Maoris: ${ }^{128}$

I say that the Native race are to be influenced more by a sense of justice and right than by all the Armed Constabulary we can maintain, and that the best policy to employ is a policy such as we propose, and not a policy of repression. 129

This 'one policeman policy', as it became known, was vigorously pursued by Ballance. By 1885 the number of Armed Constabulary units had been reduced from four hundred and twenty-eight to only forty-eight; and under the Defence Act of the same year they were replaced entirely by a new, smaller, Permanent Militia Forcé. ${ }^{130}$

Not long after the release of Te Whiti and Tohu (they had been imprisoned following Bryce's raid), activity began again in Parihaka. Marches were led out from there throughout Taranaki. By May 1885 the Pakeha press were calling for government action to quell the disorder. ${ }^{131}$ Ballance visited Parihaka late in the month, and was afterwards interviewed by the Hawera Star. He said that the reported activities of the Maoris had been 'distorted and exaggerated', and that therefore he was not going to station men at Pungarehu (a European settlement near Parihaka) as some settlers had requested. He was quite aware of Maori discontent but argued that the presence of military posts only irritated them further. 'We must simply watch the natives, be prepared for anything, and in the meantime do all we can

128. PD, 1884,50, p. 373.

129. $\overline{\mathrm{PD}}, 1884,48, \mathrm{p} .523$.

130. See PD, 1885, 55, pp. 343-44; Y, 15 Jan. 1886; EP, 7 May 1886. Ballance also enfranchised the police, see PD, $18 \overline{85}, 51$, p. 475; PD, 1886, 55, p. 344 .

131. See Dick Scott, Ask That Mountain. The story of Parihaka, Auckland, 1975, pp. 148-49. 
to remove grievances'. Prominent amongst complaints was the smal1 sum received by Maori landowners once a host of 'costs' had been deducted from the rent paid by European lessees. ${ }^{132}$

Ballance did in fact attempt to improve the position of Maori landowners. For example he reduced the amount of commission charged by the Public Trustee (which leased the land); and generally gave Maori owners more control over trusts held on their behalf. Further, through an annual Special Powers and Contracts Act a wide range of Maori grievances were dealt with. ${ }^{133}$

Back in Wellington Ballance ordered a report on the disturbances in south Taranaki. When published it showed the threats alleged by Europeans to have been made against them were almost entirely without foundation. ${ }^{134}$ A second report, on speeches delivered in Parihaka by Te Whiti and Tohu, reinforced the view that the Maoris sought only peace. ${ }^{135}$ In the House Ballance said that the whole affair had been

...got up by Europeans for the purpose of bringing back to the place a large expenditure in the shape of Armed Constabulary.

In fact he believed that the Maoris were much less disturbed now he had removed the constabulary from the area. If such a policy had been followed in 1881, he said, the 'battle of Parihaka' need never have occurred. Finally, he described the suggestion to bring into force the Peace Preservation Act (allowing the government to detain without

132. Y, 29 May 1885 .

133. See PD, 1885, 53, pp. 716ff; PD, 1886, 54, pp. 141ff; PD, 1887,
$57, \frac{\mathrm{pp}}{\text {. }}$ 29ff; Ward, pp. 295-96. 134. AJHR, $1885, \mathrm{G}-4$.

135. $\overline{\mathrm{AJHR}}, 1885, \mathrm{G}-8$ and G-8a. 
trial) as a cruel attempt' to keep in subjection harmless people who have not committed any offence against the people of this colony'.136

There was, however, some trouble ahead. It began when a group of Maoris, including Titokowaru, attempted to establish itself on a farm north of Hawera owned by a European named Hastie. Police intervened, scuffles followed, and arrests were made. The 'Battle of Hastie's farm' over, Pardy, the local Inspector of Police, received permission from Ballance to arrest Te Whiti. Te Whiti had been warned that he would be held responsible for any breaches of peace in the area, and the authorities had 'positive information' that it was upon his instructions that Hastie's farm was occupied. He was arrested on $20 \mathrm{July}$ in a lightening dawn raid made by a small group of men led by Pardy. Brought to Wellington Te Whiti was, in contrast to his treatment in 1881, given a trial; after which he was fined $\$ 100$ and jailed for three months. 137

The whole incident had been handled with great success, for Parihaka was quiet and remained so. 'All is silent', said Ballance, because the Maoris 'believe the Government of the colony is prepared to act fairly to them, and to reason out questions with them' ${ }^{138}$ Clearly much of the credit 1ay with Pardy, who continued to deal with the situation with tact and sensitivity. Yet Ballance's 'one policeman policy' was seen to have borne fruit, and his prestige justifiably enhanced. At the same time his mana amongst Maoris themselves was

136. PD, $1885,51, \mathrm{pp} .275-77$.

137. $\overline{\mathrm{PD}}, 1886,57, \mathrm{p} .19$; telegrams to Ballance re, arrest of $\mathrm{Te}$ Whiti etc., BMSS, 718-64; Ballance memo to the Governor, 3 Aug. 1886 in AJHR, 1887 (Sess. I) , A-1, pp. 18-20.

138. $\overline{\mathrm{PD}}, 1885,53, \mathrm{p} .355$. 
largely unimpaired; the arrest had been carried out in a matter of minutes, and there had been no violence. Ballance was able, for example, to persuade Te Kooti to halt a march to Poverty Bay. ${ }^{139}$ Also at Ballance's suggestion, Te Heu Heu, chief of Ngatituwharetoa, gave as a gift land in the central plateau of the North Island for the establishment of Tongariro National Park. ${ }^{140}$

The protection that Ballance sought to extend to Maoris was considerable, and his treatment of race relations in general was much more sympathetic than that of his predecessors. However he rejected claims by Maoris to any form of political independence. ${ }^{141}$ As was common amongst many late nineteenth century radicals, he regarded the European race as essentially superior to that of the Maori and, especially as a rationalist and freethinker, he would have largely accepted the tenets of Darwinism. His policy was 'qualified assimilationist', and certainly paternalistic, rather than bi-cultural. Maoris would ultimately come under European law and institutions:

We should desire to bring them (Maoris)
into the same position as the Europeans,
with the same rights and liberties, to
plant in the minds of the Natives the same
feeling of satisfaction with the laws of
the colony as prevails in the minds of The
Europeans. ... This policy is in accordance
with the Treaty of Waitangi; it is in
accordance with the principles of justice. 142

That Maoris might not survive as 'Europeans' was of course the basic flaw to such an approach, and one that Ballance could never really come

139. A visit by Te Kooti to Poverty Bay would, because of his raid on the town in 1868, have been very sensitive. See $\underline{Y}, 25$ Dec. 1885, 1 Jan. 1886.

140. PD, 1887, 57, pp. 399-401; EP, 15 Apr. 1887.

141. See for example Ballance to Tawhiao, 8 June 1886, concerning the Maori Councils, AJHR, 1886, G-14, p. 5.

142. PD, 1885,53, p. 356 . 
to terms with. Notions of racial superiority were too strong and assimilation, in that it was regarded as inevitable, seemed 'just'. Yet Ballance's promotion of special protection for Maoris, the central feature of which was the legal recognition of communal land ownership, was a major (albeit temporary) step forward. It admitted the belief that the retention of Maori custom was necessary if assimilation was not to mean destruction for Maoris. This was closer to the policy of 'amalgamation', the incorporation of Maoris on an equal basis with Pakehas into a European system, espoused by the British authorities in $1840 .{ }^{143}$ Yet experience had shown that however well meaning, such a policy, under settler pressure, quickly turned into assimilation.

Ballance's recognition of the need to retain Maori land custom was inconsistent with a long term belief in assimilation. It points rather in the direction of bi-culturalism; and a denial of the primacy of European culture that Ballance could never have made. Both amalgamation and assimilation, on the other hand, aimed at and inevitably led to, the imposition of European culture on Maoris, with al1 its consequences.

The final part of this chapter looks very briefly at Ballance's defence policy, aside from that related to his handling of Maori protest. Ballance aimed to reduce the numbers and therefore the cost of the 
permanent armed forces in the colony. The Defence Act of 1886, largely a consolidating measure, set out the three major branches of the country's defence forces. These were, aside from the civilian police: the Volunteers, the Permanent Militia, and the Militia. The volunteer force, such as Ballance had joined in Wanganui in 1868 , had declined in popularity since then, owing largely to the fact that they were little needed and to the poor conditions of service. Ballance saw that it was considerably cheaper to maintain a volunteer force than an unnecessarily large standing Armed Constabulary, which in any case had been formed to meet the temporary emergency of the war against the Maoris. He therefore encouraged the volunteers, raising their capitation allowance and appointing his old friend (now Sir) George Whitmore as their overall commander. ${ }^{144}$ The permanent militia, essentially the regular army, replaced, as we have seen, the larger constabulary. The militia remained as before, covering the adult male population, and to be called out only in cases of extreme emergency. 145

Though Ballance reduced total expenditure on the armed forces, he increased that on harbour defences in reaction to the Russian 'threat' of 1885. The threat, which was taken very seriously at the time (though it never materialised), arose from a conflict of British and Russian interests in Afghanistan. Guns were ordered from England and work begun on fortifying the harbours of the four major centres. Meanwhile Whitmore organised mock battles involving the repulsion of

144. Y, 26 Sept. 1884; PD, 1885, 52, pp. 122-23, 130-31. 145. Defence Act, 1886; EP, 7 May 1886. For further discussion on the development of New Zealand's defence forces see M.H.S. Stevens, 'New Zealand Defence Forces and Defence Administration, 1870-1900', M.A. thesis, Victoria University of Wellington, 1977. 
Russian attacks by the volunteers. ${ }^{146}$

The crisis brought to the fore the reality of New Zealand's dependency upon British naval protection, and Stout was soon negotiating a yearly colonial contribution in return. ${ }^{147}$ Ballance was reluctant to admit to any personal eagerness to see increased expenditure on defences; rather it had been forced upon him, made necessary, he said, when 'bankers came to them (the Government) and said if the ports were not defended they would ship their gold away to Australia'. 148 Generally Ballance's views on defence and New Zealand's position in the world were already strongly tinged with the nationalism, isolationism and national self-reliance that featured prominently in his later Premiership. He did not favour the federation of New Zealand, either within a British Empire or with Australia, arguing that as long as Britain had trade interests in the Bacific, the colony would be afforded protection when necessary, irrespective of any formal federation. ${ }^{149}$ Nor was he willing to commit New Zealand to any overseas military venture, declining, for example, to send colonial troops to assist Britain in the Sudan. ${ }^{150}$

Essentially, then, Ballance's defence policy rested upon the realisation that New Zealand could not hope, and therefore should not attempt, to defend herself against an attack from a major power. His nationalism was isolationist, certainly not aggressive. National self-reliance would be achieved by developing the country's natural

146. Stevens, pp. 99-101; Glynn Barratt, Russophobia in New Zealand, 147. Barratt, p. 102. 148. $\mathrm{Y}, 15 \mathrm{Jan} .1886$. See also $\underline{Y}, 8 \mathrm{Apr} .1887 . \quad$ Ballance speech.
149. $\mathrm{PD}, 1885,53$, pp. 540-43. 150. $\underline{Y}, 6$ Mar. 1885 . 
resources whilst remaining detached from the outside world; matching his long held belief in individual self-reliance it would soon lead to a policy of non-borrowing. The connection between individual and national self-reliance underlay Ballance's approach to the 1890 election; it was also to prove critical in consolidating the Ministry Ballance formed following the liberal victory. 
The fundamental ideological differences between Ballance and Stout on the one hand, and Vogel on the other, surfaced regularly during the life of their Ministry. Ballance was considerably more cautious than Vogel on the question of further borrowing, for example, whilst Vogel was equally unenthusiastic about Ballance's land policy, with its emphasis on 1easing. In the session of 1885 the Government had been defeated on a number of its most important measures, including the tariff increases and on public works expenditure. In early 1886 Ballance told his constituents that he believed the Government ought to 'formulate their policy, announce it to the country and dissolve before the session commenced'. ${ }^{1}$. There was widespread talk of dissolution over the following weeks, ${ }^{2}$ though it was not until the close of the session that Stout's request for one was turned down by the Governor. ${ }^{3}$ As Hamer points out, Vogel would resist an election until the purchase of the Waimea Plains Railway was finalised (the Bill did not pass until August 1886), a fact which gave Ballance and Stout (who in this respect had less to lose by dissolution) some leverage on him. ${ }^{4}$ Yet the splits within the Cabinet were clear for all to see; Stout and Ballance voted for the Government's Representation Bill whilst Vogel and two other Ministers, Larnach and Richardson, opposed it. The Bill, which redistributed seats in favour of the under-represented north island, failed to pass by three votes. 5

1. $Y, 15$ Jan. 1886 .

2. $\overline{\mathrm{LT}}$, in $\underline{Y}, 5 \mathrm{Feb} .1886$; see also $\mathrm{Y}, 29 \mathrm{Jan} .1886$.

3. Governor to Colonial Secretary, $2 \overline{0}$ Sept. 1886, 'Confidential despatches and telegrams to the Colonial office, 31 May 188616 May $1889^{\prime}$, National Archives, Wellington.

4. D.A. Hamer, 'The Law and the Prophet: a political biography of Sir Robert Stout', M.A. thesis, Auck1 and, 1960, p. 143.

5. PD, 1886,56, p. $728 ;$ Y, 20 Aug. 1886 . 
From Ballance's standpoint the advantages of dissolution were ambiguous. His Land Act had already been passed, and certainly by 1887 he was arguing that an election would be necessary to test the feeling of the country on his more radical Land Acquisition Bill. 6 On the other hand his settlement schemes required careful administration and vigorous promotion if they were to achieve any success, and he was optimistic that his Native Land Administration Bill would pass when it came before the House. Finally, there was always the fear that an election would only make the political situation worse.

Dissolution came in May 1887 when, following a pessimistic financial statement, the Government was defeated on its proposed tariff increases. An analysis of the division shows the extent to which political confusion reigned in the House. Opponents of the duties included liberals such as Grey and Montgomery, along with the rigid free-trader, William Barron; the independent-minded Pyke; two runholders, J.C. Buckland and W.F. Pearson; and T. Thompson, J.H. Sutter, Daniel Reese and Harry Allwright, businessmen of various types. All had helped bring the Stout-Vogel Government into office. Those in favour of the increases, but who had supported Atkinson in 1884, were Fitzgerald and Menteath (both lawyers); Cowan, an Otago runholder; Joseph Hatch and H.R. Levestam, a businessman and an engineer respectively; F.J. Moss, a government official; and E.J. o'Conor, a farmer. 7

Despite the wide range in the motives of individuals (and it should be remembered that the simple fact that the triennial election 
was in any case due in August must have assisted in the disintegration of the Government's support), it was clear that the issue of protection was now of major political importance. It had assumed increased significance for two reasons. First, by raising revenue through customs duties it was an alternative to retrenchment as a means of reducing the Government's deficit in depressed economic conditions. Secondly, it held out the possibility of the establishment of substantial local industry, broadening the base of the country's economy and at the same time increasing employment opportunities in the towns. Both factors tended to split town from country. Farmers would not only object to the higher prices of imported goods, but would tend to resist any measure that eroded the position of agriculture as the economic 'backbone of the country'. As we shall soon see, however, Ballance was at pains to emphasise an identity of interest between town and country. And it was certainly true that farmers who lived near by and supplied towns like Wanganui (rather than exporting), recognised that their prosperity was intimately linked with that of the town itself. Carson, Ballance's political opponent in Wanganui, who can be seen as representing farming interests within the electorate, was not strongly anti-protectionist.

The election was fixed for September 1887, delayed by Stout so that his Representation Bill might pass before the session's end. The Act reduced the 'country quota' from twenty-five to eighteen per cent and established a commission to redraw electoral boundaries. ${ }^{8}$

8. Representation Act, 1887. The country quota was the artificial addition of population to country electorates, in order to overrepresent them at the expense of the growing cities. Boundaries had until 1887 been fixed by Parliament. See L. Lipson, The Politics of Equality: New Zealand's adventures in democracy, Chicago, 1948, pp. 29-33. 
The campaign was fought in the midst of the worst depression the country had seen. Government revenue and expenditure were both falling, and per capita trade slumped to an all-time low. ${ }^{9}$ The excess of immigration over emigration was down to under one thousand, and by the following year a staggering nine thousand more people had left the colony than had arrived. ${ }^{10}$

Political reaction to this crisis took two major forms. Many sought severe retrenchment, and established Reform Associations throughout the country to press their demands. As Sinclair points out, these groups were 'profoundly 'conservative',... aiming at the defence of property, and of propertied and indebted persons, at the expense of the mass of the population; and... at the conservation of the serial status quo'. 11 Others emphasised protection rather than reductions in government expenditure. They tended to be liberals and supporters of the Stout-Vogel Ministry, frequently also calling for a more equitable system of taxation. 12

As we have seen, Ballance had been converted to protection a number of years earlier, and as the depression deepened it assumed for him increasing importance. ${ }^{13}$ Speaking at Lawrence in February 1886 he argued that protection was essential to the survival of the

9. M.F. Lloyd Prichard, An Economic History of New Zealand to 1939 , Auckland, 1970, p. 201 .

10. In the absence of unemployment statistics in particular, net migration is a good indication of the 'grass-roots' level of economic activity. See 'Statistical Summary of the Colony of New Zealand from 1853 to $1893^{\prime}$, Official Year Book, 1894.

11. Keith Sinclair, 'The Significance of 'the Scarecrow Ministry', 1887-1891' in R.M. Chapman and Keith Sinclair (eds.), Studies of a Sma11 Democracy: essays in honour of Willis Airey, Auckland, 1963, p. 111 .

12. On the election see T.G. Wilson, 'The Rise of the Liberal Party in New Zealand, 1877-1890', M.A. thesis, Auckland, 1951, ch. X; Clive Whitehead, 'The 1887 General Election in Canterbury', M.A. thesis, Canterbury, 1961, a1so notes the two basic reactions to depression.

13. See ch. 6, pp. 236-38. 
country's industry. Without it manufacturers would be 'crushed by an influx of shoddy goods' imported by wealthy merchants. ${ }^{14}$ In June 1887 , at a meeting in Wellington, he proposed the motion to establish a New Zealand Industrial Protection Association. It was a highly significant speech, for in it Ballance attempted to bring together the interests of manufacturers and small farmers against those of importers and large landowners. Quoting a number of statistics he showed that more farm produce was consumed within the colony than was exported. He concluded that farmers needed the large market, as well as the manufactures, of the towns, as much as the towns depended upon substantial numbers of country customers:

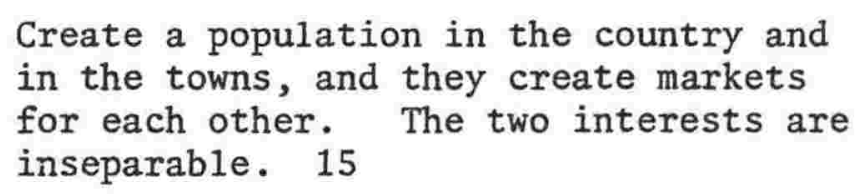

The solution lay in the protection of all industries, linked to a policy of closer settlement. The only people to be hit would be the importers and large landowners who had been doing so well under free trade.

Despite Ballance's efforts to persuade farmers that protection was in their interests (even if initially it resulted in higher prices, this was far outweighed by the long term advantages of industrial expansion), it was clear that it was primarily an urban policy. In his first major reference to the incipient trade union movement in the colony, ${ }^{16}$ he said that unions, along with employers, should be represented in the Industrial Protection Association. If free trade 
continued it would result in the 'degradation of colonial labor'. Thus

\begin{abstract}
...every artisan should join in this movement and assist in the establishment of an association where employers of labor and the employed could meet on an equal footing, and where all classes of the industrial community might be fairly represented. ...What the working people wanted was organisation, without which they had accomplished nothing in the past, and would accomplish nothing in the future. What they wanted was a patriotic and national policy.... . Too long they had been accustomed to rate their comfort on the wealth of the few and not the prosperity of the many... . 17
\end{abstract}

This was a populist appeal which looked to agreement and accommodation between classes rather than to their inevitable mutual antagonism. Ballance deprecated strikes, during which the two classes 'were brought into collision, instead of combining to oppose the common enemy' of free trade. ' $(T)$ here need not be any irreconcileable difference between employer and employed on this question', he said. ${ }^{18}$

Whilst protection was prominent amongst the issues raised by Ballance at the Wanganui election, his opponent Gilbert Carson was 'discreetly vague' on it. ${ }^{19}$ The expression of strongly antiprotectionist sentiments would have been politically unwise in an urban constituency. Carson, following seven years as a compositor and Hansard reader in the Government Publishing Office, had purchased the Wanganui Chronicle in 1874 , becoming at the same time the paper's manager and editor. ${ }^{20}$ The Chronicle was, as we have seen, a constant

17. Y, 17 June 1887 .

18. Ibid. See ch. 9 for a fuller discussion of Ballance's attitude to class conflict.

19. Y, 15 July 1887 .

20. Cyclopedia of New Zealand, vol. I, Wellington, 1897, pp. 1359-60, 1362,1400 
critic of Ballance, and this opposition naturally hardened when Carson himself entered the political fray. It published Carson's letters, attacks on Ballance which were reinforced by a stream of tendentious editorials. ${ }^{21}$ The Herald replied in equal vein.

Carson was 'respectable' in the sense that Ballance was not, in that he was a total abstainer, and an ex-Baptist lay preacher now prominent in the Y.M.C.A., who supported the Bible in schools. He had been Mayor of Wanganui. One of his leading protagonists referred to Ballance's followers as the 'scum of Wanganui'. 22 Other Carson supporters, writing to the Chronicle, pointed to Ballance's 'antagonism to Christianity' and the holding of meetings of the Freethought Association on Sunday evenings, 'apparently with the view of stultifying the work of the Christian church'.23

In his campaign speeches and through the Chronicle Carson advocated major retrenchment rather than protection, criticising the 'extravagance' of the Stout-Vogel Government and of Ballance in particular. He queried Ballance's travelling expenses and the money spent on village settlement, schemes which he described as 'miserable, poverty stricken affairs'. ${ }^{24}$ Letters in the Chronicle echoed these objections. ${ }^{25}$ Towards the end of the campaign the paper, having questioned Ballance's belief in perpetual leasing as a 'panacea for all the ills that settlement is heir to through land monopoly', brought up his participation in the Land and Loan Company ten years earlier. ${ }^{26}$ Carson was desperately

21. See, for example, WC, 14 July 1887.

22. Y, 30 Sept. 1887 .

23. $\bar{W} C, 23$ Sept. 1887 , see also 26 Sept. 1887.

24. $\overline{\text { WC }}, 16$ July 1887,21 July 1887,22 July 1887, 13 Sept. 1887.

25. For example, on the desirability of free trade, see the letter in WC, 20 July 1887.

26. $\overline{W C}, 19$ Sept. 1887 , also 20 Sept. 1887. See ch. 5 on Ballance and the Land and Loan Company. 
looking for mud he could sling and make stick.

Ballance opened his own campaign at the Princess Theatre in Wanganui on 22 June. He defended the Stout-Vogel Government and his own administration of the Lands and Native Affairs departments. His speech placed great emphasis on village and special settlements, which Ballance argued were essential if the working class and unemployed were to be settled on the land and 'congestion of labour in the towns' avoided. Where land was in short supply, large estates ought to be purchased by the government and split into small farms (here Ballance referred to his Land Acquisition Bil1). ${ }^{27}$ On retrenchment he said that any reductions must be made all round; large salary earners ought to face cuts as well as low wage earners. He was reluctant to see the school age raised as a means of reducing government expenditure on education. ${ }^{28}$ Finally, Ballance was convinced that protection was necessary for the establishment of new industry and the creation of urban employment. Having repeated many of the points made in his Wellington speech earlier in the month, he concluded:

It was not everyone who could go on to the land, and they must provide for the people in the towns, and Protection was the only way, as far as he could see, by which it could be brought about. The farmers might be hostile to Protection for a time, but he could assure them that Protection was their best friend, and that they would find a home market more profitable than a foreign one. 29

27. $Y, 24$ June 1877. The speech was printed by the Herald in pamphlet form; Mr Ballance's Speech to the Electors of Wanganui. Wanganui, 1887. (A copy of the pamphlet is in the Turnbull Library).

28. Ibid. Incidentally, at the election Ballance proposed a plan to provide free education for Maori children, and another for 'relieving destitute natives', see $\underline{Y}, 29$ July 1887.

29. $\underline{Y}, 24$ June 1887 . 
The constituency of Wanganui had been enlarged since the 1884 election; it now included Aramoho, Eastown, Castlecliff, Westmere, Campbelltown, Putiki and Durietown, all nearby settlements that had previously been part of the Waitotara electorate. The addition of Aramoho, a working class district where the railway terminus and workshops were located, would act in Ballance's favour. Speaking there in July he made his first reference of the campaign to the Liberal party: he believed that it had now more hope and confidence than before, and expected to win a majority of seats at the elections. Again he saw land settlement and protection as 'two of the most vital questions of the day'. 30

The paucity of references to the Liberal party was understandable given the position Ballance was placed in, in having to defend a Government whose composition and support included both liberals and conservatives. Ballance was able to emphasise the liberal nature of his own legislation, and to a certain extent sidestep the obvious political inconsistencies of this syncretic combination. As the election drew near, however, rumours abounded of splits within the Ministry. Candidates were allying themselves behind specific members of the Cabinet, reported the Post, the main division occurring between supporters of Ballance and Stout and those of Vogel and Larnach. 31 Certainly Felix McGuire, whom Ballance was assisting in the Egmont election, had publicly stated his opposition to Voge1; and the same was true of J.A. Tole in Auckland, and of George Hutchison, who was standing against Bryce in Waitotara. 32

30. Y, 22 July 1887.

31. EP, 6 Aug. 1887, 12 Aug. 1887; see also WC, 9 Aug. 1887, 12 Aug. 1887.

32. McGuire, a Hawera storekeeper who like Ballance was born in the north of Ireland, was defeated (on the election campaign see Judith Bassett, Sir Harry Atkinson 1831-1892, Auckland, 1975, p. 134). He won the Egmont seat on the retirement of Atkinson in 1891, however, and held it until 1902 (though he turned against the Liberal government before iong) 
Though Ballance denied that there was any plot afloat, ${ }^{33}$ it was clear that he was doing all he could to put his political weight behind the more decidedly liberal Government candidates. For example in Wellington he supported Robertson, an iron manufacturer who was a protectionist and strong advocate of Ballance's land settlement schemes. ${ }^{34}$ These attempts to influence the result of contests outside Wanganui, using his national reputation gained in particular over the past three years, marked Ballance out as never before as a major political figure.

Nearly all the issues at the Wanganui election were of national rather than merely local importance. One exception was the question of harbour improvements. The matter had been raised in 1884 when Ballance promised, if elected, to promote a rating bill providing finance for the development of the river. ${ }^{35}$ The Wanganui Harbour Board Rating Bill was in consequence introduced by him soon after the opening of the new Parliament. The Bill, which had the support of the vast majority of the town's ratepayers, ${ }^{36}$ passed a second reading, but was in effect killed by a Legislative Council amendment requiring any rate to be sanctioned by two-thirds of the electors on the roll, rather than simply two-thirds of those who voted. 37 The Yeoman immediately proposed that the Council be reformed. 38

Attempts to have similar bills passed in 1885 and 1886 also failed. A major problem was the fixing of the rating area; that is, how much of the country surrounding Wanganui should be included and thus (assuming

33. Ballance's letter to the EP, 25 Aug. 1887; Y, 10 Sept. 1887.

34. EP, 10 Sept. 1887,20 Sept. 1887,21 Sept. 1887.

35. See ch. 6, pp. 254-55.

36. See the meeting of ratepayers, reported in WC, 8 Sept. 1884.

37. PD, 1884, 49, pp. 11ff; Y, 7 Nov: 1884 .

38. $\underline{Y}, 14$ Nov. 1884 . 
a favourable local poll) made liable for rating. The cause of these country districts, generally unsympathetic to the financial plight of the Harbour Board, was championed by John Bryce, who opposed Ballance with as much persistence as the latter showed in repeatedly bringing the Bill before Parliament. ${ }^{39}$ The 1887 Bill, even after the clause including Rangitikei in the rating area was deleted, was again rejected by the Council. This time Bryce 'walked out during the second reading, saying he preferred to be neutra1'.40 In his election speeches Ballance responded to criticism that he had failed in his promises by saying simply that he had done his best, and that he had certainly more chance of getting the Bill through than had Carson. 41

The outcome of the election gave Ballance his most convincing win yet; he polled eight hundred and sixty-five votes to Carson's four hundred and twenty-three. ${ }^{42}$ This victory contrasted starkly with the performance of Government candidates elsewhere. Stout suffered a shock, and especially for a Premier a humiliating, defeat; and Tole, the Minister for Justice, also lost his seat. McGuire and Lundon (who was standing in the Bay of Islands) both failed to get elected, though Bryce was beaten by Hutchison and Rolleston defeated in Canterbury. When Parliament assembled the Stout-Vogel Government tendered its resignation and the Governor called for Atkinson. ${ }^{43}$

The reasons behind Ballance's substantial victory are twofold. First, unlike the other members of the Ministry, his personal reputation

39. PD, $1885,52, \mathrm{pp} .174 \mathrm{ff}$; PD, 1886, 55, pp. $401 \mathrm{ff}$.

40. $\overline{\mathrm{PD}}, 1887,57, \mathrm{pp} .94 \mathrm{ff} ; \mathrm{Y}, 13$ May 1887,27 May 1887.

41. $\bar{Y}, 24$ June 1887,30 Sept. 1887.

42. $\bar{Y}, 30$ Sept. 1887. Ballance gained $67 \%$ of the total vote. The Tater official result gave Carson an extra seven votes, $\underline{Y}, 7$ Oct. 1887.

43. $\underline{Y}, 7$ Oct. 1887; WC, 1 Oct. 1887; Bassett, pp. 134-38. 


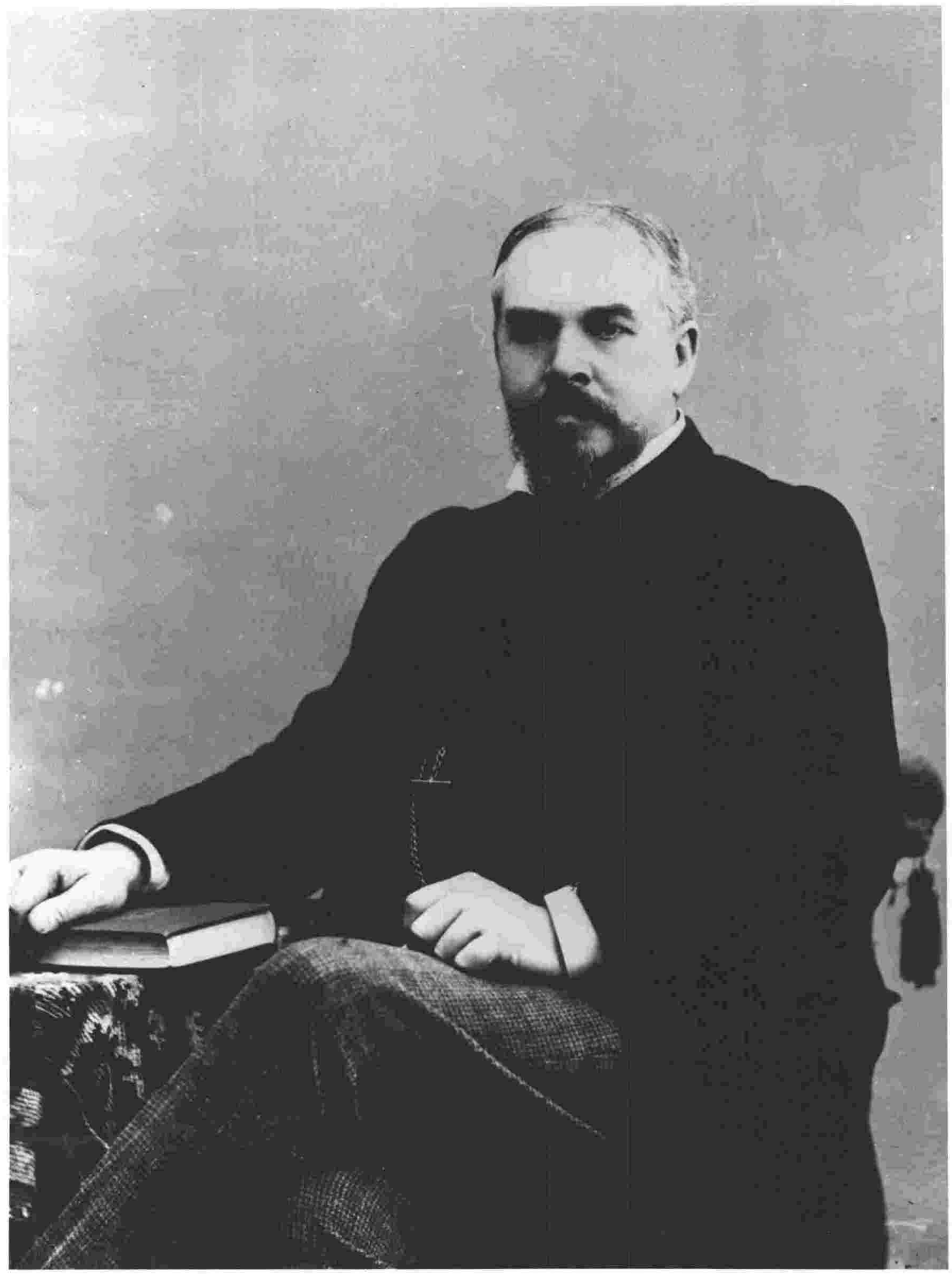

John Ballance, circa 1892 
had been greatly enhanced by three years in office. His campaign emphasised real practical achievements in the fields of land settlement and race relations. In a town close enough to feel vibrations from Maori unrest further to the north, and where the political influence Bryce might wield was always a consideration at elections, Ballance's greater success in dealing with Parihaka was an important factor. At the same time these personal accomplishments helped to obscure the Government's failure to reverse the deepening depression.

Secondly, Ballance's political platform was well-tailored to Wanganui. His victory rested on an urban alliance of the town's working class and businessmen, to whom Ballance's land settlement and protection policies appealed. Closer settlement contained social and economic benefits for both groups. Higher tariff duties were more preferable than retrenchment because they encouraged local industry and stimulated employment, and since cuts in government expenditure hit the working class and struggling small businessmen more severely than the wealthier importers and more self-sufficient farmers. This urban alliance, consisting of the land hungry and often unemployed working class, and the small businessmen attempting to expand local industry at a time of economic stagnation, was achieved much more easily in 1887 than three years later. For in 1890 it was threatened by industrial unrest and trade union growth, both of which alienated many of the town's employers. At the election of that year, standing on almost identical policies and facing the same opponent, Ballance won the Wanganui seat by the narrow margin of twenty-seven votes. 
Lack of a viable alternative brought both Atkinson and his 'Scarecrow Ministry' to power. The House was split into a number of groups, Atkinson drawing support from rural free-traders led by Russell and Ormond as well as from those who saw the need for limited protection alongside retrenchment. The Opposition included followers of Voge1, 'Stout-Ballance' liberals, and a collection of junior members, including Reeves, Ward, Perceval and Seddon, who formed yet another ephemeral 'Young New Zealand party'. Atkinson's Cabinet was inexperienced, 'makeshift', and 'doubtfully reliable'.44

Aside from its financial measures and a Representation Act, little legislation emerged from three years of the Scarecrow Ministry. It survived because the Opposition generally supported its tariff measures, and was in any case in even greater disarray than the Government itself. Vogel assumed leadership of this disparate coilection but had left the colony by early 1888, this time for good. Meanwhile from the start of the new Parliament Ballance was attempting to gather around him a separate liberal faction. In October it was noticed that he was

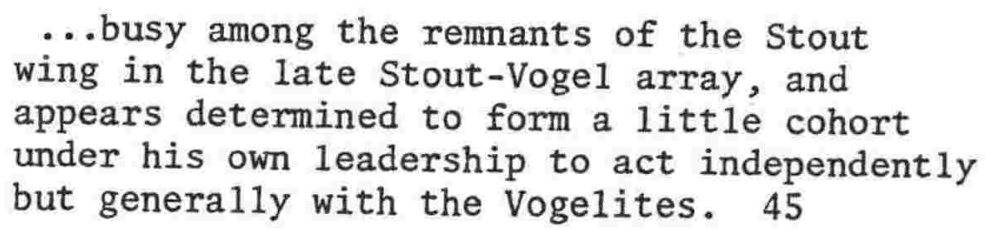

And along with John McKenzie, Cadman and others from this 1iberal group, Ballance 'held aloof' from a Vogel caucus meeting. ${ }^{46}$

44. Bassett, pp. 137-38.

45. Y, 14 Oct. 1887 .

46. $\overline{\mathrm{Y}}, 21$ Oct. 1887 . 
Yet with Vogel's departure the Opposition did not elect a new leader, appointing instead a committee to co-ordinate its activities. The committee was chaired by J.D. Lance, an ex-army Canterbury runholder, and included also Ballance, McKenzie, 0liver Samuel (a New Plymouth lawyer), R.J. Seddon from the West Coast, W.J. Steward (a journalist who became Speaker during Ballance's Premiership) and F.J. Moss. ${ }^{47}$ Ballance was not elected to, and did not accept, the leadership of the Opposition until June 1889. He was the obvious choice, on grounds of experience, ability and reputation, all along; so why the delay?

There were both personal and political reasons for Ballance's reluctance to take on the Opposition leadership. Firstly, he had been unwel1 since before the September 1887 election. ${ }^{48}$ He had never worked harder or travelled more than during his office in the Stout-Vogel Ministry, and this had clearly placed a great strain on his naturally weak constitution. Though energetic in his younger days, he suffered the fate of many in a sedentary profession that left little time for leisure, putting on a considerable amount of weight in his later years, as photographs of the period testify. His hobbies were in any case mentally rather than physically demanding. His great passion was for chess, at which he was extremely competent. ${ }^{49}$ He was a good horseman (he had owned 'Lough Neagh', a racehorse which, sold and re-named 'Fishhook', became one of the most successful of its day), ${ }^{50}$ but now

47. NZH, 8 Aug. 1888 .

48. On the first report of Ballance's illness see EP, 6 Sept. 1887. 49. Ballance played for the parliamentary team against the City of Wellington, see L.E. Ward, Early Wellington, Wellington, 1928, p. 180; see also the match between Ballance and Bryce discovered by the NZT, $13 \mathrm{Feb}$. 1983. Ballance started a chess club in Wanganui and a weekly chess column in the Herald, see WH, 19 May 1877.

50. Y, 24 Mar. 1877; J. P. Belcher, Wanganui From 1856 to 1929 , Wanganui, 1930, p. 12 . 
travelled more in carriages and on trains. This first illness lasted we11 into 1888. The Yeoman rumoured that it might be fatal, and the annual christmas gathering of the Anderson family at 'Rhymme' in Wellington was cancelled because of the seriousness of the situation. ${ }^{51}$ Soon however Ballance's health was reported to be 'fast improving' and following a recpuperation period of some months he appeared to have made a full recovery. 52 Nevertheless, the damage a stressful political life could do to his constitution had been dramatically brought home to him, and it was a consideration that remained with him until his premature death in 1893.

Secondly, Ballance's own financial position was deteriorating; he was no longer receiving a minister's salary, and returned to assume full editorial control over the Herald in January $1888 .^{53}$ That year was to be the worst of the depression, and by May the Herald Company was in dire straits. The directors cut back where they could, but told Ballance that they needed a loan of between five and seven hundred pounds to survive. When he heard of the seriousness of the situation Ballance proposed a number of remedies, including the reduction of wages to a maximum of thirty pounds per week, and the suggestion that he might take over the management of the paper from an existing employee who was reluctant to take on the responsibility. Both he and Ellen were willing to pledge all their shares in the Company as guarantee for the loan. Ballance believed that the Herald would survive:

We must not be beaten, but we must at the same time face the position. The paper will soon recover itself, if we give it the chance. ...Personally I am quite willing to

51. Y, 23 Dec. 1887; Anderson Diary, 17, 22, 25 Dec. 1887.

52. Ānderson Diary, 31 Dec. 1887, 4 Jan. 1888, 17 May 1888. See a1so Ballance to Stout, 3 Jan. 1888, Stout MiSS.

53. Ballance to Stout, 3 Jan. 1888 , Stout MSS. 
make any sacrifice on behalf of the shareholders who have invested their capital in the concern, \& begin again. But I firmly believe the loss will be quickly recouped. There is in our favour the fact that the paper has a large circulation \& hold on the people, \& consequently commands the advertising. And even a great reduction of reading matter will not affect it prejudicially. 54

As entries in David Anderson's diary indicate, the Herald's financial problems continued well into 1889. Ballance borrowed another one hundred pounds from his father-in-1aw, 55 and later sold him three hundred shares in the Mokihinui Coal Company. 56 In February 1889 David Anderson let one of his properties in Willis Street, crediting the rent to Ellen. ${ }^{57}$ He died a month later, leaving a not inconsiderable fortune to be divided amongst his children. 58

By mid-1889 the Herald had survived the crisis and the Ballances' finances were significantly healthier than they had been a year earlier. Ballance's optimism was justified. By 1891 the Herald had turned the '1arge overdraft... and heavy outside liabilities' of 1888 into a profit of four hundred and eighty pounds. Twelve months later profits increased to six hundred pounds, the debt owing to the bank was cleared, and a dividend declared for the first time in a number of years. 59

Thirdly, political considerations also encouraged Ballance's delay in accepting the leadership. Voge1 had left the country during the

54. Ballance to John Notman, 27 May 1888, letter in the possession of Mr. John Haterly of New Plymouth. See Appendix.

55. See ch. 5, pp. 210-11.

56. Anderson Diary, $15 \mathrm{Aug}$. 1888, $17 \mathrm{Feb}$. 1889. The shares may wel1 have been in lieu of the loan repayment, as the loan was for a period of six months.

57. Anderson Diary, 1 Feb. 1889.

58. Spinks Diary, 17 Mar. 1889; EP, 18 Mar. 1889; Will of David Anderson, High Court, Wellington.

59. $\underline{Y}, 12$ Nov. 1892 . 
recess so that the question of his replacement could not be resolved until Opposition members gathered for the new session in May. They were in the meantime, as the post put it,

...1ike sheep without their shepherd, and we fear it will be very difficult to find any one capable of mustering the flock and guiding it out of cold shades to the pleasant pasture which lies behind the Treasury benches. 60

Ballance recognised that skilful husbandry, to continue the quaint pastoral analogy, had been lacking. Writing to Stout at the beginning of 1888 he lamented Vogel's poor leadership, saying that it had 'almost broken up the Opposition as an organised body'. It was a depressing scenario. The Ministry's Land Bill and encouragement of cash sales involved a complete reversal of Ballance's settlement policies; though Ballance optimistically thought that 'so glaring an attempt to play into the hands of the capitalists \& runholders (would) te1l its tale' and soon destroy the Government. The Representation Act, which reduced the number of members to seventy as a retrenchment measure was, said Ballance, a 'terrible blow to the democracy. This is the Reactionary Parliament, $\xi$ the question is, where is it going to stop'. Finally, in advising Stout on the political situation, the whole tone of Ballance's letter never questioned Stout's position as de facto leader of the liberals:

I was very pleased to see how busy you are, \& trust your business can be so arranged as not to materially suffer by your return to the Assembly. ...What a splendid battlefield our (?) Opposition has if led with ordinary skill, but this(?) is impossible evidently at present. 61

60. EP, 20 Apr. 1888.

61. $\overline{\mathrm{Ba}} 1$ lance to Stout, 3 Jan. 1888, Stout MSS. 
This deference to Stout, along with a pessimistic view of political events, financial problems and his recent illness, led Ballance to consider seriously quitting politics for good. In May he wrote to his friend John Notman in Wanganui:

I am thinking of retiring from politics at the end of the session \& devoting myself entirely to business. This is very confidential for the present. 62

The session had just opened, the address in reply being adopted 'without a single word uttered'. 'The reason is that there is no leader of the Opposition', said the Post, 'nor indeed, an Opposition party'. ${ }^{63}$ Yet Atkinson was also in difficulties. A gloomy Financial statement concluded in a proposal for new tariffs that immediately exposed the fragile nature of his support in Parliament. 64 'The Government could easily be put out of office if we had a leader', McKenzie wrote to stout. ${ }^{65}$ In fact it is clear that at this stage Ballance let it be known that he would not accept the leadership; ${ }^{66}$ and that the Opposition only then appointed a committee instead to direct its affairs (see above).

Atkinson managed to pass the tariffs, though only with the assistance of the Opposition. 'It is a great victory, and it has completely disintegrated the Ministerial party', Ballance reported to Stout :

62. Ballance to Notman, 27 May 1888.

63. EP, 12 May 1888 .

64. Bassett, pp. 141-45.

65. Mckenzie to Stout, 8 July 1888, Stout MSS.

66. See Lance's retrospective statement, NZH, 27 Feb. 1890. 
...the Govt. have lost the cream of their party in the Freetraders, whose severance is complete \& whose bitterness will prevent a reconciliation. I believe we can carry a vote against the Govt. if we think it prudent to do so this session. It must be admitted however that there is a kind of demoralisation in the Opposition ranks. ... If we cd only get rid of the Representation Act we might hope for liberal legislation in the future. It is proposed in a week's time to move in going into Supply that the Representation Act be not brought into force until after the next census. We want time to enable the country to swing back again. I think it will be carried... . ... The Govt. have now about 30 followers \& no more. The Opposition number 39, and the Freetraders 25. Macarthur says 15 of these are prepared at any time to turn the Govt. out. 67

In fact the motion was lost by the substantial margin of twenty votes to forty-one, and the Atkinson Ministry survived. ${ }^{68}$ Ballance was in any case, as the above letter shows, reluctant to force an election. The Opposition was in no position to face one, nor was the mood of the country propitious. At the end of the session Ballance defended the Opposition's support for the Government tariff measures, and at the same time seemed to admit more comfurtably his position as its foremost member:

It appears to me the true functions of the Opposition are to accept all that is good and reject all that is bad, and that, when the Opposition found the tariff exactly suited its views, it acted on that principle. ...We believe that protection will be for the benefit of the country ultimately; we believe that almost immediately it will be beneficial so far as the artisans of the towns are concerned, 69

He concluded that the Opposition's success ought to be measured by the number of bills that had been thrown out, as much as by the passing 
of the tariff. ${ }^{70}$ It had indeed been a barren session; a Native Land Bill, restoring private purchasing, was the only major non-financial measure to survive. ${ }^{71}$ Even with that Bill passed, Atkinson admitted that settlement would be encouraged best by Government rather than private initiative. ${ }^{72}$

Political developments during the recess were as confused as ever. The Post predicted that the 'political flirtation, which it is notorious has long been going on' between Stout and Atkinson would, following the former's return to Parliament, become a formal alliance. ${ }^{73}$ This was largely wishful thinking, not only because such a coalition was unlikely, but since Stout was doggedly refusing to re-enter politics. In fact the Post, along with the more conservative journals, much preferred to see Stout as Opposition leader than Ballance, whom they regarded as more radical: 'Mr Ballance would be a capable leader if it were not for his extreme views on certain questions'. ${ }^{74}$ And again, in previewing the prospects for the coming session:

Can he (Ballance) gather a party which would seriously threaten the Ministerial benches? We do not think so. On many of the points which a large number of members most differ from and distrust the Premier upon, $\mathrm{Mr}$ Ballance holds even more pronounced and advanced views. They distrust him still more, and would rather keep Sir Harry Atkinson in power than assist Mr Ballance to office. 75

70. Ibid., p. 498.

71. See Ballance's speeches on the Bil1, PD, 1888, 61, pp. 671-76; 62, pp. 266-68; 63, pp. 75-78; and ch. 7 .

72. PD, 1888,63, p. 507.

73. $\overline{\mathrm{EP}}, 1 \mathrm{Feb} .1889$.

74. $\overline{\mathrm{EP}}, 11$ July 1888.

75. $\overline{\mathrm{EP}}, 12$ Apr. 1889. 
At a caucus meeting of thirty-two opposition members in early July 1889, Ballance was elected leader. W.C. Walker, the only other possible candidate, made known his support for Ballance and the vote was unanimous. 76 Ballance took on the task 'not without much hesitation', but apparently felt it his duty. ${ }^{77}$ Undoubtedly he also believed himself to be physically and mentally restored, and his business affairs to be showing sufficient signs of improvement, for him to accept what he had so firmly refused a year earlier. Politically the situation had not changed dramatically in twelve months, except that it was now less likely than before that Stout would return to politics. Further, though Ballance publicly lamented Stout's absence, ${ }^{78}$ privately he cannot have been pleased to hear the rumours, however inaccurate, of Stout's overtures to Atkinson. In his pre-sessional address Ballance had for the first time staked his leadership claim, suggesting that 'there was a very solid party in the House who did agree in the views he held'. 79

The suspicion that Ballance was 'only the nominal head of the party, a kind of locum tenens' during Stout's absence, could make for uncomfortable and half-hearted leadership. 80 It was not to be until he had firmly secured his position as Premier, succeeding where many were sure he would fail, that Ballance finally shook off Stout's shadow and established his own leadership credentials. Stout enjoyed being regarded as the person 'pulling the strings' behind the scenes, ${ }^{81}$ and he was clearly content to remain out of politics for as long as Ballance

76. $Y, 6$ July 1889; Wilson, p. 227 .

77. $\bar{Y}, 6$ July 1889 .

78. $\bar{N} Z H, 6$ June 1889.

79. $\overline{Y,} 8$ June 1889 .

80. $\overline{E P}, 29$ June 1889.

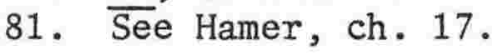


held centre stage. Only following the latter's death did he accept one of the frequently made offers of a safe seat.

Though Ballance respected Stout's intellectual ability, looking to him for moral support and acknowledging his superior claims to the leadership, his persistent presence 'in the wings' must have at times been irritating. Further, and the point has already been made, this 'dependency' was easily exaggerated by those who wished to see Stout's influence moderate the more 'dangerous' Ballance. ${ }^{82}$ Whilst the respectable Sir Robert (he had been knighted when Premier) theorised and philosophised from a distance, Ballance, the first distinctly lower-middle class leader the country had seen, concentrated his attention on practical policies. ${ }^{83}$

There was another reason for Ballance's somewhat lack-1ustre leadership. He disliked the 'negative' aspects of the job; as we have seen he was happiest when in a position of being able to initiate, legislate and administer practical measures. This was not true of all politicians, as it might at first sight appear. Grey is the archteypal politician who revels in attacking the party in power; the rhetoric of the defence of the working class, 'backs against the wall', front facing the might of the establishment, was his strength where lack of ability as an administrator and broker between divergent cabinet colleagues was his weakness. With Ballance the reverse tended to be the case. Though he was 'too original, too much of a thinker', he was a1so 'too fond of trying to reduce fine theories to practice,... to be a

82. EP, 29 June 1888 , pointed out that Ballance was more radical than many of the Opposition.

83. See Hamer, p. 346; André Siegfried, Democracy in New Zealand, Wellington, 1982 edition, p. 78. 
safe man'.$^{84}$ He therefore found the role of Opposition leader frustrating and at the same time deplored the lack of activity, the barrenness, of Atkinson's Ministry. Having been congratulated by the Premier on his assumption of the leadership, Ballance told the House how he intended the Opposition should operate:

I am confident the Opposition will pursue
no factious course in this House,
recognising as it does that its chief
function is to promote the despatch of
public business. Where we have to
dissent from the honourable gentleman
and take exception to his measures of
policy and acts of administration, we
hope to do so according to well-established
custom and upon purely constitutional lines. 85

The first major concern of the House was to debate a new Representation Bill, which confirmed the reduction of European members from ninety-one to seventy as laid down by the 1887 Act, . raișed the country quota, but also abolished plural voting. Ballance argued that the reduction in members, excused originally as a retrenchment measure, was undemocratic, since only the wealthy would be able to afford to fight the larger country seats. He said that the Bill aimed to create antagonism between town and country whereas it ought to be realised that their interests were mutual. ${ }^{86}$ Welcoming the abolition of plural voting he thought that there should also be single electorates and equal electoral districts. Not only that,

I want one woman one vote as well, and I want to make, in reality, the family the unit, the basis, of civilisation and of political influence in the country, and not single men. 87

84. Lyttelton Times, on how opponents viewed Ballance, quoted by $\underline{Y}, 6$ July 1889.

85. PD, 1889,64, p. 128 .

86. $\overline{\mathrm{PD}}, 1889,64, \mathrm{pp} .643-47$; see also PD, $1889,65, \mathrm{pp} .19-20$. 
Despite some concentrated 'stonewalling' by city members, the Bill passed; the country quota being fixed, after some manoeuvring, at twenty-eight per cent. ${ }^{88}$ Ballance rejected suggestions to turn the issue into a matter of confidence, believing that such a vote would fail and being still in any case unsure of the desirability of an early election. ${ }^{89}$ Instead he carried out a poll in order to gauge support in Parliament for the restoration of the number of members to ninety-one. 90 It was all he could do, especially considering that advocates of the quota included Cadman, McKenzie, Seddon and Ward. 91 Further, as the post pointed out, if in the unlikely event of a vote being successful, and if a dissolution were refused, Ballance would face the uphill task of trying to form a Government from the far from cohesive ranks of the Opposition. ${ }^{92}$

The Government came under more serious threat over the question of the incidence of taxation. Atkinson proposed to make minor changes to the property tax by, for example, exempting machinery (thus giving some relief to industry). The House however sought more drastic action. Generally speaking conservatives favoured reductions in the property tax to be made up by further retrenchment, ${ }^{93}$ whilst 1 iberals desired a change of incidence in the form of new income and land taxes and the lowering of duties on basic necessities. Atkinson and Ballance had earlier agreed that the debate on the financial proposals of the Government should take place in conjunction with the second reading of the Property Assessment Bill. However no sooner had Atkinson sat down having briefly moved the second reading, than the Member for

88. Y $\quad 27$ July 1889,10 Aug. 1889 .

89. $\overline{E P}, 24$ Ju1y 1889.

90. $\overline{\mathrm{EP}}, 25$ July 1889 .

91. See Wilson, p. 233.

92. EP, 8 July 1889.

93. See Barron's motion to this effect, PD, 1889, 64, p. 321. 
Parne11, F.J. Moss, proposed an amendment stating that the property tax was unfair in its incidence. The Aucklander thus forced the debate into a matter of confidence. ${ }^{94}$ Ballance had to admit that he had had no advance warning of Moss's intentions. 95

In his speech on the Bill Ballance appeared as the epitome of moderation. He simply wished the existing taxation system 'reconstructed' so that it bore 'equa11y on all classes', and fell well short of arguing for the replacement of the property tax by income and land taxes. 96 Though some saw this as a recognition of the impracticability of doing away with the property tax, 97 Ballance was in fact (as Atkinson and others were well aware), ${ }^{98}$ attempting to unite conservative and liberal opponents of the tax, and this required the minimum of comment upon what might replace it. When it came the division was close; the Government survived by four votes. 99

Moresophisticated tactical considerations were involved when Ballance moved his own resolution seeking for a dissolution and an election following the determination of the new district boundaries. The Government had lost the confidence of the country, he said, and had neither policy nor measures:

There are periods of reaction in all democratic countries, and this is one we have upon us. 100

There was no possibility that the motion would be carried and Ballance's

94. PD, 1889,65, p. 215 .

95. Ibid., p. 216.

96. $\overline{\mathrm{PD}}, 1889,65$. p. 228. See a1so PD, $1889,66, \mathrm{pp} .549-50$.

97. $\overline{\mathrm{EP}}, 14$ Aug. 1889 .

98. $\overline{\mathrm{PD}}, 1889,65$, p. 268.

99. $\overline{\mathrm{PD}}, 1889,65$, p. $434 ; \mathrm{Y}, 17$ Aug. 1889.

100. $\overline{\mathrm{PD}}, 1889,66$, p. 556; $\overline{\mathrm{Y}}, 14$ Sept. 1889. 
'tongue-in-cheek' plea met with considerable amusement from subsequent speakers. The point was that Ballance hoped to prevent Atkinson dissolving Parliament when it suited him best; the Governor would most likely refuse a request for a dissolution on the grounds that the House had already, on Ballance's motion, declared against it. ${ }^{101}$ Generally, throughout the House there was in any case considerable reluctance to force an early election, not least because with the reduction in the number of members many were uncertain of their chance of being returned.

Earlier in the year George Fisher had resigned from Atkinson's Cabinet following both personal and policy disagreements. 102 Now in September the Colonial Secretary, Hislop, was forced to retire having been censured by the Legislative Council for the misuse of ministerial influence. The position of Atkinson (who was becoming increasingly ill) was at its weakest, though he secured a reprieve when W.R. Russel1 agreed to join the Government, bringing the support of the free trade 'middle party' in the House with him. ${ }^{103}$ For these predominantly rural conservatives the only alternative to Atkinson was Ballance, a 'self-confessed radical'. 104

In his review of Government policy at the end of the session Ballance returned to old themes. He argued that emigration from the country should be reversed by promoting new settlement:

101. EP, 16 Sept. 1889.

102. See Ballance to Fisher, 16 Apr. 1889, 21 May 1889, Fisher Family Papers.

103. Y, 9 Nov. 1889 .

104. Judith Bassett, 'Sir Harry Atkinson and the Conservative Faction in New Zealand Politics, 1879-1890', NZJH, 2, 2 (1968), p. 141 . 
...we want every man who can to go upon the land and maintain himself upon it, whether he has capital or not. (But)...(t)he land-1aws have been administered for the capitalists of the colony, and unless a man is prepared to 'dummy' the land as a speculator he is heavily handicapped. ... (T) he yeoman village settler is treated to the cold shoulder. 105

Ballance also complained of political prejudice against village settlements and criticised the stream of 'improper transactions' involving Maori land that had been validated by the Government. Finally he admonished the new Railway Board, established by Atkinson to take over control of the railways from the Government. Ballance said that if the Commissioners attempted to regulate wages the Board would be abolished within five years:

I should protest in the strongest terms against any interference with or attempt any to reduce the rate of wages in the colony. 106

Criticism of the Railway Commissioners was prominent also in Ballance's first major public speech as Opposition leader, delivered at Napier in late October. He pointed out that one of Atkinson's objectives in appointing the Board was to avoid direct responsibility for a lowering of railway wages that would inevitably push down rates generally. Ballance said that he would prefer to see an increase rather than a decrease in wages. 107

It was important for Ballance that he make a first good impression at Napier. Though 'on the warpath' he had been advised by W.C. Walker, 
Member for Ashburton, to remember that he was 'addressing not only Napier and the hungry democrats of that place, but the whole colony':

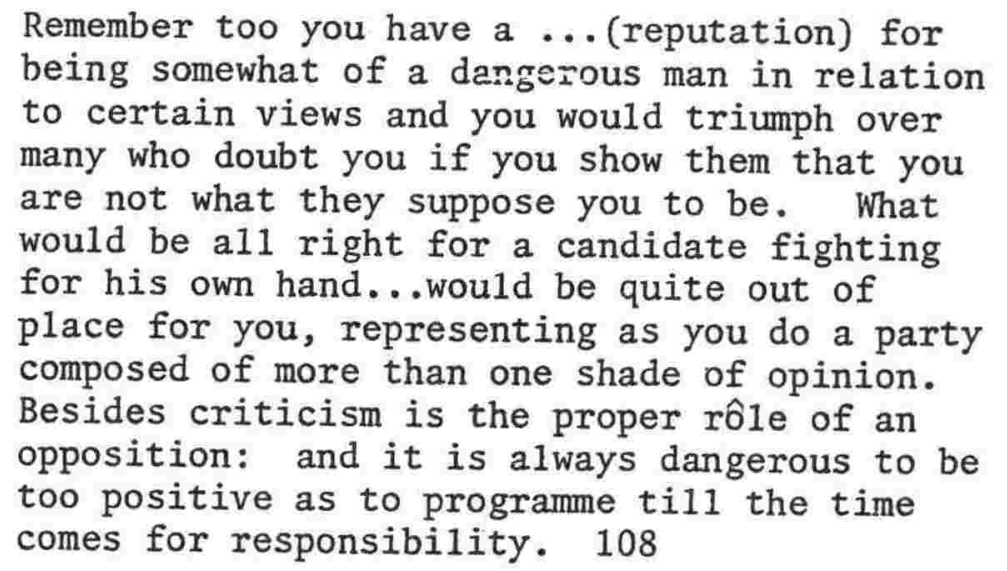

As we have seen with respect to the property tax, Ballance acknowledged the need to moderate his radicalism in the interests of 'party solidarity'. Yet he only partially followed Walker's advice at Napier. Though he talked about achieving a land tax by amending the property tax to exclude all improvements, he also made clear his support for a progressive land tax aimed at the large estates and the 'crying evil of absenteeism'. A graduated tax, with absentees paying double the rate, was the major proposal to emerge from his speech; emphasised because he believed that 'the real cause of the depression was without doubt land monopoly, and bad administration of the waste lands of the Government'. 109

The speech came in for some severe criticism. The Post in Wellington complained:

A speech less worthy of a leader of a party we never met with. It is almost impossible

108. W.C. Walker to Ba1lance, 24 Oct. 1889, BMSS, 44. 109. Y, 9 Nov. 1889 . 
by any form of words to convey an adequate idea of its weakness. ... There was really nothing new in what he said... . ...It is impossible to gather from it what line of policy Mr. Ballance would pursue if, by any chance, he succeeded to power. 110

Certainly Ballance could claim consistency rather than originality, though the Post's objection sprang in large part from its own political opposition to what it termed 'spurious Liberalism, based upon Protection'.

The adverse reaction to Ballance's speech also arose from the fact that it was only partially reported. The Napier Evening News said that considering Ballance's position as Opposition leader and the fact that he spoke for nearly two hours before nine hundred people, it was 'scandalous that such a meagre and misleading report was sent'. 111 The News blamed the other two longer established local papers, the Herald and Telegraph (whose political sympathies lay with Atkinson rather than Ballance), for it was they who had the responsibility of providing the Press Association with an account of the meeting.

There does seem to have been a deliberate effort made to suppress Ballance's speech. Stout protested; the Lyttelton Times accused the Press Association of being guilty of a 'very stupid omission'; the Dunedin Herald, describing the speech as 'one of the best, the most able, the most statesmanlike' ever to have been made in the colony, condemned its 'deliberate boycott'. Other press comment, both adverse and favourable, confirms the view that it was Ballance's radicalism rather than any personal defects, that lay behind much criticism of his 
suitability as Opposition leader. In Auckland the Herald described his 'threat' to interfere with the Railway Commissioners as 'cowardly and unconstitutional'. Meanwhile in Wanganui the Yeoman carried the banner headlines 'TAX THE BIG ESTATES', and rubbed the point in by publishing Ballance's Land Acquisition Bill of 1887 . Finally, the Otago Daily Times produced the following revealing paragraph :

It is really round the land question that the whole of Mr Ballance's policy centres, and nothing is plainer than that the country is at present very far from adopting $M r$ Ballance's views upon this or most other matters. His Radicalism is of a more uncompromising type than has yet been ventilated by any party leader in New Zealand, not forgetting either Sir George Grey or Sir Robert Stout. 112

For the remainder of his life Ballance stuck to those policies, dominated by radical proposals for the promotion of closer land settlement, that he had espoused for many years. It was to be the tide of events that made such a platform hard to resist in the unexpectedly critical year of 1890 .

112. A11 the foregoing press reaction to Ballance's speech was reprinted in the $\underline{Y}, 30$ Nov. 1889 . 
CHAPTER NINE

The Tide of Events: 1and for the people 
Life as Opposition leader was for Ballance, particularly as the election drew near, almost as hectic as that during his term in the Stout-Vogel Government. Much time was spent travelling between Wellington and Wanganui, and in January 1890 he journeyed to Dunedin to see and consult Stout. ${ }^{1}$ He was accompanied on this trip by his brother-in-law, David Anderson, with whom he had formed a close personal friendship.

Indeed the Anderson clan provided Ballance with an extended family, and the support it could offer, that would otherwise have been lacking. Having left Britain in 1866, Ballance was never to set eyes on any of his immediate family again. His only relation in New Zealand was a nephew, Robert McKnight, who lived in Palmerston North. McKnight too was brought into the Anderson family circle. On Christmas Day 1886, for example, there gathered around David Anderson senior's table at 'Rhymme' twenty-five Andersons, along with John, Ellen and Kathleen Ballance, and Robert McKnight. ${ }^{2}$

In the late summer and early autumn of 1890 , David Anderson junior and his wife Sarah Jane stayed with the Ballances in Wanganui. Sarah Jane's diary gives some impression of everyday life at 'The Knolls', the residence in St. John's Hill to which the Ballances had moved to from their previous home in the centre of town. 3 Ballance spent a good deal of his limited leisure time playing draughts and chess with his young Anderson nephew, Eddie. Clearly

1. Spinks Diary, 11, 13, 26 Jan. 1890.

2. Anderson Diary, 25 Dec. 1886.

3. Situated at the corner of Wilson and Guyton streets. Neither this property nor 'The Knolls' remain standing today. 'The Knolls' was located near the present day St. Chad's Church. 
political differences did not rule out personal friendships, for they were joined on occasion by Ballance's opponent, John Bryce. ${ }^{4}$

In the evenings Bailance was more often out than in. On 12 February, for example, he attended a meeting concerning the formation of a freezing company in the town. 'This the third evening in succession Mr Ballance has been out' wrote Sarah Jane, not entirely approving, one feels, of her host's continual absences. 5 Ba1lance was unrepentant; the following night he was out again, this time to a masonic meeting ${ }^{6}$

On Sundays Kathleen would go to church, though without her parents. ${ }^{7}$ Frequently she would be driven there by Julius, the Ballance's manservant and gardener. Domestic help was difficult to come by, and for some time during the Andersons' visit Ellen had to cope without a girl in the kitchen. When one did arrive she was, it seems, not quite up to scratch: 'we waited some time for lunch', Sarah Jane curt1y remarked. 8

E1len took a keen interest in politics, both on her own and on her husband's account. She was a woman of considerable intellect; the high opinion held of her by contemporaries was apparent when in

4. Spinks Diary, 28 Feb. 1890 .

5. Spinks Diary, $12 \mathrm{Feb}, 1890$. On the meeting see a1so $\mathrm{Y}, 15,22$ Feb. 1890, 1 Mar. 1890. Ballance was appointed a director of the Wanganui Meat Freezing Company. Its formation was of major significance to the town's economy. Meat no longer had to be sent to Wellington for freezing and exporting, and the town's own exports increased dramatically. See S.M. King, 'The Port of Wanganui and its Influence on Wanganui', M.A. thesis, Victoria University of Wellington, 1964, pp. 21-22.

6. Spinks Diary, 13 Feb. 1890.

7. E.g. Spinks Diary, 16 Feb. 1890, 2 Mar. 1890, 6 Apr. 1890.

8. Spinks Diary, 22 Mar. 1890. 
1885 the third Government steamer, to join the Hinemoa and the Stella, was launched bearing her name. ${ }^{9}$ She became increasingly involved in the feminist movement, being elected Vice-President of the Women's Progressive Society in 1892. According to Seddon it was she who had converted Ballance to woman's suffrage. ${ }^{10}$ E1len gave Ballance moral support, advice and practical assistance. She was often to be seen in the Ladies' Gallery during debates in the House. In Wanganui she took him to, and collected him from, meetings. 11 Politics dominated both their lives, and 'The Knolls' was surely the scene of many long discussions on current issues and future prospects. One evening was recorded faithfully, though again with some disapprobation, by Sarah Jane:

\begin{abstract}
At dinner we had a strange conversation; $\mathrm{Mr}$ Ballance said that in fifty years all people would travel free on the railways, as he now does; \& the expenses of the railways \& salaries of the railway officials would be defrayed by taxation; I said Ernest might be alive then, but we older ones, would not, $\xi$ he should have this book so that if he should be alive, he might refer to this date \& see if Mr Ballance's predictions were fulfilled: \& Eddie said if Ernest were to talk about Mr Ballance's prophecy at the end of fifty years he was to mind \& say "६ my brother said "Bunkum"("). Not a very suitable conversation for sunday. 12
\end{abstract}

9. EP, 27 0ct. 1885. See also E1len Ballance's entry in Lyndall Greig, 'Wives of the Prime Ministers of New Zealand', n.d., in Alexander Turnbull Library, Wellington; and her obituary, Wanganui Herald, 15 June 1935.

10. NZT, 2 Nov. 1893; see also Patricia Grimshaw, 'Politicians and Suffragettes. Women's suffrage in New Zealand, 1891-1893', in NZJH, 4, 2 (1970), p. 164n.; Patricia Grimshaw, Women's Suffrage in New Zealand, Auckland, 1972, p. 48. See ch. 12.

11. E.g. Spinks Diary, 18, 27 Feb. 1890.

12. Spinks Diary, $20 \mathrm{Apr} .1890$. 
The most prominent feature of the Liberal success of December 1890 was that for the first time trade unions played a major role in the electoral contest. Both then and now commentators note how critical 1abour organisation was to the Liberals in achieving a comprehensive victory in the four major centres of population. ${ }^{13}$

Linked to the appearance of trade unions is the fundamental question of the relevance of 'class' as the basis for political alignment. Attention had already been focused on working conditions in the cities. A sermon by the Rev. Rutherford Waddell on 'The Sin of Cheapness', and a series of articles in the Otago Daily Times on the clothing industry, led to the setting up of the 'Sweating Commission'. As the depression deepened and wages fell, labour unrest grew. The formation in 1889 of a new union organisation, the Maritime Council, was followed by an outbreak of disputes a year later. It has been argued that with the failure of the maritime strike of August to November 1890, trade unions turned to politics to seek redress of their grievances. ${ }^{14}$ Had 'class politics' arrived in New Zealand?

Rough1y speaking there are two opposing schools of thought on the role of 'class' in this period. Sinclair ${ }^{15}$ and 01 ssen $^{16}$ believe that class conflict and antagonisms were critical features of the 1890

13. E.g. H. Crook, 'The Significance of the 1890 Election', M.A. thesis, Auckland, 1953, p. 144.

14. T.G. Wilson, 'The Rise of the Liberal Party in New Zealand, 1877-1890', M.A. thesis, Auckland, 1951, p. 250.

15. Keith Sinclair, William Pember Reeves, London, 1965.

16. Erik 0lssen, 'The 'Working Class' in New Zealand', NZJH, 8, 1 (1974), pp. 44-60. 
election, whereas 01 iver $^{17}$ and Campbe11 ${ }^{18}$ argue that the Liberal victory was based in fact upon widespread support for the removal of class barriers. In this latter view working men sought not to destroy, but to join the ranks of, the capitalist class. If the upper classes of New Zealand 'heard a tramp of boots, it was not the hobnails of a proletariat on the way to a socialist utopia, but the gumboots of cow-cocking entering a capitalist society'. ${ }^{\text {es }}$ This is a dispute concerning not only the 1890 election, of course, but rather the difference between those who see New Zealand as yet another example of a society where political change came about through class conflict, and those who point instead to a rarer 'egalitarianism', where political stability and continuity were achieved through 'mobility between far from distant social strata'. 20

An examination of the political appeal of Ballance, leader of the Liberals at this critical time, can surely be expected to throw some light on this debate. In fact, as this chapter aims to show, Ballance's appeal was populist; that is, he attempted to attract broad rather than sectional support; from the working class, from shopkeepers and businessmen, and from small farmers. As we have seen the distinctive feature of his radicalism was the pre-eminence of land reform. Ballance sought to reduce rather than exacerbate conflict between classes by encouraging upward social mobility through closer

17. W.H. Oliver, 'Reeves, Sinclair and the Social Pattern', in P. Munz (ed.), The Feei of Truth, Wellington, 1969, pp. 163-178.

18. C. Campbe11, 'Parties and Special Interests in New Zealand, 1890-93', M.A. thesis, Victoria University of Wellington, 1978; C. Campbe11, 'The 'Working Class' and the Liberal Party in 1890', NZJH, 9, 1 (1975), pp. 41-49.

19. Oliver, p. 167.

20. Ibid., p. 175 . 
land settlement policies. He aimed for a society where self-help produced rewards, and so it was the monopolists of land, and thus of opportunity, who were the target for his wrath, not the urban capitalists. Both Ballance's own speeches and Herald editorials concentrated their attack throughout 1890 upon this small minority of large landowners. A 'class' war was to be waged only on behalf of the landless labourer against the political and economic might of the monopolists.

The political composition of the combination Ballance hoped to secure in 1890 looks more like the later populist alliances of Third World (particularly Latin American) countries, that sought protection and land reform at the expense of the latifundists, than any British contemporary counterpart. Though the political power of the New Zealand gentry was not nearly so great as that of the latifundists, the rhetoric of 'bursting up the large estates' was central to both situations. The similarities become more obvious when Ballance's anti-borrowing and self-reliant policy is compared to the anticolonialism, and nationalistic demand for greater self-sufficiency, of the populist movements. 21 .

The emphasis that has been given to labour issues during this period is at least partly misplaced, as is the impression of Reeves as the 'typical' radical liberal. Though sympathetic to the unionists and to calls for the reform of the capitalist system, Ballance paid scant attention to the 'labour problem' per se. This was not only political caution in not wishing to alienate business support, but

21. Peronism in Argentina is perhaps the classic example. See also a recent comparative study of development experiences, Donald Denoon, Settler Capitalism. The dynamics of dependent development in the southern hemisphere, 0xford, 1983. 
rested in the firm philosophical belief that the 'labour problem' would be resolved once the 'land problem' had been dealt with. This view was widely held amongst unionists themselves, and by the Knights of Labour in particular. Further, as Campbel1 points out, it was the question of land, not labour, reform, that saw the greatest divergence of opinion between the supporters of Ballance and Atkinson in $1890 .^{22}$ Ballance was no socialist. He believed that politics should be different in New Zealand from politics in the 01d World. Class war between employers and the employed was not inevitable in a new land.

The fact that Ballance came from Wanganui and not one of the major four centres had a significant influence on the determination of this political outlook. A populist appeal made sense in a community where Baliance could not afford to alienate the large number of small businessmen and shopkeepers, even if he had wanted to. An anti-capitalist platform aimed predominantly at attracting working class support would have been a recipe for disaster in Wanganui, whereas it might have been safe in the large city electorates. Further, that land reform should be seen as the key solution to the colony's ills was natural in Wanganui, where the intimacy and interdependency of town and country were more obvious than in the cities.

Coming from Wanganui also gave Ballance some political advantage as a leader. He was able to avoid accusations of favouring a particular major centre and could act as broker between regional rivals. (It is perhaps significant that Atkinson, Ballance, Seddon and Ward did not represent city electorates). This was more important later 
on, however, for Ballance was elected Opposition leader at a time when local political autonomy was both respected and fiercely guarded. Ballance led the Opposition in Parliament and outlined 'party' policy when speaking in Wanganui. There was as yet, however, no national party organisation, and Ballance had no say in the selection of candidates or the conduct of local campaigns.

Criticism of Ballance's performance as Opposition leader continued. Most was politically motivated. The Post, for example, called him a weak leader because he was unreliable:

$\mathrm{He}$ is always saying or doing something which surprises, without pleasing those who think they know most of his views and objects. He has not been a success as a leader of the Opposition, and he would, we are confident, fail even more completely in the role of Premier, if by any contingency he became cast for it. 23

It was quite untrue that Ballance had a tendency to do or say the unexpected. As we have seen in the previous chapter, the Post itseif. complained (and the theme continued throughout 1890) that there was 'nothing new' in what Ballance had said at Napier. If in fact Ballance was, as the Post now noted, leader of a 'very disorganised Opposition', it was the diverse political make-up of the body rather than failure on Ballance's part that was the problem. The Opposition had never been organised and Ballance faced an uphill task in trying to represent an amalgam of widely differing viewpoints. Any attempt to force his own particular beliefs upon his colleagues, though it might 
seem a sign of strong leadership, would have simply broken up the Opposition still further. Ballance was a much more impressive leader as Premier because circumstances allowed him to be. ${ }^{24}$

In early March 1890, Henry George visited Auckland en route to Australia. His reception committee included a number of the city's liberal leaders, such as Sir George Grey, W.J. Napier and W.T. Jennings, the trade unionists R.A. Hould and Arthur Withy, and a prominent member of the Knights of Labour in Auckland, H.W. Farna11. 25 Interest in George's single tax theory was at its peak. ${ }^{26}$ Only weeks earlier Farnall had addressed a Knights of Labour meeting on 'The Industria1 Depression in New Zealand', arguing that the sole cause of depression was land monopoly and the only cure a single tax upon land. ${ }^{27}$ Over the past eighteen months groups promoting the single tax idea, such as the Knights of Labour itself, the Anti-Poverty Society and the Henry George organisation, had sprung up a11 over the colony. ${ }^{28}$ Many of the single taxers were also liberal or union activists. Some were all three. W.M. Bolt of Dunedin, for example, was a prominent liberal and trade union leader, as well as being a freethinker. As far back as 1881 he had spoken to the town's Freethought Association on the subject of 'Land and Labour', drawing

24. See chs. 10-12.

25. Frank Rogers, 'The Single Tax Movement in New Zealand', M.A. thesis, Auckland, 1949, appendix, p. i.

26. On the single tax and Ballance's views on it, see ch. 6, pp. 225-28. 27. H.W. Farnall, The Industrial Depression in New Zealand, Auckland, 1890. 28. Rogers, ch. 3 \& appendix, p. 1 . 
extensively on George's 'Progress and Poverty'. 29

Though the Yeoman had reservations concerning the single tax, in particular it did not approve of the compulsory acquisition of land without compensation being paid and wanted to see other forms of wealth taxed as well, the paper pointed out that public opinion was strongly in favour of a much wider distribution of land. 'The march of events is towards State ownership', it said. ${ }^{30}$ The price of wool and wheat had risen for the first time in years, and exports in 1889 increased significantly from $\$ 7.2$ million in 1888 to 9.0 million. 31 The Yeoman argued that this brighter outlook increased demand for 1 and, so that the class of 'land sharks and speculators' was growing. In other words, the fact that the depression might be lifting made nationalisation more urgent than ever before. Speculators in the Wairarapa, for example, were 'swallowing up' the land whilst the Government 'winked at the most flagrant dummism'. The only solution was to turn out the administration and replace it with a Liberal government intent upon the promotion of bonâ fide settlement. 32

These were Ballance's views. He was in Wanganui at the time and may well have been occupying the editorial chair before returning to Wellington for the start of the new session in June. In May he delivered his first speech to his constituents as Opposition leader.

29. Echo, 20 Aug. 1881 .

30. $\overline{Y, 5}$ Apr. 1890 .

31. G.F.C. Simkin, The Instability of a Dependent Economy, Oxford, 1951, p. 166; 'Statistical Summary of the Colony of New Zealand from 1853 to 1893 Inclusive', Official Year Book, 1894.

32. Y, $5 \mathrm{Apr}$. 1890. Here three articles, reprinted from the Herald of the previous week, were on the land question: 'Single Tax', 'Land-Sharking' and 'Landlordism in New Zealand'. 
He told his audience that he had been reluctant to take on the job because of the adverse effect the extra work and responsibility might have on his health, but had agreed following the Opposition's unanimous request, feeling it his duty to his colleagues. The speech, dominated by land issues, was moderate in tone, in consequence of Ballance's realisation, as the Post remarked, that he was espousing the 'party standpoint', not simply his own. ${ }^{33}$ Thus though he condemned the property tax, he suggested that it might be too early to institute a land and income tax. Instead the property tax ought to be amended by exempting improvements. He also favoured a graduation of the tax. Depression would remain for as long as land was locked up in large estates. Further,
A graduated tax is not only desirable because it will have the effect of bringing a dispersion of these lands among a greater number of people, but it is just because it, enforces a pro- portionate payment of taxation from those who do not pay their proportion through the Customs duties as the less wealthy classes do. 34

In other words a progressive tax was equitable because of the regressive nature of existing indirect taxation.

Ballance's attack on the Atkinson administration centred on the Ministry's failure to promote closer land settlement. Government policy, he said, had led to the aggregation of holdings, and it was to be on these land issues that the coming election would be fought.

33. EP, 8 May 1890. The Post, however, again complained that there was nothing new in what Ballance had said.

34. Y, 17 May 1890, 'Hon. Mr Ballance at the Oddfellows' Hall'. 
Ballance's views on this, and on protection, education and Maori land purchasing were well known to his constituents. A number of new issues had recently arisen, however. First, he welcomed the setting-up of the Sweating Commission, whose report was soon to appear, saying simply that working conditions were of concern to both employers and employees. The question of labour and capital was 'one of those things' which had to be solved. He disapproved of the Railway Commissioners' employment of child labour but made no direct reference to the growing labour movement. 35

Secondly he criticised the Government's appointment of Judge Edwards to the Supreme Court. Edwards had been made Chief Commissioner of the Native Lands Court but had insisted in also being appointed to the Supreme Court, thus securing the higher salary of this latter post ( $\$ 1500$ per annum compared to $\$ 600$ per annum). However the Civil List Act only allowed for the payment of salaries for five judges, and Edwards's appointment brought the total to six. The Government proposed to amend the Act to get around this problem, but Ballance pointed out that though the Government could appoint a new judge it could not simultaneously grant the extra salary, and that an appointment made without first fixing the salary was incomplete and illega1. The 'Edwards Case', as it became known, proved an invaluable stick with which Ballance could beat and discredit the Government. 36

Thirdly, and this went largely unnoticed, Ballance was very firm on the question of further borrowing. People in New Zealand, he

35. Ibid.

36. Ibid.; PD, 1890,67, pp. 14, 190-200\& $307-08$; PD, 1890, 69, pp. 909-10. For press comment at the time of Edwards's appointment see e.g. EP, 14 Mar. 1890. For the resolution of the case see ch. 11, pp. 437-38. 
said, 'were being made slaves of for the sake of standing we11 in the English money market. He believed they should release themselves from these bonds of slavery by simply stopping borrowing on the London market'. Ballance was gravely concerned that dependency on overseas loans would place constraints upon the political actions of a future Liberal government. Radical measures might be hampered by a loss of confidence in London and subsequent outflow of capital from New Zealand. A policy of greater self-reliance would help resolve this problem:

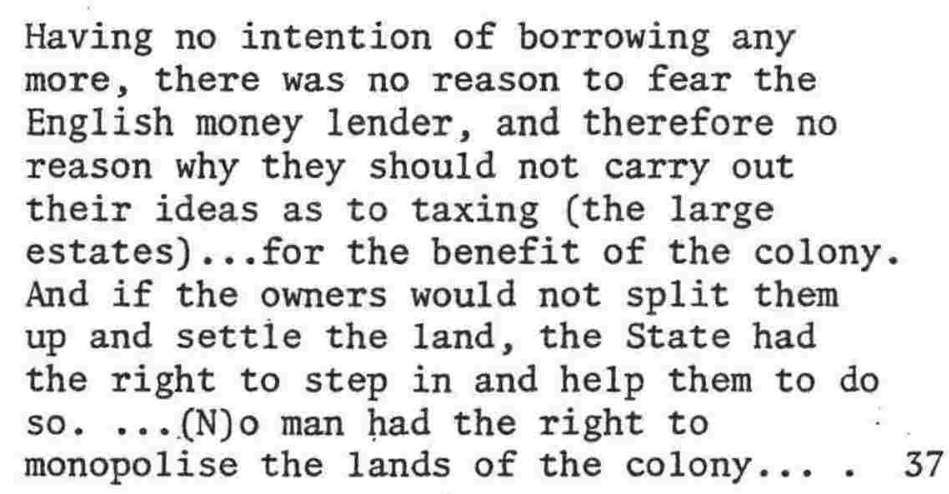

This self-reliant theme was consistent with Ballance's views on federation. Throughout the 1880s the Australian states had been moving towards unification within a federal system, and there was debate in New Zealand as to whether or not to join in. Ballance had always spoken out against the idea, concerned primarily at the loss of independence the colony would inevitably suffer. On the related question of closer links within the British Empire, he saw no sense in Imperial federation without the federation of the constituent parts of the United Kingdom, something it would be exceedingly difficult to achieve : 
...the whole thing is a dream until we get rid of monarchy- until we have a republic... . 38

In January 1890 Ballance was interviewed by the Lyttelton Times on the subject, when he repeated his objections to federation with Australia, seeing no advantage in it for New Zealand trade or defence. He criticised the Australian press, which opposed 'the most reasonable demand of the Irish for 1iberty', for the hollowness of its democratic pretensions :

I...regard the babbling of quasi-Democratic Australians about Federation as aristocratic conspiracy against Democracy- a conspiracy of people who wish to take Young Australia out of the reach of the new methods by which Democracy is going to solve the social problem in 01d England. 39

Ballance viewed Australia as 1ess democratic than England and saw dangers in close connection with it. ${ }^{40}$ Federation would involve the loss of political and economic independence, and democratic advances would be repulsed by conservative interests at supra-national level.

When the new session of Parliament opened the Government was in greater disarray than ever before. Atkinson was seriously ill and had been forbidden by his doctors to speak in the House. ${ }^{41}$

38. PD, $1885,53, \mathrm{pp}, 540-43$.

39. Reprinted in $\mathrm{Y}, 8 \mathrm{Feb}, 1890$, Ballance was interviewed in Wellington. 40. See also PD, 1890,69 , pp. 590-99.

41. Judith Bassett, Sir Harry Atkinson, Auckland, 1975, p. 157. 
Politically he was under strong pressure from his right wing (a group that became known as the 'skinflints') to carry out severe retrenchment. In the country there was increasing frustration at the Government's failure to remedy the depression, and concern at the apparent consequences of this in the form of growing industrial unrest. The report of the Sweating Commission had found that working conditions in New Zealand were little better than in the old Country and recommended the immediate passage of a new Factory Act. Meanwhile the Maritime Council grew both in membership and in its propensity to intervene in labour disputes. In July it became involved in the protracted quarrel between Whitcombe and Tombs and the Canterbury Typographical Association. ${ }^{42}$

In his opening address on 20 June Ballance expressed his surprise that the Governor's Speech had made no mention of recent events. The Government was out of touch, he said, the House no longer represented the people and so an immediate election should be held. However he believed that the labour movement would 'not find itself arrayed permanently against capital'; rather there would be a reconciliation. He blamed the depression and the exodus of population from the colony entirely on a Government land policy that encouraged the accumulation of great estates:

I attach the greatest importance to this question... (because) I think the proper settlement of people on the land- not merely the the alienation of the land in large blocks, but the disposal of it to bonâ fide settlersis the one great means of...restoring prosperity to this colony. 43

42. H. Roth, Trade Unions in New Zealand, Wellington, 1973, pp. 13-14. Sweating Commission report, AJHR, 1890, H-5.

43. PD, 1890,67, p. 10 . See a 1 so $\underline{Y}, 28$ June 1890 on the same theme. 
That same week the Herald, which had earlier in the month published figures to show that in the current year fewer settlers were taking up larger areas of 1and, ${ }^{44}$ told the unions that land nationalisation should be at the head of their programmes. The monopoly of land was a source of conflict, it said, and a 'sin against society'. 45

While Atkinson clung to the premiership, and his Government to power, Ballance hoped to bring the Ministry down so that it would face the country under the stigma of parliamentary defeat. Even before the House reassembled he was in touch with Opposition members concerning an early want of confidence motion. ${ }^{46}$ He moved it on 1 July, demanding a change in the incidence of taxation through the abolition of the primage duty (a temporary tax imposed on all imports) and the amendment of the property tax into a graduated land tax. In a largely tactical move to woo the skinflints in support of the motion Ballance said that further retrenchment was imperative, but that it should, and could, be carried out without adversely affecting the efficiency of the civil service. It was a self-assured speech, albeit in Ballance's dry and 'matter-of-fact' style, roundly condemning Government policy and ineptitude. Yet again he focused upon land reform:

...the big estates and The $_{n}$ estates of absentees in this eolons must be dealt with. We country, cannot overlook this growing evil much longer. ... (T)he question of land-settlement is...the most important of all questions that can possibly affect the present and/future of New Zealand. 47 the

44. $Y, 7$ June 1890 .

45. $\bar{Y}, 21$ June 1890.

46. $\overline{E P}, 13$ June 1890 .

47. $\underline{\text { PD }}, 1890,67$, p. 197 . On the debate see also $\underline{Y}, 5$ July 1890 . 
The motion failed by six votes. The skinflints realised that the only alternative to Atkinson was the radical Ballance, and other members that with the reduction in seats their chances of re-election were dubious, so that it was wise to hold on as long as possible. However as an effective body the Government was finished. A host of bills was presented to the House only to fall at numerous hurdles placed in their path.

Over the following weeks Ballance grew in confidence, in large part because of the political advantage gained through this picture of Government inertness and impotency, against a backdrop of growing dissatisfaction and unrest in the country. With Atkinson incapacitated the Lyttelton Times, after the Wanganui Herald the paper most sympathetic to Ballance, felt able to describe the latter as now 'the best leader in the House'. Following the no confidence debate it wrote:

...his suave, easy debating manner and quiet. air of moderation are merely the mask which covers the command of much debating and tactical talent. ...Mr Ballance speaks in a soft melodious voice, is exceeding (1y) courteous in manner, lacks excitement or much fire, but : is deeply eamest. ...It is plain his speech is logical, and has sequence, argument and continuity. The spectators say a good speech, calm, unimpassioned, without fire, excessively gentleman $1 y$ - these are its characteristics. 48

There was still the possibility, however, of the return of stout. In July a petition was signed by most Opposition members, including Ballance himself, requesting Stout to re-enter politics and it was widely believed, at least by the press, that he would comply. ${ }^{49}$ Yet 
Stout again declined, content to remain in the role of Ballance's chief advisor. ${ }^{50}$ In fact the petition may well have been designed to force Stout to come to a definite and 'public' decision earlier than he might otherwise have done.

The Atkinson Ministry continued in a downward spiral involving what the Herald termed a 'shuffle along, wait awhile...do nothing' policy. 51 Further attempts were made by Ballance to defeat it, usually centring on a motion to reduce the estimates. ${ }^{52}$ Then George Hutchison, from Waitotara, made charges against the Government concerning preferential treatment being given to the Bank of New Zealand by Cabinet members who had large personal overdrafts with the bank. A committee of enquiry was established and though the Government managed eventually to bury the affair, Ballance was able to make some political capital out of their embarrassment. 53

Much more serious for the Government was the Maritime Council's call for a strike, made in the dying days of the session. The strike arose from a dispute between the Australian Maritime Council and the Shipowners' Association concerning the right of marine officers to join a Trades and Labour Council. The Australian conflict spread across the Tasman when the Union Steam Ship Company in New Zealand refused the Maritime Council's request to forego its Australian trade during the dispute, and instead employed non-union labour in its Sydney operations. New Zealand crews immediately walked off their ships and a general seamen's strike was declared on 26 August.

50. Ballance received Stout's assistance, for example, on the drawing up of the no confidence motion, NZH, 2 July 1890.

51. Y, 9 Aug. 1890 .

52. E.g. Y, 26 July 1890,2 Aug, 1890.

53. PD, $1 \overline{8} 90,69$, pp. 197-200. Ballance was one of four opposition members on the committee. Y Y, 9 Aug. 1890 gives a full account of the affair. 
Bodies affiliated to the Council followed suit, with the exception of the railwaymen. The strike lasted until early November, collapsing after failed conciliation conferences and in the face of widespread use by employers of non-union labour. Lack of full support from the railwaymen, and especially general public and press opposition to what was seen as a conflict that originated outside, and need not have involved, New Zealand, were two other major factors. ${ }^{54}$

In determining his attitude to the strike Ballance was careful to take into account public concern at the disruption, disorder and economic costs associated with it. His basic sympathies were with the strikers, in that he recognised the right of working men to organise and to withdraw their labour. He was fiercely critical, for example, of the dismissal by the Railway Commissioners of railwaymen who refused to be used as 'blacklegs' to break the strike, and pointed out that the Commissioners were delighted with the excuse the strike provided to pursue their retrenchment policy. ${ }^{5}$ And he hoped that the unions would not be broken:

I think that the unions are calculated to do good. The union is a protection to the men; it gives them self-respect and in every way is capable of benefiting the employés. 56

On the rights and wrongs of the original dispute, however, Ballance would not be drawn. Though 'there was a great deal' in the union argument, 'he would not profess to say which (side) was right'. 57

54. See Roth, pp. 14-15; and for some press comment, EP, 5 Sept. 1890. 55. PD, $1890,69, \mathrm{pp} .749-50$ \& $810-12$; Y, 27 Sept. $18 \overline{90}$.

56. $\overline{\mathrm{PD}}, 1890,69$, p. 813 .

57. $\underline{Y}, 27$ Sept. 1890 . 
He continually emphasised that strikes were undesirable and would not be necessary if there existed a legal system of conciliation and arbitration. 'I see no difficulty', he said, 'in the way of establishing tribunals to bring the two classes together on the basis of compromise'. ${ }^{58}$ At the same time Ballance was at pains to stress the positive side to unions, and so try to counteract the 'public view' of them as essentially disruptive:

I firmly believe the unions are acting from a true spirit of brotherly feeling, and that they are not to be associated with any disorder. ...I look to the unions to preserve order, and not in any way to break it. ...I think many of the charges against the unions -are false, and I hope nothing will be done to discourage or discredit this great means of education, of preserving self-respect, and which must tend to raise the workingclasses of this country. 59

In his speech at the conclusion of the session Ballance dwelt only lightly on the strike, concentrating instead on attacking the Government's land policy. There had been no attempt to prevent dummyism and the accumulation of large estates, no recognition that closer settlement was the key to prosperity:

The Administration of the land during the last three years has been a total failure. ...There is the greatest possible difficulty in small farmers getting suitable land. Dummyism is an evil, but the greatest evil of a11... is the aggregation of large estates. There are large landowners who are watching for every opportunity of purchasing land from smaller owners... . 60

58. PD, 1890,69, p. 263. See a1so PD, 1890,69, pp. 394-95; Y 30 $\overline{\mathrm{Aug}}$. 1890. Before the strike Ballance had opposed a compulsory system (PD, 1890, 68, pp. 124-25) but he was increasing1y to come round to the view, that for arbitration to be effective rulings would need to be binding.

59. PD, $1890,69, \mathrm{p} .813$.

60. $\overline{\mathrm{PD}}, 1890,69$, p. 961. 


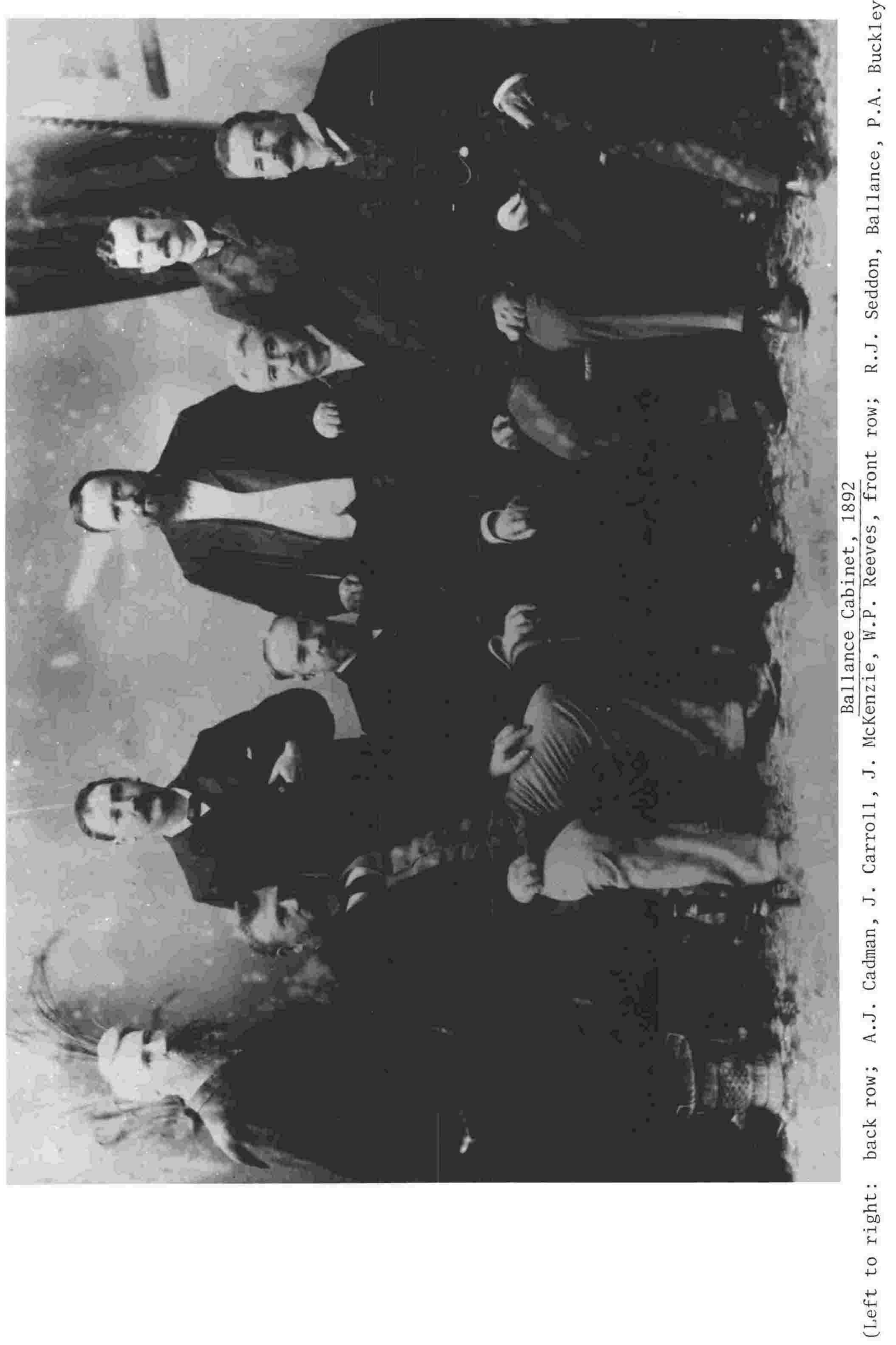


The solution, asserted Ballance in one of his more stirring and impassioned efforts, was to be found in replacing the property tax by a land tax. Significantly, there was no more talk of simply amending the property tax, the means Ballance had been using to soften his radical proposals. Only a graduated land tax, if the wholesale confiscation of land was to be avoided, could deal with the twin evils of absenteeism and monopoly:

...a graduated land tax...is a plank which every Liberal should have as one of the first in his platform. We shall never have true prosperity in this colony- it is impossibleunless the agricultural lands...are occupied by a large population. That must, in my opinion, be the secret of all prosperity. ...The time is rapidly approaching when all difficulties in the way of small settlement must be got rid of, and I believe we must say that no more land shall be disposed of except on perpetual-1ease tenure, so that the remaining lands of the colony shall be held as a heritage for the people. That doctrine may not be palatable to some, but I believe it is a growing doctrine among the people generally. 61

This emphasis upon the land question allowed Ballance to divert attention away from the industrial unrest. The strike was unpopular, and it was increasingly clear that it would ultimately be defeated. Thus politically there was little capital to be made out of it; on the contrary, there was grave danger in being too closely associated with it. So it was not only a long-held view of land monopoly as the fundamental problem in New Zealand, but tactical considerations as well, that led Ballance to concentrate his efforts upon the urgency of closer settlement. 
On 23 September in Wanganui Ballance opened the election campaign. It was more usual for the Premier to do so, but Atkinson's illness ruled this out, and indeed his inactivity during the contest gave Ballance a distinct advantage. ${ }^{62}$ It was expected that the election would take place at the end of October or early November, though the Government delayed the poll until 5 December.

Ballance's speech was carefully prepared. ${ }^{63}$ He attacked the Government over the Edwards affair and Hutchison's charges (see above). On the current labour unrest he sympathised with the unionists, paying particular attention to the plight of the dismissed railwaymen. Many local railwaymen from the workshops and terminal at Aramoho would have been in the audience. A Trades and Labour Union had been formed in Wanganui days earlier, and Ballance was now assuring himself of their support. ${ }^{64}$ It seems safe to assume that almost all unionists would vote for Ballance rather than his opponent, Gilbert Carson, who empathised much less with their cause. Some were active in Ballance's campaign; a inan named Cage, for example, was a member of both the Trades and Labour Union's and Ballance's election committees. Further, as later reminiscences of an old Wanganui citizen indicate, Ballance himself certainly knew where his strength lay. He would 'occasionally (take) ...a walk along the railway line out to Aramoho and Eastown, having a yarn to the men along the track, getting their views, in order to help him in his work. ...It was the support of the (se) two suburbs that elected him narrowly'. 65

62. ODT, 25 Sept. 1890.

63. Y, 27 Sept. 1890. 'Mr Ballance at the Oddfellows' Hall'. 64. $\bar{Y}, 13$ Sept. 1890; WC, 6 Sept. 1890.

65. Wanganui Herald, 28 May 1959. This point is discussed later in the chapter when the Wanganui poll is analysed. 
Yet in his speech Ballance again emphasised that strikes were undesirable, and should be avoided by disputes being referred to arbitration. If this were done he thought that the present strike would be the last the country would see. Above all he saw the question of 1 and monopoly, not of labour versus capital, as the key issue of the coming election. It was the land monopolists who were the priviledged class to be faced by working men, the class to be destroyed by a graduated 1and tax:

As sure as night follows day, so sure will it be found that these estates will be subdivided and disposed of, and for every one man at present there will be ten in the future. 66

This is what Ballance held out: land for the people, a means of self-improvement for the working man and his family.

The programme outlined by Ballance included a land purchasing scheme, based on his Land Acquisition Bill of 1887 (which contained a compulsory purchase clause), along with the graduated tax. He also repeated his belief that no more freehold land should be disposed of by the crown. Though land reform dominated, as the press noted, ${ }^{67}$ his speech contained other proposals. For example on the important issue of retrenchment he said that a Liberal government would not reduce any civil service salaries under $\$ 200$ per

66. Y, 27 Sept. 1890. See also the article entitled 'A Land and Income Tax', 20 Sept. 1890.

67. ODT, 25 Sept. 1890; LT, 24, 26 Sept. 1890; AES, 24 Sept. 1890; EP, 24 Sept. 1890. The Post, which had been reluctant to lend its support to either side, was greatly disturbed by Ballance's suggestion to halt freehold land sales, and now decided that a switch from Atkinson to Ballance would be a step 'out of the frying pan and into the fire'. For local comment on Ballance's speech see $\underline{\text { WC, }} 25$ Sept. 1890 . 
annum; only the higher paid employees would suffer.

The election was a long drawn out affair. Having opened his campaign on 23 September Ballance did not make his final speech until 4 December, on the eve of the poll. Meetings held throughout the constituency echoed the forthrightness and confidence of his maiden effort. ${ }^{68}$ A radical land policy was by far the dominant theme. After that Ballance dwelt equally with the Government's appointment of Judge Edwards, the need to establish tribunals to resolve industrial disputes and reform of the Legislative Council.

When during the past session there had been rumours of new Government appointments to the Council, Ballance had said that no new additions should be made until the total number of councillors fell to under the half the membership of the House, which was what Atkinson had promised in 1887. ${ }^{69}$ Now Ballance also argued that the tenure of office of councillors ought to be reduced from life to seven years. ${ }^{70}$ His fear was that the traditional use of the Council as a brake on reforming legislation would prove a critical block to the radical measures of a new liberal regime. As we shall see this problem was to assume major importance in the early days of his premiership.

The majority of the colony's newspapers declared in favour of Atkinson. Ballance was viewed as distinctly 'dangerous ', 71 and more

68. Ballance spoke at the following venues: Turakina, $\underline{Y}, 4$ Oct. 1890 , 15 Nov. 1890; Mosstown and Forde11, Y, 11 Oct. 1890; Brunswick and Okoia, Y, 18 Oct. 1890; Aramoho, $\underline{Y}, \overline{25}$ Oct. 1890; Taylorville, $\underline{Y}$, 29 Nov. 1890; and St. John's, $Y, \overline{6}$ Dec. 1890.

69. PD, $1890,68, \mathrm{pp} .176-77$.

70. $\bar{Y}, 4,11$ Oct. 1890 .

71. For example ODT, 7 Nov. 1890. The Auckland papers were especially antagonistic to Ballance. 
extreme than other prominent liberals such as Reeves ${ }^{72}$ and Stout. Stout in fact was trying to exert his influence to moderate his more radical friend, and differences between the two men began to appear, and to be commented upon by the press. Though in July Stout had expressed his confidence in Ballance, saying that the Opposition party was 'quite competent to deal with political questions without any suggestions or assistance from him', his subsequent proposal that there should be a renewal of overseas borrowing was embarrassing to Ballance and his declared policy of self-reliance. ${ }^{73}$ Again, the following month, Stout was reported to have sent Ballance a telegram 'expressing strong disapproval' of the Opposition's tactics in trying to defeat the Government through attracting 'skinflint' support for severe retrenchment motions. ${ }^{74}$ Stout's plea that he was only speaking for himself, not the party, ${ }^{75}$ did not make things any easier, for as a prominent and respected leader his opinions carried much weight.

The divergence of opinion between the two came to a head in October, when in a speech at Napier (a long way from his base in Dunedin) Stout declared that the country was not ready for a land and income tax, and that instead change should come about 'gradually and carefully'.76 At the meeting the local liberal candidate proposed a motion calling for Stout's return to politics, but he again declined. This was all very awkward for Ballance. The Herald took the offensive by pointing out how much Stout, who had 'finally made up his mind not to stand', was being praised for his 'cautious words' by the colony's tories. It then reprinted Ballance's end of session speech

72. Sinclair, p. 119 .

73. Y, 19 July 1890; see also WC, 16, 21 July 1890.

74. $\bar{W} C, 12$ Aug. 1890.

75. $\bar{Y}, 19$ July 1890 .

76. $\underline{\underline{Y}}, 1$ Nov. 1890 ; $\underline{\text { WC }}, 23,28$ Oct. 1890 . 
in which he had condemned outright the property tax. ${ }^{77}$

The Herald and its weekly version, the Yeoman, provided Ballance with an invaluable means of publicising his campaign. They regularly and unashamedly churned out Ballance propaganda, and were closely watched by other journals for that reason. ${ }^{78}$ As a journalist and politician Ballance knew well the crucial role the press could play in an electoral contest; and he had in fact just established a newspaper in Stratford called the Settler, which immediately put its weight behind McGuire's attempt to unseat Atkinson. ${ }^{79}$

In Wanganui the Herald followed Ballance's activities day-by-day. It defended him from attacks by other newspapers and expanded and explained points made by him at the many meetings held in and around the town. ${ }^{80}$ It saw the main planks of the liberal platform as follows:

(1) The arrest of the exodus of population by greatly increased facilities for occupying the crown lands.

(2) The compulsory acquisition of agricultural land out of the big estates for small farm settlement.

(3) The nationalisation of the remaining crown lands.

(4) The taxation of 1and, minus improvements.

(5) A graduated tax on the big estates.

77. Y, 8 Nov. 1890 .

78. $\overline{\mathrm{EP}}, 1$ Oct. 1890 .

79. $\overline{W C}, 8$ Aug. 1890. McGuire and George Hutchison each lent $\overline{B a} 1$ lance 150 to set up the paper; Ballance to Barnicoat, 27 Mar. 1893, LB III, p. 488. Ballance appointed C.E. Allsworth as editor, see Ballance to Allsworth, 21 July 1892, LB III, p. 224; Ballance to A1lsworth, 10 Jan. 1893, LB III, p. 409 and Ballance to Allsworth, 29 Mar. 1893, LB III, p. 489.

80. See e.g. 'The Graduated Land Tax', $\underline{Y}, 4$ Oct. 1890, 'The Land Tax', $\underline{Y}, 25$ Oct. 1890 . 
(6) The abolition of taxation on the necessaries of life, which cannot be produced in the colony.

(7) The settlement of labour disputes by means of national tribunals.

(8) The restoration of the pre-emptive right in respect of native lands. 81

With the reduction of members in the new Parliament constituencies had been enlarged. Wanganui now included the surrounding settlements of Forde11, Mosstown, Okoia, Turakina and Brunswick, with nearly one-third more electors than in $1887^{82}$ The Yeoman was careful to explain to the farmers in these outlying areas that they would not be expected to pay both a land and an income tax. Indeed small farmers would be 1iable for a lower amount under the land tax than they currently paid in property tax. 83

The Wanganui contest was fought on national issues. Carson, the editor of the Chronicle and a supporter of Atkinson, was totally opposed to a land and income tax. ${ }^{84}$ The issue was the major source of conflict between the two protagonists. As Young has shown, Carson attracted a much higher proportion of farmers to his meetings than did Ballance, ${ }^{85}$ and his paper voiced their fears. 86

81. From Y, 4 Oct. 1890.

82. In $18 \overline{8} 7$ Wanganui constituency had a population of 6,360 , and there were 1,631 electors on the roll. In 1890 the figures were 8,377 and 2,113 respectively. AJHR, 1887 (sess. II), H-13, 1890 (sess. I), $\mathrm{H}-2$.

83. Y, 29 Nov. 1890 .

84. $\bar{W} C, 15$ Oct. 1890 . Atkinson himself 'promised no extra retrenchment, no new loans, no changes in the tax system, no machinery to avert future strikes. He apparently saw no reason why 1891 should be different from 1889 or $1890^{\prime}$ ', Bassett, p. 160.

85. T.J. Young, 'The Political Career of John Ballance, 1875-1890', M.A. thesis, Victoria University of Wellington, 1964, p. 172. At Carson's opening meeting 15 of his 38 supporters on the platform were farmers; at Ballance's only 4 out of 31 .

86. For example see WC, 27 Nov. 1890 on the effect of a 1 and and income tax on farmers. 
Although he remained in Wanganui Ballance made a serious attempt to coordinate the party's national campaign. He wrote to leading liberals in the main centres advising them on tactics 87 and on occasion put his own weight behind favoured candidates. ${ }^{88}$ He was very concerned at the prospect of vote-splitting in constituencies where there was more than one anti-Government contender, ${ }^{89}$ but had only limited success in persuading people to stand down. Along with Reeves and Hutchison he publicly supported Hogg's selection for the Masterton seat, and was able to pressure the other liberal candidate into withdrawing. 90 However in Timaru the liberal W. Hall-Jones competed against J.M. Twomey, who had labour backing, and in Wairau S.J. Macalister and T.L. Buick both sought to defeat the sitting Government member, A.P. Seymour. Fortunately for Ballance in these instances one of the Opposition candidates was victorious, but the same was not true elsewhere. At Palmerston the conservative J.G. Wilson received 1,055 votes to Pirani's 994 . Pirani may well have been elected had a second opposition candidate, J. Stevens (who polled 396 votes), stood down. 91

The selection of candidates remained a predominantly local affair, and there was often little Ballance could do to sort out squabbles between factions. There were candidates supported by libera1 associations, self-appointed hopefuls with largely personal

87. For example see Rees's retrospective statement on receiving instructions from Ballance concerning the conduct of the Auckland campaign, PD, 1892,76, p. 289. Ballance's letter to Stout (see below) clearly indicates that he was receiving reports on the progress of the election from liberals throughout the country.

88. For example see Ballance's letter to Joyce in Akaroa, LT, 2 Oct. 1890; also WC, 18 Nov. 1890.

89. Ballance to Stout, 17 Nov 1890 , Stout MSS.

90. NZH, 7 Nov. 1890.

91. $\overline{\text { For }}$ the election results see AJHR, 1891 (sess. I), H-2. 
followings, and labour candidates. As Campbell points out many liberals failed to appreciate the growing political ambitions of the trade unionists, with the result that 'amicable relations between Liberals and labour were the exception rather than the rule'.92 For example in Invercargill the lack of diplomacy of the 1iberal, Henry Feldwick, led to the Trades and Labour Union putting up a candidate, who emerged the victor, against him.

Despite these problems Ballance was optimistic. He wrote to Stout on the progress of the campaign in mid-November:

In Wellington we are in a bad way with too many Liberals, \& may only win one seat. ... In Auckland we must gain heavily. Canterbury looks well, \& your account of Otago is very encouraging. This is the greatest organised effort the Liberals have ever put forth, and it will show what they can do against the classes. 93

Of his own election he held great hopes:

The election here is going on as well as possible, my Committee giving me a large majority, but we are not boasting for fear of creating over-confidence. 94

As far as policy was concerned liberal candidates generally followed Ballance in seeing the land question as of paramount importance. Even for those who had union backing, labour reform was often of only secondary concern. 95 H.S. Fish, for example, speaking

92. Campbe11 thesis, p. 34 .

93. Ballance to Stout, 17 Nov. 1890, Stout MSS.

94. Ibid.

95. Campbel1 thesis, pp. 12, 33-34; Sinclair, p. 116. 
on a platform with the other 'labour' candidates in Dunedin, Earnshaw and W. Hutchison, declared that 'upon the proper settlement of...(the land) question in the new parliament would depend in very great measure the future success or non-success, of this beautiful colony of ours'. Every class depended upon the closer settlement of the 1and, he said. 96 Finally, that the working class in particular had a great deal to gain, in this respect, from a liberal victory, was stressed by the Yeoman in its last editorial before the poll. 'One of the first duties of a Liberal administration', it promised, 'would be to introduce legislation to provide land for the location of the working classes':

The purchase of land near to towns where there are no Crown lands, and the settlement of it in small areas so as to give every man a chance of acquiring a homestead, is necessary to restore prosperity and retain our population. 97

The outcome of the Wanganui poll was for Ballance a little too close for comfort. The first return, from Fordel1, gave him a lead of fourteen, and was followed by a narrow win at Mosstown which brought his majority over Carson to sixteen. Then came a shock, for Ballance was defeated at the main Court House booth by seven votes. The remaining results were anxiously awaited; Ballance was reported to have fainted three times during the evening. ${ }^{98}$ Aramoho gave him an overwhelming victory, and was to prove critical, his overall majority being gradually whittled down to just twenty-seven votes,

96. ODT, 8 Nov. 1890 .

97. Y, 29 Nov. 1890 .

98. $\bar{W} . K$. Howitt, A Pioneer Looks Back Again, Auckland, 1947, p. 264. 
following defeats at Turakina, Okoia and Brunswick:

\begin{tabular}{lrrr} 
& Ballance & Carson \\
\cline { 2 - 2 } & & & 40 \\
Forde11 & 54 & 23 \\
Mosstown & 25 & 549 \\
Court House & 542 & 30 \\
Aramoho & 95 & 31 \\
Okoia & 20 & 76 & \\
Turakina & 44 & $\underline{32}$ & \\
Brunswick & $\underline{781}$ & 99 \\
& $\underline{808}$ & $\underline{78}$ &
\end{tabular}

The small farmers of the surrounding district were clearly unconvinced by Ballance's argument that his closer land settlement policy would favour them, and not only the landless in the town. Ballance fared worst in Okoia, Turakina and Brunswick, where the proportion of electors designating themselves as farmers or settlers was highest. 100 They were new to the enlarged constituency and their hostility to Ballance explains in part his poor showing in 1890 compared to the election held three years earlier. ${ }^{101}$ As well as this, however, the sizeable town vote for Carson indicates that many professionals, businessmen and shopkeepers must also have been unhappy with Ballance. The votes of some employers were doubtless lost through Ballance's greater sympathy for the strikers, despite the fact that he stressed the need for a mechanism that would resolve disputes before the withdrawal of labour. The turnout was down by ten per cent compared to 1887 and an over-confident Ballance campaign might have resulted in his supporters, rather than Carson's, remaining at home. What is certain is that Ballance drew his main strength from

99. $\mathrm{Y}, 13$ Dec. 1890 .

100. Analysis of Wanganui Electoral Roll of 1890 . The proportion of electors describing themselves as farmers or settlers was approximately as follows: Okoia $52 \%$, Turakina $40 \%$, Brunswick $65 \%$, Fordel1 28\%, Mosstown 30\%, Aramoho 23\%.

101. Young, p. 178 , calculates that $19 \%$ of electors in 1890 were farmers, compared to $11 \%$ in 1887 . 
the working class. Nearly two-thirds of the electors at Aramoho were labourers or artisans, ${ }^{102}$ and here Ballance received seventy per cent of the vote.

Yet this was hardly new. In 1887 Ballance had attracted even greater support for his land reform programme; with well over eight hundred out of thirteen hundred votes in a more unambiguously 'urban' constituency he must have carried the bulk of the working class. Since then his position had weakened, and it seems safe to assume that he had lost business support, rather than that of labourers and artisans. The 'new' issue of the election, the labour question, can be held partly responsible. If anything Ballance won in 1890 despite the strike, not because of it.

However it remains true that differences between Ballance and Carson during the Wanganui campaign centered around land; and that Ballance won primarily on a programme of radical land reform aimed at broad racher than sectional support. He had written to Joyce:

With respect to what is known as 'labour candidates', I think that the people generally will make a mistake if they are led away by a cry of that kind. What is wanted is a broad Liberal programme, which will protect the rights of labour and promote wholesome reforms of every description. A member of Parliament ought not to be a mere delegate from a particular class, but should be a representative pledged to principles. This kind of representative will do more good for the working-classes than a one-idea'd man sent up to Wellington to speak by the card... . 103

102. In the 1890 Electoral Poll, 51 out of 81 Aramoho electors identified were labourers or artisans.

103. Ballance to Joyce, 27 Sept. 1890, published in LT, 2 Oct, 1890. The letter was later quoted by Fisher in the House, PD, 1892, 76, p. 617 . 
Elsewhere in the country the results were more pleasing. Although Atkinson improved on his 1887 majority (ironic considering Ballance's poor showing and subsequent events), Government candidates in general fared badly. Most devastating was the Opposition victory in the major centres, and particularly significant the success of the labour candidates. All three seats in both Dunedin and Christchurch had been captured, and two out of the three in Wellington and Auckland. The closest contests were to be found in the country towns, where a number of liberals achieved narrow but crucial wins. Ballance's majority had been twenty-seven; next door in Waitotara Hutchison clung on by twenty-two. A.W. Hogg took Masterton by eighteen, and E.M. Smith New Plymouth by only twenty-three. In the South Island Opposition candidates won by more convincing margins, for example Buick by over seventy at Wairau, Ha11-Jones by fifty-two at Timaru, and $\mathrm{T}$. Duncan by nearly five hundred at Oamaru. ${ }^{104}$

The Herald declared that there had never been 'so decided a victory gained by the Liberal party on clear and defined principles. There is absolutely no doubt whatever that the Government have sustained a smashing defeat'.105 In fact though it was true that the Ministry was now in a minority, it was not immediately clear that Ballance could form an alternative administration. A number of independents, most with 'liberal' leanings, had yet to declare their loyalties. 106 In Wanganui the Chronicle optimistically argued that the Government had actually been victorious, since al1 ministers but one had been returned. 107 In Wellington the Post gave Ballance only

104. AJHR, 1891 (sess. I), H-2.

105. Y, 13 Dec. 1890 .

106. Crook, pp. 128-29.

107. WC, 6 Dec. 1890 . 
twenty-eight seats, wel1 short of a majority. ${ }^{108}$

Within a few days however, the prospect of a Ballance administration was held to be greater. ${ }^{109}$ Atkinson clung on, advice 'pouring in from all sides' as to how Ballance might be kept from office. ${ }^{110}$ In an interview the Premier said that though the election had gone badly he was not sure that the Opposition had a majority, and was certain that not all of them were followers of Ballance. 111

Whilst the Cabinet planned their strategy in Wellington, Ballance spoke from his Wanganui home of his confidence in being able to form a ministry. He pointed to his agreement with Atkinson, signed in August with the object of avoiding an extra session, whereby the Government. promised to resign immediately if the outcome of the election were clear. ${ }^{112}$ Ballance said that there could be no doubt about the result. Stout and Buckley hurried to Wanganui to advise him on the construction of a Cábinet. ${ }^{113}$ Although Stout later said that Ballance himself selected the Ministry, and that it was formed in January, not December, this early consultation was clearly decisive. ${ }^{114}$ The Otago Daily Times suggested a Ballance Cabinet including Buckley (Attorney-Genera1), Seddon (Mines), McKenzie (Lands) and also Cadman, Perceval or Reeves. ${ }^{115}$ It was to prove a very accurate prediction.

108. EP, 6 Dec. 1890.

109. $\overline{W C}, 9$ Dec. 1890 ; ODT, 8 Dec. 1890; NZT, 9 Dec. 1890.

110. Bassett, p. 163.

111. WC, 8 Dec. 1890.

112. $\overline{\mathrm{NZT}}, 11 \mathrm{Dec} .1890$, interview with Ballance. On the agreement see Y, 27 Sept. 1890, 13 Dec. 1890; EP, 9 Dec. 1890.

113. $\overline{\mathrm{EP}}, 11 \mathrm{Dec} .1890$; ODT, 12 Dec. $1 \overline{890}$; Fisher's statement, PD, 1892 , $\overline{76}$, pp. 178-79.

114. PD, 1893,79, p. 107 .

115. ODT, 12 Dec. 1890 ; also NZT, 13 Dec. 1890. 
Meanwhile, though there was some talk of a reconstructed ministry under Rolleston, ${ }^{116}$ Atkinson decided to face the new House on 23 January himself. His resignation was imminent, but the delay allowed the Government to pack the Legislative Council with conservatives intent on blocking any future radical legislation, a plan that had the full support of the Governor, Lord Onslow. 117 'It will...be a serious disaster if the Council is not strengthened before the Reds get into the saddle...', Hall had written to Ormond in mid-December. ${ }^{118}$ The question of new appointments to the Council had arisen during the election, and when seven names (including that of Atkinson himself), approved of by the Governor on 20 January, were announced when Parliament met three days later, there was little surprise. 119

In fact Atkinson's ploy proved much more trouble than it was worth, for by the time the appointments were gazetted Ballance had made out a very strong case against them. Weeks earlier he had presented Onslow with a persuasive list of reasons as to why new appointments would be unconstitutional. First, they would be contrary to the wishes of the people, for Atkinson had been rejected at the general election. Second, as the leader of a minority ministry, Atkinson had no right to nominate new councillors. Third, the election had shown a majority in favour of reform of the Council and so nothing should be done until Parliament met. Fourth, the appointments ought not to be made since the number of councillors was still greater than thirty-five, the size Atkinson had promised to

116. EP, 23 Dec. 1890; NZT, 19 Jan. 1891.

117. Bassett, p. 164 .

118. Ha11 to Ormond, 15 Dec. 1890 , Hall Letter Book, p. 236.

119. See AJHR, 1891 (sess. I), A-1a. 
retrench to in 1887. Finally, in a neat point, Ballance said that Atkinson's claim to recommend the appointments as the right of an outgoing ministry contradicted his persistent refusal to admit defeat. 120

The force of these arguments was widely recognised, even by those who were otherwise unsympathetic to Ballance. ${ }^{121}$ Rolleston realised too late that the creation of 'such a batch of Peers' could gravely damage the fight against 'Neo-Radicalism Pseudo- Liberalism and socialist violence. ${ }^{122}$. It was a serious tactical error, for Onslow's approval of the appointments not only strengthened the case for reform of the Council, but also brought into question the position of the Governor himself. 'We cannot believe', said the Yeoman,

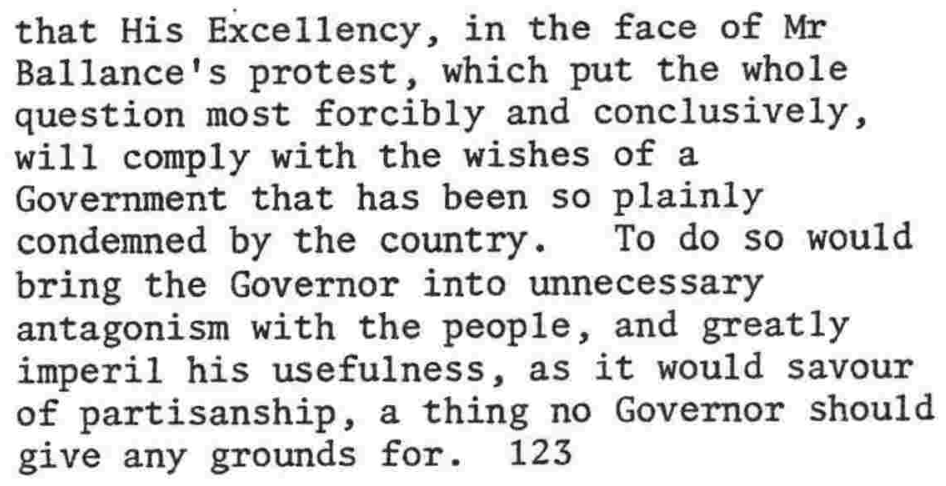

Fina11y, the short term consequence was to discredit Atkinson's Ministry, and to push liberal independents over to Ballance.

Debate on the role of the Council and the Governor continued over the next eighteen months. As we shall see, it was a godsend for

120. Y, 27 Dec. 1890 ; EP, 23 Dec. 1890.

121. For example EP, 16 Dec. 1890, $17 \mathrm{Jan} .1891$; NZT, 19 Dec. 1890. 122. W. Rolleston to J. Hall, 9 Jan. 1891, Hall MS $\bar{S}$, folder 173.

123. Y, 24 Jan. 1891 . 
Ballance, for he was able to pose the issue in terms of 'democracy' versus 'privilege'; and his personal battle with these conservative institutions, in which he was victorious, played a crucial part in consolidating support behind his regime.

The Opposition caucus met in Wellington on the evening before the opening of Parliament. There were thirty members present, with eight others said to be accounted for, and they unanimously elected Ballance to the chair. The meeting gave him a free rein in choosing his Cabinet, selected Major Steward as their nomination for Speaker, and formed a committee to draw up a further petition against the Council appointments. In a short speech Ballance said that it was the first occasion when a 'solid and united Liberal party had been constituted on clearly defined harty $_{\text {lines': }}$

Their business would be the sinking of individual ambitions for the good of the party and to work as a party for the happiness and good of the country as a whole. This would be the best reply that could be made to the ridiculous charge that they were a set of revolutionists anxious only to tear down, burn and destroy. 124

The following day the Government nominee for Speaker, William Rolleston, was beaten by thirty-six votes to twenty-nine by Steward. Mitchelson then announced Atkinson's resignation. ${ }^{125}$ Next Ballance stood up and said, deadpan and with 'not a trace of triumph' in his voice, that he was in the process of forming a Ministry. ${ }^{126} \mathrm{He}$ was we11 prepared since most of its personnel had been chosen a 
month ago. Within twenty-four hours of the Government's resignation a new Cabinet had been sworn in. ${ }^{127}$

Though caucus had given him a free hand in picking his Cabinet, Ballance had to be careful to select a team that could command the confidence of both the party and the House. Important political and geographical factions within the party had to be represented; and it was implicit that Ballance's carte-blanche, which in any case was 'granted' after the major portfolios had been allocated, must take into account these considerations.

Like Atkinson, Ballance reserved for himself the Treasury and Trade and Customs, but added Native Affairs. The Wellington lawyer, Patrick Buckley, who with Stout had closely conferred with Ballance following the election victory, became Attorney-General and Colonial Secretary, and represented the Government in the Council. The young William Pember Reeves, recognised as 'one of the coming men of the colony', ${ }^{128}$ was appointed Minister of Education and Minister of Justice. Reeves had a legal background, but was also, like Ballance, a journalist, becoming editor of the Lyttelton Times in 1889. First elected for a Christchurch seat in 1887 he had just been returned, with labour support, at the top of the pol1. ${ }^{129}$ A liberal of longer standing, Richard Seddon, received the Public Works, Mines and Defence portfolios. 
Seddon, whose power base lay with the miners of the rugged West Coast, had known Ballance since 1876. ${ }^{130}$ The other important posts, Lands, Immigration and Agriculture, went to John McKenzie, an Otago farmer who had been in the House since 1881. His appointment to the crucial Lands portfolio was particularly pleasing to the Yeoman. 'He is a farmer', it wrote, 'knows the wants of the farmers, and the tricks of the land sharks and monopolists'. ${ }^{131}$ There were two other members, Joseph Ward, an Invercargill businessman, was Minister without portfolio but soon became Postmaster-General. A.J. Cadman (Thames), whose claims had been pressed by the Te Aroha News, ${ }^{132}$ took on Stamp Duties.

The strength of Ballance's Cabinet was just the first surprise for those who had a11 along questioned his ability to form a stable Government. ${ }^{133}$ The presence of the South Islanders, Reeves, Ward, McKenzie and Seddon, helped remove one of Ballance's weaknesses, that outside the North Island he was relatively unknown, as well as admitting to the fact that it was in the South that the Liberal victory had been secured. ${ }^{134}$ Auckland was represented by Cadman and Wellington by Buckley. Politically Reeves would help secure the support of the new labour faction. Finally, having an active farmer as Minister for Lands would be an advantage when the sensitive question of a land tax came up.

The general impression was that Ballance had selected men of considerable talent, even if most of them were untried in administrative

130. G.H. Scholefield (ed.), A Dictionary of New Zealand Biography, Wellington, 1940, vol. I I, p. 281 .

131. Y, 31 Jan. 1891 .

132. $\overline{E P}, 8$ Jan. 1891.

133. For example EP, 6 Dec. 1890; NZH, 9 Dec. 1890.

134. Ballance's party won a majority of South Island seats, but a minority of those in the North Island. 
ability. The apparent speed and ease with which he had secured a combination that seemed likely to satisfy the main factions within the party was also noted. ${ }^{135}$ If there were doubts expressed they tended to centre on the choice of Seddon, who had a reputation for 'uncouthness' and as an 'obstructionist' in the House. However this tendency to 'talk a great deal' could, as the Post pointed out, be put to useful effect by the Ministry. ${ }^{136}$ In any case Seddon was experienced, and a leading member of the party. His inclusion in the Cabinet made too much sense to be seriously questioned by any persona1 'defects'.

There was undoubtedly a strong feeling at the time that the December election, and now Ballance's Cabinet, marked a distinct break with the past. These were new men: aside from Ballance only Buckley had any ministerial experience. Reeves and Ward were only in their early thirties. Ballance was the first Premier whose background could be described as decidedly lower-middle class, and only Reeves had had a secondary education. ${ }^{137}$

Ballance's mild nature and temperament would largely determine his approach to the premiership, and indeed would have an important say in his degree of success at holding together the forceful personalities of his colleagues. Commentators were already pointing out how his personal style would also see a change from the past:

Mr Ballance may not perhaps be as good a driver as his predecessor. He will use other means than those of the bullockpuncher to ensure progress, and although

135. EP, 26 Jan. 1891; ODT, 26 Jan. 1891, 7 Feb. 1891 (supplement); Y, 31 Jan. 1891. 
he may require an equally large hat as Sir Harry Atkinson is wont to wear, there can be no doubt that his boots will be found several sizes smaller and destitute of the hobnails which have now became (sic) historic. 138

Politically the Cabinet was the most radical the country had seen, and a fair reflection of the forces that had overthrown the 'continuous ministry'. If Ballance's populist appeal had only partially succeeded, in that support from businessmen and especially farmers was shown to be limited, the basis for the alliance survived. What frightened conservatives at the prospect of Ballance in power was his land policy. And it was believed that an attempt to 'burst up the land', not the carrying out of labour reforms, would be the cause of his ultimate demise. ${ }^{139}$ This chapter has argued not that the labour question and trade unions played unimportant roles in the liberal victory, but that the most contentious issue between the two sides concerned the land tax and nationalisation. 'It is not my policy to sacrifice the public estate', said Ballance, the day after announcing his Ministry. ${ }^{140}$ Instead the state was to lease 1 and on easy terms to the working class. He promised to attack absentees, those who blocked opportunities for upward social mobility; the 'public enemies' who were 'standing in the way of progress'. 141 .

138. EP, 26 Jan. 1891.

139. $\overline{\mathrm{EP}}, 23$ Jan. 1891.

140. $\overline{\mathrm{PD}}, 1891,70, \mathrm{p} .39$.

141. $\bar{Y}, 17$ Jan. 1891 . 
CHAPTER TEN

New Zealand for New Zealanders:

self-reliance and nationalism 
It was largely because Ballance's Ministry was an unknown quantity that there were doubts concerning its ability to survive. It was not clear just how radical it would prove to be, and whether or not Ballance would be able to retain control over the forces that had brought him to power. He was not regarded as a strong leader:

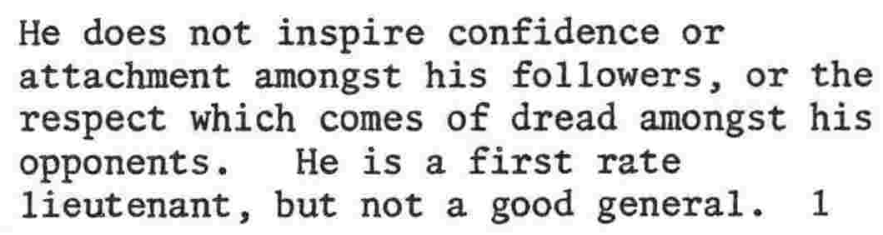

However the Post was willing to concede that it was really a matter of Ballance being untried. He had not shown leadership potential, it said, but there was 'a strong suspicion' that as Premier he would 'surprise expectation and develop qualities of practical steadiness with which he has not hitherto been credited by many'.

This prediction turned out to be quite correct. Displaying those personal characteristics and qualities that the situation demanded Ballance had, within two years, established a Liberal regime that was to remain in power for twenty years. The next two chapters look at this 'transformation' from 'unpredictable and dangerous' radical to successful statesman. The first outlines the Government's main measures, especially those concerning 1and, and discusses reaction to them. What emerges is a distinctly nationalist policy

1. EP, 3 Jan. 1891.

2. $\underline{\underline{E P}}, 26$ Jan. 1891. 
of 'self-reliance'. Chapter eleven then considers the consolidation of the regime, involving at times a compromise between Ballance's ideals and practical necessity.

Despite heavy rain there was a large crowd at the railway station to greet Ballance on his triumphal return to Wanganui on 12 February 1891. At a banquet that evening he received the congratulations of local dignitaries, and then briefly spoke of his Government's proposed legislative programme. He promised a radical change in the incidence of taxation, the taxation of large estates and the conservation of crown land. A return he had just requested indicated that there were on1y 2.8 million acres of crown land remaining for settlement, not 3.8 million acres as had been believed. Thus the Government would purchase land for small farm settlement and, at the same time, institute a system of perpetual leasing of Maori land. Secondly, it would draw up a bill to establish boards for the 'reconciliation of Labour and Capital', so that strikes 'could not occur'. Finally he confirmed that overseas borrowing would cease. 3

Whilst Ballance and his Cabinet began work on the details of these proposals the Government received a fillip in the form of a by-election victory at Egmont. The seat had been vacated by Atkinson, now in the Legislative Council, and in a close contest Felix McGuire,

3. Y, $21 \mathrm{Feb} .1891$; EP, $13 \mathrm{Feb} .1891$. McKenzie and Reeves were aiso present at the banquet, the latter making a big hit with a witty and well-delivered speech. 
Atkinson's opponent at the past two elections, defeated the conservative R.C. Bruce. ${ }^{4}$ It underscored the outcome of the general election and, coming so early on in the Government's life, was a valuable and encouraging win. Ballance believed that it 'had a marked effect in strengthening the hands of the Government throughout the country'.5

There was a number of major problems associated with Ballance's plans for radical land reform. With respect to the conservation of crown land, though he personally favoured the complete prohibition of freehold sales, Ballance recognised that it would be difficult to get such a measure through the House. Therefore he intended that as a first step the proposed Land Bill would insist upon improvement and residence conditions being fulfilled before the granting of freehold tit1e. ${ }^{6}$ In the meantime McKenzie tightened up the regulations concerning special settlements by revoking the right to convert leaseholds into freeholds. McKenzie said that the aim was to 'prevent associations selling their allotments, as soon as improvement conditions are complied with, thereby frustrating the object of association to get (closer) settlement'. ${ }^{7}$ He also announced that the Government was to institute proceedings against a Wairarapa landowner named Coleman Phillips, who was accused of dummyism. ${ }^{8}$

4. Y, 7 Feb. 1891; EP, 18 Feb. 1891. Bruce had been defeated by Hutchison for Waitotara at the general election.

5. Ballance to w.C. Smith, 2 Apr. 1891, LB II, p. 127.

6. Ballance to $W$. Tanner, 14 Mar. 1891, LB II, p. 87.

7. $Y, 28$ Mar. 1891.

8. $\quad \bar{Y}, 7$ Mar. 1891. Following lengthy proceedings Phillips 'escaped with a caution'. In 1896 he put himself forward as candidate for Wairarapa, and his 'spirited defence of the liquor traffic, his sweeping attacks on the clergy and his doubts about the wisdom of votes for women years after it had become an actuality' enlivened a dull campaign until his nomination was rejected by the returning officer. See A.G. Bagnall, Wairarapa. An Historical Excursion, Masterton, 1976, pp. 285-286, 319-20. 
The land tax was to face a number of obstacles. It would not, so Vogel advised Ballance, 'be sufficiently productive even if added to the income tax and it would deter the investment of foreign capital, which the colony has hitherto so much depended on'.9 The first concern, that the land and income taxes would raise less revenue than the property tax, proved unfounded: in 1889 the property tax had brought in $\$ 354,000$; for the year ended 31 March 1893 the 1 and and income taxes raised $\$ 374,000.10$ However related to this was an inconsistency in the objectives of the land tax. Ballance had long argued that it aimed to break up the large estates as well as raise revenue, yet if large holdings were subdivided the revenue from a graduated tax on them would fa11. Although Ballance knew of this problem ${ }^{11}$ he never tackled it, mainly because he died before any 'disintegrating' effects of the tax could be felt. And as the following chapter shows, by 1892 the Government was in a healthy financial position. Any concern at the consequences for revenue of the change in taxation quickly evaporated.

More worrying for Ballance was the suggestion that a graduated tax might 'scare' capital away from New Zealand. As we shall soon see his reaction to this was to pursue a 'self-reliant' policy involving minimal dependence upon overseas funds.

Though parts of the Government's legislative programme had been hinted at in advance, ${ }^{12}$ Ballance's Financial Statement was eagerly

9. Voge1 to Ballance, $30 \mathrm{Jan}$. 1891, BMSS, 57.

10. Official Year Book, 1894, p. 250. See appendix C, table 2.

11. See G.L. Peacocke to Ballance, 27 Oct. 1891, BMSS, 327-29.

12. Noticeably in the Herald. See Y, 11 Apr. 1891, 16 May 1891. Scobie MacKenzie said that from reading the Herald he knew of the Government's intentions at least two weeks before the statement, PD, 1891,71, p. 239. 
awaited. When it came, early in the new session, Ballance announced a package of major reforms. The property tax was to be abolished and replaced by 1 and and income taxes. The land tax, of one penny in the pound, would grant exemption on improvements up to $\mathbf{£ 3 , 0 0 0}$ in value, and 1 and up to $\$ 500$ would be tax-free. Mortgages would be deducted from the taxable value, and the tax paid instead by the mortgagee. There would also be a graduated tax on land valued at more than $\$ 5,000$, rising from $1 \frac{1}{8} \mathrm{~d}$., to $1 \frac{5}{8} \mathrm{~d}$. in the pound on land over $\$ 100,000$. The income tax, of one shilling in the pound, would commence on salaries over $\$ 300$. Companies were to be taxed at the same rate (on profits), though with no exemption. Other proposals included the complete cessation of overseas borrowing, the reduction of postal charges to a uniform 'penny post', retrenchment and reorganisation of the civil service, and the establishment of a new 'labour bureau' to collect statistics on unemployment and help the unemployed find work. There was a small surplus from the past year, which would be used to pay off the 1888 deficit and to compensate for the lower postal rate. Finally, $\$ 30,000$ was to be spent in the coming year on opening up land for settlement. 13

The House discussed the Statement over the following weeks. Bryce, now Opposition leader, praised Ballance's candour, but said that the retrenchment would be a sham, and that the new tax would scare capital from the country, an accusation made by many other conservatives. ${ }^{14}$ Scobie MacKenzie, adding to a reputation as an able and entertaining speaker, argued that the Budget would not, and

13. PD, 1891, 71, pp. 57-69; Y, 20, 27 June 1891.

14. $\overline{\mathrm{PD}}, 1891,71, \mathrm{pp} .177-83$. 
was not intended to, pass. He noted that there was no mention of the promised absentee tax. ${ }^{15}$ Members also complained of the practical difficulties in assessing and collecting the taxes, and of the problem of fraud.

The 'great debate' came to a close on 10 July when, 'at 7.30 , with crowded galleries and benches', Ballance rose to deliver what some thought 'one of the best and most statesmanlike speeches' ever heard in the House. ${ }^{16}$ He said that the land tax was a matter of justice, in making the large landowners pay their fair share of taxation, and that the effect of this would be the disintegration of their estates. Thus the tax aimed to promote closer settlement, and was much more than simply a fiscal measure. He quoted the English economist, Newman, in explaining why the land question was the cornerstone of the Government's whole programme:

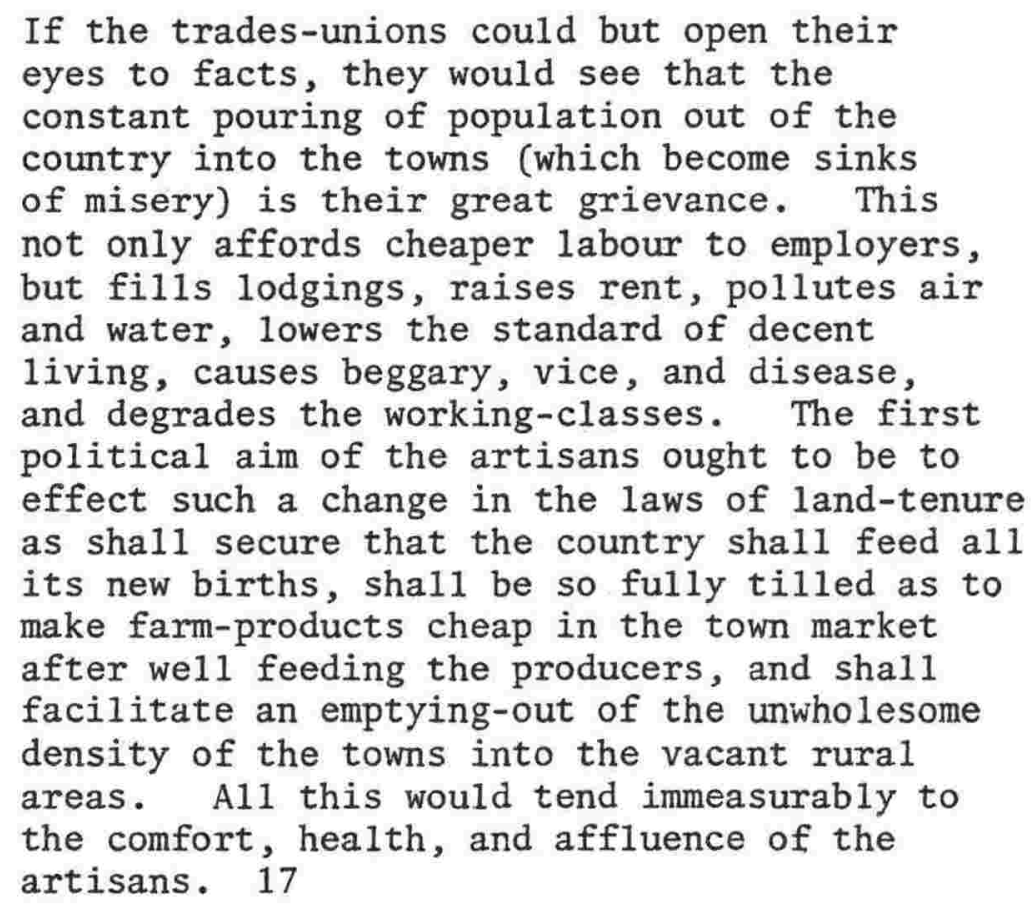

15. Ibid., pp. 239-45. See pp. 398-99.

16. EP, 11 July 1891; Y, 18 July 1891.

17. $\overline{\mathrm{PD}}, 1891,72$, p. $12 \overline{7}$. 
This was exactly Ballance's view. Closer settlement was the cure for the colony's current ills, in particular the continuing high level of unemployment, urban poverty and the exodus of population overseas. 'Now', he remarked, 'will honourable members deny that the first plank in the Liberal programme should be the land-question?'. ${ }^{18}$ Finally, Ballance disputed that capital would leave the country, as Scobie MacKenzie ('that great economist, that gentleman of lofty principles, a walking dictionary of phrase and fable') and others had predicted. If the 'dangerous' and 'suicidal' policy of borrowing was halted and confidence restored to New Zealand, he said, there would be ample investment in the country, particularly in the small farms now relieved by the exemptions. 19

Shortly after this Ballance suffered the first attack of an illness eventually diagnosed as cancer of the bowe1. ${ }^{20}$ Rumours abounded that he would, because of ill health, appoint himself Agent-General in London, to replace Sir Francis Dillon Bell who was soon due to retire. ${ }^{21}$ The notion that Ballance might also be desperate to desert the sinking Government ship was eagerly played upon by the conservative press, whilst being flatly denied by the Herald and Ballance himself. 22 In fact though Buckley's claims to the job were being pressed upon him, ${ }^{23}$ Ballance had already decided to appoint Westby Brook Perceval. It is almost certain that when constructing his Cabinet Ballance wavered between Perceval and Reeves, and that he selected the latter on the understanding that Perceval

18. Ibid.

19. Ibid., pp. 126, 128-29.

20. Spinks Diary, 30 July 1891, 1, 7 Aug. 1891.

21. EP, 6, 10 Aug. 1891, 14 Sept. 1891.

22. $\bar{Y}, 22,28$ Aug. 1891, 19 Sept. 1891; EP, 13 Aug. 1891.

23. Buckley to Ballance, 13 Aug. 1891, BMSS, 254; E.T. Gillon to Ballance, 22 Aug. 1891, BMSS, 264. 
would go to London when the post of Agent-General became available. ${ }^{24}$ It was an important job and there was considerable opposition to Perceval's appointment on the grounds of his relative youth (he was thirty-seven) and political inexperience; that he would be 'a babe and suckling compared with Sir Julius Vogel or Sir Dillon Bell'. 25 Perceval was, however, very able, confident, and socially 'presentable' (the Post described him as 'a very nice young man of the class supposed to especially adorn small tea parties'). Ballance clearly believed him to be well equipped for the vital task of countering the damaging effects of reports being received in London of the Government's radical and 'socialistic' measures. 26 In any event Ballance had never any intention of taking the job on himself. Yet even after the announcement of Perceval's appointing ${ }^{27}$ there were still allegations that it was only a temporary posting, to allow Ballance time to 'complete arrangements to abandon political life and go Home'. 28

In early August Ballance briefly introduced the Land and Income Assessment Bill, which set up the machinery for the new system of taxation. Fighting his complaint he was, as Hansard records, 'frequently inaudible in the gallery'. He stressed that the graduated tax was not merely aimed at raising revenue, but also at breaking up the large estates, so directing capital into smaller units

24. EP, 21 Aug. 1891.

25. Ibid.

26. Raewyn Dalziel, The Origins of New Zealand Diplomacy: the Agent-Genera1 in London 1870-1905, Wellington, 1975, pp. 149-50. Perceval made a good early impression, $\underline{Y}, 6$ Feb. 1892 .

27. PD, 1891, 74, pp. 620-21.

28. $\overline{\mathrm{EP}}, 15$ Sept. 1891. On criticism of the Government's treatment of Be11 see EP, 20 Nov. 1891. 
and thus encouraging closer settlement. ${ }^{29}$

The effects of his illness were still apparent when he replied, two weeks later, to the debate on the Bill. 30 Despite this

hindrance, he made perhaps the finest speech of his career. He

answered charges that his radical programme would scare capital

from the country and thus wreck havoc with the economy by turning

from defence to attack, essentially making a virtue of self-reliance

out of the necessity:

...I will tell (you) ... what our policy

means. It is a policy I have long had

at heart. It is a policy of New Zealand

for New-Zealanders. And, Sir, I have not

much regard for the speculator. I am not

much concerned for those gentlemen who are

always talking about sending capital out of

the country, and who send their sons to the

Argentine Republic, and who are continually

shaking the dust of poor New Zealand from

the soles of their feet and leaving it

altogether. ....Every man should be hardened up to this conclusion: that our policy

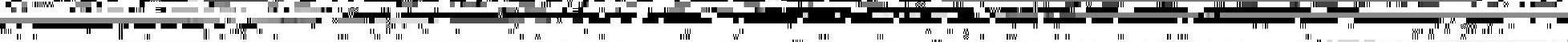

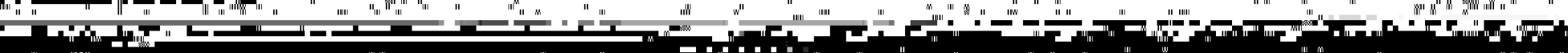
| " 
Having counter-attacked on 'foreign' opposition to the Government's policy, Ballance went on to repeat his fundamental belief in what he saw as the key to the country's prosperity:

...I say that the State should own all
land. I believe in the nationalisation
of the land. I say that the State should
not part with a single acre more of its
land, for I believe thoroughly in land-
nationalisation. ... (I) firmly believe that
the greatest, if not the sole, cause of the
intense poverty which prevails in old
countries is...the way in which the lands
of those countries are held. I believe in
that most emphatically... I believe pauperism
and poverty depend upon the state of the
land-1aws of any country. Are we to build
up a system of great landlordism similar to
that which prevails in the Old Country, with
these facts staring us in face?. ... We must
face the problem, and decide that the land
must be held by the people. ... I have every
confidence in the future of New Zealand.
Some honourable gentlemen are full of
despair. My confidence is as great as
honourable gentlemen's despair... . 32

There was ambiguity in these sentiments, in that Ballance was not making it clear whether he believed that the State should, and could, purchase all land in private hands, or that only remaining crown land should be 'nationalised' by halting further sales. The first of these options was a tall order, not least because of political opposition to it and the problem of where the money for the re-purchasing was to come from. Ballance had recognised this in his pamphlet on land nationalisation, arguing that state 'resumption' of land should be a gradual process, should begin with the large estates, and should be carried out as the prejudice for the freehold waned and the demand for the leasehold rose. 33

32. Ibid., pp. 373 \& 374.

33. Ballance, A National Land Policy, Wellington, 1887, p. 18. 
Undoubtedly Ballance saw the impracticality of wholesale nationalisation: his references to it were aimed at retaining the support of the urban radicals on the left wing of the Party. In his opening speech at the 1890 election he gave an indication of what he realistically hoped might be achieved. Then he said that there should be no further sales of crown land, and that the large estates should be either subdivided through the operation of the graduated tax, or purchased by the state. ${ }^{34}$ As we sha11 shortly see, however, even the limited aim of retaining remaining crown land in the hands of the state was to prove unattainable.

The Land and Income Assessment Bill passed by the sizable majority of fifteen. As a supply measure it could not be opposed by the Legislative Council. The Act was to come into force on 1 April 1892 and the property tax was reimposed until that time. ${ }^{35}$ Vaiuations made for the purpose of the property tax would form the basis of Government calculations as to how much revenue the land and income tax might bring in.

Meanwhile the Ministry was running into stiff opposition over its Land Bill. As we have seen Ballance accepted that at the present it would be difficult to get a complete prohibition of freehold sales through the House; instead the Bill placed strict improvement and resident conditions on cash purchases. As before land could be bought on deferred payment. The most significant change was that the Act would deny holders of the perpetual lease (the tenure introduced by Rolleston in 1882) the right to acquire 
the freehold. Ballance was resolute on this, and when the Council inserted an optional purchase clause into the Bill, he insisted that the whole measure be dropped and re-introduced in the following session. It was reported that McKenzie was willing to accept the amendment; ${ }^{36}$ at the same time the press praised the Council for halting the measure regarded as the 'thin edge of the wedge of Land Nationalisation'. ${ }^{37}$ Ballance was adamant, pointing out that a genuine perpetual leasing system was basic to the Government's programme, and threatening to go to the country over the issue. 'We could not surrender to another House', he said. 'They do not represent the people. We represent the people. We stand firm on this question'. 38

It was not only the Land Bill that fell in the Upper House, for in the 1891 session the Council ravaged Government legislation on an unprecedented scale. ${ }^{39}$ Twelve bills were either vetoed outright, or lapsed following the failure of reconciliation committees of both Houses. Labour bills were particularly vulnerable (for example the Shop Hours and Workmen's Lien bills) but the Council also threw out the Payment to Members Bill, which Ballance regarded as one of the Government's and Liberal party's principal measures. ${ }^{40}$ Speaking during the debate on the Bill he argued that the realistic remuneration was not only vital to democracy, enabling the working class majority to be fairly represented, but was the right of public men. 'I know of no man more entitled to receive the respect of the

36. NZH, 24 Oct. 1891; see also PD, 1891,74, p. 881 .

37. $\overline{E P}, 23$ Sept. 1891.

38. $\overline{\mathrm{PD}}, 1891,74, \mathrm{p} .875$.

39. $\bar{Y}, 26$ Sept. 1891; W.K. Jackson, The New Zealand Legislative Council: a study of the establishment, failure and abolition of an Upper House, Dunedin, 1972, ch. 10.

40. Ballance to Hildreth, 24 Aug. 1891, LB II, p. 361; Ballance to Parr, 24 Aug. 1891, LB II, p. 363. 
community, no man who renders more valuable service to his fellow-men', he said, 'than the public man who honestly applies himself to politics'. ${ }^{41}$ Two private members' bills, Grey's Friendly Societies Bill and Hall's Female Suffrage Bill, which had much support from the Government benches, were also killed in the Council.

Ballance knew that the Council would somehow have to be tamed if his Government was to make any significant legislative progress. Yet he did not support a Bill moved by William Rees in late July, which would have cancelled the Atkinson appointments. He agreed with Rees that the appointments were morally wrong and technically unconstitutional, but argued that once the Governor had made them, the councillors could not then be impeached. ${ }^{42}$ The Bill failed to. pass by a narrow margin.

In fact Ballance had decided on a different approach. He successfully introduced a Bill to reduce the tenure of councillors from life to seven years, a reform that had been prominent in the party's election campaign, saying that it would result in a more Liberal upper house in the future. A high turnover of councillors would allow new governments to appoint sufficient members to ensure the passage of legislation, and would also keep Liberal members (who Ballance observed, too often became conservative) on their toes. ${ }^{43}$

41. PD, 1891,74, p. 515; a1so see PD, 1891,73 , pp. 463-65.

42. $\overline{\mathrm{PD}}, 1891,72, \mathrm{p} .426$. See also Ballance to Onslow, 13 Aug. 1891, $\overline{\mathrm{LB}}$ II, 349-50. The Colonial Office essentially absolved Onslow in accepting the advice of the Government to make the appointments, but not Atkinson in giving it, Knutsford to Onslow, 11 April 1891 in AJHR, 1891 (sess. II), A-2.

43. PD, 1891,74, pp. 176-78, 187-89. See also $\underline{Y}, 27$ June 1891; Onslow to Ballance, 10 July 1891, BMSS, 212. 
The Bill did not, however, affect the tenure of existing councillors (a fact which helps explain its acceptance by the upper house), and so did not resolve the immediate problem. The next and much more difficult step, would be to insist that the Governor agree to appoint a new batch of Ballance's own nominees. The belief that the Council ought to be much more representative of public opinion was widely held, 44 and on 16 February 1892 Ballance requested Onslow to sanction eighteen further members. 45

The Council's opposition to the Government's land legislation (it would almost certainly have blocked the land tax if that had been constitutionally possible), foreshadowed more widespread criticism. A major problem with both the land tax and the move away from freehold tenure, concerned the vital matter of the availability and cost of credit. Land in New Zealand was traditionally heavily mortgaged; mortgaged often as the sole means of effecting those improvements necessary to make it productive in the first instance. Though the general tax was paid by the mortgagee, there were fears that the borrower would soon suffer through higher interest rates. Money for improvements, in other words, and the cost of existing mortgages, would become more expensive. Further, the graduated tax on the landowners and the tax on improvements over $\{3,000$, would force loan companies to $100 \mathrm{k}$ elsewhere for more profitable and secure investment. Capital, it was argued, would leave the country. The London Times went so far as to predict that the whole mortgage system on larger estates in New Zealand would come to an end. ${ }^{46}$

44. For example People of Wellington to Ballance, 4 Sept. 1891, BMSS, 281.

45. AJHR, 1893, A-7a, p. 13. See ch. 11, pp. 428-35 \& 460-63, for the outcome.

46. Times, 9 Nov. 1891. 
Equally, Ballance's attempts to deny the freehold option to lessees posed credit problems for small farmers, for it was very difficult to borrow money using only a leasehold as security. Finance for improvements, particularly crucial in the North Island where much land had still to be cleared, was thus generally unobtainable from the private sector. The alternative was for the state to advance sums to settlers. ${ }^{47}$

Reasons for Ballance's failure to acknowledge the full extent of this problem are discussed in the following chapter (see pp. 446-48). In the meantime it is sufficient to point out that he hoped that the necessary finance could be raised internally, and had an Act passed enabling the Government, through loans to local bodies, to provide money for the opening up of the land. However with the maximum fixed at $£ 50,000$ per annum this was just scratching the surface. ${ }^{48}$

The press throughout New Zealand and in London quickly joined conservative politicians in their cry that the Government's radical measures would drive capital from the country. It was not a new charge for Ballance to have to deal with, for precisely the same had been said of his land tax introduced by the Grey Government. The Herald at the time had insisted that as the tax would encourage closer settlement and thus promote prosperity, the credit of the colony could only be enhanced. 49

47. See ch. 10 of the excellent thesis by M.R. Stenson, 'The Origins of the Government Advances to Settlers Act, 1894', Auckland, 1962 .

48. PD, 1891,73 , pp. 402-03, 408-09.

49. $\overline{\mathrm{WH}}, 20$ Sept. 1879. 
Unfortunately, as in 1878, the 1891 tax came just when economic conditions were worsening. The Baring crisis of 1890 had led many English investors to withdraw their deposits from the colony, and over the next few years credit contracted. Farmers were also hit by a new fall in export prices, whilst unemployment rose and conditions in the towns remained bad. 50 In 1891 emigration exceeded immigration by more than three thousand, the greatest population loss since $1888 .^{51}$

In February 1892 Vogel wrote to Ballance from London, consoling him by saying that some funds would have left irrespective of the tax. 52 Over the past months there had been numerous reports of foreign mortgage companies withdrawing or intending to withdraw their capital from the colony. ${ }^{53}$ At the same time financial journals in London such as the Times and the Economist had published articles critical of the land and income taxes. ${ }^{54}$ Ballance asserted that these were inaccurate and misinformed, and that they originated from within the colony. 55 He was probably correct: 'Some expression of alarm from your side of the ocean, and a reported disposition to withdraw capital, might do good', Sir John Hall had written to Richard 0liver in early 1891.56 Finally, Ballance pointed out that bank deposits in New Zealand had risen, not fallen, over the past year. ${ }^{57}$

50. C.G.F. Simkin, The Instability of a Dependent Economy, Oxford, 1951 , pp. 166-67.

51. Official Year Book, 1894, statistical summary.

52. Vogel to Ballance, $19 \mathrm{Feb}$. 1892, bound as a pamphlet in the Turnbull Library.

53. Y, 7, 28 Nov. 1891, 20 Feb. 1892.

54. $\bar{W}$. Kennaway to Ballance, 12 Nov. 1891, BMSS, 353-55; Perceval to Ballance, 24 Dec. 1891, BMSS, 423-29.

55. PD, 1892,75, p. 133.

56. $\mathrm{Ha} 11$ to Oliver, $1 \mathrm{Feb} .1891$, Hall MSS.

57. PD, 1892,76, p. 483. The following were the official figures for New Zealand bank deposits: year ended March 1889 : 10.9 million 
Rightly or wrongly, Government policy was being blamed for an apparent loss of confidence in the New Zealand economy. The action of the loan companies did not surprise Ballance: 'I never supposed they would take kindly to the New Zealand Self Reliant Policy', he wrote back to Vogel. But he was also aware of the limitations to such a policy:

The assertion of our independence is, of course, subject to many qualifications: We are not independent of the London Money Market, and I am not sure whether we shal1 be for a generation, if so soon, but what I have been preaching and trying to aim at has been to get rid of that servile dependence which has so long operated, in my opinion, to our disadvantage. 58

Aside from worries over the general land and graduated taxes, particular 'fright' was taken over the taxes on absentees and debentures. The absentee tax was not part of Ballance's original programme, since he believed that the graduated tax would be sufficient to force absentees to either develop, or subdivide and se11, their properties. Instead it had been insisted upon by the Opposition, partly as a means to 'outbid' and embarrass the Government. 59 In any event it was being misinterpreted in London, as Perceval, the Agent-General, reported:

It is most difficult to get people here to understand that this tax applies to land only and it is I fear doing no little harm. I have always advocated an absentee land tax but it brings in so 1 ittle revenue $\&$ is so irritating, that I am sorry it was put in the bil1. I quite see your difficulty in altering it now. People are refusing to lend

58. Ballance to Vogel, 19 May 1892, LB II, pp. 730-33. 59. PD, 1891, 73, pp. 370-71. 
money to N.Z. in any capacity giving the absentee tax as their reason. ...I believe the absentee tax has done more to create this furore against the land act than anything e1se. 60

The problem with debentures involved double-taxation. The way the system operated was that companies borrowed funds in overseas markets (in the form of debentures or bonds) and re-1ent them at higher interest on mortgage within the colony. Under the Act the companies were taxed as mortgagors, as we11 as their debenture holders being penalised. This has been pointed out to Ballance, and he had also been told that in London it was seen as a direct attack on foreign bond holders. ${ }^{61}$ He considered the matter in early 1892 and decided to remove the income tax on foreign debentures, one of a number of changes made in the 1892 Act amending the Land and Income Assessment Act of the previous year. ${ }^{62}$

The Government's taxation proposals were not, of course, without grass roots support, and Ballance received many letters congratulating him on his reforms. Some believed that they did not go far enough: for examp1e the Otago Protection League, whilst welcoming Ballance's 'Libera1 \& progressive policy', wanted to see changes in the tariff. ${ }^{63}$ The Wellington Knights of Labour complained that there had been no significant change in the incidence of taxation, since duties on basic necessities remained una1tered. ${ }^{64}$ In Auckland the Knights of Labour and the Anti-Poverty Society passed identical resolutions against any exemptions at a11 to the land tax. ${ }^{65}$ Exemptions reduced the revenue

60. Perceva1 to Ballance, 12 May 1892, BMSS, 583-88.

61. Perceval to Ballance, 24 Dec. 1891 , BMSS, 426.

62. Ballance to Perceval, 24 Mar. 1892, LB II, p. 663.

63. See the League's resolution contained in $W$. Hutchison to Ballance, 9 July 1891, BMSS, 210-11.

64. EP, 16 July 1891.

65. Knights of Labour to Ballance, 23 May 1891, BMSS, 172; Anti-Poverty Society to Ballance, 15 June 1891, BMSS, 185 . 


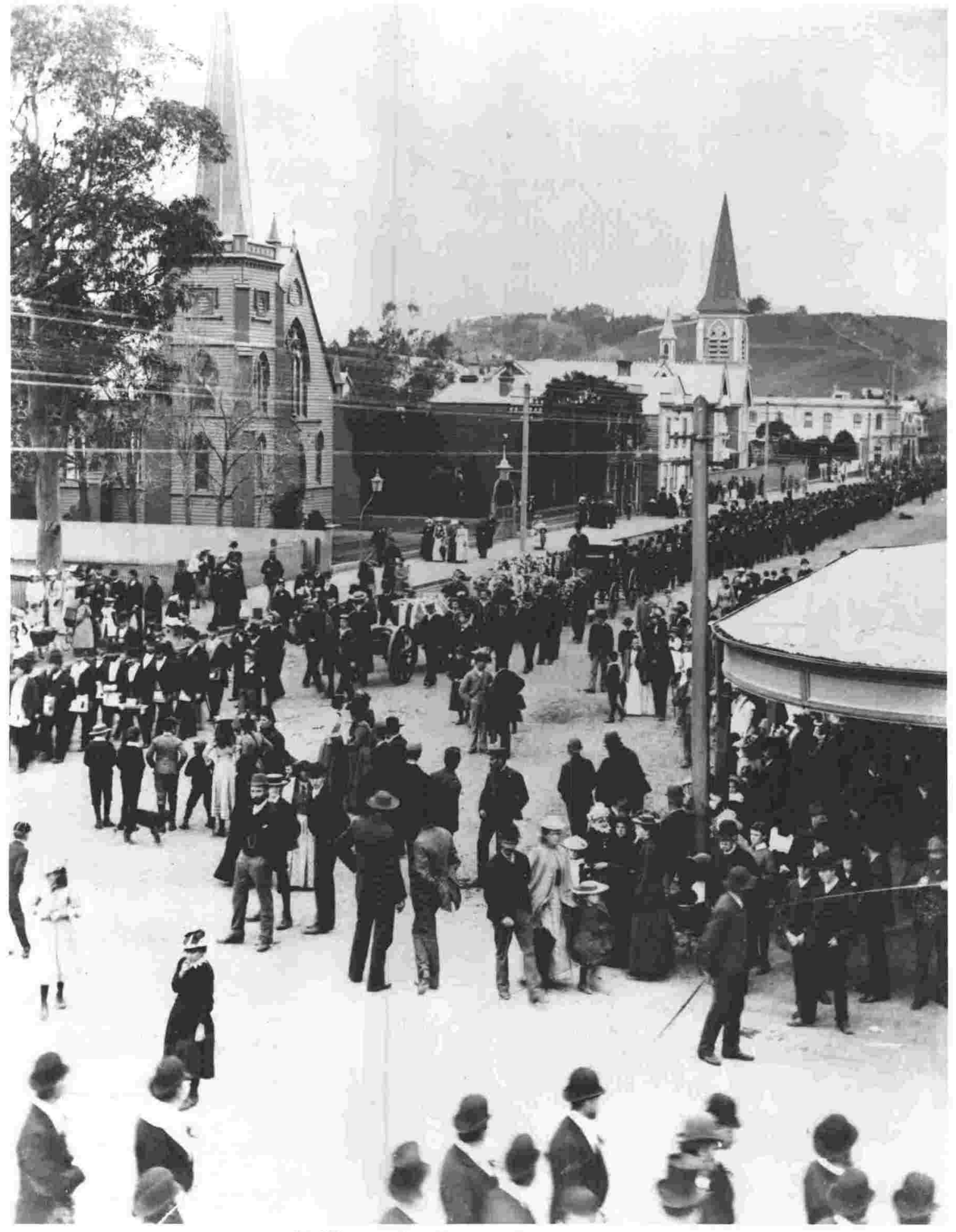

Ballance's Funeral, April 1893 
that could be raised and were anathema to those organisations sympathetic to George's 'single tax'.

Although Ballance wanted to see both the duty on basic necessities removed and protection given to local industry, he was concerned at the effect changes would have on lowering government revenue. 66 And he argued that in the meantime his taxation proposals afforded relief to the working classes. ${ }^{67}$ On the question of exemptions, to abolish them entirely would harm the sma11 farmers Baliance wished to encourage. ${ }^{68}$

In formulating his policy, therefore, Ballance had to try and meet the wishes of supporters and sympathisers, as well as defuse alarm amongst opponents. The Christchurch liberal member, W.C. Walker, believed that Ballance had at least achieved the former. The Financial Statement, he wrote, was 'bold enough for the extreme men and ought to satisfy the country constituencies who at all events in the South are cautious enough'; although personally he would have liked to 'have seen capitalist money lenders subjected to as much progressive duty as landowners'. ${ }^{69}$ Some in Auckland, however, were not so sure. A self-confessed follower of Ballance, on the staff of the New Zealand Herald, wrote that though the paper generally supported the Government (which was quite untrue), ${ }^{70}$ it was nervous about changes in taxation driving capital 'still further' out of the country:

66. See ch. 11, pp, 449-50.

67. PD, 1891, 72, pp. 119-20.

68. $\overline{\mathrm{PD}}, 1891,73, \mathrm{p} .100$.

69. W.C. Walker to Ballance, 18 June 1891, BMSS, 187. See also EP, 11 Apr. 1891.

70. See Ballance to Mills, 1 Dec. 1891, LB II, p. 509; Auckland Liberal Association to Ballance, 13 Oct. 1891, BMSS, 323. 


\author{
Capital all over the world is \\ frightened, and it will not be good \\ for New Zealand if it gets abroad that \\ it is about to take the lead in putting \\ in practice wild notions in respect \\ to land nationalisâtion \&cc. 71
}

It was in fact largely Ballance's financial caution that lay behind his willingness to pursue retrenchment. Retrenchment involved reducing civil service salaries and staffing levels, and generally improving departmental efficiency, as well as cutting back government services. It was not a policy of which the liberals could claim a monopoly. Previous governments had often seen it as the main means of dealing with economic depression in genera1, and budget deficits in particular. The need for some retrenchment was widely accepted. Political differences tended to focus upon its extent, and where the cuts should be made.

Early on Ballance had tried to make savings, and to do so without impairing efficiency. The Land and Survey departments, for example, were amalgamated, ${ }^{72}$ the customs office at the Bay of Islands closed down, ${ }^{73}$ and the cost of the country's defence reduced. ${ }^{74}$ However he argued that retrenchment had to be a gradual process. ${ }^{75}$ There was a limit to the savings that could be made, and he was not prepared to affect services seriously. There was also the political problem of retrenching party supporters. Ballance was told that in Nelson, one of only two known Liberals in government departments had

71. W. Berry to Ballance, 18 June 1891 , BMSS, 186.

72. Y, 25 Apr. 1891 .

73. This naturally faced considerable local opposition. See J.R. Moody to Ballance, 5, 7 Mar. 1891, BMSS, 95-103; J. Watkin to Ballance, 7 Mar. 1891, BMSS, 104-07; R.M. Houston to Ballance, 9 Mar. 1891, BMSS, 108-09.

74. EP, 21 Mar. 1891.

75. $\overline{\mathrm{Ba}} 1$ lance to Bond, 20 Apr. 1891, LB II, p. 160. 
been given his notice. ${ }^{76}$ Some suggestions for the amalgamation of posts he turned down. ${ }^{77}$ Further, the Government refused to accept any reductions to their estimates, and had to resort to al1 night sittings in order to get them through the House. ${ }^{78}$ Government expenditure had been cut by $\$ 44,000$, but some salaries retrenched by Atkinson were restored. 79

Linked to the question of retrenchment was reform of the civil service: a more efficient service would be cheaper. From the beginning of his Ministry Ballance had given a commitment to introduce a system of classification of public servants. ${ }^{80}$ A Civil Service Bill was duly presented to the House in 1892. As well as classification it provided for a pension scheme and established a Board to advise the government on changes that ought to be made. ${ }^{81}$ However the Bill did not get beyond a second reading, 'not because of its classification proposals but because of its provision for the compulsory deduction of a proportion of all public servants' salaries for retirement purposes'. 82

$++++++++++$

The 1891 session was characterised not only by the difficulties of getting legislation through the Council, but also by a number of

76. W.T. Bond to Ballance, 27 Apr. 1891, BMSS, 141.

77. C.H. Mills to Ballance, $30 \mathrm{Apr}$. 1891, BMSS, 143-44; Ballance to Mil1s, 20 May 1891, LB II, p. 222.

78. PD, 1891, 74, pp. 723ff.; EP, 21 Sept. 1891.

79. $\overline{\mathrm{PD}}, 1891,74$, p. $1026 ; \underline{Y}, \overline{10}$ Oct. 1891 .

80. $\overline{\mathrm{PD}}, 1891,70$, p. 58 .

81. $\overline{\mathrm{PD}}, 1892,75$, pp. 213-16, 230-32.

82. I.S. Ewing, 'Public Service Reform in New Zealand 1866-1912', M.A. thesis, Auckland, 1979, p. 137. 
highly publicised personal disputes involving Ballance. The first concerned the Dunedin Member, H.S. Fish. Though a self-confessed liberai, Fish had a history of inconsistent political action, for example voting with the free traders on the 1888 tariff. ${ }^{83}$ He had been elected in 1890 with labour support but, having failed to secure a place in Ballance's Cabinet, soon turned against the Government. ${ }^{84}$ Fish's ambitions received another setback when he failed to get elected Chairman of Committees and his personal grudge against Ballance grew still further. ${ }^{85}$ There followed an exchange of letters, with Ballance angry at Fish's 'incessant attacks' on the party, and particularly at one on a '1abour' member, William Earnshaw. ${ }^{86}$ Fish then made this correspondence public, ${ }^{87}$ and intensified his criticism of the Government in speeches during the recess. Although Ballance found it necessary to reply to these charges, Fish was too obviously motivated by personal spite for his actions to receive much support. 88

A second defection from the government benches also involved dashed expectations. George Hutchison, the Member for Waitotara, had been tipped for a Cabinet post, ${ }^{89}$ only to be disappointed. It was soon clear that he also had major political differences with the Government. He opposed the principle of progressive taxation, voting against the Land and Income Assessment Bi11, 90 and supported

83. See Ballance to Stout, 7 July 1888, Stout MSS; EP, 11 Apr. 1891.

84. See W. Earnshaw to Ba1lance, 23 Nov. 1891, BMSS, 388 ; H.S. Fish to Ballance, 23 Jan. 1891, BMSS, 50.

85. For a typical clash in the House, see PD, 1891, 73, p. 551. In Dunedin Fish's wrath was especially turned against Stout.

86. Ballance to Fish, 28 Sept. 1891, LB II, pp. 390-91.

87. EP, 24 Nov. 1891.

88. W. Earnshaw to Ballance, 16 Nov. 1891, BMSS, 360-61; Ballance to Earnshaw, 26 Nov. 1891, LB II, pp. 485-91; D. Pinkerton to Ballance, 16 Nov. 1891, Ballance BMSS, 362-63; Ballance.te Pinkerton, 24 Nov. 1891, LB II, pp. 479-83; Stout to Ballance, 16 Nov. 1891, telegram, Stout MSS, folder 75 .

89. NZT, 13 Dec. 1890.

90. $\underline{\mathrm{PD}}, 1891,73, \mathrm{pp} .173-79,210,361$. 
the Legislative Council amendment to the Land Bill, allowing lessees to become freeholders. 91 The creation of a 'state tenantry' without the option of purchase, he argued, was against the best interests of the colony. 92

Hutchison had been closely associated with Ballance and these were embarrassing criticisms. Representing a country constituency (which adjoined Wanganui town), he was voicing the fears of established, rather than the hopes and needs of prospective, farmers. ${ }^{93}$ By August he had crossed the floor of the House for good. 94 Thereafter he tried to collect around him a new 'middle party', including Fish and Fisher, that in alliance with the Opposition might hope to turn out the Government. 'It is a very old game', Ballance told Stout, 'and its methods will not take us by surprise, but for all that there is an element of danger in it'. 95

Hutchison remained a thorn in Ballance's side, but little more. In April 1892 he brought a libel action against the Premier, During the recess Ballance had alleged, in a speech at Patea, that Hutchison had voted against the Payment of Members Bill having previously indicated to the whips that he would support it. It seems that Hutchison allowed his name to be added to the list of Members in favour of the Bill, although he did not sign the paper

91. PD, 1891, 74, p. 698 .

92. $\bar{Y}, 25$ July 1891. The Yeoman suggested that at the last election Hutchison, 'to secure a large number of votes in the Momohaki district, was compelled to make terms with a large landholder there', and that his support for the freehold option was the outcome of this compact.

93. Y, 30 Apr. 1892 .

94. $\bar{Y}, 22$ Aug. 1891, 'A Lady's Letter'.

95. Ballance to Stout, 20 Nov. 1891, LB II, pp. 457-58. 
himself. Stout defended Ballance at the trial, arguing that there was no libel since Ballance could not be held responsible for the report of his speech printed in the Herald. Ballance won the case on the technical difference between libel and slander. 96

Thirdly, Ballance was involved in an unfortunate clash with the Opposition leader, John Bryce. It came during a debate in the House on charges, laid by McKenzie against his predecessor as Minister of Lands, Richardson, concerning two Otago runs. At one point Bryce queried a ruling of the Speaker, an action Ballance correctly asserted to be a breach of parliamentary procedure. Bryce then said that Ballance 'ought to be ashamed of himself'. Next he refused the Speaker's request to withdraw these words, saying he was prepared to 'take the consequences'. 97 He was subsequent1y censured by the House and resigned in disgust. ${ }^{98}$

The general feeling was that Bryce had over-reacted, behaving 'more like a petulant school boy than as a man posing to be a leader.' 99 The censure had been mild and his resignation, which was used by the Opposition as occasion for attacking the Government, unnecessary. Ballance certainly did not seek it. ${ }^{100}$ The following session Bryce failed to have the censure rescinded. ${ }^{101}$ It was a sad end to what had been a close personal friendship. Ballance told his constituents

96. EP, 6, 7 Apr. 1892, Hutchison, however, brought a new case against Ballance, and a special jury in Wanganui found in the former's favour, Y, $30 \mathrm{Apr} .1892$.

97. PD, 1891, 74, pp. 94-98; EP, 29 Aug. 1891.

98. $\overline{\mathrm{PD}}, 1891,74, \mathrm{pp} .122 \mathrm{ff}$.

99. J. Wilson to Sir W.A. Buller, 10 Sept. 1891, BMSS, 289; also W.A. Buller to Ballance, 16 Sept. 1891, BMSS, 290; EP, 1 Sept. 1891. 100. Y, 5 Sept. 1891 . 101. $\overline{\mathrm{PD}}, 1892,77$, p. 406. 
that he regretted the incident 'more than anything' that had taken place for years. 102

The session that ended in late September was an unsatisfactory one for the Government. Of the seventy new laws only a few were of major importance. The more significant bills had, as we have seen, been rejected by the Council. Despite the fact that the Ministry's position in the House itself was very strong (most divisions being won by at least ten votes), the lasting impression was of an insecure and ineffectual administration. A radical Government had been tamed, at least for the present, by the upper chamber. ${ }^{103}$

At the same time it was clear that the Ballance Ministry would intensify its efforts to overcome the impasse, and that the issues at stake were of major importance. A new regime was fighting for survival, and faced harsh criticism from the press. Ballance's policies were said to be based on 'wild and revolutionary political theories'; ${ }^{104}$ he was accused of making 'indecent' attacks on the Legislative Council, ${ }^{105}$ of scaring capital away from the country, and politicising the civil service by appointing people 'of the right colour'. 106 In Wellington the Evening Post, with an eye to a by-election due in the city early in the new year, was particularly virulent :

102. Y, 10 Oct. 1891. See also PD, $1891,74, \mathrm{p} .1025$. 103. $\overline{E P}, 26$ Sept. 1891. Sixty-five public bills introduced in the House passed whilst eighty were dropped, PD, 1891, 74, p. 1039. 104. EP, 13 Nov. 1891.

105. $\overline{\mathrm{EP}}, 18$ Nov. 1891 .

106. $\overline{\mathrm{EP}}, 9$ Nov. 1891. The 'right colour' was a favourite phrase of $\overline{\mathrm{Ba}}$ llance. 
The Government policy has gone in the direction of land nationalisation: it has assailed the freehold tenure, it has truckled to the masses, it has indicated a tendency to the increase of Protection, it has proposed extreme Radical changes in the Constitution, and has embodied rash experiments of legislation towards the realisations of fads. 107

The Government was every bit as unpopular in Auckland. The New Zealand Herald was 'exceedingly hostile', primarily because, Ballance believed, the financial interests behind the paper (the Bank of New Zealand and Assets Company) were to be affected by the new taxation. 108 As for the city's other paper, the 'reputed Liberal journal', the Evening Star, Ballance was told that it was giving support to the Government 'of very weak-kneed character'. 109

Ballance knew that the party's strength in the House had to be matched by vocal grass roots support if Government policy was to be successfully carried and effectively implemented. In this respect there were two obvious requirements: the conservative bias of the press would need to be counteracted, and a permanent party organisation estab1ished.

In late 1891 Ballance received a number of requests for financial assistance from Government sympathisers planning to establish 
new newspapers. Auckland 1iberals were particularly eager to see a new paper formed, and put forward a scheme involving an initial expenditure of $\$ 100$, ensuring the first three months of publication. It was hoped that the paper, which would be 'moderate' in tone, would attract sufficient advertising to become financially selfsupporting after that date. A previous liberal journal called The Tribune had apparently been so 'violent' and 'revolutionary' as to prove a 'curse instead of a blessing'. ${ }^{110}$ There was also a suggestion of a new publication in Wellington, ${ }^{111}$ but in many smaller towns it was more often a matter of rescuing existing ailing papers. In Hawke's Bay the Napier Evening News was in dire trouble, ${ }^{112}$ and in Gisborne the Standard was for sale. ${ }^{113}$ The depression was hitting what was an over-abundance of local newspapers.

There was not much Ballance could personally do, aside from trying to see that pro-Government journals received their fair share of official 'advertisements', 114 and giving editors the benefit of his journalistic experience. For example he suggested that the Dunedin Globe should reduce its reporting staff and rep1ace 'heavy' editorials with 'bright and racy' short paragraphs. The paper's expenses ought not to exceed $\mathbf{f} 40$ per week (they were perhaps twice that amount), and Ballance argued that this could be done without cutting wages. There was plenty of editorial talent in the country, he said, and given this, success depended instead on good management:

110. H.S. Rees to Ballance, 14 Nov. 1891, BMSS, 359; Ballance to J. Adams, 3 Nov. 1891, LB II, p. 406.

111. J.J. Smith to Ballance, 5 Oct. 1891, BMSS, 320-21; Ballance to J.J. Smith, 13 Oct. 1891, LB II, p. 401.

112. J.T.M. Hornsby to Ballance, 22 Sept. 1891, BMSS, 295. On the News's support for Ballance, see ch. 8, p. 337.

113. W.E. Akroyd to Ballance, 16 Oct. 1891, BMSS, 324. See also, on the plight of Woodville's Examiner, E.A. Haggan to Ballance, 23 Mar. 1892, BMSS, 557.

114. See, e.g., D. Pinkerton to Ballance, 7 Nov. 1891; BMSS, 346; Ballance to Pinkerton, 10 Nov. 1891, LB II, p. 424. Some argued that they got more than their 'fair share'. 
No one has seen more of the internal

workings of struggling papers than

myself, and I have come to the conclusion

that failure in nearly every case is the

result of incompetency on the part of the

man in control. 115

The p1ight of the press came up in Cabinet discussions, ${ }^{116}$ but

as far as the immediate problem was concerned, so many requests for assistance had been received that Ballance was forced to pursue a policy of turning them a11 down. 117

Ballance's frustration at being unable to provide financial support emphasised the more fundamental need to establish some form of national Liberal organisation. By November he was taking steps to set up a 'Liberal Federation', sending out circulars to prominent Liberal politicians to canvass their support. The Federation aimed to be 'an effective organisation of the whole liberal forces of the Colony':

The Federation has been called into existence really for the purpose of providing funds to assist our people in fighting elections etc, etc, without which I have seen great difficulty in keeping the party together, more especially in presence of the fact that the other side are vigorously organising and contributing 1iberally to a fund for the purpose of securing a Tory majority at the next elections. We propose to engage an organising Secretary at an adequate salary, say 250 a year, with

115. Ballance to A.L. Smith, 18 Nov. 1891, LB II, pp. 447-49. The Globe did not survive: 'I fear the Globe will not pull through - there is no business talent upon the paper, \& it wd be a pity to give it money unless it cd be placed on its feet', Ballance to Stout, 6 June 1892 , Stout MSS.

116. J.T.M. Hornsby to Bailance, 25 Nov. 1891, BMSS, 396. Hornsby had received letters from Ballance and Seddon which intimated that the matter of the press in Hawke's Bay was to be discussed at a forthcoming Cabinet meeting.

117. Ballance to Hornsby, 20 Nov. 1891, LB II, p. 460; Ballance to Rees, 20 Nov. 1891, LB II, p. 461. 
travelling expenses. ...The success of the organisation will depend to some extent upon the activity of local committees, and the assistance which they may be able to give the secretary when he visits the districts. 118

The local leaders were asked to ascertain the potential party membership in their area. Existing organisations could simply affiliate to the new Federation. They would still select candidates, the Federation then providing financial and other assistance.

In organising the Federation Ballance would have had the English precedent in mind. A National Liberal Federation had been established by Chamberlain in Birmingham in 1877 . Its influence reached a high point in October 1891 with the Newcastle conference, which passed a number of resolutions that became official party policy. 119

For Ballance the New Zealand Federation was vital to the Government's survival. Throughout the month he worked hard to set the organisation upon a sound footing. ${ }^{120}$ He had proposed a federation at least as far back as May, but not until after the session could he devote time to the project. Originally he had hoped to appoint Thomas Bracken as organiser. Significantly, Bracken had a background not dissimilar to that of Ballance. He was a

118. Ballance to Jackson, Palmer, Mil1s, Pinkerton, 13 Nov. 1891, LB II, pp. 432-35; Ballance to Fraser, 14 Nov. 1891, LB II, pp. 437-38.

119. See D.A. Hamer, Liberal Politics in the Age of Gladstone and Rosebery, Oxford, 1972, pp. 46, 173-74.

120. E.g. Ballance to Mills, 26 Nov. 1891, LB II, p. 498. 
protestant Irishman who favoured home rule. Settling in Dunedin in 1869 he became a journalist and newspaper owner, and then entered politics as a Greyite. He failed to get elected to Parliament in 1879, but won two years later with the support of the Trades and Labour Council. Retiring in 1887 he next tried to make a living as a poet. ${ }^{121}$ It was in large part his financial insecurity that led him to turn down Ballance's offer, for he seems to have regarded the post as a risky venture. ${ }^{122}$ In any case he had soon left the colony for Australia. 123

The job eventually went to the Member for Wairau, Thomas Buick. 124 It was a typical Ballance appointment of a bright, 'up and coming' young man. In his mid-twenties, Buick had a working class background and with labour support had gained his first parliamentary seat in 1890. A great believer in self-reliance he was also, like Bracken, an advocate of home rule. He was later a government whip but, falling out with Seddon, left politics in 1896 and became a journalist and historian. ${ }^{125}$

Buick's salary, and other necessary finance, was to come initially from personal donations and then also from annual subscriptions. Ballance told those seeking assistance for 'liberal' newspapers that funds would be available if the Federation succeeded. ${ }^{126}$ He said that their needs had played a major part in his decision to

121. G.H. Scholefield (ed.), A Dictionary of New Zealand Biography, vo1. 1, We11ington, 1940, pp. 84-87.

122. T. Bracken to Ballance, 7 May 1891, BMSS, 156.

123. Ballance to Bracken, 25 Nov. 1891, LB II, p. 495.

124. Ballance to Buick, 13 Nov. 1891, LB II, p. 436.

125. Scholefield, p. 117.

126. Ballance to Hornsby, 20 Nov. 1891, LB II, p. 460; Ballance to Rees, 20 Nov. 1891, LB II, p. 461. 
form an organisation in the first place. 'We must have money', he wrote to Stout,

the demands that are coming in are enough to frighten any one out of his senses. You never saw anything like itfrom all parts for assistance. Were it not for the hopes of the Federation I should be in the depths of despair. 127

Such hints of Ballance being at times overwhelmed by the task ahead were to become more frequent. Lapses in confidence and spe1ls of depression developed, and were undoubtedly related to the progression of his illness.

During the recess Ballance went on what amounted to a nationwide 'crusade' to defend Government policy (in particular the land and income taxes), and at the same time promote the new Federation. It was his first, and last, major 'stump' of the country. Buick simultaneously began his own tour to organise local party committees. ${ }^{128}$

In October Ballance had delivered his regular post-sessional address in Wanganui. He explained the defections from the party in terms of the disappointment those concerned felt at not being included in his Cabinet. With respect to the progress made during the session, he pointed out how much legislation had been destroyed by the Council. Finally, he told of the formation of the new 'Labour Bureau', which aimed to move unemployed men to parts of the colony where they could find work. ${ }^{129}$ Already jobs for 927 of the 
1,561 persons registered had been found. 'It is the duty of the Government to see that the people are employed', he concluded:

The wealth of every State must be measured by the prosperity of the great mass of the people, and if there is a large number of people weltering in poverty and misery, that country is not well governed. It is all very well to measure our conduct by the practice, usages, and experiences of old countries, but I say we are in a new country (and) we are laying the foundation of a new nation... . 130

Ballance's stump proper began when he travelled to the South Island. ${ }^{131}$ He spoke briefly (and for the first time) in Christchurch, at a banquet to W.B. Perceval, who was due to depart for London as Agent-Genera1. 132 It was Ballance's subsequent speech in Dunedin, however, that was significant. There he affirmed that the Government's new Land Bill would not permit the granting of freehold title to a perpetual lease. ${ }^{133}$ He would make no concessions on what some saw as 'the cardinal point of the Ministerial policy'. His Minister for Lands, however, was known to be more flexible. 134 Secondly, Ballance made public the Government's intention to appoint new members to the Legislative Council before the start of the next session. This would facilitate the passage of the Ministry's measures, and of the Land Bill in particular.

By 1 November Ballance was back in Wellington, on his way north. ${ }^{135}$

130. Y, 10 Oct. 1891; also EP, 8, 9 0ct. 1891 . 131. Spinks Diary, 14 Oct. $1 \overline{891}$. 132. Y, 24 Oct. 1891; EP, 6 Nov. 1891.

133. $\bar{Y}, 24$ Oct. 1891. The Yeoman was incorrect in implying that the new Bill would have only one form of tenure. There were in fact to be three, as Ballance later stressed: cash sales, deferred payment, and the perpetual lease, Y, 12 Dec. 1891.

134. EP, 21 Oct. 1891.

135. Spinks Diary, 1 Nov. 1891. 
As his tour progressed he appeared to be gaining in confidence. Speaking to the Knights of Labour at Woodville he urged liberals to organise, and said that if the Legislative Council 'persisted in defying the expressed wish of the people' it would have to go. ${ }^{136}$ The Post was horrified:

Representative and Responsible Government is to be replaced by popular convention and the plebiscite. Thought, reflection, and the knowledge which can only be obtained by study and experience, are to be discarded from public affairs, and the hastily expressed voice of the majority, or those who by violence and vociferation represent themselves as such, is to be accepted as an infallible guide and direction by those with whom the duty of administration rests. ...Mr. Ballance is the mouthpiece of the mob.... ...According to him, the multitude must always be right, and those who oppose its demands are enemies of the State. Had Mr. Ballance's lot been cast in Paris a few years ago, he must, with his present views, have embraced the Commune... . 137 .

Returning to Wellington Ballance appeared on a platform to support the Government candidate, McLean, at the forthcoming by-election. He immediately launched an attack on the political bias of the Wellington press, particularly on the Post, which though claiming to be a 'liberal' paper had been calling the Ministry a 'sham and pretence'.138 It found Ballance's assault on the freehold principle especially reprehensible and was supporting the Opposition candidate, H.D. Bell, for the city seat. It regarded Bell as the genuine liberal article. ${ }^{139}$

136. EP, 10 Nov. 1891.

137. $\overline{\mathrm{EP}}, 14$ Nov. 1891.

138. $\overline{\mathrm{EP}}, 4$ Dec. 1891.

139. For example EP, 30 Nov. 1891. 
Before Christmas Ballance spoke in New Plymouth, Patea and Auckland. 140 He repeated his criticism of the press, and reaffirmed his belief in small farm settlement of state-owned land as the main solution to unemployment and the exodus of population. Existing crown land, and land re-purchased for settlement, ought only to be leased. He said that the Land and Absentee taxes would encourage small farm settlement by exempting improvements and penalising undeveloped large estates. Finally the Legislative Council was again stigmatised as preventing the legitimate demands of the democratically elected Government being fulfilled. 'The people should rule', said Ballance, and not 'a few autocratic Tory old fogies' rule the people. ${ }^{141}$ In the new year he spoke at Aramoho, Palmerston North and Filelding in similar vein. ${ }^{142}$

The battle lines had been drawn. The Government was defending the people, particularly their right to the land, in the face of the external threats of foreign capitalists, and internal opposition from entrenched conservative landowning interests in the Council. There was popular appeal in posing the Government's plight in this fashion, as Ballance knew. 'I think that the time has come', he wrote to a liberal in Napier,

...when we should not encourage a
Landlord class. The march of democracy
is a great and incontestable fact. That
it has become a power few will deny; that
it is likely to become a still greater
power, many will admit. ...I do not in the

140. Y, 12, 19, 26 Dec. 1891.

141. $\bar{Y}, 12$ Dec. 1891 .

142. $\underline{\bar{Y}}, 30$ Jan. 1892,27 Feb. 1892, 30 Apr. 1892 respectively. 
least fear the outcry raised by people at home or in the Colony, that capital will leave the country. Capital in my opinion ought to be the servant and not the master in every industrial and self governing community. 143

In fact democratic nationalism was soon to gain a number of important victories.

143. Ballance to McLean, 26 Nov. 1891 , LB II, p. 499. 
CHAPTER ELEVEN

Consolidation and Compromise 
'(T)he Government will not have a very long life', Ballance gloomily wrote to Vogel in May 1892 ,

\begin{abstract}
our Policy tends to make enemies in all
directions: We are relying upon the good opinion of the great mass of the people whom we try to represent faithfully. The vested interests are very powerful and use every weapon that comes to their hand to damage the reputation of the Ministry. However it is of no consequence: while Ministries disappear, Parties remain, and I think we have a Party which will not fall to pieces when not in power. 1
\end{abstract}

The first part of this chapter examines why Ballance had arrived at such a pessimistic outlook. It aims to show that, in fact, dissolution was necessary only if the Legislative Council remained 'untamed'. In other respects the Government's position was quite strong.

Early in the year the Liberals had gained a significant victory in the Wellington by-election. The opposition candidate, F.H.D. Be11, was, for a number of reasons, the favourite to win. The Government nominee, William McLean, had come next to bottom of the poll at the general election, and was regarded by Ballance as personally weak, 'to the verge of almost certain disaster'. ${ }^{2}$ McLean was also a single-taxer, a fact which might seriously limit his political appeal. Be11, on the other hand, the son of Sir Francis Dillon Be11, was a well-known Wellington personality, and had recentiy been elected Mayor of the city. He had been runner-up at the general election, and had the support of all three Wellington daily papers, as well as

1. Ballance to Vogel, 19 May 1892, LB II, p. 732.

2. Ballance to Perceval, 4 Feb. 1892, LB II, p. 578. 
that of the Catholic Times. ${ }^{3}$

It was recognised that the contest would be a major test of the Government's popularity, and the campaign was fierce and bitter. The Wellington Post, for example, carried an advertisement alleging that Ballance employed men in the Wanganui Herald office at below union rates. The Herald denied this, and added that the wages were similar to those paid by other provincial papers. It also pointed out that the company had not declared a dividend for a number of years, the bulk of its income going to its employees. 4

Outside the colony, the Melbourne Age saw the election in the context of a determined effort of the 'old and privileged classes' to regain control of the State. They hoped to overthrow Ballance, whose policy, said the Age, was 'directed in its entirety, to making New Zealand, as far as possible, independent of external support'.5

Appreciating the election's importance, and seeing that the odds were stacked heavily against the Government, both Ballance and Reeves took to the platform in support of McLean. ' (M)eeting after meeting we carried by storm', Ballance later wrote to Perceval, in a rare moment of self-congratulation, 'completely nullifying the persistent assaults of the press, with the result that we carried the election

3. Y, 16 Jan. 1892. On opposition of the Catholic Times to Ballance, see H. Sheils to Ballance, 23 Sept. 1891, BMSS, 297-98; Ballance to Sheils, 29 Sept. 1891, LB II, p. 396. Sheils told Ballance that the Times was not representative of catholic opinion, and that New Zealand Irish Catholics spoke of Ballance very highly. See also W. O'Donoghue to Ballance, 18 Jan. 1892, BMSS, 456.

4. $Y, 16$ Jan. 1892 .

5. Quoted by $\underline{Y}, 23$ Jan. 1892 . 
by some 140 votes. I need not tell you that this has done the Government throughout the Colony some service, and rather alarmed the other side'. ${ }^{6}$ Speaking from his residence following the declaration of the poll, he had told a jubilant crowd that in the face of much opposition the Liberal Party had gained a decisive victory. ${ }^{7}$

Meanwhile the organisation of the Liberal Federation proceeded apace. It was able to make a fifty pound contribution to McLean's expenses, with a promise of a further sum when funds became available. 8 Sandford, who had been elected for Christchurch City to replace Perceval, also received financial assistance. ${ }^{9}$ Ballance appointed an executive Council to oversee the Federation's affairs. It consisted of nine members: Ballance himself (President of the Federation), Reeves, Cadman, F.H. Fraser, Pinkerton, Tanner, Palmer, C.H. Mills and Stout. ${ }^{10}$ Only this initial Council would be nominated. The objection was made that it should have been elected, but as Ballance pointed out, this was impossible until there were people to elect it:

...as we had to make a start, the first body necessarily had to be virtually self-constituted; but we have provided for the election to take place early in 1893, when the Organisation will, we hope, be more than a name... . 11

6. Ballance to Perceval, 4 Feb. 1892, LB II, p. 578.

7. EP, 16 Jan. 1892; Y, 23 Jan. 1892. The result was McLean 3405 , $\overline{\mathrm{Be}} 113253$.

8. Ballance to Hildreth, $20 \mathrm{Feb}$. 1892, LB II, p. 617a; Ballance to F.H. Fraser (the Federation's Treasurer), 20 Feb. 1892, LB II, p. 617b; A. Smith (Ballance's Private Secretary) to Hildreth, 25 Feb. 1892, LB II, p. 627.

9. A. Smith to Sandford, 4 Feb. 1892 , LB II, p. 566; A. Smith to Fraser, 4 Feb. 1892 , LB II, p. 569.

10. See Ballance's letter to prospective Council members, $13 \mathrm{Nov}$. 1891, LB II, pp. 432-38; also C.H. Mills to Ballance, 23 Nov. 1891, BMSS, 389 , Ballance to C.H. Mills, 26 Nov. 1891, LB II, p. 498.

11. Ballance to Firth, 3 Dec. 1891 , LB II, p. 511. 
From then on, the Council was to be elected by the Federation's members for a two year term.

There were various types of membership. Ordinary Members paid a subscription of one pound per annum (class A), or if wage earners ten shillings per annum (class B). Life membership seemed a bargain at only ten pounds, and the Council could elect Honorary Members. Fina11y, there were Private Members who paid an annual one pound subscription, whilst remaining anonymous. ${ }^{12}$

In setting up the Federation Ballance was careful not to be too explicit about its political programme, for two related reasons. First, the Federation's function was primarily to select and promote candidates at elections. This was the most urgent need. Secondly, policy laid down at national level could not be too specific if the Federation was to unite, rather than divide, Liberals throughout the colony. Local prejudices and conditions had to be catered for. For example, the radical programme of the Dunedin Liberal Association, formed in May 1891, would be asking too much of the generally more cautious Aucklanders. ${ }^{13}$ The Dunedin twenty-four point manifesto included the nationalisation of land (the leasehold was to be the sole form of tenure, but the extent of state purchasing was not made explicit), mines, railways and coastal shipping, the statutory limitation of rent and interest, and the abolition of the Legislative Council and election of the Governor. ${ }^{14}$ It made a good deal of sense, in other words, to play down the policy role of the Federation. ${ }^{15}$

12. EP, 25 Nov. 1891; see also EP, 16 Nov. 1891,1 Dec. 1891 \& $\overline{\mathrm{Y}}, 28$ Nov. 1891.

13. See the account of an Auckland Liberal Association public meeting, 14 Aug. 1891, BMSS, 256; also Ballance to Jennings, 24 Aug. 1891, LB II, p. 362 .

14. EP, 5 May 1891, 28 Apr. 1891.

15. The Post said that individual members would be subject to 'intolerable tyranny' from the top, EP, 8 Dec. 1891. 
Article Four of the Constitution said simply that the Federation would promote 'all such reforms of a liberal character as may be resolved upon at any general meeting of the Federation'. 16

Essentially Ballance hoped that the Federation would 'tie in' to the Liberal cause as many local organisations as possible. ${ }^{17}$ Groups such as the Knights of Labour, with their own particular brand of liberalism, ${ }^{18}$ could provide valuable financial and organisational assistance. Branches of the Knights of Labour had recently sprung up in a number of places. Ballance was in touch, for example, with one in Napier, ${ }^{19}$ Hamilton, ${ }^{20}$ Masterton $^{21}$ and Palmerston, ${ }^{22}$ and he had addressed the Woodville branch in November. ${ }^{23}$ These organisations, a11 sympathising with the Govermment, offered varying degrees of practical assistance. The Auckland branch said that though as a body it would not join the Federation (it wished to retain its 'individuality'), Ballance could 'rely on the support of its members'. 24

Liberal organisations themselves had to be persuaded to put their full weight behind the Federation, and this was Buick's main

16. EP, 25 Nov. 1891 .

17. See e.g., Ballance to Perceval, 7 Nov. 1891, LB II, pp. 422-23. 18. See Frank Rogers, 'The Single Tax Movement in New Zealand', M.A. thesis, Auckland, 1949, appendix, p. iii, for the constitution of the Knights of Labour, and the thesis itself for a discussion of the influence of the single tax amongst both the Knights and Liberals.

19. C.W. Reardon to Ballance, 20 Apr. 1891, BMSS, 139; Ballance to C.W. Reardon, 24 Apr. 1891, LB II, p. 170.

20. Knights of Labour to Ballance, 14 July 1891, BMSS, 220 ; Ballance to Parr, 24 Aug. 1891, LB II, p. 363.

21. Reform Special Settlement Association to Ballance, 20 Nov. 1891, BMSS, 378-79; Ballance to the Association, 23 Nov. 1891, LB II, p. 473. The Association had been formed by the Masterton Knights of Labour.

22. Palmerston North Knights of Labour to Ballance, 30 Aug. 1892, BMSS, 592 .

23. Y, 14 Nov. 1891 .

24. J. Stallworthy to Ballance, $9 \mathrm{Feb}$. 1892, BMSS, 513; see also Ballance to Knights of Labour, 19 May 1891, LB II, p. 211. 
task in the major centres of population. In the smaller towns he often had to start largely from scratch. By mid-January he was in Dannevirke, on his way to Hawkes Bay. He told Ballance that the Wellington victory would do 'enormous good', but was worried about his reception in Napier, a conservative stronghold, and suggested that Reeves be sent there to assist. ${ }^{25}$ Ballance assented and Reeves obliged. ${ }^{26}$ After Hawkes Bay Buick travelled north to Auckland, returning down the West Coast via New Plymouth and Wanganui. 27 A 'Taranaki' Liberal Association was formed a day after his meeting in the town. ${ }^{28}$

Buick's tour did not extend to the South Island, where outside Dunedin and Christchurch Liberal organisation was weak, ${ }^{29}$ and in Wellington Liberals were well able to form an Association without his assistance. ${ }^{30}$ Taking the country as a whole, in other words, his impact was inevitably limited.

It was in Auckland that he created the greatest stir. The Auckland Liberal Association, when urging Ballance to form a national organisation, had told him of the Government's unpopularity in the city. 31 Jackson Palmer, the Member for Waitamata, said that there was anger at the Government not doing away with that 'Tory institution', the

25. T.L. Buick to Ballance, 8 Jan. 1892, BMSS, 457.

26. Y, 6 Feb. 1892 .

27. $\overline{\mathrm{Y}}, 21$ May 1892 .

28. W.F. Gayne to Ballance, 15 Apr. 1892, BMSS, 569.

29. See Ballance to Carley, 12 Feb. 1892, LB II, p. 599.

30. EP, $12 \mathrm{Apr}$. 1892. Also, a Liberal Association had been formed in Gisborne in April 1891, see Ballance to Sievwright, 28 Apr. 1891, LB II, p. 166. See also R.W. Jones to Ballance, 12 Aug. 1892, BMSS, 643 , on the Cook County Association.

31. Auckland Liberal Association to Ballance, 13 Oct. 1891, BMSS, 323. 
Railway Commission, at recent Justice of the Peace appointments going to 'rank conservatives' instead of Government supporters, plus a host of other minor grievances. Ballance had a hard job persuading him to agree to serve on the Federation's Council. 32 Palmer had been one of the 'independent Liberals' at the 1890 election.

More important were worries over the effect of Ballance's taxation proposals. Auckland was the financial heart of the colony, and there the 'capital scare' was loudest heard. Further, a land tax was not of major concern to a region containing no large estates, except to the extent that its imposition might reduce customs duties. Though the Knights of Labour was active in the city, it had still to win over the working class. ${ }^{33}$ H.W. Farnall, the founder of the Auckland branch, and a follower of George, had come bottom of the poll at the 1890 election.

There were also, finally, leadership rivalries. Sir George Grey's apparent lack of enthusiasm for the Government had been noted, and rumours abounded of a plot by disaffected Liberals to replace Ballance with Seddon. ${ }^{34}$ Part of the problem was the persistence of regional rivalries, for Ballance headed a predominantly South Island (and south of the North Island) Ministry.

Ballance's visit to the city seemed to help matters, ${ }^{35}$ although the claim that, along with the Wellington victory, it had made Auckland

32. J. Palmer to Ballance, 23 Nov. 1891, BMSS, 385-86; EP, 25 Nov. 1891. 33. See W.J. Napier to Ballance, $17 \mathrm{Feb} .1892$, BMSS, $534 \overline{-35}$.

34. W. O'Donoghue to Ballance, 19 Jan. 1892, BMSS, 461-62; EP, 28 June 1892.

35. Pinkerton to Ballance, 29 Dec. 1891, BMSS, 434; Ballance to Adams, 1 Feb. 1892, LB II, p. 559; J.A. Tole to Ballance, 13 Feb. 1892, BMSS, 524-25. 
'safe' was much too optimistic. ${ }^{36}$ Undoubtedly Grey's influence was still strong. It was not unreasonable of the Post to suggest that Buick's mission had been primarily to get the city's Liberals to 'accept Mr. Ballance instead of Sir George Grey as the prophet, priest and leader of Liberalism '. ${ }^{37}$ More far-fetched was the notion that Grey would actually hold the balance of power in the coming session, and might be able to form a ministry of his own. ${ }^{38}$ Grey retained a personal following but was very old and as a national leader. a spent force.

Although Buick's visit caused something of a commotion, it does not appear to have improved the party's position in the city. 39 W.J. Napier, for example, an Auckland solicitor and prominent Liberal, was by July much more pessimistic about the situation than he had been earlier in the year. ${ }^{40}$ Appointments were sti11 causing dissatisfaction, whilst the New Zealand Herald was endeavouring to drive a wedge between Greyite and 'Ballance' Liberals. The estrangement of the two men in 1879 (see chapter 4) had been dragged up again. The 'Tories' had money to spend, said Napier, and both Shera and Rees (the two Auckland city Liberal Members) were losing ground:

We sha11 have a big- even a desperatefight up here at the next election and the Tories are moving Heaven and earth to try and carry the three city seats. You have

36. W. O'Donoghue to Ballance, 18 Jan. 1892, BMSS, 456. Incidenta1ly, the Auckland Liberals were dragging their feet over paying Ballance's expenses, Ballance to Shera, 25 Feb. 1892, LB II, p. 625. Ballance told Shera that all other associations had covered the cost of his visits.

37. 2 May 1892.

38. EP, 21 Mar. 1892. See also Y, 9 Apr. 1892, 'The Bogey Man Again'.

39. Bailance to Beeham, 20 May $18 \overline{9} 2$, LB II, p. 744.

40. W.J. Napier to Ballance, $17 \mathrm{Feb}$. 1892, BMSS, 534-35. 
no idea of the odium one incurs by prominently identifying oneself with the Government. I have been persecuted here by the big financial companies and clients have been taken from me simply because of my political opinions. In social circles too it has been very plainly hinted to me that any devotion to the Liberal cause is regarded as an unpardonable 'eccentricity'. 41

There was one bright spot, however, for the Evening Star was apparently pressing the Liberal 'line' with more conviction than before. 42

Thus the Federation was struggling to get off the ground. On top of this Buick had not, in Ballance's view, been a financial success. ${ }^{43}$ Whether this was owing to few members actually being enrolled and paying their subscriptions, or to Buick's inability to attract major personal sponsors, is unclear. Most likely it was a mixture of both.

There were more positive results from Ballance's efforts to counteract the colony's 'tory' press. As early as September 1891 he thought of establishing a new Liberal paper in Wellington. ${ }^{44}$ There was talk of setting one up first in Auckland, but with the problems of the press in the Capital exemplified at the by-election, and the Auckland Evening Star coming round, Wellington's needs were the more urgent. ${ }^{45}$ Initially Ballance was not optimistic of success, ${ }^{46}$ but as financial and moral support came in he was more

41. W.J. Napier to Ballance, 25 July 1892, BMSS, 627-28.

42. Ballance to J. Adams, 4 June 1892, LB III, p. 62; J. Adams to Ballance, 9 Aug. 1892, BMSS, 641.

43. Ballance to Beeham, 20 May 1892, LB II, p. 744.

44. Y. 19 Sept. 1891.

45. See J.A. Tole to Ballance, $13 \mathrm{Feb}$. 1892, BMSS, 524-25.

46. W.A. Buller to Ballance, 19 Jan. 1892 , BMSS, 460 . '... (T) he project i not so hopeless as Reeves says you are inclined to regard it', wrote Buller. 
hopeful and enthusiastic. ${ }^{47}$ Reeves, who had his experience on the Lyttelton Times to draw on, was put in charge of the project. He had promised $\mathbf{1 7 5 0}$ for the paper himself, and also to contribute articles. ${ }^{48}$

The cheapest and easiest method of starting a new Liberal journal was to acquire an existing paper. Ballance and Reeves originally hoped to buy the Evening Press, renaming it The People, but the deal fell through. ${ }^{49}$ Instead the Wellington morning daily, the New Zealand Times, was purchased for $£ 4,500$, and turned into a joint stock company. ${ }^{50}$ Ballance suggested a change of name, to simply New Zealand, with (significantly) the motto 'New Zealand for the New Zealander', ${ }^{51}$ but it was ultimately decided to keep it as it was. Reeves became Managing Director of the Company, its directors including Ballance, the new Wellington M.H.R., William McLean, and three trade unionists, W. C1iff, P.R. Russe11, and W. Miles. 52 R.A. Loughnan, previously of the Lyttelton Times, became editor. ${ }^{53}$

'We hope to establish the paper on a firm Commercial foundation', Ballance wrote to a Dunedin Liberal in March,

47. Ballance to Stout, 4 Feb. 1892, telegram, Stout MSS, folder 38; J.G. Ward to Ballance, $29 \mathrm{Feb} .1892$, BMSS, 549.

48. W.A. Buller to Ballance, 12 Dec. 1891, BMSS, 418.

49. Ballance to Stout, 2 Feb. 1892 , telegram, Stout MSS, folder 38 .

50. Ballance to Stout, $12 \mathrm{Feb}$. 1892, telegram, Stout MSS, folder 38. Stout gave $\$ 1,000$ to the project; see also Ballance to Perceval, 25 Feb. 1892, LB II, p. 631; Y, 5 Mar. 1892.

51. Ballance to Stout, 5 Feb. 1892, telegram, Stout MSS, folder 38.

52. See the Company Prospectus, printed in $Y, 12$ Mar. 1892.

53. Ballance wanted a Wanganui man, J.M. BuIllock, for the job, J.M. Bullock to Ballance, 3 Dec. 1891, BMSS, 409. As with the choice of name for the paper, Ballance seems to have given in to Reeves's preference. 
for unless that is done it is utterly useless to aim at having a political organ. A mere flash in the pan would have done no service to the party, but, on the contrary, a positive injury.

There is reason to suppose that the paper can be made a sound commercial concern. It is now showing a respectable surplus... . 54

The paper faced a number of early problems, however. There was criticism of its content, and a high turnover of editors. 55 The Board of Directors had been appointed with the various factions within the Liberal Party in mind (the inclusion of labour representatives was a novelty for such enterprises) $)^{56}$ and there was undoubtedly a fair amount of political in-fighting. 57

Turning from Party to broader political concerns, there were complications surrounding Ballance's attempts to secure the appointment of eighteen new Legislative Councillors. The Governor, Onslow, refused to accept more than eight names, after which Ballance sought a compromise on an 'irreducible minimum' of twelve. ${ }^{58}$ There were no immediate efforts made to bridge the gap between eight and twelve, for Onslow was due to leave the colony, and had decided to let his successor deal with the problem. 59

54. Ballance to Smith, 29 Mar. 1892, LB II, 645.

55. See Ballance to Reed, 23 Mar. 1892, LB II, p. 661.

56. G.H. Scholefield, Newspapers in New Zealand, Wellington, 1958, p. 35.

57. See, e.g., W.P. Reeves to Ballance, 28 Feb. 1893, BMSS, 695.

58. Ballance to Perceva1, 25 Feb. 1892 , LB II, p. 631.

59. Y, 12 Mar. 1892 . 
Ballance would have liked to have had some say in the appointment of the new Governor. His immediate hope was that Onslow's replacement might be more sympathetic, or at least not so hostile, to the Government's stance on the Council nominations. On the broader constitutional issue, he later made it clear that he thought a Government ought to have an established right to be told of the candidates for the Governorship, and so be able to ensure that the person selected would not be 'distasteful to the colonists'. 60

In fact Onslow had already asked for Ballance's view on two possible replacements:- Sir William Robinson and Sir Robert Hamilton, current Governors of West Australia and Tasmania respectively. 61 And from London Perceval told Ballance that Sir William Jervois, who had already been Governor from 1883 to 1889 , wanted the job. ${ }^{62}$ Ballance replied that Jervois 'would not do', since he was 'mixed up with money rings and speculators', had been consistently unsympathetic to the Government, and was generally 'a thorough intriguer'. 63

Through Perceval Ballance requested to be informed by the Colonial Office of the name of the new Governor, before the official announcement was made, and had been promised that he would be consulted 'as far as possible'. ${ }^{64}$ However he did not realistically expect to be able to do more than prevent a 'very objectionable person' being sent out. ${ }^{65}$ In the event, both Ballance and Onslow first heard

60. PD, $1892,77, \mathrm{p} .434$.

61. Onslow to Ballance, 12 Dec. 1891, BMSS, 416-17.

62. Perceval to Ballance, 11 Dec. 1891, BMSS, 410-15.

63. Ballance to Perceval, 4 Feb. 1892, LB II, p. 578; see also Ballance to Vogel, 19 May 1892 , LB II, p. 732.

64. Perceval to Ballance, 8 Jan. $189(2)$, BMSS, 49.

65. Ballance to Perceval, 4 Feb. 1892, LB II, p. 578. Perceval had suspected that he was being kept in the dark, see Perceval to Ballance, 22 Jan. 1892, BMSS, 469-72. 
of the appointment of the Earl of Glasgow as Governor, through a telegram from London published in the colony's newspapers on 10 February. ${ }^{66}$ 'I think we have been badly treated by the Colonial Office', Ballance wrote to Perceval,

and that you have a right to complain, that the Press was taken into the confidence of the Authorities before the Representative of the Colony. Have they not broken faith in not keeping their promise to inform you at the earliest possible moment(?). ... I am told that Glasgow is Sir James Ferguson's appointee. If so we may expect trouble, unless he is a man of great discretion. Ferguson, from a letter he wrote to Lord Onslow, bears the Colony a good deal of ill-will over the absentee taxation. 67

Unknown to Ballance at the time, Onslow had taken the unusual step of leaving Glasgow a confidential memorandum concerning the Council appointments. In it he told of Ballance's original request for eighteen new members, and explained why he had declined to approve more than eight:

I should have been accused of lending myself to a scheme which might alter the complexion of the Upper House in order to enable the Ministry of the day to carry measures upon which the voice of the country had not been directly heard, and without the direct authority of the electors given to the proposal to bring the Upper House into harmony with the Lower. 68

66. Y, 12 Mar. 1892, 'Interview with the Premier'; Onslow to Ballance, $\overline{2} 3$ Jan. 1892, BMSS, 474, makes it clear that the Governor was also not privy to discussions on his successor. See also R.M. Dalziel, The Origins of New Zealand Diplomacy, Wellington, 1975, pp. 139-40.

67. Ballance to Perceval, $25 \mathrm{Feb}$. 1892, LB II, p. 631; also Ballance to Perceva1, 4 Jan.(?) 1892, telegram, BMSS, 444.

68. Onslow to Glasgow, 16 Feb. 1892, AJHR, 1893, A-7a, pp. 13-14. For Onslow's views see also his speech on leaving the colony, EP, $13 \mathrm{Feb} .1892$. 
Two days after his arrival in the country, Glasgow was confronted by Ballance. The Premier asked that the appointments be made and announced before the opening of the new session. 69 'It is plain that no Government can carry on the business of the House satisfactorily when in one Chamber they exist only on sufferance', he told Glasgow. He suggested that Onslow would have agreed to twelve, and was no doubt taken aback when Glasgow pointed to the memorandum he had received from his predecessor. 70

Glasgow quickly reaffirmed Onslow's view: he would appoint eight new members, plus an additional one to fill a recent vacancy. The decision of both men was essentially a political one. As has been noted elsewhere, ${ }^{71}$ the argument that the appointments would 'swamp' the Upper House required an assessment of the political allegiance of councillors. In fact Glasgow overestimated the effect of twelve new members: as the Colonial Office later pointed out, even with them the Government could still only count on seventeen supporters in a Council of forty-seven. ${ }^{72}$ Further, along with Onslow he 'underestimated' the widespread feeling in the country in favour of the Government. And the view that the Party's policies had not been 'directly' placed before the people, rested upon a highly political interpretation of the 1890 election. Both Glasgow and Onslow (the latter especially considering his collusion in the Atkinson appointments) were, quite simply, politically biased.

69. Glasgow to Knutsford, 8 Aug. 1892, AJHR, 1893, A-1, pp. 7-8.

70. Glasgow to Knutsford, 22 June 1892, AJHR, 1893, A-7, pp. 1-3.

71. W.K. Jackson, The New Zealand Legislative Council: a study of the establishment, failure and abolition of an Upper House, Dunedin, 1972, p. 147.

72. Ripon to Glasgow, 26 Sept. 1892, AJHR, 1893, A-7, p. 5. 
With the two sides unwilling to compromise, it was eventually agreed that the dispute be referred to the Colonial office for a ruling. Glasgow sent the correspondence relating to the affair to the Secretary of State for the Colonies, Lord Ripon. In London Perceval argued the Government's case, and passed on to the office some papers that Glasgow had withheld. ${ }^{73}$ In defending his position, Glasgow said that he did not want to run the risk 'of making the Legislative Council a mere echo of the other House'. ${ }^{74}$ Ballance had attempted to apply some pressure by pointing out that although he personally favoured the preservation of the Upper House, there would undoubtedly be a demand for its abolition if the appointments were rejected. However Glasgow countered that the Council's abolition 'would be preferable to its retention in a condition so manipulated as to possess merely a semblance of independence! ${ }^{75}$ When the matter was debated in Parliament, Ballance argued that although the Governor clearly had the power to refuse the appointments, as a matter of right, and as long as the Government had a majority in the House, responsible government required him to take the advice of his Ministers. ${ }^{76}$

The alternative to arbitration by the Colonial office was for Ballance to seek a dissolution. His hinting at resignation was of course another weapon in his duel with the Governor; ${ }^{77}$ and as we have just seen, Glasgow knew that if an election was held, the very

73. Ballance to Perceva1, 10 Aug. 1892, LB III, pp. 276-77; Dalzie1, p. 136. Ripon was a Liberal in the recently elected Gladstone

74. Glasgow to Knutsford, 22 June 1892, AJHR, 1893, A-7, pp. 1-3. 75. Ibid.

76. $\overline{\mathrm{PD}}, 1892,77, \mathrm{p} .249$.

77. The possibility of a dissolution had been mooted for some time, see e.g., Y, 12 Mar. 1892 . 
existance of the Council would be a major issue. However the consequences of Ballance's resignation being accepted were by no means clear. The Governor could refuse a dissolution and encourage instead the formation of a new ministry from the existing House. Even if granted, it was not certain that an election would turn out favourably for the Government. Ballance's letter to Vogel, quoted at the opening of this chapter, suggests that he did not expect to win.

Nevertheless, as early as May 1892 Ballance thought a dissolution likely. Although Glasgow had yet to arrive in the colony and so a decision on the appointments had still to be made, Ballance predicted that he would be less sympathetic than Onslow. ${ }^{78}$ It was the prospect of Government measures being rejected by the Council for a second year in succession, that led the Yeoman to believe an election 'quite possible'. 79

At the end of the month Ballance wrote to Willis, to let him know that he would soon be in Wanganui in order to prepare for an early election. He set out a detailed campaign plan, involving the cutting up of the town into blocks of fifty to one hundred electors, each district thus created being under the direct supervision of a chairman and committee. Ballance refuted rumours in the press that he might seek election elsewhere:

78. Ballance to Perceva1, 25 Feb. 1892, LB II, p. 631. On Ballance's opinion of Onslow (and it should be borne in mind that at the time Ballance was unaware of the confidential memo), see Ballance to Perceva1, 4 Feb. 1892, LB II, p. 578. Later, looking back, Ballance was most critical of Onslow's behaviour, see Ballance to Perceva1, 9 Jan. 1893, LB III, pp. 404-07.

79. $\underline{Y}, 4$ June 1892 . 
You need not be afraid of my leaving Wanganui, I sha11 stand or fall by the old place; I never had any other intention... . You know I cannot be responsible for all that is said about me in the papers: especially the Conservative papers. 80

Ballance thought that his chances of re-election, with a larger majority, were favourable; if he lost he would retire from politics for good. ${ }^{81}$

Although in late June Ballance told $\mathrm{J}$. Boyle, of the Herald, that the Government did not want an election and were 'not going to court it, ${ }^{82}$ a month later the Cabinet was still wavering. ${ }^{83}$ Ballance had, meanwhile, told the Governor that he intended to reintroduce those measures thrown out by the Council the previous year, and to seek an election if they were rejected for a second time. ${ }^{84}$

It has been suggested that in deciding to turn the matter over to London Ballance was most likely responding to advice from his colleagues. $^{85}$ In fact it was not until 4 August that Glasgow agreed to obtain the opinion of the Colonial Office, ${ }^{86}$ and thus only then that the necessity of resignation could be discounted. Until that date Ballance did not want an election, rather it was simply that he did not see any alternative.

80. Ballance to Wiilis, 30 May 1892, LB III, p. 28. George Hutchison had suggested that Ballance believed himself unlikely to be re-elected in Wanganui and so had decided to stand for a Wellington seat. See also T.W. Rapley to Ballance, 18 June 1892 , BMSS, 603.

81. Ballance to Pirani, 25 May 1892 , LB III, p. 10.

82. Ballance to J. Boyle, 24 June 1892 , LB III, p. 122.

83. Ballance to Kerr, 21 July 1892 , LB III, p. 221.

84. Glasgow to Knutsford, 22 June 1892 , AJHR, 1893, A-7, p. 2.

85. Keith Sinclair, William Pember Reeves, London, 1965, p. 147.

86. Glasgow to Ballance, 4 Aug. 1892, AJHR, $1892, \mathrm{~A}-7, \mathrm{pp} .4-5$. 
In any case Ballance was genuinely concerned (it was not merely a bargaining tactic) at the constitutional consequences of the problem not being resolved in the Government's favour. He made this clear when suggesting to Perceval the arguments to present to the Colonial Office:

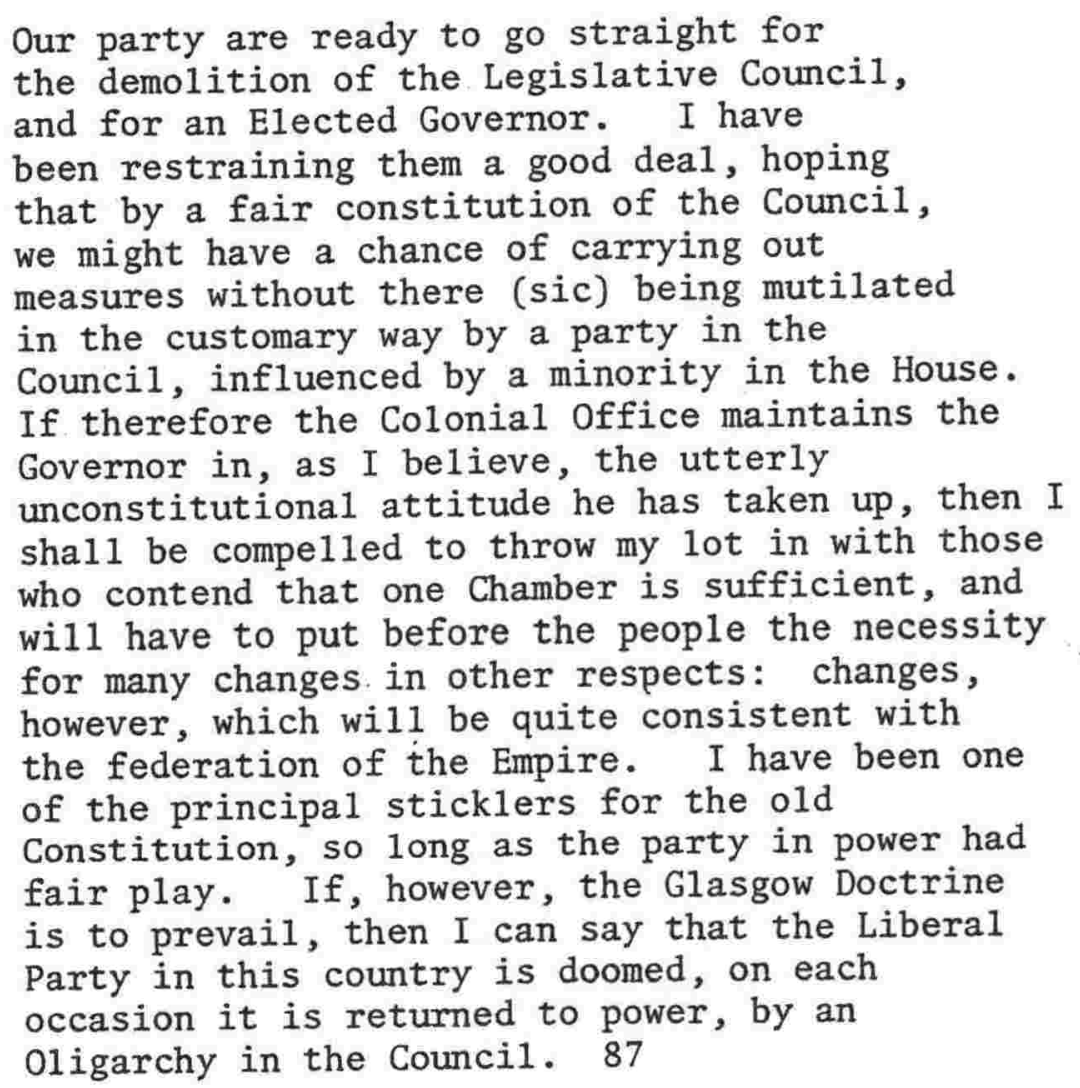

Ballance concluded by asking Perceval to impress upon the Colonia1 Office 'how completely the action of the Governor is playing into the hands of those who would be inclined to change the Constitution, and perhaps not stop short of the independence of the Colony'.

Finally, it is interesting to note that at this time Ballance in effect turned down a knighthood. He had long opposed the granting of titles: when Vogel received his in 1875 the Evening Herald condemned 
them as 'cheap honours which cost little to the givers and have but a dubious merit with the majority of colonists'. 88 In 1892 Ballance, as Premier, would have been offered a knighthood had he not suggested Buckley instead. ${ }^{89}$ 'My own opinion', he wrote early in the year, 'is that as the Democratic party in the State we should not touch titles- the time is coming when they will be less valued than at present, \& when the only title of honor will be that following upon services rendered to the state'. 90

Thus although Ballance hoped to retain 'the old Constitution' he had distinct republican, and certainly very strong democratic, tendencies. He opposed the idea of an elected Council and Governor on the grounds that the political system would as a consequence become less, rather than more, democratic. 'If we are to have a Democracy in this country', he wrote, 'then the Upper House must either be made weak, or abolished altogether'. 91

Two other considerations would have helped persuade Ballance not to rush into an early dissolution. Over the past few months he had been closely watching Government revenue, and the news was good. Customs receipts, the major source of income, had risen significantly, suggesting an increase in economic activity. ${ }^{92}$ Further, the land tax was expected to bring in what had been anticipated. ${ }^{93}$ In February a surplus of $£ 100,000$ was predicted; by June this had grown to $£ 300,000.94$

88. 15 June 1875 .

89. Ballance to Willis, 30 May 1892, LB III, p. 28; EP, 30 May 1892; Y, 20 May 1893, 'The Dead Tribune'; A.D. MacLaren to Ballance, 1 June 1892, BMSS, 593; C. Hall to Ballance, 25 June 1892, BMSS, 613

90. Ballance to Steward, 15 Jan. 1892, BMSS, 448.

91. Ballance to Hal1-Jones, 30 May 1892, LB III, p. 34.

92. Ballance to Perceva1, 4 Feb. 1892, LB II, p. 578.

93. Ballance to Shrimski, 9 Feb. 1892, LB II, p. 591.

94. Ballance to Perceva1, 16 June 1892 , LB III, p. 87. 
A second bright spot concerned the Edwards Case. It will be remembered (see chapter 9, p. 351) that the Atkinson Government had appointed W.B. Edwards Chief Commissioner of the Native Lands Court, and that he also sat as (and received the salary of) a Supreme Court Judge. It had been objected that the appointment was illegal, since the civil list only allowed for the salaries of five Supreme Court judges, and Edwards's elevation brought the total to six. Atkinson's intention of amending the relevant Act had been thwarted when he lost the 1890 election. Subsequently, the Ballance Ministry refused to make provision for Edwards's salary. ${ }^{95}$ The case soon went to the Supreme Court, which ruled three to two (the Chief Justice and Judge Connolly), in Edwards's favour. 96 Undaunted, and encouraged by the Chief Justice and Stout, ${ }^{97}$ Ballance appealed to the Privy Council in England, and won. 98

Throughout the affair, Ballance emphasised the constitutional principle at stake; that is, the obligation of a government to abide by the statutory limitation on the number of judges, rather than the question as to whether another judge was needed. ${ }^{99}$ Undoubtedly the outcome of this appeal to the Privy Council made Ballance more optimistic of the Colonial Office's ruling on the Legislative Council appointments. He wrote to J.A. Tole in Auckland:

95. See the correspondence between Ballance and Edwards published in Y, 23 May 1891.

96. $Y, \overline{3} 0$ May 1891 .

97. Ballance to Kelly, 17 June 1892 , LB III, p. 98.

98. See the correspondence in AJHR, 1892, H-28; Y, 4 June 1892; also Edwards's petition to Parliament, AJHR, $1892, \mathrm{~J}-2$.

99. In fact $\mathrm{Ba} 1 \mathrm{lance}$ argued that an extra judge was not needed, Ballance to Hal1-Jones, 30 May 1892, LB III, p. 34; Ballance to Kel1y, 17 June 1892, LB III, p. 98. 
We sha11 await the verdict of the Home Office with some anxiety, but I am just as confident that the reply will be favourable as I was in the Edwards Case. The whole spirit of Colonial Office relations to the Colonies is in the direction of throwing the entire responsibility upon Local Governments. 100

Before the start of the new session in June, Ballance reorganised his Cabinet. 101 On the suggestion of Cadman, the Native Department was closed down. The Department's role had declined over the preceding decade, and increasingly Pakeha politicians saw it as both desirable and feasible that Maoris should be 'placed upon the same footing as Europeans'. 102 When established, the Department had been regarded as essentially a political device for bringing Maoris under European 1aw, and it had not been intended that a separate administration for Maoris continue once this objective had been achieved. 103

Thus the remaining functions of the Department were dispersed. The Land Court was placed under the Justice Department, and the land purchasing activities of the Native Department transferred to McKenzie at the Department of Lands. Cadman was to hold the Justice, and related Native, portfolios. At the same time, James Carrol1, the Member for Eastern Maori, became Native Member of the Executive,

100. Ballance to J.A. Tole, 29 Aug. 1892, LB III, p. 306.

101. Y, 4 June 1892 .

102. A.J. Cadman interviewed by the Auckland Star, reported in $\underline{Y}, 5$ Mar. 1892; also Y, 27 Feb. 1892, 'Abolition of the Native Department'. 103. Alan Ward, A Show of Justice, Auckland, 1974, p. 302. 
responsible for the welfare of the Maori race. ${ }^{104}$

In looking at Ballance's term as Native Minister in the Stout-Voge1 Government, it was pointed out that a1though he regarded the amalgamation of the European and Maori races as desirable, at the same time he recognised that the retention of Maori custom, specifically communal land ownership, was necessary if amalgamation was not to result in the latter's total destruction. ${ }^{105}$ As Premier, (and Ballance initially held the Native portfolio himself), he was again caught somewhere between these two positions.

Although Ballance moved towards a re-imposition of crown pre-emption, ${ }^{106}$ which can be seen as an attempt to protect Maori land from 'voracious' private purchasers and speculators, Government land purchasing proceeded apace. The exercise of crown pre-emption, of course, removed private competition from Government purchasing efforts, and undoubtedly as a consequence Maoris obtained a lower price for their land. On the other hand, it was generally true that less Maori land was sold under crown pre-emption than a laissez-faire system. 107

104. Y, $27 \mathrm{Feb}$. 1892, 'Mr Carro11's Appointment'. The Pakeha press was concerned primarily about the effect the changes would have on the rate of Maori land purchasing. In 1900, as Native Minister, Carroll established a system of Maori Land Councils.

105. Ch. 7, pp. 303-04.

106. Section 15 of the Native Land Purchases Act gave the Government the power to prohibit, through order in council, private purchasing in declared areas. Crown pre-emption was fully restored under the Native Land Court Act, 1894. A year later an amendment allowed some exceptions to be made.

107. Ward, p. 350, n. 52, gives a figure of 3.6 million acres of Maori land purchased by the Liberals between 1891 and 1911, a slightly lower average than that of the preceding twenty years. It is difficult to put a figure on sales during Ballance's tenure; a lot of land purchased arose from negotiations that had been going on for a number of years, with respect to the North Island trunk railway. 


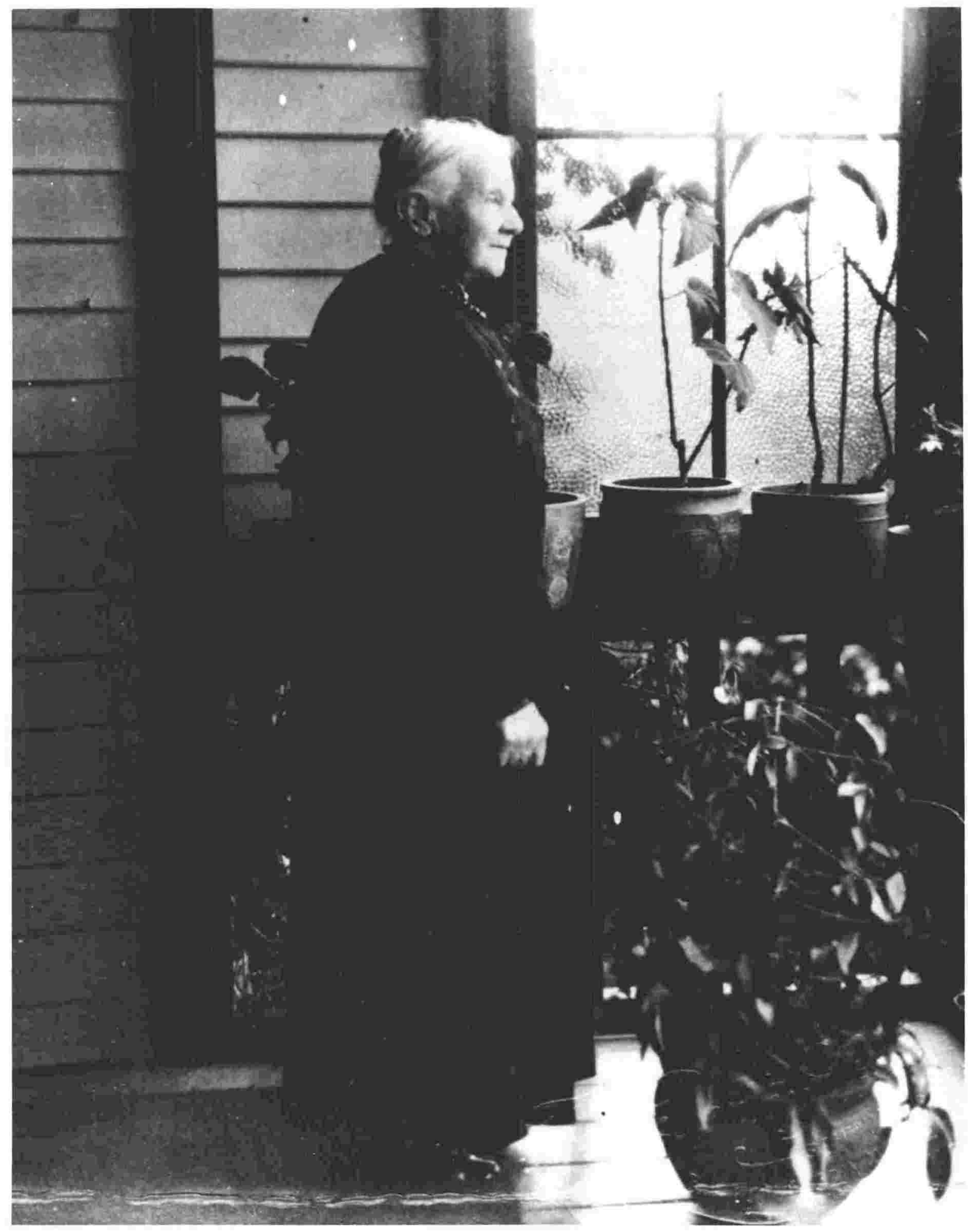

Ellen Ballance in 01d Age 
Under the Native Land Purchases Act of 1892 the Government was provided with a maximum of $\$ 50,000$ a year for purchasing Maori land. The money would be raised by issuing debentures, and so was a form of internal borrowing. There was little good crown land left available for settlement and considerable pressure on the Government, especially from Auckland, to replenish the stock by purchasing Maori, rather than re-purchasing European, land. Most of the members (both Government and Opposition) who spoke on the Bill, argued that much more than $£ 50,000$ be made available. 108

Ballance acknowledged the urgent need for more land, but also emphasised that the Act made provision for half the purchase money to be invested with the Public Trust office, as an endowment for the owners and their descendants. He hoped that in this way the 'permanent welfare of the Maori people' would be ensured. ${ }^{109}$ Yet Ballance went little further than this. He did not, for example, revive his earlier idea of placing Maori land in the hands of locally elected committees. In his short term as Premier, and having relinquished direct control over Maori affairs, it was perhaps understandable that he paid little attention to these problems. In any case his committee scheme had already been rejected once.

Despite this, there can be no doubt about the direction in which he wished to move. He told Stout shortly before his death that he was intending to introduce a new Native Reserves Bill in the coming

108. PD, 1892, 77, pp. 221ff. One Maori member, Taipua, complained that crown pre-emption reduced the amount of land that could be sold, and lowered its price. Ibid., p. 229.

109. PD, 1892,75, p. $127 ; 78$, pp. $\overline{276-77 . ~ C y n i c s ~ s a i d ~ t h a t ~ t h e ~}$ Maoris would never see the money, and that the provision was simply a means of obtaining land cheaply and at the same time boosting trust funds. 
session. Under it a Board would have power to administer all

Maori reserves. Maori owners would be encouraged to offer land for perpetual leasing; they would retain ownership and receive rents, whilst settlement would be increased. Ballance viewed the Bill as essentially a move towards nationalisation. The Government would not actually have to purchase the land (thus no need to borrow), but could control settlement conditions through the Board. There would also be provision for Maori owners to sell the land outright, but only to the crown. ${ }^{110}$

A Native Land Purchase and Acquisition Act was passed, and it bore some resemblance to Ballance's proposal, but the whole emphasis was upon the outright sale of Maori land to the crown. From Ballance's point of view, the leasing of land by Maoris themselves was, arguably, preferable to its purchase. Purchased land would come under the ordinary land laws of the colony and much would end up as freehold.

We will now return to Ballance's reorganisation of his Cabinet. Reeves, who had held both the Justice and Education portfolios, lost the former when it was seen desirable to link it to Native Affairs under Cadman. If Reeves's position within the Government was to be maintained, he required new duties of equivalent importance. He had wanted the Colonial Secretaryship, but Buckley refused to give it up. In fact Ballance had decided to create the new post of Minister of Labour, and Reeves eagerly responded to the Premier's suggestion that he take on the job. ${ }^{111}$ Reeves had been supervising the 'Bureau Purchases Act. Ballance to Stout, 10 Jan. 1893, LB III, pp. 415-16. 111. Reeves to Ballance, 1 May 1892, BMSS, 578. 
of Industry and Labor', established the previous June, and was the obvious choice. In just under twelve months the Bureau had found jobs for 2,974 men, 2,000 in the private sector and the remainder on public works. ${ }^{112}$ Under Reeves and his Secretary, Edward Tregear, the Department would, with the growth of factory legislation and the passing of the Industrial Conciliation and Arbitration Act, greatly expand its activities.

In general terms the alterations Ballance made to the Cabinet simply reflected the changing roles of government. At the same time the work load amongst ministers was distributed more evenly. Ballance himself lost Native Affairs, and Ward, originally Minister without portfolio, now took over as Postmaster General from Buckley. This latter post was to become more important as telephone communication was established throughout the country.

As far as the relative strength of personalities or 'factions' within the Cabinet is concerned, little needs to be said. Ballance appears to have achieved a high degree of harmony and consensus; divisions inside the Cabinet only emerged when his illness prompted the question of a successor. This is discussed in the final chapter. In the meantime it is sufficient to note that Ballance was keen to maintain Reeves's position and influence; the Labour portfolio was no mere bagatelle. Also, although Reeves wanted to retain his status in the Government, he asked Ballance to be relieved of as much work in the House as possible:

I fe1t the strain last session very much and rather fear the coming tax upon a 
health which has never been very strong.

Family and private matters...have told

on me a good dea1. Moreover I have now

the N.Z. Times to attend to. 113

Ironically Ballance was dead within a year, whilst Reeves was to live to a ripe old age.

These Cabinet changes were completed just in time for the opening of the new session. Ballance brought down his Financial Statement early on, and happily announced the record budget surplus of $\$ 330,000.114$ The satirist Joseph Evison, under the pseudonym 'Phiz', described the scene as Ballance delivered the good news:

Then, more especially when the appreciative gentlemen, mostly on Mr Speakers' right (i.e., on the Government benches), howled encomium, he beamed the largest-sized Ballance beam. He made every point with aplomb, and if he halted now and again, and in the proper places, sure his unkindest critic will admit that most Financial Statements require a little condiment of this description to make them go down. 115

Ballance had reason to be pleased, for the surplus enabled him to maintain his self-reliant policy of non-borrowing. ${ }^{116}$ over two-thirds

113. Reeves to Ballance, 1 May 1892 , BMSS, 578.

114. PD, 1892,75, p. 131 . G.F.C. Simkin, The Instability of a Dependent Economy, Oxford, 1951, p. 147 gives the following figures for calendar years: Current Surplus : $\$ 000$

1883

1884

1885

1886

1887

1888

1889

1890

1891

1892

1893

115. Phiz, Political Portraits, Wellington, 1892, p. 2. 
of the surplus would be transferred to the Public Works Account, so that the continuation of colonisation and settlement, traditionally financed through overseas loans, could be funded directly out of revenue. For Ballance this was how things should be, although he well knew that such a favourable situation might not last, as he explained to S. Saunders, editor of the Lyttelton Times:

It is true that in future years we may not have a surplus, and yet be compelled to carry on certain necessary works for the opening up of lands and the settlement of the country, but there are at the same time great possibilities, if we continue to prosper and carefully guard the revenue on one side and the expenditure on the other, that we sha11 have a surplus, I hope, for several years. If on the other hand the people of the Colony say that they are determined to have the surplus disposed of by remitting the duties upon the necessaries of life, and reducing taxation, then one of two results must follow. Either we must cease to colonise, or resume borrowing operations: I. do not see any other alternative, and it would be well to make this clear to the people. 117

In fact it was the demands of small farmers for credit for improvements, rather than pressure to reduce taxation, that resulted in the abandoning of the Liberals' self-reliant policy after Ballance's death.

It must be stressed that Ballance's opposition to borrowing rested not simply on the financial burden of debt repayment. Certainly one of his arguments against it was that the Government wo'sld have to pay a high rate of interest. ${ }^{118}$ Yet if he was a 'conservative' financier, it was because he regarded reliance on overseas loans as endangering the Government's, and the country's, 
independence. Self-reliance would wean the colony 'from a servile dependence on foreign dealers in money'. 119 Foreign capital could not be controlled, nor could it be trusted to act in the colony's interests; it had helped build the large estates, instead of contributing to genuine development. ${ }^{120}$ Self-reliance, seen in this light, was therefore a fairly radical doctrine.

In a sense Ballance also viewed borrowing as immoral. In the past, he said, it had 'disorganised our industries and corrupted our people, and driven many from our shores whem it would have been well to have kept here'. ${ }^{121}$ Non-borrowing was a political and social creed, not merely an economic necessity. It would 'train the people to a policy of industry and self reliance'. ${ }^{122}$ It was the central thrust, finally, of the Government's whole philosophy. '(T)he only safe policy for the colony is one of self-reliance', Ballance concluded his Financial Statement,

one which fosters colonial enterprise and creates a colonising spirit; which recognises that the capitalist equally with the labourer must be identified, by residence and fulfilling all the duties of a colonist, with the progress and destiny of New Zealand.

But, above a11, it is essential that the Legislature should be free to effect those reforms it may resolve upon without obstruction from outside influences. The Parliament of New Zealand has already shown that it prefers the interests of the people it represents, and I cannot believe it will retire humiliated and beaten before the menaces of a sordid self-interest which resides outside the sphere of its dominion.

119. PD, 1892,75, p. 131 .

120. $\overline{\mathrm{PD}}, 1892,76$, p. 473.

121. Ibid., p. 472 .

122. Ballance to Meath, 20 Oct. 1892, LB III, p. 358.

123. PD, 1892,75, p. 133. 
A non-borrowing policy, and the need, exemplified by the dispute over the Council appointments, to secure political independence from London, were for Ballance just the two sides of the same self-reliant, nationalist coin.

The arguments against borrowing overseas did not apply to internal loans. Thus Ballance did not rule out the possibility of raising money within the colony, in order to promote development. He was unperturbed by the accusation that securities for this purpose would ultimately find their way to lenders overseas. The Government itself would still not be entering the London loan market. ${ }^{124}$ Ballance admitted that internal borrowing would be required for the purchase of Maori land but argued that it would be 'very limited', and that the Government would 'have the land as an equivalent for the money expended'. 125

The cry of 'borrowing on the sly' also went up in connection with Ballance's plan to make foreign investment companies deposit funds with the Public Trust Office 'as a guarantee of good faith'. 126 The companies would receive four per cent interest, the money being re-lent at a slightly higher rate to small farmers, or to local bodies for public works projects. The exercise would also, so Ballance hoped, reduce the general rate of interest. ${ }^{127}$ Following objections from the insurance companies Ballance agreed not to press the matter. 'So long as they shov' to the satisfaction of the Government that they have a stake in the country', he said, they could 'lend their money

124. Ibid., p. 131.

125. Ballance to Saunders, 11 July 1892, LB III, p. 190.

126. PD, 1892,75, p. 132 .

127. Ballance to Saunders, 11 July 1892, LB III, p. 190; Y, 16 July 1892. 
out directly to small farmers, (at five or six per cent,) provided that the mortgage deeds are deposited in the Public Trust Office' ${ }^{128}$

It has been pointed out that this did little to make credit more readily, or cheaply, available for small farmers. ${ }^{129}$ In fact in mid-1892 Ballance had good grounds to believe that loans generally were becoming easier to obtain. After a sharp decline over the preceding six years, bank advances were now on the increase. 130 Further, loans made by the Life Insurance and Public Trust Offices had risen substantially over the past twelve months. At the same time, the average rate of interest for these loans had fallen from 6.3 to 5.7 per cent. ${ }^{131}$ Ballance wrote to Vogel:

The money we have received from the Public Trust office, the Government Insurance and Post-Office Savings Bank has given us large control of money for investment, and deposits in the Banks here were never so large, perhaps, and as a fact the rate of interest never was so low. We have been (sic) actually been lending money from the Public Trust Office at $5 \frac{1}{2} \%$. 132

128. PD, 1892,76, p. 486.

129. M.R. Stenson, 'The Origins of the Government Advances to Settlers Act, 1894', M.A. thesis, Auckland, 1962, p. 66.

130. Keith Sinclair \& W.F. Mandle, Open Account, Wellington, 1961, p. 242. It turned out to be a short term rise only.

131. The following figures are from AJHR, 1892, H-38:

Return of Loans on Mortgage of Real Estate Life Insurance Department:

Year ended 31 March $1891, £ 53,430$, at average of $£ 6115 \%$ 31 March 1892 , $\$ 185,720$, at average of $\$ 5156 \%$ Public Trust Office

31 March 1891 , $\$ 46,340$, at average of $\$ 5198 \%$ 31 March 1892 , $£ 80,392$, at average of $\$ 5137 \%$

132. Ballance to Vogel, 19 May 1892, LB II, p. 732; also PD, 1892, 76, p. 484 . 
Yet it was true that 'trust' money could only be lent out on freehold security, and that leaseholders were perhaps in greatest difficulties, unable to meet the improvement conditions required under the perpetual lease. ${ }^{133}$ There was even a limit to freehold lending, in that fifty per cent of trust funds were legally required to be invested in government securities. 134

Ballance's whole emphasis was on Government policies that aimed to make as much land as possible available in the first place. He concentrated on the political arguments justifying general and graduated land taxes that would encourage improvements and promote closer settlement; and on the acquisition of private land and the subdivision of large estates. Beyond this he was by no means convinced that the provision of substantial credit to 1 easeholders was critical to the success of that tenure. The great advantage of a leasing system was, after ail, that it could place on the land large numbers of working class men who had insufficient funds to acquire land on deferred payment. Ballance had argued that given low annual rents (much smaller than the repayments under deferred payment), 'there would be no struggle at a1l' for lessees to make improvements. 135

In his Financial Statement Ballance announced that the 1 and and income taxes would, taken as a whole, produce a slightly greater revenue than had been predicted. ${ }^{136}$ He knew of the difficulties in

133. Stenson, p. 68 .

134. PD, 1892, 76, p. 484.

135. $\overline{\mathrm{Ba}} 1$ lance, A National Land Policy, Wellington, $1887, \mathrm{p} .12$.

136. Even this estimate was lower than that which eventuated, see Ballance to Stout, $10 \mathrm{Jan}$. 1893, LB III, p. 414. Figures on the revenue derived from the land, income and property taxes are given in the previous chapter. 
assessing improvements but told the House that in the vast majority of cases valuations had been quickly reached. ${ }^{137}$

The land tax soon ceased to be a major political issue. At first sight this might seem surprising, given the outcry against the tax when it was first announced. In fact most people found that they paid only a little more, or actually fared better, under the new system compared to the old. As the table in the appendix shows, professionals and farmers were slightly worse off than under the property tax, whilst tradesmen, shopkeepers, agents and clerks now paid less tax. The new system was certainly more equitable, in that the working classes contributed only $\$ 543$, as compared to $£ 4,053$ before the change, to direct taxation revenue. Widows were substantially better off.

As far as the tariff was concerned, Ballance said that for the present it would remain as it was. As he had told Saunders (see above), a reduction in duty on basic necessities was ruled out as long as borrowing was to be resisted, and the surplus devoted to the work of colonisation. Ballance was adamant that it was preferable to maintain employment and wage levels through spending on public works, than to reduce the price of a ' lestain articles of consumption,...however much we may appreciate the advantage of cheapness'. 138

He did however, as he had mentioned in a letter to Stout, hope to see increased protection for New Zealand manufactures; ${ }^{139}$ but the

137. $\mathrm{PD}, 1892,75, \mathrm{p} .128$. On charges that assessors were appointed who would 'go after' certain landowners, see PD, 1892, 76, pp. 466-67. 138. PD, 1892, 75, pp. 131-32. 139. Ballance to Stout, 6 June 1892, Stout MSS, folder 23. 
'mass of details' required to determine what changes to make, along with the existing work-1oad connected with the Government's taxation and other measures, meant that Ballance was forced to postpone the matter until the following session. He suggested that a select committee be appointed to collect information on possible revisions, and argued that increased taxation on imports that could be manufactured inside the colony, should offset any reductions in duties on basic items. 140

Finally, in his Statement Ballance promised that a Bill for the purchase of private land would soon be brought down. There would be no compulsion (although he did not discount its necessity in the future), and the large estates in Canterbury, where land was scarce, would be the first to receive the Government's attention. ${ }^{141}$

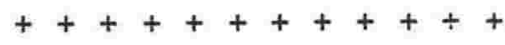

During the first half of the 1892 session, Ballance's energies were absorbed in his dispute with the Governor, and the possibility of dissolution, and in pursuing and promoting his self-reliant policy. He was directly concerned with the Electoral Bill (which along with

140. PD, 1892,75, p. 131. This equality would be tricky to achieve, a lot depending on the elasticity of demand of the goods involved. Higher taxation (thus price) on certain imported goods could result in a reduction in demand, so reducing the revenue obtained. On the other hand, reducing the cost of basic necessities might raise demand and so maintain revenue despite the lower price.

141. PD, 1892,75, p. 127 . See the discussion in ch. 12, pp. 467-71. 
the provision for the female franchise is discussed in the final chapter), a Civil Service Bill (see the previous chapter), and the Wesleyan Property Trust Amendment Bil1. ${ }^{142}$

The most important piece of legislation of the session, however, was the Land Bill. It was introduced in the second week of August, and following a fairly short debate, went to the Waste Lands Committee for more detailed discussion. When it returned to the House Ballance had just suffered a relapse in his illness. From the beginning of September until the end of the session in October, he was seldom well enough to attend debates.

It has been shown that Ballance had intended that the new Land Bill be closely modelled on the measure rejected by the Council the previous year. He did not want to attach to the perpetual lease the right to acquire the freehold: this was basic to the preservation of the remaining crown lands. The Bill that passed did not allow lessees this right, but conceded all of the other major features of the freehold tenure. The lease-in-perpetuity, as it was called, ran for 999 years, and unlike the perpetual lease could be mortgaged. ${ }^{143}$ Further, there would be no revaluations of rents. The State could impose residence and improvement conditions, but would not receive the 'unearned increment' as the land rose in value.

142. The chief aim of this private bill, which Ballance had agreed to promote, was to enable Methodist ministers to be re-appointed to a circuit after the expiry of the existing maximum three year term. PD, 1892, 76, pp. 249, 307-08; Wesleyan Conference to Ballance, 8 June 1891, BMSS, 180-81; Ballance to Wesleyan Conference, 4 June 1892, LB III, p. 66; Rev. Lewis to Ballance, 29 July 1892, BMSS, 635; Ballance to Rev. Lewis, 2 Aug. 1892, LB III, p. 258; Ballance to Rev. Dewsbury, 18 Oct. 1892, LB III, p. 352. Lewis told Ballance that although his church was not committed to any particular political party, he knew that many of its members were Government sympathisers. Ballance replied that some of his strongest supporters in Wanganui were Wesleyans.

143. Holders of the lease-in-perpetuity had the 'power of sale, sub-lease, disposition by will, or mortgage', Official Year Book, 1894, p. 201. 
This was more than a 'compromise' between the advocates of freehold and leasehold tenures; it was an outright defeat for the 1atter. In April James Taylor had written to Ballance suggesting that loans be made available to leaseholders and that the term of the lease be unlimited. Ballance's response is illuminating, given that what he deprecated (the loss of the unearned increment) was soon to be conceded:

In reply to the first question you refer to, namely, the propriety of advancing money against Perpetual Leases, I am giving the matter attention and think it quite possible that we may be able to so alter the law as to permit advances of the kind to be made. The other subject, that is to say, the doing away with any limit to the Leases, is of course a matter of more serious importance. You will, upon reflection, recognise that your proposition means nothing less than the giving up of the Unearned Increment... (I) $t$ would be a violation of all the principles laid down by the greatest advanced thinkers on the subject of Political Economy during the last thirty or forty years.

Let see how it would work; Say a Perpetual Lease is disposed of without any limits to the tenure, and a Goldfield, or a Coalfield is discovered to abound, what was worth, previous to this, two shillings an acre rent is worth one hundred pounds rent. Do you contend, seriously, that that sent belongs to the Leaseholder instead of the state? I cannot think that is your opinion. It has, for some time appeared to me pretty clear that we must adhere to the principle of the unearned Increment, or failing that, we must have a Fair Rent Court which will sit periodically, and assess the value of the property similar to the Irish Land Courts. Now until I am convinced that the Unearned Increment is a wrong principle, I cannot abandon it and there(fore) must differ from you on this point. 144

144. Ballance to J. Taylor, 27 Apr. 1892, LB II, p. 707. The example Ballance used was extreme (and it could be countered that all the State had to do was to retain mining rights), but it emphasised the basic problem. 
Thus with the lease-in-perpetuity passed into law, Ballance would have wanted to introduce some form of rent revaluation. In 1894 William Earnshaw told the House that he had only supported the Land Bill having been promised by Ballance that a Fair Rent Bill would be brought down. 145

McKenzie proposed the lease-in-perpetuity under pressure from some of the Government's own supporters representing country districts. ${ }^{146}$ 'If I were bringing in a Land Bill entirely to suit my own views', he said, 'it would be a very different Land Bill from what is before the House at present. ...But we have to be practical: we must study public opinion, and we must study the opinions of members of this House. ...(A) 11 legislation on this matter must be to a certain extent a compromise' 147

Ballance spoke briefly on the second reading, but revealed little, saying simply that McKenzie had recognised 'that the time has not come for confining himself entirely to the perpetual lease'. ${ }^{148}$ In his reply to the debate on the financial statement Ballance had drawn the distinction between on the one hand his own belief in the preservation, though leasing, of all remaining Crown 1 and, and on the other the popularity of the freehold:

...if the people of the colony wish for the freehold tenure, of course they must have it. Who will gainsay the people of the colony? who resist them? I say we believe that the public estate should be saved for the people...for all generations to come- through all time. We say that

145. PD, 1894, 84, pp. 171-72. Earnshaw said he had this assurance from Ballance in writing.

146. PD, 1892,76, p. $574 ; 77$, p. 497.

147. $\overline{\mathrm{PD}}, 1892,77, \mathrm{pp} .529-30$.

148. $\overline{\mathrm{PD}}, 1892,76$, p. 549. 
we shall reason this matter out with the people of the colony, and we believe that if the position is fairly put before them they will come to...look upon the lands of the colony as a heritage which should be sacred to the people. 149

Nowhere, either in the House, or in his private correspondence, did Ballance admit to the full extent of the compromise involved in the lease-in-perpetuity. It has been suggested that his illness was a factor in his conceding the issue, ${ }^{150}$ yet McKenzie had devised the new tenure well before Ballance's relapse. As we have seen had Ballance lived he would have tried to introduce periodic revaluation. At the time, however, there was little he could do. If the House had been persuaded to accept the 'genuine' perpetual lease (and it must be remembered that such a measure was passed the previous year), the Council would almost certainly have thrown it out a second time. It might well be that had Ballance been able to appoint the new batch of councillors at the start of the new session (which, of course, is what he had urged of Glasgow), instead of after its conclusion, he would have been more inclined to persist with the perpetual lease.

Undoubtedly Ballance's prime concern was the survival of the Government. As he wrote to Perceval the day after the second reading of the Land Bill:

The discussion on the Financial Statement is just over: no amendment was tabled, and the result of the debate is that the Government is strengthened. The Opposition, however, are exceedingly active and will table a No Confidence motion on the Land Bill, supposed to be our weakest point as regards the question of the 
Freehold, but McKenzie has completely dumbfoundered them by turning the Perpetual Lease with renewals into a Perpetual Lease for ever at the first rent. This seems to have completely captivated a large number of Members who were formerly in favor of the Freehold. 151

The last line suggests that Ballance saw the lease-in-perpetuity as granting distinctly less than the freehold; that he believed McKenzie to have convinced the House to accept less, and in doing so strengthened the position of the Government.

Clearly Ballance was not content with a lease that did not allow for revaluation. Yet was it realistic for him to expect to be able to convince the country on the advantages of a 'pure' leasing system? What lay behind the strong support for the lease-in-perpetuity, and what were the consequences of this for the Liberal Party? These are issues fundamental to the economic and political development of New Zealand. Their detailed examination is beyond the scope of this thesis, although a few points can be made.

The perpetual lease had been very popular; between 1881 and 1891, land held on freehold increased by about one-fifth, whilst that on leasehold rose by just under one half. ${ }^{152}$ Yet the lease had been favoured not because of any 'sentimental' or 'philosophical' attachment to it, but because the depressed economic conditions that prevailed throughout this period ruled out, for many, the possibility of acquiring the freehold. Conversely, as conditions improved in the 1890 s there was less need for a tenure tailored to the requirements of 
those with very little capital. Seen in this light the demand for credit for carrying out improvements came not so much from impoverished leaseholders but from those (both leaseholders and freeholders), who were now well enough placed to finance a loan. The political force of this demand was acknowledged first, by the lease-in-perpetuity (which it will be remembered permitted mortgaging) and secondly, by the Advances to Settlers Act of 1894 .

The lease-in-perpetuity was also a popular tenure, but because it had all the advantages, without the cost, of the freehold. It was the political prejudice in favour of the freehold, rather than any inherent economic flaw in the leasing system, that was Ballance's major problem. Increasingly it would be the more prosperous farmers who would be able to wield political muscle. Of the $\mathbf{z}$ million advanced to settlers (under the $1894 \mathrm{Act}$ ) by 1900 , approximately $\$ 2.7$ million went to freeholders. Leaseholders received a mere $£ 350.000 .^{153}$

Thus it would seem reasonable to speculate that Ballance would have soon had to borrow overseas, and that he would have done so to provide credit for freeholders rather than leaseholders. He did not recognise a major need for loans for lessees, and at the same time would have found it impossible to resist the powerful freehold lobby. In 1891 he turned down a request that the Public Trust office lend money to holders of perpetual leases. ${ }^{154}$ A year later the

153. AJHR, 1900, B-13. There were, of course, more freeholders than leaseholders. In 1895 there were 28,965 freeholders, 11,751 leaseholders, and 5,960 part freehold, part leasehold holdings; (Statistics of New Zealand, 1895, p. 380), but it remains true that advances went disproportionately to freeholders.

154. EP, 13 July 1891. 
Public Trustee, J.K. Warburton, was working on a scheme to encourage the flow of loan money for freeholders to New Zealand. Under it the government would set up a Mortgage Office in London and act as intermediary and guarantor for loans. ${ }^{155}$ Clearly this was an acknowledgement of the demand for credit, and an attempt to meet it without resorting to overt government borrowing.

This writer's contention is that there was no inherent interdependency between a self-reliant, non-borrowing, policy and a 'genuine' perpetual lease because the two were quite separate issues. ${ }^{156}$ Simply raising a new overseas loan would not resolve the political difficulty of persuading the country to accept a revaluable lease as the only tenure for the remaining crown lands. Before Ballance's death existing lessees were already pressing for the freehold, and it is unlikely that this demand would be satisfied by providing them with cheap loans (assuming Ballance recognised the need in the first place). 157

This can be looked at another way. Ballance saw land 'nationalisation' (the ambiguities of this term have already been noted- here it means at least no further crown land sales and a revaluable lease) as the solution to urban ills; and the political support for it came from the cities and to a lesser extent the towns. Further, nationalisation would prevent the aggregation of holdings in

155. The details of the scheme were not revealed until after Ballance's death. See NZT, 4 Nov. 1893.

156. A self reliant policy would, however, seriously restrict land repurchasing, see ch. 12, pp. 470-71.

157. As the Land Bill was being considered, a number of petitions were presented to Parliament by leaseholders and small farm associations. Generally speaking they sought the right to purchase the freehold, and a relaxation of the regulation requiring residence, rather than simply financial assistance to develop their holdings, AJHR, 1892, I-5, p. 3 . 
the future and, along with a graduated tax aimed at breaking up existing estates, would destroy the political power of the 'squattocracy'. For urban Liberals nationalisation also sought to secure for the State a continuing share of rural prosperity. Not surprisingly McLean, Tanner, Earnshaw, Buick and Joyce al1 voted against the 1892 Land Bill, which sacrificed this share. ${ }^{158}$ Equa1ly, urban Liberal politicians would be unsympathetic to the demands of freeholders for credit. If there was borrowing to be done, it ought to be either for the re-purchase of private land (see chapter 12), or to support the leaseholders. In both cases the State would reap the benefit.

Ultimately Ballance's self-reliant policy aimed to establish greater economic independence and to stabilise the economy. With this achieved a return to limited borrowing would be possible. Yet this would not resolve Ballance's dilemma, which was how to combat the forces that underlay the demand to borrow in the first piace. These forces were operating against Ballance's own prejudice for land nationalisation and against the predominantly urban political composition of the party in 1890 .

With respect to this Ballance was in a weak position, for as the pressure for the freehold rose land nationalisation became increasingly irrelevant as a central urban issue. First, though closer settlement was one of the major aims of rationalisation, this was in fact being achieved without it. At the same time the political position of the landed oligarchy was being successfully eroded. The Liberals abolished but recorded their disapproval in a later division (PD, 1892, 77, p. 531). See p.453 concerning the basis for Earnshaw's support. 
the property vote; reduced the tenure of Legislative Councillors from life to seven years; and throughout the 1890s the large estates would be (most often voluntarily) subdivided. Secondly, with less and less land available for settlement, a declining proportion of the growing urban population could be expected to be placed upon it. It was increasingly naive to believe that closer land settlement could hope to solve urban problems. Finally, as far as nationalisation as the means of securing the unearned increment for the State was concerned, this came up against political opposition from the farmers themselves. In any case, as the interrelationship between city and country became more obscure, and as urbanisation advanced, it was natural that purely 'urban' issues would soon dominate 'urban' politics. 159

As these crucial developments were coming to a head Ballance was dying. He was in extreme discomfort and pain throughout early September. ${ }^{160}$ He made slow progress after this relapse, but, against the advice of his doctors and colleagues, was back in the House the middle of the month. ${ }^{161}$ He spoke there last on 23 September, being forced to return to his bed, his condition worse than ever, days later. ${ }^{162}$

159. The position of towns is more ambiguous. See D.A. Hamer, 'Towns in Nineteenth-Century New Zealand', NZJH, 13, 1 (1979), pp. 5-20.

160. Y, 10 Sept. 1892; EP, 5, 8 Sept. 18 $\overline{92}$ A fancydress ball, to be held in Kathleen Ballance's honour, had to be postponed for a week. When it took place, there were about 200 guests: see the delightful account, 'Mrs Ballance's Butterfly Ball', in $x, 24$ Sept. 1892.

161. EP, 13 Sept. 1892; Y, 24 Sept. 1892; Ballance to Wellington Liberal Association, 10 Sept. 1892, BMSS, 657.

162. PD, 1892,78, p. $361 ; \underline{Y}, 1$ Oct. 1892 . 
The Herald played down the seriousness of the attack; there was every hope, it said, that his condition would continue to improve, and that with rest he would soon be back on his feet. ${ }^{163}$ At the same time it blamed Ballance's illness on the 'shameful' obstruction of business by the Opposition; mentioning in particular the activities of Fish, Fisher, George Hutchison and Scobie MacKenzie, and suggesting that these members' constituencies would do well to turn them out at the next election:

Mr Ballance has had to work from 16 to 18 hours a day ever since the session began, and to put up with an amount of obstruction and worry that would kill many a less courageous man. But late hours, bad air and worry have at last compelled him to take a much needed rest... . 164

Ballance was still in his bed, at his Tinakori home, when he received the news that the Colonial office had ruled that Glasgow should agree to make a11 the new appointments to the Legislative Council. ${ }^{165}$ It was, perhaps, Ballance's greatest and most sifnificant victory. Regarded as a vindication of his whole policy, it immediately strengthened the Government's position, and in the longer term established an important constitutional precedent. The further consolidation of the Liberals at, and following, the 1893 election, meant that '(b)y 1897 the Council's teeth had to all intents and purposes been drawn'. 166

The rest of the Cabinet were jubilant. However, according to Stout, Ballance told them to do everything they could to let the

163. Y, 17 Sept. 1892, 'Our Parliamentary Letter'. 164. $\bar{Y}, 10$ Sept. 1892 . 165. $\bar{Y}, 1$ Oct. 1892; Spinks Diary, 26 Sept. 1892. 166. Jackson, p. 121. 
Governor down as lightly as possible. Party members were to be informed straight away of the news, so that when the public announcement was made in the House, there would be 'no cheering or other demonstration'. 167

Although only now could the appointments be made, Ballance had long been considering exactly whom to nominate. His aim was not simply to increase the Government's voting strength in the Council, but in selecting the twelve new members to fairly represent, reward, and as far as possible help secure the loyalty of, the various factions within the party. As far back as September 1891, the Yeoman had acknowledged that a number of the new councillors would be labour representatives. 168

During the recess Ballance approached individuals and organisations for suggestions, and these names were subsequently considered by the Cabinet. 169 The final selection included four trade unionists, the first to be appointed to the Council: William Bolt, the Secretary of the National Liberal Association in Dunedin, and whom we have come across before in connection with his views on land nationalisation and freethought; a Christchurch boilermaker, J.E. Jenkinson; the prominent Auckland Liberal, printing foreman, and member of the Knights of Labour, W.T. Jennings; and finally John Rigg, who was President of the Wellington Trades and Labour Council. The

167. Sir Robert Stout, 'Character Sketch: The Hon. John Ballance', Review of Reviews for Australasia, May 1893, p. 114.

168. YY, 19 Sept. 1891, 'A Lady's Letter From Wellington'.

169. Ballance to J.T. Fisher, 9 Feb. 1892, LB II, p. 590. Fisher had asked to be appointed. Ballance replied that he hoped he was, and promised to put Fisher's name to the Cabinet. See also S.P. Andrews to Ballance, 9 Sept. 1891, BMSS, 285, and Ballance's note: 'Reply-when time arrives question submitted to the cabinet'. 
other eight were: Henry Feldwick, the Invercargill Liberal who had lost his seat at the last election; Thomas Kelly, a farmer and ex-Member for New Plymouth; two journalists, McCullough and Kerr, from Auckland and Greymouth respectively; MacGregor, a Dunedin lawyer; William Montgomery, who had held office in the Stout-Vogel Government; Edward Richardson, the Christchurch politician who had been Minister for Public Works in a number of administrations (including Atkinson's); and W.C. Walker, a farmer and ex-Member for Ashburton.

Naturally there were a number of disappointed people, those who had hoped to be included. William Fraser, the, Member for Te Aroha, for example, had asked to go to the Council, ${ }^{170}$ and there was considerable lobbying on behalf of a liberal (and cousin of an English Radical M.P.) named Cunninghame-Graham. ${ }^{171}$ Apparently others actually turned down the offer of seats, as in the case of two Aucklanders, J.C. Firth and T.W. Leys (of the Evening Star) $:^{172}$ Ballance undoubtedly hoped to use the appointments to help the position of the Government in that city.

It was the presence of the unionists that drew most comment from the press. The Evening Post saw Bolt's elevation as a reflection of the influence of Stout, and of 'revolutionary Socialistic doctrines',

170. Fraser to Ballance, 30 Jan. 1892, BMSS, 478.

171. W.J. Stewart to Ballance, 20 Sept. 1891, BMSS, 293; G. Beaven to Ballance, 16 Nov. 1891, BMSS, 364-67; S. Buxton to Ballance, 6 Feb. 1892, BMSS, 500; Ballance to Hall-Jones, 28 Jan. 1892, LB II, p. 553. A Christchurch 1iberal and President of the Amalgamated Miners and Labourers Association of New Zealand, Lomas, was also suggested, Ballance to Sandford, 2 Feb. 1892, LB II, p. 561; Sandford to Ballance, 9 Feb. 1892, BMSS, 512 .

172. Ballance to Firth, 29 Oct. 1892, LB III, p. 379; Ballance to Leys, 29 Oct. 1892 , LB III, p. 380 . 
on the Government. ${ }^{173}$ The other selections were generally seen as reward for services rendered to the Liberal cause. ${ }^{174}$

The Government still did not have a majority in the Upper House, but with these and later appointments, and the constitutional position having been sorted out, its measures would from now on have a much easier passage. Ballance barely lived to see this vital success.

173. EP, 28 June 1892. Bo1t had been considered a likely nominee early on. He was a prominent Liberal, and a natural choice, see W. Earnshaw to Ballance, 4 Jan. 1892, BMSS, 445.

174. Y, 22 Oct. 1892 . 
When Ballance became seriously ill in September 1892, the Cabinet unanimously appointed Seddon acting-Premier. ${ }^{1}$ After Ballance Seddon was the most prominent member of the Party in Parliament. In his end of session speech he lamented that Ballance's health had failed just as the Government's policies were beginning to bear fruit. Ballance, said Seddon, had been vindicated by the decisions on the Legislative Council appointments and the Edwards case, and more important, by the success of his self-reliant policy. Financial journals in London, that had previously been hostile, were now praising New Zealand: 'confidence has been restored not only amongst ourselves in this colony, but also in the old World'. ${ }^{2}$

It was essentially the coincidence of a firm non-borrowing policy and a budget surplus that had worked this 'wonder'. Self-reliance was seen to be a viable proposition. In England the Financial News said that the policy, which had been forced on the colony by the depression and the accompanying withdraw1 of capital, was a great success. The surplus indicated an 'inherent prosperity', enabling the people to 'put their trust in themselves'. 3 The Pall Mall Gazette-meanwhile, saw the central feature of Ballance's policy as the recognition that ' $(t)$ he country exists for itself, not to supply a high rate of interest for capitalistic speculators'. 4

Despite making only a very slow recovery from his relapse, Ballance did share in this optimism. 'The Land Tax has turned out very well indeed, and I am looking forward to find the Income Tax

1. NZT, 7 Sept. 1892 .

2. $\overline{\mathrm{PD}}, 1892,78$, p. 901.

3. Quoted by $Y, 15$ Oct. 1892 .

4. Quoted by $\underline{\underline{Y}}, 4$ June 1892 . 
equally successful', he wrote to Alfred Saunders:

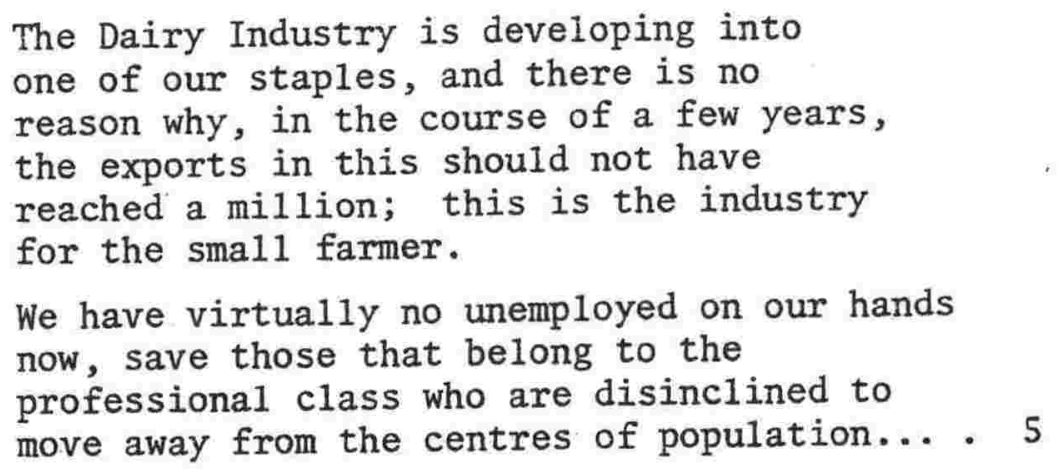

There was also some good personal news for Ballance: the Herald Company was showing the best profit for years. 6

Not until the last weeks of the year did Ballance's health improve sufficiently to allow him to return to any work. ${ }^{7}$ He had been able to travel to Wanganui for a brief visit in November, ${ }^{8}$ but on returning to Wellington suffered another relapse. 9 His recovery in the new year was only temporary. E11en was 'sad at heart about her husband', Sarah Jane Spinks wrote in her diary for 26 January. Four days later was the entry:

Mr Ballance very ill. David saw Ellen this morning: another consultation was held... result not satisfactory: patient disobeyed orders, dressed, took a chop \& attended to business... . 10

In his final months there were two specific political questions that dwelt on Ballance's mind. The first was the purchase of the Cheviot Estate, the second the women's franchise.

5. Ballance to Saunders, 30 Dec. 1892, LB III, pp. 395-96.

6. Y, 12 Nov. 1892; Ballance to J. Boyle, $10 \mathrm{Jan} .1893$, LB III, p. 412.

7. Ballance to Saunders, 30 Dec. 1892 , LB III, p. 395.

8. Spinks Diary, 26 Oct. 1892; Y, 26 Nov. 1892.

9. Spinks Diary, 10 Dec. 1892; $\bar{Y}, 3$ Dec. 1892.

10. 30 Jan. 1893. 
For Ballance and many on the left wing of the Liberal Party land nationalisation meant not only the preservation of existing crown lands through leasing, but the re-purchase of land in private hands. In his recent Financial Statement Ballance had promised a purchasing bil1, ${ }^{11}$ and during the session a Land for Settlements Act was duly passed. It established a Land Purchase Board that was empowered to inspect freehold land being offered for sale. If suitable, the land could be acquired by the crown and settled under the lease-in-perpetuity. The Board could not compel a sale, government spending was 1 imited to $\$ 50,000$ per year, and the Act did not meet with much initial success. Two years later a new Act was passed, providing for compulsion and raising the purchasing limit to $£ 250,000$ in any one year. As Condliffe points out, although compulsion was rarely resorted to, the provision was 'probably of some importance as a bargaining factor on the Government's side'. ${ }^{12}$ By'1901 eighty-one estates had been purchased (containing 331,128 acres), and 1,789 tenants settled on the 1 and. ${ }^{13}$

Before the purchasing of land under these Acts began in earnest, the Government bought the Cheviot Estate. This Canterbury estate, of some 85,000 acres, was acquired under the provisions of the Land and Income Assessment Act, whereby an owner who refused to accept the official valuation of his property, could sell it to the government. The land had been valued at $\$ 359,126$ (including improvements), whilst the trustees of the estate, hoping to force the Government to lower this figure, offered it for sale at $£ 260,220.14$

11. PD, 1892, 75, p. 127 .

12. J.B. Condliffe, New Zealand in the Making, London, 1930, p. 189. Ballance had recognised that compulsion might be necessary. See ch. 11, p. 450 .

13. Ibid.

14. Official Year Book, 1895, pp. 264-65. 
Ballance was not particularly keen to purchase the land, but the alternative, reducing the valuation, 'would have established a most dangerous precedent'. 15

Thus the Government took Cheviot, calling the bluff of the trustees. Ballance believed that he had 'established for all time the object lesson in the way of cutting up the large estates, which must act as a stimulus to voluntary promptings for the large holders'. 16

Historians have disputed the extent to which the land tax and the Land for Settlement Acts influenced the subsequent reduction in the size of land holdings. It has been argued that rising export and 1 and prices, refrigeration and the spread of small dairy farms were more important factors; that irrespective of the legislation large landowners were quite willing to sub-divide. ${ }^{17}$ Condliffe points out that the tax 'was successful mainly because it worked with and through the economic forces which were already operating to encourage farming industries like dairying, where land value was a relatively small item of cost compared to labour and capital'. ${ }^{18}$ In other words the tax gave 'a further impetus to forces already at work'. ${ }^{19}$ It was not particularly burdensome, since valuations lagged behind rising prices. Had prices been falling, it would have been a different story.

15. Ballance to Saunders, 16 Jan. 1893, LB III, p. 396; also Ballance to Perceval, 9 Jan. 1893, LB III, p. 404.

16. Ballance to Walker, 10 Jan. 1893, LB III, pp. 410-11.

17. W.H. Oliver, The Story of New Zealand, London, 1960, p. 144; see also J.D. Gould, 'The Twilight of the Estates, 1891 to 1910', Australian Economic History Review, X, 1 (1970).

18. Condliffe, p. 184.

19. Ibid. On the trend towards smaller holdings see pp. 240-42. 
Ballance hoped that the Cheviot purchase would enable the Government to 'settle a large number of people on the land, and at the same time avoid a loss to the Treasury'. ${ }^{20}$ Although he was ever-conscious of the desirability of making the exercise self-financing, he did not believe that this required the sale of the land. 'I do not care if we sell not an acre', he wrote to Stout. 'As the Land Tax department has the disposal of it, I propose to save the unearned increment by leasing it for terms of 30 and 21 years perpetual on a mere rental system'. ${ }^{21}$. In the long run the State would receive back in rents what he had paid for the 1and.

The transactions for the purchase of Cheviot were not completed until 19 April 1893, a week prior to Ballance's death. By March $1894,6,546$ acres of the estate had been sold, 23,945 acres settled on the lease-in-perpetuity (rather than a perpetual lease as Ballance had intended), and another 43,628 acres taken up as grazing runs. ${ }^{22}$ Thus the unearned increment was not being saved.

Speaking on the Land for Settlements Bill of 1894, William Earnshaw, an urban Liberal on the left of the Party who favoured land nationalisation, complained that McKenzie had tried to sell as much of the estate as he could:

It is entirely purposeless to purchase land from private owners to sell again... . ... (T) he Government have really taken up the functions of a land-transfer agency company: that is really their position. It is simply the bursting-up of the large estates and handing them over to others... . 23 
Earnshaw regarded the Land for Settlements Act in much the same 1ight. Land purchased under the Act was disposed of under the lease-in-perpetuity. Even if the land was not actually sold, the State had lost the right to the unearned increment. The Act was not, in Earnshaw's view, in the interests of town dwellers at a11. $^{24}$

Essentially, given that the lease-in-perpetuity had been conceded, there was little for the land nationalisers in either the Cheviot purchase or the Land for Settlements Acts. The cry for 'more Cheviots' at the 1894 election was based on a desire for more land and closer settlement, not for nationalisation?

Land nationalisation faced a number of critical problems. A 'pure' policy, involving the re-purchase of all alienated land, would require vast sums of money: the Yeoman suggested $\$ 200$ million and recognised that this was a quite impossible proposition. ${ }^{25}$ Limited purchasing of the large estates was, of course, viable, and indeed was what happened. By 1924 f13 million had been spent on the acquisition of two million acres under the Land for Settlement Acts. ${ }^{26}$ In general the difficulty for Ballance was that the extent of repurchasing was dependent upon the amount of borrowing he would allow. 27 Thus land nationalisation, meaning the re-purchasing of

24. Ibid., p. 174. As with the 'ordinary' lease-in-perpetuity of the Land Act, tenants on land covered by the Land for Settlements Acts were eventually given the right to purchase the freehold.

25. 28 May 1892 ,

26. W.R. Jourdain, Land Legislation and Settlement in New Zealand, Wellington, $1925, \mathrm{p} .36$.

27. In his pamphlet on land nationalisation Ballance realised this, and wrote that as long as the colony's credit was maintained there would be no difficulty in raising the necessary funds. A National Land Policy, 1887, pp. 18-19. Borrowing could be internal (as Ballance stressed with respect to the purchase of Maori land), but there was a limit to this source. 
land in private hands, conflicted with self-reliance. In the end, however, even given Ballance's acceptance of the need to borrow, the fact was that nationalisation had few supporters, was opposed by the prosperous and increasingly influential small farmers, and was not viewed as necessary to promote closer settlement. ${ }^{28}$

The second issue of concern to Ballance in his final days was women's suffrage, something he had long advocated.... It will be remembered that in 1879 he had unsuccessfully attempted to amend an Electoral Bill to enfranchise women. And he had supported Hall's Bill of 1890 , saying,

...I believe in the absolute equality of the sexes, and I think they should be in the enjoyment of equal privileges in political matters. 29

In 1891 Ballance moved the second reading of the Electoral Bill, the main feature of which was to remove the right of property voters to appear on more than one roll (plural voting had been abolished in 1889 but property voters could, for example, vote at a by-election in a different constituency to the one they voted in at a general election). Despite the growing pressure being exerted by women's organisations outside the House, and the considerable support inside, there was no provision for the female franchise. 30

28. See ch. 11, pp. 458-59.

29. PD, 1890,68, p. 394 .

30. PD, 1891,71 , pp. 51-53. 
Ballance knew that there were Liberals opposed to the measure, some on the grounds that the majority of women would vote against the Government at an election. James Duigan had advised him that it was 'dead against the interests of the Liberal Party to extend the franchise to women', suggesting that in Wanganui women would vote for Carson 'because in their opinion he is a good man, and against you because they have been led to believe by your enemies that you are an athiest (sic) '. 31

When speaking on Hall's Bill Ballance had argued that the vote should be given irrespective of the political effect it might have. ${ }^{32}$ His problem when Premier was that his Cabinet colleagues were not nearly so enthusiastic:

It is no secret that $\mathrm{Mr}$ Ballance is the only one of the Ministry who is heartily in favour of the concession and confident of its immediate beneficial influence. The warm support such an advanced proposition has received from the Conservative benches has naturaIly aroused distrust in the breasts of those Liberals who have not thought much on the subject... . 33

In fact Ballance was intent on putting his own weight behind an amendment to the Electoral Bill that would enfranchise women, that Hall had announced in advance he would move. Ballance's efforts in this respect were acknowledged both by women's groups ${ }^{34}$ and in the press. 35 The amendment was carried by a large majority. ${ }^{36}$ According

31. Duigan to Ballance, 27 Aug. 1891, BMSS, 267. See also E. Hackett to Ballance, 28 Aug. 1891, BMSS, 268-69.

32. $\mathrm{PD}, 1890,68, \mathrm{p} .394$.

33. $\bar{Y}, 19$ Sept. 1891, 'A Lady's Letter From Wellington'.

34. Women's Franchise Committee to Ballance, 13 July 1891, BMSS, 217; Miss L.W. Dalrymple to Ballance, 7 Sept. 1891, BMSS, 284.

35. EP, 19 June 1891.

36. $\overline{\text { See }} \underline{Y}, 29$ Aug. 1891. 
to Grimshaw, when, during the debate, one speaker 'declared strongly that the women did not want the vote, Mrs Ballance passed around a petition in the Ladies' Gallery, which drew sixty-eight signatures, assuring the House that they did in fact desire to vote'. 37

The important clauses of the Electoral Bill (the one affecting the property vote and the women's franchise) were, however, thrown out by the Council. ${ }^{38}$ The following session Ballance introduced a new Bill, this time containing the female franchise from the start. 39 Ballance said that although the Bill did not allow women to stand for parliament, he was personally in favour of it. He suggested that Ha11 wanted women enfranchised only because he (Hall) ..believed it would be of benefit to the 'conservative' party. Ballance argued that the Bill would, on the contrary, have the opposite effect. In other respects the Bill was similar to that of the previous year. ${ }^{40}$

The Council again made some changes to the Bill, this time allowing women to vote, but only by post. ${ }^{41}$ Alfred Saunders, a leading suffragist, then attempted to get the House to accept this alteration, rather than drop the whole Bill. Meanwhile Ballance had taken $i 11$, and with the rest of the Cabinet opposed to the measure ('J. MacKenzie (sic) admits to me that none of the Ministers want the franchise except Ballance' Saunders wrote to Kate Sheppard), ${ }^{42}$ the amendment was lost.

37. Patricia Grimshaw, Women's Suffrage in New Zealand, Auckland, 1972 , p. 68.

38. See PD, 1891, 74, pp. 719-22, 898-99; EP, 10 Sept. 1891.

39. See $\overline{\mathrm{Ba}} 1$ lance to Mrs A. Daldy, 12 July $1 \overline{892}$, LB III, p. 196.

40. PD, 1892,75 , pp. 151-52, 189-93; Y, 16 July 1892 .

41. The problem here, of course, was that without a secret ballot women would be open to instruction on how to vote from men. See $\underline{Y}, 15$ Oct. 1892 .

42. Quoted by Grimshaw, p. 72. The spelling of McKenzie is wrong: it is not clear from Grimshaw if the error was in the original. 
Public debate on women's suffrage continued throughout the recess. A meeting of the Women's Christian Temperance Union in Christchurch was called to censure the Government on its failure to pass the franchise by rejecting the whole Electoral Bill. 43 In Wanganui the Yeoman argued that the Council's amendment fitted in with Hall's motives, in that it destroyed the secret ballot, thus 'giving the head of a Tory family several votes through the enfranchisement of his wife, daughters, and female domestics'. 44

In his final months Ballance began to consider the prospects of the Party at the coming election, ${ }^{45}$ and in particular to show concern at the effect enfranchisement might have on the result. In July 1892 he had told H.R. Rae of Wellington: 'We believe the wives and daughters of working men will vote with their male relations, and that on the whole women's votes will be progressive in the best sense of the term', adding that 'democracy' would triumph as long as it was organised. 46 However early in the new year he was suggesting that the vote be given, but its operation delayed until January 1894:

The Women's Franchise Bill will of course be introduced again next session, and it will no doubt pass both Houses. If it be brought into operation before the General Election, there will not be time for the whole of the women of the country to be placed upon the Register. Only the ones who are already organised will be there, and outside the large cities these are al1 against us. The Party, in my opinion, will be seriously damaged unless there is time to place the whole of the women of the colony on the rolls. ...I do not myself like to... disappoint the women workers who are looking

43. The censure was not passed, $\underline{Y}, 29$ Oct. 1892 .

44. Ibid.

45. See e.g. Ballance to Duigan, 16 Jan. 1893, LB III, pp. 434-45.

46. Ballance to Rae, 19 July 1892 , LB III, p. 214. 
forward to the franchise as a means of redressing their grievances: but the present Liberal Party has done very much for the cause of labor generally. I cannot think they would refuse to wait for one Parliament in order to obtain so great a boon which has been granted in no other country in the world, with the exception of one State in America. 47

Ballance probably regarded the temperance element in the women's rights movement as essentially conservative. He himself, it will be remembered (see chapter 6), was against prohibition. ${ }^{48}$

Nevertheless, with this one qualification, Ballance remained strongly in favour of the franchise, and believed it would be 'one of the first measures introduced in the next session'. ${ }^{49}$ He wrote the following to Saunders, less than three weeks before his death:

My own strong opinion is, that we want on the Statute Book as a foundation of our constitution a broad measure taking in all the adults of the colony, male and female, without any experimental legislation such as voting through the Post Office. Then we shall have the freest political system in the world.

I have myself the utmost faith in the good sense of the women of the colony, and have never changed in the slightest for the last fourteen years my views on the subject. I was the first to carry a resolution in favour of the franchise in the House, and believed then, as I believe still, that it would be one of the greatest of social reforms. 50

47. Ballance to Pinkerton, 11 Jan. 1893, LB III, p. 420. See the very similar sentiments in Ballance to W.C. Smith, 11 Jan. 1893, LB III, p. 422, and Ballance to Stout, $10 \mathrm{Jan} .1893$, LB III, pp. 416-17.

48. See Raewyn Dalziel's important article, 'The Colonial Helpmeet. Women's Role and the Vote in Nineteenth-Century New Zealand', NZJH, 11,2 (1977).

49. Ballance to Saunders, 30 Dec. 1892, LB III, p. 396.

50. Ballance to Saunders, 11 Apr. 1893, LB III, p. 766. 
The second paragraph suggests that despite Ballance's concern for the position of the Liberal Party, he was optimistic that women's enfranchisement would not, in the long term, harm it. An Act did get passed in the 1893 session, and women voted for the first time at the general election at the end of the year. ${ }^{51}$

Although Ballance's worsening illness was interrupted by brief periods of recovery and some optimism that his complaint might not prove fatal, he had by February 1893 at the latest, decided to retire from politics. The seriousness of his condition he kept to himself as much as possible, primarily because of concern over who would succeed him. As early as December 1892 T.M. Haultain (who incidentally had been Defence Minister at the time of the war against Titokowaru) wrote to his old friend Edward Stafford:

Ballance's party have a very decided majority both in the House and in the Country. I hear from Wellington that there is very little hope of their leader's restoration to health and they are keeping this very quiet, for his retirement whether from death or otherwise would be a serious difficulty to them, as there would be a struggle for the Premiership. 52

The previous month Ballance had told his constituents that he expected to be in 'perfect health' in a matter of a few weeks. 53 By January he had lost four stone in weight, ${ }^{54}$ yet on the 16 th put out the

51. See Grimshaw, ch. 9 .

52. T.M. Haultain to Stafford, 13 Dec. 1892, Stafford Papers, vol. 6. 53. $Y, 5$ Nov. 1892; also Manawatu Standard quoted in $\underline{Y}, 26$ Nov. 1892. 54. R.M. Burdon, King Dick, Christchurch, 1955, p. 104 . 
following statement:

The Hon. the Premier is much concerned at some statements that have appeared in print to the effect that he was so ill he was unlikely to enter political life again. He has requested the Press Association to state that his present condition is most satisfactory, that he is recovering rapidly, and has every expectation of being in his seat next session. 55

There was a temporary reprieve in his illness over the following weeks, ${ }^{56}$ which helped him to maintain the pretence. On1y a week before his death he insisted on contradicting the suggestion of a Westland paper that his case was hopeless. The journal was speculating on the chances of the 'local' man, Seddon, succeeding him. 57 Ballance went to extraordinary lengths to conceal his condition. In early April he travelled by train back to Wellington from Wanganui. He was lying in considerable pain when some journalists entered his compartment :

He at once got up, assumed an appearance of ease, and remained standing while he spoke to them; but as they thoughtlessly continued asking him questions, and he felt unable to combat the pain and weakness under which he laboured, he placed his hand upon his side, excused himself, said he felt tired with the journey, and lying down, concluded the interview in that position, his questioners little thinking the agony they were causing him. 58

55. Y, 21 Jan. 1893.

56. For example Spinks Diary, 30 Jan. 1893, 3 Apr. 1893;

E.D. Hoben, John Ballance. Premier of New Zealand. The Story of his Illness, Death, and Burial, Wellington, 1893, p. 8. Pamphlet in the Turnbull Library.

57. Hoben, p. 11.

58. Ibid., pp. 11-12. 
Ballance's problem was that he wanted Stout to succeed him, but that Stout was not in parliament and so in no position to contest the leadership with Seddon. 'I have been longing very much to have a chat with you, and hope to see you in February', he wrote to Stout on 10 January. ${ }^{59}$ They were to get together in Wanganui. Ballance had returned home in the hope of an improvement in his health. 'I...look forward with pleasure to be able to spend a fortnight or three weeks in my own house,' he told Duigan. 'This is very different from hotel iife, where one thing and another tends to pu11 me down again'. 60

When they met Ballance said that he intended to resign, and urged Stout to re-enter politics. 'I must go and Stout must come', he told E1len. ${ }^{61}$ He grew weaker but, outwardly at least, 'retained his old cheerfulness'. He discussed plans to publish a new 'Liberal Review' with his old friend, A.D. Willis. When Willis suggested Ballance 'write a political work, embodying his ideas and schemes for the future', the latter 'laughed, and said, " $(t)$ hat is exactly what I have been thinking about, and if I get over this illness, I shall set about it shortly"', 62

In the beginning of April Ballance returned to Wellington, where he held a number of Cabinet meetings in his own house. ${ }^{63}$ Ellen later wrote to Stout:

59. LB III, p. 415.

60. Ballance to Duigan, 16 Jan. 1893, LB III, p. 434.

61. See Ellen Ballance's letters to Stout printed in EP, 11 Aug. 1894.

62. Y, 6 May 1893, 'Persona1 Reminiscences of the Late John Ballance'.

63. Hoben, p. 10 . 
When on our return from Wanganui my husband found he was not getting stronger, he said- 'Stout must come into the House, and the day the House meets I shall resign; I have not the strength for the work, and I sha11 not attempt to do what I am incapable of doing'. We decided to say nothing about it for a time, but our intention was to return to Wanganui together. He was very anxious to see you on that awful Sunday morning. His relations with his colleagues were most friendly, but none can imagine better than you how many anxieties he had, and how far before his own interests came the interests of New Zealand. He thought if his intention were known it might injure the Party. 64

As he received with great pleasure and satisfaction figures from the various government departments showing another substantial surplus, Ballance was nearing the end. After taking a trip on Wellington harbour in the government launch, the Hinemoa, he suffered a complete intestinal obstruction. 65 On Thursday 20 April a consultation of five doctors decided that an operation was essential.

It was carried out three days later, on the Sunday morning referred to by Ellen Ballance (above). Before it began Ballance spoke briefly to Stout. Stout had just arrived in Wellington, to. find waiting for him on the wharf a message from Ballance asking him to go immediately to the Premier's residence. ${ }^{66}$

64. EP, 11 Aug. 1894 .

65. Having read the limited medical details available, Dr. John Chrisp of Wellington suggested to the writer that an annular (constricting) carcinoma (cancer) of the upper sigmoid colon was the most likely cause of Ballance's illness and death. The tumour would have led to the bowel obstruction and dehydration. 'The illness was organic. It would have weakened him and debilitated him but could not I think be said to have been worsened by the stresses of his political life at that time'.

66. Hoben, pp. 10-12; Spinks Diary, 20, 21 \& 22 Apr. 1893. 


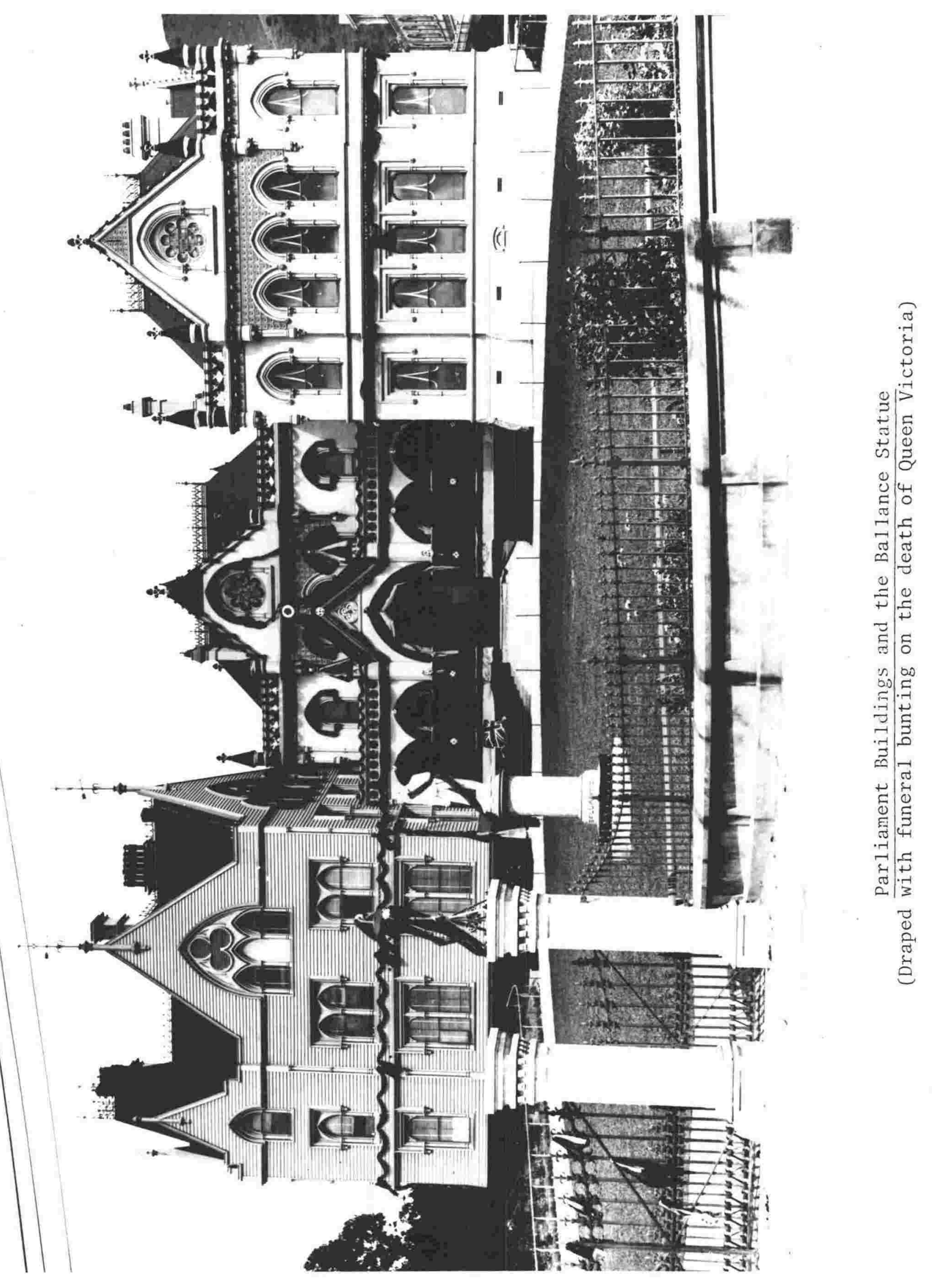


The operation lasted two and a half hours. A11 the members of the Cabinet, alongside Stout and Ballance's relatives, anxiously awaited its outcome. There was a temporary hope that it had been successful, but Ballance did not recover full consciousness, and a second operation was undertaken on the Thursday morning, 27 Apri1. 67 This too failed and Ballance died at 6.20 that evening. ${ }^{6}$ He had only just celebrated his fifty-fourth birthday. Many newspapers, including the Wanganui Herald, had already announced his death in their 4.00 p.m. editions. ${ }^{69}$

67. Y, 29 Apr. 1893; Spinks Diary, 23, 24, 25 \& 26 Apr. 1893; Hoben, pp. 13-14. The operation probably hastened Ballance's death rather than caused it.

68. Spinks Diary, 27 Apr. 1893.

69. Hoben, p. 15. 
Stout was conspicuously absent at the unveiling of Ballance's statue (which someone described as adding a 'new terror to death') ${ }^{1}$, in 1897. Ellen Ballance simply sent some flowers. At the ceremony Seddon made a speech in praise of statues as much as in praise of Ballance. The Evening Post complained that the Premier's words would not have been approved of by Ballance, who had 'not a particle of vainglorious aspiration' about him. ${ }^{2}$

Stout had re-entered Parliament in June 1893 in order to contest the leadership with Seddon. 'Poor Ballance's death I am sure you would deplore, as in fact all must', R. 01iver wrote to Sir John Hall in May:

The existance of the party he led is a fact which there is no ignoring.... . I suppose Stout will be in parliament next session which will make a difference. I suppose eventually he will join the Government. Seddon altho' he would not stand aside for him is trying all he knows to placate him. The labour party are going to stick to Seddon, at all events for the present. 3

In his bid for the premiership Stout rightly claimed that he was Ballance's favoured successor, but in spite of this recommendation failed to unseat Seddon. The reasons for his failure have been well presented elsewhere: essentially Stout moved too late, and pinning his hopes on the prohibition issue, which only divided the left wing of the Party, became increasingly isolated from mainstream

1. Quoted by Diana \& Jeremy Pope, Mobil New Zealand Travel Guide, Wellington, 1975, p. 236.

2. 8 Apr. 1897 .

3. Oliver to Hal1, 16 May 1893, Hall MSS, folder 196. 
liberalism. ${ }^{4}$ In the years following Ballance's death the Party came to be dominated by its rural right wing.

As the Party changed, Ballance's memory was invoked by protagonists on both sides. To a remarkable degree politicians sought approval for their policies by claiming them to be within the Ballance 'tradition'. This strength of Ballance's influence after his death is at the same time an indication of his success as a politician and his importance in New Zealand history.

Ballance had led the first reforming and Liberal administration through its difficult early years, and had come out on top. Reeves said of him:

He had to build up a party which his critics said at the time had no basis or solidarity, hardly even existance; he had to carry a policy which, alike in finance, land law, and labor reform, was so bold and innovating that it was certain to provoke extraordinary and bitter opposition. ...Nearly all the larger and abler newspapers were angrily against him, and though he had a faithful majority in the Lower House, he was utterly without a follower in the Upper. In these straits you know what he did. He turned to the people and used the platform against the press. 5

This was his greatest contribution. He established party government and secured it through constitutional struggle. He posed the crisis over the Legislative Council appointments in terms of the right of

4. R.T. Shannon, 'The Liberal Succession Crisis in New Zealand, 1893', Historical Studies, 8, 30 (1958); D.A. Hamer 'The Law and the Prophet: a political biography of Sir Robert Stout', M.A. thesis, Auckland, 1960, ch. 18.

5. $Y, 10$ June 1893 . 
the people to govern themselves. ${ }^{6}$ By promoting economic (non-borrowing) and political (in his dealings with the Governor) self-reliance, he inspired a progressive nationalist sentiment and a new confidence in New Zealand. His premiership brought a new 'mood' of optimism. He had of course been fortunate that his term in office coincided with the beginning of economic recovery, but this association simply served to exaggerate his success. The budget surplus of 1892 in particular was seen as evidence that self-reliance had worked.

There was great personal attachment to Ballance, his followers according him a degree of respect and loyalty unknown in the case of previous leaders. His conciliatory personality and style of leadership were particularly attractive, and 'even those who differed from him acknowledged his sincerity of purpose. Some of his opponents...really loved the man, as his friends undoubtedly did'. 7

The Ballance tradition sprang also from the fact that he died before the stresses and strains within the Party came to a head. He was associated with Party unity. The retreat from land nationalisation pleased the rural and more conservative members, whilst the urban radical wing accepted that Ballance was doing all he could in their interests. He had, after all, promised to introduce some form of rent revaluation. Again, Ballance died before the pressure for new borrowing became irresistible. In fact, he would almost certainly have soon admitted the need for a loan, as Ward, amongst others, was quick to claim. ${ }^{8}$ Two weeks prior to his

6. $\mathrm{PD}, 1892,77, \mathrm{p} .242$.

7. $\overline{\text { W.K. }}$. Howitt, A Pioneer Looks Back Again, Auckland, 1947, p. 268.

8. $\quad \mathrm{PD}, 1894,86, \frac{\mathrm{p} .152 ; \text { PD, } 1896,95, \mathrm{p} .}{18} 135$. Also Buick, PD, $\overline{18} 96,94$, p. 72 . 
death Ballance wrote to Alfred Saunders:

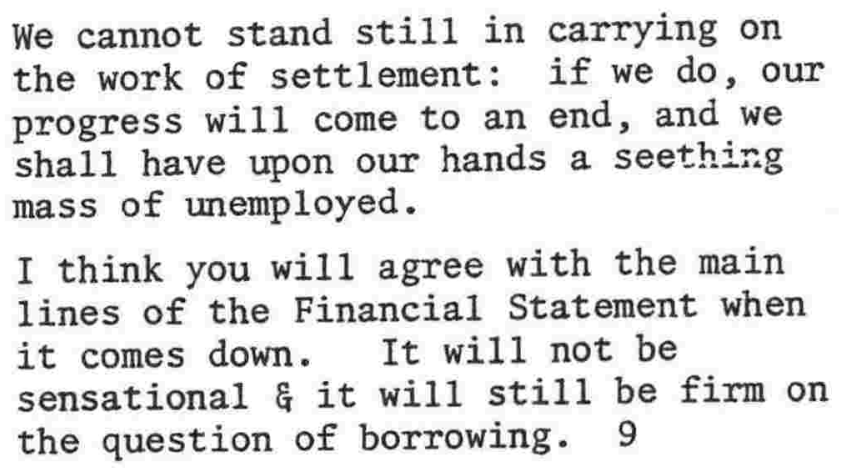

We cannot stand still in carrying on the work of settlement: if we do, our progress will come to an end, and we shall have upon our hands a seething mass of unemployed.

I think you will agree with the main lines of the Financial Statement when it comes down. It will not be the question of borrowing. 9

Here Ballance seems to imply that the non-borrowing policy would some time in the future be relaxed. He knew how crucial finance was to development, and had conceded the need for internal borrowing for this purpose. When Ward sought approval for a new loan in 1894 it was precisely on these grounds of promoting 'the work of settlement'. Borrowers and non-borrowers alike, however, could claim Ballance in support of their arguments.

Essentially Ballance represented a brand of liberalism that held out the possibility of the Party maintaining both its urban and rural support. It was broad based rather than sectional; it emphasised land reform that aimed to benefit the country as a whole, and stressed the need for cooperation, rather than the inevitability of conflict, between the classes. It was humanitarian and sought change through evolution rather than revolution. These were the central features of the Liberal appeal and success in 1890 .

Throughout the Liberal period there were accusations that the Party was departing from these principles as laid down by Ballance. ${ }^{10}$

9. Ballance to Saunders, 11 Apr. 1893, BMSS, 767 .

10. For example, PD, 1896, 93, p. 574; PD, 1896, 95, p. 131; PD, 1900,115, p. 236. 
His style of leadership was contrasted unfavourably with the brashness and autocracy of Seddon. He was held up by some as representative of the only true liberalism; it was as if had he not died when he did things would have been quite different. ${ }^{11}$

Clearly Ballance's greatest problem, had he lived, would have been to retain the support of the urban radicals within the Party given that there was no prospect of land nationalisation, and that political pressure was being exerted instead to return to borrowing in the interests of small 'freehold' farmers. The situation might not have been so serious had Ballance's liberalism been concerned as much with labour as land reforms ort Yet this would be to deny the very nature of the forces that had brought the Party into power in 1890: the extent to which land reform was the raison d'etrê of the populist movement.

By 1912 the Liberal Party was no longer a broad coalition but had come to represent the sectional interests of small farmers. Just how inevitable this transformation was is a question we11 beyond the scope of this thesis. Had Ballance lived longer he may only have been able to delay this process. There would have been some differences, however, as the Evening Post suggested at the time of the unveiling of his statue:

...had Mr. Ballance lived a great many things that have happened since he died would never have taken place, and could not have come about, were he Premier. Who, for example, would be more shocked than John Ballance, were he to come amongst us now, on finding that our public debt had

11. PD, 1907,139, p. 128 ; PD, 1909,148, p. 160. 
been increased millions by the

"non-borrowing" party he left after

him...? What would he think, too, of

the increase of Customs duties to the

extent of nearly $\$ 30,000$ per annum on

articles almost exclusively used by the

working community?...(A)nd we should

have had a free Parliament and free

speech all the time such a man (as

Ballance) remained on the Treasury benches. 12

The Ballance tradition was, not surprisingly, particularly strong in Wanganui, where it was kept alive by A.D. Willis and the Herald. As K.L. Stewart has put it:

In the early Twentieth Century there was a ghost abroad in Wanganui. A11 those who courted political office and who wished to strike a responsive note among the local electorate paid homage to it. The ghost's name was John Ballance. 13

For the town's politicians the key to success was to be found, as Ballance had shown, in forging an alliance between the working class and small businessmen: rural development bringing trade to the town and work at the railway yards was regarded as much more important than industrial development. 'Lib-labism', epitomised by William Veitch, Wanganui's Member from 1911 to 1935, rather than socialism has held sway. The perception of the dependency of the town's prosperity on rural development has also meant strong support for Social Credit.

Different types of leaders are more suited to different times. Ballance, who became Premier through the lack of any alternative as much as through any personal ambition of his own, possessed those 
qualities ideally suited to the task he faced. Like Campbe11-Bannerman, who was also Premier for just two years, he held a party together under difficult conditions. The two men, indeed, share many other characteristics. Both were modest, both happiest delivering wel1-prepared rather than extempore speeches. Both were under-estimated on their accession to office, and possessed a political toughness and determination often hidden and seldom acknowledged. Like another British Prime Minister, Clement Attlee, they were effective chairmen of their cabinets, maintaining unity amongst strong, forceful and in some respects frequently more able colleagues.

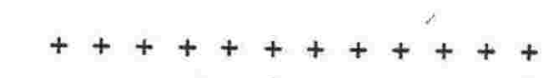

The land question was central to Ballance because his experiences had shown closer settlement to be the key to the prosperity of the individual and of the State. He regarded land monopoly as the foremost evil in the country of his birth, and its avoidance his primary aim in the country of his adoption. His views on religion were strongly coloured by the part the established church played in this monopoly in Ireland. In New Zealand he increasingly saw the need for State intervention to counteract the accumulation of large estates, to preserve remaining crown 1and, and to promote bonâ fide, sma11 farm, settlement.

In broader philosophical terms Ballance had, by the end of his life, moved towards 'positive liberalism'. That is, he acknowledged 
that state intervention was essential if the liberty of the individual was to be maximised. He is in the tradition of English writers such as T.H. Green and L.T. Hobhouse, who argued that individual liberty required opportunity, and that the creation of opportunity often demanded action by the state. They saw that the 1aissez-faire system produced losers, and that those losers were unable to enjoy the freedom of a 'free' society.

Thus Ballance's non-borrowing and other 'nationalist' policies were means to an end, rather than ends in themselves. They aimed at greater independence for the State and greater freedom and liberty for the individual. Explaining his opposition to the federation of New Zealand with Australia, he said:

The great question for us is, How would our liberties be protected? I do maintain that history does not show that any subordinate State has enjoyed anything like the same amount of liberty that we enjoy. ...Looked at from every point of viewlegislative, political, judicial, and fiscal- and bearing in mind the extent of the liberties that are enjoyed in this country... I say that, if this colony surrenders to any federal body that may be set up the powers it now possesses, the people will become discontented, just as has happened in the case of Ireland and of other countries similarly situated. 14

Ballance was a liberal rather than a socialist because he emphasised the rights and we1l-being of the individual rather than of the 'community' as a whole. Welfare measures would be justified as long as they increased, rather than decreased, individual freedom 
or 'positive' 1iberty. Equally individual 1iberty required a degree of respect for the rights of property: Ballance was reluctant to see the compulsory acquisition of large estates (as it turned out compulsion was not necessary), and he insisted that owners should receive full compensation for land that they wished to dispose of to the State.

The dividing line between 'positive' 1iberals and socialists (especially fabians) is of course a thin one. That Ballance belonged at least in the former category there can be no doubt. In his last few years his favourite book was The Physiology of Industry, by A.F. Mummery and J.A. Hobson, which was publishedin 1889. ${ }^{15}$ In this work Mummery and Hobson attacked the classical liberal orthodoxy that saving enriched and spending impoverished both the community and the individual. They argued that, in fact, undue saving depressed the economy by limiting consumption. This was the starting point for J.M. Keynes, who suggested that governments should deal with depressed economic conditions by boosting rather than contracting demand, so raising production. The appeal of the book to Ballance is highly significant. Hobson later wrote a number of important treatises that were to wield considerable influence over British and New Zealand socialists.

Many positive liberals have acknowledged an acceptance of some elements of socialism. Would Ballance, had he lived longer, have eventually admitted, as John Stuart Mill did himself, ${ }^{16}$ to a belief in 'qualified Socialism'?

15. See Sir Robert Stout, 'Character Sketch: The Hon. John Ballance', Review of Reviews for Australasia, May 1893, p. 113.

16. J.S. Mil1, Autobiography, London, 1971 edn., p. 115. 


\section{APPENDIXES}

A The Development of Ballance's Career and Philosophy

B Ballance to John Notman, 27 May 1888

C Statistical Tables:

1 Land disposed of under various conditions, 1885-93

2 Classification of tax payers according to occupation

3 Owners of land classified according to the value of holding, 1891 
畜)
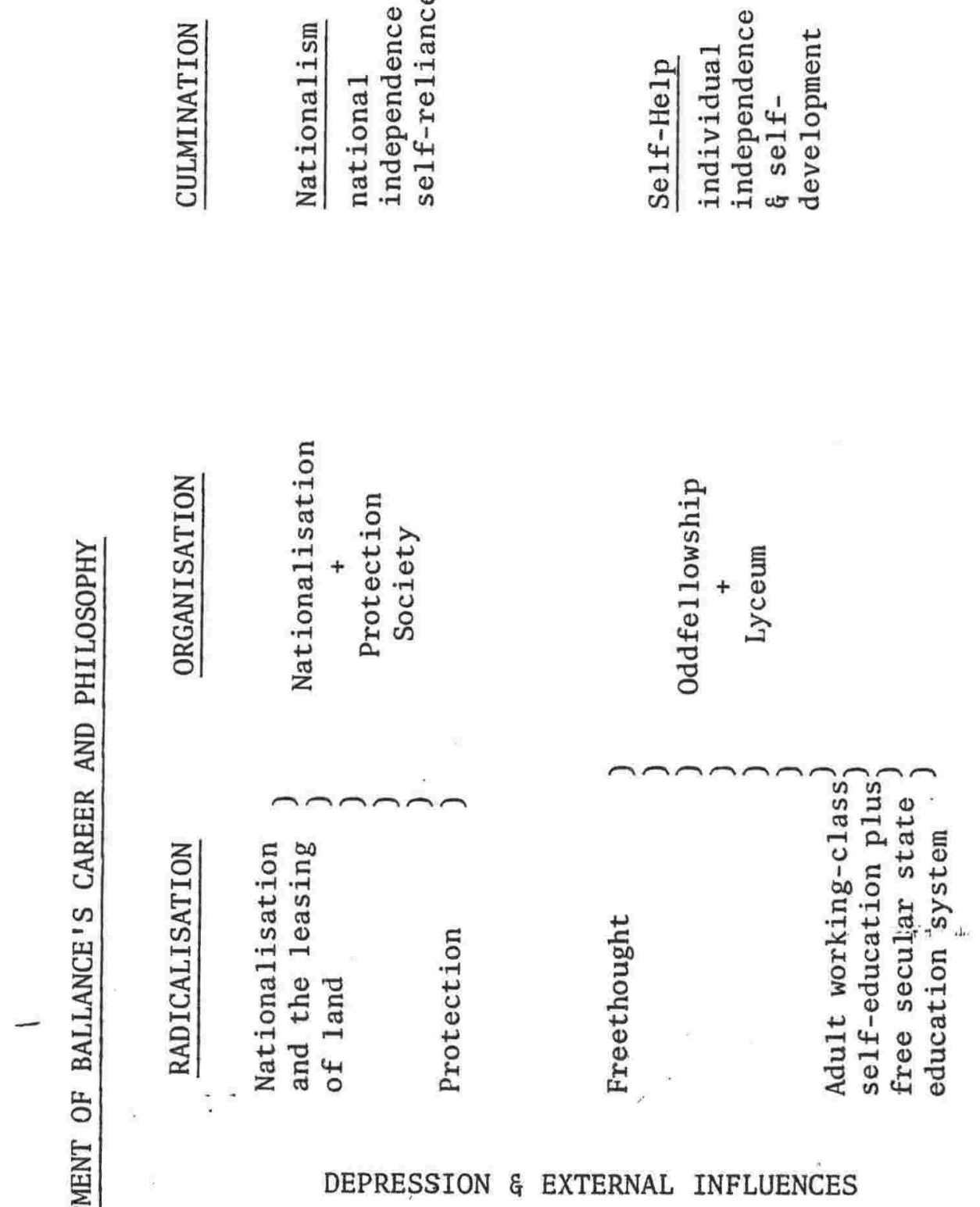

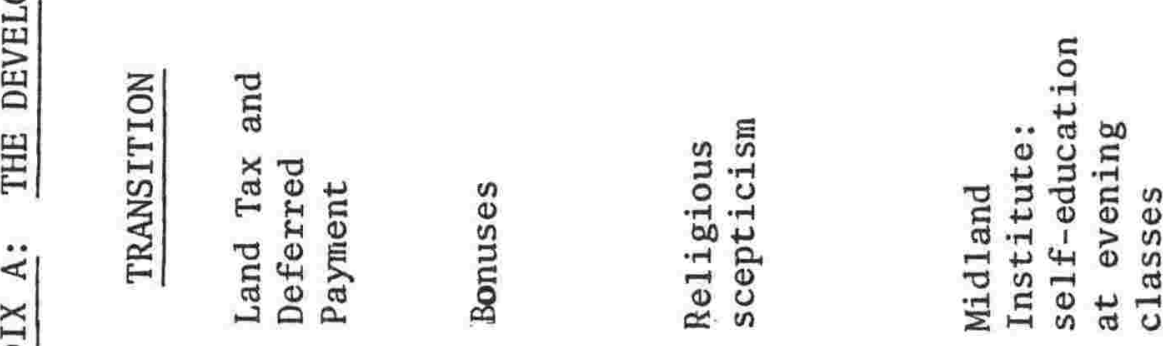

亩

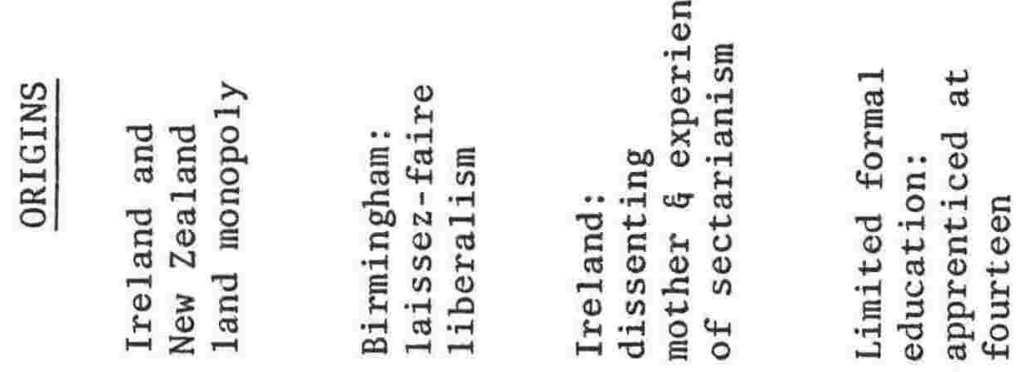

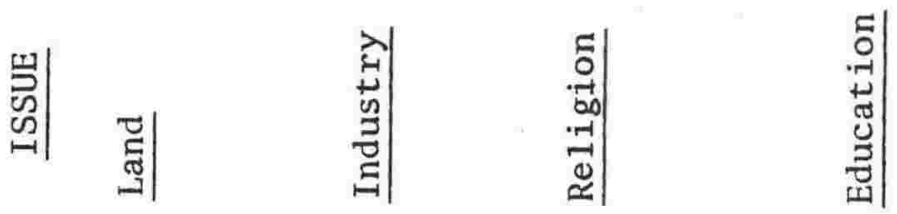


APPENDIX B: Ballance to John Notman, 27 May 1888.

Dear Mr Notman,

I have again to thank you for your statement of the position. Before attempting to raise the money, I shd like to have the opinion \& advice of the Directors. There is first the difficulty of inducing outsiders to give a guarantee while the Directors reform. I am quite willing to pledge all my shares, \& my wife is willing to pledge her own, making altogether nearly $£ 6000$, which is a large proportion of the whole concern, \& no doubt be readily accepted for $\$ 500$ or 700 . The Bank or a Bank sd I think accept a guarantee of three or four respectable men. If not I think I might be able to negotiate the lesser amount, or even $\$ 600$ down here.

If certain things are done, the position is not positively bad, tho comparatively its not encouraging to those looking on from the outside. The following steps seem imperative. To reduce the total wages to not exceeding $\$ 30$ a week. Items:

$\begin{array}{lr}\text { Publishing } & 4.13 .0 \\ \text { Editorial } & 9.0 .0 \\ \text { Tabbing(?) } & 3.10 .0 \\ \text { Pressman } & 1.10 .0 \\ \text { Printing } & 11.10 .0\end{array}$

Mr Wilkinson shrinks from the responsibility of the management, and therefore I wd propose his salary shd be $\$ 3 / 10 / 0$. When I return I cd take the management. I give on a slip(?) the details wh I think cd be carried out. I wd urge strongly that Wrightson(?) receive a months notice, for two reasons that he deliberately conspired with Young to deceive- of that I am certain- \& that he is notoriously lazy. There is a very fine young fellow who was with Beattie at Eastown, but has been retrenched, called Shackleton, who wil (sic) come up for $33 / 0$ week \& do all the clerical work. We must not be beaten, but we must at the same time face the position. The paper will soon recover itself, if we give it the chance. Wd you kindly give the Directors the benefit of your advice. I am thinking of retiring from politics at the end of the session \& devoting myself entirely to business. This is very confidential for the present. Personally I am quite willing to make any sacrifice on behalf of the shareholders who have invested their capital in the concern, \& begin again. But I firmly believe the loss will be quickly recouped. There is in our favour the fact that the paper has a large circulation \& hold on the people, \& consequently commands the advertising. And even a great reduction of reading matter will not affect it prejudicially.

yours very truly

$\mathrm{J}$ Ballance.

Source: Letter in the possession of Mr John Hatherly of New Plymouth. 


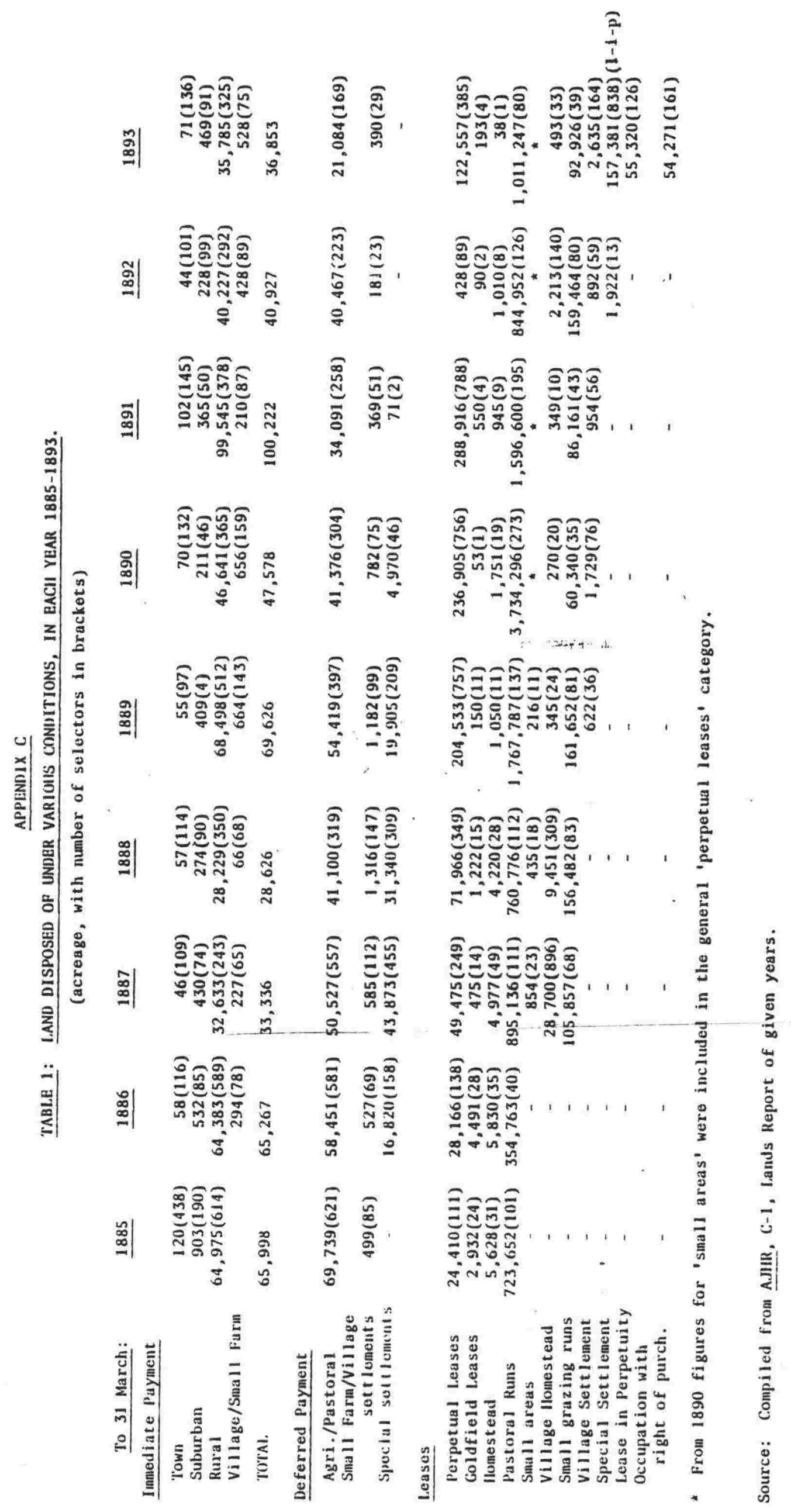




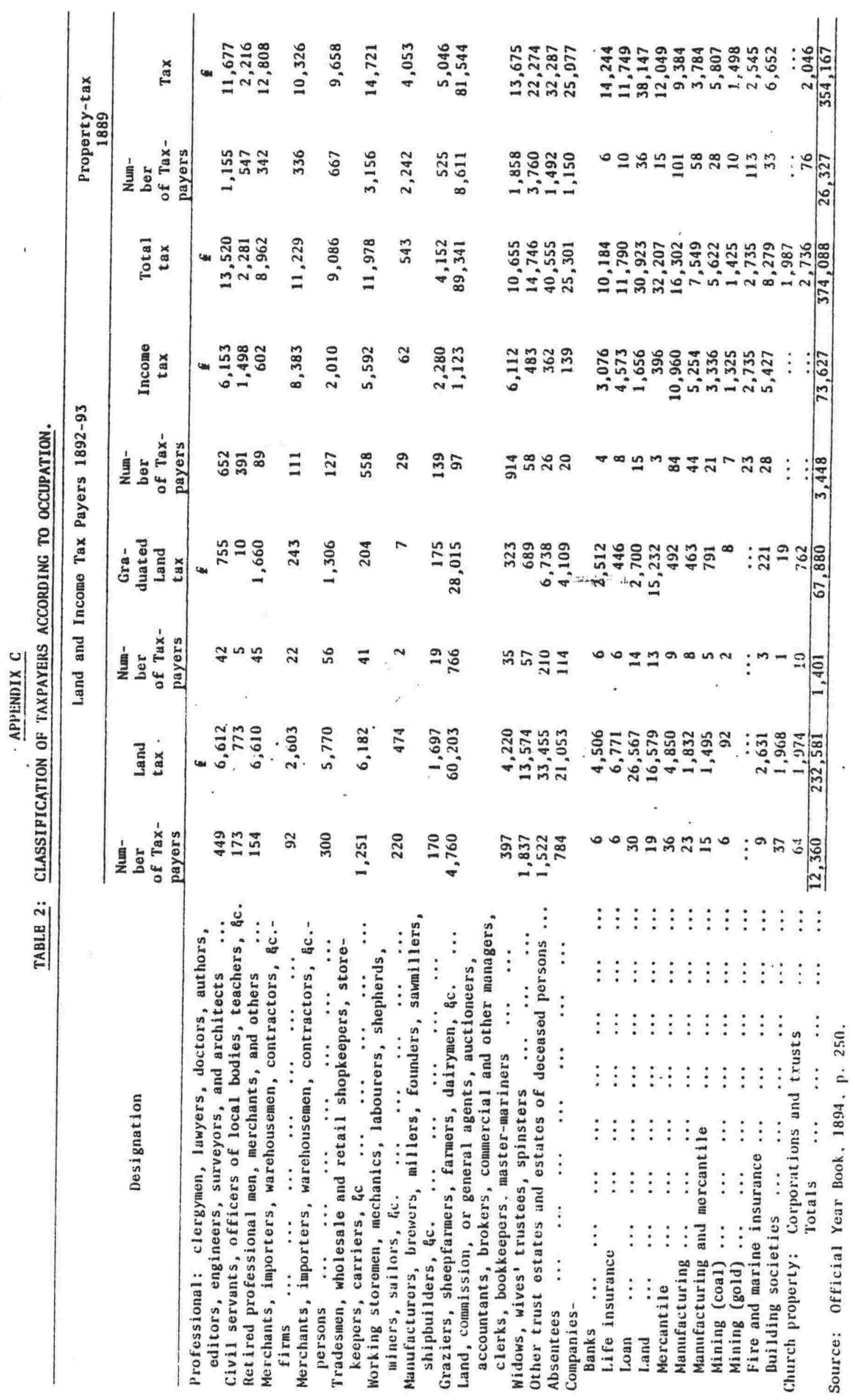




\section{APPENDIX C}

Table 3: Owners of Land Classified According to the Value of Holding, 1891

Value of Holding

Under $\$ 100$

$\$ 100$ and under $\$ 200$

$£ 200$ and under $\$ 300$

$£ 300$ and under $\$ 400$

$£ 400$ and under $\$ 500$

$£ 500$ and under $\$ 600$

$£ 600$ and under $\$ 700$

$£ 700$ and under $\$ 800$

$\$ 800$ and under $\$ 900$

$\$ 900$ and under $\$ 1,000$

$£ 1,000$ and under $\$ 2,000$

$£ 2,000$ and under $\$ 3,000$

$£ 3,000$ and under $\$ 4,000$

$£ 4,000$ and under $\$ 5,000$

$\$ 5,000$ and under $\$ 10,000$

$£ 10,000$ and under $\$ 20,000$

$\$ 20,000$ and under $\$ 50,000$

$\$ 50,000$ and under $\$ 100,000$

$\$ 100,000$ and under $\$ 200,000$

£200,000 and over
Number of Owners Total Value

\begin{tabular}{|c|c|c|}
\hline 20,752 & 垂 & 843,561 \\
\hline 15,069 & & $2,115,529$ \\
\hline 10,904 & & $2,592,172$ \\
\hline 7,270 & & $2,469,159$ \\
\hline 5,230 & & $2,292,344$ \\
\hline 3,594 & & $1,937,442$ \\
\hline 2,995 & & $1,894,849$ \\
\hline 2,232 & & $1,666,184$ \\
\hline 1,821 & & $1,533,435$ \\
\hline 1,394 & & $1,306,615$ \\
\hline 6,755 & & $9,403,253$ \\
\hline 2,299 & & $5,578,261$ \\
\hline 1,175 & $5 \quad=$ & $4,076,691$ \\
\hline 704 & & $3,133,151$ \\
\hline 1,237 & & $8,516,672$ \\
\hline 623 & & $8,417,460$ \\
\hline 338 & & $9,535,543$ \\
\hline 107 & & $7,107,479$ \\
\hline 37 & & $4,953,568$ \\
\hline 11 & & $4,853,862$ \\
\hline 84,547 & & $84,208,230$ \\
\hline
\end{tabular}

Source: AJHR, 1891, B-6, p. 44. 


\section{PRIMARY}

\section{OFFICIAL PAPERS}

(i) New Zealand Government Records, National Archives, Wellington

Army Department AD 1: Inwards letters, Colonial Defence Office, 1863-72.

$\mathrm{AD}$ 6: Outward letter books.

Lands and Survey LS 22: Special Settlement records, 1871-1903.

LS 36 (13): Crown Lands Guide No. VIII, published by authority of Minister of Lands, Wellington, 1887.

Maori Affairs MA 4 (40-47): Letter books 1884-87.

MA 5 (17-23): Telegrams 1884-87.

MA 30 (3): Travelling letter book. Trip to

King Country, 3 Feb. 1885 - 26 Feb. 1885.

Treasury T1 (91-99): Correspondence 1878-79,

(ii) Public Record Office of Northern Ireland, Belfast.

1A/1/63: Valuation map, Glenavy (compliments 1B/171).

1B/171: Glenavy Townland valuation, $4 \mathrm{Feb} .1835$.

5A/147: Tithe applotment book, Glenavy 1834 .

\section{MANUSCRIPTS}

(i) Alexander Turnbull Library, Wellington

Ballance Papers.

Fisher Family Papers.

Ha11 Papers.

Thomas McDonnell Papers.

Stafford Papers.

Stout Papers.

Voge1 Papers.

(ii) Wanganui Pub1ic Library

Lovegrove Papers.

\section{DIARIES}

David Anderson (Turnbu11).

Sarah Jane Spinks (in the possession of Mrs Carol Anderson, We11ington). 
OFFICIAL PUBLICATIONS

Appendices to the Journals of the House of Representatives. Electoral Ro11, Wanganui, 1884 \& 1890.

Journal of the Proceedings of Wellington Provincial Council. New Zealand Census.

New Zealand Gazette.

New Zealand Parliamentary Debates.

New Zealand Statistics.

New Zealand Statutes.

Official Year Book.

Wellington Provincial Council, Land Regulations, 1872.

\section{PERIODICALS}

Auckland Evening Star.

Belfast Telegraph.

Echo (Dunedin).

Evening Chronicle (Wellington).

Evening Herald (Wanganui).

Evening Post (Wellington).

Freethought Review (Wanganui).

Lyttelton Times (Christchurch).

New Zealand Herald (Auckland).

New Zealand Times (We11ington).

Otago Daily Times (Dunedin).

Wanganui Chronicle.

Wanganui Herald.

Wanganui Times.

Weekly Hèrald (Wanganui).

Yeoman (Wanganui).

\section{PAMPHLETS}

Ballance, John, A National Land Policy Based on the Principle of State Ownership; with the regulations of the village homestead system, Wellington, 1887 .

Ballance, John, Speech to the Electors of Wanganui, Wanganui, 1887.

Be11, James, A Farmer's View on Land Nationalisation and the Working of the New Zealand Land Act, Palmerston North, 1886.

Farnal1, H.W., The Industrial Depression in New Zealand, Auckland, 1890.

Hoben, E.D., John Ballance. Premier of New Zealand. The Story of his Illness, Death, and Burial, Wellington, 1893.

Interesting Chapters from the Early History of Wanganui, Wanganui, 1887. Lovegrove, C.L., When Wanganui Stood to Arms in the 'Sixties, pamphlet reprinted from the Wanganui Herald, 1953(?), in the Turnbull Library.

McDonne11, Thomas, An Explanation of the Principal Causes which led to the Present War on the West Coast of New Zealand, Wanganui, 1869.

Wanganui Herald, Report of the Proceedings in the Election Petition of A.D. Willis and others against W.H. Watt, Wanganui, 1882 .

Wanganui Herald, Handbook of the Law Relating to Crown Land in New Zealand,

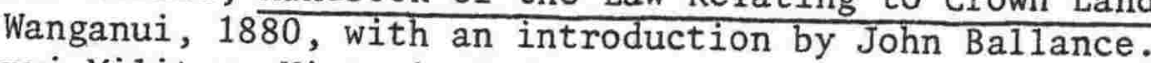

Wanganui Military Historical Society, Wereroa Redoubt, Wanganui, 1948. 


\section{UNPUBLISHED THESES}

Armstrong, W.R., 'The Politics of Development: a study of the structure of politics from 1870 to $1890^{\prime}$, M.A., Victoria University of Wellington, 1960.

Arnold, R.D., 'The Opening of the Great Bush, 1869-1881. A social history of the bush settlements of Taranaki, Hawke's Bay and Wellington', Ph.D., Victoria University of Wellington, 1971.

Belich, James, 'Titokowaru's War and its Place in New Zealand History', M.A., Victoria University of Wellington, 1979.

Bohan, E., 'The General Election of 1879 in Canterbury', M.A., University of Canterbury, 1958.

Campbe11, Christopher, 'Parties and Special Interests in New Zealand, 1890-93', M.A., Victoria University of Wellington, 1978.

Charman, E.J., 'Land Tenure Reform in New Zealand, 1875-1896. A study of the opinions of some leading land reformers', M.A., University
of Auckland, 1953.

Costorphine, D., 'Grey's Liberalism as a Factor in the Development of Party Government in New Zealand', M.A., University of Canterbury,
1950 .

Crook, Harry, 'The Significance of the 1890 Election', M.A., University of Auckland, 1953.

Dempsey, P.E., 'The Land Policy of the Stout-Vogel Ministry, 1884-1887', M.A.; University of Auckland, "1945.

Dighton, J.L., 'The Life and Work of John Ballance', M.A., Victoria University of Wellington, 1929.

Evans, A.M., 'A Study of Canterbury Politics in the Early 1880s with Special Reference to the General Election of 1881', M.A., University of Canterbury, 1959.

Ewing, I.S., 'Public Service Reform in New Zealand, 1866-1912', M.A., University of Auckland, 1979.

Hamer, D.A., 'The Law and the Prophet: a political biography of Sir Robert Stout (1844-1936)', M.A., University of Auckland, 1960.

Hoar, J.K., 'A Descriptive History of the Major Aspects of the Friendly Society Movement in New Zealand, 1840-1900', M.A., University of Idaho, 1963.

Hunt, J.L., 'The Election of 1875-6 and the Abolition of the Provinces', M.A., University of Auckland, 1961.

King, S.M., 'The Port of Wanganui and its Influence on Wanganui', M.A., Victoria University of Wellington, 1964. Maloney, G.S., 'A History of the Ballance Ministry', M.A., University
of Canterbury, 1931.

Mullins, R.M., 'The Division of Power between the General and Provincial Governments, 1853-1867', M.A., Victoria University of We11ington, 1953. Rogers, Frank, 'The Single Tax Movement in New Zealand', M.A., University
of Auckland, 1949 .

Shepherd, H., 'The Nature and Role of Friendly Societies in Later Nineteenth Century New Zealand', Research Essay, Massey University,
1976.

Stenson, M.R., 'The Origins of the Government Advances to Settlers Act, 1894 ', M.A., University of Auckland, 1962.

Stevens, M.H.S., 'New Zealand Defence Forces and Defence Administration, 1870-1900', M.A., Victoria University of Wellington, 1977. 
Stewart, K.L., 'The Ballance Tradition and its Permeation in Wanganui', M.A., Massey University, 1970.

Thompson, G.F., 'The Politics of Retrenchment: the origin and some aspects of the politics of the Hall Ministry, 1879-82', M.A., Victoria University of Wellington, 1967.

Whitehead, C., 'The 1887 General Election in Canterbury', M.A., University of Canterbury, 1961.

Wilson, T.G., 'The Rise of the Liberal Party in New Zealand, 1877-1890', M.A., University of Auckland, 1951.

Young, John, 'The Politics of the Auckland Province, 1872-1876', M.A., University of Auckland, 1960.

Young, T.J., 'The Political Career of John Ballance, 1875-1890', M.A., Victoria University of Wellington, 1964.

\section{ARTICLES}

Bassett, Judith, 'Sir Harry Atkinson and the Conservative Faction in New Zealand Politics, 1879-1890', NZJH, 2, 1 (1968).

Bohan, E., 'The 1879 General Election in Canterbury', Political Science, XII, 1 (1960).

Campbe11, C., 'The 'Working Class' and the Liberal Party in 1890', NZJH, 9, 1 (1975).

Fairburn, Miles, 'The Rural Myth and the New Urban Frontier. An Approach to New Zealand Social History, 1870-1940', NZJH, 9, 1 (1975).

Fairburn, Miles, 'Social Mobility and Opportunity in Nineteenth-Century New Zealand', NZJH, 13, 1 (1979).

Franklin, S.H., 'The Village and the Bush. The Evolution of the Village Community, Wellington Province, New Zealand', Pacific Viewpoint, 1,2 (1960).

Gardner, W.J., 'The Rise of W.F. Massey, 1891-1912', Political Science, XIII, 1 (1961).

Gould, J.D., 'The Twilight of the Estates, 1891 to 1910', Australian Economic History Review, X, 1 (1970).

Grimshaw, Patricia, 'Politicians and Suffragettes. Women's suffrage in New Zeal and, 1891-1893', NZJH, 4, 2 (1970).

Hamer, D.A., 'The Agricultural Company and New Zealand Politics, 1877-1886', Historical Studies of Australia and New Zealand, X, 38 (1962).

Hamer, D.A., 'Towns in Nineteenth-Century New Zealand', NZJH, 13, 1 (1979).

Herron, D.G., 'The Franchise and New Zealand Politics, 1853-8', Political Science, XII, 1 (1960).

Oliver, W.H., 'Social Policy in the Liberal Period', NZJH, 13, 1 (1979).

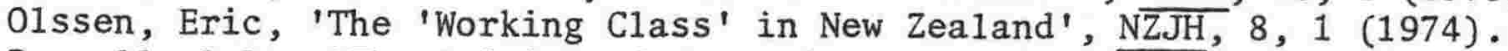

Pownal1, L.L., 'The Origins of Towns in New Zealand', New Zealand Geographer, XII (1956).

Shannon, R.T., 'The Liberal Succession Crisis in New Zealand, 1893', Historical Studies of Australia and New Zealand, VIII, 30 (1958).

Stone, R.C.J., 'The Maori Lands Question and the Fall of the Grey Government, 1879', NZJH, 1, 1 (1967).

Stout, Sir Robert, 'Character Sketch: The Hon. John Ballance', Review of Reviews for Australasia, May 1893.

Toynbee, Claire, 'Class and Social Structure in Nineteenth Century Zealand, NZJH, 13, 1 (1979).

Wood, G.A., 'The 1878 Electoral Bill and Franchise Reform in Nineteenth Century New Zealand', Political Science, XXVIII, 1 (1976).

Young, John, 'The Political Conflict of 1875 ', Political Science, XIII, 2 (1961). 
Arnold, R.D., The Farthest Promised Land. English Villagers, New Zealand Immigrants of the 1870s, Wellington, 1981.

Bagna11, A.G., Wairarapa. An Historical Excursion, Masterton, 1979.

Barnard, T.C., Cromwellian England: English Government and Reform in Ireland, 1649-1660, London, 1975. Barratt, Glynn, Russophobia in New Zealand, 1838-1908, Palmerston North,
1981.

Bassett, Judith, Sir Harry Atkinson, 1831-1892, Auckland, 1975.

Beckett, J.C., The Making of Modern Ireland, 1603-1923, London, 1981.

Beckett, J.C., The Ang10-Irish Tradition, New York, 1976.

Belcher, J.P., Wanganui from 1856 to 1929, Wanganui, 1930.

Bradshaw, John, New Zealand To-Day (1884-1887), London, 1888.

Briggs, Asa, Victorian Cities, London, 1963.

Briggs, Asa, History of Birmingham. Volume II, Borough and City, 1865-1938, London, 1952 .

Budge, Ian \& $0^{\prime} L e a r y$, Cornelius, Belfast: Approach to Crisis. A Study of Belfast Politics, 1613-1970, London, 1973.

Burdon, R.M., King Dick, Christchurch, 1955.

Burdon, R.M., The Life and Times of Sir Julius Vogel, Christchurch, 1948.

Burdon, R.M., New Zealand Notables, 2 vols., Christchurch, 1941, 1945.

Chapman, R. \& Sinclair, K., Studies of a Small Democracy: essays in honour of Willis Airey, Hamilton, 1963.

Chapple, L.J.B. \& Veitch, H.C., Wanganui, Hawera, 1939.

Condliffe, J.B., New Zealand in the Making. A Study of Economic and Social Development, London, 1959.

Cox, Alfred, Men of Mark of New Zealand, Christchurch, 1886.

Cullen, L.M., The Emergence of Modern Ireland, 1600-1900, London, 1981.

Cyclopedia of New Zealand, vol. 1, Wellington, 1897.

Dalton, B.J., War and Politics in New Zealand, 1855-1870, Sydney, 1967.

Dalzie1, Raewyn, The Origins of New Zealand Diplomacy: the Agent-General in London 1870-1905, Wellington, 1975.

Davis, R.P., Irish Issues in New Zealand Politics 1868-1922, Dunedin, 1974 .

Denoon, Donald, Settler Capitalism. The dynamics of dependent development in the southern hemisphere, Oxford, 1983.

Downes, T.W., Old Whanganui, Hawera, 1915.

Gardner, W.J., William Massey, Wellington, 1968.

George, Henry, Progress and Poverty, London, 1932 edn.

Gill, Conrad, History of Birmingham. Volume I, Manor and Borough to 1865 , London, $1 \overline{952}$.

Gisborne, William, New Zealand Rulers and Statesmen: from 1840 to 1897 , London, 1897.

Gorton, E., Some Home Truths about the Maori War 1863-1869 on the West Coast of New Zealand, London, 1901.

Gourlay, H.W., Odd Fellowship in New Zealand, Christchurch, n.d.

Grampp, W.D., The Manchester School of Economics, Stanford, 1960.

Grimshaw, Patricia, Women's Suffrage in New Zealand, Auckland, 1972.

Gudgeon, T.W., The Defenders of New Zealand, Auckland, 1887.

Hamer, D.A., Libera1 Politics in the Age of Gladstone and Rosebery. A Study in Leadership and Policy, Oxford, 1972.

Harrison, J.F.C., Learning and Living, 1790-1960. A Study in the History of the English Adult Education Movement, London, 1961.

Howitt, W.K., A Pioneer Looks Back Again, Auckland, 1947.

Jackson, W.K., The New Zealand Legislative Council: a study of the establishment, failure and abolition of an Upper House, Dunedin, 1972.

Jay, Richard, Joseph Chamberlain. A Political Study, Oxford, 1981. 
Jourdain, W.R., Land Legislation and Settlement in New Zealand, Wellington, 1925 .

Lipson, L., The Politics of Equality: New Zealand's adventures in democracy, Chicago, 1948.

Lloyd Prichard, M.F., An Economic History of New Zealand to 1939, Auckland, 1970.

Macmillan Brown, John, The Memoirs of John MacMillan Brown, Christchurch, 1974 .

Morre11, W.P., The Provincial System in New Zealand, 1852-76, London, 1932 .

Newman, P.C., The Development of Economic Thought, New York, 1952.

Oliver, W.H., The Story of New Zealand, London, 1960.

Pakenham, Thomas, The Year of Liberty, London, 1969.

Reeves, W.P., The Long White Cloud, London, 1899 edn.

Reeves, W.P., State Experiments in Australia and New Zealand, 2 vols., London, 1902 .

Roll, Eric, A History of Economic Thought, London, 1938 edn.

Roth, H., Trade Unions in New Zealand. Past and Present, Wellington, 1973.

Ross, Angus, New Zealand Aspirations in the Pacific in the Nineteenth Century, Oxford, 1964 .

Rusden, G.W., History of New Zealand, 3 vols., London, 1883.

Rutherford, James, Sir George Grey, K.C.B., 1812-1898: a study in colonial government, London, 1961 .

Scholefield, G.H., A Dictionary of New Zealand Biography, 2 vols., Wellington, $19 \overline{40}$.

Scholefield, G.H., Newspapers in New Zealand, Wellington, 1958.

Scholefield, G.H., Notable New Zealand Statesmen: twelve Prime Ministers, Christchurch, (1946).

Scholefield, G.H., William Ferguson Massey, Wellington, 1925.

Scott, Dick, Ask That Mountain. The Story of Parihaka, Auckland, 1975.

Senior, H., Orangeism in Ireland and Britain, 1795-1836, London, 1966.

Siegfried, A., Democracy in New Zealand, Wellington, 1982 edn., with introduction by D.A. Hamer.

Simkin, C.G.F., The Instability of a Dependent Economy. Economic Fluctuations in New Zealand, 1840-1914, Oxford, 1951.

Sinclair, Keith, A History of New Zealand, London, 1980 edn.

Sinclair, Keith, William Pember Reeves, London, 1965.

Sinclair, Keith, The Origins of the Maori Wars, Auckland, 1957.

Sinclair, Keith \& Mandle, W.F., Open Account. A History of the Bank of New South Wales in New Zealand 1861-1961, Wellington, 1961.

Smart, M.J.G. \& Bates, A.P., The Wanganui Story, Wanganui, 1972 .

Stein, Gordon, Freethought in the United Kingdom and Commonwealth. A descriptive bibliography, Westport, 1981.

Stewart, A.T.Q., The Narrow Ground. Aspects of U1ster, 1609-1969, London, 1977.

Stewart, W.D., Sir Frances H.D. Bell. His life and times, Wellington, 1937.

Stewart, W.D., William Rolleston. A New Zealand statesman, Christchurch, 1940.

Sutch, W.B., Poverty and Progress in New Zealand, Wellington, 1941.

Sutch, W.B., Colony or Nation? Economic Crises in New Zealand from the $1860 \mathrm{~s}$ to the $1960 \mathrm{~s}$, Sydney, 1966.

Tholfsen, Trygve R., Working Class Radicalism in Mid Victorian England, London, 1976.

Wakefield, E.J., Adventure in New Zealand, from 1839 to 1844, London, 1845.

Wallace, A.R., Land Nationalisation, London, 1882. 
Ward, Alan, A Show of Justice. Racial 'amalgamation' in nineteenth century New Zealand, Auckland, 1978.

Watson, Charles, The Story of the United Parishes of Glenavy, Camlin, and Tullyrusk, Belfast, 1892 .

Whitmore, Sir George Stoddart, The Last Maori War in New Zealand under the Self-Reliant Policy, London, 1902 .

Wild, T.J., The Life and Times of Sir James Wilson of Bulls,

Christchurch, 1953.

Wilson, J.G., Early Rangitikei, Christchurch, 1914.

Woodham-Smith, Cecil, The Great Hunger. Ireland 1845-9, London, 1962. 


\section{ABSTRACT}

This thesis is a biography of John Ballance, New Zealand's first Liberal Premier. It examines his career as journalist and politician, from his arrival in New Zealand and Wanganui in 1866 until his death in 1893. Ballance is viewed from a number of different perspectives: as editor and owner of a 'frontier' town's newspaper, as a prominent Wanganui personality closely involved in promoting local development, as Member of the House of Representatives and, finally, as a national political leader.

The first chapter looks briefly at Ballance's early life in the north of Ireland and Birmingham. Chapter two then discusses his arrival in Wanganui, the establishment of the Evening Herald, and his participation in the war against Titokowaru. The following chapter begins with an examination of Ballance's attitude to politica1 and economic issues of the 1870 s, in particular his opposition to the provincial system, and ends with his entering Parliament for the first time in 1875. A little over two years later he became Colonial Treasurer in the Grey Government (chapter four). Chapter five covers the period 1879 to 1884 , and Ballance's only electoral defeat, in 1881. Chapter six examines the broad base of his liberal philosophy, and shows how its different strands are inter-related, all pointing to a democratic, secular society, with considerable emphasis on individual and national self-reliance.

In 1884 Baliance re-entered Parliament, and became Minister of Lands and Native Minister in the Stout-Vogel Government. His activities and initiatives when holding these two portfolios are the 
subject of chapter seven. Chapters eight and nine lead up to the crucial election of 1890 . Ballance, after some initial hesitation, accepted the leadership of the Opposition in 1889. Land reform predominated his campaign at the election. Chapters ten to twelve discuss Ballance in power (1891-93). His major problem was to secure and consolidate the new Liberal regime, in the face of opposition to government measures from the Legislative Council and an alleged withdrawal of capital from the country. Ballance's reaction was to pursue a non-borrowing, self-reliant policy, and to establish a Liberal Federation to organise support for the Government at grass roots level. The conclusion discusses the 'Ballance tradition'. 